G $E \cup S$

Report file no.

22208

GRøNLANDS GEOLOGISKE UNDERSøGELSE

Bulletin No. 56

DE DANSKE NÛGSSUAQ EKSPEDITIONER 1938-39

Under Ledelse af Alfred Rosenkrantz

\title{
AMMONITES
}

\section{FROM THE UPPER CRETACEOUS OF WEST GREENLAND}

BY

TOVE BIRKELUND

WITH 125 FIGURES IN THE TEXT AND 49 PLATES

Reprinted from

Meddelelser om Grenland, Bd.179, Nr. 7

KØB ENHAVN

BIANCO LUNOS BOGTRYKKERI A/S

1965 
GRøNLANDS GEOLOGISKE UNDERSØGELSE

BUlletin No. 56

DE DANSKE NÛGSSUAQ EKSPEDITIONER 1938-39

Under Ledelse af Alfred Rosenkrantz

\section{AMMONITES}

\section{FROM THE UPPER CRETACEOUS OF WEST GREENLAND}

BY

TOVE BIRKELUND

WITH 125 FIGURES IN THE TEXT

AND 49 PLATES

Reprinted from

Meddelelser om Grenland, Bd.179, Nr. 7

KØB ENHAVN

BIANCO LUNOS BOGTRYKKERI A/S

1965 
Denne afhandling er af det matematisk-naturvidenskabelige fakultet ved Københavns universitet antaget til offentlig at forsvares for den filosofiske doktorgrad.

København, den 14. december 1964.

W. Fenchel

h. a. dec. 


\section{CONTENTS}

Abstract $\ldots \ldots \ldots \ldots \ldots \ldots \ldots \ldots \ldots \ldots \ldots \ldots \ldots \ldots \ldots \ldots \ldots \ldots \ldots \ldots \ldots$

Introduction $\ldots \ldots \ldots \ldots \ldots \ldots \ldots \ldots \ldots \ldots \ldots \ldots \ldots \ldots \ldots \ldots \ldots$

Acknowledgements . . . . . . . . . . . . . . . . . . . . . . . . . 9

Description of the localities $\ldots \ldots \ldots \ldots \ldots \ldots \ldots \ldots \ldots \ldots \ldots \ldots \ldots \ldots$

Systematic descriptions . . . . . . . . . . . . . . . . . . . . . 21

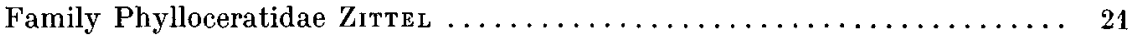

Subfamily Phylloceratinae ZitTé..................... 21

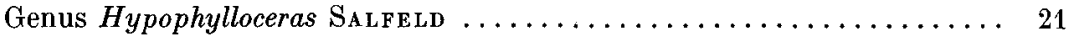

Subgenus Hypophylloceras (Neophylloceras) Sнiмız ........... 21

Hypophylloceras (Neophylloceras) groenlandicum n. sp......... 23

Family Tetragonitidae $\mathrm{HyatT}_{\text {a }} \ldots \ldots \ldots \ldots \ldots \ldots \ldots \ldots \ldots \ldots \ldots \ldots \ldots$

Genus Saghalinites Wright \& Matsumoto............... 30

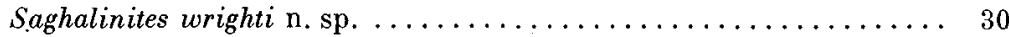

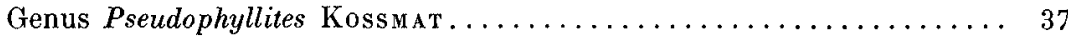

Pseudophyllites skoui n. sp..................... 37

Pseudophyllites sp....................... 42

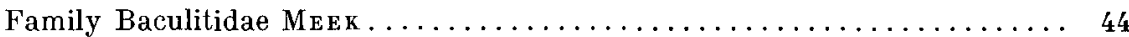

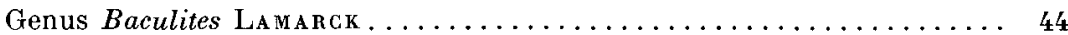

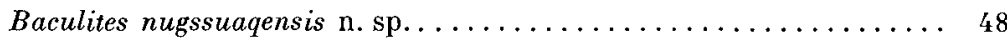

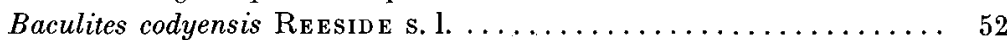

Baculites cf. haresi $\mathrm{REESIDE} \ldots \ldots \ldots \ldots \ldots \ldots \ldots \ldots \ldots \ldots \ldots$

Baculites obtusus MEЕ s. $1 \ldots \ldots \ldots \ldots \ldots \ldots \ldots \ldots \ldots \ldots \ldots \ldots$

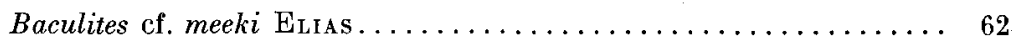

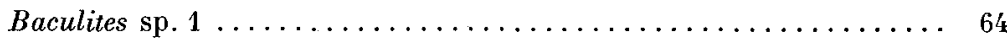

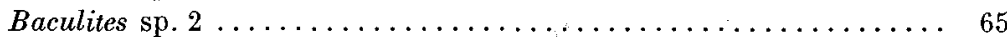

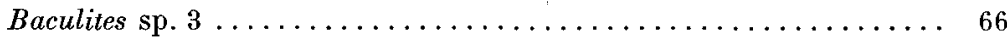

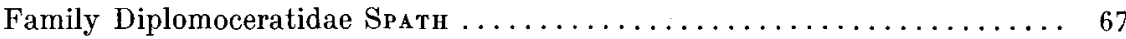

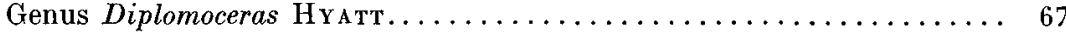

Diplomoceras sp. ......................... 67

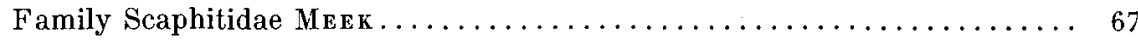

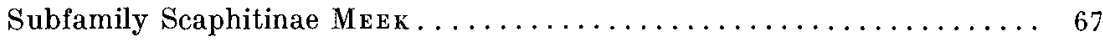

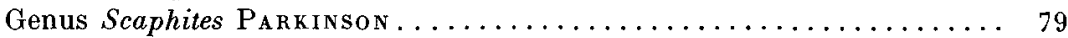

Subgenus Scaphites (Scaphites) Parkinson ............. 79

Scaphites (Scaphites) cf. corvensis Coв вап ............. 79

Scaphites (Scaphites) mariasensis Сов Ban umivikensis n. subsp. ... 81

Scaphites (Scaphites) preventricosus Cов ваN svartenhukensis n.subsp. 83

Scaphites (Scaphites) ventricosus MEЕ \& HaYden.......... 87

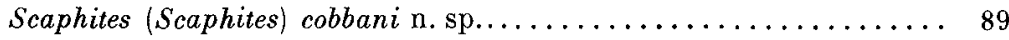

Scaphites (Scaphites) rosenkrantzi n. sp............... 97 
Subgenus Scaphites (Hoploscaphites) Nowaк............. 102

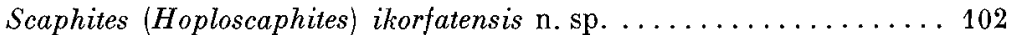

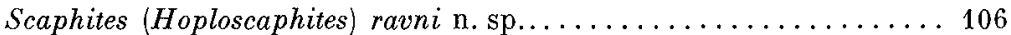

Scaphites (Hoploscaphites) greenlandicus Donovan............ 110

Scaphites (Hoploscaphites?) sp...................... 116

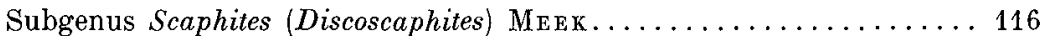

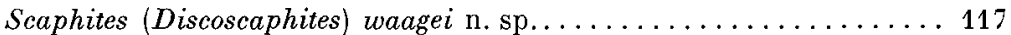

Scaphites (Discoscaphites) angmartussutensis n. sp........... 124

Scaphites (Discoscaphites) sp. aff. angmartussutensis n. sp....... 130

Scaphites (Discoscaphites) sp........................ 130

Genus Clioscaphites Соввам........................ 131

Clioscaphites saxitonianus (MCLEARN) septentrionalis n. subsp. ... 132

Clioscaphites sp. aff. saxitonianus (MCLEARN) ............. 135

Genus Haresiceras ReEside.......................... 137

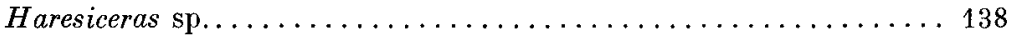

Family Binneyitidae Resside........................... 139

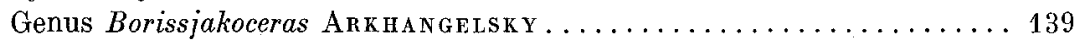

Borissjakoceras rosenkrantzi $\mathrm{n} . \mathrm{sp} . \ldots \ldots \ldots \ldots \ldots \ldots \ldots \ldots \ldots$

Unidentified material. ............................ 143

Palaeoecology .................................... 144

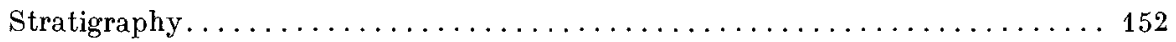

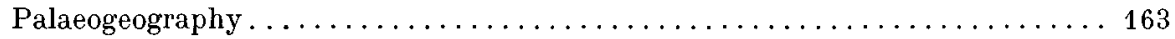

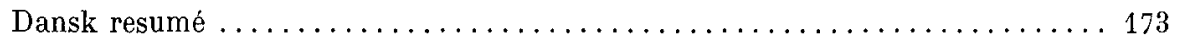

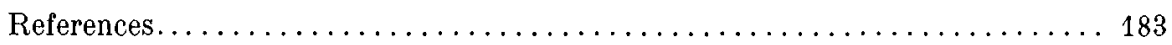

Plates......................................... 193 


\begin{abstract}
Ammonites from Nûgssuaq and Svartenhuk, belonging to the genera Hypophylloceras, Saghalinites, Pseudophyllites, Baculites, Diplomoceras, Scaphites, Clioscaphites, Haresiceras and Borissjakoceras, are described. Baculites and Scaphites are richly represented, and the material provides a basis for evaluating the subgenera Hoploscaphites and Discoscaphites. The ontogeny and the phylogeny of most of the genera are discussed and juvenile stages of Saghalinites and Scaphites described. Eleven new species and three new subspecies are introduced.

The stratigraphical, palaeogeographical and palaeoecological aspects of the ammrnite assemblages are considered, and a discussion of sexual dimorphism in Scaphites is given.

The presence of 12 biozones from the Upper Turonian?, Coniacian, Santonian, Campanian and Maastrichtian is demonstrated. The stratigraphical correlation of European and North American Upper Cretaceous deposits is discussed and the West Greenland zones are correlated with North American and European ammonite zones.

All the Upper Turonian?-Santonian species have affinities with species endemic to the Western Interior of North America. One of the genera, Clioscaphites from the Santonian, occur only within that area. The Campanian scaphites and baculites are at first mostly like species from the Interior of North America, later, in the Upper Campanian, European affinities are more prominent. Haresiceras from the Lower Campanian is endemic to the Western Interior of North America. The Maastrichtian scaphites and baculites are closely related to endemic species from the Interior of North America, principally from the Fox Hills Formation of the type area. Hypophylloceras, Saghalinites and Pseudophyllites from the Campanian-Maastrichtian have Indo-Pacific relations and Diplomoceras may be related to European forms.

The ammonites, together with the belemnites and inoceramids from the area, so far as they are identified, show that a sea-way to the north, through the Arctic Seas, connected this area with the Interior of North America from the Upper Turonian or Coniacian to the Maastrichtian. The area apparently was also connected with Europe by a sea-way during that part of the Upper Cretaceous. The occurrence of ammonites with Indo-Pacific affinities may further indicate the presence of a northern sea-way between the Pacific and the Arctic Seas during parts of the Campanian-Maastrichtian interval.
\end{abstract}




\section{INTRODUCTION}

$\mathrm{M}$ ost of the material described in this paper was collected during the Nùgssuaq Expeditions in 1938-1939 and, subsequently, during the current geological mapping of Svartenhuk and Nûgssuaq under the auspices of the Geological Survey of Greenland. Both the Nugssuaq Expeditions and the field work of the Geological Survey in this area were carried out under the leadership of Professor A. RosenKRANTZ.

The ammonites of West Greenland were first mentioned by HoFF (1865). He suggested that some fragments labelled "Cornu Amonis aus Grönland" and a fragment from the Umanak area proved the occurrence of Jurassic deposits. Later HeER (1868) referred the fragments other than that from Umanak, to Macrocephalites. In 1878-1880 K. J. V. STEENSTrup collected some scaphites at Niaqornat and DE Loriol $(1882,1883)$ suggested that these were closely related to scaphites from the Fox Hills Group described by MEe all the ammonites from West Greenland were probably Cretaceous. Also White \& Schuchert collected scaphites at Niaqornat in connection with the Arctic Peary Expedition of 1897 (mentioned by STANTon in White \& Schuchert, 1898).

Madsen (1897), using partly old collections and partly new material collected by HeNDRIKSEN in 1885, described all the ammonites from West Greenland known at that time. He tentatively referred the ammonites labelled "Cornu Amonis aus Grönland" to "Scaphites" and those from Niaqornat to "Scaphites roemeri D'ORBIGNY". Later RAVN (1918) described more comprehensive material from Niaqornat. He referred the scaphites from this locality to Scaphites nicolletii, but both MADsEN and Ravn considered Scaphites roemeri and Scaphites nicolletii to be conspecific.

Rosenkrantz $(1940,1942)$ showed that the ammonites labelled "Cornu Amonis aus Grönland" probably came from Umîvik, Svartenhuk, where a locality with similar forms was discovered during the Nûgssuaq Expeditions, and he referred these to the Scaphites ventricosus 
group. Rosenkrantz (1942) also mentioned the occurrence of a Borissjakoceras species at Umîvik and gave new valuable information on the Scaphites fauna from Niaqornat. He called attention to the fact that Scaphites nicolletii and Scaphites roemeri are two distinct species belonging to different genera, and he referred the scaphites from Niaqornat to Scaphites roemeri. Later RosenkRANTz also mentioned the occurrence of Scaphites cf. nodosus (1953) and lytoceratids $(1951,1953)$. 


\section{ACKNOWLEDGEMENTS}

I owe a special debt of gratitude to Professor A. Rosenkrantz for allowing me to join two of his expeditions to West Greenland, for handing over the ammonite collections from West Greenland to me for study, for his stimulating interest in my work on this material, and his instructive and valuable advice.

During my work on these ammonites I have visited a number of institutes in Europe and the United States for comparative studies:

Sveriges Geologiska Undersökning, Stockholm, Sweden, Dr. F. BROTZEN.

Paleontologiska Institutionen, Lunds Universitet, Lund, Sweden. Docent J. E. HedE.

Instytut Geologiczny, Warsaw, Poland. Professor W. Pożaryski. Mag. A. Beaszkiewicz. Dr. S. Ciéśliński.

Polska Akademia Nauk, Warsaw, Poland. Zakład Paleozoologii: Professor K. Pożaryska. Zakład Stratygrafii: Dr. H. Makowski. Prace Muzeum Ziemi, Warsaw, Poland. Professor R. Kongrel. Národní Museum, Prague, Czechoslovakia. Dr. V. Zázvorka. Amt für Bodenforschung, Hanover, Germany. Dr. F. Schmid. Institut Royal des Sciences Naturelles de Belgique, Brussels, Belgium. Dr. L. van de Poel.

Laboratoire de Paléontologie, Université de Liège, Belgium. Professor G. Ubaghs. Dr. M. M. J. Meijer.

Natuurhistorisch Museum te Maastricht, Maastricht, the Netherlands. Dr. E. M. Kruytzer.

British Museum, Natural History, London, England. Dr. L. BaIRstow.

United States National Museum, Washington, D.C., U.S.A. Dr. N. F. SoHL.

Peabody Museum, Yale University, New Haven, Conn., U.S.A. Professor K. M. WaAGe.

United States Geological Survey, Denver, Col., U.S.A. Dr. W. A. Cobbar.

United States Geological Survey, Great Falls, Mont., U.S.A. Dr. G. E. Erdmann. 
Professor H. K. ErвEN, Geologisch-Paläontologisches Institut der Universität, Bonn, Professor H. Hölder, Geologisch-Paläontologisches Institut der Universität, Münster, and Dr. C. A. Fleming, New Zealand Geological Survey, have placed material for comparison at my disposal.

Professor T. Matsumoto, Department of Geology, Kyushu University, Fukuoka, Japan, Dr. M. K. Howarth, British Museum, Natural History, London, Mr. C. W. Wright, London, Dr. J. A. Jeletzky, Geological Survey of Canada and Dr. K. P. VoGel, Geologisch-Paläontologisches Institut der Universität, Tübingen, also gave me valuable information on foreign material during the course of the study.

I am most indebted to each of these persons and institutes for the helpfulness with which they have promoted my studies.

In particular Professor K. M. WAAGe, Yale University, and Dr. W. A. Cobban, U. S. Geological Survey, Denver, have given me much important information on their collections from the Western Interior of the United States and I am greatly indebted to both of them for much stimulating discussion and comment on the manuscript, and for the instructive excursions which they and Dr. C. E. Erdmann arranged.

During my studies I have received financial support from the Danish State Research Foundation, from the Carlsberg Foundation, from the Denmark-America Foundation, from the Rask-Ørsted Foundation, and from the University of Copenhagen.

I am most grateful to Professor Dr. A. Noe-Nygaard for the excellent facilities made available to me in the Mineralogical Museum of the University of Copenhagen during the present study, and I am much indebted to Professor Dr. Chr. Poulsen and to my colleagues in the museum for help and fruitful discussions.

The specimens were prepared by Mr. Kr. Skov and Mrs. Erna Nordmann, the drawings by stud. scient. Gunni Jørgensen and Mrs. Ragna LaRsen, and the photographic work was carried out by Mr. Chr. Halkier. I wish to express my most sincere thanks to all these persons for their patience and skill in preparing the fossils and the illustrations.

My thanks are due to Dr. G. LARwoon, University of Durham, for correcting the English text. 


\section{DESCRIPTION OF THE LOCALITIES}

All the ammonites described in this paper were collected from localities situated on Svartenhuk and Nûgssuaq, West Greenland. Since most of the results of field work carried out in this area are not yet published, the descriptions of most of the localities given below are based on personal communications from Professor A. Rosenkrantz and his collaborators (mag. scient. S. Floris, mag. scient. B. E. Косн, Preparator Kr. Skou and Dr. H. Wienberg Rasmussen).

SVARTENHUK. (Text-figs. 1, 2). The Cretaceous marine sediments at Umivik were described by Rosenkrantz (1942). They extend from Niaqornak along the south coast of Umivik bay and continue northward along the eastern side of Firefjeld. Along the southern margin of the delta of the Usuit-kûgssuat river the deposits consist of thinly laminated, bituminous, dark-grey shales, containing subordinate intercalations of yellowish, rather finely grained sandstone, which also occurs as thin lenses in the shales. Ammonites sometimes occur in lens-shaped calcareous concretions in the shales or they may occur filled with calcite and pyrite and with a weathered limonitic crust. The beds dip slightly to the south-west. The top of the shale series was observed at an altitude of at least one hundred metres, overlain by Tertiary pillow lavas. Here no fossils were found. Somewhat to the south of this locality similar sediments were observed to an altitude of about $135 \mathrm{~m}$, but again no ammonites were found. Rosenk Rantz (1942) suggested that the marine beds were more widely distributed to the north-west through the valley, which from the northern point of Firefjeld is connected with the Simiútapkûa valley, leading into the Umiarfik Fjord (Rosenkrantz, 1942, textfigs. 9, 10). The occurrence of Upper Cretaceous belemnites at Simiútapkûa (BirKELUND, 1956) confirms that suggestion. Some of the shales at Itsako, described by Gry (in Rosenkrantz et al., 1942), have also since yielded Upper Cretaceous ammonites.

During recent years the Upper Cretaceous sediments in the southern part of Umivik bay have been mapped. In the southern tributary of Lille Tange V Kløft there is a well exposed outcrop of dark, bituminous shales with calcarous concretions. In other valleys in the same area there 


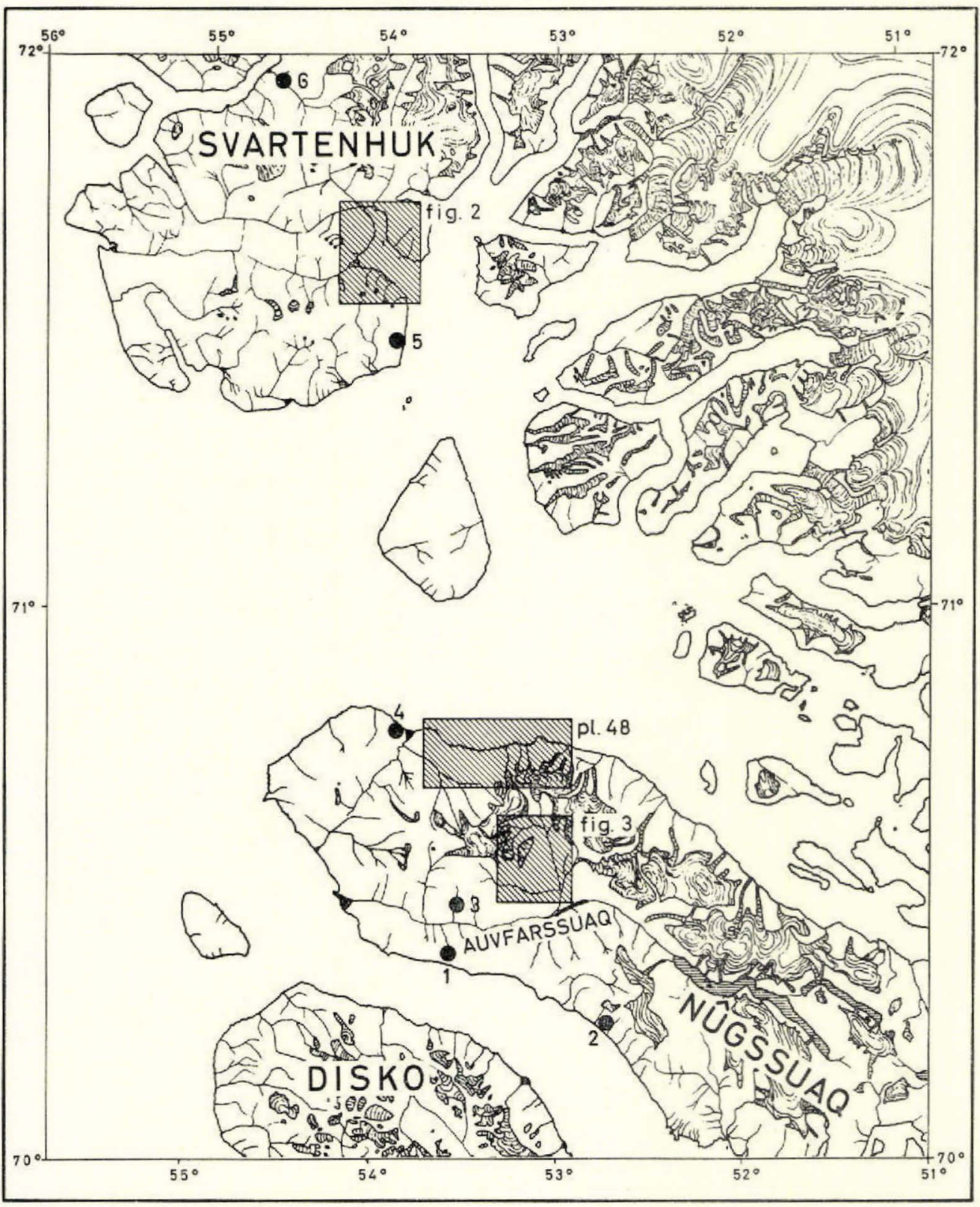
0

Fig. 1. Map of Nûgssuaq and Svartenhuk showing areas reproduced on a larger scale in text-figures and plates, and localities out-side these areas mentioned in the text. 1: Alianaitsúnguaq; 2: Pautût; 3: Ilugigsoq ; 4: Tuperssuartâ; 5 : Store Niaqornak Kløft; 6: Simiútap-kûa. 


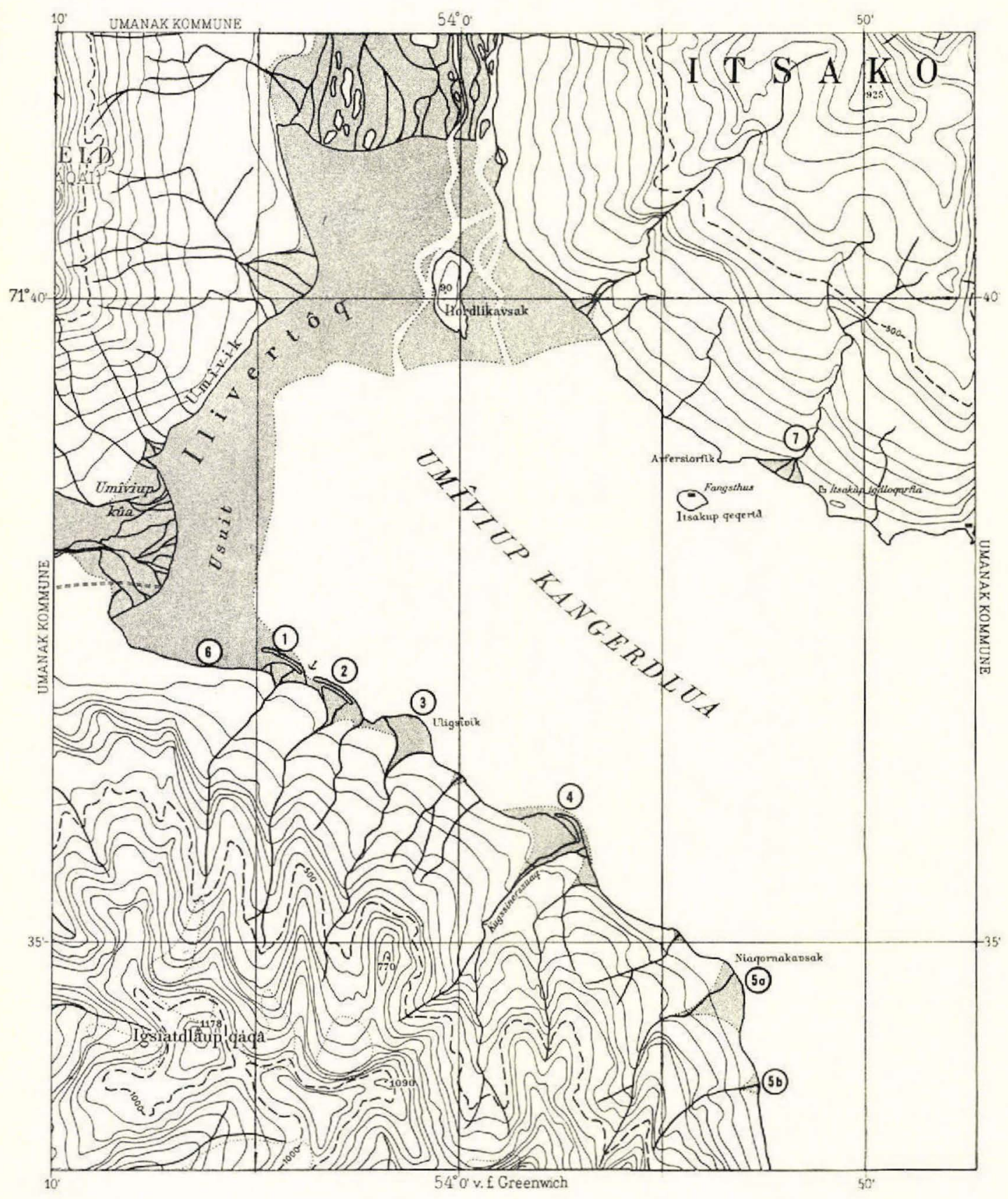

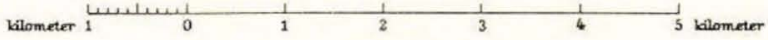

Fig. 2. Map of the Umîvik area and surroundings 1:100,000. 1: Tange I; 2: Tange II; 3: Tange III; 4 : Tange IV; $5 \mathrm{a}$ : Store Tange V; $5 \mathrm{~b}$ : Lille Tange V; 6 : The ammonite locality at Umîvik; 7: Sydelv, Itsako.

Copyright: Geodetic Institute, Copenhagen. 
are no good fossiliferous exposures, but scattered ammonites, displaced from the shales, were collected in the river valleys and deltas.

At sea-level the deposits at Umîvik contain Scaphites mariasensis umivikensis n. subsp. and Scaphites preventricosus svartenhukensis n. subsp. and indicate Lower Coniacian (Scaphites preventricosus Zone). Also, there are displaced blocks which occur at low levels containing Clioscaphites sp. aff. saxitonianus (McLearn), Scaphites cobbani n. sp., and Scaphites rosenkrantzi n. sp., which indicate deposits of Santonian and Lower Campanian age somewhere in this area.

The beds in Lille Tange V Kløft, 180-200 $\mathrm{m}$ above sea-level, are referred to the Lower Santonian on the basis of the occurrence of Clioscaphites saxitonianus septentrionalis n. subsp. Layers with large radially ribbed inoceramids (of the steenstrupi group) rest on these Clioscaphites beds. Lose specimens of Scaphites ef. corvensis Соввал in Store Tange V Kløft may indicate the presence of Upper Turonian beds (Scaphites corvensis Zone). The ammonites from Itsako belong to the genus Haresiceras and indicate a Lower Campanian age for these ammonite-bearing layers.

NÛGSSUAQ. (Text-figs. 1, 3-7; pl. 48, 49). The Cretaceous deposits of Nùgssuaq include both marine and non-marine sediments. All the marine horizons belong to the Senonian. The Cretaceous rests directly upon Precambrian rocks and is overlain by Danian and Paleocene deposits covered by Tertiary pillow lavas and basaltic flows. In a few localities, the pillow lavas cover the Cretaceous beds directly. A prominent conglomerate commonly enclosing derived Maastrichtian concretions, forms the base of the Danian. The base of the Paleocene is also marked by a conglomerate. Within the Paleocene, conglomerates containing reworked concretions from the upper part of the Lower Campanian indicate that there was continued erosion of the Cretaceous sediments. The area was faulted both before and after the extrusion of the Tertiary basalts.

The Cretaceous is exposed on both south and north coasts, and in the big river valleys traversing the peninsula. However, well exposed outcrops are few and ammonite-bearing horizons are only seldom met with. It has not been possible to construct composite sections through the Cretaceous series.

The south const. (Text-fig. 1). On the south coast of Nûgssuaq ammonites occur in a coast section at Alianaitsúnguaq.

The section is up to $30 \mathrm{~m}$ high and well exposed for about two kilometres along the coast, the strata dipping gently eastward. In the lower part of the section, shales, sandy shales and sandstones, some cross-bedded, alternate. Plant remains and trails, mud-cracks and ripplemarks occur in this part of the sequence. 


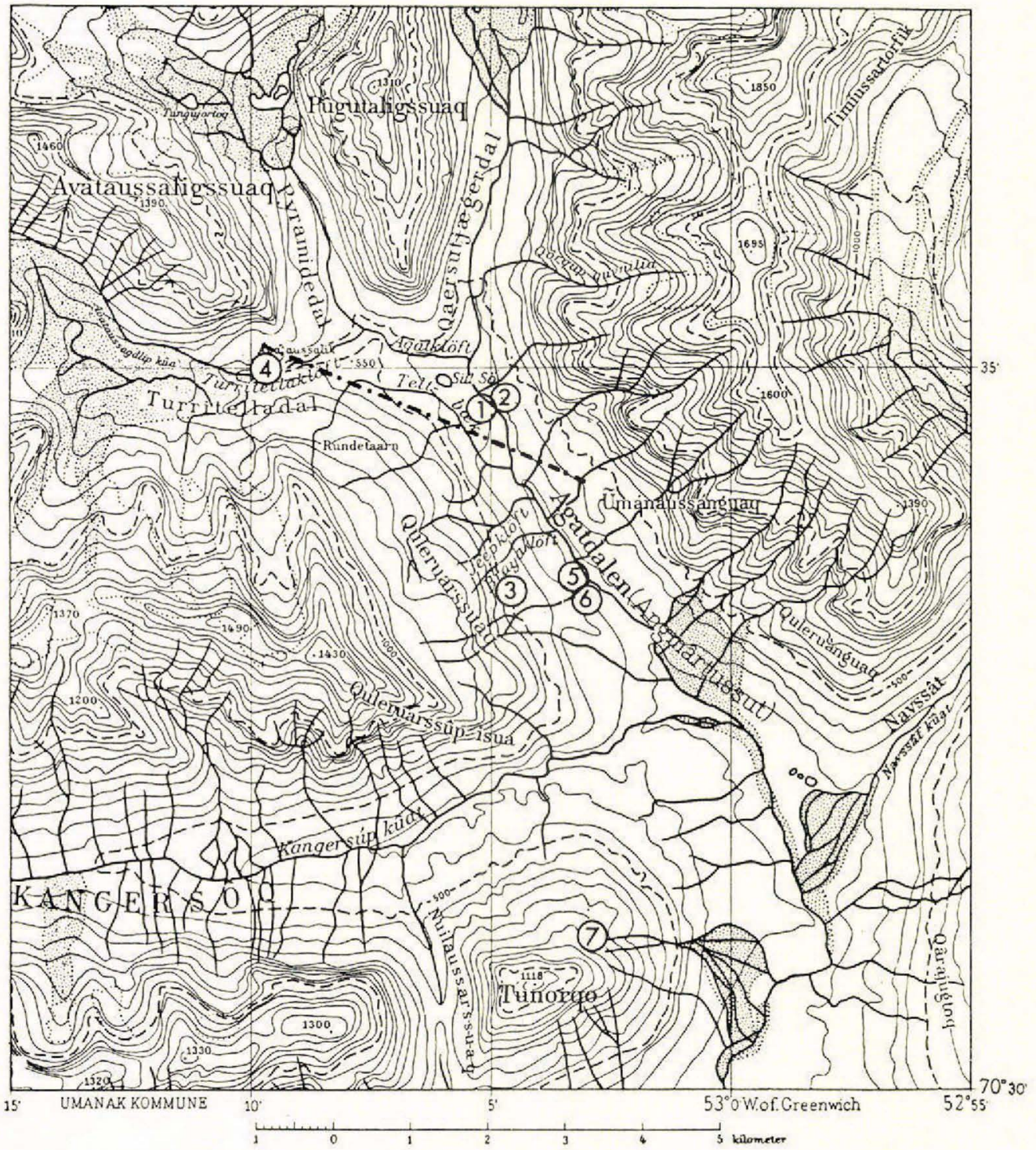

Danish Geodetic Institule, copminh.

Fig. 3. Map of the Agatdalen area 1:100,000, showing ammonite localities and fault (the fault-line after a map of Professor A. RosenkRANTz). 1: Oyster-ammonite Conglomerate loc. I; 2: Oyster-ammonite Conglomerate loc. II; 3: Oyster-ammonite Conglomerate loc. III ; 4 : Scaphitesnæsen; 5 : Nordre Baculiteskløft; 6 : Søndre Baculiteskløft; 7: Tunorqo. 


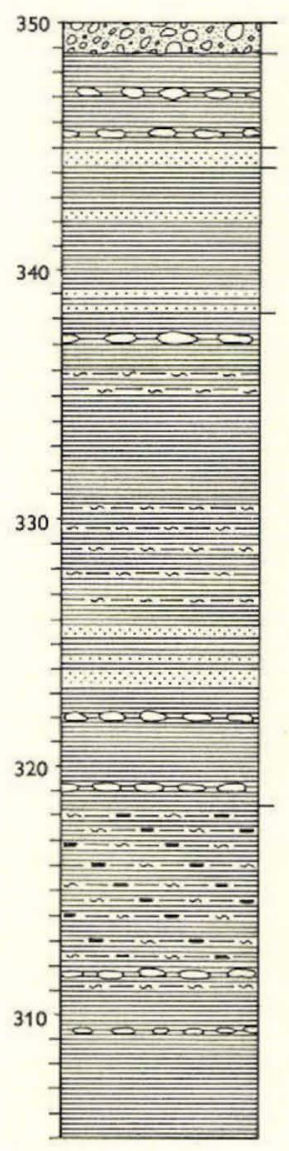

Moraine.

Dark bituminous shales with calcareous concretions.

Fossil plants.

Sandstone with fossil plants.

Dark bituminous shales with sandstones.

Baculites codyensis ReEside (late form).

Inoceramids. Fossil plants.

Dark bituminous shales with sandstones and calcareous concretions.

Inoceramids.

Dark bituminous shales with calcareous concretions.

Inoceramids.

Fossil wood.

Fig. 4. Søndre Baculiteskløft. Schematic section. The figures indicate height (in metres) above sea-level.

These beds are overlain by horizon 20 which consists of dark, bituminous shales with subordinate, light coloured sandy intercalations and yellowish concretionary layers. Calcareous concretions at this level contain ammonites, other marine fossils and plant remains.

Above horizon 20 the upper part of the section consists of alternating sandstones and shales similar to those of the lower part of the section but with subordinate coals.

The ammonite-bearing beds are here referred to the Coniacian (Scaphites ventricosus-Inoceramus involutus Zone) on the basis of the occurrence of Scaphites ventricosus MeEk \& HAYDEN.

The central Part. (Text-figs. 1,3-5). In the eastern part of the Auvfarssuaq valley Cretaceous sediments are exposed on both sides, but ammonites were collected only at Ilugigsoq and at Tunorqo. At both localities the ammonites were rather rare and poorly preserved and occur 


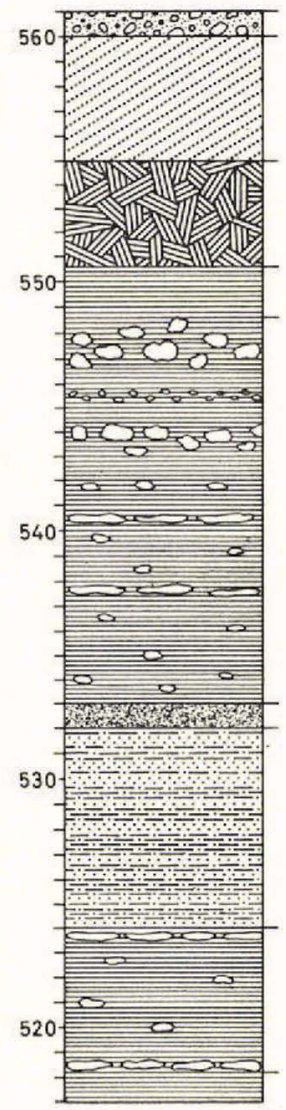

Moraine.

Agatdal Formation.

Tectonically disturbed dark bituminous shales of uncertain age.

Dark bituminous shales.

Dark bituminous shales with calcareous concretions and concretionary rusty layers.

Pseudophyllites skoui n.sp.

Baculites obtusus MeEK (early form).

Baculites cf. haresi ReEside.

Scaphites cobbani n.sp.

Scaphites rosenkrantzi n.sp.

Obscured.

Alternating sandy shales and sandstones.

Dark bituminous shales with calcareous concretions and concretionary layers.

Baculites cf. codyensis ReEside (late form).

Inoceramids.

Fig. 5. Scaphitesnæsen. Schematic section. The figures indicate height (in metres) above sea-level.

in dark shales above alternating shales and sandstones. At Ilugigsoq Clioscaphites saxitonianus septentrionalis $\mathrm{n}$. subsp. occurs and at Tunorqo Clioscaphites sp. aff. saxitonianus (McLeArN); both indicate a Lower Santonian age.

In Agatdalen (Angmârtussut), Senonian, Danian and Paleocene deposits are exposed. A prominent NNW-SSE fault crosses Agatdalen and Agatkløft about hundred metres north of the outlet of Teltbæk and appears in Turritellakløft at Scaphitesnæsen. Southwest of this fault Senonian deposits outcrop extensively in the bottom and the sides of the valley, for example at Søndre and Nordre Baculiteskløft and at Scaphitesnæsen. NE of the fault Danian and Paleocene deposits are exposed.

Søndre and Nordre Baculiteskløft, two small canyons in Agatdalen, have yielded some determinable baculites. Text-fig. 4 shows a schematic section of the exposed sediments in Søndre Baculiteskløft. The presence of late forms of Baculites codyensis REESIDE and radially ribbed inocera- 
mids of the steenstrupi group indicates a Santonian age (Clioscaphites montanensis Zone).

Scaphitesnæsen is a spur, situated on the south slope of Turritellakløft, just west of the fault which passes across the upper Agatdalen. A section was measured from the Turritella river, through the Senonian sandstones and shales to the tectonically disturbed overlying Paleocene Agatdal Formation (Rosenkrantz in Косн, 1959, p. 75; Косн, 1963, p. 13) (text-fig. 5). Baculites similar to Baculites codyensis REESIDE from Søndre and Nordre Baculiteskløft were collected in the lowermost horizons at river level. Above the sandy series Pseudophyllites skoui n. sp., Baculites obtusus MeEк s. l., Scaphites cobbani n. sp. and Scaphites rosenkrantzi $\mathrm{n}$. sp. were collected. These layers are here referred to the upper part of the Lower Campanian (Baculites obtusus Zone).

Shales exposed in ravines west of Scaphitesnæsen contain a fauna similar to that of the Lower Campanian part of the Scaphitesnæsen section.

In the Paleocene Turritellakløft-section on the northern side of Turritellakløft, NE of the fault, Maastrichtian discoscaphites and Lower Campanian Scaphites cobbani n. sp. have been collected from derived concretions in the conglomeratic beds.

The so-called "Oyster-ammonite Conglomerate" localities I, II and III are outcrops of a Danian basal conglomerate containing a huge number of derived concretions, mainly of Maastrichtian age, in a shaly matrix containing Danian oysters and other pelecypods. Localities I and II are situated in Agatkløft, the former west of and the latter east of the river. These two outcrops are both $\mathrm{NE}$ of the fault, $410 \mathrm{~m}$ above sea-level. Locality III is an outcrop SW of the fault at a high level ( $510 \mathrm{~m}$ above sea-level) on the western side of Agatdalen. The derived Maastrichtian calcareous concretions in the Oyster-ammonite Conglomerate enclose a rich fauna including Hypophylloceras (Neophylloceras) groenlandicum n. sp., Saghalinites wrighti n. sp., Baculites cf. meeki EliAs, Scaphites (Discoscaphites) waagei n.sp., and $S$. (D.) angmartussutensis n. sp. In addition Scaphites (Hoploscaphites) ef. ravni n. sp., $S .(H$.$) cf. green-$ landicus Donovan, $S$. cobbani $\mathbf{n}$. sp. and $S$.rosenkrantzi n. sp. occur very occasionally and indicate that some concretions have been derived from the Campanian.

The nORTh const. (Text-figs. $1,6,7 ;$ pl. 48, 49). In the central area of the north coast of Nûgssuaq deeply weathered basement rocks are overlain directly by Lower and Upper Cretaceous fresh-water deposits belonging to the Kome and Atane Formations (references listed in Troelsen, 1956, p. 53, p. 7). The fresh-water deposits are overlain by marine Campanian-Maastrichtian shales. Further west, marine Senonian, Danian and Paleocene beds outcrop in several coast sections and in 


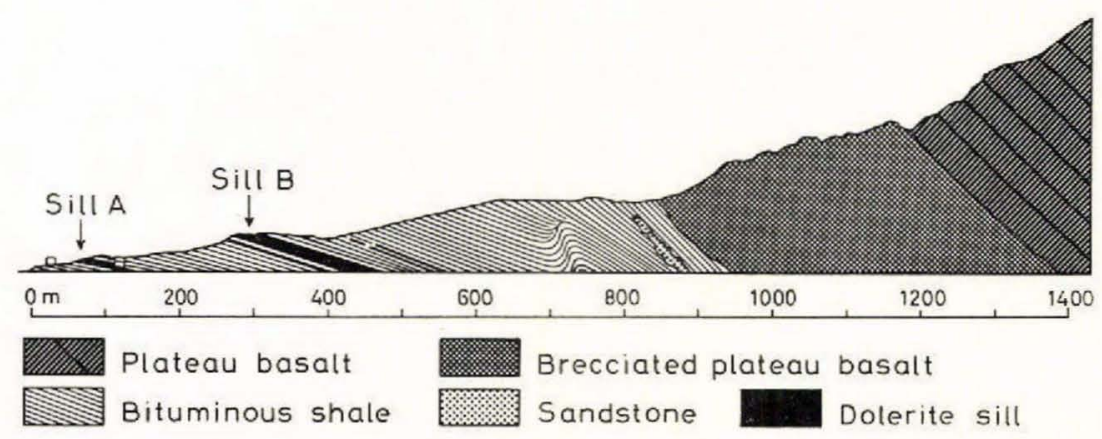

Fig. 6. Tuperssuartâ. Sketch by A. Rosenknantz.

river valleys. The sediments are covered by Tertiary pillow lavas. Several faults cut the coast and many land-slides occur.

At Tuperssuartâ ammonites occur in a section which extends for about one kilometre along the coast (text-fig. 6). The deposits consist of dark shales with more massive horizons and concretions enclosing ammonites. The beds dip slightly to the west. Clioscaphites sp. aff. saxitonianus (McLEARN) and Baculites nugssuaqensis n. sp. occur together with radially ribbed inoceramids of the steenstrupi group. The beds belong to the Lower Santonian.

The ammonite-bearing shales in the Niaqornat area were already noticed by Stennstrup (1883) and material from that area mentioned by de Loriol (1882, 1883), Madsen (1897), Stanton (in White \& Schuchert, 1898), Ravn (1918) and Rosenkrantz (1942). At Niaqornat, dark, bituminous shales, exposed $220 \mathrm{~m}$ above sea-level in Scaphiteskløften, contain calcareous concretions enclosing ammonites. Most of the material, however, was collected from displaced concretions in the river beds. Upper Campanian Scaphites (Hoploscaphites) species (S. (H.) greenlandicus Donovan, $S$. (H.) ravni n. sp.) are present, with additionally species of Pseudophyllites, Diplomoceras, and Scaphites (Discoscaphites) fragments, probably of Maastrichtian age, from displaced concretions presumably derived from the overlying poorly exposed deposits.

In Hamiteskløft, 240-247 $\mathrm{m}$ above sea-level, Maastrichtian fossils were collected in situ (Scaphites (Discoscaphites) sp. aff. angmartussutensis n. sp., Diplomoceras sp.) and in Tunorssuaq also it seems that Maastrichtian deposits are present.

In Vestre Konglomeratkløft at Angnertuneq, 103-110 m above sealevel, bituminous shales containing Scaphites (Hoploscaphites) greenlandicus Donovan, and $S .(H$.$) ravni n. sp. are recognized. I refer these$ beds to the uppermost Campanian as at Niaqornat. Beds at the Skiferperidotitnæsen at Kûk-anernilik, $40 \mathrm{~m}$ above sea-level, are also referred to the same level, $S$. $(H$.$) greenlandicus being present at this locality.$ 


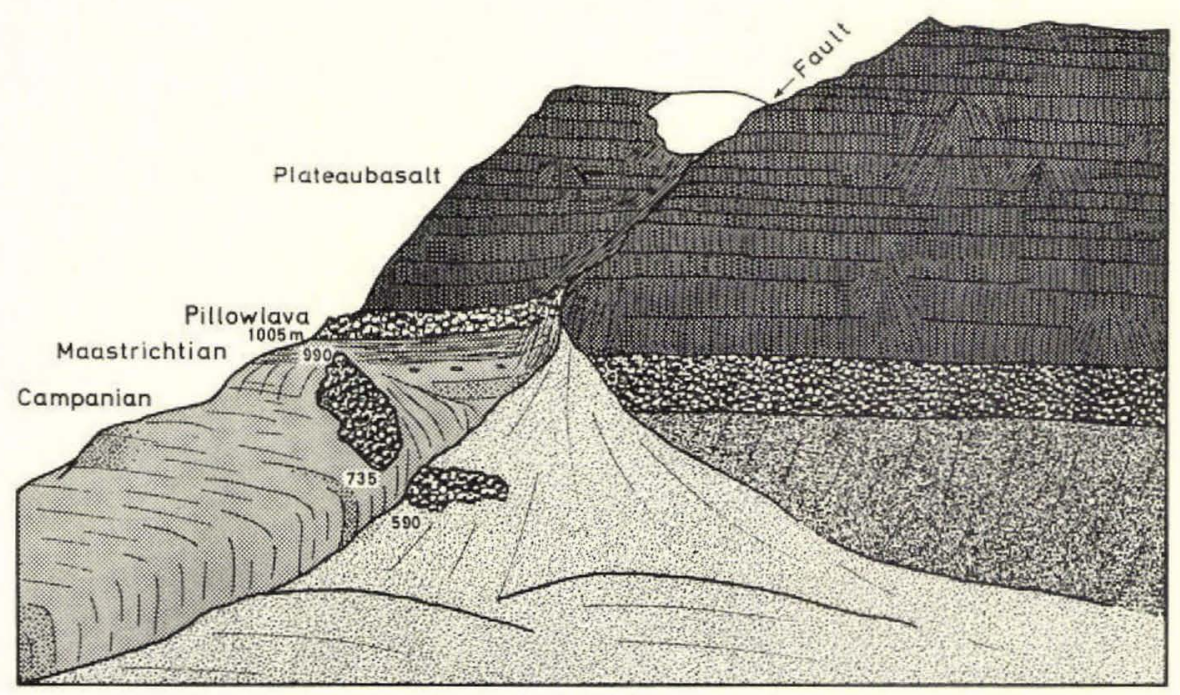

Fig. 7. Ikorfat. Sketch by A. Rosenkrantz.

At higher levels in Vestre Konglomeratkløft, $165-200 \mathrm{~m}$ above sealevel, a species of Pseudophyllites, probably of Maastrichtian age, occurs.

In Brudkløft at Ikorfat the strata are very steeply inclined, being part of a flexure associated with a fault-zone traversing Nûgssuaq (Rosenkrantz in Munck, 1945, p. 8, text-fig. 1). Crushed and very disturbed, dark, bituminous shales with derived sandstone concretions and sandstone blocks, tectonically pressed into the sequence, are exposed in the ravine (text-fig. 7). From $550 \mathrm{~m}$ to $700 \mathrm{~m}$ above sea-level calcareous concretions enclosing Pseudophyllites skoui n. sp., Scaphites (Hoploscaphites) ikorfatensis n. sp., $S$. (H.) rasni n. sp. and poorly preserved baculites occur. I refer these beds to an Upper Campanian level slightly older than that at Niaqornat. The presence of Actinocamax sp. aff. groenlandicus Birkelund shows that derived older Cretaceous fossils may also be present (Brikelund, 1956). At a level of 825-885 m fragments occur which may be assigned to $S$. $(H$.$) greenlandicus Donovan. Higher in$ the section, at Ikorfatnæsen, 980-990 m above sea-level, at the Ikorfat pass, $970 \mathrm{~m}$ above sea-level, and at a tuff-ridge east of the Ikorfat pass, $930 \mathrm{~m}$ above sea-level, a Maastrichtian fauna containing Scaphites (Discoscaphites) sp. aff. angmartussutensis n. sp. and undetermined discoscaphites occurs in nearly horizontal, poorly exposed strata, covered by Tertiary pillow lava. East of Brudkløft these Maastrichtian layers occur at a lower level in a land-slide (in the large ravine east of Ikorfat, 200-325 $\mathrm{m}$ above sea-level) and west of Brudkløft, in the Breccieelv valley, which is situated in the fault-zone, mixed Maastrichtian and Campanian species occur (S. (Hoploscaphites) species and S. (Discoscaphites) species) at $150-200 \mathrm{~m}$ above sea-level. 


\section{SYSTEMATIC DESCRIPTIONS}

Most of the ammonites described in this paper are very well preserved, some with both the inner nacreous layer and the outer porcellaneous layer present. Because of this fine preservation it has been possible to work out the ontogeny of most of the genera.

The terminology used in the systematic descriptions in the present work is largely in accordance with the "Treatise on Invertebrate Paleontology", part L, Mollusca 4, Ammonoidea (edited by R. C. Moore, 1959). As in that work, the use of formulas for description of the sutures is avoided, as none of the existing formula-systems are accepted generally. Thus, here, the lobes of the external suture, from the venter to the umbilical seam are termed the ventral lobe, the lateral lobe, and first, second, third etc. auxiliary lobes. It should be emphazised that the designations of the auxiliary lobes do not refer to their ontogeny.

To facilitate measurement of true whorl height, rather than oblique whorl height, calipers, fitted with an extra long upper jaw, as shown by CASEX (1960, text-fig. A), were used.

All ammonites described and figured in this paper are in the collections of the Mineralogical Museum of the University of Copenhagen. The numbers refer to the type collection of this museum and, in the text, are prefixed by the letters "MMH" (Museum Mineralogicum Hafniense).

Family P H Y L L O C E R A T I D A E Zittel, 1884

Subfamily PHYLLOCERATINAE ZitTel, 1884

Genus $H Y P O P H Y L L O C E R A S$ Salfeld, 1924

Subgenus NEOPH YLLOCERAS SHIMIzu, 1934

Type Species. Ammonites (Scaphites?) ramosus MeE 1858.

Emended diagnosis. Phylloceratidae with very involute shell; whorls compressed with rounded venter and flattened or rounded sides; shell with fine, equally spaced, uniform ribs or occasionally with periodic stronger ribs or folds; suture very complex, extremely incised, the 
lateral lobe much larger than the external and first auxiliary lobes, and with a very enlarged outer branch, saddle terminations slightly phylloid.

Remarks. According to Wright \& Matsumoto (1954, p. 108), the genus Neophylloceras was established by Shimizu (1934, p. 61, in Shrmizu \& Овата, in Japanese) and Neophylloceras ramosum (Меек) was designated as type species. Shimizu added that the so-called Phylloceras ramosum in Japan must be called Neophylloceras subramosum n. sp. because of the considerable differences from the type of $N$. ramosum. N. subramosum was figured but left undescribed. Later Shimizu (1935) appeared to ignore his own genus including apparently only as misprints "Neophylloceras aff. velledae" (p. 193) and "Phylloceras subramosum gen. et sp. nov." (p. 171). It was further stated that Phylloceras velledae of Yokoyama seemed to be identical with his P. subramosum (p. 177). Because of Shimizu's work (from 1935) Sратн (1939, p. 454) validated Neophylloceras subramosum and accepted that species as the type species of Neophylloceras. N. subramosum has been mentioned as type species in several works until Wright \& MATSumoto (1954) pointed out that the genus Neophylloceras was valid from 1934 and N. ramosum was clearly designated in that work as the type species.

Wright (1957, p. L189) and Wiedmann (1962, p. 139) considered Neophylloceras to be a subjective synonym of Hypophylloceras, whereas Usher (1952, p. 49), Sратн (1953, p. 4), Collignon (1956, p. 12), Wright \& Matsumoto (1954, p. 108), Matsumoto (1959a, p. 55; $1959 \mathrm{c}$, p. 1) and Jones (1963, p. 22) all regard the genus as valid.

MAтsumoto $(1959 \mathrm{a}$, p. 56) has stated that the type specimen of Neophylloceras ramosum MEк (the type species) differs considerably in suture pattern from Hypophylloceras onoense (STANTON) - the type species of that genus. According to Matsumoto Neophylloceras ramosum has, even in immature stages, a very complex suture in which the elements are multipartite, deeply and finely incised, and the phylloid terminations of the saddles tend to be lost. In Hypophylloceras onoense, even on the larger outer whorl, the suture is not so complicated as that of Neophylloceras ramosum and the terminations of the minor saddles are distinctly phylloid.

Generally there seems to be little difference in the phylloid terminations of the saddles in the two genera. Thus, specimens from Greenland, closely allied to $N$. ramosum, have extremely complex sutures with as distinct phylloid terminations as the type species of Hypophylloceras (see Packard, 1960, text-fig. 1). In addition, Spath (1953, p.4) has pointed out that Neophylloceras ultimum SPAтH, a very late species from the Sphenodiscus beds of Angola, still retains very typical phylloid terminations to the saddles. 
I prefer to treat Neophylloceras as a subgenus and consider that the difference in complexity of the sutures, though distinct, is too slight for separating two genera.

Hypophylloceras s. s. occurs in the Lower Cretaceous and $H$. (Neophylloceras) from the Upper Albian to the Maastrichtian.

\section{Hypophylloceras (Neophylloceras) groenlandicum n. sp.} Pl. 1. figs. 1-4; text-figs. 8-13.

Holotype. MMH No. 9737. Figured pl. 1, figs. $1 \mathrm{a}-\mathrm{b}$, text-fig. 8. From the Oyster-ammonite Conglomerate loc. I, Nûgssuaq. Maastrichtian.

Diagnosis. H. (Neophylloceras) of medium size; umbilical ratio $6-8 \%$; whorls increasing rapidly in height and with flattened sides and rounded venter; ratio between whorl width and height in late growth stages about $3 / 5$; maximum whorl width at umbilical shoulder; surface with extremely fine, distinctly flexuous ribs; at the middle of the sides two or more ribs coalesce at small regular intervals forming flat major ribs; suture extremely finely divided with a very asymmetric lateral lobe and saddles with small phylloid terminations.

Material. 12 specimens from the Oyster-ammonite Conglomerate loc. I and 12 specimens from the Oyster-ammonite Conglomerate loc. III, Nûgssuaq. The specimens are rather well preserved, although none is complete.

Measurements.

Specimen figured text-fig. 13.

\begin{tabular}{ccc} 
Whorl height & Whorl width & W/H \\
$0.6 \mathrm{~mm}$ & $0.7 \mathrm{~mm}$ & 1.17 \\
$0.8-$ & $0.9-$ & 1.13 \\
$1.3-$ & $1.3-$ & 1.00 \\
$2.2-$ & $1.8-$ & 0.82 \\
$4.2-$ & $2.8-$ & 0.67 \\
$7.3-$ & $4.2-$ & 0.58 \\
$12.5-$ & $7.4-$ & 0.59 \\
\multicolumn{4}{c}{$180^{\circ}$ between the measurements. }
\end{tabular}

Specimen figured text-fig. 12.

\begin{tabular}{ccc} 
Whorl height & Whorl width & W/H \\
$3.0 \mathrm{~mm}$ & $2.2 \mathrm{~mm}$ & 0.73 \\
$5.6-$ & $3.6-$ & 0.64 \\
$10.0-$ & $5.8-$ & 0.58 \\
\multicolumn{3}{c}{$180^{\circ}$ between the measurements. }
\end{tabular}


Shell diameter, whorl ratio, and umbilical ratio at youngest suture:

$\begin{array}{cccccc}\begin{array}{c}\text { Shell } \\ \text { diameter }\end{array} & \begin{array}{c}\text { Whorl } \\ \text { height }\end{array} & \begin{array}{c}\text { Whorl } \\ \text { width }\end{array} & \text { W/H } & \begin{array}{c}\text { External } \\ \text { umbilical } \\ \text { diameter }\end{array} & \begin{array}{c}\text { Umbilical } \\ \text { ratio }\end{array} \\ \begin{array}{r}63 \mathrm{~mm} \\ 38.4 \mathrm{~mm}\end{array} & ? & ? & 3.6 \mathrm{~mm} & 6 \% \\ \text { Holotype } 55- & 31.5- & 18.3 \mathrm{~mm} & 0.58 & 3.2- & 6 \% \\ 32- & 18.6- & 10.5- & 0.56 & 2.3- & 7 \% \\ 12- & 7.0- & 4.3- & 0.61 & 0.9- & 8 \% \\ 10- & 5.3- & 3.7- & 0.70 & ? & ?\end{array}$

Description. Only the phragmocone and the oldest part of the body chamber are known. The shell diameter of the largest well preserved phragmocone is $63 \mathrm{~mm}$. A fragment shows, however, that the phrag-

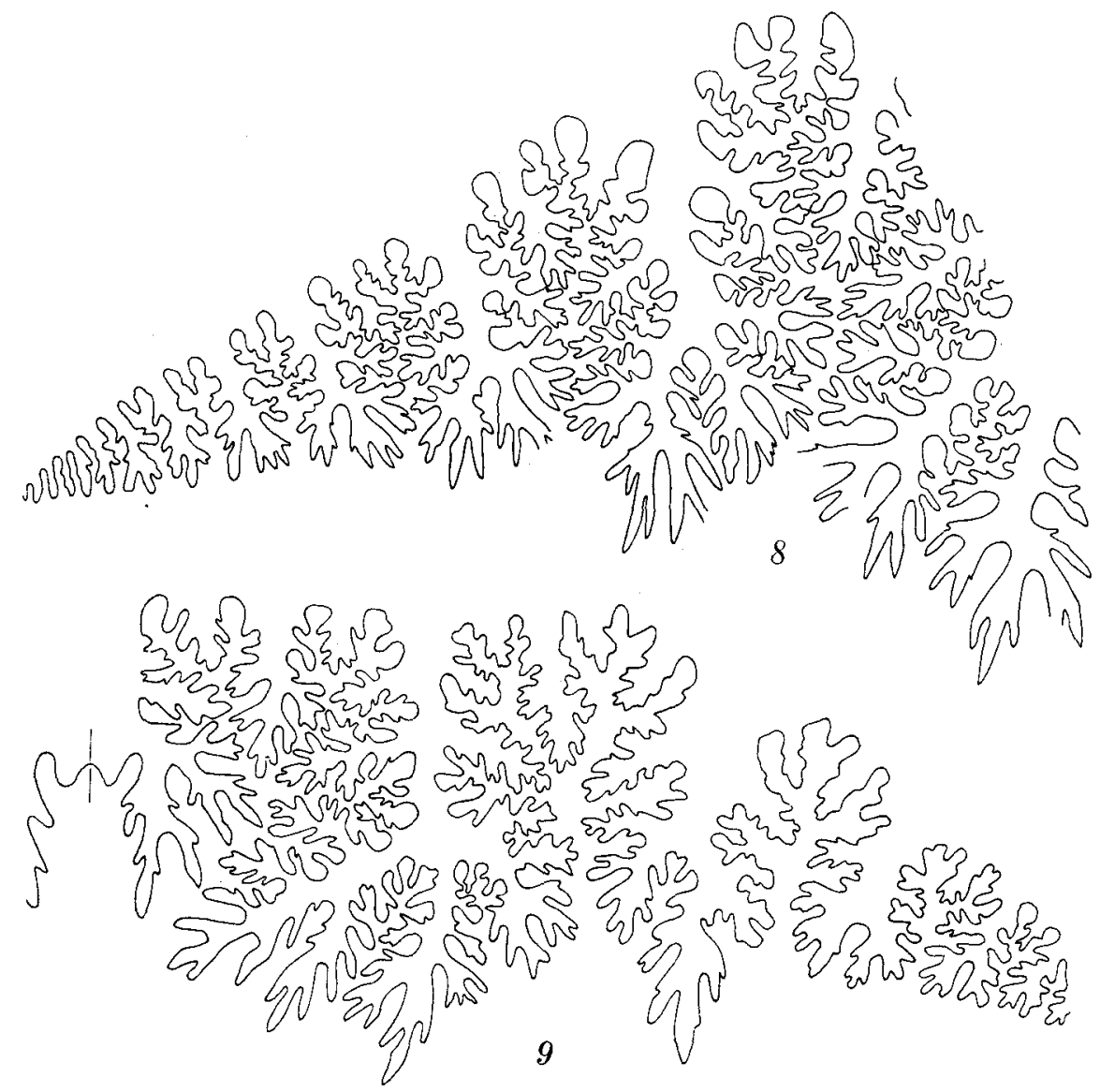

Figs. 8-9. Hypophylloceras (Neophylloceras) groenlandicum n.sp.

8. Holotype. MMH No. 9737. $\times 6$, part of the external suture at a whorl height of about $22 \mathrm{~mm}$. Oyster-ammonite Conglomerate loc. I.

9. MMH No. 9876. $\times 8$, external suture at a whor] height of about $13 \mathrm{~mm}$. Oyster-ammonite Conglomerate loc. III. 


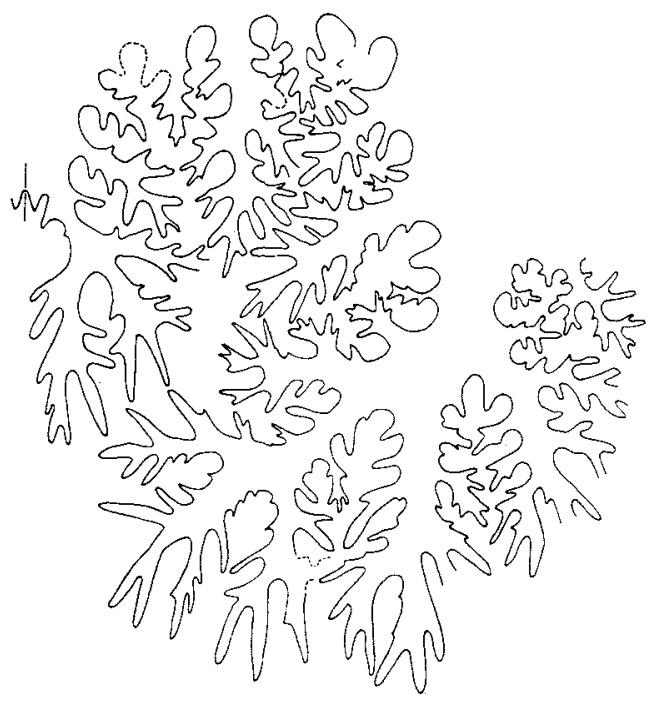

10

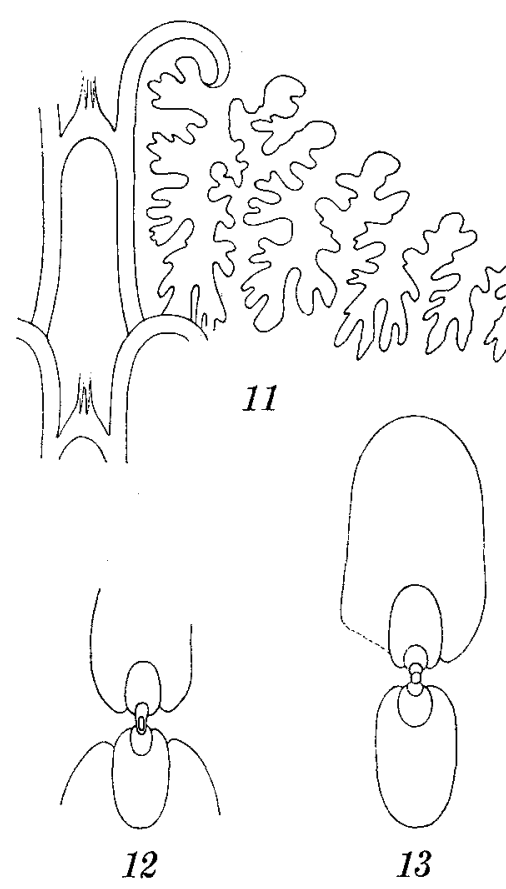

Figs. 10-13. Hypophylloceras (Neophylloceras) groenlandicum n.sp. from Oysterammonite Conglomerate loc. I.

10. MMH No. $9738 . \times 3$, part of the external suture at a whorl height of about $43 \mathrm{~mm}$.

11. MMH No. 9877. $\times 6$, the internal suture at a whorl height of about $27 \mathrm{~mm}$.

12. MMH No. $9878 . \times 1$, cross section of phragmocone.

13. MMH No. $9879 . \times 2$, cross section of phragmocone.

mocone may be even larger. None of the specimens seem to be mature. The umbilicus is small, the umbilical ratio ranging from 6 to $8 \%$ at shell diameters exceeding $10 \mathrm{~mm}$. At earlier stages the umbilical ratio is higher.

The innermost whorls are slightly depressed. At a shell diameter of $2.6 \mathrm{~mm}$, the whorl height and width are equal. At greater diameters the whorl height exceeds the width. From a shell diameter of about $12 \mathrm{~mm}$, the relation between whorl width and height is about $3 / 5$. The innermost whorls are evenly rounded. From a shell diameter of about $4 \mathrm{~mm}$ the sides gradually flatten, and at greater diameters are more and more parallel. The maximum whorl width is at the umbilical shoulder, from which the sides gradually slope towards the umbilicus. From a shell diameter of about $10 \mathrm{~mm}$, immediately ventral to the umbilical shoulder, a slight depression is discernible. Because of this depression the umbilical shoulders appear slightly raised.

The surface is covered by extremely fine ribs. They have a slight forward inclination on the umbilical slope and beyond the umbilical 
shoulder they bend forward even more. At the middle of the sides, they form a distinct sigmoidal curve bending first forward, then backward, and again slightly forward on crossing the venter. The ribs are less curved at earlier growth stages, thus, the projection of the ventral ribs is not discernible at shell diameters less than $15 \mathrm{~mm}$.

From a shell diameter of about $12 \mathrm{~mm} \mathrm{2-4}$ ribs coalesce regularly at small intervals on the umbilical half of the sides forming flat major ribs. These are most closely spaced in the later growth stages, thus at a shell diameter of $35 \mathrm{~mm}$ about 11 major ribs are developed per half whorl, and at a shell diameter of $53 \mathrm{~mm}$ about 18 major ribs are developed per half whorl.

The sutures are extremely deeply cut and with distinctly phylloid saddle terminations - these are especially clear in pl. 1, fig. 4a. In this specimen the sutures are seen through the inner layer of the shell, and the terminations of the saddles are completely preserved, which is not the case with exposed suture lines. The external lobe is very short. The lateral lobe is the largest and asymmetrically trifid with a very extended ventral branch. The first auxiliary lobe is not so deeply divided as the lateral lobe; it is also asymmetrically trifid. The first and second lateral saddles are of about the same size and bifid. The suspensive lobe is retracted and has developed up to 11 auxiliary lobes and saddles. The size of the auxiliaries decreases evenly towards the umbilicus. The internal suture has a simple, deep, narrow dorsal lobe and 6-7 deeply cut internal lateral lobes and saddles decreasing evenly in size towards the umbilicus (text-fig. 11).

Affinities. The species is very similar to Hypophylloceras (Neophylloceras) ramosum (MEEK). A cast of the type, figured by MEeK $(1876 \mathrm{~b}$, pl. 5, figs. 1, 1a, 1b) and refigured by ANderson (1958, pl. 40, figs. 4, 4a) and Матsuмото (1959c, pl. 1, figs. $1 \mathrm{a}-\mathrm{d}$; pl. 2, fig. 2), differs only from the material described here in having weaker and considerably more widely spaced major ribs, slightly less projecting ventral ribs, and a less pronounced umbilical shoulder. Some other specimens in the collections of the United States National Museum in Washington and specimens figured by Matsumoto (1959c, pl. 8, figs. 1a-c), by Usher (1952, pl. 1, figs. 4-5) and by Jones (1963, pl. 6, figs. 1-8) seem to differ in the same way.

According to a personal communication from Professor T. MATsuмото, larger specimens, probably of $N$. ramosum, from the Senonian of Japan, Sakhalin, and Alaska, may have as closely spaced major ribs on the outer whorls as specimens from West Greenland, but when all characters are taken into consideration the specimens from Greenland fall outside the range of variation of $N$. ramosum. 
$H .(N$.$) subramosum (SpATH, 1939), figured by YABE (1927, pl. 9(7),$ figs. $3 \mathrm{a}-\mathrm{b}$ ), differs from $H$. $(N$.) ramosum in having a more distinct elevation at the umbilical shoulder and shows in that character more similarity with the species from Greenland. However, according to YABE's figure, and a personal communication from Professor T. MATSUмото, $H$. (N.) subramosum differs from the Greenland species in ribbing pattern, the ribs being coarser and less curved, only few and rather indistinct major ribs being developed.

$H .(N$.$) nera (FonBes, 1846) is very similar in sculpture to the$ species from Greenland in that it has rather closely spaced, distinct major ribs (according to Kossmat's figure (1895, pl. 16, figs. 2a-d)). It differs however, in having less curved ribs, and in cross section, the maximum whorl width is much closer to the venter.

$H .(N$.$) velledaeforme (SchlÜTER, 1871) has very fine sigmoidally$ curved ribs like the species from Greenland, but apparently no major ribs are developed (SchlüTER, 1871-72, pl. 18, figs. 4-5). It differs further in cross section having a greater whorl height in relation to width, and more rounded sides.

$H .(N$.$) hoepeni (Collignon, 1956) is rather similar in cross section$ and in suture pattern to the species from Greenland, but differs in sculpture, having less curved ribs and no major ribs.

I have established a new species on the material from Greenland because of the constant, though small, differences from $H$. (N.) ramosum which is apparently the most closely related species.

Stratigraphy. H. (Neophylloceras) groenlandicum n. sp. occurs in derived concretions in Danian conglomeratic beds. Scaphites (Discoscaphites) species which occur together with $H .(N$.$) groenlandicum n. sp. in$ the same concretions suggest a Maastrichtian age. It is thus stratigraphically slightly younger than $H .(N$.$) ramosum which, according to MAT-$ suмото $(1959 \mathrm{c}, \mathrm{p} .4-5$, and pers. comm.) ranges from the Turonian to the Upper Campanian along the West Coast of North America and in Japan and Sakhalin.

Family TET RAGO N I T I DAE Hyatt, 1900 sensu Wiedmann, 1962

Wright (1957, p. L200) ranked the Tetragonitidae Hyatt, 1900, as a family within the superfamily Lytocerataceae. Like Breistroffer (1953) he ranked the Gaudryceratinae SpATH, 1927, and Tetragonitinae Hyatт, 1900, as subfamilies. He referred the genera Tetragonites KossMat, 1895, Epigoniceras SPath, 1925 (with the subgenus Saghalinites Wright \& Matsumoto, 1954), Pseudophyllites Kossmat, 1895, and Gabbioceras Нхатт, 1900, to the subfamily Tetragonitinae. 
Recently Wiedmann (1962, p. 147) has revised this group. He ranks Hyatr's family Tetragonitidae as a superfamily Tetragonitaceae. According to WIEDMarn no forms with sutures intermediate between the Lytocerataceae and Tetragonitaceae are known. The Gaudryceratidae and Tetragonitidae are ranked by WIEDMANN as families, following SPATH (1927) and many others. Wredmann includes in the family Tetragonitidae the genera Tetragonites, Saghalinites and Pseudophyllites. Gabbioceras is shown to belong to the Gaudryceratidae and Epigoniceras is considered invalid. WIEDMANN's systematic arrangement is considered to be very useful by the writer and is used in the present work.

Species belonging to the genera Saghalinites and $\boldsymbol{P}_{\text {seudophyllites occur }}$ in West Greenland. The relations between Tetragonites and these genera are discussed here together with a review of the genus Epigoniceras which has uncertain status.

Spatн $(1925$, p. 29) established the genus Epigoniceras, and Tetragonites epigonus (Kossmat, 1895) was made the type. The new genus was established by Sратн because he considered that there are significant morphological differences between the sutures of Tetragonites timotheanus (Pictet, 1847), the type species of Tetragonites, and T. epigonus (Kossmat, 1895). Spath based his opinion on a suture figured by Kossmat (1895, pl. 17, fig. 11) and referred by Kossmat to T.timotheanus. KossMAT's figure shows a suture with a straight suspensive lobe and four saddles in the internal suture, whereas $T$. epigonus has a suture with a retracted suspensive lobe and two saddles in the internal suture. The genus Epigoniceras has been considered valid in many recent works: for example by Usher (1952, p. 54), Wright \& Matsumoto (1954, p. 110), Wright (1957, p. L203) and by Collignon (1956, p. 81), the previously mentioned differences being quoted. According to Wright (1957) Tetragonites ranges from the Middle Albian to the Upper Cenomanian and Epigoniceras from the Lower Turonian to the Maastrichtian.

However, Howarth $(1958$, p. 9) has examinated all the AlbianCenomanian and Turonian-Campanian Tetragonites and "Epigoniceras" in the British Museum (Natural History) and has reviewed all published figures of the suture lines. He concluded that recurved, straight and even "upcurved" suspensive lobes are found throughout the stratigraphical range and Epigoniceras is invalid.

Matsumoto (1959a, p. 78) agrees with Howarth's view. He figures a suture of a specimen of Tetragonites timotheanus, from St. Croix, Switzerland, which has an internal suture with two saddles and a retracted suspensive lobe showing no morphological differences from T. epigonus.

WiEDMANN (1962, text-fig. 31) figures the suture of the lectotype of $T$. timotheanus. It shows no important differences from $T$. epigonus, and 
Howarth's and Matsumoto's view is thus justified. The so-called $T$. timotheanus from India-Madagascar with sutures of the type figured by Kossmat, is referred by WIEdMann to a new species, T. subtimotheanus (p. 131).

The genus Tetragonites thus includes specimens with a straight or retracted suspensive lobe and an internal suture with two or more saddles. The specimens are also characterized by having a moderately evolute shape. The whorls are depressed or whorl height and width is about equal. The whorl section is squarish to rounded, most often with the maximum width near the umbilical shoulder. The shell is smooth. Oblique constrictions are often present.

The genus Saghalinites was established by Shimizu (1935, p. 181). Ammonites cala Forbes, 1846, and Saghalinites saghalinensis n. sp. were referred to the genus and $S$. saghalinensis chosen as type species. No description of $S$. saghalinensis was given, nor was a holotype designated and the genus was thus invalid until Wright \& Matsumoto (1954, p. 110) designated Ammonites cala Forbes, 1846, as the type species and gave the following diagnosis: "Very evolute and widely umbilicated, the whorl height increasing slowly. Whorl section rounded octagonal". Wright \& Matsumoto ranked Saghalinites as a subgenus of Epigoniceras SРАтн which as mentioned above, has since been shown to be invalid.

The suture of Saghalinites cala, as figured by Fories (1846, pl. 8, fig. 4) and by Kossmat (1895, pl. 17, fig. 12) is rather simple with a retracted suspensive lobe. No internal suture of any Saghalinites species has so far been described or figured. The Saghalinites species from Greenland has an internal suture with two saddles, the second one being small and extremely narrow (text-figs. $23 \mathrm{a}-\mathrm{c}$ ), differing in that character from Tetragonites and Pseudophyllites species. I rank Saghalinites as a genus because of the characteristic internal suture and the shape of the shell (vide Wright \& Matsumoto's diagnosis). As mentioned by Collignon $(1956$, p. 82) and Wiedmans $(1962$, p. 148) the genus Saghalinites must be an offshoot of Tetragonites.

Pseudophyllites Kossmat, 1895, is also considered by Wiedmann (1962, p. 148) to be an offshoot of Tetragonites.

The type species of Pseudophyllites (P. indra (Fon в $\mathrm{S}, 1846))$ differs from the type species of Tetragonites (T. timotheanus (Pictet, 1847)) in having a smaller umbilical ratio, a maximum width of the inner whorls at the middle of the sides, a much higher and more rounded section of the outer whorls and a finely striated surface. It also lacks constrictions and the sutures are very deeply incised with slightly phylloid terminations to the saddles.

A study of species which have been referred to the two genera shows an even transition between them, not only in shape, but also 
in cross section of the whorls, and in the characters of sutures and ornamentation.

Two species, which may be referred to the Tetragonites-Pseudophyllites group, occur in West Greenland. Unfortunately the shape of the body chamber of these species is poorly known. One of these species (P. skoui n. sp.) shows in its umbilical ratio and in the character of the whorl section of the phragmocone, affinity with typical Pseudophyllites species. Its suture pattern is intermediate between the types of the two genera. In ornamentation it is most similar to Tetragonites, showing only weak and scattered growth lines. The other species ( $P$ seudophyllites sp., p. 42) from a slightly higher level, shows more complicated sutures and a finely striated surface. I have no doubt that this last mentioned species must be referred to Pseudophyllites. P. skoui n. sp. I also refer to that genus because of the degree of involution and the character of the cross section of the whorls, although sutures and ornamentation are not typical. This is supported by a comparison with other Pseudophyllites species: P. peregrinus Spath, 1953, P. whangaroaensis Marshall, 1926, which in suture pattern show rather close affinities with the species in question. The internal suture is known in $P$. whangaroaensis Marshall, 1926 (pl. 21, fig. 11). It has, as $P$. skoui n. sp., one large and one smaller saddle.

Genus $S$ A GHALINITES Wright \& Matsumoto, 1954 (Shimizu, 1935 nomen nudum).

Type species. Ammonites cala Forbes, 1846.

Emended diagnosis. Tetragonitidae with very evolute shell; whorl height increasing slowly; whorls slightly depressed; whorl section rounded or octagonal; oblique constrictions present; suture simple with trifid major saddles, a retracted suspensive lobe and two internal saddles.

\section{Saghalinites wrighti n. sp.}

Pl. 1, fig. 5; pl. 2, figs. 1-5; pl. 3, fig. 1; text-figs. 14-25.

Name. The species is named after Mr. C. W. Wright, London.

Holotype. MMH No. 9747. Figured pl. 2, figs. 5 a-c; text-fig. 19. From the Oyster-ammonite Conglomerate loc. III, Nûgssuaq. Maastrichtian.

Diagnosis. Saghalinites of medium size; umbilical ratio 37 to $46 \%$ in late growth stages; whorl section of the greatest part of phragmocone 
rounded; whorl section of youngest part of the phragmocone and body chamber octagonal with a flat or slightly concave venter; 6-7 oblique constrictions present per whorl except for the youngest one or two whorls, which have no constrictions; mature specimens with a marginal constricted area at the aperture; suture rather simple with one large and one small and extremely narrow saddle in the internal suture.

Material. About 470 specimens from the Oyster-ammonite Conglomerate loc. I, a few specimens from the Oyster-ammonite Conglomerate loc. II and about 60 specimens from the Oyster-ammonite Conglomerate loc. III, Nûgssuaq. The material is excellently preserved, about 80 specimens showing a complete or nearly complete body chamber.

\section{Measurements.}

Shell diameter and ratio between the whorl width and height at last suture in mature specimens, and in the nearly mature holotype:

$\begin{array}{cccc}\text { Shell diameter } & \text { Whorl height } & \text { Whorl width } & \text { W/H } \\ 85 \mathrm{~mm} & 17.5 \mathrm{~mm} & 22.1 \mathrm{~mm} & 1.26 \\ 84- & 18.5- & 21.5- & 1.16 \\ 82- & 18.9- & 23.0- & 1.22 \\ 79- & 17.0- & 22.4- & 1.32 \\ 74- & 15.6- & \text { c. } 19.0- & ? \\ \text { Holotype } 73- & 16.3- & 20.5- & 1.26\end{array}$

Measurements showing variation in size, umbilical ratio, length of body chamber, and constrictions in 35 mature and juvenile specimens:

\begin{tabular}{|c|c|c|c|c|c|c|c|c|c|}
\hline $\begin{array}{l}\text { Oyster- } \\
\text { ammonite } \\
\text { conglom- } \\
\text { erate loc. }\end{array}$ & $\begin{array}{l}\text { She } \\
\text { diame }\end{array}$ & etl & $\begin{array}{l}\text { Umbil } \\
\text { diame }\end{array}$ & $\begin{array}{l}\text { lical } \\
\text { eter }\end{array}$ & $\begin{array}{l}\text { Umbilical } \\
\text { ratio }\end{array}$ & $\begin{array}{c}\text { Length of } \\
\text { body } \\
\text { chamber }\end{array}$ & $\begin{array}{c}\text { Distance } \\
\text { from aperture } \\
\text { to youngest } \\
\text { constriction, } \\
\text { about }\end{array}$ & $\begin{array}{c}\text { Con- } \\
\text { stricted } \\
\text { peristome }\end{array}$ & $\begin{array}{r}\text { Younges } \\
\text { sutures } \\
\text { approx- } \\
\text { imated }\end{array}$ \\
\hline I & $95 \mathrm{x}$ & $\mathrm{mm}$ & $43 \mathrm{r}$ & $\mathrm{mm}$ & $45 \%$ & $240^{\circ}$ & $600^{\circ}$ & + & + \\
\hline III & 85 & - & 38 & - & $45 \%$ & c. $210^{\circ}$ & $?$ & + & + \\
\hline I & 84 & - & 39 & -- & $46 \%$ & $235^{\circ}$ & $595^{\circ}$ & + & + \\
\hline I & 84 & - & 37 & - & $44 \%$ & $220^{\circ}$ & $570^{\circ}$ & $?$ & + \\
\hline I & 83 & - & 37 & - & $45 \%$ & $240^{\circ}$ & $590^{\circ}$ & + & + \\
\hline I & 82 & - & 35 & - & $43 \%$ & $240^{\circ}$ & $620^{\circ}$ & - & - \\
\hline I & 82 & - & 35 & - & $43 \%$ & $240^{\circ}$ & $590^{\circ}$ & - & - \\
\hline I & 82 & - & 35 & - & $43 \%$ & c. $200^{\circ}$ & c. $620^{\circ}$ & + & $?$ \\
\hline III & 81 & - & 36 & - & $44 \%$ & $220^{\circ}$ & $?$ & - & - \\
\hline I & 79 & - & 32 & - & $41 \%$ & $230^{\circ}$ & $?$ & $?$ & + \\
\hline I & 79 & - & 33 & - & $42 \%$ & $220^{\circ}$ & $610^{\circ}$ & + & + \\
\hline I & 75 & - & 31 & - & $41 \%$ & $235^{\circ}$ & $415^{\circ}$ & - & - \\
\hline 1 & 74 & - & 30 & - & $41 \%$ & $230^{\circ}$ & $450^{\circ}$ & + & + \\
\hline
\end{tabular}




\begin{tabular}{|c|c|c|c|c|c|c|c|c|c|}
\hline $\begin{array}{l}\text { Oyster } \\
\text { ammonite } \\
\text { conglom- } \\
\text { erate loc. }\end{array}$ & $\begin{array}{r}\text { She } \\
\text { diame }\end{array}$ & ter & $\begin{array}{l}\text { Lmbi } \\
\text { diam }\end{array}$ & $\begin{array}{l}\text { lical } \\
\text { eter }\end{array}$ & $\begin{array}{l}\text { Umbilical } \\
\text { ratio }\end{array}$ & $\begin{array}{c}\text { Length of } \\
\text { body } \\
\text { chamber }\end{array}$ & $\begin{array}{c}\text { Distance } \\
\text { from aperture } \\
\text { to youngest } \\
\text { constriction, } \\
\text { about }\end{array}$ & $\begin{array}{c}\text { Con- } \\
\text { stricted } \\
\text { peristome }\end{array}$ & $\begin{array}{c}\text { Youngest } \\
\text { sutures } \\
\text { approx- } \\
\text { imated }\end{array}$ \\
\hline *III & 731 & $\mathrm{~nm}$ & $29 r$ & $\mathrm{~mm}$ & $40 \%$ & $230^{\circ}$ & $620^{\circ}$ & - & - \\
\hline III & 73 & - & 33 & - & $45 \%$ & $240^{\circ}$ & $570^{\circ}$ & - & - \\
\hline I & 73 & - & 30 & - & $41 \%$ & $270^{\circ}$ & $630^{\circ}$ & - & - \\
\hline I & 72 & - & 30 & - & $42 \%$ & $250^{\circ}$ & $600^{\circ}$ & - & - \\
\hline I & 72 & - & 32 & - & $44 \%$ & $230^{\circ}$ & $590^{\circ}$ & - & - \\
\hline I & 71 & - & 30 & - & $42 \%$ & $260^{\circ}$ & $380^{\circ}$ & - & -- \\
\hline I & 68 & - & 27 & - & $40 \%$ & $230^{\circ}$ & $590^{\circ}$ & - & - \\
\hline I & 67 & - & 27 & - & $40 \%$ & $255^{\circ}$ & $435^{\circ}$ & - & - \\
\hline I & 66 & - & 29 & - & $44 \%$ & $245^{\circ}$ & $445^{\circ}$ & - & - \\
\hline I & 65 & - & 27 & - & $42 \%$ & $255^{\circ}$ & $485^{\circ}$ & - & - \\
\hline I & 64 & - & 28 & - & $44 \%$ & $240^{\circ}$ & $510^{\circ}$ & - & - \\
\hline I & 61 & - & 24 & - & $39 \%$ & $250^{\circ}$ & $430^{\circ}$ & - & - \\
\hline $\mathrm{I}$ & 52 & - & 20 & - & $38 \%$ & $270^{\circ}$ & $270^{\circ}$ & - & -- \\
\hline I & 51 & -. & 22 & - & $43 \%$ & $250^{\circ}$ & $370^{\circ}$ & - & - \\
\hline I & 51 & - & 19 & - & $37 \%$ & c. $250^{\circ}$ & c. $410^{\circ}$ & - & - \\
\hline 1 & 51 & - & 20 & - & $39 \%$ & $250^{\circ}$ & $250^{\circ}$ & - & - \\
\hline III & 51 & - & 19 & - & $37 \%$ & $250^{\circ}$ & $430^{\circ}$ & - & - \\
\hline I & 50 & - & 20 & - & $40 \%$ & $260^{\circ}$ & $320^{\circ}$ & - & - \\
\hline I & 46 & - & 19 & - & $41 \%$ & $260^{\circ}$ & $30^{\circ}$ & - & - \\
\hline I & 30 & - & 12 & - & $40 \%$ & $270^{\circ}$ & c. $10^{\circ}$ & - & - \\
\hline I & 29 & - & 12 & - & $41 \%$ & $250^{\circ}$ & $0^{\circ}$ & - & - \\
\hline I & 18 & - & 8 & - & $44 \%$ & $270^{\circ}$ & c. $10^{\circ}$ & - & -- \\
\hline
\end{tabular}

Description. The size of mature specimens is about $74-95 \mathrm{~mm}$. The length of the body chamber of these specimens ranges between $200^{\circ}$ and $240^{\circ}$. All the mature specimens have a remarkable peristome, showing a marginal area, $10-15 \mathrm{~mm}$ broad, separated from the older part of the body chamber by a constriction (pl. 3, fig. 1). The marginal area may indicate the presence of a marginal attachment band as known from living Nautilus (Stenzel, 1964, p. K69, fig. 52).

Most specimens are not mature. The length of the body chamber of juvenile specimens range between $230^{\circ}$ and $270^{\circ}$ in the largest (shell diameter $60-74 \mathrm{~mm}$ ) to between $250^{\circ}$ and $270^{\circ}$ in the smallest (shell diameter $18-60 \mathrm{~mm}$ ). In specimens of about the same size the body chamber may show a wide range of variation (see measurements). The umbilical ratio ranges from 41 to $46 \%$ in mature specimens.

In mature specimens there are 6-7 constrictions on each whorl, except for the youngest whorls, $450^{\circ}-620^{\circ}$, which have no constrictions. On internal moulds the constrictions are distinctly impressed, forming a very faint sinus ventrally and passing the sides and the umbilical slope rectilinearly, but in a retracted direction. When covered by the shell-layers, the constrictions are hardly visible. 


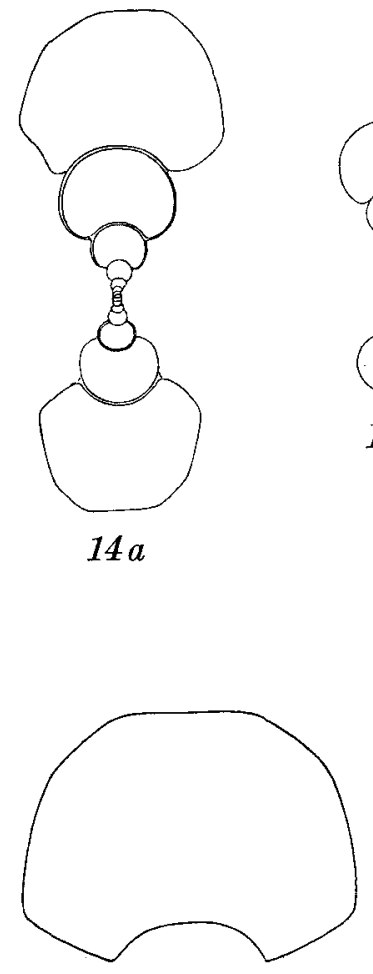

16

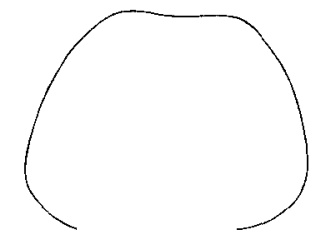

19

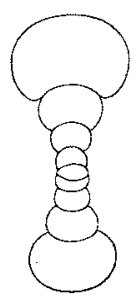

$14 b$

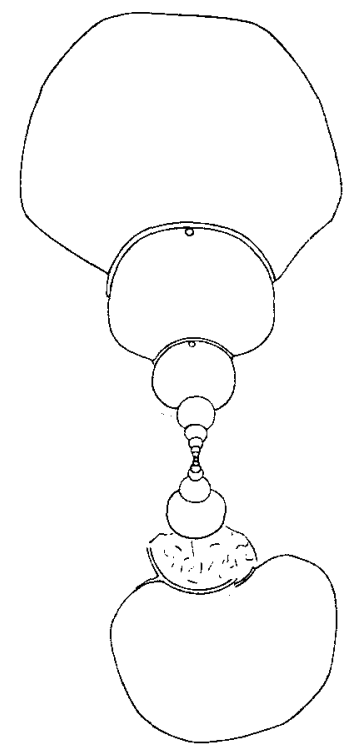

$15 a$

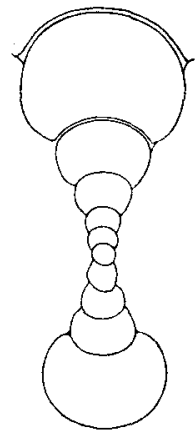

$15 b$

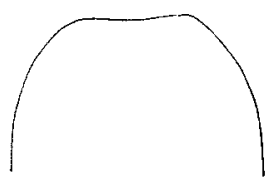

17

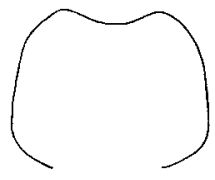

$20 a$

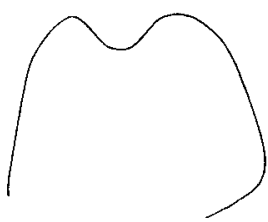

$20 b$

Figs. 14-20. Saghalinites wrighti $\mathbf{n} . s p$. Cross sections. All from Oyster-ammonite Conglomerate loc. I except 19 and 20 which are from loc. III.

14. MMH No. $9880 . a, \times 1 ; b, \times 4$.

15. MMH No. $9881 . a, \times 1 ; b, \times 4$.

16. MMH No. $9882 . \times 1$, body chamber.

17. MMH No. $9883 . \times 1$, body chamber.

18. MMH No. $9884 . \times 1$, body chamber.

19. Holotype. MMH No. $9747 . \times 1$, body chamber.

20. MMH No. 9741. $a, b, \times 1$, body chamber of abnormal specimen. 

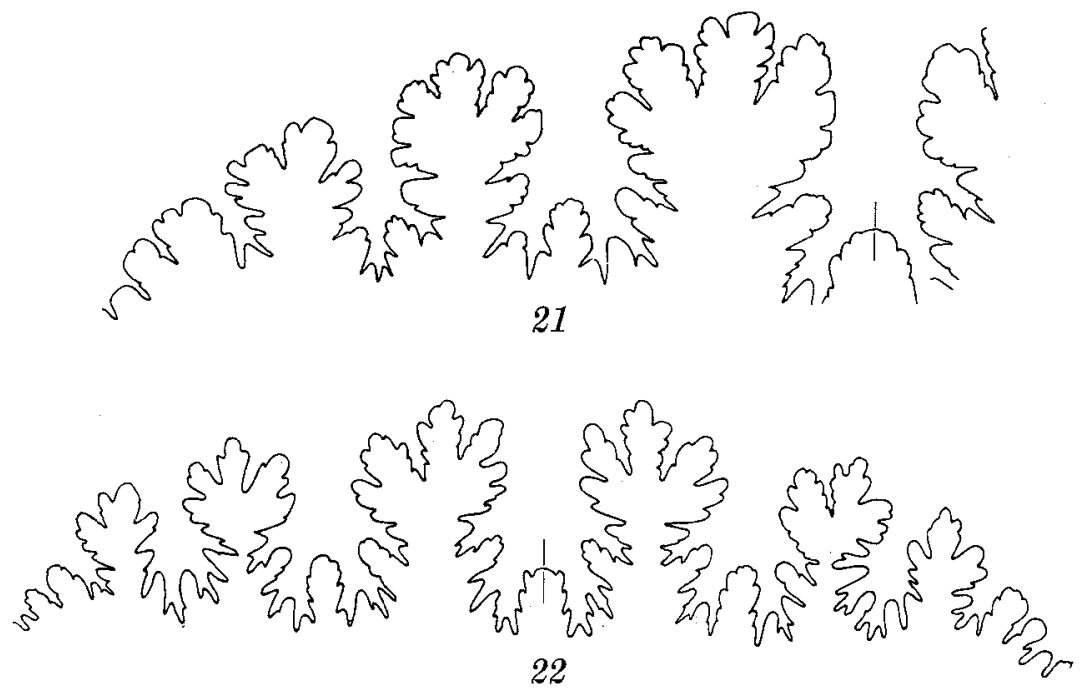

Figs. 21-22. Saghalinites wrighti n.sp. Oyster-ammonite Conglomerate loc. I.

21. MMH No. 9884. $\times 3$, the external suture at a whorl height of $16.5 \mathrm{~mm}$.

22. MMH No. 9885. $\times 3$, the external suture at a whorl height of $11.7 \mathrm{~mm}$.

The whorls are depressed and the whorl section rounded except for the youngest one or two whorls, which are octagonal with a flattened or concave venter and a flattened ventrolateral area, forming an obtuse angle with the venter and the sides. The umbilical slope also forms an obtuse angle with the sides. Specimens from the Oyster-ammonite Conglomerate loc. III often show a slightly more concave venter than specimens from the Oyster-ammonite Conglomerate loc. I. Thus, all specimens from loc. III are at least as concave as the specimen shown in text-fig. 19, whereas only a small part of the very large collection from loc. I have a similar concavity (text-fig. 17-18), the remainder have a more evenly rounded venter as in the specimen shown in text-fig. 16. In pl. 1, fig. 5 and text-fig. 20 an abnormal specimen from the Oysterammonite Conglomerate loc. III is shown in which the venter is extremely concave. The difference in cross section of some of the specimens from the two localities is too insignificant for distinguishing two subspecies. The difference may be due to a slight difference in geological age.

The surface is smooth except for very weak growth lines, visible in well preserved specimens. The growth lines form a sinus ventrally and are retracted laterally.

The external suture is rather simple with lobes and saddles of about the same width. The lobes decrease gradually in size from the external lobe to the first auxiliary lobe. The lateral lobe is bifid and the first auxiliary lobe trifid. The first lateral saddle is large with three 

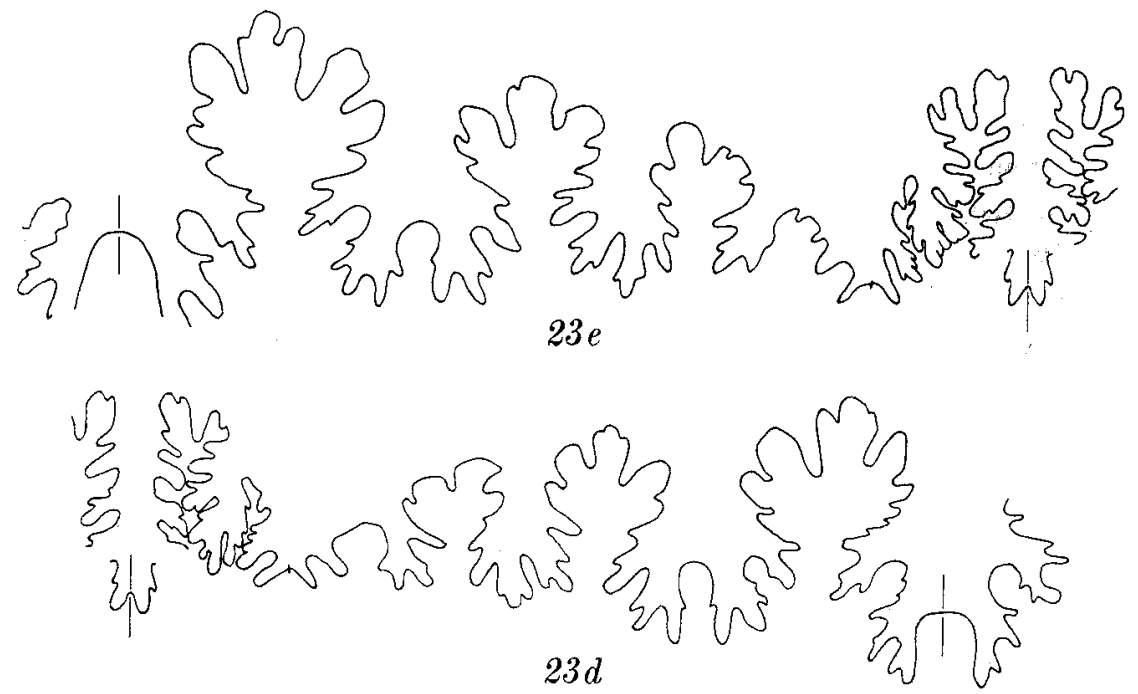

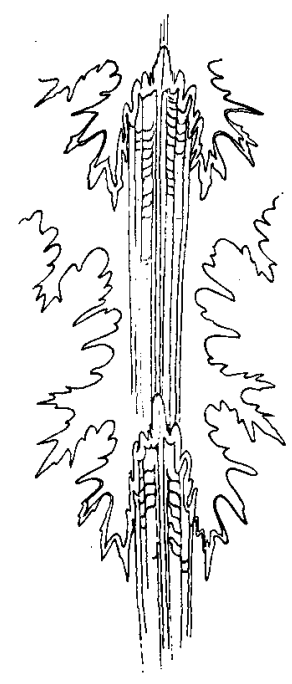

25

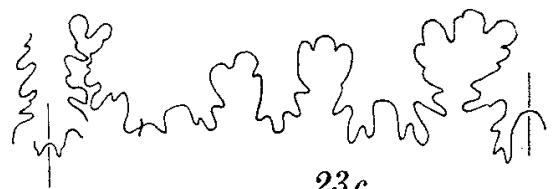

$23 c$
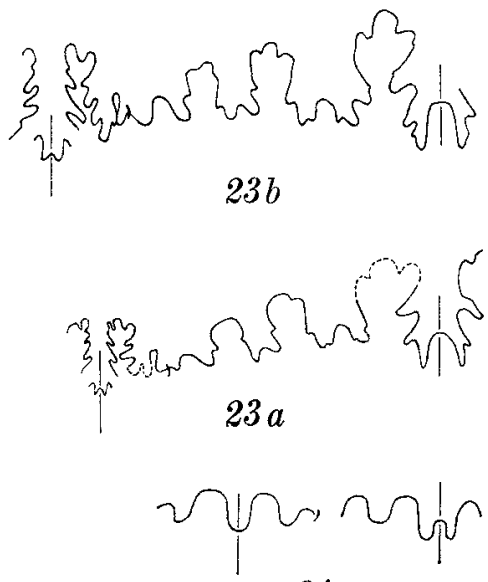

24

Figs. 23-25. Saghalinites wrighti n.sp.

23. MMH No. 9886. Ontogeny of sutures. $a, \times 8$, at a whorl height of $1.7 \mathrm{~mm}$; $b, \times 8$, at a whorl height of $2.1 \mathrm{~mm} ; c, \times 8$, at a whorl height of $3.3 \mathrm{~mm}$; $d, \times 8$, at a whorl height of $5.8 \mathrm{~mm} ; e, \times 8$, at a whorl height of $6.5 \mathrm{~mm}$. Oyster-ammonite Conglomerate loc. I.

24. MMH No. $9887 . \times 24$, suture at a whorl height of $0.3 \mathrm{~mm}$. Oyster-ammonite Conglomerate loc. I.

25. MMH No. 9888. $\times 4$, traces of so-called attachment ligaments between the siphuncle and the shell. Oyster-ammonite Conglomerate loc. III. 
branches of the same size. The second lateral saddle is a smaller reproduction of the first. The suspensive lobe is very retracted and has up to 6 auxiliary lobes and saddles rapidly decreasing in size. The internal suture has a deep dorsal lobe and a narrower lateral lobe which is about half as deep. Two saddles are developed, the second being small and already extremely narrow in early growth stages. The ontogeny of the sutures is shown in text-figs. 23-24.

Text-fig. 25 shows a very characteristic structure visible ventrally on well preserved internal moulds. Similar structures are described as traces of attachment ligaments between the siphuncle and the shell by Grandjean (1910, p. 502-503) and i.a. later by HöLder (1955) and VoGEL $(1959$, p. 510-511). In the present species the traces consist of longitudinal striae closely connected with the minor incisions of the ventral saddle and distinctly visible all the way between the ventral saddles. The longitudinal striae converge slightly adapically. Especially in the adoral part of the area between two succeeding ventral saddles, the longitudinal striae are connected by fine transverse, slightly backward curved, striae, called suture-"Schleppstreifen" by HöLDER (1955, p. 374).

Affinities. The present species is a very distinct new species. It is related to Saghalinites nuperus (van Hoepen, 1921, p. 13, fig. 8; pl.3, figs. 3-4) (compare also Collignon, 1956, p. 95, pl. 11, figs. 1, 1 a-b) in the character of the constrictions, which are retracted in the same way in both species, but the present species differs in its octagonal whorl section and in having no constrictions on the youngest whorls.

According to Professor T. Matsumoto (verb. comm.) the constrictions characterizing the present species ally it to an undescribed Saghalinites species from the Santonian of Japan, in which the constrictions are weak and infrequent throughout life. That species differs, however, like $S$. nuperus, in having a subrounded whorl section and in its more involute shape.

Saghalinites cala (Forbes, 1846, p. 104, pl. 8, figs. 4a-c) (compare also Kossmat, 1895, p. 136, 163, pl. 17, figs. 12a-d) is very similar in shape and whorl section to the species described here but differs in having sigmoidally curved constrictions, and in having constrictions on all the whorls. Also the poorly known S. cala var. zeugitana (Pervinquiere, 1907, p. 79, pl. 3, figs. 30a-b) (= S. zeugitanus Pervinquiere in Shimizu (1935, p. 181)) differs in the character of the constrictions.

Stratigraphy. Saghalinites wrighti n. sp. occurs in derived concretions in Danian conglomeratic beds. Scaphites (Discoscaphites) species have 
been collected together with $S$. wrighti n. sp. in the same concretions, indicating presumably a Maastrichtian age. The related $S$.nuperus occurs in Madagasear (Collignon, 1956, p. 95), in Pondoland (van Hoepen, 1921, p. 13; Sратн, 1922, p. 119) and in Japan (Tetragonites cfr. cala in Y $\mathbf{A B E}, 1915$, p. 16, pl. 1, fig. 7; pl. 3, fig. 2) in Santonian, Campanian, and possibly Maastrichtian deposits.

\section{Genus PSEUDOPHYLLITES Kossmat, 1895}

Type Species. Ammonites indra Forbes, 1846.

Emended diagnosis. Tetragonitidae with a moderately evolute shell in the early growth stages, more involute in late growth stages; whorl height increasing rapidly; early whorls depressed and squarish, often with the maximum width near the middle of the sides; cross section of body chamber rounded and compressed, or whorl height and width equal; surface often finely striated; constrictions absent; sutures finely divided with asymmetrically trifid or asymmetrically bifid major saddles with slightly phylloid terminations; suspensive lobe retracted.

\section{Pseudophyllites skoui n. sp.}

Pl. 3, figs. 2-6; text-figs. 26-33.

Name. The species is named after Preparator Kristian Skov.

Holotype. MMH No. 9751. Figured pl. 3, figs. 4a-b; text-fig. 29. From Scaphitesnæsen, Nûgssuaq. Upper part of the Lower Campanian.

Diagnosis. Pseudophyllites of rather small size; umbilical ratio about $25 \%$ in late growth stages; whorl section of phragmocone slightly depressed and squarish with the greatest width near the middle of the sides; obscure growth lines visible on the surface; sutures rather simple with only slightly discernible phylloid terminations; internal suture with two saddles, the second being smaller than the first.

Material. Nûgssuaq: 24 specimens from Brudkløft at Ikorfat, 550$625 \mathrm{~m}$ above sea-level; one specimen collected at Breccienæsen, lkorfat, $700 \mathrm{~m}$ above sea-level; 19 specimens from Scaphitesnæsen, $536-540 \mathrm{~m}$ above sea-level. Most specimens have only the phragmocone or parts of the phragmocone preserved. 
Measurements.

Phragmocone figured text-fig. 26. Ikorfat.

$\begin{array}{cccccc}\begin{array}{c}\text { Shell } \\ \text { diameter }\end{array} & \begin{array}{c}\text { Whorl } \\ \text { height }\end{array} & \begin{array}{c}\text { Whorl } \\ \text { width }\end{array} & \text { W/H } & \begin{array}{c}\text { Umbilical } \\ \text { diameter }\end{array} & \begin{array}{c}\text { Umbilical } \\ \text { ratio }\end{array} \\ 0.7 \mathrm{~mm} & 0.5 \mathrm{~mm} & 0.8 \mathrm{~mm} & 1.60 & & \\ 1.1- & 0.5- & 0.7- & 1.40 & & \\ 1.5- & 0.6- & 0.8- & 1.33 & & \\ 2.2- & 0.8- & 1.0- & 1.25 & & \\ 2.9- & 1.0- & 1.4- & 1.40 & 1.1 \mathrm{~mm} & 38 \% \\ 4.0- & 1.4- & 1.9- & 1.36 & 1.5- & 38 \% \\ 5.4- & 2.0- & 2.5- & 1.25 & 1.8- & 33 \% \\ 7.7- & 3.3- & 4.0- & 1.21 & 2.5- & 32 \% \\ 11.3- & 4.9- & 5.8- & 1.18 & 3.0- & 27 \% \\ 17.0- & 7.7- & 8.6- & 1.12 & 4.3- & 25 \% \\ 25.0- & 11.3- & 12.9- & 1.14 & 6.2- & 25 \%\end{array}$

$180^{\circ}$ between the measurements, beginning within the innermost whorl.

Phragmocone figured text-fig. 27. Ikorfat.

$\begin{array}{cccccc}\begin{array}{c}\text { Shell } \\ \text { diameter }\end{array} & \begin{array}{c}\text { Whorl } \\ \text { height }\end{array} & \begin{array}{l}\text { Whorl } \\ \text { width }\end{array} & \text { W/H } & \begin{array}{c}\text { Umbilical } \\ \text { diameter }\end{array} & \begin{array}{c}\text { Umbilical } \\ \text { ratio }\end{array} \\ 4.7 \mathrm{~mm} & 1.9 \mathrm{~mm} & 2.4 \mathrm{~mm} & 1.26 & 1.8 \mathrm{~mm} & 38 \% \\ 6.8- & 2.7- & 3.4- & 1.26 & 2.2- & 32 \% \\ 9.9- & 4.4- & 5.3- & 1.20 & 2.8- & 28 \% \\ 14.6- & 6.7- & 7.4- & 1.10 & 3.7- & 25 \% \\ 22.3- & 10.3- & 11.5- & 1.12 & 5.5- & 25 \%\end{array}$

$180^{\circ}$ between the measurements, beginning within the third whorl.

Phragmocone figured text-fig. 28. Scaphitesnæsen.

$\begin{array}{clllll}\begin{array}{c}\text { Shell } \\ \text { diameter }\end{array} & \begin{array}{l}\text { Whorl } \\ \text { height }\end{array} & \begin{array}{l}\text { Whorl } \\ \text { width }\end{array} & \text { W/H } & \begin{array}{c}\text { Umbilical } \\ \text { diameter }\end{array} & \begin{array}{c}\text { Umbilical } \\ \text { ratio }\end{array} \\ 1.4 \mathrm{~mm} & 0.7 \mathrm{~mm} & 0.9 \mathrm{~mm} & 1.29 & & \\ 2.0- & 0.9- & 1.1- & 1.22 & & \\ 3.0- & 1.2- & 1.5- & 1.25 & 1.1 \mathrm{~mm} & 37 \% \\ 4.2- & 1.7- & ? & ? & 1.4- & 33 \% \\ 5.8- & 2.3- & 3.0- & 1.30 & 1.9- & 33 \% \\ 8.3- & 3.6- & 4.2- & 1.17 & 2.6- & 31 \% \\ 12.2- & 5.3- & 6.1- & 1.15 & 3.3- & 27 \% \\ 18.2- & 8.1- & 8.9- & 1.10 & 4.6- & 25 \%\end{array}$

$180^{\circ}$ between the measurements, beginning within the second whorl.

Measurements of holotype:

Shell diameter: $40.8 \mathrm{~mm}$

Umbilical diameter: $10.4 \mathrm{~mm}$

Umbilical ratio: $25 \%$

Whorl height at last suture: $10.1 \mathrm{~mm}$

Whorl width at last suture: $11.3 \mathrm{~mm}$

$\mathrm{W} / \mathrm{H}: 1.12$ 


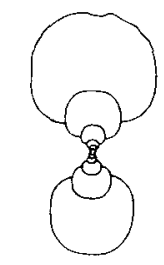

$26 a$

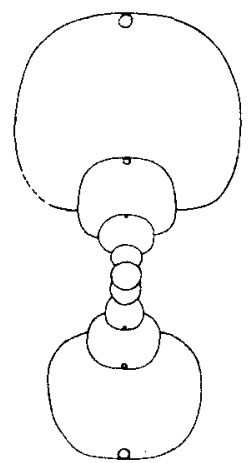

$26 b$

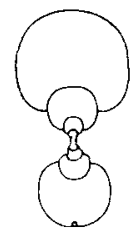

27

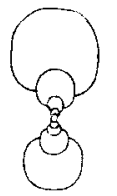

28

7

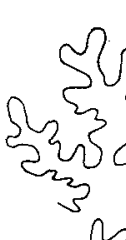
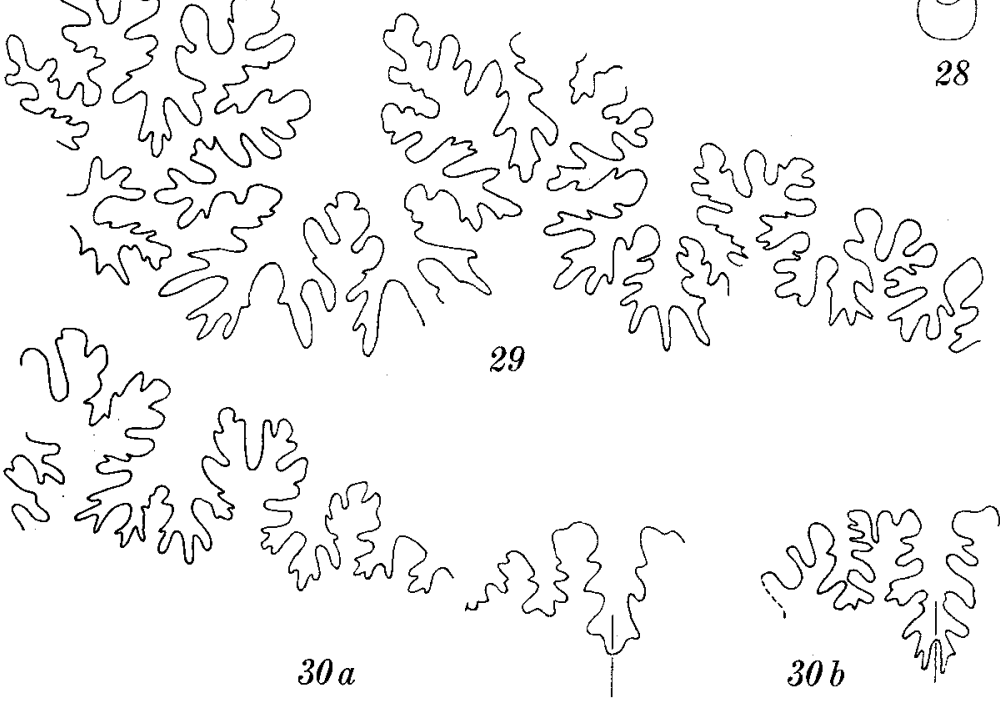

Figs. 26-30. Pseudophyllites skoui n.sp.

26. MMH No. 9889. $a, \times 1 ; b, \times 4$. Cross section of phragmocone. Brudkløft at Ikorfat, $550 \mathrm{~m}$ above sea-level.

27. MMH No. 9890. $\times 1$, cross section of phragmocone. Brudkløft at Ikorfat, $625 \mathrm{~m}$ above sea-level.

28. MMH No. 9891. $\times 1$, cross section of phragmocone. Scaphitesnæsen, $536 \mathrm{~m}$ above sea-level.

29. Holotype. MMH No. 9751. $\times 8$, part of the external suture at a whorl height of $10.1 \mathrm{~mm}$. Scaphitesnæsen.

30. MMH No. 9892. $\times 8$. $a$, suture at a whorl height of $4.4 \mathrm{~mm} ; b$, internal suture at a whorl height of $5.1 \mathrm{~mm}$. Scaphitesnæsen, $538-540 \mathrm{~m}$ above sea-level.

Description. The shell diameter of the largest specimen is about $60 \mathrm{~mm}$. This specimen is the only one which can be shown to be mature. Eleven specimens, the phragmocones of which range in diameter from $10.2 \mathrm{~mm}$ to $30.7 \mathrm{~mm}$ are juvenile. The remainder are so fragmentary 
that it is impossible to find out if they are mature or not. The umbilical ratio decreases from early to late growth stages, ranging from about $38 \%$ at shell diameters of about $3-4 \mathrm{~mm}$ to about $25 \%$ at later growth stages.

The whorls of the phragmocone increase rapidly in size. The section of the innermost $1 \frac{1}{2}$ whorls is rounded. The ventral side of the younger part of the second whorl becomes gradually flatter and the younger whorls are flattened both ventrally and laterally resulting in a subrectangular section. The whorls of the phragmocone are always depressed, the width being considerably greater than the height in early growth stages and slightly greater in later growth stages. In the earliest 3-4 whorls the maximum width is at or just exterior to the umbilical shoulder. In younger whorls the greatest width is near the middle of the sides. The umbilical slope forms an obtuse angle with the sides.

Three of the figured specimens (pl. 3, figs. 4-6) show the body chamber. The length of the body chambers of these specimens is about $260^{\circ}$. The relative length of the body chamber seems to decrease slightly as the individual matures, one smaller specimen (shell diameter about $30 \mathrm{~mm}$ ) showing a body chamber of $270^{\circ}$. All the preserved body chambers are crushed, the exact character of the cross section is thus unknown. It seems, however, to be more rounded than that of the phragmocone.

The surface appears smooth in most specimens. A few well preserved specimens show fine growth lines passing straight up the umbilical wall. At the umbilical shoulder they bend forward and pass across the sides and venter where they are slightly curved forward. Additionally the sides may be finely strigated (pl. 3 , figs. $3 \mathrm{a}-\mathrm{b}$ ).

The external suture is less incised than in most other Pseudophyllites species. The lobes and saddles are of nearly equal width. The lobes decrease evenly in size from the venter to the umbilicus. The lateral lobe is bifid and the first auxiliary lobe is asymmetrically trifid. The first lateral saddle is large and asymmetrically divided into two main branches, the outer branch being most developed. The second lateral saddle is slightly smaller than the first and also bifid, but with the inner branch most developed. The suspensive lobe is retracted and has up to six auxiliary lobes and saddles. The internal suture has a deep dorsal lobe and a lateral lobe about $2 / 3$ as deep as the dorsal lobe. Two internal saddles are developed, the second being half as large as the first.

No difference between the specimens from Scaphitesnæsen and the specimens from Ikorfat can be shown, either in shape or in complexity of the suture lines.

Affinites. The species seems rather closely related to Pseudophyllites peregrinus Spaтн, 1953 (p. 7, pl. 1, figs. 6-9). Thus, it is very similar to 

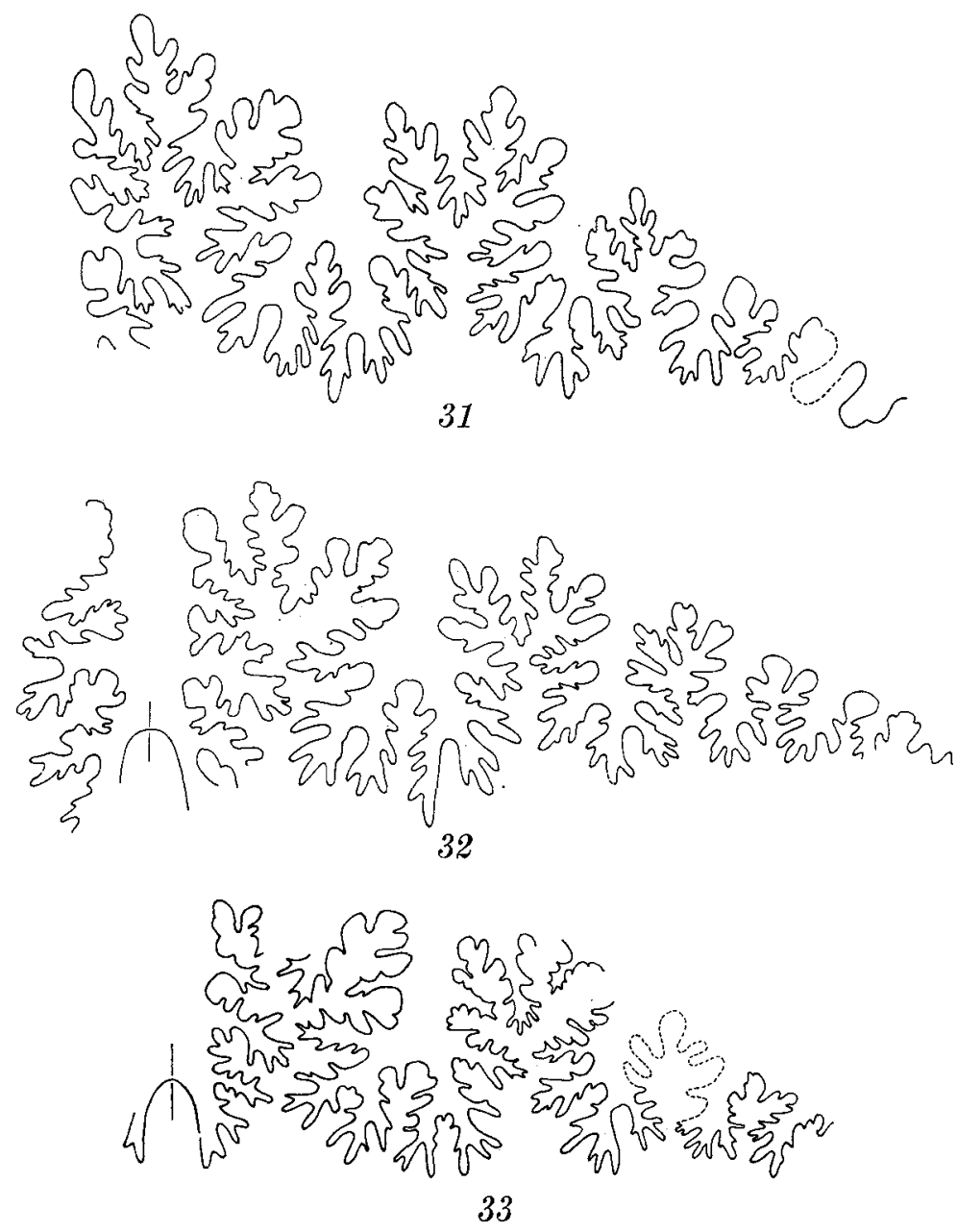

Figs. 31-33. Pseudophyllites skour n.sp. External sutures.

31. MMH No. $9750 . \times 8$, at a whorl height of $8.8 \mathrm{~mm}$. Scaphitesnæsen.

32. MMH No. 9749. $\times 6$, at a whorl height of $10.7 \mathrm{~mm}$. Brudkløft at Ikorfat.

33. MMH No. 9893 . $\times 4$, at a whorl height of $14.0 \mathrm{~mm}$. Brudkløft at Ikorfat, $560 \mathrm{~m}$ above sea-level.

that species in whorl section and in umbilical ratio, but differs in its smaller size, in its less incised sutures, and in having no distinct striae developed.

Marshall (1926, p. 152, pl. 20, fig. 1; pl. 29, figs. 3-5) described a Pseudophyllites, which he referred to $P$. indra (FonBes), but which later Spath (1953, p. 7, with a query) and Collignon (1956, p. 92) referred to $P$. peregrinus Spath. Plaster casts of Marshall's types and a phragmocone, showing the inner whorls, kindly presented to the Mineralogical 
Museum in Copenhagen by Dr. C. A. Freming, New Zealand Geological Survey, confirms the close relations between $P$. peregrinus and the present species.

Tetragonites? garuda (Forbes, 1846) has been referred to Pseudophyllites by Kossmat (1895, p. 138) and by Spath (1953, p. 7) and to "Epigoniceras" (= Tetragonites) by Collignon (1956, p. 88). It seems to be intermediate between the two genera. It is more closely related to Tetragonites in suture pattern and in umbilical ratio than the present species (see Stroliczka, 1865, p. 149, pl. 74, figs. 5a-b).

Pseudophyllites? subepigonus (Вӧнм, 1909, p. 52, pl. 1, figs. 5a-b; $10 \mathrm{a}-\mathrm{c}$ ) is poorly known (only the inner whorls are known). The whorl section of this species seems to differ from the present species in having the maximum width closer to the umbilical shoulder.

Stratigraphy. Pseudophyllites skoui n. sp. occurs in the upper part of the Lower Campanian, together with Baculites obtusus MEEK s. 1., in Scaphitesnæsen, and in the upper part of the Upper Campanian, together with Hoploscaphites ikorfatensis n. sp., at Ikorfat. P. peregrinus SPATH, the most closely related species, has been recorded from the Antarctic by Spath (1953, p. 53), from Madagascar by Colligron (1956, p. 94) and from New Zealand ( $P$. indra in Marshall, 1926, p. 152) in Campanian and possibly in Santonian and Maastrichtian deposits.

\section{Pseudophyllites sp. \\ Pl. 3, fig. 7; text-fig. 34.}

Material. Nûgssuaq: one displaced incomplete specimen with a well preserved phragmocone from Niaqornat and one barely determinable specimen from Vestre Konglomeratkløft, $165 \mathrm{~m}$ above sea-level. A small juvenile specimen from Vestre Konglomeratkløft, $200 \mathrm{~m}$ above sea-level, possibly also belongs to this species.

Measurements. Specimen figured pl. 3, fig. 7; text-fig. 34. At a phragmocone diameter of $28.6 \mathrm{~mm}$ :

Whorl height: $14.2 \mathrm{~mm}$; whorl width: $15.0 \mathrm{~mm}$; W/H: 1.06 ; umbilical ratio $23 \%$.

Description. The preservation of the specimens is extremely poor and no satisfactory description can be given.

The figured specimen shows the inner part of a phragmocone. A fragmentary younger part of this phragmocone is also preserved, showing that the diameter of the phragmocone exceeded $55 \mathrm{~mm}$. The whorl section of the exposed part of the phragmocone of the figured specimen is rounded and slightly depressed, the whorl width being slightly greater than the height (text-fig. $34 \mathrm{~b}$ ). The umbilical ratio is about $23 \%$. On a 


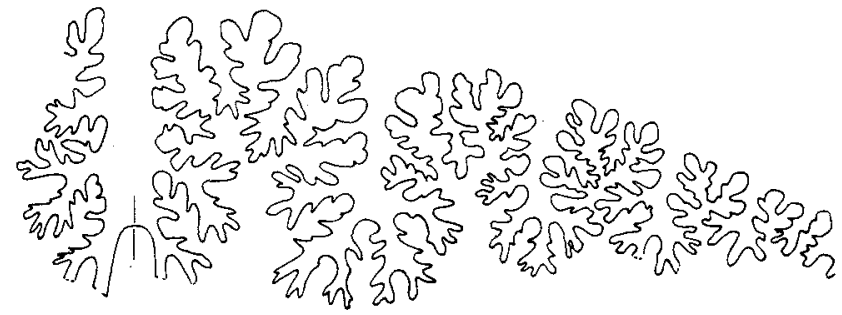

$34 a$

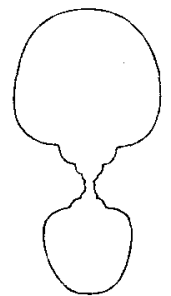

$34 b$

Fig. 34. Pseudophyllites sp. MMH No. 9754. $a, \times 6$, the external suture at a whorl height of $8.1 \mathrm{~mm} ; b, \times 1$, cross section. Niaqornat.

small part of the surface the shell is preserved, showing extremely fine striae. The suture is very incised with lobes decreasing evenly in size from the venter to the umbilicus. The lateral lobe and the first auxiliary lobe are very constricted, the lateral lobe being bifid, and the first auxiliary lobe asymmetrically trifid. The first lateral saddle is large and asymmetrically divided into two main branches. The outer branch is much larger than the inner and is additionally so deeply divided into two branches, that the saddle acquires an asymmetrically trifid outline. The second lateral saddle is smaller than the first and asymmetrically bifid with the inner branch most developed. The suspensive lobe is retracted and has five auxiliary lobes and saddles. The internal suture is not known.

The other specimen referred to this species is even more fragmentary than that described above, it shows a similar shape and suture.

Affinities. The phragmocone from Niaqornat differs from that of Pseudophyllites skoui n. sp. in its greater size, its slightly more rounded whorl section, in having more incised sutures, and in its finely striated surface.

The phragmocone seems rather closely related to $P$. indra (ForBes) both in cross section, sutures, and sculpture. The material is, however, too poorly preserved for any final determination.

Stratigraphy. The species occurs in Vestre Konglomeratkløft above layers from the uppermost Campanian containing Scaphites (Hoploscaphites) greenlandicus Donovan. A Maastrichtian age may be suggested. The specimen from Niaqornat may be derived from badly exposed overlying Maastrichtian deposits. 


\section{Family B ACU L I T I D A E Meek, 1876}

\section{Genus $B A C U L I T E S$ Lamarck, 1799}

Type Species. Baculites vertebralis Lamarck, 1801*.

Emended diagnosis. Baculitidae with initial coil of one or two whorls followed by a straight shaft; cross section subcircular, elliptical, ovate or acute, the venter often more narrowly rounded than the dorsum; aperture with a short dorsal projection and a longer ventral projection; shell smooth (except for growth lines) or with curved ribs, rursiradiate dorsolaterally, prorsiradiate ventrolaterally; the lateral sinus of the ribs often thickened into curved bullae or blunt nodes; suture with symmetric saddles, auxiliary elements absent.

Measurements. Whorl height, whorl width and the degree of tapering are measured. Additionally, the number of ribs for a given whorl height is indicated. By indicating whorl width in relation to the same whorl height in several species I show the range of variation of whorl width to whorl height directly. The range of variation in individual specimens is shown by drawings of cross sections. The degree of tapering at a given whorl height is always measured immediately adapically to the whorl height in question. The number of ribs for a particular whorl height has also been counted adapically from the whorl height in question.

Morphology. There is wide morphological variation in the baculites, and a great number of specimens are necessary for satisfactory description. Measurements show that the degree of tapering of the shell changes between juvenile and mature stages, and that there is some variation at equivalent stages. Also, it appears that there are some ontogenetic changes in whorl section, and that the whorl ratio may vary considerably in specimens of similar size.

Growth lines are visible on baculites with well preserved shell (pl. 5, fig. 4; pl.11, fig. 1). The growth lines show no ontogenetic change in Baculites obtusus MrEK s. l., the only species from Greenland with well preserved juvenile growth lines.

Commonly, the peristome is simple, but some species from Greenland have a flared peristome as shown in pl. 13 , figs. 2 a-c. It is remarkable that several specimens have flared peristomes in the juvenile stages (pl. 9, figs. $3 \mathrm{a}-\mathrm{c}$ ).

In all species from Greenland, the ribs on the surface of the shell seem to conform with the growth lines. The development of the ribs and

* Wright $(1957$, p. L218) inadvertently indicated Baculites vertebralis DEFRANGE, 1830, as the type species. 
all the characters connected with these, is of great systematic value, though the variation in these characters may again be rather wide.

The sutures are of limited value for specific determination, but the degree of incision, and the general form of lobes and saddles make it possible often to refer a specimen to a particular group of related Baculites species.

Evolution. The earliest baculites, from the Turonian, are small with rather simple sutures. They gave rise to a great complexity of species, the inter-relations of which are not yet explained except for a few lineages.

The baculites from California show certain evolutionary trends. According to Matsumoto (1959b, p. 112), all the Californian Lower Senonian baculites have simple sutures very similar to those of Sciponoceras bohemicum (Fritsch) which they resemble also in size and cross section. They have a Pacific or Indo-Pacific distribution, and some of them are rather closely related to species from the Western Interior of the United States. In the Campanian and Maastrichtian a general evolutionary series from relatively simple to complex sutures can be recognized. This is exemplified by Baculites chicoensis Trask from the Lower (to Middle?) Campanian, B. occidentalis Merk from the Upper Campanian and B. rex ANDERSON from the Maastrichtian (and possibly uppermost Campanian). It should be noted, however, that additional species with a different suture pattern occur together with these. According to Mатsumoто, baculites with simple or simplified(?) sutures (e.g., B. columna Monton) occur again in beds of late Cretaceous age in California.

Basing their studies mainly on baculites from Japan, Matsumoto \& Овата (1963b, p. 101-103) gave a more detailed outline of the evolution of the baculitid species in the Indo-Pacific region and related areas. The Upper Turonian Sciponoceras intermedium Matsumoto \& Овата is an immediate ancestor of the Coniacian Baculites yokoyamai ТокUNAGA \& Shimizu. From B. yokoyamai at least three evolutionary lines are recognized. The first is from B. yokoyamai, through B. bailey Woons and $B$. inornatus MeEK, to B. vertebralis LamarcK, in which slow tapering, a subelliptical cross section and a nearly smooth surface are retained. It seems to have led to various offshoots (Baculites kirki MATsumoto, B. chicoensis Trask, B. anceps Lamarck, B. occidentalis Meek, B.regina Овата \& Matsumoto and possibly B.teres Forbes and B.columna Morton). The second line is from $B$. yokoyamai, through $B$. uedae MAtsuмото \& Овата and probably B. hochstetteri Liebus, to B. rex Anderson, in which there is more rapid tapering and complication of sutures. The third line is from B. yokoyamai, through B. boulei Collignon, B. capensis 
Woods and B.tanakae Matsumoto \& Овата, to B. lomaensis Anderson, in which tubercles are acquired and strengthened. Most of the species from Japan are Indo-Pacific, some are endemic and a few are cosmopolitan. Species common to California and Japan constitute the highest percentage of the whole fauna and it is evident that there was an intimate connection between the faunas of California and Japan during the Upper Cretaceous.

It is rare for species to be common to the Pacific and the Gulf and Atlantic regions. Only two species, Baculites columna Morton and $B$. lomaensis ANDersox, occur in both regions.

Evolutionary series in the baculites from the Western Interior of the United States have been particularly considered by Dr. W. A. СовваN in a number of recent publications (CoBban, 1951c; 1952a; 1958; $1962 \mathrm{a} ; 1962 \mathrm{~b})$ and in personal communications.

The sutures of Coniacian-Santonian baculites from this region are fairly simple, like those of B. codyensis REESIDE (1927a, pl. 2) as are also those from the Lower Campanian. During the Upper Campanian the sutures become more and more complex. Comparison of the sutures of B. perplexus Cobban (1962 b, text-fig. 1c), B. gregoryensis Cobban (1951 c, text-fig. 12), and B. rugosus СовваN (1962a, text-fig. 1 c), shows this increasing complexity. However, the youngest Upper Campanian baculites gradually develop somewhat less complicated sutures than those of $B$. rugosus, although they are still of the same type. The sutures of some of the species of this series have been illustrated by CовBAN (1962a, text-fig. 1). There is also a slow decrease in size from B. rugosus to the last representative of this series, B. eliasi Cobban, from the uppermost Campanian. B. baculus MeEk, a species with rather simple sutures, migrated into the area from the south in the uppermost Campanian. During the Maastrichtian larger baculites with more complex sutures developed from $B$. baculus, notably B. grandis Hall \& Meek, and $B$. clinolobatus Elias. After the extinction of $B$. clinolobatus, only small baculites with rather simple sutures, are known from the younger Maastrichtian.

Species with different suture patterns are also known from the same horizons of the Western Interior region. B. asper Monton and B. codyensis REESIDE, both species with simple sutures, are accompanied by baculites with extremely complex sutures with strongly asymmetric bifid saddles. Cobban (1952a) referred these to the new genus Pseudobaculites. Similarly, B. eliasi СовваN, with its complex sutures, occurs with B. baculus Meек, a species with rather simple sutures. Most of the baculites of the Western Interior region are endemic, but certain connections can be shown with the Gulf area, and, during Lower Senonian times, with more distant regions. 
The baculites of other regions, e.g., the Mexican Gulf area, the coastal plains of the Eastern United States, Europe, and areas in the southern hemisphere, are either very scarce, or the sequences are very incomplete, or no recent studies have been made. In all cases our knowledge is too poor to be certain of any evolutionary series.

According to Marsumoto (1959b) evolutionary changes in the sutures of baculites from California and from the Western Interior of the United States are similar but not identical. He suggested that the forms evolved in parallel in the two provinces. Also Matsuмото \& OBata (1963b) explain the presence of Indo-Pacific species resembling species from North American Interior-Gulf Coast provinces by parallel evolution.

In the Upper Campanian of the Western Interior of the United States some mature baculites have a flared peristome, as shown in the figures of $B$. asperiformis ME E , in CoBBan (1962 b, pl. 106, figs. 14-16). B. rex Anderson from the Lower Maastrichtian (Upper Campanian?) of California, and specimens related to the European $B$. anceps LAmarck from the Upper Campanian of the same area, also show this feature (Matsumoto, 1959 b, p. 140, pl. 40, figs. $1 \mathrm{a}-\mathrm{c}$ ). Thus it seems that this character developed in just the same way about the same time in different faunal provinces.

To some extent there are also parallel changes in size of the baculites in different faunal provinces, the largest occurring during Upper Campanian-Lower Maastrichtian times.

The baculites from West Greenland are closely related or identical with species from the Western Interior of the United States, except for the scarce material from the late Upper Campanian which seems to be related to European species. Species from the Santonian (B. nugssuaqensis n. sp., B. codyensis REESIDE s. 1.) are rather small and have simple sutures. The baculites of late Lower Campanian age ( $B$. obtusus MEEK s. l., $B$. cf. haresi REESIDE) are slightly bigger and have rather more complex sutures, and some specimens have a flared peristome. The rapid evolution of large baculites during the Upper Campanian and lowermost Maastrichtian in the Western Interior of the United States cannot be traced in West Greenland where either deposits of that age are lacking or only European baculites occur. The few specimens from the Maastrichtian of West Greenland ( $B$. cf. meeki ELIAS) are rather small with simple sutures.

Because of the wide range of variation within the baculites, and largely because of the absence of distinctive diagnostic characters, the species are interpreted here in a very broad sense. 
Baculites nugssuaqensis $\mathrm{n}$. sp.

Pl. 4, fig. 1; pl. 5, figs. 1-4; pl. 6, figs. 1-2; text-figs. 35-41.

Holotype. MMH No. 9755. Figured pl. 4, figs. 1 a-c, text-figs. 35 a-e. From Tuperssuartâ, $47 \mathrm{~m}$ west of dolerite sill A, $10 \mathrm{~m}$ above sea-level. Lower Santonian.

Diagnosis. Baculites of medium size; tapering slightly; whorl section elliptical to ovate; surface smooth or with faint ribs; 3 to 7 lateral ribs and 3 to 8 ventral ribs per whorl height when visible; sutures simple with a narrow lateral lobe and broad, squarish to slightly trapezoidal lateral saddles.

Material. Nûgssuaq: about 200 specimens are available, many only fragmentary, from a coast section at Tuperssuartâ, collected 7 to $87 \mathrm{~m}$ west of dolerite sill A, 2 to $12 \mathrm{~m}$ above sea-level. The beds dip slightly to the west so that the specimens from the western part of the section are stratigraphically younger. Additionally, one displaced specimen from Danienkløft, Tunorssuaq, probably belongs to this species.

Measurements.

\begin{tabular}{|c|c|c|c|c|c|c|c|c|}
\hline $\begin{array}{l}\text { Number } \\
\text { of } \\
\text { specimens }\end{array}$ & $\begin{array}{l}\text { Who } \\
\text { heig }\end{array}$ & & $\begin{array}{l}\text { Whorl } \\
\text { width }\end{array}$ & & $\mathrm{W} / \mathrm{H}$ & Tapering & $\begin{array}{c}\text { Number } \\
\text { of ventral } \\
\text { ribs per } \\
\text { whorl } \\
\text { height }\end{array}$ & $\begin{array}{c}\text { Number } \\
\text { of lateral } \\
\text { ribs per } \\
\text { whorl } \\
\text { height }\end{array}$ \\
\hline 1 & $32.0 \mathrm{n}$ & $\mathrm{nm}$ & 22.0 & $\mathrm{~nm}$ & 0.69 & $1^{\circ}$ & & 7 \\
\hline 1 & 30.0 & - & 20.0 & - & 0.67 & $2^{\circ}$ & & \\
\hline 4 & 26.0 & - & $18.0-19.0$ & - & $0.69-0.73$ & $4^{\circ}-5^{\circ}$ & & \\
\hline 4 & 24.0 & - & $15.5-17.1$ & - & $0.65-0.71$ & $5^{\circ}$ & c. 5 & c. 5 \\
\hline 3 & 22.0 & - & $13.9-15.4$ & - & $0.63-0.70$ & $4^{\circ}-5^{\circ}$ & $4-6$ & $3-4$ \\
\hline 7 & 20.0 & - & $13.0-14.0$ & - & $0.65-0.70$ & $2^{\circ}-4^{\circ}$ & c. 7 & $3-4$ \\
\hline 6 & 18.0 & - & $11.6-12.5$ & - & $0.64-0.69$ & $2^{\circ}-3^{\circ}$ & $3-4$ & 7 \\
\hline 8 & 16.0 & - & $10.0-11.0$ & - & $0.63-0.69$ & $2^{\circ}-4^{\circ}$ & $5-6$ & \\
\hline 9 & 14.0 & - & $9.0-10.0$ & - & $0.64-0.71$ & $2^{\circ}-5^{\circ}$ & $6-8$ & \\
\hline 5 & 12.0 & - & $7.6-8.6$ & - & $0.63-0.72$ & $4^{\circ}-5^{\circ}$ & $6-7$ & \\
\hline 2 & 10.0 & - & $6.2-7.5$ & - & $0.62-0.75$ & $4^{\circ}-5^{\circ}$ & c. 6 & \\
\hline 1 & 8.0 & - & 5.8 & - & 0.73 & $4^{\circ}$ & 5 & \\
\hline 3 & 6.0 & - & $4.3-5.0$ & - & $0.72-0.83$ & $5^{\circ}-6^{\circ}$ & 5 & \\
\hline
\end{tabular}

All from Tuperssuartâ.

Description. The largest specimen has a whorl height of $32 \mathrm{~mm}$ at the younger part of the body chamber, but most specimens are much smaller. The largest septate whorl height is $28 \mathrm{~mm}$. Tapering is slight, greatest $\left(5^{\circ}\right.$ to $\left.6^{\circ}\right)$ at whorl heights of about $6 \mathrm{~mm}$ and somewhat less $\left(2^{\circ}\right.$ to $\left.5^{\circ}\right)$ at greater whorl heights. Where whorl heights reach $30 \mathrm{~mm}$ to $32 \mathrm{~mm}$ the tapering decreases to $1^{\circ}$ to $2^{\circ}$. From the smallest whorl height ob- 


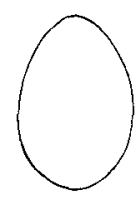

$35 a$

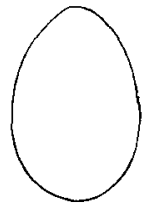

$35 b$

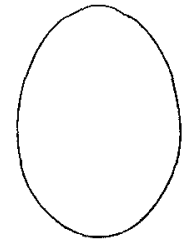

$35 c$

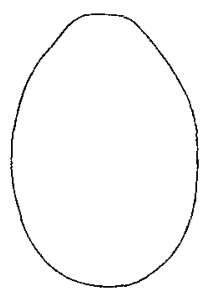

$35 d$

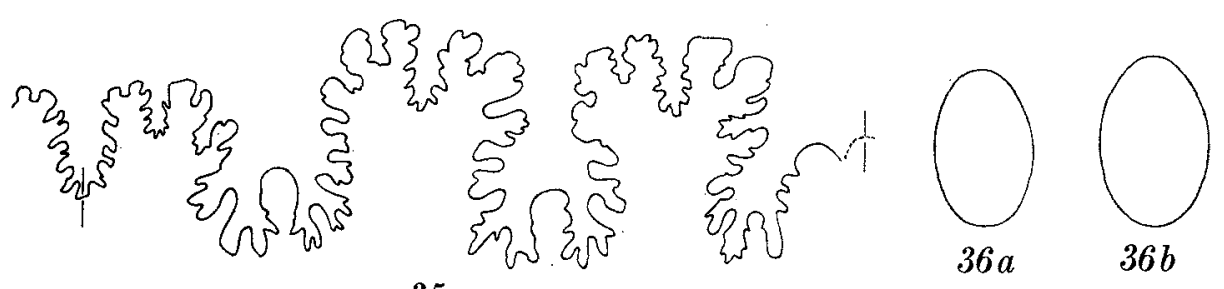

$35 e$

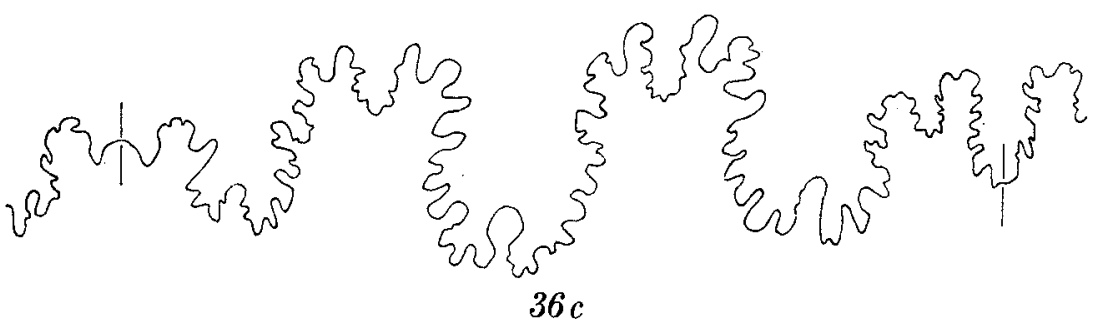

Figs. 35-36. Baculites nugssuaqensis n.sp. Tuperssuartâ, $47 \mathrm{~m}$ west of dolerite sill A.

35. Holotype. MMH No. 9755. $a-d, \times 1$, cross sections; $e, \times 3$, suture at a whorl height of $20.7 \mathrm{~mm}$.

36. MMH No. 9761. $a, b, \times 1$, cross sections; $c, \times 4$, suture at a whorl height of $17.0 \mathrm{~mm}$.

served $(6 \mathrm{~mm})$ to about $15 \mathrm{~mm}$ the whorl section is subelliptical, the venter being only slightly more narrowly rounded than the dorsum. At greater whorl heights the venter is a little narrower and very weak and shallow longitudinal depressions may be developed on both sides of the siphonal area. The dorsum is always evenly rounded and the maximum width is slightly closer to the dorsum than to the venter.

The growth lines (pl. 5, figs. 4a-b) form a rather deep rounded sinus dorsolaterally, a low rounded projection dorsally and a more marked rounded ventral projection. Weak ventral ribs can be seen on most of the specimens, 4 to 8 per whorl height. The sides are smooth or have only weak ribs or undulations. These may be visible as early as the ventral ribs, but are usually more prominent at greater whorl heights. At the maximum whorl height the lateral ribs are as pronounced as the ventral. The number of lateral ribs per whorl height may be the same or 


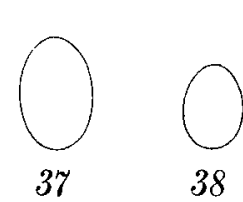

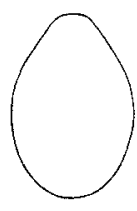

$39 a$

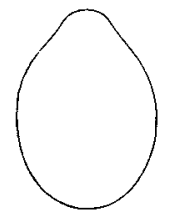

$39 b$

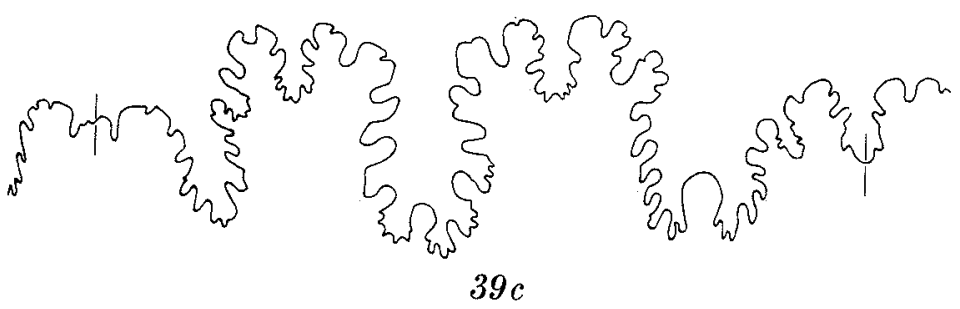

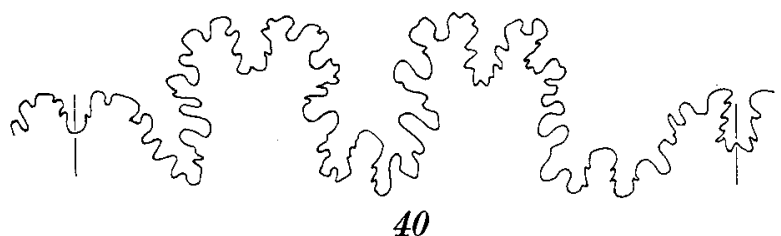

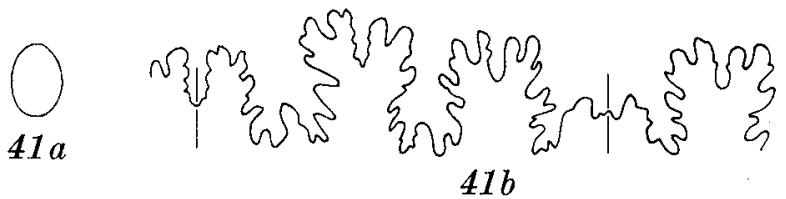

Figs. 37-41. Baculites nugssuaqensis n.sp.

37. MMH No. 9894. $\times 1$, cross section. Tuperssuartâ, $48 \mathrm{~m}$ west of dolerite sill A.

38. MMH No. $9757 . \times 1$, cross section. Tuperssuartâ, $30 \mathrm{~m}$ west of dolerite sill A.

39. MMH No. 9760. $a, b, \times 1$, cross sections; $c, \times 3$, suture at a whorl height of $20.1 \mathrm{~mm}$. Tuperssuartâ.

40. MMH No. 9758. $\times 4$, suture at a whorl height of $12.8 \mathrm{~mm}$. Tuperssuartâ, $75 \mathrm{~m}$ west of dolerite sill $\mathrm{A}$.

41. MMH No. 9895. $a, \times 1$, cross section; $b, \times 4$, suture at a whorl height of $7.4 \mathrm{~mm}$. Tuperssuartâ, $30 \mathrm{~m}$ west of dolerite sill A.

less than the number of ventral ribs. The lateral ribs show no kind of thickening, but they vary from being just visible to more distinct and broader. The distance between them is extremely variable.

The suture is relatively simple with rather narrow lobes and broad saddles. The lateral lobe and the umbilical lobe are as deep or slightly deeper than the ventral lobe, and both have a prominent but simple median minor saddle. The lateral lobe may be slightly constricted just above the major lateral branches especially in later stages. First and 
second lateral saddles are nearly equal in size, bifid, and squarish to slightly trapezoidal in general outline.

Two specimens have less incised sutures than the others and a lateral lobe of the same width as the first and second lateral saddles (textfig. $36 \mathrm{c}$ ). They do not differ in other characters.

One specimen (pl. 6, figs. $1 \mathrm{a}-\mathrm{c}$, text-figs. $39 \mathrm{a}-\mathrm{c}$ ), which is only tentatively referred to this species, has a more slight tapering, more pronounced longitudinal depressions on both sides of the venter, and less incised sutures than typical specimens.

Affinities. The species has close affinity with Baculites mariasensis CobBan, 1951. According to CobBan (1951 c, p. 818) B. mariasensis is smaller, but new collecting of that species from Wyoming shows that occasionally it may be equal in size to the largest specimen of $B$. nugssuaqensis n. sp. from Tuperssuartâ. The tapering of $B$. mariasensis is less pronounced except in early stages (at whorl heights of less than $10 \mathrm{~mm}$ ) where it is the same. The relation between whorl height and width is the same. The type specimen of B. mariasensis (СовваN, 1951 c, pl. 118, fig. 12, text-figs. 5,6 ) shows a narrower venter than the specimens from Tuperssuartâ. Examination of a great number of specimens from the type locality of $B$. mariasensis, and from other localities of similar age in the Western Interior of the United States, confirms that most of the specimens have a rather narrowly rounded venter similar to that of the type specimen, although some with a broader venter also occur. Many specimens from the type locality of $B$. mariasensis have more distinct ventrolateral longitudinal depressions than those from Tuperssuartâ. However, specimens of $B$. mariasensis collected from localities older than the type locality, and some from beds of the same age, have crosssections which are more like those of specimens from Tuperssuartâ, specimens with a broadly rounded venter and extremely weak ventrolateral longitudinal depressions being predominate. The sculpture of B. mariasensis is similar to that of specimens from Tuperssuartâ as are the sutures though these are a little less complicated.

As mentioned in the description, one questionable specimen from Tuperssuartâ differs from others in a more slight tapering, more pronounced longitudinal depressions, and less incised sutures. This exceptional specimen is more close to $B$. mariasensis than the other specimens from that locality. The exact position in the section of this specimen is unknown.

The species also resembles $B$. codyensis ReEside, 1927 s. l., but differs from it in whorl section, the dorsum being flatter in $B$. codyensis, and in sculpture, $B$. codyensis having stronger lateral ribbing. 
Stratigraphy. The inoceramids which occur near the baculites at Tuperssuartâ show that this locality may be referred to the Lower Santonian. Scaphites fragments, referable to Clioscaphites (described p. 135) confirms this. Accordingly, the baculites from this locality are stratigraphically much younger than $B$. mariasensis. No differences have been noticed between the stratigraphically younger specimens from the western part of the section and the older ones from the eastern part.

Baculites codyensis REESIDE, 1927 s. 1.

PI. 6, figs. 3-5; pl. 7, fig. 1 ; text-figs. 42-45.

1927 a Baculites codyensis REESIDE, p. 4, pl. 2, figs. 6-19.

1952 Baculites codyensis Reeside: Cobban \& Reeside, chart 10 B.

Holotype. Yale Peabody Museum, catalogue No.6408. Figured by ReEside, 1927 a, pl. 2, figs. 6-10. From Cody Shale, 800 feet above base, near Cody in Park County, Wyoming.

Emended diagnosis. Baculites with a rather small shell; tapering slight; whorl section elliptical in juvenile stages, later ovate with a broad flattened dorsum and a more narrowly rounded venter; ribs weak or strong, rather closely set, lateral ribs strongest in the dorsolateral sinus, 2 to 6 lateral ribs and 4 to 7 ventral ribs per whorl height; suture simple with a narrow lateral lobe and usually with broad, squarish saddles.

Remarks. ReESIDE (1927a) refers only strongly sculptured specimens to this species. By further study of enlarged collections from the type area, and from other regions in the Western Interior of the United States, Dr. W. A. Coвban has shown (personal communication) that the typical Baculites codyensis develops into generally more weakly ribbed forms, which occur in slightly higher levels. Because of the range of variation this late form is not separated from the typical early form.

The material from Greenland, described below, comprises only the late weakly sculptured form.

Material. Nûgssuaq: 10 rather well preserved specimens and several poorly preserved fragments from Søndre Baculitetskløft and a few fragments from Nordre Baculitetskløft. Additionally, some fragments from the Baculites-Inoceramus beds in the Scaphitesnæsen section, $519-523 \mathrm{~m}$ above sea-level, probably belong to this species. 
Measurements.

$\begin{array}{cccrrrr}\begin{array}{c}\text { Number } \\ \text { of } \\ \text { specimens }\end{array} & \begin{array}{l}\text { Whorl } \\ \text { height }\end{array} & \begin{array}{c}\text { Whorl } \\ \text { width }\end{array} & \text { W/H } & \begin{array}{r}\text { Taper- } \\ \text { ing }\end{array} & \begin{array}{r}\text { Number } \\ \text { of ventral of lateral } \\ \text { ribs per } \\ \text { whorl } \\ \text { height }\end{array} & \begin{array}{c}\text { Number } \\ \text { whorl } \\ \text { height }\end{array} \\ 1 & 16.0 \mathrm{~mm} & 10.6 \mathrm{~mm} & 0.66 & 3^{\circ} & ? & 3 \\ 1 & 14.0- & 9.2- & 0.66 & 2^{\circ} & ? & ? \\ 3 & 12.0- & 7.8-8.9- & 0.65-0.74 & 2^{\circ} & 4-6 & 2-3 \\ 5 & 10.0- & 6.6-7.0- & 0.66-0.70 & 2^{\circ} & 4-7 & 3-6 \\ 3 & 8.0- & 5.6-5.7- & 0.70-0.71 & 3^{\circ}-4^{\circ} & & \\ 3 & 6.0- & 4.5-4.7- & 0.75-0.78 & 4^{\circ} & & \end{array}$

All from Søndre Baculiteskløft.

Description. The largest specimen available is apparently not mature, its whorl height is $17 \mathrm{~mm}$ at the younger part of the body chamber and $13 \mathrm{~mm}$ at the youngest suture. Most specimens are smaller. Thus, in the five specimens which can be shown to be mature, whorl height at the

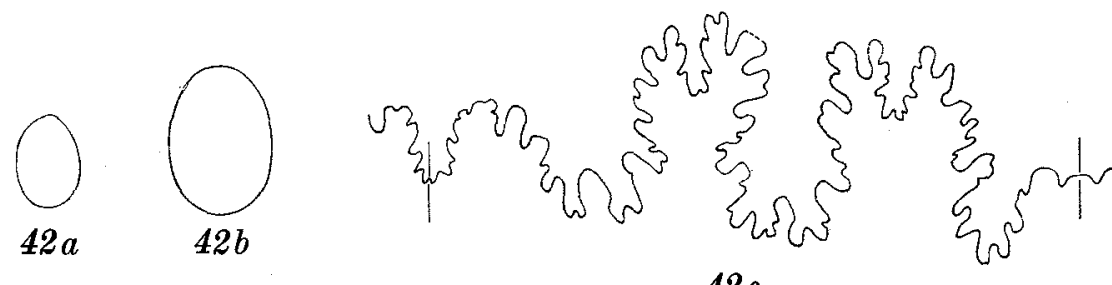

$42 c$

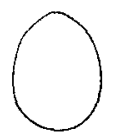

$43 a$

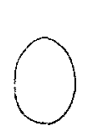

$44 a$

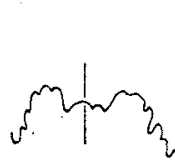

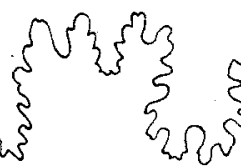

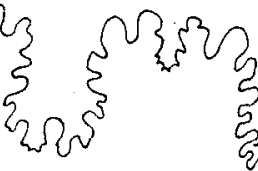

436

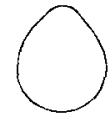

$44 b$

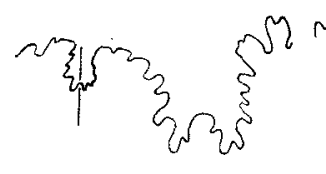

45

Figs. 42-45. Baculites codyensis REEsIn E (late form). Søndre Baculiteskløft.

42. MMH No. 9765. $a, b, \times 1$, cross sections; $c, \times 4$, suture at a whorl height of $12.4 \mathrm{~mm}$.

43. MMH No. 9762. $a, \times 1$, cross section; $b, \times 4$, suture at a whorl height of $12.4 \mathrm{~mm}$.

44. MMH No. 9763. $a, b, \times 1$, cross sections.

45. MMH No. 9764. $\times 4$, suture at a whorl height of $11.1 \mathrm{~mm}$. 
last suture ranges from $9 \mathrm{~mm}$ to $11.5 \mathrm{~mm}$. Tapering is very slight; most marked at the smallest whorl heights observed (about $4^{\circ}$ at 5 to $6 \mathrm{~mm}$ ), later decreasing to about $2^{\circ}$. At a whorl height of about $16 \mathrm{~mm}$, in the only specimen attaining that size, the degree of tapering is slightly higher $\left(3^{\circ}\right)$. The whorl section is subelliptical up to a whorl height of about $10 \mathrm{~mm}$, the venter being only slightly more narrowly rounded than the dorsum. At later stages the venter is narrower and very weak ventrolateral depressions may be developed. The dorsum becomes broader and slightly flatter and the maximum width of the whorls moves towards the dorsal side, the whorl section becoming more or less subtriangular.

The growth lines form a lateral rounded sinus very close to the dorsum, a rather low rounded dorsal projection and a much higher rounded ventral projection. No sculpture has been observed at whorl heights of less than $8 \mathrm{~mm}$. From this size onwards very fine or slightly coarser ribbing is visible in most specimens. The number of lateral ribs (3 to 6 ) and ventral ribs ( 4 to 7 ) per whorl height is about equal at whorl heights of less than $10 \mathrm{~mm}$, at later stages the number of ventral ribs per whorl height ( 4 to 6 ) exceeds the number of lateral ribs (2 to 3 ). The lateral sinus of the ribs, situated very close to the dorsum, is often slightly thickened from whorl heights of about $10 \mathrm{~mm}$.

The suture is relatively simple with rather broad, squarish, lateral saddles and a narrower lateral lobe. All the lobes are of about equal depth. The medium minor saddle of the lateral lobe is rather small and simple and that of the umbilical lobe is also simple but more prominent. One specimen (text-fig. 42c) has narrower lateral saddles than the remaining material.

Affinities. Baculites codyensis ReEside is here interpreted in a wider sense than originally defined and my material is referred especially to the later representatives of that species. B. codyensis (s. s.), as described and figured by ReEside (1927a, p. 4, pl. 2, figs. 6-19) differs from the specimens described here in its much stronger sculpture but is very similar in all other characters. Examination of that species in the collections of the United States Geological Survey, Denver, shows that the majority of the specimens have a broad flat dorsum and a rather broad venter, as does the specimen from Greenland (pl. 6, fig. 3; text-fig. 43), whereas more slender specimens with a less flattened dorsum and a more narrowly rounded venter, the commonest type from Greenland, is comparatively rare. Late forms of $B$. codyensis seem to be about the same size or slightly larger than the specimens from Greenland. Their cross section is identical with that of specimens described here except that most are slightly more inflated and have a rather flatter dorsum 
as in B. codyensis s. s. The sutures are similar. Many late forms of $B$. codyensis have a sculpture which is similar to that of the specimens from Greenland. However, when large collections are studied, some are seen to be more strongly ornamented. Senile specimens of late $B$. codyensis are completely smooth with a subcircular cross section. No senile specimens are known from Greenland.

In the Western Interior of the United States B. codyensis occurs together with B. asper Morton, 1834, and Reeside (1927a, p. 4) has suggested that morphologically intermediate specimens might occur also. Dr. W. A. СовBan (personal communication) has established that $B$. asper is most common in the lower levels and B. codyensis in the higher levels and that intermediate forms do occur. Accompanying late forms of $B$. codyensis with its characteristically weak sculpture are specimens with widely spaced nodes resembling those of $B$. asper, only weaker. No specimens from Greenland are related to $B$. asper.

Species very similar to, and of about the same age as, $B$. codyensis have been described from other areas. Dr. W. A. Coвban (personal communication) has mentioned the Canadian species $B$.trifidolobatus Warren, 1930, B. borealis Warren, 1930, and B. albertensis Warren, 1930. From Texas, and possibly also from Madagascar (Collignon, 1931, p. 22), B. aspero-anceps LASSwitz, 1904, from South Africa B. sulcatus BAILY, 1855, and from Europe B. brevicosta SGHLÜter, 1876, are also similar. But all these species are more heavily sculptured than the late specimens of $B$. codyensis and the specimens from Greenland with the exception of specimens referred to $B$. cf. brevicosta Schlüter and to B. sulcatus Baily by Collignon (1931, pl. 5, figs. 1, 3-5), having less pronounced ribs than the type material originally figured by ScHLÜTER (1876, pl. 39, figs. 9-10) and by BAILY (1855, pl. 11, fig. 5c). They are rather similar to the specimens from Greenland in sculpture, differing only in their smaller size and possibly in their cross section.

Although small differences are evident between the specimens from Greenland and those from the Western Interior of the United States, the Greenland material is here referred to the late form of B. codyensis. Because of the enormous range of variation no subspecies are established either for the late forms of $B$. codyensis, which may be a true stratigraphical subspecies, or for the specimens from Greenland.

Stratigraphy. Typical specimens of $B$. codyensis occur in the ConiacianSantonian of the Western Interior of the United States from the Scaphites ventricosus Zone to the Clioscaphites saxitonianus Zone. In the Clioscaphites montanensis Zone the ribbing of $B$. codyensis begins to be reduced so that the late form predominate. In the succeding Clioscaphites choteauensis Zone smooth or nearly smooth baculites appear for the 
first time. I suggest that the beds with $B$. codyensis in West Greenland may be referred to the Clioscaphites montanensis Zone. The inoceramids from these localities, according to Professor A. Rosenkrantz, belong to the Inoceramus steenstrupi DE LORIOL group.

\section{Baculites ef. haresi Reeside, 1927}

PI. 7, fig. 2; text-fig. 46.

1927 c Baculites ovatus var. haresi ReEside, p. 10, pl. 6, figs. 5-10.

1952 Baculites haresi ReEsIDE: CobBan \& ReEsIDe, p. 1019, chart 10 B.

1959 Baculites cf. haresi Reeside: Robinson, Mapel \& Cobban, p. 115.

1962 Baculites haresi REESIDE: REESIDE, p. 114.

Holotype. U. S. Nat. Mus. catalogue No. 73296. Figured by Reeside, 1927 c, pl. 7, figs. 9-10. From the Elk Basin Sandstone Member of the Telegraph Creek Formation, Carbon County, Montana.

Material. Nûgssuaq: one well preserved specimen from Scaphitesnæsen, collected 535-537 m above sea-level.

Measurements.

$\begin{array}{lccccc}\begin{array}{l}\text { Whorl } \\ \text { height }\end{array} & \begin{array}{l}\text { Whorl } \\ \text { width }\end{array} & \text { W/H } & \text { Tapering } & \begin{array}{c}\text { Number of } \\ \text { ventral } \\ \text { ribs per } \\ \text { whorl } \\ \text { height }\end{array} & \begin{array}{c}\text { Number of } \\ \text { lateral } \\ \text { ribs per } \\ \text { whorl } \\ \text { height }\end{array} \\ 19.0 \mathrm{~mm} & 14.0 \mathrm{~mm} & 0.74 & 3^{\circ} & 3 & 2 \\ 18.0- & 13.4- & 0.74 & 1^{\circ} & 5 & 2 \\ 16.0- & 10.0- & 0.63 & 3^{\circ} & 4 & 2 \\ 14.0- & 9.3- & 0.66 & 3^{\circ} & 3 & 2 \\ 12.0- & 8.6- & 0.72 & 1^{\circ} & 5 & 2 \\ 10.0- & 7.0- & 0.70 & 5^{\circ} & & \end{array}$

Description. The only specimen available in the collection from Greenland has a whorl height of $19.5 \mathrm{~mm}$ at the younger part of the body chamber and $17 \mathrm{~mm}$ at the youngest suture. The specimen is mature. The tapering is rather irregular, ranging between $1^{\circ}$ and $5^{\circ}$, highest at the smallest diameter. $14 \mathrm{~mm}$ behind the youngest preserved part of the body chamber the shell is slightly flared, showing the presence of a flared peristome at that growth stage. The whorl section is ovate with an evenly rounded dorsum and a slightly more narrowly rounded venter. The maximum width is a little closer to the dorsum than to the venter. The width increases slightly faster than the height in the youngest part of the mature body chamber.

The specimen has a weak sculpture from a whorl height of $11 \mathrm{~mm}$. The ribs are most distinct ventrally, although they vary in intensity. 


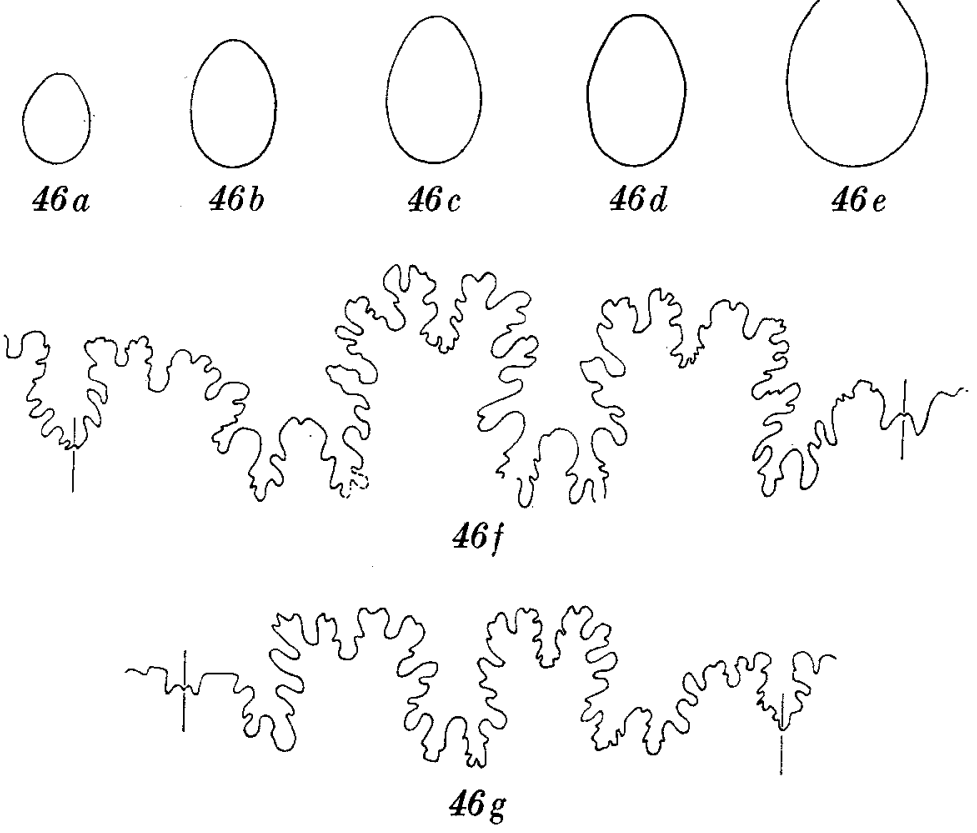

Fig. 46. Baculites cf. haresi Reeside. MMH No. 9766. a-e, $\times 1$, cross sections; $f, \times 4$, suture at a whorl height of $16.4 \mathrm{~mm} ; g, \times 4$, suture at a whorl height of $11.4 \mathrm{~mm}$. Scaphitesnæsen, 535-537 m above sea-level.

Lateral ribs are hardly discernible. There are no thickening of the lateral sinus of the ribs.

The suture is comparatively simple with a rather narrow lateral lobe and wider squarish saddles. All the lobes are of about the same depth, the median minor saddles of the lateral lobe and the umbilical lobe are very large and slightly incised.

Affinities. The specimen compares closely with Baculites haresi REEsIDE. The type specimen is of similar size and cross section. The two specimens figured by ReEsID E (1927 c, pl. 6, figs. 5-8) are slightly larger and somewhat flatter laterally. Examination of the specimens in the collections of the United States National Museum has shown that there are no differences in the sutures or the sculpture. The specimen figured by Reeside (1927 c, pl. 6, figs. 9-10) is of much greater size than that described here and therefore shows much more complicated sutures.

The specimen described here is provisionally referred to Baculites haresi, but more material may show a difference in range of variation.

Stratigraphy. According to Cobban \& Reeside (1952, chart 10B), Baculites haresi ranges from the Desmoscaphites bassleri Zone to the 
Baculites asperiformis Zone in the Western Interior of the United States. According to a personal communication from Dr. W. A. CовBAN, further investigations have shown that $B$.haresi does not occur above the Haresiceras natronense Zone in the United States. The beds in the Scaphitesnæsen are referred to the upper part of the Lower Campanian, this horizon being determined by the scaphites and the most common baculite (an early form of B. obtusus).

\section{Baculites obtusus MeEк, 1876 s. l.}

Pl. 8, fig. 1; pl. 9, figs. 1-3; pl. 10, fig. 1; pl. 11, figs. 1-2; pl. 12, figs. 1-2; pl. 13, figs. 1-2; pl. 14, fig. 1; text-figs. 47-52.

1876 a Baculites anceps LamarcK var. obtusus MEEK, p. 406, text-figs. 57-60.

$1876 \mathrm{c}$ Baculites anceps LAMARGK var. obtusus MEEK: Meek, p. 130, pl. 2, figs. 1a-h. 1940 Baculites obtusus MEEK: LANDEs, p. 169.

1962 b Baculites obtusus Méк: CoвBAN, p. 706, pl. 105, figs. 1-14.

Lectotype (designated by Cobban, 1962b, p. 707). U. S. Nat. Mus. catalogue No. 1934 a. Figured by MeEk, 1876 a, p. 406, figs. 58-60. From "Deer Creek on the North Platte; from the Fox Hills Group of the Upper Missouri Cretaceous Series". Cobban (1962 b, p. 707) gives further information on MEek's localities and errors as to the stratigraphy (compare p. 62).

Emended diagnosis. Baculites with somewhat larger than average shell; tapering extremely slight; whorl section elliptical, with more or less flattened sides, to ovate, with the venter a little more narrowly rounded than the dorsum; lateral ribs strong to extremely weak, strongest at the lateral bend, occasionally forming blunt nodes; 1-4 lateral ribs per whorl height; venter smooth or ribbed with 1-7 ribs per whorl height; suture of average complexity with rather squarish to trapezoidal lobes and saddles of about equal width.

Remarks. Meek (1876a, 1876c), Landes (1940), and Cobban (1962b) refer only strongly sculptured baculites to this species. New collections from the Western Interior of the United States show a gradation from weakly ribbed to more strongly sculptured forms going from older to younger layers. According to personal communication from Dr. W. A. Соввал, these more weakly ribbed forms cannot be separated from Baculites obtusus s. s. because of the great range of variation, although the character of the sculpture has a certain stratigraphical significance. Sсотт \& СовваN (1963) mention B. obtusus s. s. with strong sculpture as " $B$. obtusus (late form)" and the earlier more weakly ribbed ones as "B. obtusus (early form)". The material from Greenland, the description of which is given below, comprises only early forms of this species. 
Material. Nûgssuaq: about 100 specimens from Scaphitesnæsen, collected in situ 535-541 m above sea-level, the remainder displaced or the height above sea-level not indicated. Most of the material is well preserved. One specimen from a small ravine west of Scaphitesnæsen.

Measurements.

\begin{tabular}{|c|c|c|c|c|c|c|c|c|}
\hline $\begin{array}{l}\text { Number } \\
\text { of } \\
\text { specimens }\end{array}$ & $\begin{array}{l}\text { Wh } \\
\text { heig }\end{array}$ & & $\begin{array}{l}\text { Whorl } \\
\text { width }\end{array}$ & & $\mathrm{W} / \mathrm{H}$ & $\begin{array}{c}\text { Taper- } \\
\text { ing }\end{array}$ & $\begin{array}{c}\text { Number } \\
\text { of ventral } \\
\text { ribs per } \\
\text { whorl } \\
\text { height }\end{array}$ & $\begin{array}{l}\text { Number } \\
\text { of lateral } \\
\text { ribs per } \\
\text { whorl } \\
\text { height }\end{array}$ \\
\hline 1 & $44.0 \mathrm{I}$ & $\mathrm{nm}$ & 33.6 & $\mathrm{~nm}$ & 0.76 & $4^{\circ}$ & & \\
\hline 1 & 38.0 & - & 26.1 & - & 0.69 & $2^{\circ}$ & 5 & 4 \\
\hline 4 & 36.0 & - & $24.7-30.0$ & - & $0.69-0.83$ & $1^{\circ}-3^{\circ}$ & $5-6$ & $2-4$ \\
\hline 2 & 34.0 & - & $23.5-24.3$ & - & $0.69-0.71$ & $1^{\circ}-2^{\circ}$ & 7 & \\
\hline 1 & 32.0 & - & 23.5 & - & 0.73 & $2^{\circ}$ & 5 & \\
\hline 3 & 30.0 & - & $18.6-20.2$ & - & $0.62-0.67$ & $2^{\circ}$ & $2-5$ & $2-3$ \\
\hline 5 & 26.0 & - & $17.8-21.7$ & - & $0.68-0.83$ & $1^{\circ}-3^{\circ}$ & & $2-3$ \\
\hline 6 & 24.0 & - & $15.5-17.7$ & - & $0.65-0.74$ & $0^{\circ}-3^{\circ}$ & $2-5$ & 2 \\
\hline 4 & 22.0 & - & $14.5-16.6$ & - & $0.66-0.75$ & $0^{\circ}-3^{\circ}$ & $1-5$ & $2-3$ \\
\hline 5 & 20.0 & - & $14.6-15.8$ & - & $0.73-0.79$ & $1^{\circ}-2^{\circ}$ & $2-5$ & $2-3$ \\
\hline 5 & 18.0 & - & $13.0-14.2$ & - & $0.72-0.79$ & $1^{\circ}-3^{\circ}$ & $2-4$ & $2-4$ \\
\hline 2 & 16.0 & - & $11.8-12.7$ & - & $0.74-0.79$ & $1^{\circ}$ & 2 & $1-2$ \\
\hline 1 & 13.0 & - & 14.0 & - & 0.85 & $1^{\circ}$ & & 2 \\
\hline 2 & 10.0 & - & $7.2-8.3$ & - & $0.72-0.83$ & $3^{\circ}$ & 4 & 2 \\
\hline 2 & 8.0 & - & $6.0-6.2$ & - & $0.75-0.78$ & $3^{\circ}-5^{\circ}$ & & 2 \\
\hline 1 & 6.0 & - & 4.6 & - & 0.77 & $5^{\circ}$ & & \\
\hline 1 & 3.0 & - & 2.7 & - & 0.90 & $6^{\circ}$ & & \\
\hline
\end{tabular}

All from Scaphitesnæsen.

Description. The largest specimen has a whorl height of $46 \mathrm{~mm}$ in the younger part of the body chamber. The largest septate whorl height is $38 \mathrm{~mm}$. Tapering is slight, highest at whorl heights less than $10 \mathrm{~mm}$ $\left(3^{\circ}-6^{\circ}\right)$. At greater whorl heights the ventral and dorsal sides are parallel or have a very low degree of tapering $\left(1^{\circ}-3^{\circ}\right)$. The largest specimen tapers $4^{\circ}$ at the younger part of the body chamber. From a whorl height of $3 \mathrm{~mm}$ (the smallest observed) to about $10 \mathrm{~mm}$, the whorl section is subelliptical with dorsum and venter almost equally rounded. From that size the sides are flatter in most specimens, in some the venter becomes slightly more narrowly rounded. Some specimens have very weak longitudinal depressions on both sides of the siphonal area at whorl heights of $22-26 \mathrm{~mm}$. The whorl ratio $(\mathrm{W} / \mathrm{H})$ is greatest at the smallest diameters but a few specimens retain a similar great width in relation to height and a subelliptical cross section with rounded sides at later stages. The range of variation in cross section is extremely wide.

Pl. 9, figs. $2 \mathrm{a}-\mathrm{c}$ and pl. 11, figs. $1 \mathrm{a}-\mathrm{c}$ show the course of the growth lines at a juvenile and a later stage. No ontogenetic change can be seen. 


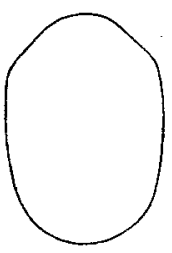

$47 a$

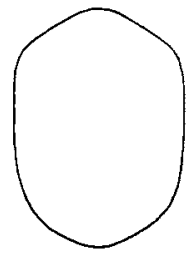

$47 b$

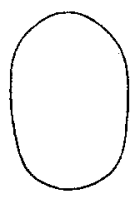

$48 a$

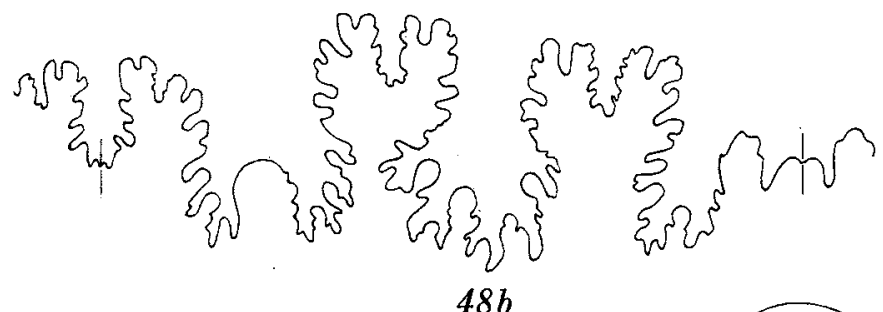

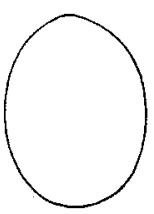

$49 a$

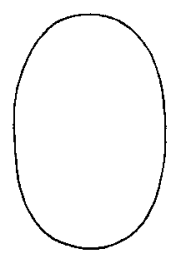

$49 b$

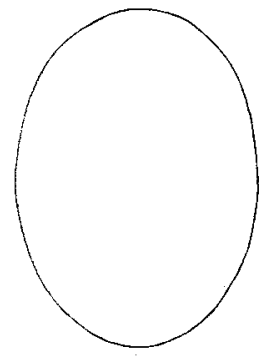

50

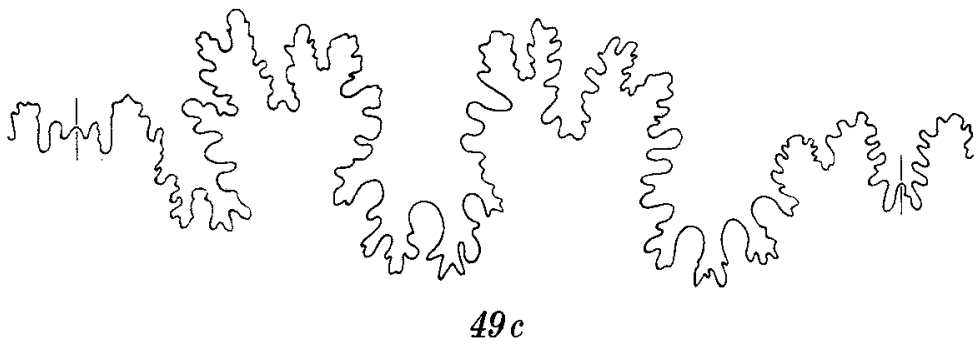

Figs. 47-50. Baculites obtusus MEEK (early form).

47. MMH No. 9896. $a, b, \times 1$, cross sections. Scaphitesnæsen.

48. MMH No. 9770. $a, \times 1$, cross section; $b, \times 3$, suture at a whorl height of $17.3 \mathrm{~mm}$. Scaphitesnæsen.

49. MMH No. 9771. $a, b, \times 1$, cross sections; $c, \times 3$, suture at a whorl height of $19.6 \mathrm{~mm}$. Scaphitesnæsen, 539-540 m above sea-level.

50. MMH No. 9774. $\times 1$, cross section. Scaphitesnæsen.

The lateral sinus of the growth lines is situated rather close to the middle of the sides, the rounded ventral projection is much higher than the rounded dorsal projection. From a whorl height of about $8 \mathrm{~mm}$ weak lateral and ventral ribs are discernible; they are strongest at whorl 


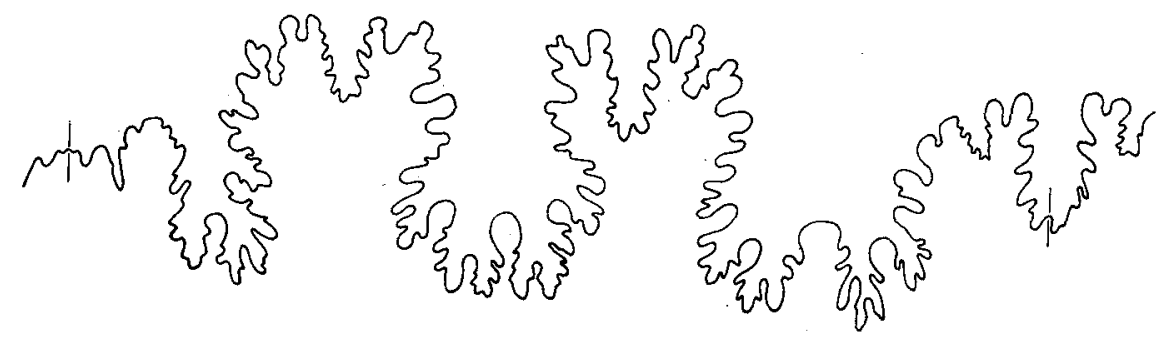

51

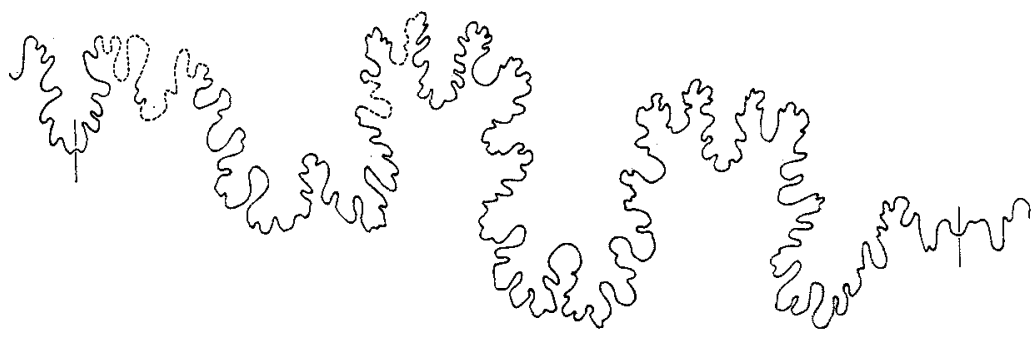

52

Figs. 51-52. Baculites obtusus MeEk (early form).

51. МMH No. $9773 . \times 3$, suture at a whorl height of $24.5 \mathrm{~mm}$. Scaphitesnæsen, about $537 \mathrm{~m}$ above sea-level.

52. MMH No. $9897 . \times 3$, suture at a whorl height of $22.8 \mathrm{~mm}$. Scaphitesnæsen, $538 \mathrm{~m}$ above sea-level.

heights of $15-25 \mathrm{~mm}$, later stages are smooth or with extremely weak ribs. The lateral ribs are broad, often forming blunt nodes at the lateral sinus, which is situated dorsolaterally rather close to the middle of the sides. The lateral ribs are not very prominent on the sides closest to the venter. Most frequently there are two lateral ribs per whorl height, but in some specimens they are spaced twice as close. The number of ventral ribs varies widely (1-7 per whorl height). Also, in the same specimen, both the distance between the ventral ribs and the strength of them may show a wide range of variation. Some specimens seem to be smooth, both lateral and ventral ribbing being extremely weak or lacking.

The sutures are of average complexity. The lateral lobe has a simple median minor saddle of rather small size, the lobe is of similar or a little greater depth than the umbilical lobe, it may be very slightly constricted just above the major lateral branches. Also the median minor saddle of the umbilical lobe is simple but may be of rather large size. The first and second lateral saddles are rather squarish or trapezoidal in general outline and of similar width or a little wider than the lateral lobe. 
Two specimens have complete body chambers $113 \mathrm{~mm}$ and $118 \mathrm{~mm}$ long with whorl heights at the aperture of $26 \mathrm{~mm}$ and $24 \mathrm{~mm}$ respectively. Both specimens are apparently mature, the last two sutures being slightly closer than the earlier ones and the peristome of one being slightly flared (pl. 10, figs. 1a-c). Some other specimens have extremely flared apertures (pl. 13, figs. $2 \mathrm{a}-\mathrm{c}$ ) and one retains a trace of an earlier flared peristome in the septate part of the shell (pl. 9, figs. $3 a-c$ ), thus showing that growth does not necessarily stop when a flared aperture has been formed.

Affinities. The specimens compare closely with "early forms" of Baculites obtusus Merk, 1876. The only difference between early and late specimens of B.obtusus is in sculpture, usually weaker in the early than in the late forms. Comparison of the specimens described here with early $B$. obtusus reveals no differences in size, tapering, sculpture or sutures. The variation in shape of the cross section of the whorls of early $B$. obtusus is similar to that of the specimens from Greenland except for the whorl ratio $(\mathrm{W} / \mathrm{H})$, which is often a little smaller in the early B. obtusus than in the material from Greenland.

Stratigraphy. According to MeEk (1876a, p. 408) the type specimens came from "Deer Creek on the North Platte; from the Fox Hills group of the Upper Missouri Cretaceous series". Coвban (1962 b, p. 707) has shown that $B$. obtusus occurs only in the lower part of the Pierre Shale and equivalent rocks in the Western Interior and not at all in the Fox Hills Formation. It occurs in the upper part of the Lower Campanian. According to Scott \& Cobban (1963) and Cobban \& Scott (1964) it is possible, on the character of the ribbing of B. obtusus to separate two zones, one with early $B$. obtusus and one with late.

Baculites cf. meeki EliAs, 1933

PI. 14, figs. 2-3; pl. 15, fig. 1; text-figs. 53-55.

1933 Baculites meeki Elias, p. 312, pl. 30, figs. 4 a-b.

Holotype. Kansas University catalogue No. Ku. 1702A1. Figured by Elias, 1933, pl. 30, figs. 4a-b. From the Beecher Island Shale Member, Pierre Formation, 2 miles northwest of Beecher Island, Yuma County, Colorado.

Material. 15 specimens, most of them rather poorly preserved, from the Oyster-ammonite Conglomerate loc. I and two fragments from the Oyster-ammonite Conglomerate loc. III, Nûgssuaq. 
Measurements.

$\begin{array}{ccrrrr}\begin{array}{c}\text { Number } \\ \text { of } \\ \text { specimens }\end{array} & \begin{array}{c}\text { Whorl } \\ \text { height }\end{array} & \begin{array}{c}\text { Whorl } \\ \text { width }\end{array} & \text { W/H } & \text { Tapering } & \begin{array}{c}\text { Number of } \\ \text { lateral ribs } \\ \text { per whorl } \\ \text { height }\end{array} \\ 1 & 22.0 \mathrm{~mm} & 19.2 \mathrm{~mm} & 0.87 & 2^{\circ} & 3 \\ 1 & 20.0- & 15.2- & 0.76 & 1^{\circ} & 2 \\ 1 & 17.0- & 13.0- & 0.76 & 1^{\circ} & 2 \\ 2 & 16.0- & 11.7-12.9- & 0.73-0.81 & 1^{\circ} & 2 \\ 2 & 14.0- & 9.6-11.1- & 0.69-0.79 & 2^{\circ} & 1\end{array}$

Description. The largest specimen, a fragment of a body chamber, has a maximum whorl height of $22 \mathrm{~mm}$. The tapering of all fragments is small, $1^{\circ}-2^{\circ}$. Within the observed whorl heights from $13 \mathrm{~mm}$ to $22 \mathrm{~mm}$, the cross section is ovate, with a slightly more narrowly rounded venter than dorsum, or subelliptical, with rather flattened sides. The width of the fragments is rather great in relation to height. The maximum width is at the middle of the sides.

The fragments have rather weak lateral ribs, strongest at the lateral sinus, which is rather close to the dorsum. The ribs are also well devel-

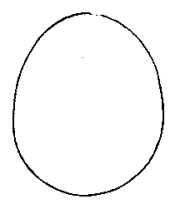

$53 a$

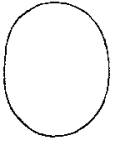

54
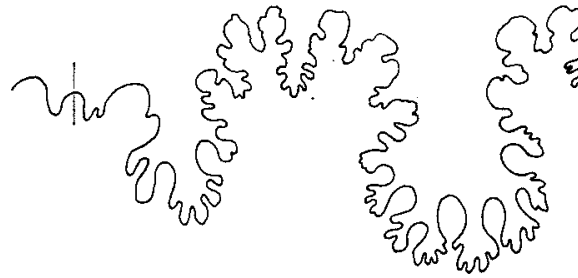

$53 b$

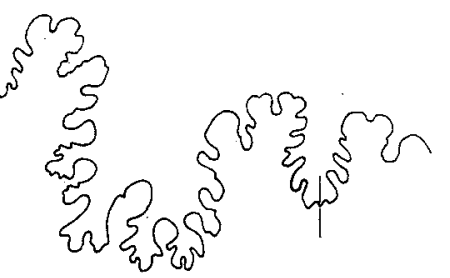

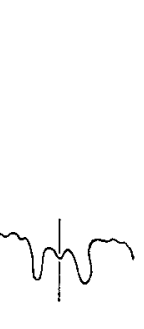

\section{5}

Figs. 53-55. Baculites cf. meeki Elias.

53. MMH No. 9781. $a, \times 1$, cross section; $b, \times 4$, suture at a whorl height of $19.5 \mathrm{~mm}$. Oyster-ammonite Conglomerate loc. I.

54. MMH No. 9779. $\times 1$, cross section. Oyster-ammonite Conglomerate loc. I.

55. MMH No. 9898. $\times 4$, suture at a whorl height of $13.7 \mathrm{~mm}$. Oyster-ammonite Conglomerate loc. III. 
oped on the area between the lateral sinus and the venter running nearly straight from the lateral sinus in an oblique direction to the venter. There are 1-3 lateral ribs per whorl height. On two of the specimens closely spaced ventral ribs (6 per whorl height) are just discernible.

The sutures are very simple (pl. 14, fig. 3 ) or a little more complex (text-figs. 53b, 55). The lateral lobe may be narrower or the same width as the first and second lateral saddles. The median minor saddle of the lateral lobe is rather small and simple; the median minor saddle of the umbilical lobe is the same size or only a little larger. The first and second lateral saddles are of equal size and squarish to slightly trapezoidal in general outline.

Affinites. Unfortunately Baculites meeki ELIAS is a poorly known species. Elias (1933) described one fragment and referred one fragment figured by Мекк (1876a, pl.39, figs. 10b-c) to that species, but the last mentioned fragment was later assigned by Соввам (1962b) to $B$. asperiformis Mекк. The sutures are unknown. The fragments from Greenland do not seem to differ from the specimen figured by Elias except for a slightly weaker ribbing and are provisionally referred to that species.

The specimens also have some affinity with B. baculus MeEк, 1876. The suture especially is rather similar to that of the type specimen of B. baculus (MeEк, 1876a, p. 397, figs. 51-52). However, all the specimens from Greenland have a smaller tapering than B. baculus, and they differ also in size and sculpture.

Stratigraphy. Elias's specimen came from the upper part of the Pierre Shale, according to Coвbax from the Baculites clinolobatus Zone. The accompanying fauna is here thought (p. 161) to indicate that the specimens from Greenland are slightly younger.

\section{Baculites sp. 1}

Three derived, undeterminable fragments of large size (largest whorl height of the phragmocone $43 \mathrm{~mm}$ ) were collected in the Oyster-ammonite Conglomerate loc. I (Nûgssuaq). They may be derived from the same horizon as $B$. cf. meeki, which occurs at the same locality. They differ so much in size from the specimens of $B$. cf. meeki that they may belong to another species.

The whorl section is broad subelliptical, the venter being slightly more narrowly rounded than the dorsum. The sutures seem to be similar to that of $B$. ef. meeki. The sculpture is not preserved. 


\section{Baculites sp. 2}

Pl. 15, figs. 3-4; text-fig. 56.

Material. Nûgssuaq: one fragment of a body chamber and one fragment of a phragmocone from Brudkløft at Ikorfat, $550-560 \mathrm{~m}$ above sea-level.

Measurements.

$\begin{array}{ccc}\text { Whorl height } & \text { Whorl width } & \text { W/H } \\ 19.5 \mathrm{~mm} & 12.0 \mathrm{~mm} & 0.61 \\ 19.3- & 12.6- & 0.65\end{array}$

Description. Both fragments are small with very slight tapering. The whorl section is subelliptical, the venter being only slightly more narrowly rounded than the dorsum. The sides are flattened. The width of the whorls is rather small in relation to the height.

On the ventrolateral part of the sides, and on the venter, weak, closely spaced ribs are discernible.

The suture is simple. The lateral lobe is rather narrow with a small median minor saddle. The lateral saddles are broad and squarish. The internal lateral saddle is also squarish, but slightly narrower than the lateral saddles and only half as high.

Affinities. The cross section of these fragments is similar to that of Baculites vertebralis LamarcK, 1801. It agrees especially with the cross section figured by SchlÜter (1876, pl. 39, fig. 12). The suture differs from some of the figured sutures of $B$. vertebralis (for example SCHLÜter, 1876, pl. 40, fig. 5) in having a shorter internal lateral saddle. However, the suture is most similar to those of $B$. vertebralis figured by Nowak (1908, p. 331, fig. 12) and by Picard (1929, p. 440, text-fig. 4) and may also be similar to the suture of $B$. cf. vertebralis described by Schlüter (1876, p. 143). The Greenland specimens differ from B. vertebralis in having weak ribs.

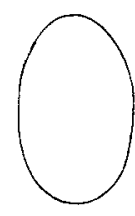

$56 a$

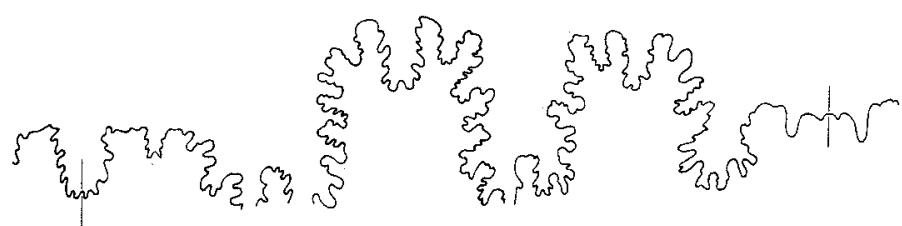

$56 b$

Fig. 56. Baculites sp. 2. MMH No. 9784. $a, \times 1$, cross section; $b, \times 3$, suture at a whorl height of $19.6 \mathrm{~mm}$. Brudkløft at Ikorfat, $560 \mathrm{~m}$ above sea-level. 
Baculites angustus Moвerg, 1885 (p. 39, pl.4, fig. 10) is similar in cross section and ribbing pattern to the specimens described here, but the suture differs in having a much narrower internal lateral saddle.

Stratigraphy. The specimens occur together with Scaphites (Hoploscaphites) ikorfatensis $\mathrm{n}$. sp. and $S .(H$.$) ravni \mathrm{n}$. sp. in deposits referred to the Upper Campanian. The type specimen of $B$. vertebralis (Corne d'Ammon droite, Faujas de Sain t Fond, 1798, pl. 21, figs. 2-3) is from the Upper Maastrichtian (St. Petersberg). It is also mentioned from the Upper Maastrichtian of Denmark (RAvN, 1902). In Sweden it occurs in the Lower Maastrichtian (Moberg, 1885). Schlüter (1876, p. 143-144) records $B$. ef. vertebralis from the Upper Campanian and, according to Nowak $(1908$, p. 347), B. vertebralis ranges from the Lower Campanian to the Maastrichtian.

\section{Baculites sp. 3.}

Pl. 15, fig. 2.

Material. Nûgssuaq: five poorly preserved fragments from Brudkløft at Ikorfat, 550-650 $\mathrm{m}$ above sea-level.

Measurements.

$\begin{array}{ccc}\text { Whorl height } & \text { Whorl width } & \text { W/H } \\ 28.7 \mathrm{~mm} & 20.2 \mathrm{~mm} & 0.70\end{array}$

Description. The greatest whorl height is about $35 \mathrm{~mm}$, tapering is very slight and the whorl section is ovate, the venter being more narrowly rounded than the dorsum.

One specimen (pl. 15, fig. 2) shows very weak lateral ribs.

The suture is rather incised. The lateral saddles are broad and squarish as in the specimen figured pl. 15, fig. 2 or narrower with a trapezoidal outline. The internal lateral saddle is very narrow and asymmetric, the dorsal branch being much higher than the ventral.

Affinities. The affinity of these fragments is uncertain.

Stratigraphy. The fragments occur in the Upper Campanian at Ikorfat together with Baculites sp. 2. 


\section{Family D I P L O M O CE R A T I D A E Spath, 1926}

Genus DI PLO MOCERAS Hyatt, 1900

Type species. Baculites cylindracea Defrance, 1816

\section{Diplomoceras sp.}

Pl. 16, figs. 1-2.

Material. Two displaced fragments, probably of the same specimen, from Niaqornat, and one fragment from Hamiteskløft, $247 \mathrm{~m}$ above sea-level, Nûgssuaq.

Description. All the fragments belong to the straight part of the shell. The whorl height of the fragments ranges from $34 \mathrm{~mm}$ to about $46 \mathrm{~mm}$. The cross section is nearly circular, the whorl width being $33 \mathrm{~mm}$ at a whorl height of $34 \mathrm{~mm}$, and $44 \mathrm{~mm}$ at a whorl height of $46 \mathrm{~mm}$. The surface is covered by rather coarse, regularly spaced, slightly oblique ribs. The distance between the ribs is about $4 \mathrm{~mm}$. The sutures are poorly preserved.

Affinities. The fragments are very similar to Diplomoceras cylindraceum (Defrance), as described and figured by Favre $(1869$, p. 26, pl. 7, figs. 1 a, 1 b), Binкновsт (1861, p. 36, pl. 5b, figs. 5a-c, 6a-b), Nowak (1913, p. 382, pl. 41, fig. 10; pl. 43, fig. 35; pl. 45, fig. 47) and SchlÜter (1871-72, p. 103, pl. 31, figs. 10-11), in size, cross section and ribbing, but the material is too poor for any specific identification.

Stratigraphy. The fragments occur together with Maastrichtian Scaphites (Discoscaphites) forms in Hamiteskløft. The fragments from Niaqornat are probably derived from the Maastrichtian.

Diplomoceras cylindraceum occurs in the Lower Maastrichtian of Europe.

\section{Family S C A P H I T I D A E MeEK, 1876 \\ Subfamily SCAPHITINAE MeEK, 1876}

Species belonging to the genera and subgenera Scaphites Parkinson, 1811, Clioscaphites Cobban, 1951, Hoploscaphites Nowak, 1911, and Discoscaphites MeEk, 1870, occur in West Greenland. The material is abundant and well preserved and is a suitable basis for some phylogenetic and systematic considerations.

NowaK (1911) and ReEside (1927b) reviewed all important preceding theories on the phylogenetic relations of scaphites. Briefly, the 
scaphites were thought to be monophyletic until J. P. Sмгтн (1901) suggested that they were polyphyletic, a point of view maintained in many later works (W. D. Smith, 1905; Pervinquiere, 1907; Yabe, 1910; Nowak, 1911; Spath, 1922a; Reeside, 1927b), although the genera were considered derived in different ways. However, Sратн (1933, p. 427 ; 1931-43, p. 496) suggested that all scaphites originated in the Lytoceratidae and that Scaphites circularis (Sowerby, 1836) (=Eoscaphites Breistroffer, 1947), or closely related forms, from the Lower Cretaceous were ancestral to all scaphites, possibly with the exception of Worthoceras ADkrrs, which might belong to an earlier lytoceratid offshoot.

Spath's point of view has been stated in later works and further confirmed by CoBbar's studies on the evolution of sutures in scaphites from the Western Interior of the United States (1951 a), showing how the trifid lateral lobe of Clioscaphites gradually develops from the bifid lytoceratid lateral lobe of species belonging to the Scaphites ventricosus group.

This is also confirmed by Wiedmans (1962, p. 214, text-fig. 53), who shows that the trifid lateral lobe of early stages of Scaphites aequalis Sowerby (see Pervinquiere, 1907, p. 119, text-fig. 37) actually develops from a bifid lateral lobe. In later stages the lateral lobe of Scaphites aequalis again becomes bifid (see Nown K, 1911, text-fig. 6).

Schindewolf $(1960$, p. 740) also suggests that the scaphites have their origin in the Lytoceratidae, but doubts a direct relationship between Eoscaphites and other scaphites, because Eoscaphites has only a very few suture elements. He suggests that Eoscaphites is an independent offshoot from the Lytoceratidae.

Although it is evident that the scaphites had their origin in the Lytoceratidae, there are still many unsolved problems concerning their evolution and systematics. Only those problems concerning the genera represented in Greenland, and closely related genera, are discussed further here.

Méк (1870, p. 429) established the subgenus Discoscaphites. Among important diagnostic characters he mentions $(1876 \mathrm{a}, \mathrm{p} .415)$ that the body chamber is scarcely free at the aperture in most species and that about four to nine rows of tubercles are developed on each side. Most species referred to the subgenus by Meек (1876a) are multinodose as is the type species $S .(D$.) conradi (Monton), but exceptions occur (S. (D.) nicolletii (Morton) and S. (D.) mandanensis (MorTon)).

Nowak (1911) compared Scaphites aequalis Sowerby, S.tridens (KNer) and $S$. constrictus Sowerby and concluded that they belong to three different evolutionary series, derived from Holcostephanus, Acanthoceras and Hoplites respectively. He established the genus Holcoscaphi- 
tes for Scaphites aequalis and related forms, the genus Acanthoscaphites for Scaphites tridens and related forms and the genus Hoploscaphites for Scaphites constrictus and related forms. The genera were based on differences-partly of doubtful diagnostic value-in cross section, sculpture, and sutures. Even Nowak had doubt about the systematic position of some well known species, referring for example Scaphites nodosus (OWen) to Holcoscaphites in 1911 and to Acanthoscaphites in 1916.

As Scaphites aequalis is the type species of Scaphites Parkinson, Nowak's name Holcoscaphites is invalid.

Nowa (1916) accepted the identity of Scaphites conradi var. intermedius MeEk and Scaphites constrictus Sowerby suggested by Frech (1915a). Also ReEside (1927b) suggested that the relations between MeEk's Discoscaphites and Nowan's Hoploscaphites were close and he consequently used the oldest name, Discoscaphites, for both groups.

Nomenclature aside, ReESIDE (1927b) accepted NowaK's main ideas. In addition to Nowak's genera he included Desmoscaphites ReESIDE, $1927 \mathrm{c}$, which he derived from the Desmoceratidae.

Although, in later works, a monophyletic origin of the scaphites is usually suggested the above mentioned genera are mainly considered valid either on a generic or a subgeneric level.

In his important work on scaphitoid cephalopods of the Colorado Group, Соввал (1951 a) showed some evolutionary lineages (text-figs. 1-2). The evolutionary pattern of these scaphites is of great importance also for the interpretation of the evolution of the younger scaphitoid stocks. The earliest scaphites of the Colorado Group, represented by $S$. delicatulus Warren, are part of a cosmopolitan fauna. Cobban suggests that they descended from some form like Scaphites aequalis SowERBY from the European Cenomanian. The subsequent development in the Western Interior of the United States is distinctly endemic. СовваN indicates several evolutionary lineages. The main line of scaphitoid descent at first shows increase in size, decrease in the density of ribbing and a simplification of the suture. Subsequently, size continues to increase but the suture becomes more complex. Finally there is a decrease in size and simplification of sutures is seen.

More remarkable is the evolution of the shape of the body chamber and the symmetry of the lateral lobe within this main lineage. Thus, the body chamber of all the early forms, from the Greenhorn Limestone and the Carlile Shale, is markedly beyond the phragmocone and has an extremely recurved shape with a small apertural angle. By the beginning of Niobrara time, these scaphites show a tendency to become less unrolled and by late Niobrara time, the dorsum of the adult body chamber is completely in contact with the phragmocone. Simultaneously the apertural angle becomes wider and in late Niobrara time the lateral 
lobe shows an evolution from a more or less symmetrical bifid outline through an asymmetrical phase to a trifid outline (text-fig. 2).

The youngest species within this lineage, with a body chamber entirely in contact with the phragmocone and with an asymmetrical bifid or trifid lateral lobe, are referred by Coвban to the new genus Clioscaphites.

According to CоBBan a new lineage developed from the main stock in late Carlile time. The later representatives of this new lineage have ventrolateral nodes and parallels the main stock in size, in becoming more tightly coiled, in developing a wider apertural angle, and in developing a suture with trifid lobes. Also, within this lineage, scaphites with the above mentioned clioscaphitoid characters are referred to Clioscaphites. Finally this lineage develops into Desmoscaphites, characterized by constrictions on the early whorls.

A third lineage is represented by some small species which gradually develop projections of the lateral margin of the aperture. By early Niobrara time they have prominent lateral lappets. Late representatives of this group, from late Niobrara time, have a trifid lateral lobe. This lineage shows no tendency to tighter coiling, but the apertural angle gradually becomes wider. Representatives of this lineage have been referred to the genus Pteroscaphites by Wright (1953).

The status of the stratigraphically younger genera Acanthoscaphites, Discoscaphites and Hoploscaphites is still uncertain. In some works the genera Hoploscaphites and Discoscaphites are thought to be congeneric (as by Reeside, 1927b), in others, for example Spath (1953) and Wright (1953, 1957), both genera are considered valid. Cobban \& ReEside (1952, p. 1028) mentioned the difficulties regarding the use of the names Discoscaphites and Acanthoscaphites, and, because too little is known concerning the evolution of the scaphites in the Campanian and Maastrichtian, Соввал \& Jeletzky (in press) interpret the genus Scaphites in a broad sense and Hoploscaphites on a subgeneric level.

The genus Acanthoscaphites Nowak, 1911, was primarily based on Scaphites tridens (KNER) and closely related subspecies or variants. The Scaphites tridens group, which occurs in the Maastrichtian of Europe, differs from other scaphites in the shape of the body chamber, ribbing pattern and often in having a median row of tubercles on the ventral side of the body chamber. Nowak $(1911,1916)$ referred several other species to that genus, for example Scaphites nodosus, Owen (in 1916) and "S. roemeri" D'OrbignY, but none of these species seem to be closely related to the Scaphites tridens group. I prefer, as JELETzKy in CoBbaN \& ReESIDE (1952, p. 1027), to restrict that genus to the Acanthoscaphites tridens group. The origin of this group is uncertain. 
It is difficult to distinguish early representatives of the Scaphites nodosus group from Scaphites s. s. on a generic or a subgeneric level. However, during the Upper Campanian a rapid evolution took place within this group. Thus, a tendency to develop a more tightly coiled shell and a wider apertural angle can be seen just as in the main lineages of the Coloradoan scaphites described by Coвban. Comparison of early representatives of the Scaphites nodosus group from Greenland (pl. 2023), with late representatives of that group as figured by MEEK (1876a, pl. 25-26) evidently shows this evolutionary tendency. Changes in shape were accompanied by changes in the tubercle pattern. Thus, early forms have ventrolateral nodes and umbilical nodes on the body chamber and youngest chambers of the phragmocone only, later the two rows become more extensive on the phragmocone and finally some species developed lateral nodes in addition to the umbilical and ventrolateral nodes-as in Discoscaphites described by МЕЕк. Also by becoming more compressed, and by acquiring more flexuous ribs, some of the later representatives of this group gradually become similar to Discoscaphites species, whereas others retain a depressed cross section.

Thus, it is obvious that at least some of the Discoscaphites species developed from the Scaphites nodosus group (Dr. W. A. CoBbar, pers. comm.; Jeletzky in Cobban \& Reeside, 1952) and that the discoscaphites are representatives of late stages of one or more evolutionary lineages, characterized by a rather compressed shape, usually a tightly coiled shell, a wide apertural angle, flexuous ribs and often by having many rows of lateral tubercles.

Scaphites constrictus, the type species of the genus Hoploscaphites Nowak, is similar to some species of Discoscaphites in being rather compressed, in having the body chamber only slightly extended beyond the phragmocone, in having a wide apertural angle, and in having flexuous ribs. It differs from most species of Discoscaphites in the absence of lateral nodes.

"Scaphites roemeri" sensu Schlüter was referred by NowaK and many later authors to the genus Acanthoscaphites, but a study of $S c a-$ phites greenlandicus Donovan (which is closely related to "S.roemeri" sensu SchlütER) convinced me (1958) that these forms were much more closely related to Scaphites consirictus and I thus referred these species to Hoploscaphites. CoBBan \& JELETzKy (in press) also refer these to Hoploscaphites, but on a subgeneric level. It is likely that the Scaphites constrictus group was derived from the finely ribbed Upper Campanian Hoploscaphites.

The ancestors of "S. roemeri" sensu SchLÜTER and related forms (S. (H.) ikorfatensis n. sp., $S .(H$.$) raoni n. sp., S .(H$.$) greenlandicus$ 
Donovan, $S .(H$.$) gilli Cobban \& Jeletzky) from the Upper Campanian$ are uncertain. It seems probable that they were derived from the same ancestors as the Scaphites nodosus group. The hoploscaphites were distinct much earlier than the discoscaphites and I am inclined to suggest that Hoploscaphites represents one or more lineages derived from the scaphites about the beginning of the Upper Campanian and in many respects showing an evolution parallel to Discoscaphites. Because of the parallel evolution it is difficult to distinguish between the two groups. The type of Discoscaphites, Scaphites conradi (MonToN), and that of Hoploscaphites, Scaphites constrictus Sow RBвY, show distinct differences in tubercle pattern, $S$. conradi having many rows of nodes and $S$. constrictus having only a ventrolateral and an umbilical row of nodes. Other species, however, which show intergradation with typical multinodose Discoscaphites, and certainly belonging to that plexus (described p. 116), may be difficult to distinguish from Hoploscaphites because of the absence of lateral nodes. As specimens belonging to the very same species or species-group have to be referred to different genera if the presence or absence of lateral rows of nodes is used diagnostically, I refer all species which are evolutionarily closest to the type of Discoscaphites, to that genus, even when lateral rows of nodes are missing (for example $S$. mandanensis, S. nicolletii and species from Greenland). From a practical point of view, this solution is not quite satisfactory, as it may be diffcult to refer imperfectly known species to the correct group and further investigations may show the justice of referring both groups to the same genus.

Until more is known on the evolution of the scaphites, the genus Scaphites must be interpreted in a broad sense as a plexus of lineages of uncertain status. During the evolution of the scaphites, offshoots with certain diagnostic characters appear, for example Pteroscaphites Wright, Clioscaphites CobBan, Desmoscaphites Reeside, Trachyscaphites СоввAN and Acanthoscaphites Nowak. These are interpreted on a generic level. The genus Clioscaphites is, according to CoBbaN (1951 a), polyphyletic in the sense that the species are derived from contemporary related species. This may also be the case with some of the other genera. I do not consider the morphological differences between Hoploscaphites and Discoscaphites sufficiently marked to justify separate generic status and I prefer to treat them as subgenera of Scaphites.

The relations between representatives of the Scaphites ventricosus group, the Scaphites nodosus group, Hoploscaphites and Discoscaphites are indicated in text-figs. 57-71, showing the ontogeny of cross section, sculpture and sutures in these groups.

It can be seen from the figured cross sections that in all these groups the early whorls are depressed and rounded. The later whorls 

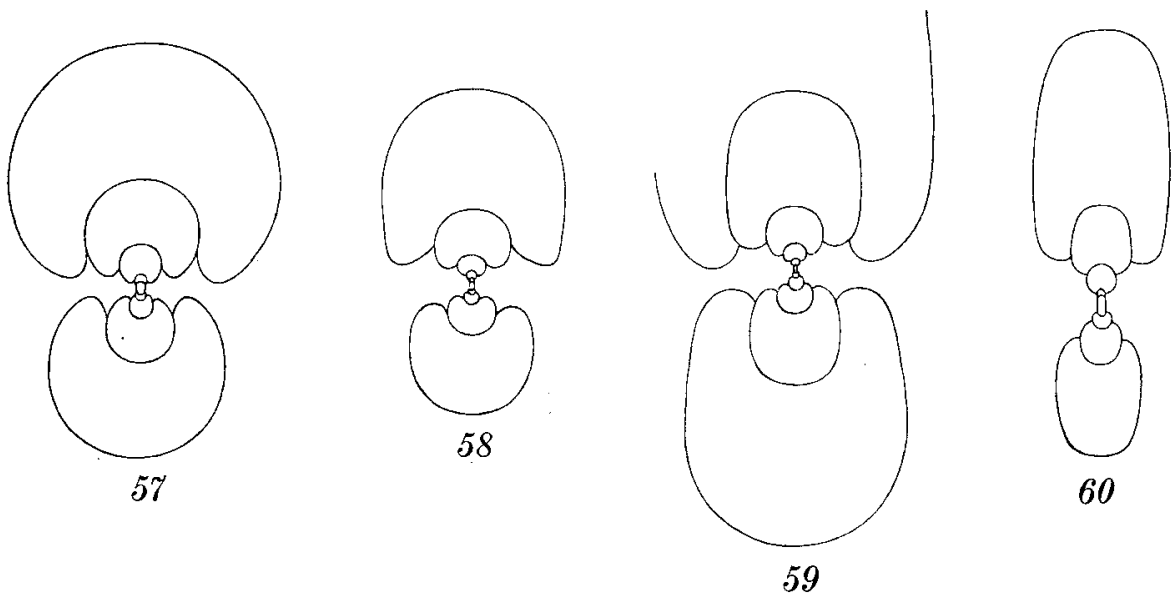

Figs. 57-60. Cross sections of phragmocones.

57. Scaphites mariasensis umivikensis n.subsp. MMH No. 9899. $\times 1$. Coniacian. The ammonite locality at Umîvik.

58. Scaphites rosenkrantzi n.sp. MMH No. 9900. $\times 1$. Lower Campanian (upper part). Scaphitesnæsen, $538-540 \mathrm{~m}$ above sea-level.

59. Scaphites (Hoploscaphites) ikorfatensis n.sp. MMH No.9901. $\times 1$. Upper Campanian (upper part). Brudkløft at Ikorfat, $550 \mathrm{~m}$ above sea-level.

60. Scaphites (Discoscaphites) angmartussutensis n.sp. MMH No.9902. $\times 1$. Maastrichtian. Oyster-ammonite Conglomerate loc. I.

are still depressed in the Scaphites ventricosus group. In the Scaphites nodosus group the youngest part of the phragmocone may be compressed and in Hoploscaphites and Discoscaphites more of the phragmocone is compressed.

The innermost whorls are smooth in all the groups. On the third whorl rounded ribs gradually appear, first laterally and then ventrally, and intercalated ribs are developed. The early ribs always form a weak projection laterally, later ribs are straight or nearly straight in the Scaphites ventricosus group and in early representatives of the Scaphites nodosus group, whereas they are more flexuous in the stratigraphically younger groups (Hoploscaphites and Discoscaphites), where they form lateral and ventral projections. The ventral projection is most pronounced in Discoscaphites.

It can be seen from text-figs. 68-71 that the ontogeny of the sutures of the Scaphites nodosus group, Hoploscaphites and Discoscaphites is very similar. In the late ontogeny of Hoploscaphites and Discoscaphites the sutures are more incised than those of stratigraphically early Scaphites nodosus forms and show a tendency to acquire a more asymmetric lateral lobe and a narrower second lateral saddle.

The basis on which species may be diagnosed, is first and foremost the morphological characters of the younger part of the phragmocone 


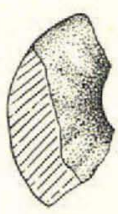

$61 a$

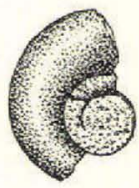

62

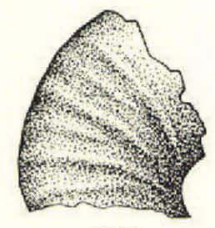

$61 b$

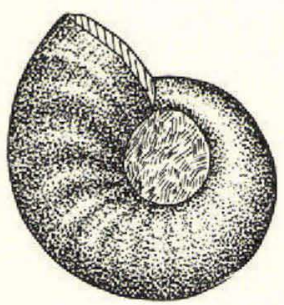

$63 a$

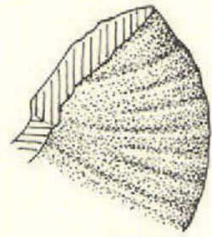

$61 c$

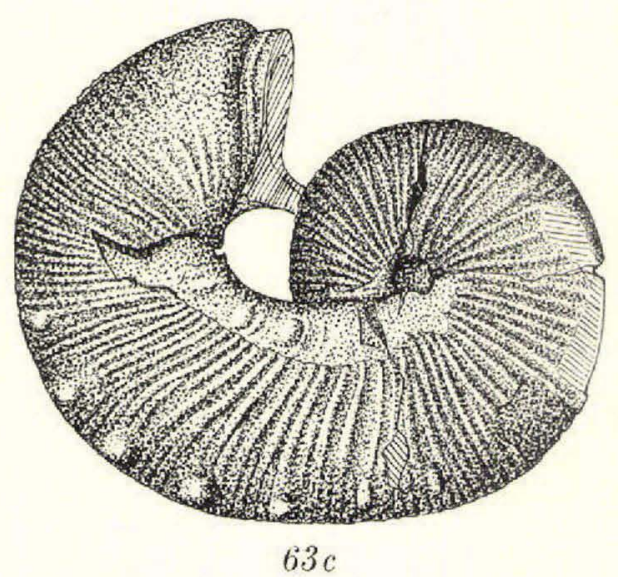

Figs. 61-63. Ontogeny of sculpture.

61. Scaphites sp. belonging to the Scaphites ventricosus group. MMH No. 9903. $a, b, \times 3 ; c, \times 2$. Coniacian. The ammonite locality at Umîvik.

62. Scaphites cobbani n.sp. MMH No. 9904. $\times 10$, innermost smooth whorls, Lower Campanian (upper part). Scaphitesnæsen, 539-540 m above sea-level.

63. Scaphites cobbani n.sp. MMH No. 9905. $a, \times 4 ; b, \times 2 ; c, \times 1$. Lower Campanian (upper part). Scaphitesnæsen; $538 \mathrm{~m}$ above sea-level.

and the mature body chamber. The shape of the body chamber, both in side view and in ventral view, is one of the most significant characters. The rate of curvature of the terminal hook of the body chamber is indicated by the size of the apertural angle (pl. 17, fig. 1a). The angle may vary up to $25^{\circ}$ within one species.

It is noticeable that at four distinct horizons in the Upper Cretaceous of West Greenland pairs of species or subspecies occur together. 

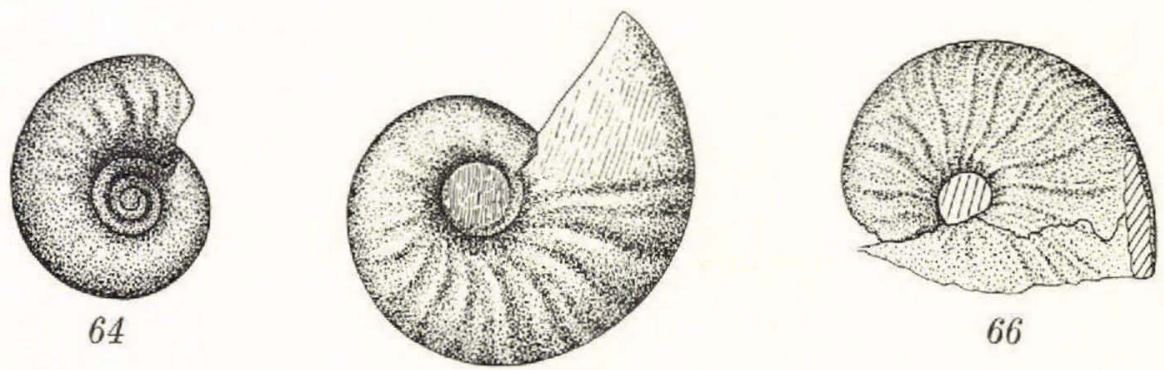

66

65

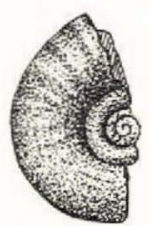

$67 a$
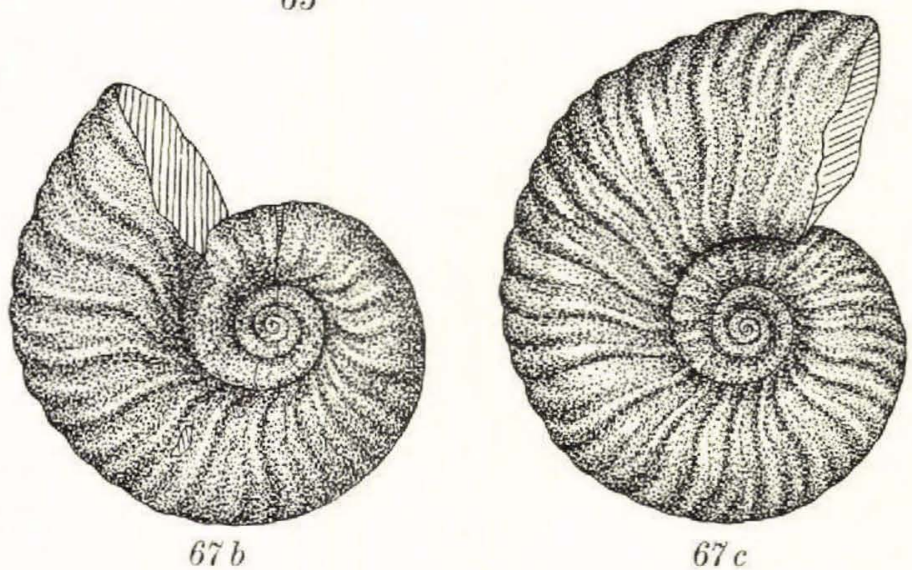

Figs. 64-67. Ontogeny of sculpture.

64-66. Scaphites (Hoploscaphites) greenlandicus Dovovis. Upper Campanian (upper part). Niaqornat.

64. MMH No. 9906. ×4.

65. MMH No. 1743. ×3. Figured by Ravn, 1918, pl. 8, fig. 18 .

66. ММH No. $9907 . \times 2$.

67. Scaphites (Discoscaphites) waagei n.sp. MMH No. 9908, $a, b, \times 4 ; c, \times 2$. Maastrichtian. Oyster-ammonite Conglomerate loc. I.

These pairs comprise a somewhat more inflated form and a more slender form. In the Coniacian at Umivik the more inflated Scaphites mariasensis umisikensis $\mathrm{n}$. subsp. occurs together with the more slender $S$. preventricosus spartenhukensis $\mathrm{n}$. subsp. In the same way in the Campanian at Scaphitesnæsen $S$. rosenkrantzi n. sp. occurs with $S$. cobbani n. sp. and at Ikorfat $S$. (Hoploscaphites) ikorfatensis n. sp. occurs with $S$. (H.) ravni n. sp. Again in the Maastrichtian, in the Oyster-ammonite Conglomerate, $S$. (Discoscaphites) angmartussutensis n. sp. occurs with $S$. (D.) waagei $\mathrm{n}$. sp. Although there are these repeated associations of scaphites with body chambers of different shapes I do not consider them to be sexual dimorphs of single taxa but distinct species or subspecies. The differences in the shapes of the body chambers correlate with other distinctive characters and intermediate forms occur only very rarely. 

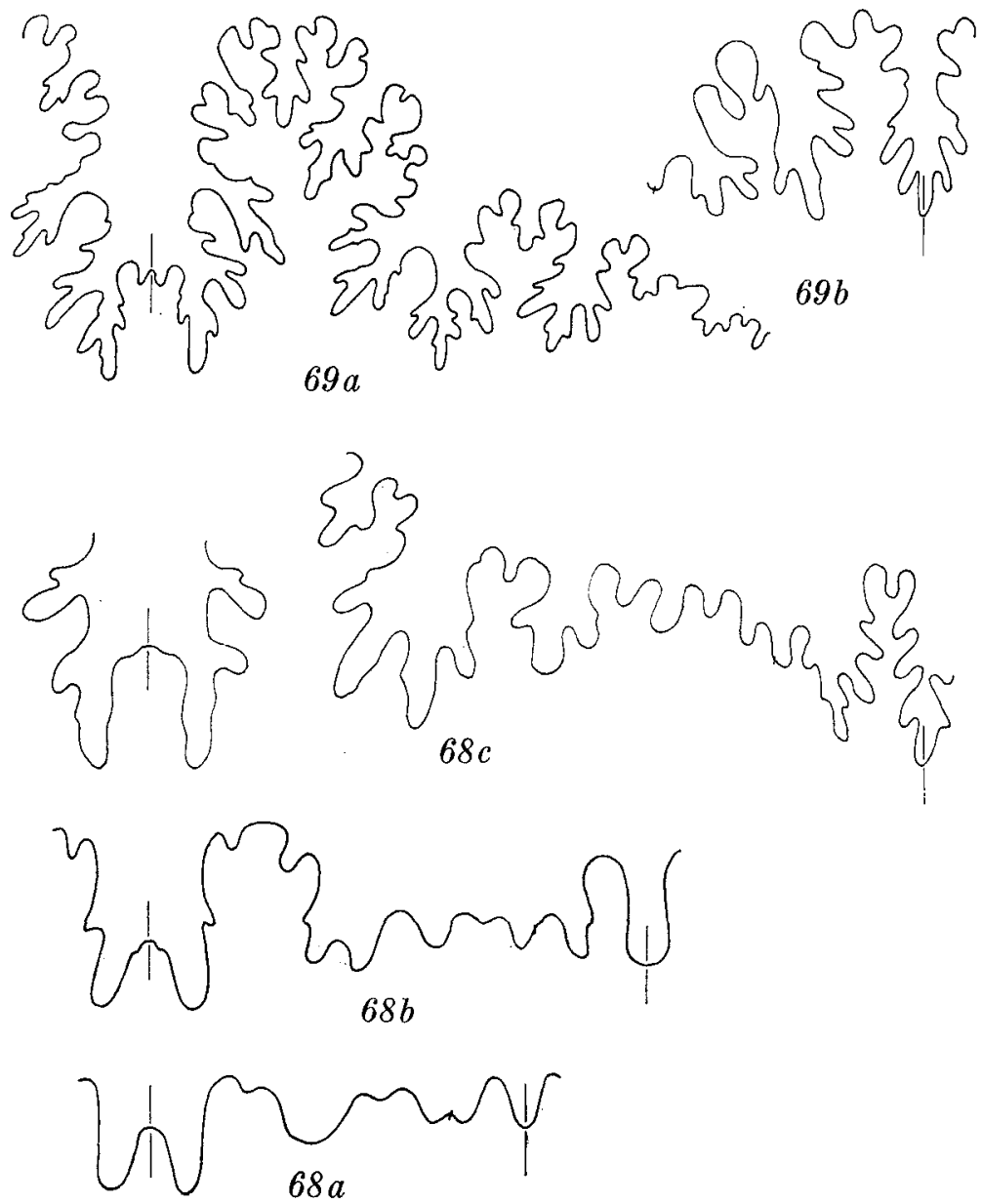

Figs. 68-69. Ontogeny of sutures in representatives of the Scaphites nodosus group. Lower Campanian (upper part).

68. Scaphites rosenkrantzi n.sp. MMH No. 9909. $a, \times 30$, at a whorl height of $0.9 \mathrm{~mm} ; b, \times 30$, at a whorl height of $1.3 \mathrm{~mm} ; c, \times 16$, at a whorl height of $2.4 \mathrm{~mm}$. Scaphitesnæsen.

69. Scaphites cobbani n.sp. MMH No. 9905. a, $\times 4$, external suture at a whorl height of $12.2 \mathrm{~mm} ; b, \times 4$, internal suture at a whorl height of $16.2 \mathrm{~mm}$. Scaphitesnæsen, $538 \mathrm{~m}$ above sea-level.

In mature specimens of the species described here, the last suture crosses the umbilical wall $0-10 \mathrm{~mm}$ from the adapical part of the umbilicus. The direction of the last suture varies slightly in some species (for example less than $5^{\circ}$ in $S$. cobbani n. sp.), but there is a wider range in other species (for example up to $50^{\circ}$ in $S .(D$.) angmartussutensis $\mathrm{n}$. sp.). The angle between the last suture and the long axis of the shell 

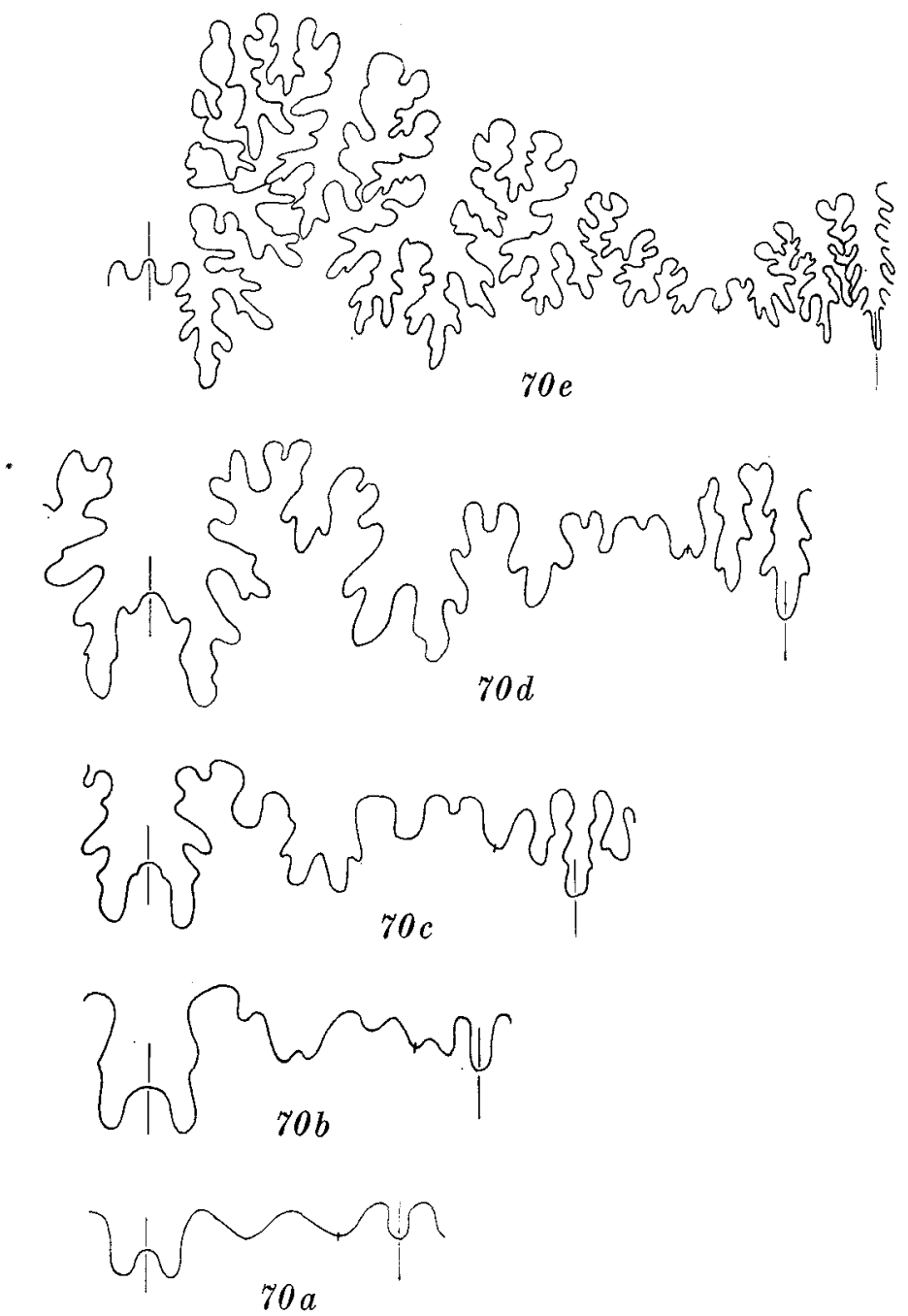

Fig. 70. Ontogeny of sutures in Scaphites (Hoploscaphites) sp. MMH No. 9910. $a, \times 40$, at a whorl height of $0.6 \mathrm{~mm} ; b, \times 30$, at a whorl height of $0.8 \mathrm{~mm} ; c, \times 16$, at a whorl height of $1.5 \mathrm{~mm} ; d, \times 16$, at a whorl height of $2.4 \mathrm{~mm} ; e, \times 4$, at a whorl height of $11.2 \mathrm{~mm}$. Upper Campanian (upper part). Brudkløft at Ikorfat.

tends to be very wide in late stages of some evolutionary lineages, for example in Clioscaphites and Discoscaphites. This angle may also be wider in species with an inflated body chamber than in closely related species with a more slender body chamber and may thus in certain cases have some systematic value.

The shape of the aperture may be an important generic or subgeneric character, but is less significant for species identification. 

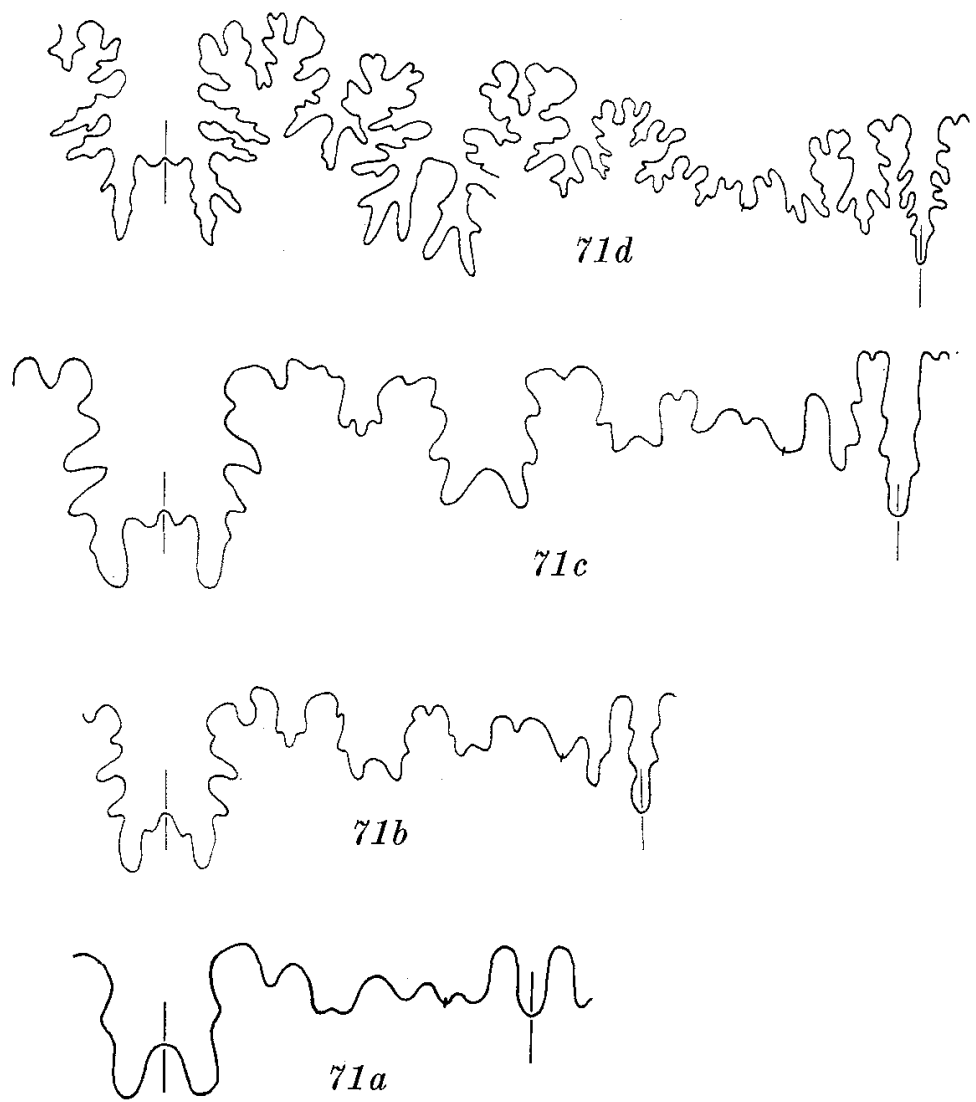

Fig. 71. Ontogeny of sutures in Scaphites (Discoscaphites) waagei n.sp. MMH No. 9911. $a, \times 30$, at a whorl height of $0.9 \mathrm{~mm} ; b, \times 16$, at a whorl height of $1.7 \mathrm{~mm}$; $c, \times 16$, at a whorl height of $2.6 \mathrm{~mm} ; d, \times 4$, at a whorl height of $11.7 \mathrm{~mm}$. Maastrichtian. Oyster-ammonite Conglomerate loc. I.

The ribbing pattern of the exposed shell has great systematic value, partly on a generic level, and partly on a species level, although it may show a rather wide individual variation.

The development of tubercles also shows a wide range of individual variation, especially in species from the Campanian and Maastrichtian. In some cases the tubercle pattern gradually changes during evolution. Although some species groups may be characterized by a particular tubercle pattern, in most cases it is difficult to use this as the basis of generic diagnosis. In the discoscaphites especially there is a wide range of variation-from forms with many rows of nodes on the entire shell to forms with a few ventrolateral nodes on the body chamber.

On a species level the systematic value of the sutures is rather restricted, especially within the Scaphites nodosus group, Hoploscaphites 
and Discoscaphites, but they may, in the complexity and symmetry of the lobes, show some diagnostic features.

Text-figs. 87, 97 and 109 show aptychi of representatives of the S. nodosus group, Hoploscaphites and Discoscaphites. No diagnostic differences can be seen.

\section{Genus $S C A P H I T E S$ Parkinson, 1811 \\ Subgenus SCAPHITES Parkinson, 1811}

syn. Anascaphites Hy AтT, 1900.

Jahnites Hy AтT, 1900.

Yezoites YABE, 1910.

Holcoscaphites Nowa , 1911.

Type species. Scaphites aequalis Sowerby, 1813.

Emended diagnosis. Scaphites with involute phragmocone and scaphitoid body chamber with a rather long shaft and a very recurved hook; umbilical ratio decreases with increasing age; aperture constricted and commonly collared, in some with a long dorsal lappet touching the phragmocone; early whorls depressed, later whorls depressed or slightly compressed; surface with branching or intercalated, straight or nearly straight ribs; ventrolateral, umbilical and lateral rows of tubercles may be present on body chamber and occasionally on parts of phragmocone; suture with a bifid lateral lobe and a bifid or trifid first auxiliary lobe.

\section{Scaphites (Scaphites) ef. corvensis CoBBar, 1961} Pl. 18, fig. 1; text-fig. 72.

1951 a Scaphites corvensis Coвban, p. 26, pl. 7, figs. 6-10.

1951 b Scaphites corvensis СовваN: Соввал, p. 2189, 2197.

1952 Scaphites corvensis СовваN: СовваN \& Reeside, chart 10 B.

Holotype. U. S. Nat. Mus. catalogue No. 106755. Figured by Coвbax, $1951 \mathrm{a}$, pl. 7, figs. 6-10. From the Cody Shale, $180 \mathrm{~m}$ above the base of the Carlile Shale Member, 33 miles south of Hardin, on the Crow Indian Reservation, Big Horn County, Montana. Upper Turonian.

Material. Svartenhuk: one derived specimen, a nearly complete body chamber, from Store Tange V Kløft, $60 \mathrm{~m}$ above sea-level, and one derived phragmocone possibly belonging to the same species from the same locality, $20 \mathrm{~m}$ above sea-level.

Measurements.

\begin{tabular}{|c|c|c|c|c|}
\hline $\begin{array}{l}\text { Length } \\
\text { of body } \\
\text { chamber }\end{array}$ & $\begin{array}{c}\text { Whorl height } \\
\text { at last } \\
\text { suture }\end{array}$ & $\begin{array}{c}\text { Whorl width } \\
\text { at last } \\
\text { suture }\end{array}$ & $\begin{array}{l}\text { Maximum } \\
\text { height of } \\
\text { body chamber }\end{array}$ & $\begin{array}{l}\text { Whorl width } \\
\text { at aperture }\end{array}$ \\
\hline $57 \mathrm{~mm}$ & c. $21 \mathrm{~mm}$ & c. $21 \mathrm{~mm}$ & $28 \mathrm{~mm}$ & $22.7 \mathrm{~mm}$ \\
\hline
\end{tabular}




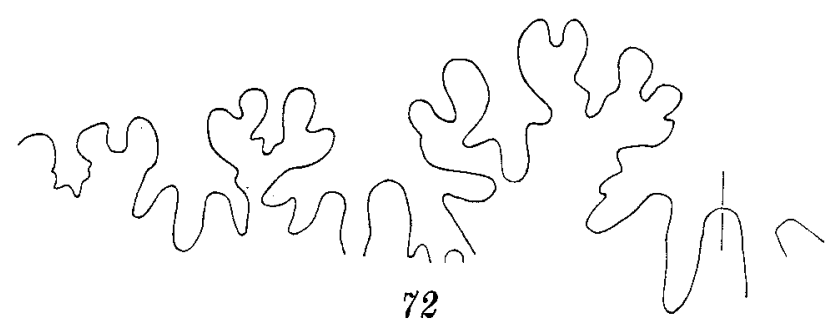

Fig. 72. Scaphites cf. corvensis Cоввал? MMH No. 9912. $\times 4$, external suture at a whorl height of about $17 \mathrm{~mm}$. Store Tange V Kløft, $20 \mathrm{~m}$ above sea-level.

Description. It is evident from the shape of the body chamber that it extended considerably beyond the phragmocone. The apertural angle is $65^{\circ}$. The straighter part is slightly compressed, possibly because it has been crushed laterally. Maximum whorl height is at the middle of the body chamber, and the whorl width does not vary from the last suture to the aperture.

The body chamber has 20 primary ribs and 65 equally spaced ventral ribs. On the straighter part of the body chamber the secondary ribs are visible only ventrally and ventrolaterally close to the venter. Closer to the aperture the secondary ribs are longer and some extend nearly to the umbilical wall.

A phragmocone, possibly referable to this species, has simple sutures, figured text-fig. 72 . The lobes are rather wide and decrease evenly in size. The first auxiliary lobe is trifid.

Affinities. The body chamber shows close affinity with Scaphites corvensis Соввал in size, shape and ribbing. It seems to be slightly more compressed, but that may be due to crushing. It has also a greater number of primary ribs, in relation to ventral ribs, than the type specimen of $S$.corvensis, which has 15 primaries and 67 ventral ribs. The range of variation in ribbing of $S$. corvensis is poorly known because material is rare, and the difference between the type and the specimen from Greenland may fall within the normal range of variation.

The phragmocone, which may belong to this species, is very similar to $S$.corvensis in shape, whorl ratio, and sculpture. The suture is of similar complexity but it has wider lobes.

Scaphites nigricollensis Соввал (1951 a, p. 25, pl. 6, figs. 1-17; pl. 7 , figs. 1-5) is closely related to $S$. corvensis. The body chamber of the Greenland specimen differs from that of $S$. nigricollensis in its distinct ribbing of the internal cast, in its ribbing pattern and in having no swelling at the base of the body chamber. The phragmocone differs in shape, having more depressed whorls, but the sutures are very similar to those of $S$.nigricollensis both in complexity and in the width of the lobes. 
Stratigraphy. Cobban (1951 b) and Cobban \& Reesine (1952) used Scaphites corvensis as an index fossil for the uppermost zone of the Upper Turonian in the Western Interior of the United States. The species is not known from other areas. The fragments from Store Tange V Kløft may indicate the presence of Turonian marine deposits in West Greenland.

\section{Scaphites (Scaphites) mariasensis Coввал, 1951} umivikensis n. subsp.

Pl. 17, fig. 1; text-figs. 57, 73-74.

? 1942 Scaphites ventricosus MeEK \& HAYden var. stantoni ReESIDE: Rosenk RANTZ, p. 38 , pl. 1, figs. 1-3.

Holotyp e. MMH No. 9788. Figured pl. 17, fig. 1, text-fig. 73. From the ammonite locality at Umîvik, Svartenhuk. Coniacian.

Diagnosis. Scaphites of large size with body chamber extending only slightly beyond phragmocone; whorl section depressed and rounded; middle part of body chamber very stout; apertural angle about $80^{\circ}$; surface with rather widely spaced ribs, on exposed whorls $2-3$ ventral ribs to each primary; suture rather complicated, lateral lobe symmetrically bifid, wide, and of similar depth as the ventral lobe, first auxiliary lobe asymmetrically trifid.

Material. One complete specimen, two rather well preserved specimens, about 40 determinable fragments from the ammonite locality at Umivik, and some fragments from the beach and the river beds on the south coast of Umîvik bay, Svartenhuk.

Measurements.

Specimen figured text-fig. 57.

\begin{tabular}{ccc} 
Whorl height & Whorl width & W/H \\
$2.2 \mathrm{~mm}$ & $2.4 \mathrm{~mm}$ & 1.09 \\
$4.0-$ & $4.4-$ & 1.10 \\
$6.3-$ & $7.3-$ & 1.16 \\
$10.0-$ & $11.7-$ & 1.17 \\
$16.1-$ & $?$ & $?$ \\
$24.1-$ & $27.6-$ & 1.15 \\
\multicolumn{3}{r}{$180^{\circ}$} \\
between the measurements.
\end{tabular}

Whorl ratios of 3 body chambers.

\begin{tabular}{|c|c|c|c|c|c|c|c|c|}
\hline \multirow{4}{*}{$\begin{array}{l}\text { Holo- } \\
\text { type }\end{array}$} & $\begin{array}{l}\text { Whorl } \\
\text { height } \\
\text { at } \\
\text { last } \\
\text { suture }\end{array}$ & $\begin{array}{l}\text { Whorl } \\
\text { width } \\
\text { at } \\
\text { last } \\
\text { suture }\end{array}$ & $\begin{array}{c}\mathrm{W} / \mathrm{H} \text { at } \\
\text { last } \\
\text { suture }\end{array}$ & $\begin{array}{c}\text { Maximum } \\
\text { whorl } \\
\text { height } \\
\text { of body } \\
\text { chamber }\end{array}$ & $\begin{array}{l}\text { Maximum } \\
\text { whorl } \\
\text { width } \\
\text { of body } \\
\text { chamber }\end{array}$ & $\begin{array}{l}\text { Whorl } \\
\text { height } \\
\text { at } \\
\text { aper- } \\
\text { ture }\end{array}$ & $\begin{array}{l}\text { Whorl } \\
\text { width } \\
\text { at } \\
\text { aper- } \\
\text { ture }\end{array}$ & $\begin{array}{l}\mathrm{W} / \mathrm{H} \text { at } \\
\text { aperture }\end{array}$ \\
\hline & c. $35 \mathrm{~mm}$ & c. $41 \mathrm{~mm}$ & ? & $40 \mathrm{~mm}$ & $47 \mathrm{~mm}$ & $26 \mathrm{~mm}$ & $37 \mathrm{~mm}$ & 1.42 \\
\hline & $36-$ & $43-$ & 1.20 & $41-$ & $48-$ & $?$ & $?$ & $?$ \\
\hline & 31 & 36 & 1.16 & $39-$ & $41-$ & $?$ & $?$ & $?$ \\
\hline 179 & & & & & & & & 6 \\
\hline
\end{tabular}



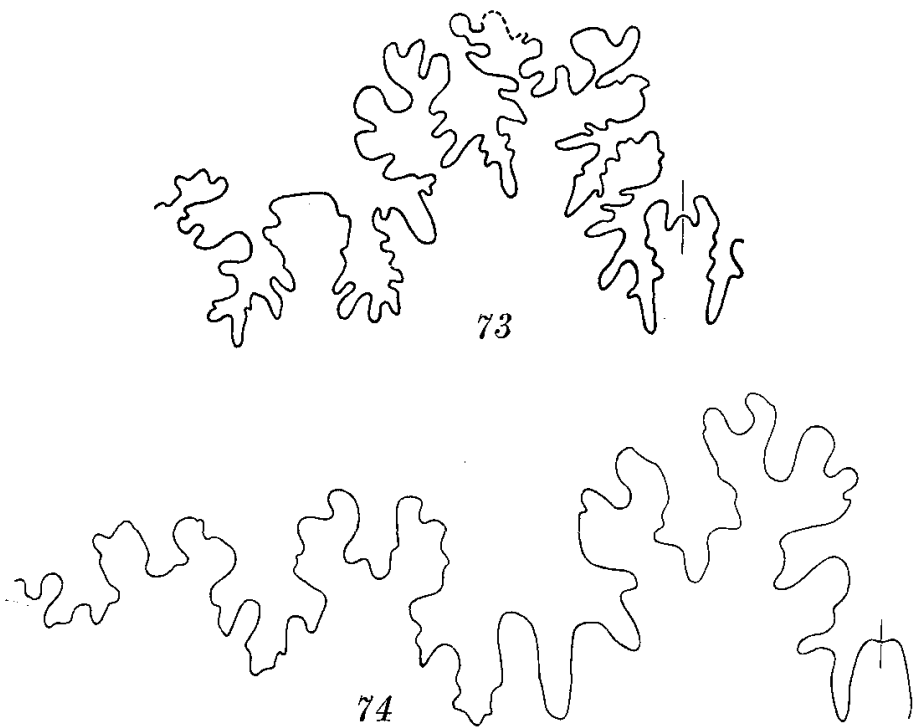

Figs. 73-74. Seaphites mariasensis umivikensis n.subsp. The ammonite locality at Umîvik.

73. Holotype. MMH No. 9788. $\times 3$, part of the external suture at a whorl height of $18 \mathrm{~mm}$.

74. MMH No.9913. $\times 2$, eroded external suture at a whorl height of about $25 \mathrm{~mm}$.

Description. All the specimens seem to be mature. There is little variation in size, the smallest being about $75 \mathrm{~mm}$ long, the largest $97 \mathrm{~mm}$. The umbilicus has an external diameter of about $4 \mathrm{~mm}$.

The whorl section of the phragmocone is slightly depressed and rounded. The body chamber extends only slightly beyond the phragmocone. The last suture in mature specimens forms an angle of $150^{\circ}$ $170^{\circ}$ with the long axis of the shell. In side view the venter of the body chamber forms a subcircular curve, whereas the umbilical wall of the older part of the body chamber is straight. The apertural angle is about $80^{\circ}$. The body chamber is extremely inflated, whorl height and width rapidly increase up to the middle and then quickly decrease to the aperture. Small specimens are less inflated than larger ones. The body chamber is slightly depressed from the last suture to about where the umbilical wall begins to curve, from there to the aperture it gradually becomes more depressed.

The sculpture of the inner whorls is poorly known. Specimens from the same locality, but not definitely determinable, show that lateral ribs appear at a whorl height of about $2 \mathrm{~mm}$. These ribs are weak and blunt, gradually becoming sharper, extending across the venter, and secondaries are intercalated. On the exposed part of the shell the sculpture consists of straight, high, rather sharp ribs, which may bifurcate, 
trifurcate or be intercalated. The secondary ribs are visible on about $2 / 3$ of the sides of the uncoiled part of the body chamber, on other parts of the exposed shell they extend nearer to the umbilical wall. The ventral ribs on the body chamber are almost equally spaced. The exposed whorls of the holotype show 31 primary and 76 ventral ribs of which about 17 primaries and about 44 ventral ribs are visible on the body chamber. The ribbing of the other specimens is very similar to that of the holotype except for a few which have slightly finer ribs. The specimen with the most closely spaced ribs has 29 primaries and 85 ventral ribs on the exposed shell of which 16 primaries and 50 ventral ribs are visible on the body chamber. The length of this specimen is $80 \mathrm{~mm}$.

In one specimen a rather well preserved suture is visible, the other specimens have only eroded sutures. The well preserved suture (text-fig. 73 ) is rather complex; the ventral lobe and the lateral lobe are of equal depth with large median minor saddles, the lateral lobe is extremely wide and symmetrically bifid and the first auxiliary lobe is much smaller and asymmetrically trifid.

Affinities. The specimens show close affinity with Scaphites mariasensis Cobban, $1951 \mathrm{a}$. The type of that species (Cobban, $1951 \mathrm{a}$, pl. 8, figs. 14-17) falls within the range of size variation of adult specimens from Greenland, equalling the smallest ones in size. The range of size variation of $S$. mariasensis is unknown because material is scarce. No differences in the shape of the shells have been noticed, and the ribbing of the holotype is extremely similar to that of the finer ribbed specimens from Greenland. The only distinct difference is in the sutures, the specimens here described having much more incised sutures with a deeper lateral lobe. Because of the difference in suture pattern the material is referred to a new subspecies. The difference may be a result of geographical speciation or be explained by a slight difference in age.

Stratigraphy. According to Cobsan (1951 a, 1951b) and Cobban \& REesIDE (1952) Scaphites mariasensis occurs in Montana in the Colorado Shale in beds referred to the lowermost Coniacian (Inoceramus erectus Zone). It occurs also in Alberta at a similar horizon (JeLEtSKY in Sтотт, 1961). It is a typical endemic species of the Western Interior of North America and of connected Arctic Seas.

\section{Scaphites (Scaphites) preventicosus Соввал, 1951 svartenhukensis n. subsp.}

Pl. 16, fig. 3; pl. 18, figs. 2-3; pl. 19, fig. 1; text-figs. 75-77.

Holotype. MMH No.9791. Figured pl. 18, figs. 3a-c, text-fig. 76. From the ammonite locality at Umîvik, $2 \mathrm{~m}$ above sea-level, Svartenhuk. Coniacian. 
Diagnosis. Scaphites of moderately large size; body chamber extending markedly beyond the phragmocone; whorl section depressed and rounded except for straighter part of body chamber which is subquadrangular; height of body chamber slowly decreases and width slowly increases from last suture to aperture; apertural angle $70^{\circ}-80^{\circ}$; surface with rather widely spaced ribs, 2-3 ventral ribs to each primary on exposed whorls; suture rather complicated, lateral lobe asymmetrically bifid, rather wide, and slightly deeper than ventral lobe, first auxiliary Iobe asymmetrically trifid or bifid.

Material. One complete specimen, three rather well preserved specimens, about 60 determinable fragments from the ammonite locality at Umivik and some fragments from the beach and the river beds on the south coast of Umîvik bay, Svartenhuk.

Measurements.

Whorl ratios of two body chambers.

$\begin{array}{lccccccc}\text { Whorl } & \text { Whorl } & \text { W/H } & \begin{array}{c}\text { Whorl } \\ \text { height }\end{array} & \begin{array}{c}\text { Whorl } \\ \text { width }\end{array} & \text { Whorl } & \text { Whorl } & \text { W/H } \\ \text { height } & \text { width } & \text { at } & \text { at } & \text { at } & \text { height } & \text { width } & \text { at } \\ \text { at last } & \text { at last } & \text { last } & \text { middle } & \text { middle } & \text { at } & \text { at } & \text { aper- } \\ \text { suture } & \text { suture } & \text { suture } & \text { of body } \\ \text { ch body } & \text { aper- } & \text { aper- } & \text { ture } \\ & & & \text { chamer chamber } & \text { ture } & \text { ture } & \\ 30 \mathrm{~mm} & 31 \mathrm{~mm} & 1.03 & 29 \mathrm{~mm} & 33 \mathrm{~mm} & 26 \mathrm{~mm} & 33 \mathrm{~mm} & 1.27 \\ 28- & 31- & 1.11 & 28- & 32- & 23- & ? & ?\end{array}$

Description. All specimens are apparently mature and some are slightly larger than the holotype. The range in length is small, from about $60 \mathrm{~mm}$ to about $85 \mathrm{~mm}$. The umbilicus has an external diameter of $3-4 \mathrm{~mm}$.

The whorl section of the innermost whorls is unknown. At a whorl height of $0.8-3 \mathrm{~mm}$ the section is nearly circular, whorl height and width being equal. The younger part of the phragmocone is slightly depressed and evenly rounded except for the youngest exposed part which is slightly flattened ventrally.

The body chamber extends greatly beyond the phragmocone. In mature specimens the last suture forms an angle of $90^{\circ}-120^{\circ}$ with the long axis of the shell. In side view the venter of the body chamber forms a curve similar to that of the umbilical wall, the whorl height decreasing only slightly from the last suture to the aperture. The apertural angle is $70^{\circ}-80^{\circ}$. The whorl width of the body chamber increases slightly from the last suture to the aperture. Thus, the apertural part of the body chamber is more depressed than the older part.

On the exposed part of the shell the sculpture consists of straight, high, sharp or somewhat rounded ribs, which may bifurcate, trifurcate, or 

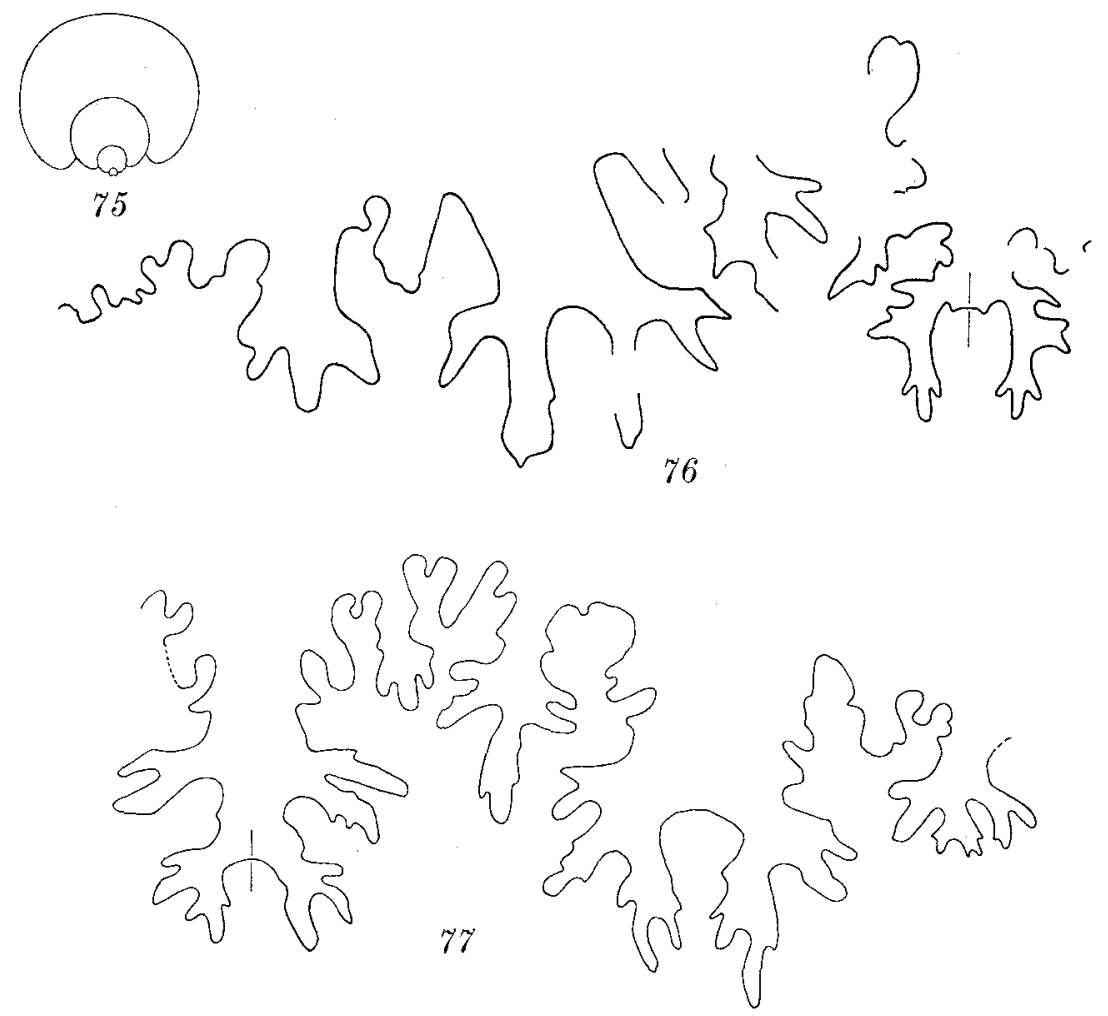

Figs. 75-77. Scaphites preventricosus umivikensis n.subsp. The ammonite locality at Umivik.

75. MMH No. $9914 . \times 1$, cross section of phragmocone.

76. Holotype. MMH No. 9791. $\times 3$, eroded external suture at a whorl height of about $27 \mathrm{~mm}$.

77. MMH No. 9915. $\times 3$, external suture at a whorl height of about $29 \mathrm{~mm}$.

be intercalated. Secondary ribs extend across about $1 / 2^{-3} / 4$ of the sides of the uncoiled part of the body chamber, here the primaries are often strongest from the point where the secondaries disappear to the umbilical wall. On other parts of the exposed shell most secondaries extend nearer to the umbilical wall. On the body chamber the ventral ribs are nearly equally spaced. In the holotype the exposed whorls have 28 primary ribs and 74 ventral ribs of which 14 primary ribs and 40 ventral ribs are on the body chamber. The body chamber figured pl. 16, fig. 3 is $55 \mathrm{~mm}$ long and shows 16 primary ribs and 42 ventral ribs, another of similar size shows 16 primary ribs and 41 ventral ribs. The other fragments have a very similar ribbing pattern.

The sutures are rather poorly preserved. Text-fig. 76 shows an eroded suture of the holotype and fig. 77 shows a better preserved suture 
of another specimen. The suture is rather complex; the lateral lobe is rather wide, slightly deeper than the ventral lobe, and it seems always to be somewhat asymmetrically bifid, the ventral branch being considerably shorter than the umbilical one. The first auxiliary lobe is small and asymmetrically trifid or bifid.

Affinities. The specimens are closely related to Scaphites preventricosus Cobban, 1951 a. In addition to the typical $S$. preventricosus (p. 26 , pl. 9, figs. 1-16) CoвBan describes two variants, $S$. preventricosus var. sweetgrassensis (p. 27, pl. 10, figs. 18-25) and $S$. preventricosus var. artilobus (p. 27, pl. 8, figs. 1-6). S. preventricosus and S. preventricosus var. sweetgrassensis occur together and show an even transition. CoBbaN refers the large and stout specimens to $S$. preventricosus s. s. and the smaller, more slender specimens, with a very extended body chamber, to the variant sweetgrassensis. The material from Greenland also varies from large, rather stout specimens to smaller and more slender ones. $S$. preventricosus var. artilobus differs from $S$. preventricosus and $S$.preventricosus var. sweetgrassensis in suture- and ribbing patterns, and in being more compressed, it occurs only in the lowermost Scaphites preventricosus layers and may be considered to be a subspecies of $S$. preventricosus and not merely a variant.

The material from Greenland differs from $S$. preventricosus and $S$. preventricosus var. sweetgrassensis chiefly in its ribbing pattern. Thus, the ribs of the specimens from Greenland are coarser and only 2-3 ventral ribs to each primary are developed on the body chamber. In contrast the types of $S$. preventricosus and $S$. preventricosus var. sweetgrassensis have 5-6 ventral ribs to each primary on the body chamber. Additional material of that species and its variant, from the type area, shows that no specimens have less than 3-4 ventral ribs to each primary on the body chamber. The suture of the specimens from Greenland is very similar to that of $S$. preventricosus. It is, however, slightly more complex and the lateral lobe is slightly wider. In mature specimens from Greenland the last suture crosses the umbilical wall closer to the umbilicus than in Scaphites preventricosus.

I suggest that the specimens from Greenland constitute a new subspecies of $S$. preventricosus. It differs from $S$. mariasensis umivikensis n. subsp., occurring in the same beds, in its slightly smaller size, in the shape of its body chamber, and in its sutures, the lateral lobe usually being more asymmetric.

Stratigraphy. According to Cobban (1951 a, $1951 \mathrm{~b}$ ) and Cobban \& REESIDE (1952) Scaphites preventricosus occurs in the Western Interior of the United States in beds referred to the lowermost Coniacian. It appears in the Inoceramus erectus Zone, where it occurs together with 
Scaphites mariasensis, and is also important in the Inoceramus deformis Zone, where it occurs together with Scaphites impendicostatus Coвban, 1951. It is also known from Alberta in strata of similar age (JELETZSKY in Sтотт, 1961). Like Scaphites mariasensis it is an endemic species of the North American Western Interior Sea and the connected Arctic Seas.

Scaphites (Scaphites) ventricosus MeEk \& Hayden, 1862

Pl. 19, figs. 2-3, text-fig. 78 .

1862 Scaphites ventricosus MEEK \& HAYDEN, p. 22.

1876a Scaphites ventricosus MEEK \& HAY DEN: MEEK, p. 425, pl. 6, figs. 7-8.

1893 Scaphites ventricosus Meek \& Hayden: Stanton (partim), p. 186, pl. 44, figs. 8-9; pl. 45, fig. 1 (non pl. 44, fig. 10).

1898 Scaphites ventricosus MEEK \& HAYDEN: LOGAN (partim), p. 476, pl. 104, figs. 8-9; pl. 105, fig. 1 (non pl. 104, fig. 10).

1927 a Scaphites ventricosus MeEK \& HAYDEN : ReEside, p. 6, pl. 3, figs. 11-18; pl.4, figs. 1-4.

1927b Scaphites ventricosus Mén \& Hayden: Reeside, p. 35, pl. 10, figs. 1-2.

1944 Scaphites ventricosus MeEK \& HaYdeN: SHIMER \& SHROcK, p. 591, pl. 244, fig. 10 .

1951 a Scaphites ventricosus MeEк \& Hayden: Coвban, p. 31, pl. 12, figs. 1-10; pl. 13, figs. 11-13.

1951 b Scaphites ventricosus Méк \& Hayden: Cobban, p. 2194, 2197.

1952 Scaphites ventricosus Menk \& Hayden: Cobban \& Reeside, chart $10 \mathrm{~B}$.

1961 Scaphites ventricosus MeEк \& Hayden: JeLEtZsky in Stott, fig. 2.

Lectotype (chosen by Mекк, 1876a). U. S. Nat. Mus. catalogue No. 1903. Figured by Мекк, 1876a, pl. 6, figs. $7 \mathrm{a}-\mathrm{b}$. From the upper part of the Colorado Shale about twenty miles northeast of Fort Benton, Montana.

Emended diagnosis. Scaphites frequently of large size with body chamber to a large extent in contact with phragmocone; whorl section of phragmocone depressed and rounded; straighter part of body chamber very wide in large specimens, relatively narrower and occasionally flattened laterally in smaller specimens, maximum whorl height at the middle; apertural angle about $100^{\circ}$; surface with rather widely spaced ribs, ventral ribs more widely spaced on middle part of body chamber than on extremities, exposed whorls with $2-5$ ventral ribs to each primary; suture complex in large specimens, lobes rather narrow with deeply incised minor saddles.

Material. One nearly complete specimen, two rather well preserved fragments, and several poorly preserved fragments from Alianaitsúnguaq, Nûgssuaq. All the specimens are collected from horizon 20 . 
Measurements.

$\begin{array}{cccccc}\text { Shell } & \text { Whorl } & \text { Whorl } & \text { W/H at } & \text { Maximum } & \text { Whorl } \\ \text { length } & \text { height } & \text { width } & \text { last } & \text { height } & \text { height } \\ \text { at last } & \text { at last } & \text { suture } & \text { of body } & \text { at } \\ \text { suture } & \text { suture } & & \text { chamer } & \text { aperture } \\ 56 \mathrm{~mm} & 21 \mathrm{~mm} & 21 \mathrm{~mm} & 1.00 & \text { c. } 25 \mathrm{~mm} & \text { c. } 16 \mathrm{~mm}\end{array}$

Description. The only complete specimen is of moderate size, the fragments are from shells of similar size or even smaller. The umbilicus has an external diameter of $3-4 \mathrm{~mm}$.

The whorl section of the innermost whorls is unknown. From a whorl height of $6 \mathrm{~mm}$ to the last suture the section is rounded and slightly depressed.

To a large extent the body chamber is in contact with the phragmocone. In mature specimens the last suture forms an angle of $140^{\circ}-$ $160^{\circ}$ with the long axis of the shell. In side view the venter of the body chamber is more curved than the umbilical wall. The apertural angle is about $100^{\circ}$. Whorl height increases slightly to the middle of the body chamber and then decreases to the aperture. The width of the body chamber increases slightly from the last suture to the aperture or it is equally wide throughout. In the only complete specimen the middle of the body chamber seems slightly compressed but it may be due to deformation.

On the exposed part of the shell the sculpture consists of high, often sharp ribs, which may bifurcate, trifurcate, or be intercalated. Secondary ribs extend across about $1 / 2^{-3} / 4$ of the sides of the straighter part of the body chamber, but they extend nearer to the umbilical wall on other parts of the exposed shell. On the straighter part the primaries are strongest laterally from the point where the secondaries disappear. The ventral ribs are more widely spaced on the middle part of the body chamber than on other parts of the venter. The exposed whorls of the specimen figured pl. 19 , figs. $2 \mathrm{a}-\mathrm{c}$ have about 25 primary ribs and about 70 ventral ribs. The body chamber has about 3 ventral ribs to each primary.

The sutures are extremely poorly preserved. The early suture shown in text-fig. 78 is rather simple, later sutures are more complex. The lateral

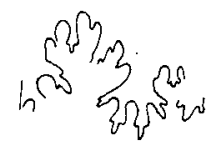

78

Fig. 78. Scaphites ventricosus MeEK \& Hayden. MMH No. 9916. $\times 3$, part of the external suture at a whorl height of $6.5 \mathrm{~mm}$. Alianaitsúnguaq (horizon 20). 
lobe is of about the same depth as the ventral lobe and has developed deep minor saddles in the two main branches. The first auxiliary lobe is asymmetrically trifid.

Affinities. The specimens differ from all figured specimens of Scaphites ventricosus MEEK \& HAYDEN in their smaller size and less depressed whorl sections. However, examination of collections of Scaphites ventricosus from the Western Interior of the United States shows that small mature specimens of similar size as the specimens from Greenland commonly occur. These specimens show a wide range of variation in whorl section and the specimens from Greenland fall within the limits of that variation. There are no differences in the shape of the shells or in the sculpture. Sutures of the specimens from Greenland have a similar degree of complexity as those of similar size from the Western Interior but are, of course, less complex than the last sutures of specimens of greater size.

Stratigraphy. Cobban (1951 a, 1951 b) and Cobban \& Reeside (1952) have shown that Scaphites ventricosus characterizes a zone just above the Scaphites preventricosus Zone in the Western Interior of the United States. It occurs together with Inoceramus umbonatus MEEK \& HAYDEN (later referred by CobBan (1955) to Inoceramus involutus Sowerby). The zone is referred to the Coniacian.

Scaphites (Scaphites) cobbani n. sp.

Pl. 19, fig. 4; pl. 20, figs. 1-4; pl. 21, fig. 1; pl. 22, fig. 1; text-figs. 62, 63, 69, 79-88, 121 (1), 122.

Name. The species is named after Dr. W. A. Coвban.

Holotype. MMH No. 9800. Figured pl. 21, figs. 1 a-c, text-fig. 81 . From Scaphitesnæsen, 536-537 m above sea-level, Nûgssuaq. Upper part of the Lower Campanian.

Diagnosis. Large Scaphites with body chamber extending markedly beyond the phragmocone; whorl section depressed and rounded except for youngest part of phragmocone and straighter part of body chamber which are compressed and subquadrangular; height of body chamber decreases slowly and width increases slowly towards aperture; apertural angle $70^{\circ}-85^{\circ}$; surface rather finely ribbed; 4-8 ventrolateral nodes and 1-5 umbilical nodes or bullae on the straighter part of the body chamber and occasionally on youngest part of phragmocone; suture rather incised, ventral lobe deepest, first auxiliary lobe trifid.

Material. Nûgssuaq: about 100 well preserved specimens and many fragments from Scaphitesnæsen, mainly collected in situ 533-542 m 
above sea-level; two specimens from a small ravine west of Scaphitesnæsen; one displaced specimen from Kangersôq valley and some derived specimens collected in the Paleocene section in Turritellakløft and in the Oyster-ammonite Conglomerate loc. I and III. Svartenhuk: one displaced specimen from Tange I Kløft, $50 \mathrm{~m}$ above sea-level.

\section{Measurements.}

Specimen figured text-fig. 79. (Shell length about $80 \mathrm{~mm}$ )

$\begin{array}{rrr}\begin{array}{l}\text { Whorl } \\ \text { height }\end{array} & \begin{array}{l}\text { Whorl } \\ \text { width }\end{array} & \text { W/H } \\ 0.9 \mathrm{~mm} & 1.2 \mathrm{~mm} & 1.33 \\ 1.3- & 1.7- & 1.31 \\ 2.1- & 2.9- & 1.38 \\ 3.6- & 4.7- & 1.31 \\ 6.6- & 8.4- & 1.27 \\ 11.0- & 13.3- & 1.21 \\ 18.8- & 21.2- & 1.13 \\ 32.6- & 26.3- & 0.81\end{array}$

$180^{\circ}$ between the measurements, beginning about $21 / 2$ whorls from the protoconch and finishing close to the last suture.
Specimen figured text-fig. 80 . (Shell length about $20 \mathrm{~mm}$ )

$\begin{array}{lll}\begin{array}{l}\text { Whorl } \\ \text { height }\end{array} & \begin{array}{l}\text { Whorl } \\ \text { width }\end{array} & \text { W/H } \\ 0.4 \mathrm{~mm} & 0.6 \mathrm{~mm} & 1.50 \\ 0.5- & 0.7- & 1.40 \\ 0.6- & 0.8- & 1.33 \\ 0.9- & 1.1- & 1.22 \\ 1.2- & 1.7- & 1.42 \\ 2.0- & 2.8- & 1.40 \\ 3.3- & 4.4- & 1.33 \\ 5.8- & 6.6- & 1.14\end{array}$

$180^{\circ}$ between the measurements, beginning about one whorl from the protoconch and finishing close to the last suture.

Shell length and whorl ratios of 16 mature specimens from Scaphitesnæsen:

\begin{tabular}{|c|c|c|c|c|c|c|c|c|c|c|c|}
\hline \multicolumn{2}{|c|}{$\begin{array}{l}\text { Shell } \\
\text { length }\end{array}$} & \multicolumn{2}{|c|}{$\begin{array}{l}\text { Whorl } \\
\text { height } \\
\text { at last } \\
\text { suture }\end{array}$} & \multicolumn{2}{|c|}{$\begin{array}{l}\text { Whorl } \\
\text { width } \\
\text { at last } \\
\text { suture }\end{array}$} & $\begin{array}{c}\text { W/H at } \\
\text { last } \\
\text { suture }\end{array}$ & \multicolumn{2}{|c|}{$\begin{array}{c}\text { Whorl } \\
\text { height } \\
\text { at } \\
\text { aperture }\end{array}$} & \multicolumn{2}{|c|}{$\begin{array}{c}\text { Whorl } \\
\text { width } \\
\text { at } \\
\text { aperture }\end{array}$} & $\begin{array}{c}\text { W/H at } \\
\text { aper- } \\
\text { ture }\end{array}$ \\
\hline c. $98 \mathrm{r}$ & $\mathrm{nm}$ & 40.8 & $\mathrm{~mm}$ & 37.1 & $\mathrm{~nm}$ & 0.91 & 33.0 & $\mathrm{~mm}$ & 41.2 & $\mathrm{~nm}$ & 1.25 \\
\hline$* 78$ & - & 31.1 & - & 26.1 & - & 0.84 & 26.3 & - & 32.9 & - & 1.25 \\
\hline 78 & - & 31.2 & - & 29.5 & - & 0.95 & 25.7 & - & 35.5 & - & 1.38 \\
\hline 76 & - & 30.0 & - & 26.2 & - & 0.87 & 25.4 & - & 32.6 & - & 1.28 \\
\hline 74 & - & 30.5 & - & 26.7 & - & 0.88 & 25.7 & - & 32.8 & - & 1.28 \\
\hline c. 71 & - & 29.9 & - & 26.0 & - & 0.87 & 25.3 & - & 30.6 & - & 1.21 \\
\hline 69 & - & 27.7 & - & 24.0 & - & 0.87 & 24.2 & - & 28.0 & - & 1.16 \\
\hline 67 & - & 28.9 & - & 25.2 & - & 1.87 & 24.3 & - & 30.4 & - & 1.25 \\
\hline 65 & - & 25.9 & - & 21.3 & - & 0.82 & 20.7 & - & 26.0 & - & 1.26 \\
\hline 60 & - & 25.1 & - & 21.7 & - & 0.86 & 20.0 & - & 26.3 & - & 1.32 \\
\hline 59 & - & 24.4 & - & 21.5 & - & 0.88 & 19.6 & - & 24.8 & - & 1.27 \\
\hline 55 & - & 21.0 & - & 18.9 & - & 0.90 & 19.5 & - & 23.7 & - & 1.22 \\
\hline 54 & - & 21.1 & - & 17.9 & - & 0.85 & 18.3 & - & 22.7 & - & 1.24 \\
\hline 45 & - & 18.3 & - & 15.5 & - & 0.85 & 15.6 & - & $?$ & & $?$ \\
\hline 26 & - & 9.0 & - & 8.3 & - & 0.92 & c. 8 & - & 10.6 & - & $?$ \\
\hline 22 & - & 7.6 & - & 7.0 & - & 0.92 & 8.5 & -. & 9.2 & - & 1.08 \\
\hline
\end{tabular}



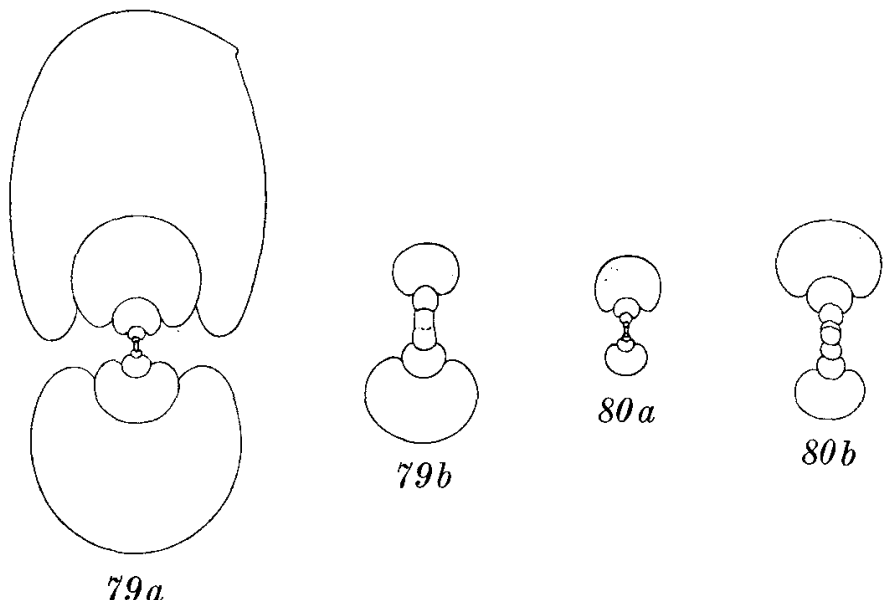

$80 b$

Figs. 79-80. Scaphites cobbani n.sp. Cross sections of phragmocones. Scaphitesnæsen.

79. MMH No. 9917. $a, \times 1 ; b, \times 4$.

80. MMH No. 9918. $a, \times 1 ; b, \times 4$.

Description. The length of mature specimens ranges between $17.6 \mathrm{~mm}$ and $98 \mathrm{~mm}$. Text-fig. 121(1) shows that the bulk of specimens range in length from $50 \mathrm{~mm}$ to $80 \mathrm{~mm}$, but that specimens ranging from $20 \mathrm{~mm}$ to $30 \mathrm{~mm}$ are also abundant, and there are rather few intermediate specimens. The uneven variation in length could indicate the occurrence of two different species of different size. However, a closer examination of the material seems to show that this remarkable size variation may be conditioned by sexual dimorphism or by ecological factors (see p. 146) and all the material is thus thought to belong to the same species.

The first part of the description deals with that material which shows a normal range in length $(40-98 \mathrm{~mm})$ while the abnormal small specimens are described in the last part.

All the larger specimens are mature. The external diameter of the umbilicus ranges from $3 \mathrm{~mm}$ to $5 \mathrm{~mm}$.

The inner whorls are evenly rounded and depressed, the innermost whorl being more depressed than the younger ones. Within the younger part of the phragmocone the height increases faster than the width, resulting in a compressed section of the last 3-4 chambers.

The body chamber is rather long and extends markedly beyond the phragmocone. The last suture forms an angle of $75^{\circ}-80^{\circ}$ with the long axis of the shell. The maximum whorl height is close to the youngest suture. Whorl height decreases very slowly in the straighter part of the body chamber and somewhat faster in the youngest curved part of the body chamber. Whorl width increases evenly towards the aperture except for some specimens in which there is a shallow lateral depression 

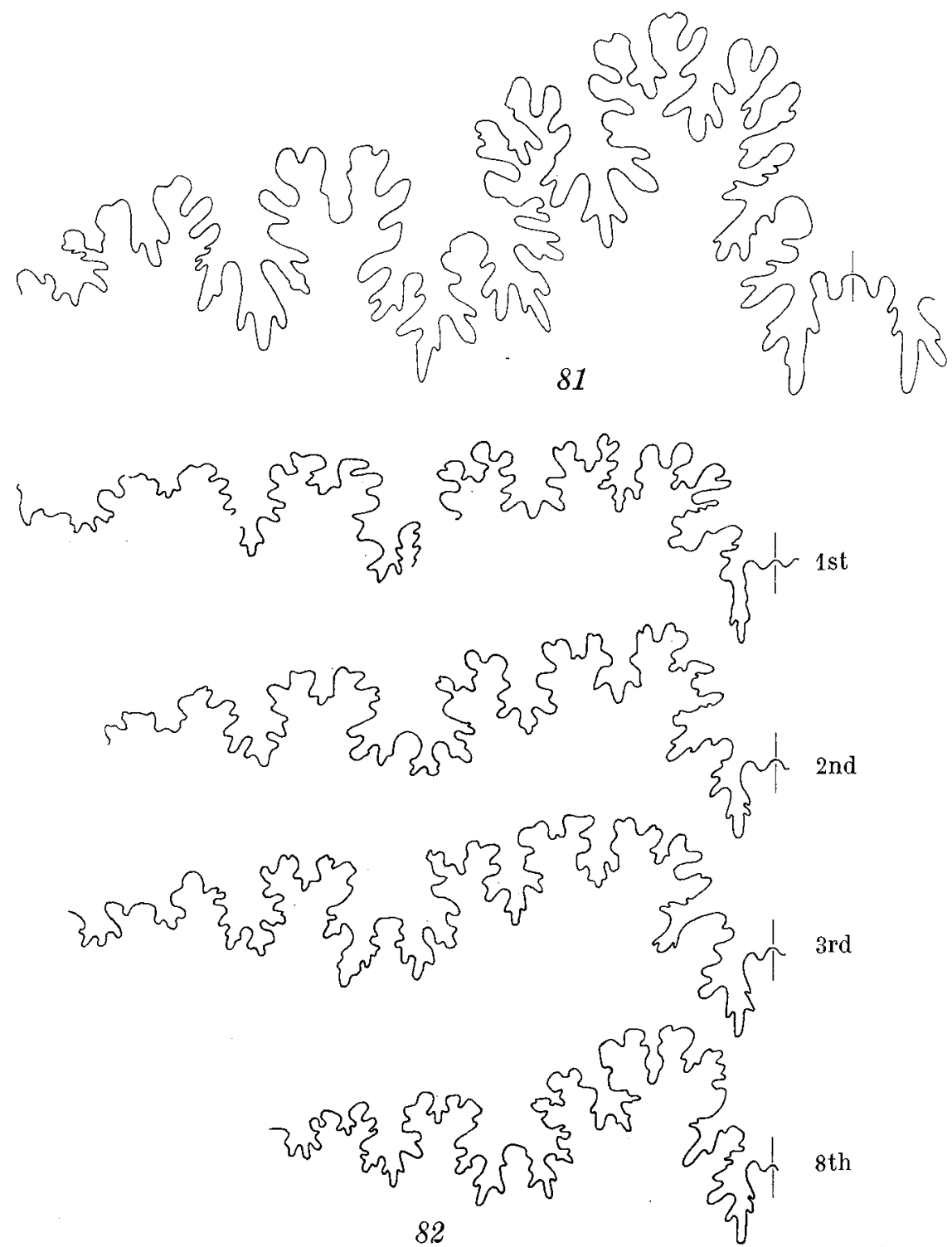

Figs. 81-82. Scaphites cobbani n.sp.

81. Holotype. MMH No. $9800 . \times 3$, external suture at a whorl height of $29 \mathrm{~mm}$. Scaphitesnæsen, $536-537 \mathrm{~m}$ above sea-level.

82. MMH No. 9905. $\times 3$, variation of youngest sutures (1st., 2nd., 3rd., and 8th.). Scaphitesnæsen, $538 \mathrm{~m}$ above sea-level.

at the last suture. The straighter part of the body chamber is compressed and subquadrangular with flattened sides and venter, as are the last 3-4 chambers of the phragmocone. The youngest part of the body chamber again becomes depressed and rounded (see measurements). At the 


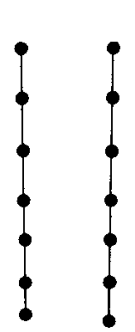

$83 a$

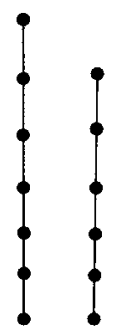

$83 b$

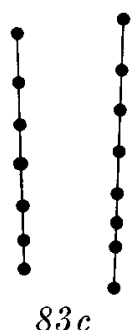

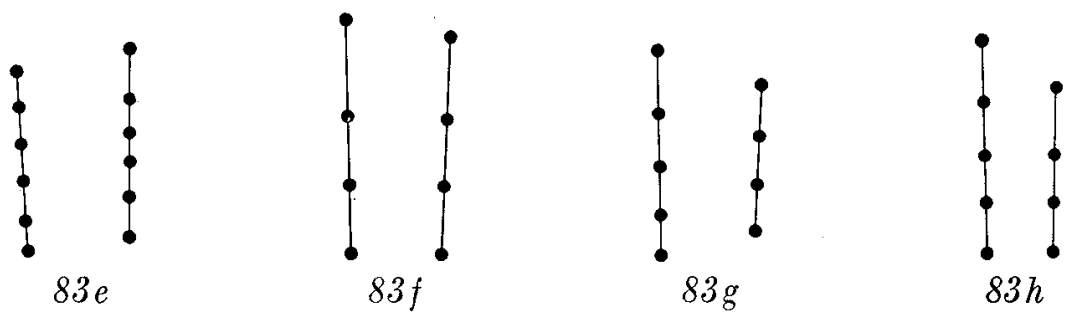

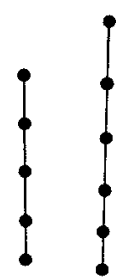

$83 d$

Fig. 83. Scaphites cobbani n.sp. $\times 1 / 2$, schematic diagrams showing variation in the frequency of ventrolateral nodes.

umbilicus the umbilical wall has a small swelling which is more pronounced in large specimens than in smaller ones. The older part of the umbilical wall is only slightly rounded. The apertural angle is $70^{\circ}-85^{\circ}$.

The innermost whorls are smooth. On the third whorl rounded ribs gradually appear first laterally and later ventrally. On the fourth whorl intercalatory ribs are developed. Further on third and fourth whorl fine longitudinal lirae are visible between the ribs. On the last whorl of the unexposed shell the ribs become sharper (text-figs. 62-63). On the exposed part of the shell the sculpture consists of sharp closely spaced ribs, which are slightly curved on the middle part of the body chamber. The ribs may bifurcate, trifurcate or be intercalated. The secondaries begin $1 / 4^{-3} / 4$ of the whorl height from the umbilical wall. The exposed whorls have 38-60 primary ribs of which 21-33 are on the body chamber. There are two to four ventral ribs to each primary on the exposed whorls. The holotype has 50 primaries and 153 ventral ribs on the exposed whorls of which 21 primaries and 77 ventral ribs are on the body chamber. The ribs are most widely spaced on the straighter part of the body chamber.

On the straighter part of the body chamber and usually on the last two chambers of the phragmocone 4-8 strong, pointed nodes are developed ventrolaterally. The number of nodes on each side of the same specimen may differ by one. The nodes on each side may be placed opposite each other, irregularly intercalated or occur quite irregularly 
(text-fig. 83). Also the distance between the nodes is extremely variable. Additionally, 3-5, or more rarely 1 or 2 , umbilical nodes or bullae may be developed close to the umbilical wall of the straighter part of the body chamber. One specimen, from Tange I Kløft, Svartenhuk, has no umbilical tubercles developed.

The suture is rather incised. The height of the lobes decreases gradually from the ventral lobe to the first auxiliary lobe, or, especially in later stages, the lateral lobe is nearly as deep as the ventral lobe. The lateral lobe is usually symmetrically bifid, but may be asymmetrically bifid in later stages, the inner branch being somewhat longer than the outer branch. The first auxiliary lobe is trifid. The first lateral saddle is very wide, especially in the youngest sutures; it has two deep minor lobes, the inner being deeper than the outer. The second lateral saddle is bifid and as wide as the first auxiliary lobe.

The small specimens referred to the present species are morphologically very close to the larger specimens and occur in the same beds. Both mature and juvenile specimens of small size occur. Apparently, the small mature specimens differ from the larger ones in umbilical ratio, in sculpture and in suture pattern, but these characters are exactly like those of the juvenile stages of larger specimens. The sculpture of the exposed whorls of the small mature specimens has, for example, ribs which are more strongly developed laterally than ventrally, this stage of ornamentation being hidden by later whorls in the larger specimens. Text-fig. 88 shows one of the youngest sutures of a small mature specimen, which agrees very closely with juvenile sutures in larger specimens.

Measurements of whorl height and width of larger specimens and small specimens (p. 90) show that the whorl ratios of the inner whorls agree very closely. At the stage where the final body chamber begins to develop, the small specimens become more compressed than the larger specimens at corresponding diameters. The larger specimens obtain their greater size by having a phragmocone which is up to two whorls longer than in small specimens. It is evident from the diagram (text-fig. 121(1)) that specimens of intermediate length occur, these also have an intermediate number of whorls.

The curves shown in text-fig. 122 show that the growth ratio of small specimens is identical to that of larger specimens until the final stage.

One small specimen has a concentrically striated aptychus preserved in the body chamber (text-fig. 87). It is strongly folded about the harmonic margin which is equal in length to the height of the aperture. The apparent width of the valves, however, is slightly greater 


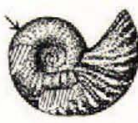

84

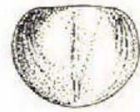

87

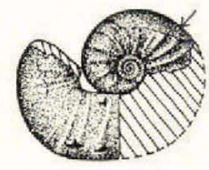

85

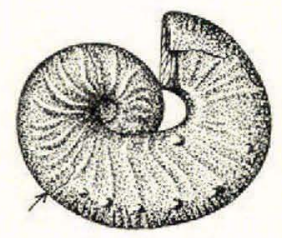

86

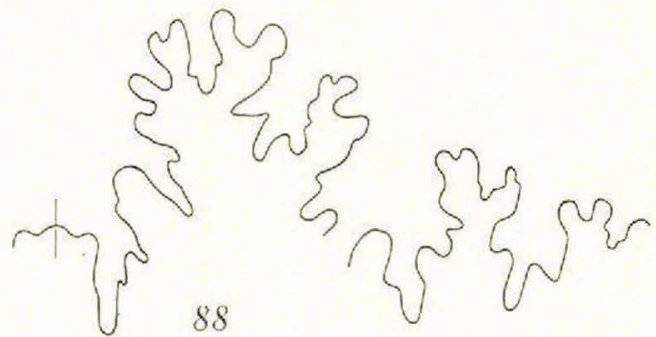

Figs. 84-88. Scaphites cobbani n.sp.

84. MMH No. 9919. $\times 1$, juvenile specimen. Scaphitesnæsen, $539-540 \mathrm{~m}$ above sea-level.

85. MMH No. $9920 . \times 1$, juvenile specimen. Scaphitesnæsen, $538-540 \mathrm{~m}$ above sea-level.

86. ММН No. 9795. $\times 1$, mature specimen. Scaphitesnæsen, $536-537 \mathrm{~m}$ above sea-level.

87. MМH No. 9921. $\times 1$, aptychus. Scaphitesnæsen, $535-536 \mathrm{~m}$ above sea-level.

88. MMH No. 9799. $\times 10$, external suture of small specimen at a whorl height of $5 \mathrm{~mm}$. Scaphitesnæsen, 539-540 $\mathrm{m}$ above sea-level.

(Figs. 84-86, the arrow indicates the position of the last suture).

than the width of the aperture and the valves would only fit in a slightly folded position. The aptychus is rather poorly preserved, especially at the harmonic margin, and no adharmonic ridge is visible.

Text-figs. 84 and 85 show juvenile stages of small specimens. The earliest juvenile stage represented in the collections (text-fig. 84), has a relatively wide umbilicus. The body chamber is very long (about $2 / 3$ whorl) and it seems to show an incipient scaphitoid coiling. The oldest part of the exposed shell has weak lateral ribs, a little later the ribs are also discernible ventrally. The ribs gradually become stronger on the body chamber. On the younger part of the body chamber weak ventrolateral bullae are visible. The youngest sutures are very simple. The aperture is not constricted and has no lappets. This stage has not yet developed the characters diagnostic of the species described here and 
could as well belong to Scaphites rosenkrantzi n. sp. (described p. 97) which occurs in the same beds.

The specimen shown in text-fig. 85 is nearly fully grown and can certainly be referred to the species described here. It has developed a more distinctly scaphitoid body chamber and strong ventrolateral nodes on the middle part of the body chamber. At the umbilical wall a few nodes are developed. The body chamber is still relatively longer than in mature specimens. The aperture has a dorsal lappet and is not constricted.

Affinities. The present species is allied to a species group including i. a. Scaphites nodosus Owen, 1852, Scaphites quadrangularis MeEK \& Hayden, 1860, Scaphites plenus MeEx \& HAyden, 1860, and Scaphites brevis Mекк, 1876. The last three were considered by Мекк to be variants of Scaphites nodosus, but were later mentioned by STEPHENson (1941) and by CobBan \& Reeside (1952) as distinct species.

Dr. W. A. CobBan's material of this group in the United States Geological Survey in Denver shows certain evolutional lineages. Thus, the early forms have a rather small apertural angle, nearly straight ribs, rather few ventrolateral nodes and rather indistinct bullae or thickened ribs at the umbilical wall. Later the apertural angle becomes larger, the ribs more curved, the rows of nodes more extensive on the coiled shell, and the outer part of the bullae at the umbilical wall more distinct and node-like, but still with thickened ribs on the inner side. Still later forms have an umbilical row of distinct nodes with weakened ribs on the inner side. As mentioned p. 71 this group gave rise to some of the multinodose discoscaphites. All the specimens described and figured by MeEr (1876a) are late forms of this group. The same is true of Scaphites rugosus Stephenson, 1941, which is closely related to $S$. quadrangularis. The early forms are not yet described.

The present species is very closely related to some of the early forms of the Scaphites nodosus group in shape, apertural angle, ribbing pattern, sutures, and in having rather few nodes. The early forms differ in having a wider umbilicus and in having no swelling of the umbilical wall at the umbilicus. Furthermore the sculpture on the inner side of the umbilical row of bullae differs in having thickened ribs.

Among the late forms, the type of Scaphites quadrangularis (MEек, $1876 \mathrm{a}$, pl. 25, figs. $3 \mathrm{a}-\mathrm{c}$ ) is rather close to the present species in cross section of the whorls, but differs in having a greater apertural angle, in its more extensive ventrolateral row of nodes, in having many distinct umbilical nodes, and, as with most other representatives of the group, in having a wider umbilicus and no umbilical swelling at the umbilicus. 
Scaphites rosenkrantzi n. sp., described below, also belongs to the Scaphites nodosus group. It occurs together with the present species and the two species are closely related (the species are compared p. 100).

Scaphites aquisgranensis Schlüter (1876, p. 81, pl. 24, figs. 7-9) is similar to the present species in coiling, in apertural angle, and in having rather few nodes, but differs i.a. in being more compressed, in having no swelling of the umbilical wall at the umbilicus, and in having the rows of nodes extending to the aperture.

Scaphites tuberculatus GIEBEL, 1849 (= Scaphites compressus sensu RoEmER, 1841, pl. 15, fig. 1) seems to be close to late Scaphites nodosus forms. It differs mainly from the present species in having umbilical and ventrolateral nodes on all the exposed shell, and in having the umbilical row of nodes placed in a greater distance from the umbilical wall.

Stratigraphy. The species occurs together with Baculites obtusus MEE K (early form) at Scaphitesnæsen. The most closely related early forms of the Scaphites nodosus group appear in the Lower Campanian Baculites obtusus Zone in the Western Interior of the United States and are known from much of the Upper Campanian (up to the Baculites pseudovatus Zone).

\section{Scaphites (Scaphites) rosenkrantzi n. sp.}

Pl. 21, figs. 2-3; pl. 22, figs. 2-3; pl. 23, figs. 1-3; text-figs. 58, 68, 89-92, 121 (2).

Name. The species is named after Professor A. Rosenkrantz.

Holoty pe. MMH No. 9802. Figured pl. 21, figs. 3a-c; text-fig. 89. From Scaphitesnæsen. Upper part of the Lower Campanian.

Diagnosis. Large Scaphites with body chamber extending only slightly beyond phragmocone; whorl section rounded and depressed except for youngest part of phragmocone and straighter part of body chamber, which are compressed; body chamber very stout with maximum height at the middle, the width increasing rather rapidly towards the aperture; apertural angle $90^{\circ}-110^{\circ}$; surface finely ribbed; straighter part of body chamber with $0-8$ ventrolateral nodes and $0-2$ umbilical bullae; suture rather incised, ventral lobe deepest, first auxiliary lobe bifid or trifid.

Material. Nùgssuaq: about 50 well preserved specimens and some fragments from Scaphitesnæsen, mainly collected in situ $533-548 \mathrm{~m}$ above sea-level; 2 specimens from a small ravine west of Scaphitesnæsen; 2 derived specimens from Oyster-ammonite Conglomerate loc. I. Svartenhuk: one displaced specimen from Tange I Kløft, $50 \mathrm{~m}$ above sea-level. 
Measurements.

Specimen figured text-fig. 58 . (Shell length $52 \mathrm{~mm}$ )

$\begin{array}{ccc}\text { Whorl height } & \text { Whorl width } & \text { W/H } \\ 0.3 \mathrm{~mm} & 0.5 \mathrm{~mm} & 1.67 \\ 0.4- & 0.6- & 1.50 \\ 0.6- & 0.8- & 1.33 \\ 0.8- & 1.1- & 1.38 \\ 1.2- & 1.7- & 1.42 \\ 2.0- & 3.0- & 1.50 \\ 3.7- & 5.0- & 1.35 \\ 6.2- & 8.0- & 1.13 \\ 10.6- & 12.9- & 1.22 \\ 17.6- & 19.0- & 1.08\end{array}$

$180^{\circ}$ between the measurements, beginning about one whorl from the protoconch and finishing close to the last suture.

Shell length and whorl ratios of 10 mature specimens from Scaphitesnæsen:

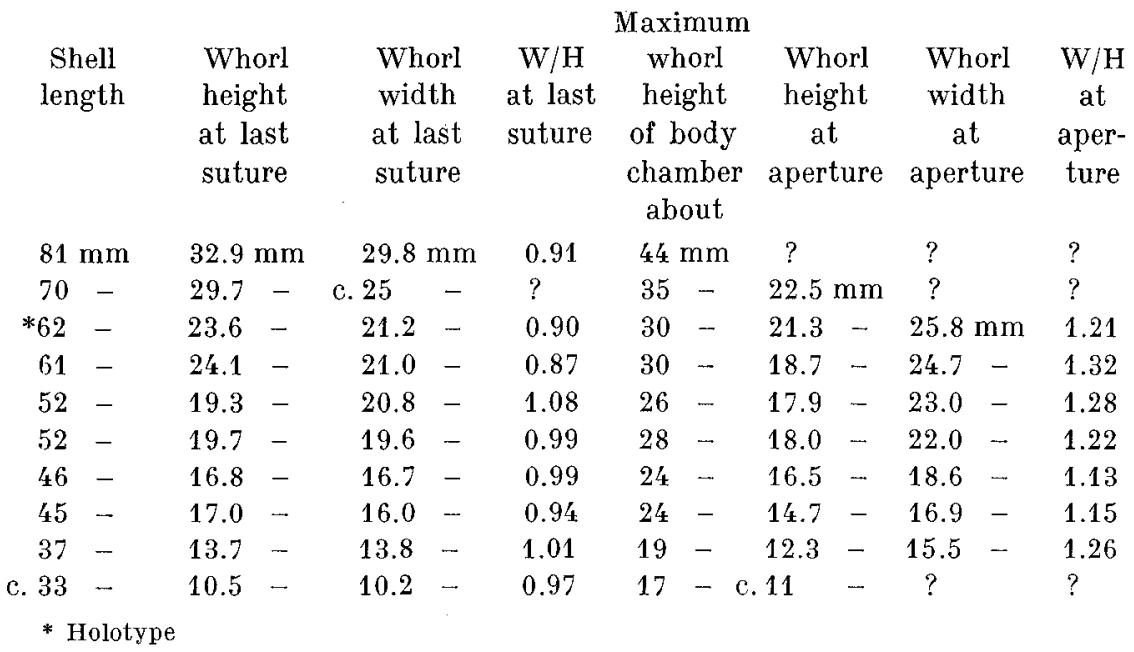

Description. The length of mature specimens ranges between $22.5 \mathrm{~mm}$ and $91.5 \mathrm{~mm}$. It appears from text-fig. 121(2) that the size variation is uneven as in Scaphites cobbani n. sp. from the same locality. Thus, the bulk of specimens range in length from $50 \mathrm{~mm}$ to $70 \mathrm{~mm}$, but a smaller group, ranging in size from $30 \mathrm{~mm}$ to $40 \mathrm{~mm}$, also occurs. The peculiar size variation may be an sexual or ecological effect (see p. 146). The small specimens are described separately in the last part of the description.

All the larger specimens are mature. The external diameter of the umbilicus ranges between $2 \mathrm{~mm}$ and $5 \mathrm{~mm}$. 

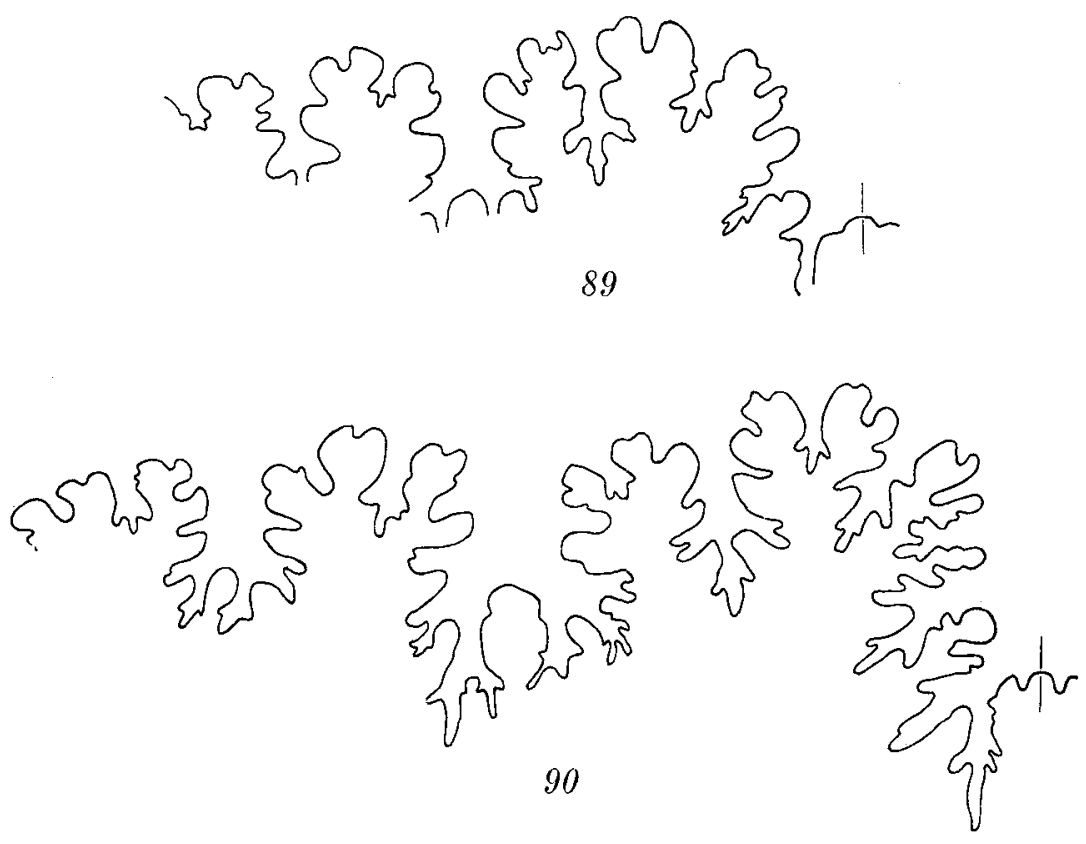

Figs. 89-90. Scaphites rosenkrantzi n.sp.

89. Holotype. MMH No. 9802. $\times 3$, external suture at a whorl height of $23.6 \mathrm{~mm}$. Scaphitesnæsen.

90. MMH No. 9922. $\times 3$, external suture at a whorl height of $29.1 \mathrm{~mm}$. Scaphitesnæsen.

The inner whorls are evenly rounded and depressed, as in $S$. cobbani n. sp. In the younger part of the phragmocone height increases faster than width, resulting in a less depressed or most often a slightly compressed section of the last 3-4 chambers (text-fig. 58).

The body chamber extends only slightly beyond the phragmocone. The last suture forms an angle of $90^{\circ}-130^{\circ}$ with the long axis of the shell. The maximum whorl height is at the middle of the body chamber. Measurements show marked differences in whorl height at the last suture, at the middle of the body chamber and at the aperture. Whorl width increases evenly towards the aperture, except in some specimens which have a shallow lateral depression at the last suture. The straighter part of the body chamber is compressed and the youngest part depressed. The straighter part also has flattened sides as have the last 3-4 chambers of the phragmocone. At the umbilicus the umbilical wall has a small swelling which is more pronounced in the larger specimens. Except for the swelling the older part of the umbilical wall is nearly straight. The apertural angle is $90^{\circ}-110^{\circ}$. 
Ribbing on the inner whorls is similar to that of $S$. cobbani n. sp. On the exposed part of the shell the ribs may be slightly finer and more closely spaced. The exposed whorls show 38-52 primary ribs of which 18-30 are on the body chamber. There are two to five ventral ribs to each primary on the exposed whorls. The holotype has 40 primaries and 160 ventral ribs on the exposed whorls of which 25 primaries and 89 ventral ribs are on the body chamber. The ribs are nearly evenly spaced on the exposed shell.

A very variable number of ventrolateral nodes may be developed on the straighter part of the body chamber. The nodes also vary greatly in strength. Usually 3-8 nodes are developed but a few specimens have only one or two nodes. Seven specimens are quite without nodes. Textfig. 92 gives an impression of the variation in number and spacing of the ventrolateral nodes. Since there is great variety in noded specimens, those without nodes are thought to be extreme variants of the same species. In addition to the ventrolateral nodes umbilical bullae may be developed on the middle part of the body chamber $1 / 3^{-1 / 4}$ of the whorl height from the umbilical wall.

The suture is very similar to that of $S$. cobbani n. sp. with the exception that in the youngest sutures the first auxiliary lobe is usually bifid. Thus, among 22 specimens, 16 have a bifid first auxiliary lobe and only 6 have a trifid first auxiliary lobe. Text-fig. 91 shows the late ontogeny of the first auxiliary lobe. The ontogenetic evolution of the sutures is shown in text-figs. $68 \mathrm{a}-\mathrm{c}$.

The smaller, mature specimens referred to the present species have an umbilical ratio, a sculpture, and sutures which correspond to juvenile stages of larger specimens. The umbilical swelling is weaker than in larger specimens, and some have up to 9 ventrolateral nodes. In one specimen (pl. 22, fig. 3) the ventrolateral nodes extend close to the aperture.

All definitely determinable smaller specimens are mature, but some of the juvenile specimens described p. 95 could as well belong to this species as to Scaphites cobbani n. sp.

Affinities. Scaphites rosenkrantzi n. sp. is closely allied to $S$.cobbani n. sp. but differs primarily from that species in the shape of the body chamber and often in having a smaller number of nodes and finer ribbing. The two species occur together. No intermediate forms have been found.

$S$. rosenkrantzi n. sp. is closely allied to some of the early representatives of the $S$. nodosus group which have a similarly inflated body chamber. It usually differs from the most closely related specimens in having a smaller umbilicus, in being more finely ribbed and in having 

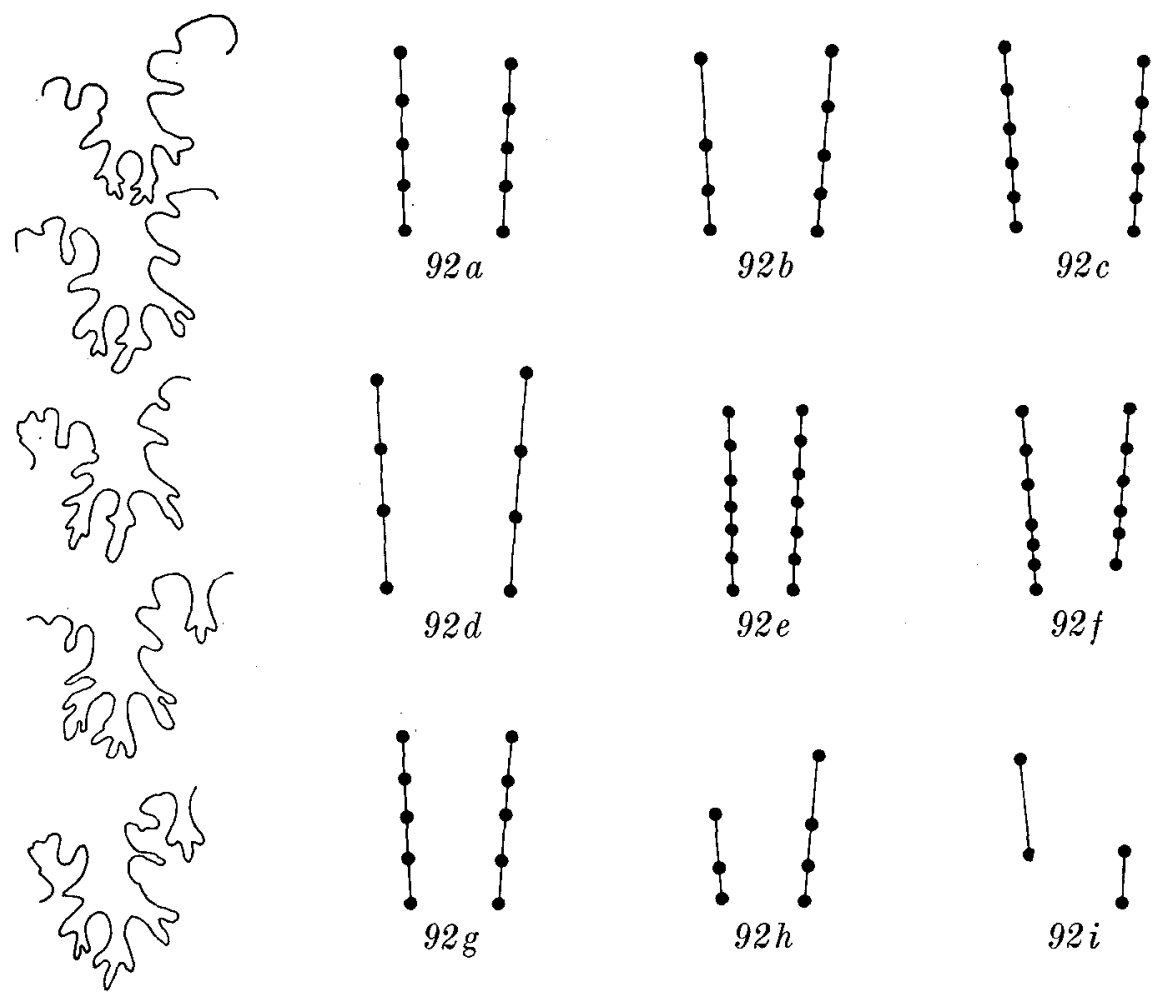

91
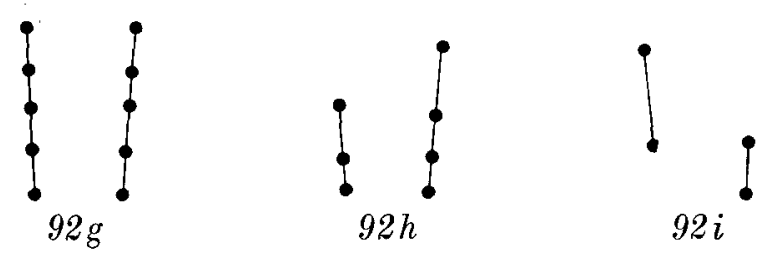

Figs. 91-92. Scaphites rosenkrantzi n.sp. Scaphitesnæsen.

91. MMH No. 9804. $\times 3$, first auxiliary lobe of five last sutures.

92. $\times 1 / 2$, schematic diagrams showing variation in the frequency of ventrolateral nodes.

weaker ribs between the umbilical bullae and the umbilical wall. One specimen from the Baculites perplexus Zone, Salt Creek oil field, 30 miles north of Casper, Wyoming (United States Geological Survey, Mesozoic locality D3261) is extremely similar to the small specimen figured pl. 22, fig. 3, differing only in being more compressed and in having stronger ribs between the umbilical nodes and the umbilical wall.

The relationship between the early forms of the $S$. nodosus group with a slender body chamber, related to $S$. cobbani n. sp., and the early forms with a more inflated body chamber, related to the present species, has not yet been studied in detail, but it seems that there is very wide variation in shape of the body chamber in early Scaphites nodosus forms.

Stratigraphy. The species occurs together with Baculites obtusus Мек к (early form) and Scaphites cobbani n. sp. The beds are referred to the 
Baculites obtusus Zone (Lower Campanian). The early forms of the Scaphites nodosus group appear in that zone in the United States.

\section{Subgenus HOPLOSCAPHITES Nowak, 1911}

Type species. Scaphites constrictus Sowerв , 1818.

Emended diagnosis. Scaphites with very involute phragmocone; body chamber usually with a short shaft and a slightly recurved hook; aperture with a dorsal lappet and occasionally with a weak ventral projection; younger part of phragmocone always compressed with flattened sides and rounded venter; ribs flexuous with a weak lateral projection and occasionally with a very weak ventral projection; surface with or without umbilical and ventrolateral nodes on body chamber; suture with a symmetric to slightly asymmetric bifid lateral lobe.

\section{Scaphites (Hoploscaphites) ikorfatensis n. sp.}

Pl. 24, figs. 1-4; pl. 25, figs. 1-2;

pl. 26, fig. 1 ; text-figs. $59,93,121$ (3).

? 1871-72 Scaphites Römeri d'Orbigny: Schlüter (partim), p. 89, pl. 27, figs. 1-3 (non pl. 27, fig. 4).

? 1885 Scaphites Römeri D'OrbignY: MoberG, p. 29, pl. 3, fig. 9.

? 1911 Acanthoscaphites Römeri D'Or BIGNY: NowaK, p. 585.

? 1916 Acanthoscaphites Römeri D'OrBIGNY: NowaK, p. 62.

? 1953 Scaphites (Acanthoscaphites) roemeri D'ORBIG NY: ØD UM, p. 25, pl. 2, fig. 2.

? 1954 Scaphites greenlandicus Donovan: Donovan (partim), p. 8, pl.2, fig. 4 (non pl. 2, fig. 5 and text-fig. 1).

Holotype. MMH No. 9815. Figured pl. 26, figs. 1 a-c. From Brudkløft at Ikorfat, $550 \mathrm{~m}$ above sea-level. Upper Campanian.

Remarks. Some confusion on the so-called Scaphites roemeri D'Orbign occurs. Roemer (1841) established Scaphites compressus and figured one specimen (pl. 15, fig. 1) from Ahlten, Westphalia (refigured by FrEch, 1915a, text-fig. 14), showing an inflated body chamber, rather fine ribs, and a ventrolateral and an umbilical row of nodes extending over all the exposed shell. The umbilical row of nodes is rather markedly distant from the umbilical margin. The name Scaphites compressus was, however, preoccupied, and GiEBEL $(1849$, p. 20) therefore changed the name of Roemer's species to Scaphites tuberculatus. D'OrBigNy (1850), being unaware of the name proposed by GIEBEL, established the name $S c a$ phites roemeri for RoEmer's species. Thus, Scaphites roemeri D'ORBIGNY is an objective junior synonym of Scaphites tuberculatus Giebel. Schlü- 
TER (1871-72) interpreted Scaphites roemeri as a widely variable species including specimens with two rows of nodes as well as those with one row or with none. Therefore, although he was aware of Giebel's name, he retained Scaphites roemeri D'ORBIGNY as the name for the species.

No material like the figured type of Scaphites tuberculatus has since been described, but Mag. A. Błaszkiewicz (Instytut Geologiczny, Warsaw) has very kindly drawn my attention to some specimens from Kolonia Ciszyca (Upper Campanian), which agree very well with the type in shape, development of nodes and ribbing pattern.

The specimens from Haldem, figured by Schlüter (1871-72, pl. 27, figs. 1-4) have few or many ventrolateral nodes on the body chamber. Further material from Haldem and Darup, borrowed from Professor H. HöLdER, Münster, shows that some of the specimens also have umbilical nodes on the body chamber and some are nodeless, as mentioned by Schlüter. However, none of the available specimens from these localities have nodes extending over the whole exposed phragmocone as does the type species of Scaphites tuberculatus.

Scaphites tuberculatus GIEB EL may be related to late representatives of the Scaphites nodosus group. It is not known from West Greenland, where material closely related to the species group described by ScHL TER occurs.

Since there are large collections from Greenland of specimens related to Schlüter's specimens from Haldem, it is now clear that two species of different stratigraphical distribution $(S .(H$.$) ikorfatensis n. sp.$ and $S .(H$.$) raoni n. sp.) are present in addition to S .(H$.$) greenlandicus$ Donovan. The relations between these species and their affinities with European and North American material are discussed p. 113.

Diagnosis. S. (Hoploscaphites) of large size with body chamber extending very slightly beyond phragmocone; exposed part of phragmocone compressed with flattened sides and rounded venter; straighter part of body chamber compressed with flattened sides and rounded or slightly flattened venter, younger part slightly compressed to depressed with rounded venter; body chamber with maximum height at the middle, width increasing slowly to the aperture; apertural angle $90^{\circ}-$ $110^{\circ}$; surface with coarse to fine, evenly spaced ribs; 3-10 ventrolateral nodes on the body chamber or, very rarely, nodeless; suture rather incised with a symmetric to slightly asymmetric bifid lateral lobe and a bifid to trifid first auxiliary lobe.

Material. Nûgssuaq: about 70 determinable specimens, mostly fragments, from Brudkløft at Ikorfat, 550-665 $\mathrm{m}$ above sea-level. 
Measurements.

Specimen figured text-fig. 59 .

$\begin{array}{ccc}\text { Whorl height } & \text { Whorl width } & \text { W/H } \\ 0.6 \mathrm{~mm} & 0.7 \mathrm{~mm} & 1.17 \\ 0.8- & 0.9- & 1.13 \\ 1.2- & 1.5- & 1.25 \\ 1.8- & 2.3- & 1.28 \\ 2.8- & 3.8- & 1.36 \\ 5.4- & 5.9- & 1.09 \\ 9.4- & 9.2- & 0.98 \\ 16.1- & 13.8- & 0.86 \\ 25.5- & 22.6- & 0.89\end{array}$

$180^{\circ}$ between the measurements. Last measurement about half a whorl from last suture.

Shell length and whorl ratios of 7 mature specimens:

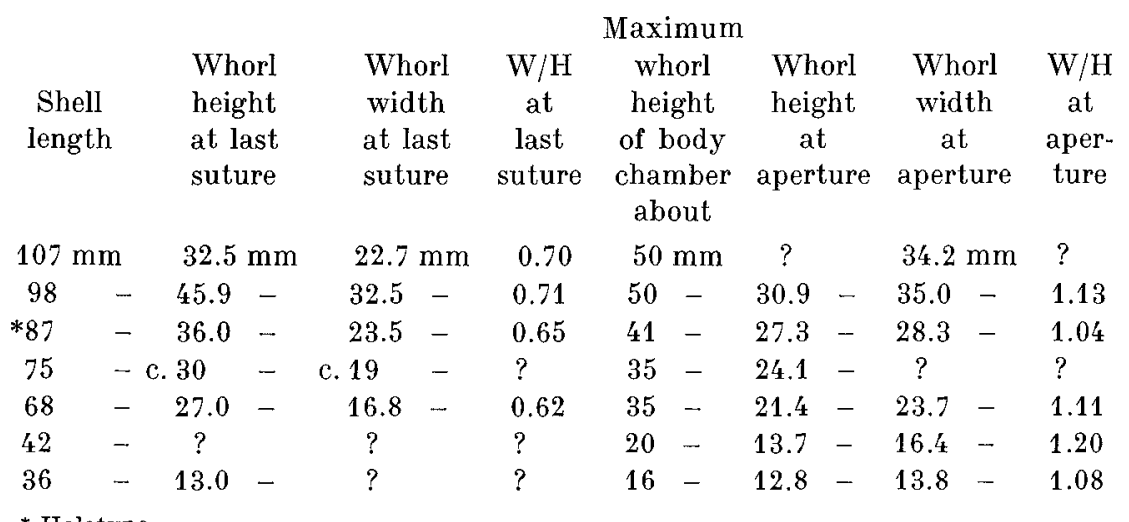

Description. The length of mature specimens ranges from $34 \mathrm{~mm}$ to $107 \mathrm{~mm}$, specimens ranging between 30 and $50 \mathrm{~mm}$ and between 80 and $110 \mathrm{~mm}$ being most abundant. The wide size variation and the uneven size distribution (see text-fig. 121(3)) may indicate special ecological conditions or sexual dimorphism (discussed p. 146). All the specimens are mature and are considered to belong to the same species.

The umbilicus is very small, the external diameter ranging between $2 \mathrm{~mm}$ and $4 \mathrm{~mm}$.

To a whorl height of $5-6 \mathrm{~mm}$ the whorls are evenly rounded and depressed. From that height they slowly become more and more compressed and the sides become flattened.

The body chamber extends slightly beyond the phragmocone. The last suture forms an angle of $90^{\circ}-110^{\circ}$ with the long axis of the shell.

Maximum whorl height is at the middle of the body chamber. The measurements show marked differences in whorl height at the last suture, 


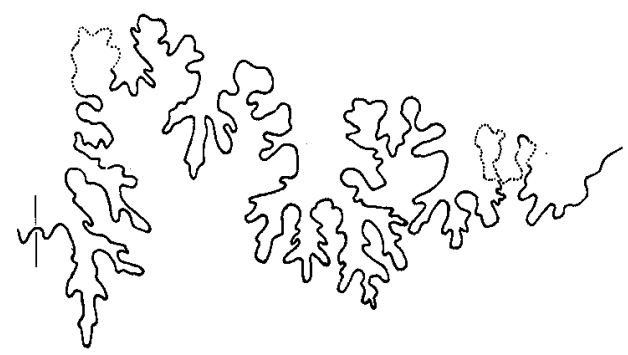

Fig. 93. Scaphites (Hoploscaphites) ikorfatensis n.sp. MMH No. 9923. ×3, external suture at a whorl height of $16 \mathrm{~mm}$. Brudkløft at Ikorfat, $560 \mathrm{~m}$ above sea-level.

at the middle of the body chamber, and at the aperture. Whorl width increases fast within the oldest part of the body chamber and more slowly within the younger part. The straighter part of the body chamber is compressed and the youngest apertural part slightly depressed, the sides are flattened and the venter rounded or occasionally somewhat flattened within the straighter part. At the umbilicus the umbilical wall may have a small swelling. Apart from this swelling the umbilical wall is nearly straight almost to the aperture. The venter has, in side view, an oval or occasionally a subcircular outline. The apertural angle is $90^{\circ}-110^{\circ}$. The aperture shows no ventral projection.

The innermost whorls are smooth. On the youngest part of third whorl weak, rounded ribs appear laterally, later they also become visible ventrally and secondaries are intercalated. Most of the early secondaries are only visible ventrally, later they become more extended laterally. The earliest ribs form a rounded projection on the sides, but later the lateral ribs become nearly straight. The ventral ribs are straight in all stages. With increasing diameter the ribs become finer and more evenly spaced and it is characteristic that on the youngest part of the phragmocone large mature specimens usually have a finer ribbing pattern than small mature specimens. From 2 to 4 ventral ribs to each primary rib are developed on the phragmocone. On the straighter part of the body chamber the ribs are often slightly wider spaced than on the younger part of the phragmocone. On this straighter part the ribs curve backward from the umbilical margin, then they curve forward on the main part of the sides and towards the venter they finally become radial. The rather even ribbing pattern arises from repeated bifurcation of the ribs or by secondaries being continuously intercalated across the sides. There are 3-5 ventral ribs to each primary on the body chamber. On the older ventrolateral part of the body chamber 5-14 ribs per centimetre are developed.

Ventrolateral nodes are present in all specimens except for one (pl. 25, figs. $1 \mathrm{a}-\mathrm{c}$ ). They are developed on the body chamber, except for 
the youngest part, and occasionally on the youngest chambers of the phragmocone. They are of medium size, pointed and range in number from 3-10. One abnormal specimen, which may belong to the species described here, shows two lateral nodes on the body chamber close to the ventrolateral nodes (pl. 24, figs. 4a-b).

The suture is rather simple. The lateral lobe is less deep than the ventral lobe in early stages, but in late stages it may be as deep or deeper than the ventral lobe. It may, further, be slightly asymmetric in later stages, the dorsal branch becoming enlarged. The first auxiliary lobe is about half as deep as the lateral lobe, it may be asymmetrically bifid to trifid in early stages and more symmetrically bifid in later stages. The first lateral saddle is rather wide and divided into two main branches, the ventral branch being much larger than the dorsal branch. The second lateral saddle is narrow and divided into two branches of equal size. The last sutures of small mature specimens are much more simple than those of larger specimens and have a juvenile character.

Affinities and stratigraphy are discussed p. 113-116.

\section{Scaphites (Hoploscaphites) raeni n. sp.}

Pl. 26, figs. 2-4; pl. 27, figs. 1-4; pl. 28, fig. 1;

pl. 29, fig. 1; text-figs. 94-97, 100, $121(4,5)$.

1918 Scaphites sp.: RAyN, p. 364.

Name. The species is named after the late J. P. J. Ravn.

Holoty p e. MMH No. 9819. Figured pl. 27, figs. 1 a-c; text-fig. 95. From Brudkløft at Ikorfat, $550 \mathrm{~m}$ above sea-level, Nûgssuaq. Upper Campanian.

Diagnosis. S. (Hoploscaphites) of large size with body chamber extending markedly beyond the phragmocone; exposed part of phragmocone compressed with flattened sides and rounded venter; straighter part of body chamber compressed and usually subquadrangular in cross section, younger part slightly compressed to depressed with rounded venter; height of body chamber nearly constant, width increases slowly towards aperture; apertural angle $80^{\circ}-100^{\circ}$; surface usually with rather coarse, evenly spaced ribs; $0-10$ ventrolateral nodes on the body chamber and occasionally on youngest part of the phragmocone; suture rather incised with a symmetric to slightly asymmetric bifid lateral lobe and a bifid to trifid first umbilical lobe.

Material. Nûgssuaq: about 100 determinable specimens, mostly fragments, from Brudkløft at Ikorfat, 550-650 m above sea-level; 28 specimens, mostly poorly preserved fragments, from Niaqornat, some col- 
lected in situ in Scaphiteskløft $220 \mathrm{~m}$ above sea-level; one fragment from Vestre Konglomeratkløft at Angnertuneq, $110 \mathrm{~m}$ above sea-level and one displaced specimen from Kangilia (collected in the delta). Additionally, one specimen from the Oyster-ammonite Conglomerate loc. III, probably belong to this species.

Measurements.

Specimen figured text-fig. 94 .

$\begin{array}{ccc}\text { Whorl height } & \text { Whorl width } & \text { W/H } \\ 1.5 \mathrm{~mm} & 1.8 \mathrm{~mm} & 1.20 \\ 2.4- & 2.8- & 1.17 \\ 4.6- & 5.1- & 1.11 \\ 8.0- & 7.9- & 0.99 \\ 13.9- & 12.8- & 0.92\end{array}$

$180^{\circ}$ between the measurements. Last measurement about half a whorl from last suture.

Shell length and whorl ratios of 12 mature specimens:

\begin{tabular}{|c|c|c|c|c|c|c|c|c|c|c|c|c|}
\hline $\begin{array}{l}\text { Loca- } \\
\text { lity }\end{array}$ & \multicolumn{2}{|c|}{$\begin{array}{l}\text { Shell- } \\
\text { length }\end{array}$} & \multicolumn{2}{|c|}{$\begin{array}{l}\text { Whorl } \\
\text { height } \\
\text { at last } \\
\text { suture }\end{array}$} & \multicolumn{2}{|c|}{$\begin{array}{l}\text { Whorl } \\
\text { width } \\
\text { at last } \\
\text { suture }\end{array}$} & $\begin{array}{c}\mathrm{W} / \mathrm{H} \\
\text { at } \\
\text { last } \\
\text { suture }\end{array}$ & \multicolumn{2}{|c|}{$\begin{array}{l}\text { Whorl } \\
\text { height } \\
\text { at aper- } \\
\text { ture }\end{array}$} & \multicolumn{2}{|c|}{$\begin{array}{l}\text { Whorl } \\
\text { width } \\
\text { at aper- } \\
\text { ture }\end{array}$} & $\begin{array}{l}\mathrm{W} / \mathrm{H} \\
\text { at } \\
\text { aper- } \\
\text { ture }\end{array}$ \\
\hline $\mathrm{N}$ & $91 \mathrm{r}$ & $\mathrm{nm}$ & 31.9 I & $\mathrm{mm}$ & 23.2 & $\mathrm{~mm}$ & 0.73 & 29.61 & $\mathrm{~nm}$ & 28.01 & $\mathrm{~nm}$ & 0.95 \\
\hline $\mathrm{N}$ & 82 & -- & 30.8 & - & 20.8 & - & 0.68 & c. 25 & - & 26.3 & $\ldots$ & $?$ \\
\hline$* I$ & c. 75 & - & 30.5 & - & 23.2 & - & 0.76 & 24.9 & $\ldots$ & c. 25 & - & $?$ \\
\hline I & $?$ & & 27.4 & - & 21.2 & - & 0.77 & 23.0 & - & 24.8 & - & 1.08 \\
\hline I & $?$ & & 18.7 & - & 14.7 & - & 0.79 & 16.2 & - & 18.8 & - & 1.16 \\
\hline I & 43 & - & 16.3 & - & 13.0 & - & 0.80 & c. 15 & - & c. 16 & - & $?$ \\
\hline I & ? & & 14.4 & - & 10.5 & - & 0.73 & 12.1 & - & 13.8 & - & 1.14 \\
\hline I & c. 39 & - & 14.2 & - & 10.8 & - & 0.76 & 12.8 & - & 14.3 & - & 1.12 \\
\hline I & 36 & - & 12.5 & - & 8.7 & - & 0.70 & $?$ & & $?$ & & $?$ \\
\hline I & c. 29 & - & 9.0 & - & 8.1 & - & 0.90 & 10.9 & - & 10.7 & - & 0.98 \\
\hline I & 26 & - & 7.6 & - & 6.5 & - & 0.86 & 8.9 & - & $?$ & & $?$ \\
\hline I & 22 & - & 7.2 & - & 6.0 & - & 0.83 & 7.4 & - & 8.0 & - & 1.08 \\
\hline
\end{tabular}

Description. This species occurs rather frequently at two localities, the type locality Ikorfat, and Niaqornat. All specimens seem to be mature. The specimens from Ikorfat range from about $20 \mathrm{~mm}$ to about $84 \mathrm{~mm}$ in length, specimens from $20 \mathrm{~mm}$ to $50 \mathrm{~mm}$ in length being most abundant. On average the specimens from Niaqornat are larger, ranging from $44 \mathrm{~mm}$ to $97 \mathrm{~mm}$, specimens from $80 \mathrm{~mm}$ to $90 \mathrm{~mm}$ being most abundant. The size variation of measurable specimens from the two localities is shown in text-fig. 121(4,5). The wide size variation and the uneven size distribution may indicate special ecological conditions 


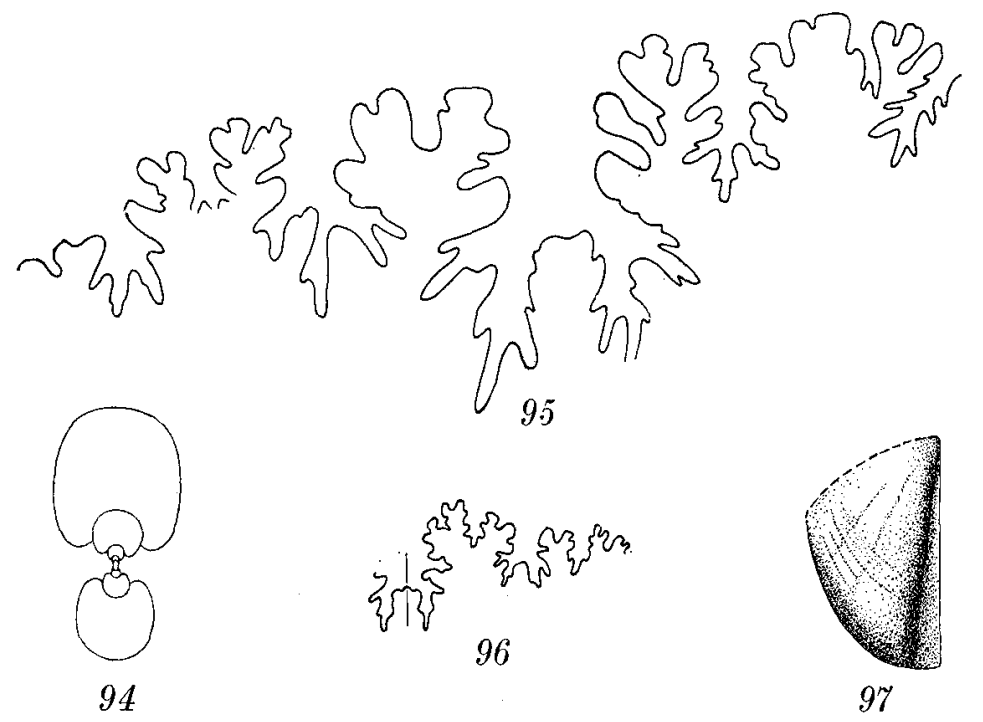

Figs, 94-97. Scaphites (Hoploscaphites) ravni n.sp.

94. MMH No. 9924. $\times 1$, cross section of phragmocone. Brudkløft at Ikorfat, $550 \mathrm{~m}$ above sea-level.

95. Holotype. MMH No. 9819. $\times 3$, part of the external suture at a whorl height of $28 \mathrm{~mm}$. Brudkløft at Ikorfat, $550 \mathrm{~m}$ above sea-level.

96. MMH No. 9822. $\times 3$, external suture of small specimen at a whorl height of $7.7 \mathrm{~mm}$. Brudkløit at Ikorfat, $625 \mathrm{~m}$ above sea-level.

97. MMH No. 9925. $\times 1$, aptychus. Niaqornat.

or sexual dimorphism (discussed p. 146) and all the specimens are considered to belong to the same species.

The external diameter of the umbilicus is $4-6 \mathrm{~mm}$ in larger specimens and smaller (often about $2 \mathrm{~mm}$ ) in small specimens. The umbilical ratio, however, is greatest in small specimens.

To a whorl height of $5-6 \mathrm{~mm}$ the whorls are evenly rounded and depressed. Succeeding whorls are increasingly compressed and the sides become flattened.

The body chamber extends markedly beyond the phragmocone. The last suture forms an angle of $90^{\circ}-130^{\circ}$ with the long axis of the shell, the angle being usually smallest in larger specimens.

In larger specimens the height of the body chamber decreases very slightly from the last suture to the aperture, but is constant or slightly increasing in small specimens (length less than $30 \mathrm{~mm}$ ). The width increases slowly from the last suture to the aperture in all specimens. At the last suture the cross section is always rather compressed, whereas at the aperture the height and width are about equal or the section is slightly depressed. The sides of the body chamber are flattened. Also the venter of the straighter part of the shell is usually flattened, the 
cross section here being subquadrangular. In side view the venter and the umbilical wall are nearly parallel. The apertural angle is $80^{\circ}-100^{\circ}$. The aperture shows no ventral projection.

The ribbing of the phragmocone is similar to that of $S$. (H.) ikorfatensis $\mathrm{n}$. sp. The exposed part of the phragmocone of larger specimens has fine, evenly spaced ribs. The sculpture of the exposed phragmocone of small specimens has a juvenile aspect and is similar to that of larger specimens at similar whorl dimensions. On the straighter part of the body chamber the ribs are usually more widely spaced than on the phragmocone, especially on the sides. Nearer the aperture the ribs again become more closely spaced. The ribs on the straighter part of the body chamber curve slightly backward from the umbilical margin, they then curve forward on the main part of the sides and toward the venter they become radial. The ribs bifurcate (often repeatedly) or secondaries are continuously intercalated across the sides. Both on the body chamber and on the exposed phragmocone 3-4 secondary ribs are developed to each ventral rib. Specimens from Niaqornat have $5-12$ ribs per centimetre on the older ventrolateral part of the body chamber (the variation is shown in text-fig. 100) and specimens from Ikorfat show similar numbers.

The specimens from Ikorfat have 4-10 ventrolateral nodes on the older part of the body chamber and on the youngest part of the phragmocone. The nodes are rather small and often pointed. Additionally, in a few specimens, some of the ribs may be slightly thickened, forming weak bullae at the umbilical margin (pl. 26, fig. 4). True umbilical nodes are never developed. A few of the specimens from Niaqornat are without nodes (pl. 29, figs. $1 \mathrm{a}-\mathrm{c}$ ), the remainder from that locality have up to 6 ventrolateral nodes.

The sutures are rather poorly preserved. They seem to be similar to the sutures of $S$. (H.) ikorfatensis $\mathrm{n}$. sp. As in that species the last sutures of small mature specimens are much more simple than those of larger specimens and have a juvenile character.

One fragment from the Oyster-ammonite Conglomerate loc. III may be related to this species. It differs in that the ventrolateral row of nodes extends to the aperture and in having more complex sutures.

Text-fig. 97 shows an incomplete aptychus belonging to a body chamber of the species described here.

Affinities and stratigraphy are discussed p. 113-116. 
Scaphites (Hoploscaphites) greenlandicus Donovan, 1953

PI. 28 , figs. $2-3$; pl. 29 , fig. 2 ; pl. 30 , figs. $1-3 ;$ pl. 31 , figs. $1-2 ;$ pl. 32 , fig. 1 ; pl. 33 , fig. 1 ; text-figs. $64-66$, $98-100,121(6)$.

? 1871-72 Scaphites Römeri D’Orвigny: Schl Üтек (partim), p. 89, pl. 27, fig. 4 (non pl. 27, figs. 1-3).

? 1876 Scaphites Römeri D'OrBigNy: SchlÜter, p. 163, pl. 42, fig. 4.

1882 Scaphites sp.: DE LORIOL, p. 206.

1897 Scaphites Roemeri D'OrbignY: Madsen, p. 49, pl., figs. 1-3.

1918 Scaphites Nicolletii Morton: Rayn, p. 363, pl. 8, fig. 18; pl. 9, figs.1-2; text-fig. 2.

1942 Scaphites roemeri d'Orbigny: Rosenkrantz, p. 40.

1951 Acanthoscaphites roemeri: Rosenkrantz p. 156.

1953 Scaphites greenlandicus Dovovan, p. 121, pl. 24, figs. 9-10.

1954 Scaphites greenlandicus Donovan: Donovan (partim), p. 7, text-figs. 1a-e; pl. 2, fig. 5 (non pl. 2, fig. 4).

1957 Scaphites greenlandicus Donovan: Donovan, p. 154.

Holotype. MMH No. 1745. Figured by Madsen (1897, fig. 3) and refigured by Rave (1918, pl. 9, fig. 2). From Niaqornat, Nûgssuaq. Upper Campanian. The specimen figured by RAvn (1918, pl. 9, fig. 1, MMH No. $1744)$ is regarded as a paratype by Donovan (1953, p. 123).

Emended diagnosis. S. (Hoploscaphites) of rather large size with body chamber extending slightly beyond phragmocone; whorl section very compressed with flattened sides and rounded venter; height of body chamber decreases slowly and width increases slowly toward aperture, or body chamber may be slightly inflated; apertural angle usually $95^{\circ}-$ $100^{\circ}$; surface with extremely fine, perfectly evenly spaced ribs; no tubercles or occasionally only a few ventrolateral ones on body chamber; suture rather incised with a symmetric to slightly asymmetric bifid lateral lobe and a bifid first auxiliary lobe.

Material. Nûgssuaq: several hundred specimens, mostly poorly preserved fragments, from Niaqornat, some collected in situ in Scaphiteskløft, $220 \mathrm{~m}$ above sea-level; a few specimens from Vestre Konglomeratkløft and Scaphitesryggen at Angnertuneq, 103-110 m above sea-level, and from Skifer-peridotitnæsen at Kûk-anernilik, $40 \mathrm{~m}$ above sea-level. Additionally, two fragments from Ikorfat, $825-885 \mathrm{~m}$ above sea-level, one specimen from the Oyster-ammonite Conglomerate loc. II, and a few fragments from the Oyster-ammonite Conglomerate loc. III, probably belong to this species.

Description. The length of mature specimens ranges from about $50 \mathrm{~mm}$ to about $100 \mathrm{~mm}$, specimens ranging between $60 \mathrm{~mm}$ and $90 \mathrm{~mm}$ being most abundant (text-fig. 121(6)). No juvenile specimens are known. The external diameter of the umbilicus is $3-5 \mathrm{~mm}$. 


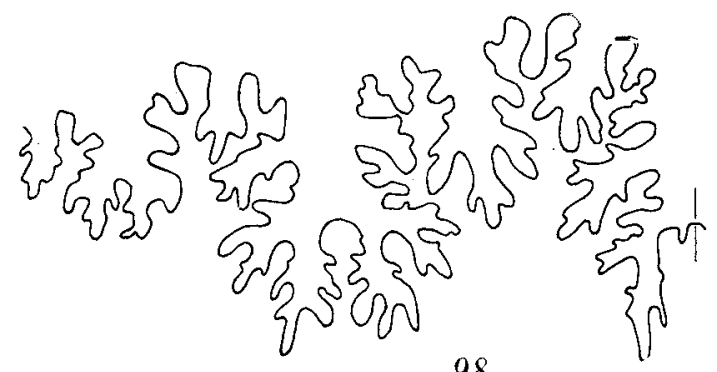

98

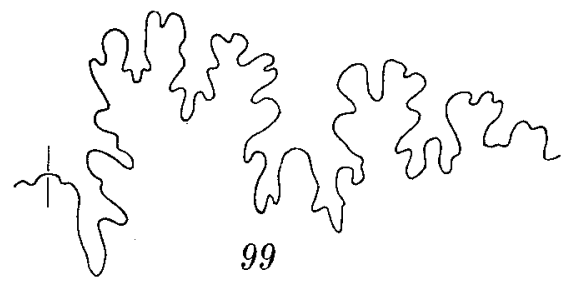

Figs. 98-99. Scaphites (Hoploscaphites) greenlandicus Donovan. Niaqornat.

98. MMH No. 9926. $\times 3$, external suture at a whorl height of $24 \mathrm{~mm}$.

99. MMH No. 9927. $\times 10$, external suture at a whorl height of $4 \mathrm{~mm}$.

The variation in cross section of the whorls is rather poorly known because of imperfect preservation. Except for the innermost whorls the phragmocone is compressed with flattened sides.

The body chamber extends only slightly beyond the phragmocone. The last suture forms an angle of $90^{\circ}-125^{\circ}$ with the long axis of the shell.

Usually the height of the body chamber is constant or decreases very slightly adapically within the straighter part of the body chamber, whereas it decreases somewhat faster within the curved part. The width increases slowly from the last suture to the aperture in these specimens. Some specimens, however, have a slightly inflated body chamber with the maximum height and width at the middle. They occur together with typical specimens and intermediate forms occur (compare pl. 29, fig. 2 and pl. 31, fig. 1). All the specimens are less compressed closer to the aperture than in the older part of the body chamber. The sides of the body chamber are flattened and the venter rounded.

In side view the venter of the older part of the body chamber is nearly straight but it becomes more curved in the younger part, or it forms a subcircular curve (in inflated specimens). The older part of the umbilical wall is nearly straight. The apertural angle is usually $95^{\circ}-$ $100^{\circ}$, but may occasionally be up to $120^{\circ}$. There is no ventral projection. 


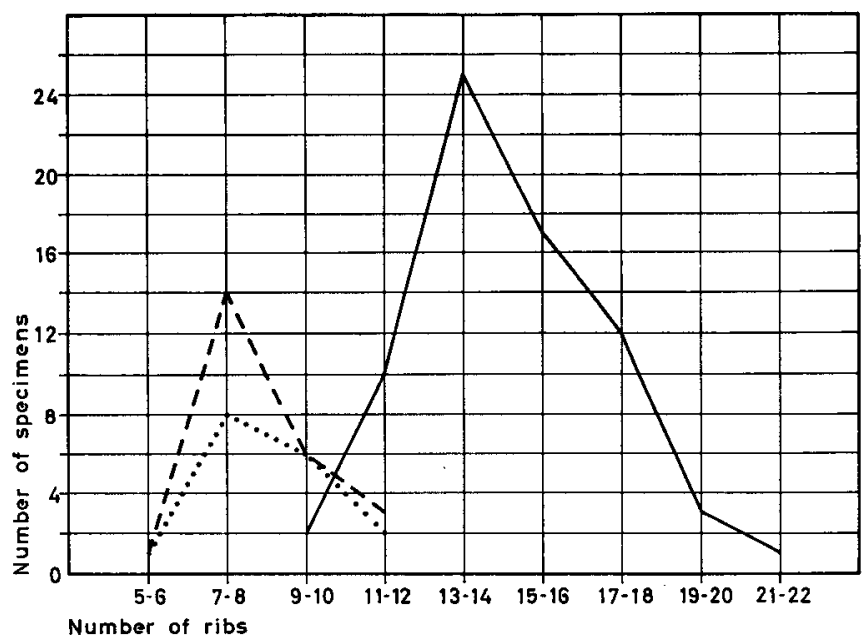

Fig. 100. Diagram showing the range of variation in number of ribs per centimetre on the older, ventrolateral part of the body chamber in $S$. $(H$.$) greenlandicus from$ Niaqornat (full line), $S .(H$.$) ravni n.sp. from Niaqornat (broken line) and S .(H$. ravni n.sp. from Ikorfat (dotted line).

The innermost whorls are smooth. On the youngest part of third whorl weak, rounded ribs become visible. At first they are most distinct laterally, where they form a rounded projection. On the fourth whorl they become visible ventrally and intercalatory ribs develop. Most of the early intercalatory ribs are only visible ventrally, later they become more extended laterally. The ribs gradually develop a weak, rounded ventral projection in addition to the weak lateral curvature (text-figs. 64-66). The ribs become finer and sharper on the younger whorls and the ventral projection of the ribs disappears. On the older part of the phragmocone about 3 ventral ribs are developed to each primary rib. The exposed part of the phragmocone and the body chamber have extremely fine, sharp, evenly spaced ribs all over the surface or the ribs may be slightly closer spaced within the apertural part. The even ribbing pattern arises from repeated bifurcation of the ribs or by secondaries being continuously intercalated across the sides. The ribs on the straighter part of the body chamber curve strongly backward from the umbilical margin, they then curve strongly forward on the main part of the sides and toward the venter they finally become radial. On the younger part of the phragmocone, and on the body chamber, there are 3-4 ventral ribs to each primary rib; 10-21 ribs per centimetre are developed on the older ventrolateral part of the body chamber (the variation is shown in text-fig. 100). 
The majority of specimens have no tubercles at all. Two specimens, only, show one or two weak ventrolateral nodes on the middle part of the body chamber (pl. 28, fig. 2).

The suture is rather incised and very similar to that of $S$. (H.) ikorfatensis n. sp.

A few finely ribbed specimens from the Oyster-ammonite Conglomerate may be referred to this species. The only complete specimen (pl. 30 , figs. $3 \mathrm{a}-\mathrm{c})$ differs in having a slightly more extended body chamber than usual and, in this character, is similar to $S$. (H.) raoni n. sp., but in other characters the fragments most resemble the species described here.

Two nodeless specimens with evenly spaced ribs from Vestre Konglomeratkløft and Scaphitesryggen at Angnertuneq may be closely related to the species described here (pl. 32, figs. 1a-c; pl. 33, figs. 1a-c). They differ, however, in being less compressed, in a coarser ribbing pattern and in having a wider umbilicus. One fragment from Niaqornat may have a similar morphology. These specimens have also some affinity with $S$. (H.) ikorfatensis n. sp. from Ikorfat.

Affinities between S. (H.) ikorfatensis n.sp., S. (H.) ravni n.sp., S. (H.) greenlandicus Donovan and related species. The three S. (Hoploscaphites) species described above are very closely related. $S .(H$.$) ikorfatensis n. sp. and S$. $(H$.$) greenlandicus occur at different$ levels. $S .(H$.$) raoni n. sp. has a longer stratigraphical range and occurs$ together with $S .(H$.$) ikorfatensis n. sp. as well as with S$. (H.) greenlandicus.

Old collections of scaphites from Niaqornat were referred to Scaphites roemeri by MADsen (1897) and to Scaphites nicolletii by RavN (1918). Both authors interpreted $S$. roemeri and $S$. nicolletii as synonymous. This opinion was rejected by RosenkRANTz (1942), who very clearly pointed out the great morphological differences between the two species.

Donovar (1953) established a new species, S.greenlandicus, on material described from Niaqornat and new material from East Greenland. Donovan also placed a specimen referred to Scaphites roemeri by SCHLÜTER (1871-72, pl. 27, fig. 4) in that species, thus indicating the relations to that group.

Ravn (1918) mentioned that a few fragments from Niaqornat differed from "Scaphites nicolletii" (=S. (H.) greenlandicus) by having ventrolateral nodes and by having coarser ribs and more flattened sides. These fragments are here referred to $S$. (H.) rasni n. sp.

Typical $S .(H$.$) ikorfatensis n. sp. from Ikorfat differs from typical$ $S$. (H.) greenlandicus from Niaqornat in being less compressed, in having 179 
a more inflated and less extended body chamber, in having coarser and less flexuous ribs and in having many ventrolateral nodes. However, a few specimens may be intermediate in some of these characters. Thus some $S .(H$.$) greenlandicus may be slightly inflated and the ribbing$ pattern of the two species may be very much alike; $S$. $(H$.$) greenlandicus$ may have a few nodes and $S$. (H.) ikorfatensis n. sp. may be without nodes. The two specimens from Angnertuneq, figured pl. 32, figs. $1 \mathrm{a}-\mathrm{c}$ and pl. 33 , figs. $1 \mathrm{a}-\mathrm{c}$, seem to be intermediate between the two species. Although the morphological difference between the two species is small they are maintained as distinct species, particularly as each has a different stratigraphical range.

$S$. (H.) ikorfatensis n. sp. and $S$. $(H$.$) raoni n. sp. are even more$ closely related than $S$. (H.) ikorfatensis n. sp. and $S$. (H.) greenlandicus. $S$. (H.) ikorfatensis $\mathbf{n}$. sp. differs mainly from $S$. (H.) raoni n. sp. in the shape of the body chamber, the former having an inflated body chamber, only slightly extended beyond the phragmocone and usually with a rounded venter, whereas the latter has a very extended body chamber, with, in side view, the venter and dorsum nearly parallel, and usually with a flattened venter.

$S$. (H.) ravni n. sp. differs from $S$. $(H$.$) greenlandicus in having the$ body chamber more extended beyond the phragmocone, in having the venter of the older part of the body chamber commonly flattened, in having coarser and less flexuous ribs and in having ventrolateral nodes, but some nodeless specimens also occur. It seems that late forms of $S$. $(H$.$) ravni n. sp. have fewer ventrolateral nodes than early forms.$

Comparison with material from Europe shows that the Greenland $S$. (Hoploscaphites) species are related to "Scaphites roemeri" sensu Schlüter (1871-72) but not to the true Scaphites tuberculatus Giebel, as mentioned p. 103.

SCHLÜTER's specimen figured in pl. 27, figs. 1-3, seems to be closely related to $S$. (H.) ikorfatensis n. sp. Exact comparison of the shape of the shells is not possible because SchцÜтеR's specimen is deformed. The body chamber seems to be inflated in a similar way as $S$. $(H$.) ikorfatensis n. sp. and the ribbing pattern is also very similar. The specimen differs from $S .(H$.$) ikorfatensis n. sp. in that the ventrolateral row of nodes$ extends to the aperture.

The other specimen figured by Schlüter (1871-72, pl. 27, fig. 4) was referred to $S$.greenlandicus by Donovan. This specimen also is deformed, but may well belong to $S$. (H.) greenlandicus as well as the specimen figured by ScHLÜTER (1876, pl.42, fig. 4). Both specimens differ slightly in ribbing pattern, having less flexuous ribs on the body chamber. 
Among some additional specimens of "Scaphites roemeri" from Haldem and Darup, Westphalia, borrowed from Professor H. Hölder, Münster, one is similar in the shape of the body chamber and has a ribbing pattern like that of $S$. $(H$.$) rawni n. sp., but differs in having many$ rather distinct umbilical bullae on the body chamber and in having no ventrolateral nodes. A specimen figured by Miknailov (1951, pl. 16, figs. 74-75), referred to Acanthoscaphites roemeri var. tuberculata (GIEв ЕL), is similar to $S$. $(H$.$) ravni n. sp. in shape and ribbing pattern, but$ also differs in having rather distinct umbilical bullae on the body chamber. As $S$. (H.) raoni n. sp. shows in a few cases very slight umbilical bullae, it is thought to be closely related to the specimen from Haldem and to the specimen described by Mrkнailov. The name "tuberculata" should, however, not be used for these specimens, because in the type specimen of Scaphites tuberculatus GIEBEL the rows of umbilical nodes and ventrolateral nodes extend along all the exposed shell and the row of umbilical nodes is noticeably much more distant from the umbilical wall.

From the Western Interior of the United States and Canada СoвBAN \& JELETZKY (in press) have described a new $S$. (Hoploscaphites) species, $S .(H$.$) gilli, which is closely related to S .(H$.$) greenlandicus. It$ differs from that species in its smaller size and slightly coarser ribbing. $S$. $(H$.$) gilli may also be very similar to small specimens of S$. (H.) ikorfatensis n. sp., but differs in its more compressed shape, by having more flexuous ribs and, usually, in the absence of nodes. Some other specimens from the United States in Dr. W. A. CobBan's collections in the United States Geological Survey in Denver are more closely related to $S$. (H.) ikorfatensis n. sp., but not yet described.

Stratigraphy. In West Greenland $S$. (H.) ikorfatensis n. sp. occurs at Ikorfat. $S$. (H.) greenlandicus occurs at Niaqornat and possibly above the $S$. $(H$.$) ikorfatensis level at Ikorfat. S$. $(H$.$) ravni n. sp. occurs together$ with $S$. (H.) ikorfatensis n. sp. at Ikorfat as well as together with $S$. (H.) greenlandicus at Niaqornat. Both $S$. $(H$.) greenlandicus and $S$. (H.) ravni n. sp. also occur at Angnertuneq and $S$. $(H$.$) greenlandicus occurs$ at Kûk-anernilik. The $S .(H$.$) ikorfatensis level at Ikorfat seems to$ belong to a slightly older horizon than the other localities here mentioned.

The most closely related forms from Europe occur in the Upper Campanian (Bostrychoceras polyplocum Zone). They are not known from the Lower Maastrichtian in Europe, but often mentioned from that level, because $S$. (H.) constrictus tenuistriatus (KNER, 1848) was thought to be identical with "S. roemeri" (for example by Schlüter, 1871-72, p. 89) 
or it was misidentified and referred to "S. roemeri" (for example by Ravn, 1902, p. 255).

The European " $S$. roemeri" forms related to the species from Greenland are of very scattered occurrence and no exact studies on their stratigraphical range within the uppermost Campanian have yet been made.

According to Cobban \& Jeletzky (in press) $S$. (H.) gilli occurs in the Western Interior of North America in the Upper Campanian from the Baculites perplexus Zone to the Didymoceras stevensoni Zone. Forms closely related to $S$. $(H$.$) ikorfatensis n. sp. occur at similar levels; spec-$ imens from the Baculites gregoryensis Zone are particularly similar.

\section{Scaphites (Hoploscaphites?) sp.}

Pl. 34, figs. 1-2.

Material. Nûgssuaq: two fragments from Brudkløft at Ikorfat, $550 \mathrm{~m}$ above sea-level and one displaced fragment from Breccieelv west of Ikorfat, 150-200 $\mathrm{m}$ above sea-level.

Remarks. The three specimens are fragments of very large scaphites. The cross section is less compressed than usual in Hoploscaphites.

In shape of the body chamber, ribbing pattern and nodes the fragments are very similar to $S$. (H.) ikorfatensis n. sp., but because of the difference in size and cross section they may belong to a separate species.

The fragments occur together with $S .(H$.$) ikorfatensis n. sp. and$ $S$. (H.) rawni n. sp. at Ikorfat.

\section{Subgenus DISCOSCAPHITES MeEk, 1870}

Type species. Ammonites Conradi Morton, 1834.

Emended diagnosis. Scaphites with more or less involute phragmocone; body chamber usually with a short shaft and a slightly recurved hook; aperture with a dorsal lappet and usually with a rather prominent ventral projection; greater part of phragmocone compressed, often with flattened sides and venter; ribs very flexuous with a lateral and a ventral projection; surface with umbilical, ventrolateral, and lateral rows of tubercles extending over both the phragmocone and body chamber, tubercles may be restricted to a single ventrolateral row on body chamber; suture usually with an asymmetric bifid lateral lobe. 
Scaphites (Discoscaphites) waagei n. sp.

Pl. 35, figs. 1-2; pl. 36, figs. 1-3; pl. 37, figs. 1-2;

pl. 38, fig. 1; text-figs. 67, 71, 101-105, 121 (7).

Name. The species is named after Professor K. M. WAaGE.

Holotype. MMH No. 9837. Figured pl. 35, figs. 1 a-c. From the Oysterammonite Conglomerate loc. I, Nûgssuaq. Maastrichtian.

Diagnosis. Large S. (Discoscaphites) with a very wide umbilicus and a body chamber extending markedly beyond the phragmocone in large specimens, and only slightly beyond this in small specimens; whorl section of exposed whorls extremely compressed and with flattened sides; venter of youngest part of phragmocone and straighter part of body chamber mostly flattened; body chamber with slightly increasing height and width towards aperture; apertural angle $100^{\circ}-125^{\circ}$; surface of exposed phragmocone with strong widely spaced ribs; the sides of older part of the body chamber undulating and with rather scattered distinctly bundled ribs, the sides of younger part of body chamber usually with more evenly spaced fine ribs; 11-19 ventrolateral nodes or clavi on older part of body chamber and youngest part of phragmocone, and 7-9 umbilical bullae on body chamber; suture complicated with an asymmetric bifid lateral lobe and an asymmetric trifid to bifid first auxiliary lobe.

Material. Nûgssuaq: 32 complete or nearly complete specimens and about 60 determinable fragments from the Oyster-ammonite Conglomerate loc. I; a few specimens from the Oyster-ammonite Conglomerate loc. II and 8 nearly complete specimens and about 25 determinable fragments from the Oyster-ammonite Conglomerate loc. III.

Measurements.

Specimen figured text-fig. 101.

$\begin{array}{rrl}\begin{array}{l}\text { Whorl } \\ \text { height }\end{array} & \begin{array}{l}\text { Whorl } \\ \text { width }\end{array} & \text { W/H } \\ 0.3 \mathrm{~mm} & 0.5 \mathrm{~mm} & 1.67 \\ 0.4- & 0.6- & 1.50 \\ 0.7- & 0.9- & 1.29 \\ 0.8- & \text { c. } 1.2- & ? \\ 1.4- & 1.7- & 1.21 \\ 2.2- & 2.5- & 1.14 \\ 3.1- & 3.5- & 1.13 \\ 5.5- & 5.0- & 0.91 \\ 8.3- & 6.9- & 0.83 \\ 14.6- & 10.2- & 0.70 \\ \text { c. } 27- & \text { c. } 17- & ?\end{array}$

$180^{\circ}$ between the measurements. Last measurement close to last suture.
Specimen figured text-fig. 102.

$\begin{array}{ll}\text { Whorl } & \text { Whorl } \\ \text { height } & \text { width }\end{array}$

$\begin{array}{rrr}0.9 \mathrm{~mm} & 1.2 \mathrm{~mm} & 1.33 \\ 1.5- & 1.8- & 1.20 \\ 2.3- & 2.7- & 1.17 \\ 3.6- & 3.9- & 1.08 \\ 6.2- & 5.7- & 0.92 \\ 9.5- & 8.3- & 0.87 \\ 16.2- & 13.2- & 0.81 \\ 27.9- & 20.5- & 0.73\end{array}$

$180^{\circ}$ between the measurements. Last measurement close to last suture. 
Shell length and whorl ratios of 9 mature specimens:

\begin{tabular}{|c|c|c|c|c|c|c|c|c|c|c|c|}
\hline \multirow{2}{*}{\multicolumn{2}{|c|}{$\begin{array}{c}\text { Shell } \\
\text { length }\end{array}$}} & \multicolumn{2}{|c|}{$\begin{array}{l}\text { Whorl } \\
\text { height } \\
\text { at last } \\
\text { suture }\end{array}$} & \multicolumn{2}{|c|}{$\begin{array}{l}\text { Whorl } \\
\text { width } \\
\text { at last } \\
\text { suture }\end{array}$} & \multirow{2}{*}{$\begin{array}{c}\mathrm{W} / \mathrm{H} \\
\text { at } \\
\text { last } \\
\text { suture } \\
?\end{array}$} & \multicolumn{2}{|c|}{$\begin{array}{l}\text { Whorl } \\
\text { height } \\
\text { at aper- } \\
\text { ture }\end{array}$} & \multicolumn{2}{|c|}{$\begin{array}{l}\text { Whorl } \\
\text { width } \\
\text { at aper- } \\
\text { ture }\end{array}$} & \multirow{2}{*}{$\begin{array}{l}\mathrm{W} / \mathrm{H} \\
\text { at } \\
\text { aper- } \\
\text { ture } \\
?\end{array}$} \\
\hline & & c. 35 & $\mathrm{~mm}$ & c. 22 & $\mathrm{~mm}$ & & 40.8 & $\mathrm{~mm}$ & c. 31 & $\mathrm{~mm}$ & \\
\hline 92 & - & 30.6 & - & 23.1 & - & 0.75 & 33.9 & - & c. 30 & - & $?$ \\
\hline 91 & - & 29.6 & - & $?$ & & $?$ & 31.7 & - & 31.3 & - & 0.99 \\
\hline c. 90 & - & 32.3 & - & 23.1 & - & 0.72 & 35.0 & - & 31.0 & - & 0.89 \\
\hline$* 87$ & - & 31.1 & - & $?$ & & $?$ & 31.7 & - & $?$ & & $?$ \\
\hline$?$ & & 30.6 & - & 19.1 & - & 0.62 & 30.8 & - & 26.4 & - & 0.86 \\
\hline 71 & - & c. 22 & - & c. 16 & - & $?$ & 28.6 & - & 23.7 & - & 0.83 \\
\hline c. 59 & - & 21.0 & - & 16.4 & - & 0.78 & 24.0 & - & $?$ & & $?$ \\
\hline c. 58 & - & 20.0 & - & 12.5 & - & 0.63 & $?$ & & $?$ & & $?$ \\
\hline
\end{tabular}

Description. The length of mature specimens ranges from about $33 \mathrm{~mm}$ to about $113 \mathrm{~mm}$. The wide variation in size and the grouping of specimens according to length is demonstrated in the histogram textfig. 121 (7). Together with mature specimens many juvenile discoscaphites representing various growth stages also occur. Some of these are shown in text-figs. 106-108. The figures show how the relative length of the body chamber decreases with increasing age, being about $230^{\circ}$ at a shell diameter of $5.9 \mathrm{~mm}$ and only a little more than $180^{\circ}$ in later stages. The complete length of the body chamber of the earliest growth stages represented in the collections is not known. Text-fig. 107 shows a juvenile specimen with a well preserved aperture. At this stage the apertural margin projects slightly laterally and has also a very weak ventral projection. Later the lateral projections disappear and the ventral projection becomes more distinct. Only some of the late juvenile stages are determinable, the early juvenile stages could as well belong to $S$. (D.) angmartussutensis described p. 124 .

In mature specimens the diameter of the umbilicus ranges between $6.2 \mathrm{~mm}$ and $13.5 \mathrm{~mm}$ at the last suture, the umbilical ratio being $17-24 \%$ in specimens exceeding $60 \mathrm{~mm}$ in length and up to $27 \%$ in smaller mature specimens. The umbilical ratio decreases considerably with increasing age. The umbilical slope is rather steep and the youngest whorl usually has a sharp umbilical neck.

The inner whorls are depressed and evenly rounded. Whorl height and width are equal at a whorl height of about $5 \mathrm{~mm}$, younger whorls become increasingly compressed with increasing age. At the same time the sides and the venter become flatter and the cross section subquadrangular (text-fig. 101a). Occasionally specimens have more rounded whorls as seen from the cross section in text-fig. 102. 


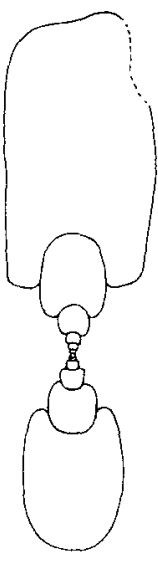

$101 a$

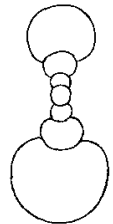

$101 b$

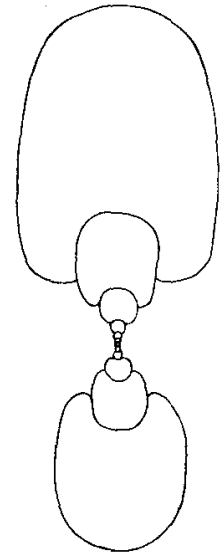

102

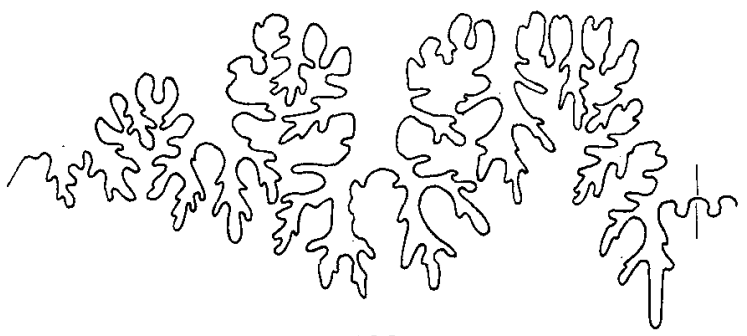

103

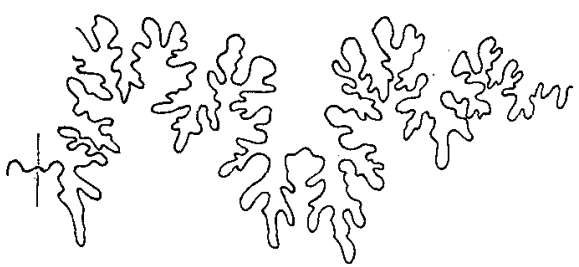

104

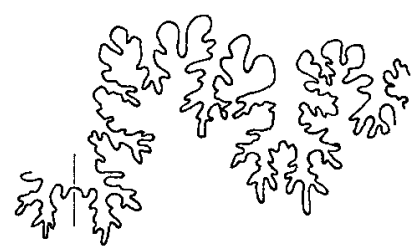

105

Figs. 101-105. Scaphites (Discoscaphites) waagei n.sp. All from the Oyster-ammonite Conglomerate loc. I.

101. MMH No. 9928. $a, \times 1 ; b, \times 4$, cross section of phragmocone.

102. MMH No. 9929. $\times 1$, cross section of phragmocone.

103. MMH No. 9841. $\times 3$, external suture at a whorl height of $17 \mathrm{~mm}$.

104. MMH No. 9908. $\times 3$, external suture at a whorl height of $15 \mathrm{~mm}$.

105. MMH No. 9942. $\times 3$, external suture at a whorl height of $12 \mathrm{~mm}$.

In large specimens the body chamber extends markedly beyond the phragmocone, whereas the dorsum in many smaller specimens (shell length less than $70 \mathrm{~mm}$ ) may be almost entirely in contact with the phragmocone. The last suture of mature specimens forms an angle of $110^{\circ}-170^{\circ}$ with the long axis of the shell. The height of the body chamber increases slightly from the last suture to the aperture or it may decrease slightly in the youngest apical part. The width increases evenly and 
slowly towards the aperture. The younger part of the body chamber is less compressed than the older part. The sides and the older part of the venter of the body chamber are always flattened. In side view the venter and the umbilical wall are nearly parallel and evenly curved. There is a rather strong ventral apertural projection. The apertural angle is $100^{\circ}-125^{\circ}$.

The innermost whorls are smooth. On the youngest part of the third whorl weak, rounded ribs appear forming a rounded projection. On the fourth whorl the ribs extend ventrally, intercalatory ribs develop and the ribs gradually become sharper and more curved, showing a distinct, rounded lateral projection and a weak, rounded ventral projection. On the younger part of the phragmocone the lateral projection gradually gets weaker. The exposed part of the phragmocone has 4-6 ventral ribs per centimetre on the older part and 4-8 on the younger part, individual specimens usually have 1-3 ribs more per centimetre on the younger part than on the older part. On the exposed part of the phragmocone 3-6 ventral ribs are developed to each primary rib, the range of variation in this character being very wide. The holotype has 5-6 ventral ribs to each primary on that part of the shell. The primary ribs may be slightly thickened at the umbilical angle. In some specimens most secondary ribs disappear close to the ventrolateral shoulder and the ribs are therefore more widely spaced on the sides than on the venter. In other specimens the ribs appear more evenly spaced since a greater number of secondaries extend closer to the umbilicus. The ribs bifurcate or secondaries are intercalated. One rib may bifurcate twice.

On the body chamber the ribs become more closely spaced towards the aperture and are united in bunches at the umbilical nodes. The number of ventral ribs on the youngest part of the body chamber ranges from 5 to 11 per centimetre. Most secondaries disappear rather close to the ventrolateral shoulder on the straighter part of the body chamber and here the bunches of ribs are most distinct. On the younger, more curved, part of the body chamber the secondaries usually extend closer to the umbilical wall and because of repeated bifurcation the ribs are evenly spaced over all this part of the shell, making the rib-bunches more obscure. In some specimens, however, the secondary ribs are less extended on this youngest part of the body chamber and the sculpture is similar to that of the straighter part of the shell. The ventral ribs are curved parallel to the ventral projection of the aperture.

On the oldest $2 / 3$ of the body chamber and often on the youngest chambers of the phragmocone 11-19 ventrolateral tubercles are developed. The tubercles are mostly strong and pointed nodes, but in some specimens they may be rather weak and occasionally they are developed as clavi. The tubercles on the phragmocone and oldest part of the body 

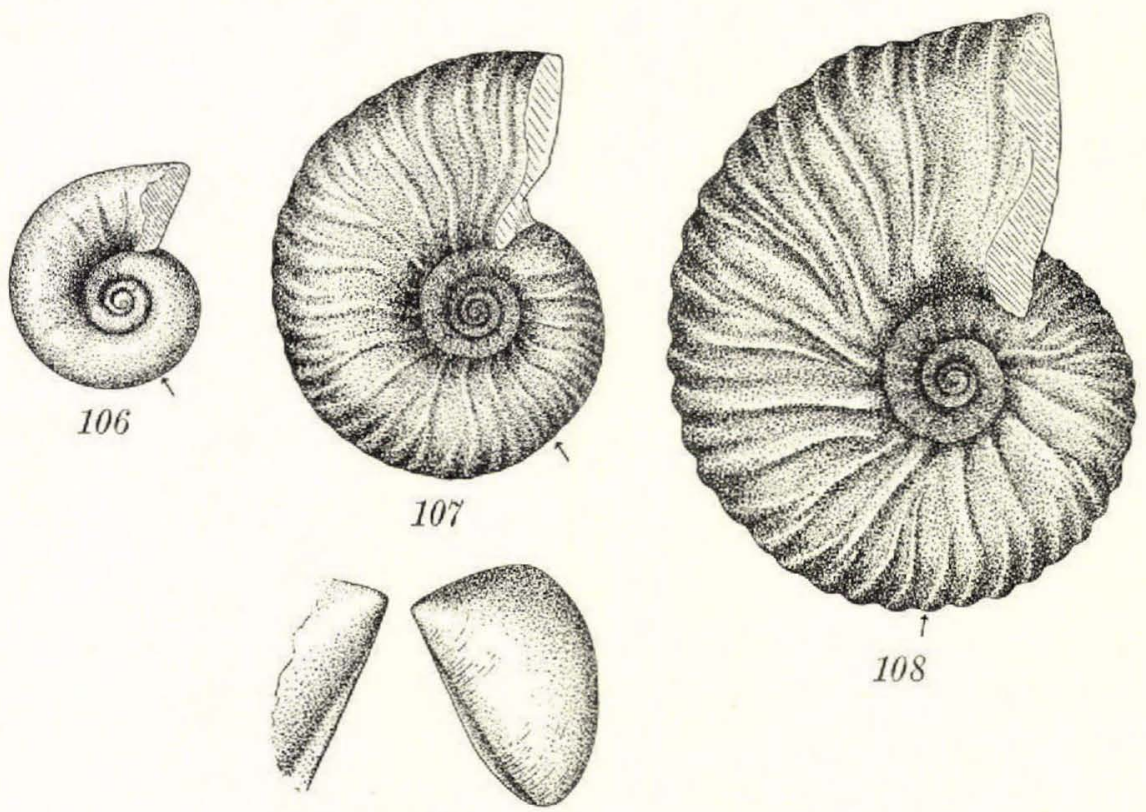

108

109

Figs. 106-109. Scaphites (Discoscaphites) species. Oyster-ammonite Conglomerate loc. III.

106. MMH No. 9930. $\times 4$, juvenile specimen.

107. MMH No. 9931. $\times 2$, juvenile specimen.

108. MMH No. 9932. $\times 1$, juvenile specimen.

109. МMH No. $9933 . \times 1$, aptychus.

(Figs. 106-108, the arrow indicates the position of the last suture).

chamber are often weaker than those on the younger part. In a few specimens the tubercles are regularly developed on each rib (pl. 36, figs. $1 \mathrm{a}-\mathrm{c}$ ), but in most specimens there is no regular connection between tubercles and ribs. One specimen has weak ventrolateral tubercles on the entire exposed phragmocone and another shows a few lateral nodes on the middle of the body chamber. Where the ribs unite in bunches at the umbilical wall of the body chamber $7-10$ nodes or bullae are developed.

The suture is very incised with the lateral lobe as deep or slightly deeper than the ventral lobe. In later stages the lateral lobe is extremely asymmetric with the dorsal branch becoming very enlarged. The first auxiliary lobe is about half as deep as the lateral lobe and trifid or bifid in later stages. The saddles are very incised. The first lateral saddle is rather wide and deeply divided into two main-branches, the ventral branch being somewhat larger than the dorsal. The second lateral saddle is narrow and divided into a rather large dorsal branch and a smaller ventral branch. 
It appears from the description and the figures that the range of variation in size, cross section and ribbing pattern is very wide. As these characters vary independently, it is impossible to divide the material. The material from the Oyster-ammonite Conglomerate loc. I and III appears more heterogeneous than that from loc. II. This may indicate that specimens from more than one horizon are mixed together at localities I and III.

In general, the specimens from loc. II have a smaller size, a slightly more rounded cross section, and coarser ribs on the younger part of the body chamber (pl. 36, figs. $2 \mathrm{a}-\mathrm{b}$ ). As these specimens are within the range of variation of the material from the other localities no new subspecies is introduced.

Text-fig. 109 shows an aptychus, probably belonging to a $S$. (Discoscaphites) species. It shows the adharmonic ridge and traces of concentric ribbing.

Affinities. This species has affinities with Scaphites (Discoscaphites) cheyennensis (Owen, 1852), $S$. (D.) abyssinus (Morton, 1842) and $S$. (D.) mandanensis (MoRToN, 1842).

According to Professor K. M. WaAge, Owen's type of $S .(D$. cheyennensis (1852, pl. 7, fig. 2) seems to be lost. It has only parts of the phragmocone preserved and is not definitely determinable. The types of Monton's $S$. (D.) abyssinus (1842, pl. 10, fig. 4) and his $S$. (D.) mandanensis (1842, pl. 10, fig. 2) also seem to be lost. Morton's figures of $S$. (D.) abyssinus show only the phragmocone and are not determinable with any certainty, whereas his figures of $S$. (D.) mandanensis show a complete specimen and agree very well with MEEK's figures of that species (1876a, pl. 35, figs. 1a-c). MEEK (1876a) also described and figured $S .(D$.$) cheyennensis and S .(D$.$) abyssinus and since that time$ MEЕK's interpretation of these species has largely been used.

The specimen of $S$. (D.) cheyennensis figured by MEEK (1876a, pl. 35 , figs. $3 \mathrm{a}-\mathrm{b})$ is similar in size to the larger specimens of the material described here and the shape and umbilical ratio also agree very closely. MEEK's specimen is certainly less compressed and has more rounded sides than the holotype of $S$. (D.) waagei n. sp., but even these characters are within the range of variation of that species. However, MEEk's specimen differs significantly in sculpture, having ventrolateral nodes on all the exposed phragmocone and, in addition, several lateral rows of nodes on the phragmocone and on the older part of the body chamber.

$S$. (D.) abyssinus as figured by MEEK (1876a, pl. 35, figs. 2a-b, 4) is much smaller than his $S$. (D.) cheyennensis and it is similar in size to the smaller of the specimens described here. Both specimens figured by МЕек have a smaller umbilicus than those of similar size from Green- 
land and differ also in having ventrolateral nodes on all the exposed phragmocone. The specimen figured in pl. 35 , fig. 4 also has two rows of weak lateral nodes on the phragmocone.

$S$. (D.) mandanensis as figured by MonToN (1842, pl. 10, fig. 2) and by Мекк (1876 a, pl. 35, figs. 1 a-c) ranges in size with the smallest Greenland specimens. It has a wide umbilicus similar to that of most of the specimens from Greenland and differs only in having fine, closely spaced ventrolateral nodes, one on each rib, on all the exposed phragmocone.

Professor K. M. WAAGE's excellent collections from the Fox Hills type area show that these three species are not clearly defined; they occur together and all kinds of transitional forms are known. Thus, the material shows a wide range of variation in size, umbilical ratio, cross section, ribbing pattern and development of tubercles, and all these characters apparently vary independently. Мевк (1876a, p. 442) has already pointed out that $S$. (D.) abyssinus is very closely allied to $S$. (D.) mandanensis and that it may possibly be only a variety of the same.

The specimens from Greenland also show a very wide range of variation in size, cross section and ribbing pattern, but a smaller range of variation in umbilical ratio and in the development of tubercles.

A significant difference between the material from the two areas is in development of ventrolateral tubercles, the North American specimens (with very few exceptions) having ventrolateral tubercles on the entire exposed phragmocone and the specimens from Greenland (with a single exception) having ventrolateral tubercles only on the youngest part of the exposed phragmocone. Another conspicuous difference is the development of many lateral tubercles in most of the American material. Only one specimen from Greenland shows a slight tendency to develop lateral tubercles. Additionally, some of the American specimens have a more pronounced ventral projection at the aperture.

It has been clearly stated that the American Scaphites nodosus group gradually becomes more tuberculate at younger stratigraphical horizons and that some develop into multinodose forms. This could indicate that the Greenland material belongs to an older stratigraphical level than the Fox Hills material. However, all other characters show that the Greenland specimens belong to a similar evolutionary stage as the material from the Fox Hills Formation.

The poorly known Scaphites monasteriensis Schl Ü т ER (1871-72, p. 91, pl. 27, figs. 6-7) is similar to the present species in shape and ribbing pattern, but differs $i . a$. in having ventrolateral nodes on the entire exposed shell.

Stratigraphy. All the Discoscaphites "species" which are closely related to the species described here occur in all the fossiliferous horizons of 
the Fox Hills Formation of the type area. Forms similar to MeEK's figures of $S$. (D.) abyssinus occur also in the Baculites clinolobatus Zone of the Pierre Shale (Professor K. M. WAAGE, pers. comm.). The Greenland species may be of similar age to the discoscaphites from the Maastrichtian of the Fox Hills type area.

Scaphites (Discoscaphites) angmartussutensis n. sp.

Pl. 38, fig. 2; pl. 39, fig. 1; pl. 40, figs. 1-2; pl. 41, fig. 1; pl. 42, fig. 1; pl. 44, figs. 1-2; text-figs. 60, 110-113, 121 (8).

Holotype. MMH No.9846. Figured pl. 39, figs. 1a-c; pl. 40, fig. 1. From the Oyster-ammonite Conglomerate loc. III, Nûgssuaq. Maastrichtian.

Diagnosis. Large $S$. (Discoscaphites) with a wide umbilicus and a body chamber extending very slightly beyond the phragmocone; whorl section of exposed whorls extremely compressed, sides of exposed whorls and venter of straighter part of body chamber usually flattened; body chamber with maximum height at the middle, the width increasing rather slowly to the aperture; apertural angle $125^{\circ}-145^{\circ}$; surface of exposed phragmocone and older part of body chamber with strong, rather widely spaced ribs, younger part of body chamber finely ribbed; 9 to 16 ventrolateral nodes on the body chamber; suture complex with an asymmetric bifid lateral lobe and an asymmetric trifid to bifid first auxiliary lobe.

Material. Nûgssuaq: 15 complete or nearly complete specimens and about 38 determinable fragments from the Oyster-ammonite Conglomerate loc. I, a few fragments from the Oyster-ammonite Conglomerate loc. II and two nearly complete specimens and about 10 determinable fragments from the Oyster-ammonite Conglomerate loc. III.

Measurements.

Specimen figured text.fig. 60 .

$\begin{array}{lll}\begin{array}{l}\text { Whorl } \\ \text { height }\end{array} & \begin{array}{l}\text { Whorl } \\ \text { width }\end{array} & \text { W/H } \\ 0.7 \mathrm{~mm} & 0.9 \mathrm{~mm} & 1.29 \\ 1.7- & 2.1- & 1.24 \\ 2.8- & 3.0- & 1.07 \\ 4.1- & 4.2- & 1.03 \\ 6.9- & 6.2- & 0.90 \\ 12.3- & 8.7- & 0.71 \\ 23.8- & 14.2- & 0.60\end{array}$

$\begin{array}{rrr}\begin{array}{l}\text { Whorl } \\ \text { height }\end{array} & \begin{array}{l}\text { Whorl } \\ \text { width }\end{array} & \mathrm{W} / \mathrm{H} \\ & & \\ & & \\ 3.2 \mathrm{~mm} & 3.4 \mathrm{~mm} & 1.06 \\ 5.0- & 4.8- & 0.96 \\ 8.3- & 6.9- & 0.83 \\ 16.7- & 10.2- & 0.61 \\ 27.8- & 15.2- & 0.55\end{array}$

$360^{\circ}$ between the two first measurements, $180^{\circ}$ between the remainder. Last measurement about half a whorl from $180^{\circ}$ between the measurements. Last measurement about half a whorl from last suture. 
Shell length and whorl ratios of six mature specimens:

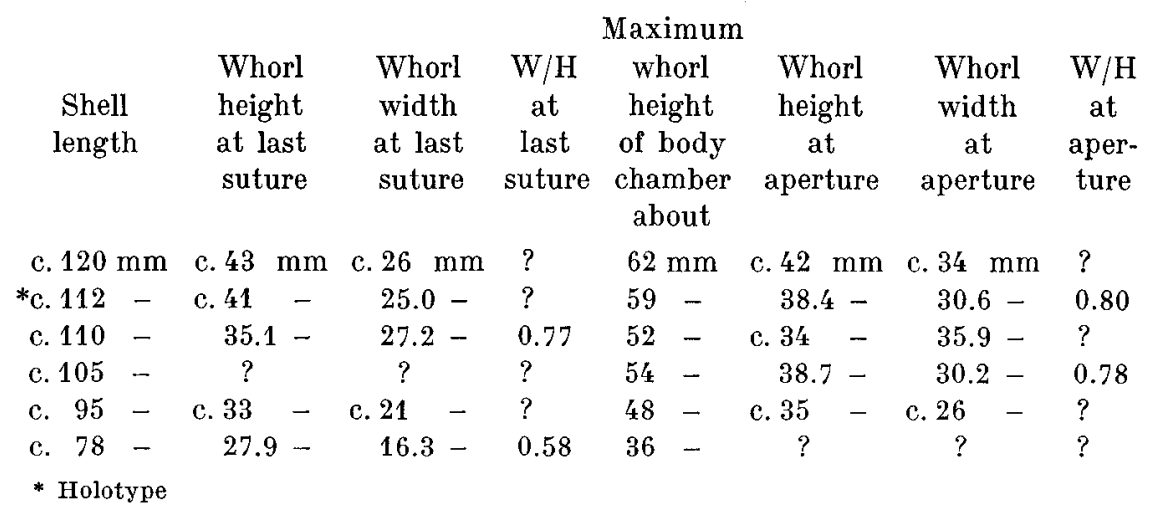

Description. The length of mature specimens ranges from $78 \mathrm{~mm}$ to $130 \mathrm{~mm}$ (see histogram text-fig. 121 (8)). In addition to mature specimens there are a few fragmentary, but determinable, juvenile specimens of rather large size. Some of the smaller juveniles, mentioned p. 118, could as well belong to this species as to $S$. (D.) waagei n. sp.

In mature specimens the diameter of the umbilicus ranges between $6.8 \mathrm{~mm}$ and $13.0 \mathrm{~mm}$ at the last suture, the umbilical ratio being 11$21 \%$; it decreases considerably with age. The umbilical slope is usually very steep and the youngest whorl of most specimens has a sharp umbilical neck.

The inner whorls are depressed and evenly rounded. The whorls become compressed at a whorl height of about $5 \mathrm{~mm}$ and, with increasing age, the phragmocone becomes extremely compressed. From a whorl height of about $5 \mathrm{~mm}$ the cross section of the whorls of the phragmocone is sub-quadrangular, the sides and venter being flattened (text-fig. 60).

The body chamber extends only slightly beyond the phragmocone. In mature specimens the last suture forms an angle of $130^{\circ}-180^{\circ}$ with the long axis of the shell. The maximum whorl height is at the middle of the body chamber, the differences in whorl height at this point, at the last suture and at the aperture being very remarkable. The width of the older part of the body chamber is uneven because close to the last suture there is a depression along the sides which is followed by a swelling at the middle of the straighter part of the umbilical wall; the width of the younger part increases slowly and evenly towards aperture. The older part of the body chamber is extremely compressed, and the younger part less so. Usually the older part of the venter and all parts of the sides are flattened. Except for the weak swelling in the middle part, the umbilical wall is straight, the dorsal projection of the aperture forming the last curve at the aperture. The venter has, in side view, a subcircular outline. The aperture has a rather strong ventral projection; the apertural angle is $125^{\circ}-145^{\circ}$. 
Ribbing on the phragmocone is similar to that of $S$. (D.) waagei n. sp. The exposed part of the phragmocone has $4-7$ ventral ribs per centimetre on the older part and apparently slightly more closely spaced ribs on the younger part. The holotype has 5-6 ventral ribs to each primary rib on the older part of the exposed phragmocone and other specimens seem to show similar relations between primary and ventral ribs. The primary ribs may be slightly thickened at the umbilical angle. Most secondary ribs disappear close to the ventrolateral shoulder. On the greater part of the sides the ribs are therefore more widely spaced than on the venter. Secondary ribs may be intercalated or the ribs may bifurcate, occasionally twice.

The lateral ribs of the depressed area of the older part of the body chamber are widely spaced, but $1 / 3{ }^{-1 / 2}$ of the length of the body chamber from the last suture, the ribbing pattern suddenly changes. This feature is particularly clear in a cast of the external mould of the holotype shown in pl. 40, fig. 1. The ribs become much finer and, because of repeated bifurcation, perfectly evenly spaced over all the younger part of the body chamber. The number of ventral ribs on the youngest part of the body chamber ranges from 9 to 21 per centimetre. As in $S$. (D.) waagei the ventral ribs are curved parallel to the ventral projection of the aperture.

On the oldest $2 / 3$ of the body chamber, and occasionally on the youngest third, ventrolateral tubercles are developed. The tubercles show a wide range of variation in number (from about 9 to 16), in spacing, and in shape, ranging from strong pointed nodes to rather weak clavi. Three specimens show additional lateral bullae. Thus, one specimen has a row of three weak bullae about one centimetre from the umbilical margin on the older part of the body chamber, one fragment has two bullae close to the ventrolateral nodes on the younger part of the body chamber and one fragment (pl. 44, fig. 2) has, also on the younger part of the body chamber close to the ventrolateral nodes, weak lateral bullae.

The suture is very incised. The lateral lobe is as deep as, or slightly deeper than, the ventral lobe and extremely asymmetric in later stages, the dorsal branch becoming much enlarged. The first auxiliary lobe is about half as deep as the ventral lobe and asymmetrically trifid, except in the latest stages where it develops an asymmetric bifid outline. The saddles are very incised. The first lateral saddle is rather wide and deeply divided into two mainbranches, the ventral branch being somewhat larger than the dorsal. The second lateral saddle is narrow and divided into a rather large dorsal and a smaller ventral branch.

The specimen figured pl. 42, figs. $1 \mathbf{a}-\mathbf{b}$ differs from typical specimens in being less compressed, in having more rounded whorls with 

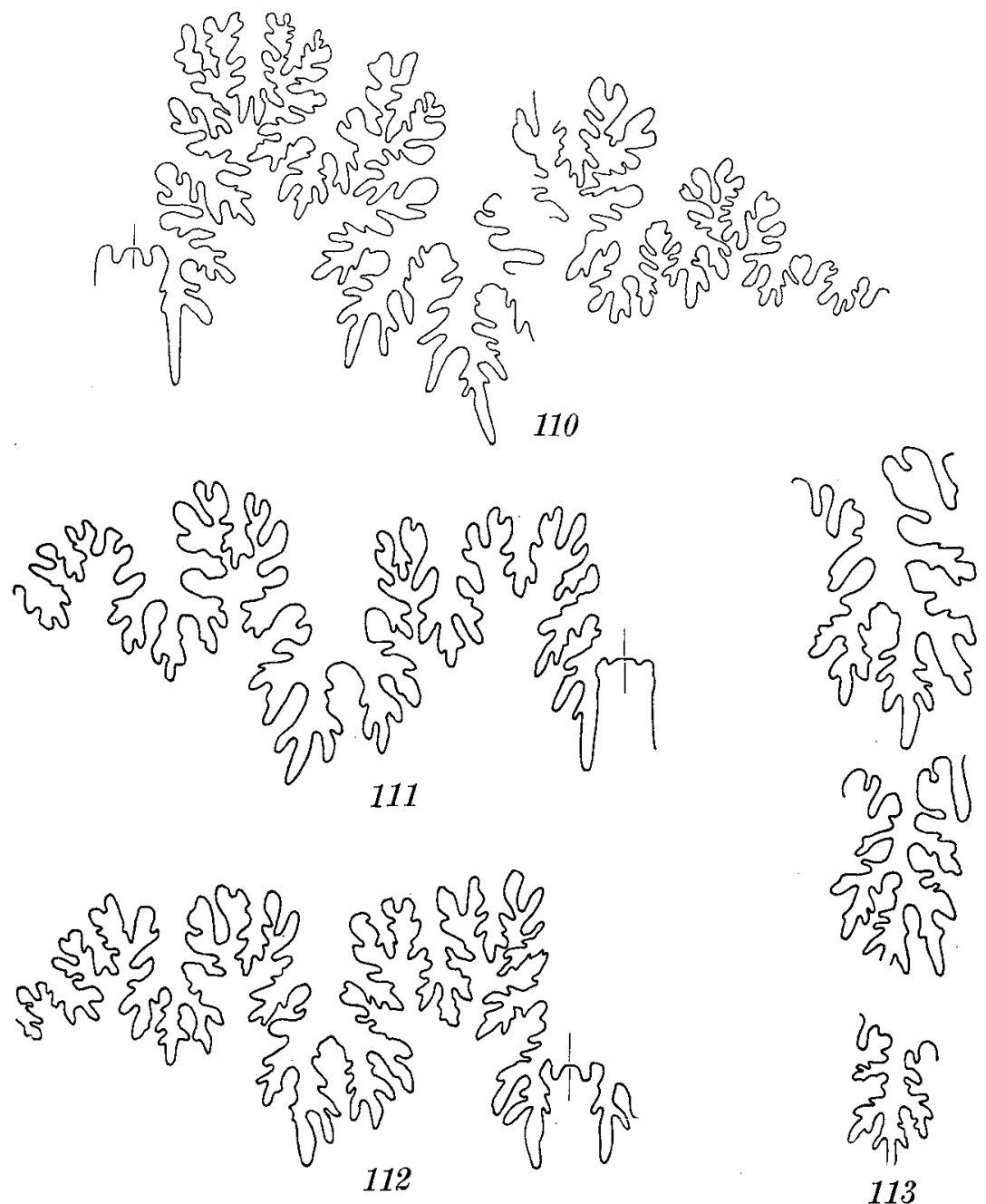

113

Figs. 110-113. Scaphites (Discoscaphites) angmartussutensis n. sp. All from the Oyster-ammonite Conglomerate loc. I, except 110, which is from loc. III.

110. MMH No. 9847. $\times 2$, external suture at a whorl height of $33 \mathrm{~mm}$.

111. MMH No. 9845. $\times 3$, external suture at a whorl height of $21 \mathrm{~mm}$.

112. MMH No. 9934. $\times 3$, external suture at a whorl height of $20 \mathrm{~mm}$.

113. MMH No. $9935 . \times 3$, late ontogeny of the first auxiliary lobe.

no lateral depression or swelling on the body chamber and in having evenly spaced ribs throughout. It occurs together with typical specimens in the Oyster-ammonite Conglomerate loc. I. A few fragments seem to be intermediate in shape and sculpture between this specimen and typical ones. Fragmentary material from the Oyster-ammonite Conglomerate loc. II seems to show that similar, although slightly more compressed, 
specimens are more common here. This may indicate that the morphological differences reflect a slight difference in age. These forms are not described as a separate species because material is scarce and there seems to be gradual morphological transition.

The specimen figured pl. 40 , figs. $2 \mathrm{a}-\mathrm{b} ; \mathrm{pl} .41$, fig. 1 , is an extreme size variant with heavy nodes; again intermediate specimens also occur.

Affinities. This species has affinities with Scaphites (Discoscaphites) nebrascensis (OWEN, 1852) and $S .(D$.$) nebrascensis var. intermedius$ (MEEK, 1876).

The specimens of $S .(D$.$) nebrascensis figured by OWen (1852, pl. 8,$ fig. $3 ;$ pl. 8a, fig. 2) have only parts of the phragmocone preserved and appear to be conspecific with the specimen referred to $S$. (Discoscaphites) conradi (MоRтоN) by Мекк (1876a, p. 430, pl. 36, figs. 2a-c). The specimen figured by MEEK differs mainly from the Greenland specimens in being larger, in having a smaller umbilical ratio, and in having rows of tubercles extending over all the exposed shell. The phragmocone differs in being less compressed and in having more rounded whorls than most specimens from Greenland.

The type specimen of $S$. (D.) nebrascensis var. intermedius МЕек $(1876 \mathrm{a}$, p. 433 , pl. 34, figs. $3 \mathrm{a}-\mathrm{c})$ is similar in size to small specimens from Greenland. It differs in having a smaller umbilical ratio, ventrolateral nodes which extend over the entire exposed shell, weak lateral rows of tubercles on the phragmocone and two rows of weak lateral tubercles on the body chamber. One of these rows is close to the ventrolateral tubercles and the other is about one centimetre from the umbilical margin.

According to WAAGE (1961, p. 238) D. nebrascensis is characteristic of the younger fauna of the Fox Hills Formation in the type area, but it also has a more extensive range downward into beds equivalent, at least, to the Lower Trail City Member. WAAGE further states that large specimens are not found in the typical faunal associations of the Lower Trail City Member but that they are occasionally found together with large sphenodiscids which are found lower in the sequence as it is traced westward in the type area. Apparently both of these ammonites favoured near-shore areas.

Professor K. M. WaAge's excellent collections from the Fox Hills Formation of the type area show that $S$. (D.) nebrascensis from the upper fauna are usually large and multinodose like the specimen figured by Мекк, but that rather small specimens also occur. Some specimens have a compressed cross section similar to that of most Greenland specimens. The $S$. (D.) nebrascensis forms from the lower fauna are similar to the specimens from Greenland in size. They range from compressed forms 
with flattened sides to rather bulbous forms with more rounded sides. They differ from the Greenland specimens in that the ventrolateral tubercles extend along all the exposed shell and several rows of lateral tubercles may occur on the phragmocone. On the body chamber one row of lateral tubercles, close to the ventrolateral tubercles, and one row of umbilical tubercles are usually present, and some specimens tend to develop several rows of tubercles on the body chamber. MEen's $S$. (D.) nebrascensis var. intermedius is one of the variants of this group. Although some specimens of the $S$. (D.) nebrascensis group resemble the specimens from Greenland, they always differ in having a smaller umbilical ratio, and in having ventrolateral tubercles along the entire exposed shell. The nearly complete absence of lateral tubercles in the specimens from Greenland may be explained by different ecological conditions.

Some small $S .(D$.$) nebrascensis-like forms from the lower fauna$ of the Fox Hills Formation have extremely fine and evenly spaced ribs on the younger part of the body chamber and tend to lose the ventrolateral tubercles on the younger part. In these characters they approach some of the older members of the $S$. (D.) nicolletii group in the type Fox Hills area, but they are rather obviously different in other respects. The specimens from Greenland also show a $S$. (D.) nicolletii-like ribbing pattern: ribs are scattered on the depressed area at the beginning of the body chamber and finer ribs occur on the younger part. However, all the specimens differ from $S$. (D.) nicolletii in other characters, such as the much larger umbilicus.

It is evident that this Greenland species is closely related to characteristic representatives of the Fox Hills Discoscaphites fauna, but that it has a morphology which combines characters of some of the previously described species of that group. The relations of the Discoscaphites species of the Fox Hills area are not yet clear, but Professor K. M. WaAgE's collections from that area form an excellent basis for new investigations.

Stratigraphy. The $S$. (Discoscaphites) species, which are closely related to the species described here, range throughout the Fox Hills Formation and $S$. (D.) nicolletii at least ranges as far as 200 feet into the Upper Pierre Shale (WaAge, 1961). Dr. W. A. Cobban's collections in the United States Geological Survey in Denver show that the $S$. (D.) nebrascensis group has ancestors in the Baculites clinolobatus Zone and in the Baculites grandis Zone. The Greenland species may be of similar age as the discoscaphites from the Maastrichtian Fox Hills Formation of the type area. 
Scaphites (Discoscaphites) sp. aff. angmartussutensis n. sp.

PI. 42, fig. 2 ; pl. 43, figs. $1-2 ;$ pl. 45, fig. 1.

Material. Nûgssuaq: seven fragments from Ikorfatnæsen, $980-990 \mathrm{~m}$ above sea-level; one fragment from a tuff-ridge east of Ikorfat pass, $930 \mathrm{~m}$ above sea-level; one fragment collected west of Ikorfat pass, $820 \mathrm{~m}$ above sea-level; one displaced specimen collected east of Ikorfat, $150 \mathrm{~m}$ above sea-level; one fragment from Hamiteskløft, $240 \mathrm{~m}$ above sea-level; one fragment from Tunorssuaq, section I and two displaced specimens from Niaqornat.

Remarks. The fragmentary material most resembles $S$. (D.) angmartussutensis $\mathrm{n}$. sp. in size, umbilical ratio, cross section of the phragmocone, and in suture pattern. It also lacks umbilical tubercles and the body chamber seems only to extend very slightly beyond the phragmocone. The shape of the body chamber is poorly known.

The specimens differ from $S$. (D.) angmartussutensis $\mathrm{n}$. sp. in being more finely ribbed (6-10 ribs per centimetre on the older part of the exposed phragmocone) and the sides of the body chamber seem always to be undulating with slightly bundled ribs (pl. 43, fig. 1).

$S$. (D.) waagei $\mathrm{n}$. sp. has a body chamber with undulating sides and bundled ribs, like the material described here, but differs in other characters, principally in having a row of distinct umbilical nodes, but also in its coarser ribbing and in having the body chamber more extended beyond the phragmocone.

As the shape of the body chamber is poorly known, no definite name is proposed.

Stratigraphy. At Ikorfat the specimens occur in beds which overlie Upper Campanian horizons. The beds are referred to the Maastrichtian, but because of small differences in the Discoscaphites faunas of this locality and the Oyster-ammonite Conglomerate there may be a slight difference in geological age. The two specimens from Niaqornat could be derived from Maastrichtian deposits.

\section{Scaphites (Discoscaphites) sp.}

Pl. 44, figs. 3-5; text-fig. 114.

Material. Nûgssuaq: seven fragments from Ikorfatnæsen, 980-985 m above sea-level; one fragment from Ikorfat pass, $970 \mathrm{~m}$ above sea-level; one fragment from a large ravine east of Ikorfat, $200-325 \mathrm{~m}$ above sealevel; one fragment from Breccieelv, west of Ikorfat, 150-200 m above sea-level and one displaced fragment from Tunorssuaq (Sandstenskløft), 


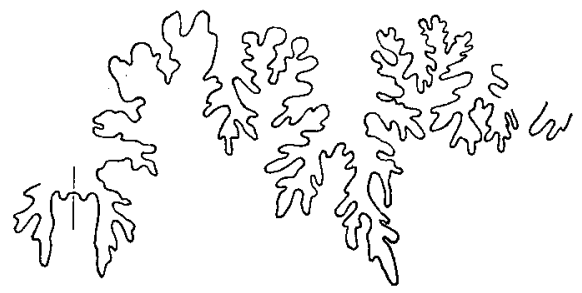

Fig. 114. Scaphites (Discoscaphites) sp. MMH No. $9855 . \times 3$, external suture at a whorl height of $14 \mathrm{~mm}$. Ikorfatnæsen, $980-985 \mathrm{~m}$ above sea-level.

$465 \mathrm{~m}$ above sea-level. In addition two fragments from the Oysterammonite Conglomerate loc. I and one displaced fragment from Niaqornat may also belong to this species.

Remarks. All the fragments have coarser ribs on the phragmocone than any other $S$. (Discoscaphites) species. On the older part of the phragmocone 3-4 ventral ribs per centimetre are developed and laterally the ribs are even more widely spaced because the secondaries disappear close to the ventrolateral angle. There are 3-4 secondaries to each ventral rib. In size, umbilical ratio, cross section and suture pattern the fragments closely resemble $S$. (D.) waagei n. sp. and the sculpture of the body chamber also seems closely related to that species in having a ventrolateral and an umbilical row of nodes, and in having the ribs united in bunches at the umbilical nodes. However, in the specimen figured pl. 44, fig. 4, the rib-bunches are much more distinct than in $S$. (D.) waagei n. sp.

As the shape of the body chamber is poorly known, no definite name is proposed.

Stratigraphy. At Ikorfat the specimens occur together with $S .(D$. sp. aff. angmartussutensis n. sp. in Maastrichtian beds.

\section{Genus CLIOSCAPHITES Cobban, 1952}

Type species. Clioscaphites montanensis Cоввал, 1952.

Emended diagnosis. Scaphitinae with very involute phragmocone; dorsum of mature body chamber entirely in contact with phragmocone; umbilical ratio decreasing with increasing age; aperture constricted and without dorsal lappet; early whorls depressed, younger whorls depressed or compressed; surface with branching or intercalated, straight ribs; ventrolateral tubercles occasionally present on body chamber; suture usually with an asymmetric bifid to trifid lateral lobe and a trifid first auxiliary lobe. 
Clioscaphites saxitonianus (McLearN, 1929) septentrionalis n. subsp.

Pl. 45, figs. 2-5; pl. 46, figs. 1-3; text-figs. 115-116.

Holotype. MMH No. 9862. Figured pl. 46, figs. $1 \mathrm{a}-\mathrm{b}$. From Lille Tange $\mathrm{V}$ Kløft, $180 \mathrm{~m}$ above sea-level (horizon IV). Santonian.

Diagnosis. Clioscaphites of rather small size; whorl section slightly depressed to compressed with a rounded shape except for the older part of the body chamber which has flattened sides; maximum whorl height of body chamber is at its middle, its whorl width increasing slightly from the last suture to the aperture; apertural angle $110^{\circ}-120^{\circ}$; surface with rather strong ribs, on the body chamber $2-3$ ventral ribs to each primary; suture rather simple with a bifid lateral lobe.

Material. Svartenhuk: from a section in the southern tributary of Lille Tange V Kløft, 180-200 m above sea-level (horizon I-IV), about 50 complete or nearly complete specimens and many fragments, all badly weathered; two displaced specimens from Store Tange V Kløft, $70 \mathrm{~m}$ and $30 \mathrm{~m}$ above sea-level; one displaced specimen from Store Niaqornak Kløft, $60 \mathrm{~m}$ above sea-level, and one displaced, poorly preserved fragment from the same canyon $50 \mathrm{~m}$ above sea-level. Nûgssuaq: several poorly preserved fragments from Ilugigsoq, about $200 \mathrm{~m}$ above sea-level, may be referred to this subspecies.

Measurements.

Shell length and whorl ratios of 4 specimens from Lille Tange V Kløft (horizon IV) (Nos. 1-4), one specimen from Store Tange V Kløft (No. 5), and one specimen from Store Niaqornak Kløft (No.6):

\begin{tabular}{|c|c|c|c|c|c|c|c|c|c|c|c|}
\hline No. & $\begin{array}{l}\text { Shell } \\
\text { length }\end{array}$ & $\begin{array}{c}\text { Whorl } \\
\text { height } \\
\text { within } \\
\text { oldest } \\
\text { exposed } \\
\text { part }\end{array}$ & $\begin{array}{l}\text { Whol } \\
\text { widt } \\
\text { withi } \\
\text { oldes } \\
\text { expos } \\
\text { part }\end{array}$ & & $\begin{array}{l}\text { W/H } \\
\text { within } \\
\text { oldest } \\
\text { exposed } \\
\text { part }\end{array}$ & $\begin{array}{l}\text { Whorl } \\
\text { height } \\
\text { at } \\
\text { middle } \\
\text { of } \\
\text { body } \\
\text { cham- } \\
\text { ber c. }\end{array}$ & $\begin{array}{l}\text { Whorl } \\
\text { width } \\
\text { at } \\
\text { middle } \\
\text { of } \\
\text { body } \\
\text { cham- } \\
\text { ber c. }\end{array}$ & $\begin{array}{l}\text { Whorl } \\
\text { height } \\
\text { at } \\
\text { aper- } \\
\text { ture }\end{array}$ & $\begin{array}{c}\text { Who } \\
\text { widt } \\
\text { at } \\
\text { aper } \\
\text { ture }\end{array}$ & & $\begin{array}{l}\mathrm{W} / \mathrm{H} \\
\text { at } \\
\text { aper- } \\
\text { ture }\end{array}$ \\
\hline 1 & $33 \mathrm{~mm}$ & $9.8 \mathrm{~mm}$ & $9.0 \mathrm{n}$ & $\mathrm{nm}$ & 0.92 & $14 \mathrm{~mm}$ & $?$ & $11.8 \mathrm{~mm}$ & $13.8 \mathrm{n}$ & $\mathrm{mm}$ & 1.17 \\
\hline$* 2$ & $43-$ & $12.5-$ & 12.5 & - & 1.00 & $18-$ & $17 \mathrm{~mm}$ & $16.3-$ & 19.5 & - & 1.20 \\
\hline 3 & 44 & 12.5 & 12.5 & - & 1.00 & 20 & $18-$ & 15.7 & 19.3 & - & 1.23 \\
\hline 4 & 50 & 14.0 & 16.5 & - & 1.18 & 23 & $?$ & $?$ & $?$ & & $?$ \\
\hline 5 & 48 & 14.0 & 10.9 & - & 0.78 & 21 & 18 & 17.3 & 19.3 & - & 1.12 \\
\hline 6 & $?$ & 12.7 & 10.5 & - & 0.83 & 18 & 16 & $?$ & $?$ & & $?$ \\
\hline
\end{tabular}

* Holotype 

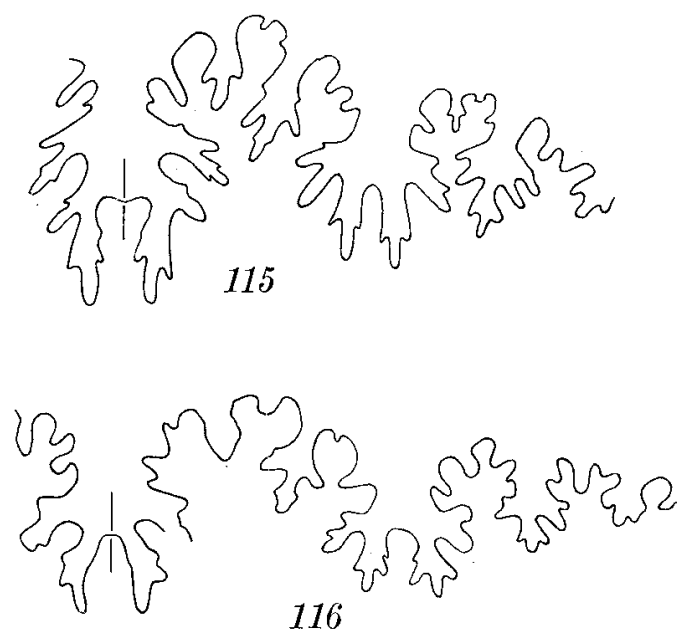

Figs. 115-116. Clioscaphites saxitonianus septentrionalis n.subsp.

115. MMH No. 9936. $\times$ 4, external suture at a whorl height of $12 \mathrm{~mm}$. Lille Tange V Kløft, horizon IV.

116. MMH No. 9858. $\times 4$, external suture at a whorl height of $13 \mathrm{~mm}$. Store Niaqornak Kløft, $60 \mathrm{~m}$ above sea-level.

Description. Typical specimens from the same horizon as the holotype range in size from 32 to $58 \mathrm{~mm}$, only few of these exceed $50 \mathrm{~mm}$. All the specimens seem to be mature. The size of the umbilicus ranges from $1.5 \mathrm{~mm}$ to $3.0 \mathrm{~mm}$. The whorl section of the exposed part of the phragmocone is rounded and varies from slightly depressed to slightly compressed. The last suture is approximately parallel to the long axis of the shell. The older part of the body chamber is flattened laterally. In side view the venter of the body chamber forms a circular outline, whereas the older part of the umbilical wall is only very slightly curved. Whorl height increases slightly up to the middle of the body chamber and then decreases, whorl width increases slightly from the last suture to the aperture. The middle part of the body chamber is compressed, whereas the apertural part is depressed. The apertural angle is $100^{\circ}-110^{\circ}$. The surface of the specimens is badly weathered and the ribbing pattern somewhat obscured. The ribs are rather coarse and they may bifurcate, trifurcate or be intercalated. There seems to be $2-3$ ventral ribs to each primary on the body chamber and about the same on the exposed part of the phragmocone. The secondaries extend across about $2 / 3$ of the sides of the straighter part of the shell. The sutures are mostly badly preserved, they show a bifid lateral lobe and a trifid first auxiliary lobe.

About $20 \mathrm{~m}$ above horizon IV (the horizon of the holotype) some specimens attain a greater size than those from that horizon. All the 
specimens from this higher level (horizon VI) tend to be more compressed and some have 3-4 ventral ribs to each primary rib on the body chamber (pl. 46, fig. 3; pl. 45, fig. 5).

Two of the displaced specimens also differ in being more compressed and in having more ventral ribs in relation to primaries on the exposed part of the shell (pl.45, fig. 2). They are probably derived from a horizon of similar age as the higher level mentioned above.

Thus, it seems that the subspecies evolved into larger, more compressed forms with more secondary ribs. These stratigraphically younger forms are not described as a separate subspecies because material is scarce and there is a gradual morphological transition.

The material from Ilugigsoq is extremely poorly preserved, the specimens seem to be most closely related to the material from the horizon of the holotype.

Affinities. The specimens have affinity with Clioscaphites saxitonianus (McLearn, 1929). They differ from typical C. saxitonianus as figured by McLeari (1929, p. 17, pl. 18, figs. 1-3; pl. 19, figs. 1-2) and CobBan (1951 a, p. 36, pl. 13, figs. 1-10) in their smaller size, in being more compressed, in their laterally flattened body chamber, and in having nearly equally spaced ribs on the venter of the body chamber. The specimens are most similar to that figured and described by CoBBan (1951 a, p. 37, pl. 20, figs. 5-7) as Clioscaphites saxitonianus var. keytei. This variant differs from typical specimens in its much smaller size and more slender shape. An examination of Dr. CobBan's rich collections in the United States Geological Survey, Denver, has shown that there is an even transition from the typical, large, stout form to the smaller more compressed variant. The small variants are of similar size to the small specimens described here and some are as compressed, but the body chamber always differs in having more rounded sides and more widely spaced ventral ribs on the middle part.

Late forms, from the highest Clioscaphites level at the type locality, show in their size, in the increasing number of secondary ribs in relation to primary ribs, and in their more flattened sides certain affinities with Clioscaphites montanensis Cовв ал (1951 a, p. 34, pl. 16, figs. 1-11; pl. 17, figs. 1-3; pl. 20, figs. 1-4), but differ in having a more compressed whorl section, in still having more primary ribs in relation to ventral ribs, and in having a bifid lateral lobe.

The material is referred to a new subspecies of Clioscaphites saxitonianus. The differences may be due to geographical speciation or slight differences in stratigraphical level.

Stratigraphy. According to Scotт \& CoBban (1962) Clioscaphites saxitonianus (McLEARN) can be regarded as a guide fossil for a distinct 
zone immediately underlying that of Clioscaphites vermiformis and overlying that of Scaphites depressus at Pueblo, Colorado. C. saxitonianus is also known from several other localities in the Western Interior of the United States (Coвban, 1951 a) and Canada (McLearn, 1929; Stott, 1961). C. saxitonianus was previously believed to occur at the level of Clioscaphites vermiformis (CoBBan, $1951 \mathrm{a}$, text-fig. 1). The C. saxitonianus Zone can be referred to the lowermost Santonian.

\section{Clioscaphites sp. aff. saxitonianus (McLearn, 1929)}

Pl. 46, figs. 4-7; pl. 47, figs. 1-2; text-fig. 117.

1956 Scaphites cf. ventricosus saxitonianus McLearn: Rosenkrantz in BirkeLUND, p. 6.

Material. Svartenhuk: three displaced specimens, two of which are poorly preserved, from the ammonite locality at Umivik; one displaced, well preserved specimen from the beach or river-beds on the south coast of Umîvik bay; one displaced, poorly preserved specimen from Tange III Kløft, and one displaced specimen from the delta at Store Tange V. Nûgssuaq: two poorly preserved specimens from Tunorqo (collected in a ravine just opposite Navssât in the middle ridge with conglomerate, $770 \mathrm{~m}$ above sea-level); six fragments from Tuperssuartâ, $82 \mathrm{~m}$ west of dolerite sill A, $6 \mathrm{~m}$ above sea-level; one displaced specimen $150 \mathrm{~m}$ west of dolerite sill $A$ at Tuperssuartâ.

Measurements.

Shell length and whorl ratios of two specimens from the Umîvik area:

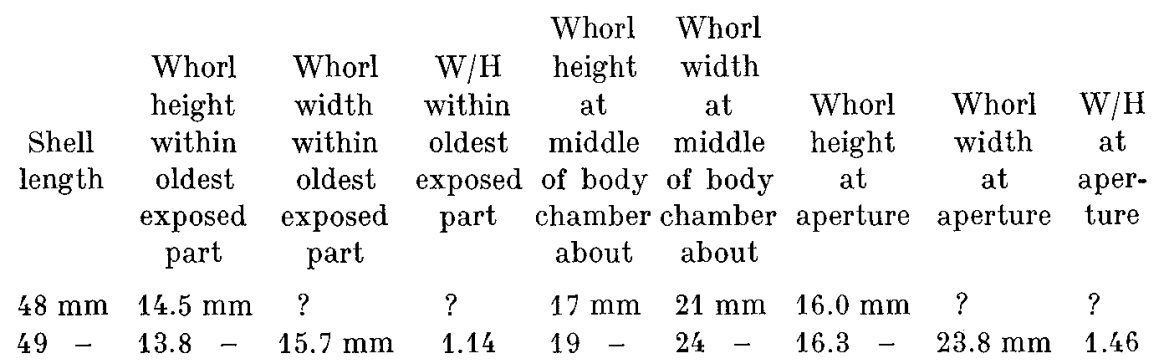

Description. The amount of material is rather limited. The best preserved specimens, from the Umivik area, are rather small, ranging in length from $35 \mathrm{~mm}$ to $49 \mathrm{~mm}$. The specimens are mature. The external diameter of the umbilicus is $2.5-3.5 \mathrm{~mm}$. The whorl section of the phragmocone is rounded and slightly depressed. The body chamber is very long, $230^{\circ}-270^{\circ}$. The last suture forms an angle of $210^{\circ}-250^{\circ}$ with the long axis of the shell. In side view the venter of the body chamber is 


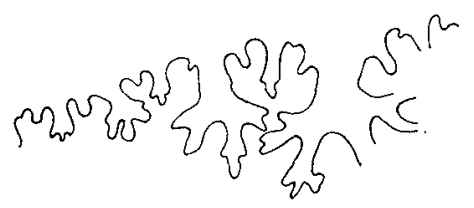

Fig. 117. Clioscaphites sp.aff. saxitonianus (McLeArN). MMH No. 9937. ×3, external suture at a whorl height of $14 \mathrm{~mm}$. Tunorqo, $770 \mathrm{~m}$ above sea-level.

circular, while the umbilical wall forms a slightly less curved line. Thus, the whorl height increases up to the middle of the body chamber and then decreases to the aperture. The width of the body chamber increases slightly from the last suture to the aperture. The body chamber is depressed. On the exposed part of the shell the sculpture consists of high, sharp ribs, which may bifurcate or be intercalated. The primaries are strongest where they bifurcate. The body chamber of the specimen shown in pl. 47, figs. 1 a-c has 14 primary ribs and 28 ventral ribs, that shown in pl. 47, figs. $2 \mathrm{a}-\mathrm{b}$ has 15 primaries and about 31 ventral ribs. The ventral ribs are slightly wider spaced on the middle of the body chamber than on the extremities. The sutures of the specimens from the Umîvik area are extremely poorly preserved. They seem to be rather simple, the lateral lobe is bifid and the first auxiliary lobe trifid. One specimen shows an asymmetrically bifid to trifid lateral lobe.

One of the specimens from Tunorqo is shown in pl. 46, fig. 7. The specimens from that locality show no differences from the material from the Umivik area.

The fragments from Tuperssuartâ, figured pl. 46, figs. 4-6, differ from the specimens from the other localities in having extremely high coarse ribs and at least one of the fragmentary body chambers differs in being more depressed (pl. 46, fig. 6). However, the ribs show the same characteristic pattern as the material from the other localities, with about equal numbers of primaries and secondaries on the body chamber. The coarser ribbing and the slightly larger size may be due to a small difference in stratigraphical age.

One specimen, from the delta at Store Tange V (displaced), may be referred to the species described here. It is large, $75 \mathrm{~mm}$ long, and depressed, and in these characters it is similar to some of the material from Tuperssuartâ. It differs in having lower, more rounded ribs and in having a slightly greater number of secondaries in relation to primaries on the body chamber.

Affinities. The specimens have close affinity with Clioscaphites saxitonianus (McLears) (1929, p. 17, pl. 18, figs. 1-3; pl. 19, figs. 1-2). They are often smaller, and, with few exceptions, less depressed than 
the typical specimens as figured by McLearn and by Cobban (1951 a, pl. 13, figs. 1-10). They differ also in having more primary ribs in relation to ventral ribs on the body chamber. Thus, an examination of typical specimens in the United States Geological Survey in Denver from Alberta, Montana and Colorado (Trinidad) has shown, that all the American specimens have at least 3 ventral ribs to each primary on the body chamber. The ventral ribs of Clioscaphites saxitonianus also differ in being much more closely spaced near the aperture than on the older part of the body chamber. The body chamber of $C$. saxitonianus is also shorter, occupying only about half a whorl.

The specimen from the delta at Store Tange V which has about 3 ventral ribs to each primary rib on the body chamber, seems to be more closely related to the typical $C$. saxitonianus than the remainder.

Clioscaphites saxitonianus var. keytei Coвban (1951 a, p. 37, pl. 20, figs. 5-7), merely a small and more slender $C$. saxitonianus, is similar in whorl section and size to most of the specimens described here, but differs in ribbing pattern.

C. saxitonianus septentrionalis n. subsp. differs in having more ventral ribs in relation to primaries on the exposed shell, in being more compressed and laterally flattened, and in having a shorter body chamber.

The material described probably belongs to a new species or subspecies related to C. saxitonianus but because of the limited amount of material, some of which is displaced, no new name is proposed.

Stratigraphy. The inoceramids from the Clioscaphites localities at Tuperssuartâ and Tunorqo, belonging to the Inoceramus steenstrupi group, may show that these horizons are slightly younger than the Clioscaphites saxitonianus septentrionalis level. The same inoceramid level is present just above the youngest $C$. saxitonianus septentrionalis level in Lille Tange V Kløft, but no clioscaphites have been collected from that level either at that locality or at other Svartenhuk localities. It is possible that some of the displaced specimens came from that level. The level may be referred to the lowermost Santonian like the Clioscaphites saxitonianus level in the United States.

\section{Genus HA RE S I C E R A S Reeside, 1927}

Type species. Haresiceras placentiforme Reeside, 1927.

Remarks. This genus was referred by Reeside (1927c) to the family Cosmoceratidae and the subfamily Hoplitinae. However, Cоввan suggests, in a monograph on the genus Haresiceras (1964), that the genus was probably derived from Clioscaphites. 
According to Rexside (1927c) the genus is characterized by: "compressed whorls with flat venter bordered by two rows of nodes, very narrow umbilicus, and subparallel flanks; obscure sigmoid ribs curving sharply forward from the umbilicus to the middle of the flank, then passing radially to the venter, and crossing it uninterruptedly but with a forward bend; suture with long triangular first lateral lobe and numerous auxiliary lobes."

CobBan (1964) adds to REESIDE's generic description that the early whorls of the older species have a rounded venter and weak constrictions, whereas those of the younger species have a flattened venter and no constrictions. The suture is complex and has four or five trifid lateral lobes separated by bifid saddles, the first lateral saddle is typically scaphitid in its large size and form.

\section{Haresiceras sp.}

Pl. 47, figs. 6-7.

Material. Svartenhuk: seven poorly preserved, crushed specimens from the western part of Itsako at the Sydelv torrent, $95 \mathrm{~m}$ above sea-level (displaced).

Description. The shell diameter of the largest specimen is about $23 \mathrm{~mm}$, but none of the specimens are complete. The figured specimens show a flat venter bordered by two rows of fine, closely spaced nodes on the ventrolateral angles. The sides seem to be flat. The umbilicus is extremely small. Parts of the inner whorls show through the crushed outer whorl. Ribbing is hardly discernible, but sigmoidally curved growth lines are present.

Affinities. The fragments seem to be most closely related to Haresiceras species from the upper part of the Lower Campanian (Haresiceras placentiforme ReEside, 1927 c, p. 18, pl. 13, figs. 1-14; pl. 45, fig. 4; СоввAN, 1964, p. 13, pl. 3, figs. 1-6, text-fig. 7, and Haresiceras natronense Renside, 1927 c, p. 19, pl. 14, figs. 4-16; СовbAn, 1964, p. 15, pl. 3, figs. 14-21), but the material is too poorly preserved for specific determination.

Stratigraphy. No other species are known from the Haresiceras locality. The Haresiceras species indicates a Lower Campanian age for the deposits. 
Family B I N N E Y I T I D A E Reeside, 1927

\section{Genus $B O R I S S J A K O C E R A S$ Arkhangelsky, 1916}

Type species. Borissjakoceras mirabilis Arkнangelsky, 1916.

Emended diagnosis. Binneyitidae with moderately evolute to involute shell; whorls compressed, whorl height increasing rapidly; whorl section trapezoidal to rounded; surface smooth or with very faint sigmoidally curved ribs; ventrolateral nodes present in some species; suture rather simple with a bifid, parallel-sided, deep lateral lobe; first lateral saddle smaller than the second lateral saddle.

Remarks. The genus has been recorded from the Lower Turonian of Turkestan (ARkhaNGelsky, 1916, p. 55-56), the Cenomanian of Bathurst Island, Northern Australia (Wright, 1963, p. 602), the Upper Cenomanian-Lower Turonian of the Western Interior of the United States (Morrow, 1935, p. 463; Соввan, 1961, p. 747), the Upper Cenomanian of Texas (Stephenson, 1955, p. 64) and the Lower Turonian of Alaska (CobBan \& Gryc, 1961, p. 187). In West Greenland a species belonging to this genus may be present in rocks as young as Coniacian and mentioned by Rosenkrantz (1942, p. 39).

Wright (1952, p. 222; 1957, p. L418) refers the genus to the family Binneyitidae, which was established by ReEside (1927a, p. 4) for the genus Binneyites ReEside and he states (1952, p. 222) that Borissjakoceras is clearly the ancestor of Binneyites. A Borissjakoceras(?) sp. from the Cenomanian of Bathurst Island, Northern Australia, apparently link the family with Falciferella CASEY, 1954, which is known to be derived from the haploceratacean family Aconeceratidae (CASEY, 1961, p. 118-119, 137-138) (vide Wright, 1963, p. 603).

In his important work on the family Binneyitidae CobBan (1961) establishes a new genus Johnsonites, which he includes in the family in addition to Binneyites and Borissjakoceras.

The genus Binneyites, recorded from the Turonian to the Lower Santonian (according to CoBBAN, 1961, p. 740), agrees more closely in age with the species from West Greenland than the genus Borissjakoceras. However, all species referred to Binneyites differ from the species from Greenland in having flatter sides and distinct ventrolateral shoulders. Also they always have ventrolateral tubercles, the only exception being B. aplatus (Monrow, 1935) which is a poorly known species. Furthermore all the Binneyites species differ in having simpler sutures and a smaller number of auxiliaries.

The only described species of the genus Johnsonites Cobban (1961, p. 743), J. sulcatus CoвbaN from the Cenomanian, differs from Borissja- 
koceras species in being more involute and in having a flat to slightly convex or concave venter.

Evolution. Cobban (1961, p. 741) states that the Borissjakoceras species from the Western Interior of the United States and Texas show some evolutionary trends. Thus, the species decrease in size, the umbilical ratio increases and the ventrolateral noding is more marked at successively younger horizons. CoBBAN also considers that Borissjakoceras gave rise to Binneyites in the late Turonian.

The species from West Greenland, B. rosenkrantzi n. sp., appears to be confined to the Coniacian and is thus much younger than the latest Lower Turonian members of Соввах's evolutionary trends. The material from the Lower Turonian of Alaska described by СовваN \& Gryc (1961) and from the Coniacian of West Greenland shows that, in these northern areas, the evolution of the genus differs from that trend described by Cobban (1961). Thus, the Lower Turonian B. ashurkoffae Cobban \& GrYc from Alaska and B. rosenkrantzi n. sp. from the Coniacian? of West Greenland are both rather large and in both the development of ventrolateral nodes is suppressed. CobBan \& Gryc (1961, p. 178) mention that an arctic source seems likely for the Borissjakoceras species from Alaska. $B$. rosenkrantzi n. sp. shows close affinity with $B$. ashurkoffae from that area, and it may be a descendant of that species.

All the Turonian Borissjakoceras species have a shallower and narrower first lateral saddle than the species from the Cenomanian and show, in that character, a certain affinity with Binneyites. In some Binneyites species the narrowing of the first lateral saddle goes much further than in Borissjakoceras, especially in Binneyites parkensis REESIDE, the type species, which has a finger-like first lateral saddle. $B$. rosenkrantzi $\mathrm{n}$. sp. from the Coniacian? has a first lateral saddle very similar to that of many Turonian Borissjakoceras species, though slightly smaller and narrower in relation to the second lateral saddle. The suture also differs from Turonian species in having a greater number of auxiliary elements. The auxiliary lobes and saddles are more simple with an undivided or nearly undivided outline, whereas the remaining part of the suture is more incised.

Borissjakoceras rosenkrantzi n. sp.

Pl. 47, figs. 3-5; text-figs. 118-120.

1942 Borissjakoceras sp. Rosenkrantz, p. 39.

Name. The species is named after Professor A. Rosenkrantz.

Holotype. MMH No.9873. Figured pl. 47, figs. 5 a-c. From the ammonite locality at Umîvik, Svartenhuk. Coniacian? 
Diagnosis. A Borissjakoceras of rather large size; umbilical ratio about $20 \%$ in late growth stages; venter rounded; sides rounded to flattened; ratio between width and height of last whorl $0.5-0.7$; surface smooth except for faint sigmoidally curved growth lines; suture with rather incised lateral lobe and saddles; second lateral saddle twice as wide and high as the first lateral saddle; up to ten auxiliary lobes and saddles, the last seven auxiliary lobes and saddles undivided.

Material. About 30 specimens from the ammonite locality at Umîvik, Svartenhuk; 4 of these are complete, and 7 have rather well preserved phragmocones, the remainder are poorly preserved. A few specimens are also available from displaced concretions in Tange II Kløft, $10 \mathrm{~m}$ above sea-level, Tange IV Kløft, $20 \mathrm{~m}$ above sea-level, and Store Tange V Kløft, $20 \mathrm{~m}$ above sea-level, Svartenhuk.

Measurements.

Shell diameter, whorl ratio and umbilical ratio of all available complete specimens:

$\begin{array}{ccccccc}\begin{array}{c}\text { Shell } \\ \text { diameter }\end{array} & \begin{array}{c}\text { Whorl } \\ \text { height at } \\ \text { aperture }\end{array} & \begin{array}{c}\text { Whorl } \\ \text { width at } \\ \text { aperture }\end{array} & \begin{array}{c}\text { W/H at } \\ \text { aperture }\end{array} & \begin{array}{c}\text { Umbilical } \\ \text { diameter }\end{array} & \begin{array}{c}\text { Umbilical } \\ \text { ratio }\end{array} \\ \text { Holotype } & 37 \mathrm{~mm} & 18.6 \mathrm{~mm} & 11.0 \mathrm{~mm} & 0.59 & 7.2 \mathrm{~mm} & 19 \% \\ & 33- & 15.9- & 10.7- & 0.67 & 6.5- & 20 \% \\ \text { c. } 25- & ? & ? & ? & 5.5- & \text { c. } 22 \% \\ 21- & 11.0- & 7.0- & 0.64 & 3.2- & 15 \%\end{array}$

Description. The size of the four complete specimens ranges from 37 to $21 \mathrm{~mm}$. The two largest specimens are definitely mature. The umbilical ratio is $19-22 \%$ in mature or nearly mature specimens. Earlier stages show a smaller umbilical ratio.

The section of the innermost whorls is rounded. The sides become flatter at a whorl height of about $1.5 \mathrm{~mm}$. On the youngest part of the phragmocone, and on the body chamber, the sides again become slightly more rounded. The venter is rounded at all growth stages and a distinct ventrolateral shoulder is never developed. Already at the smallest whorl height observed, $1.1 \mathrm{~mm}$, the whorl height exceeds the width. The shallow umbilicus has rather steep walls.

The length of the body chamber is about $180^{\circ}$ in mature specimens. The apertures are badly preserved. A few specimens seem to show a distinct ventral projection and a very slight lateral projection.

The surface is ornamented by faint sigmoidally curved growth lines. They arch forward on crossing the venter, forming a ventral rostrum and laterally they form a crest. The growth lines may be grouped in faint, closely spaced ribs. Well preserved specimens are also weakly strigated (pl. 47, fig. 5). 

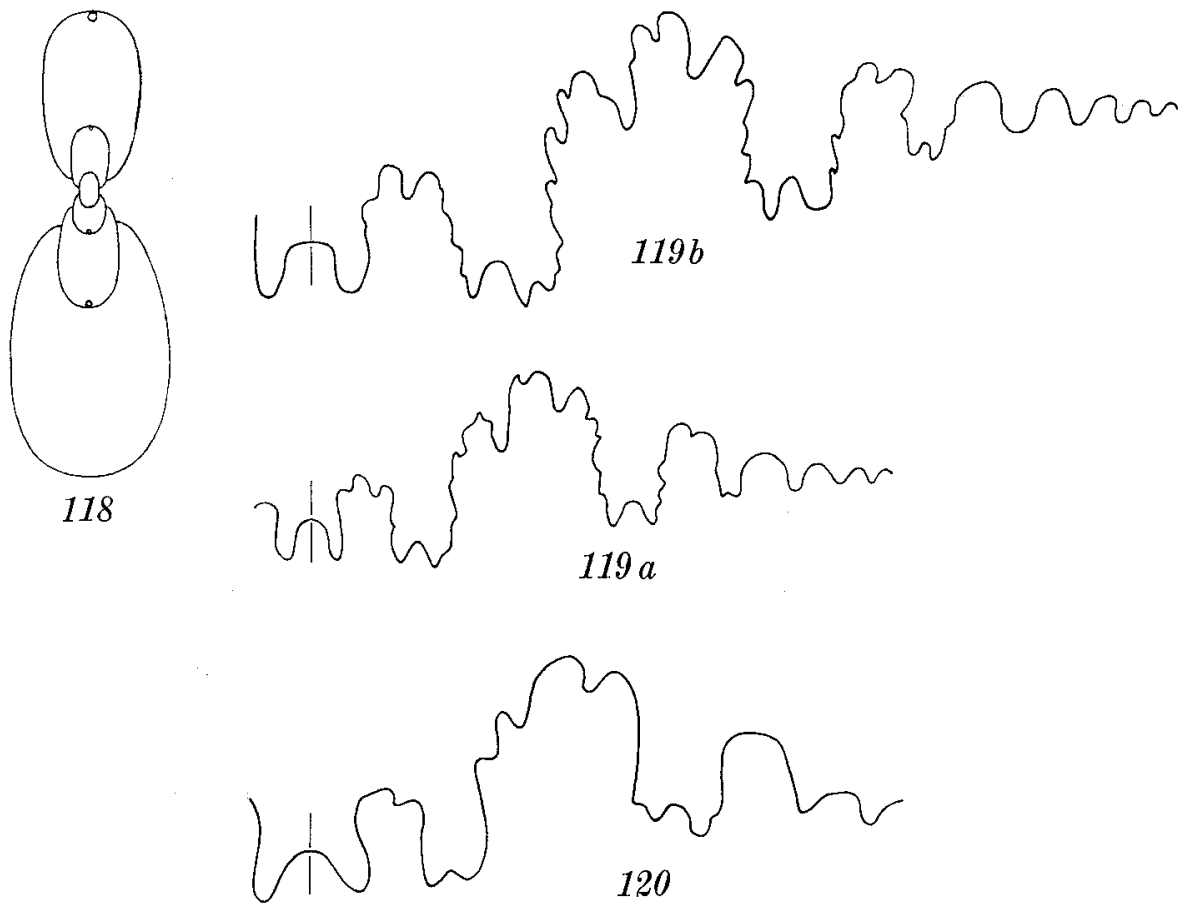

Figs. 118-120. Borissjakoceras rosenkrantzi n.sp. The ammonite locality at Umîvik.

118. MMH No. 9938. $\times 4$, cross section of phragmocone.

119. MMH No. 9939. $a, \times 8$, external suture at a whorl height of $6.5 \mathrm{~mm} ; b, \times 8$, external suture at a whorl height of $8.5 \mathrm{~mm}$.

120. MMH No. 9940. $\times 36$, external suture at a whorl height of $1.5 \mathrm{~mm}$.

The body chambers of the specimens exceeding $25 \mathrm{~mm}$ in shell diameter show one or two broad constrictions parallel to the growth lines. The constrictions occur on the younger half of the body chamber, but never close to the aperture. They are poorly defined with indistinct boundaries, being deepest and most distinct ventrally.

The suture is complex for the genus. The ventral lobe is rather narrow. The lateral lobe is asymmetrically bifid and of about the same depth as the ventral lobe. The first lateral saddle is asymmetrically bifid to trifid and of similar size as the lateral lobe. The second lateral saddle is asymmetrically trifid and about twice as high and wide as the first. The first auxiliary lobe is shorter than the lateral lobe. The first auxiliary saddle is slightly incised and of about the same width as the first auxiliary lobe, the remaining auxiliaries are considerably smaller and decrease evenly in size toward the umbilicus. With exception of the first auxiliary saddle and the first and second auxiliary lobe, all the auxiliaries are undivided and have an evenly rounded outline. 
Affinities. The present species has closest affinity with Borissjakoceras ashurkoffae Совваn \& Gryc (1961, p. 188, pl. 38, figs. 38-43; text-figs. $2 \mathrm{j}, 2 \mathrm{k}, 2 \mathrm{~m})$. The holotype of that species, figured by CoвBan \& GRyc (1961, pl. 38, figs. 42-43), is very similar to B. rosenkrantzi n. sp. in size, shape and sculpture, and it is also strigate and with an irregular constriction on the body chamber. The holotype is only slightly more compressed than the specimens from Greenland, but other specimens figured by Сobban \& Gryc (text-fig. $2 \mathrm{~m}$; pl. 38, figs. 38-41), and most of the paratypes in the National Museum in Washington show a more distinct difference in that character. Some specimens differ also in having ventrolateral nodes at juvenile stages. The suture of $B$. ashurkoffae differs in having a less incised lateral lobe and first auxiliary lobe and less incised lateral saddles, a relatively wider and higher first auxiliary saddle, and in having a smaller number of auxiliaries of a more incised outline.

Stratigraphy. Displaced specimens of this species occurs in the Umîvik area together with displaced Scaphites mariasensis umivikensis n. subsp. and Scaphites preventricosus svartenhukensis n. subsp. from the Lower Coniacian. The most closely related species, B. ashurkoffae, occurs in the Lower Turonian (Inoceramus labiatus Zone) of Northern Alaska.

\section{U N I D E N T I F I E D M T E R I AL}

A few indeterminable fragmentary specimens, in addition to the ammonites described here, are available from West Greenland. There is a fragment of an Anapachydiscus from Ikorfat, and two desmoceratid fragments, one from the Umivik area (Tange II Kløft) and one from Tunorssuaq, both of uncertain age. Fragmentary baculites have also been found at a number of localities on Svartenhuk and Nûgssuaq (Ilugigsoq, Kangersôq, Tunorqo). A few poorly preserved indeterminate scaphites are also known from Svartenhuk and Nûgssuaq (Kangersôq and the north coast).

A few isolated anaptychi from the Upper Campanian at Angnertuneq and Niaqornat (see pl.1, fig. 6) cannot be assigned to particular species. 


\section{PALAEOECOLOGY}

The mode of life of ammonites has been discussed extensively by many authors. Arkell (1957) reviews the most important contributions. Within one group, as for example the scaphites, some authors have considered them benthonic (for example Pompeck (1894), Diener (1912), and FRECH (1915b)), others have suggested a nectonic mode of life (for example Sснмірт (1930) and Sсотт (1940)) and yet others a planktonic mode (for example Pia (1923), Beurlen (1928), Berry (1928) and Trumann (1940)). Bidder's recent discovery of the presence of liquid in the chambers of living Nautilus (BIDDER, 1962) has a bearing on many ideas on this subject (vide Donovan, 1964), most authors having suggested that the chambers of ammonites contained no liquid in life.

Arkell (1933, p. 562-567) gave an analysis of the distribution of ammonites in relation to various sediments in the British Jurassic. $\mathrm{He}$ demonstrated a noticeable absence of ammonites in coral reef facies and in false-bedded sands and oolites which had accumulated swiftly. ZIEGLER (1963) also stated that the distribution of many ammonites is related to the sedimentary facies. This implies that some ammonites at least were not planktonic but probably had a necto-benthonic habit like living nautiloids.

Opinions on the evidence for transportation of ammonite shells after death are as conflicting as the theories on the mode of life of these animals. Reyment (1958) reviewed this subject and, on the basis of some experimental observations, he concluded that, depending mainly on the shape of the shell and the size of the body chamber, some ammonites were good floaters, like living Nautilus. Others, especially those with a very extended body chamber or those with a very compressed or very depressed shell according to REYMENT did not float. He suggested that scaphites may have sunk posthumously and considered that baculites floated almost horizontally, but when damaged, water could enter the chambers and the shells would then sink. Saghalinites, which occurs in the West Greenland material, has a very long body chamber and may have sunk posthumously. The presence of aptychi in some Scaphites body chambers in a few of the West Greenland specimens suggests lack of transport and swift posthumous sinking. 
In some of the Greenland scaphite assemblages juveniles are missing, in others both juvenile and mature specimens occur. I am inclined to suggest that scaphite assemblages exclusively composed of mature specimens may represent migration swarms. The migrational habits of many recent squids (for example those described by Tinbergen \& VERWEy, 1945) support this theory. Other Greenland assemblages composed of juvenile as well as mature specimens may represent assemblages preserved at or near the reproduction area.

In the Coniacian and Santonian of West Greenland, ammonites occur in dark bituminous shales with concretions together with infrequent crustaceans, gastropods and pelecypods. In some areas inoceramids are markedly abundant associates. All the scaphites collected from Coniacian and Santonian horizons are mature except a few displaced specimens. The range of size variation within the species is rather small, from $3: 4$ to $1: 2$ and the species have bell-shaped size distribution curves (e. g., text-fig. 121 (9)). Scaphites predominate except in two Santonian localities (Tuperssuartâ, Søndre Baculitetskløft), where baculites are dominant. I suggest that the scaphite assemblages from the ConiacianSantonian, especially the rich assemblages from the Coniacian at Umivik and from the Santonian at Lille Tange V Kløft, may represent remains of breeding swarms, migrating en masse as in recent cephalopods. The breeding swarms may have been sensitive to changes in salinity, temperature etc. (vide Wright in Ager \& Nichols, 1964).

The Campanian ammonite-bearing deposits are also dark bituminous shales with calcareous nodules. The associated fauna is sparse as in the Coniacian-Santonian. Scaphites predominate and all other ammonite genera are poorly represented, except at Scaphitesnæsen where both scaphites and baculites are frequent. At this late Lower Campanian locality juvenile scaphites occur together with mature specimens, whereas the late Upper Campanian horizons at Ikorfat and Niaqornat contain exclusively mature specimens.

The mature Scaphites specimens from Scaphitesnæsen (S. cobbani n. sp., S. rosenkrantzi n. sp.) have an extremely wide range of size (1:6 and $1: 4$ respectively) and a remarkable size distribution in two groups (text-fig. $121(1,2)$ ), large and small specimens occurring together in single concretions. Late juvenile growth stages of small specimens are frequent, but among the scaphites of larger size, only mature specimens are present.

The scaphites from Ikorfat, $(S .(H$.$) ikorfatensis n. sp. and S .(H)$. ravni n. sp.) have a similarly wide range of size and a similar size distribution (text-fig. $121(3,4))$. The scaphites from Niaqornat $(S .(H)$. greenlandicus and $S$. $(H$.$) ravni n. sp.) have nearly bell-shaped distribu-$ 
tion curves, small specimens being less abundant or lacking (textfig. $121(5,6))$.

The unusual size distribution of the scaphites from Scaphitesnæsen and Ikorfat could possibly be an effect of sexual dimorphism.

The problem of sexual dimorphism in ammonites has often been discussed, especially in ammonites from the Jurassic, where large forms with a simple aperture are often found together with small forms bearing lappets. Recently the problem was discussed by MAKowsk (1962), who also gave a historical review of the subject (p. 1-7).

Макошsк I suggested that differences in size and in other characters of the mature shell of ammonites occurring together, and with identical inner whorls, are due to sexual dimorphism. He investigated mostly Jurassic ammonites, but also some goniatites and scaphites $(S .(H)$. constrictus), and stated that one of the principal differences between shells of males and females is in the number of whorls, the males having a smaller number than females. In all the species he examined, $\mathrm{M}_{\mathrm{A}-}$ kowski always found a morphological hiatus of at least one whorl between males and females.

MaKowski especially investigated $S .(H$.$) constrictus assemblages$ from the Upper Maastrichtian deposits in the vicinity of Kazimierz, on the Vistula, and found two size groups, one ranging from 47 to $68 \mathrm{~mm}$ (22 specimens) and the other from 22 to $35 \mathrm{~mm}$ (10 specimens). He explained the presence of these two size groups by sexual dimorphism, postulating that the larger specimens were female and smaller male. MAKowski suggested that, in general, smaller specimens (males) have $5-6$ (?) whorls and larger specimens (females) have 7 whorls. This opinion is based mainly on comparative material from North America (Scaphites nodosus var. plenus МеЕк) and specimens figured by Соввак (1951 a).

According to Макоwsкi specimens of $S$. $(H$.$) constrictus, figured by$ Nowa (1911), occur in two distinct sizes. In contrast, MıкнаiLov (1951) described some large specimens of the same species, ranging in size from 35 to $70 \mathrm{~mm}$ and a series of smaller ones, which he named var. niedzwiedzkii (UhLIG), ranging from 25 to $35 \mathrm{~mm}$. Makowski considered that this size distribution may reflect variation in the length of the straighter part of the body chamber or may result from collecting heterogenous material from many widespread localities.

The size distribution of Scaphites cobbani n. sp. and S. rosenkrantzi n. sp. from Scaphitesnæsen is very similar to that of $S$. (H.) constrictus as described by Макоwsкi. In agreement with Mакоwsкi's theory the smaller specimens have a smaller number of whorls than the larger specimens. However, contrary to Maкоwsкi's $S$. (H.) constrictus material, specimens occur which are intermediate in size between the two groups (text-fig. 121) and these intermediate specimens also have an intermediate number of whorls (5-7). 


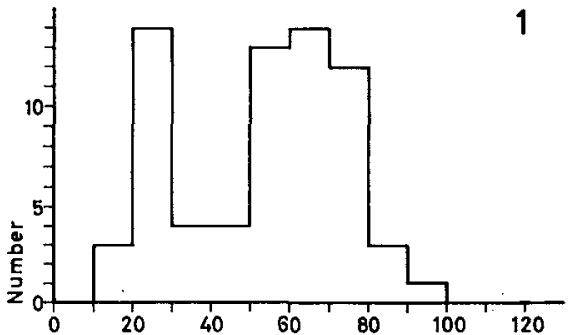

Shell length in $\mathrm{mm}$.

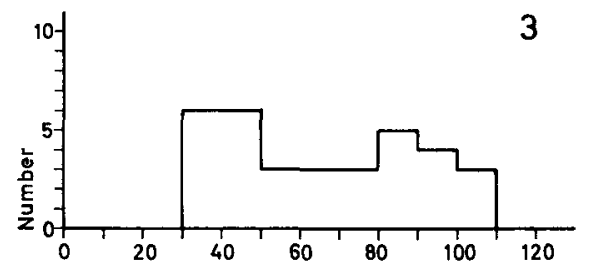

Shell length in $\mathrm{mm}$.
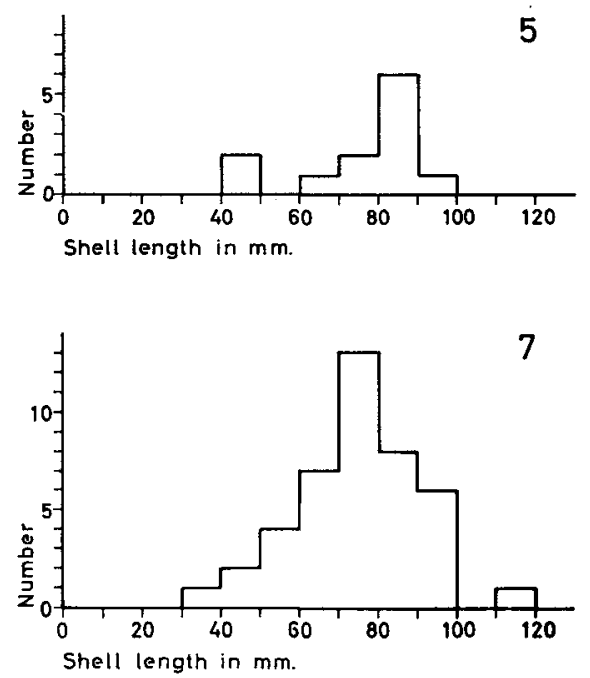

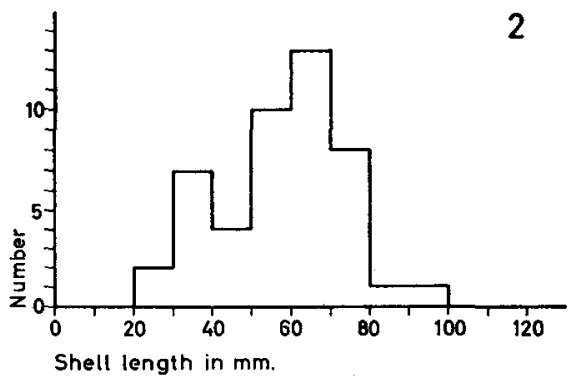

4

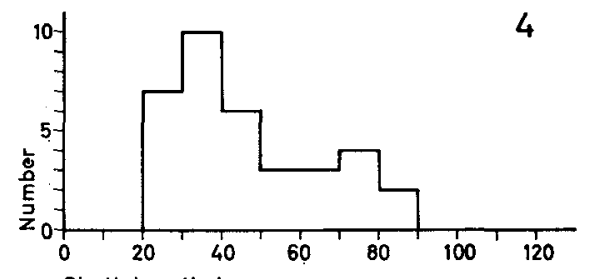

Shell length in $\mathrm{mm}$.

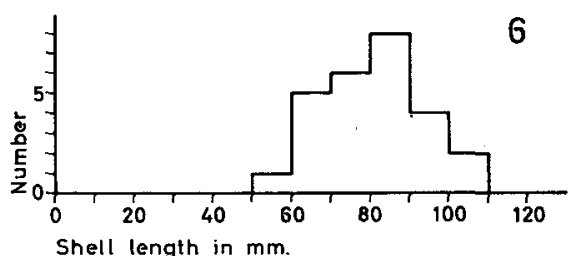

8

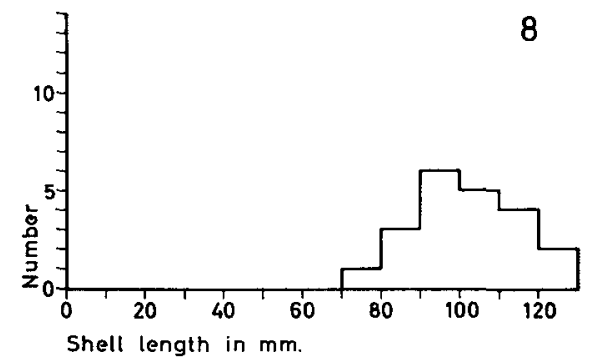

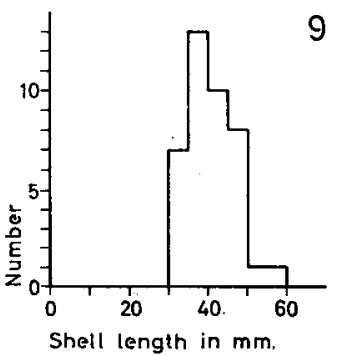

9

Fig. 121. Histegrams showing the range of size variation of mature specimens of:

1. Scaphites cobbani n.sp. Scaphitesnæsen.

2. Scaphites rosenkrantzi n.sp. Scaphitesnæsen.

3. Scaphites (Hoploscaphites) ikorfatensis n.sp. Ikorfat.

4. Scaphites (Hoploscaphites) ravni n.sp. Ikorfat.

5. Scaphites (Hoploscaphites) ravni n.sp. Niaqornat.

6. Scaphites (Hoploscaphites) greenlandicus Dovovan. Niaqornat.

7. Scaphites (Discoscaphites) waagei n.sp. Oyster-ammonite Conglomerate.

8. Scaphites (Discoscaphites) angmartussutensis n.sp. Oysterammonite Conglomerate.

9. Clioscaphites saxitonianus septentrionalis n.subsp. Lille Tange V Kløft, horizon IV. 
The size distribution of $S$. (H.) ikorfatensis n. sp. and $S$. (H.) raoni n. sp., from Ikorfat, is similar to that of $S$. cobbani n. sp. and $S$.rosenkrantzi n. sp. from Scaphitesnæsen, whereas other scaphite assemblages from West Greenland usually have bell-shaped size distribution curves (text-fig. 121).

As dimorphism is present in only a few of the West Greenland assemblages, I doubt that it is an effect of sexual dimorphism.

Nowak (1911) also noticed the wide range of size in $S .(H$. constrictus and suggested that the small specimens were merely dwarf individuals.

Although so-called dwarfed ammonites have often been recorded in the literature, a closer examination of these "dwarfs" often shows that they are only juveniles or specimens with the outer whorls destroyed (KummeL, 1948). An example of adequately documented dwarfed ammonites is that of a Polyptychites assemblage described by VogeL (1959). He showed that the retarded growth of the dwarfed specimens could be recognized on the basis of the suture interval in relation to whorl dimensions, dwarfed specimens having more closely spaced sutures than specimens of larger size (primäre Lobendrängung).

Measurements of suture spacing in relation to whorl width in Scaphites cobbani n. sp. in specimens of both small and large size (textfig. 122) show that no "primäre Lobendrängung" is present as in real dwarf specimens with retarded growth as described by VogeL. There is no evidence of "primäre Lobendrängung" in small $S .(H$.$) constrictus$ specimens from Denmark. The small size of some of the scaphites seems to be due solely to early establishment of the mature body chamber.

It follows that neither the theory of sexual dimorphism nor the theory of dwarf growth adequately explain the dimorphism present in some of the scaphites.

The small scaphites from Scaphitesnæsen apparently grew up in that area, many juveniles of the small specimens being present. Since no juveniles of larger size occur, the larger mature specimens may represent individuals from migration swarms. In this case local ecological conditions may have induced maturity at an earlier stage in the small specimens. This theory is partly confirmed by the baculites from this locality which occasionally show a flared aperture in their early stages, a character ordinarily developed in mature specimens only.

However, much more work on other Scaphites assemblages is needed before we can reach a full understanding of dimorphism in the scaphites generally.

In the concretions in the Oyster-ammonite Conglomerate discoscaphites and a lytoceratid ammonite, Saghalinites, occur in huge numbers, there are also a few Baculites fragments and some Hypophylloceras 


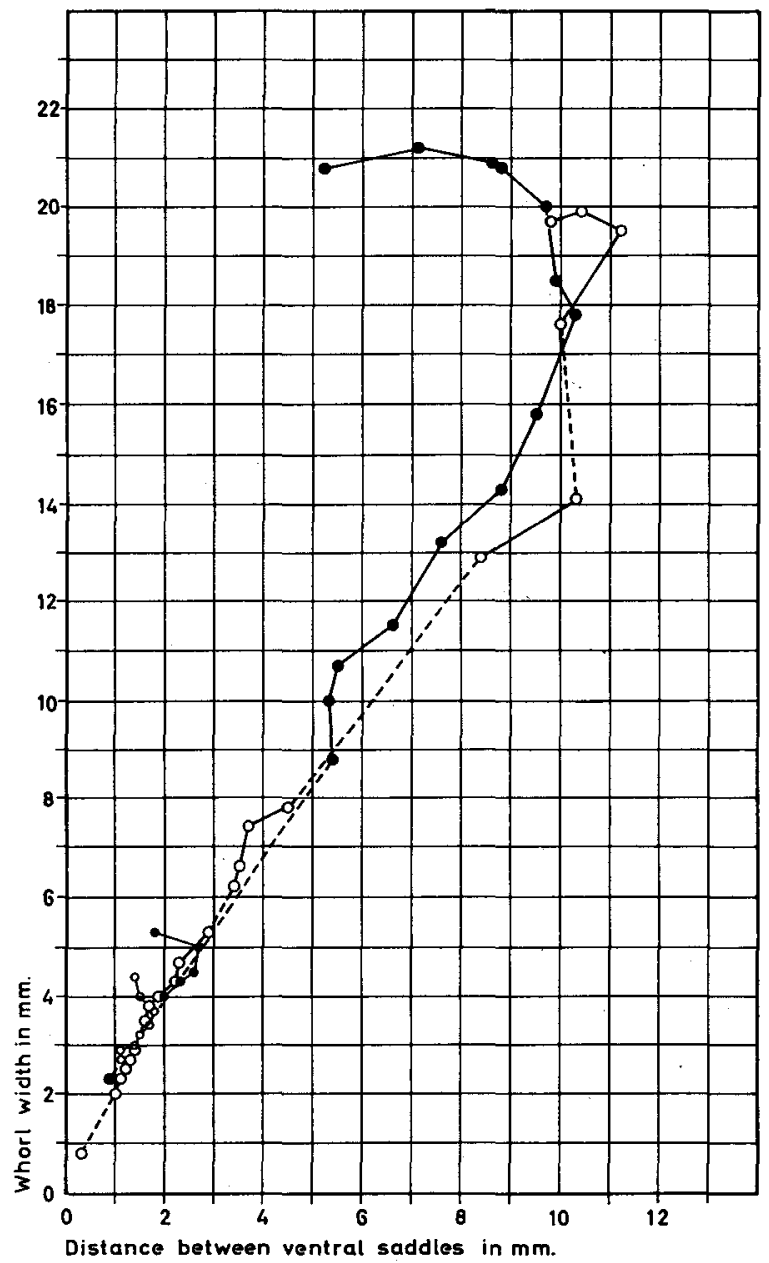

Fig. 122. Scaphites cobbani n.sp. Diagram showing the relations between whorl width and suture spacing (measured between the ventral saddles) in two small and two large specimens. Scaphitesnæsen.

specimens. Text-fig. 123 shows three juvenile discoscaphites from a concretion.

This Maastrichtian Scaphites assemblage differs from all other West Greenland assemblages in its rich representation of juvenile specimens. The ratio between the number of juvenile and mature scaphites in the conglomerate is about $2: 3$ at loc. I and $3: 2$ at loc. III, but these ratios are of restricted value because of the conglomeratic character of the deposits. The size variation of mature discoscaphites from this conglomerate $(S .(D$.$) waagei n. sp., S .(D$.$) angmartussutensis n. sp.) is$ shown in the histograms (text-fig. $121(7,8)$ ). It is apparent that the species have normal bell-shaped size distribution curves. 
The Saghalinites wrighti specimens which occur in the same concretions as the discoscaphites are mainly juveniles. The histogram (text-fig. 124) shows the relative size distribution of all Saghalinites wrighti specimens, in which the final suture is preserved, from the Oyster-ammonite

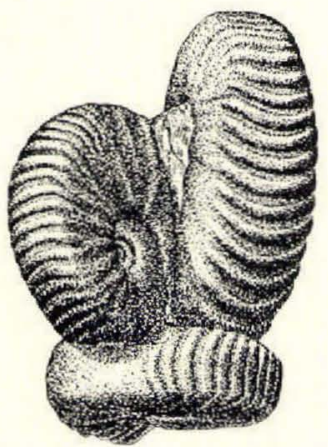

Fig. 123. Scaphites (Discoscaphites) species. MMH No. 9941. $\times 3 / 2$, three juvenile specimens from one concretion. Oyster-ammonite Conglomerate loc. III.

Conglomerate loc. I. The histogram is based on the size variation of the whorl width at the last suture and not on variation in shell diameter since the shell is broken in most specimens. The whorl width at the last suture of mature specimens is at least $17 \mathrm{~mm}$. Juvenile Hypophylloceras (Neophylloceras) specimens also occur in the concretions.

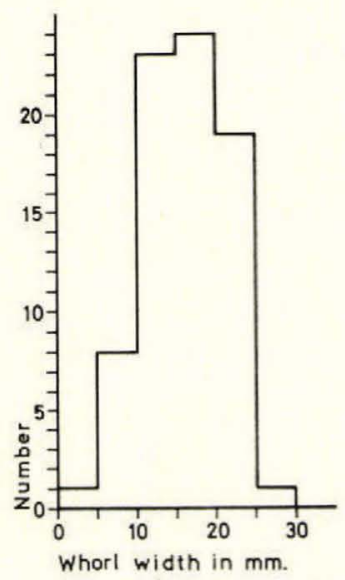

Fig. 124. Saghalinites wrighti n.sp. Histogram showing the relative size variation of both juvenile and mature specimens. Oyster-ammonite Conglomerate loc. I.

The abundant occurrence of juvenile scaphites, lytoceratids and phylloceratids tends to show that all these ammonites reproduced in this area. Judging from the richer and more diverse benthonic associates of pelecypods and gastropods the ecological conditions were better suited than in other known West Greenland ammonite-bearing deposits. 
Other Maastrichtian ammonite-bearing layers (dark shales at Ikorfat and in Hamiteskløft) have yielded only very poor faunas probably slightly older.

Scotт (1940) attempted to define various bathymetric environments by morphological types in ammonites, based on observations in the Texas Cretaceous sequence. He suggested that lytoceratid and phylloceratid ammonites, similar to Saghalinites and Hypophylloceras, lived in the "infrabathyal" zone. The Maastrichtian assemblage in the Oyster-ammonite Conglomerate does not accord with ScotT's suggestion since phylloceratid and lytoceratid ammonites occur together with thickshelled, ornamented discoscaphites. Also, in several other ammonite assemblages, there is a lack of support for ScotT's opinion (e.g., REYMENT, 1955; JoNes, 1963). On the other hand, the palaeogeographical distribution of phylloceratid and lytoceratid ammonites in the Upper Cretaceous (p. 168) suggests that these had a distinct mode of life. A "free swimming life" in the open seas is postulated by many authors for these phylloceratid and lytoceratid forms (e.g., Arkell (1957) and Wright in Ager \& Nichols (1964)). 


\section{STRATIGRAPHY OF THE AMMONITE FAUNAS OF THE UPPER CRETACEOUS WITH SPECIAL REFERENCE TO WEST GREENLAND}

The zonal scheme adopted here for the Upper Cretaceous marine sequence of West Greenland is based mainly on the ammonites and, in a few cases, on inoceramids (pers. comm. from Professor A. RosenKRANTZ). Further work, now in progress, on the associated marine fauna, and on the plant spores and pollen, is necessary to complete our knowledge on the Upper Cretaceous of this area.

It is evident from the systematic descriptions that most of the ammonites are related to North American forms from the Western Interior Region, and correlation with the Western Interior sequence is thus relatively simple.

Correlation of the deposits with the European stages is, on the other hand, difficult, because the stratigraphy of the Western Interior sequence is based mainly on endemic species.

More recently Cobban, ReEside, Seitz and Jeletzky attempted to correlate the Western Interior sequence with European stages (СoBBan, 1951 b, 1963, 1964; Cobban \& Reeside, 1952; Jeletzky in CobBaN \& Reeside, 1952; Jeletzky, 1956; Jeletzky in StotT, 1961; Jeletzky, 1962; SeItz, 1959). These correlations are based mainly on ammonites and inoceramids.

The detailed zonation of the Western Interior sequence indicated in table 1 (p. 154), is based primarily on the results of stratigraphical investigations in that area by CoBBAN and others (CoBBAN, 1951 a, 1951 b, 1951 c, 1958, 1962a, 1962b, 1962c, 1963, 1964; Cobban \& Retside, 1952; Robinson, Mapel \& Cobban, 1959; Cobban, Erdmax, Lemke \& Maugham, 1959; Gill \& Cobban, 1961; Scott \& Cobban, 1962; Совban, Scott \& Gill, 1962; Grll \& Cobban, 1962; Scotт \& Cobban, 1963; CobbaN \& Scotr, 1964). The extremely fine zonation of the Interior Region sequence, especially of the Upper Campanian, is possible because there were frequent migrations of ammonites, especially heteromorphs, into the area from the south accompanied by rapid evolution of endemic species. 
There are many diverging opinions on the delimitation of the European Upper Cretaceous stages and substages and much work needs to be done on the type sections. The delimitations used in the present work are based on the zonal fossils indicated in table 1.

There is some confusion concerning the boundary between the Turonian and the Coniacian. In the type region of the Coniacian two zones are generally distinguished: the Barroisiceras haberfellneri Zone and the Paratexanites emscheris Zone (Colloque sur le Crétacé supérieur, Dijon, 1959). In Germany the boundary is usually placed between the Inoceramus deformis Zone and the I. involutus Zone (SErTz, 1959). In the U.S.S.R. Dobrov (in Moskvin, 1959) places the boundary immediately below the I. deformis Zone and in the United States Cobban (1951 b), Cobban \& Reeside (1952) and Cobban, Erdmann, Lemke \& MaUghan (1959) place the boundary below the I. erectus-I. deformis Zones. In Canada Jeletzky (in Sтотт, 1961) places the boundary between the $I$. deformis Zone and the $I$, involutus Zone in accordance with German usage. As Barroisiceras occurs in the North American Inoceramus erectus Zone together with another typical Coniacian ammonite, Peroniceras (Dr. W. A. Cobban, pers. comm.), I am inclined to place the boundary below this zone. This is apparently in accordance with the conditions in the Coniacian type region.

Because of the occurrence of the important European guide fossils Texanites texanus, Inoceramus undulatoplicatus, I. cordiformis, Marsupites and Uintacrinus in the Interior Region of the United States, correlation of North American and European Santonian biozones is possible.

According to SeITz (1959) Inoceramus lundbreckensis, described from Canada by McLearn (1929), belongs to the I. lingua-I. patootensis group. I. lingua occurs in the upper part of the Santonian and in the lower part of the Lower Campanian in Europe (Seitz, 1959, table 1).

In their work on inoceramids from Alaska, Jones \& Gryc (1960) considered I. lundbreckensis to be conspecific with $I$. patootensis described by De Loriol (1882) and Ravn (1918) from West Greenland. They also described the occurrence of another West Greenland species from Alaska, I. steenstrupi DE LORIOL, and indicated that the two species occur together. Ravn was already in 1918 of this opinion.

In the Western Interior of the United States Coвban (1964) has shown that $I$. patootensis DE LORIOL appears in the Upper Santonian Desmoscaphites erdmanni Zone and disappears in the Scaphites hippocrepis Zone.

Extensive new collecting of $I$. steenstrupi and I. patootensis in West Greenland shows (according to Professor A. Rosenkrantz, pers. comm.) that the I. steenstrupi group appeared earlier in the sequence than I. patootensis. Thus, the I. steenstrupi group appears at a horizon which 
Table 1. Stratigraphical distribution of ammonites in the Senonia. West Greenland Upp

\begin{tabular}{|c|c|c|c|c|}
\hline & \multicolumn{2}{|c|}{$\begin{array}{l}\text { Stages and } \\
\text { substages } \\
\text { in Europe. }\end{array}$} & $\begin{array}{l}\text { Ammonite } \\
\text { zones in } \\
\text { Europe. }\end{array}$ & $\begin{array}{l}\text { Ammonite zones in } \\
\text { the Western Inte- } \\
\text { rior of the United } \\
\text { States }\end{array}$ \\
\hline \multirow{35}{*}{ 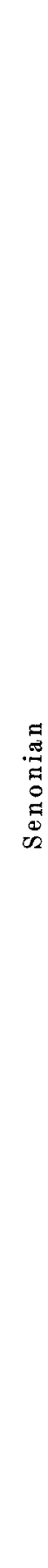 } & \multirow{4}{*}{\multicolumn{2}{|c|}{ Maastrichtian }} & \multirow{4}{*}{$\begin{array}{l}\text { S. }(\text { Hoploseaphites }) \\
\text { constrictus }\end{array}$} & S. (Discoscaphites) spp. \\
\hline & & & & Baculites clinolobatus \\
\hline & & & & Baculites grandis \\
\hline & & & & Baculites baculus \\
\hline & \multirow{23}{*}{ 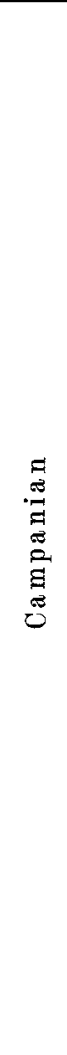 } & \multirow{15}{*}{ Upper } & \multirow{12}{*}{$\begin{array}{l}\text { Bostrychoceras } \\
\text { polyplocum }\end{array}$} & Baculites eliasi \\
\hline & & & & Baculites jenseni \\
\hline & & & & Baculites reesidei \\
\hline & & & & Baculites cuneatus \\
\hline & & & & Baculites compressus \\
\hline & & & & Didymoceras cheyennensis \\
\hline & & & & Exiteloceras jenneyi \\
\hline & & & & Didymoceras stevensoni \\
\hline & & & & Didymoceras nebrascense \\
\hline & & & & Baculites scotti \\
\hline & & & & Baculites gregoryensis \\
\hline & & & & Baculites perplexus \\
\hline & & & \multirow{4}{*}{$\begin{array}{l}\text { Hoplitoplacenticeras } \\
\text { coesfeldiense } \\
-\ldots-\ldots-\ldots-\ldots\end{array}$} & Baculites sp. (smooth) \\
\hline & & & & Baculites asperiformis \\
\hline & & & & Baculites mclearni \\
\hline & & \multirow{8}{*}{ Lower } & & Baculites obtusus (late form) \\
\hline & & & \multirow{6}{*}{$\begin{array}{l}\text { Scaphites hippocrepis } \\
\text { Seaphites aquisgranensis }\end{array}$} & Baculites obtusus (early form) \\
\hline & & & & Baculites sp. (weakly ribbed) \\
\hline & & & & Baculites sp. (smooth) \\
\hline & & & & Haresiceras natronense \\
\hline & & & & Haresiceras placentiforme \\
\hline & & & & Haresiceras montanaense (late form) \\
\hline & & & Diplacmoceras bidorsatum s.l. & Haresiceras montanaense (early form) \\
\hline & \multirow{5}{*}{\multicolumn{2}{|c|}{ Santonian }} & \multirow{5}{*}{ Placenticeras "syrtale" } & Desmoscaphites bassleri \\
\hline & & & & Desmoscaphites erdmanni \\
\hline & & & & Clioscaphites choteauensis \\
\hline & & & & $\begin{array}{l}\text { Clioscaphites montanensis } \\
\text { Clioscaphites vermiformis }\end{array}$ \\
\hline & & & & Clioscaphites saxitonianus \\
\hline & \multirow{3}{*}{\multicolumn{2}{|c|}{ Coniacian }} & Paratexanites emscheris & Scaphites depressus \\
\hline & & & \multirow{2}{*}{ Barroisiceras haberfelneri } & Seaphites ventricosus \\
\hline & & & & Scaphites preventricosus \\
\hline & \multicolumn{2}{|c|}{ Upper Turonian } & Subprionocyclus neptuni & Scaphites corvensis \\
\hline
\end{tabular}


d part of Turonian, in Europe and North America and horizons of etaceous localities.

\begin{tabular}{l|c} 
Distribution in the Western & \\
iterior of the United States of & Horizons of the West Greenland \\
index fossils common to the & localities \\
'estern Interior and to Europe. &
\end{tabular}

Oyster-ammonite Conglomerate locs. I, II and III (derived).

Ikorfat, $970-990 \mathrm{~m}$ above sea-level. Tunorssuaq. Hamiteskloft, $240 \mathrm{~m}$ above sea-level. Angnertuneq, $165-200 \mathrm{~m}$ above sea-level.

phenodiscus sp.

\section{?}

Niaqornat, $220 \mathrm{~m}$ above sea-level.

Angnertuneq, $103-110 \mathrm{~m}$ above sea-level.

Kûk-anernilik, $40 \mathrm{~m}$ above sea-level.

? Ikorfat, $825-885 \mathrm{~m}$ above sea-level.

Ikorfat, 550-665 m above sea-level.

Toplitoplacenticeras Desfeldiense

'rachyscaphites spiniger
?

No ammonites.

Scaphitesnæsen, 533-548 $\mathrm{m}$ above sea-level.

No ammonites.

Itsako.

?

No ammonites.

Scaphitesnæsen, 519-523 m above sea-level.

Nordre Baculiteskløft. Søndre Baculiteskløft.

Tuperssuartâ. Tunorqo.

Lille Tange V Kløft. Ilugigsoq.

No ammonites.

Alianaitsùnguaq.

Umîvik area. 
may be correlated with the upper part of the Clioscaphites saxitonianus Zone and is widely distributed in the $C$. montanensis Zone, whereas Inoceramus patootensis is not known from these horizons. I. patootensis is known exclusively from Pautût on the southern coast of Nûgssuaq, where, according to RAvN (1918), it occurs together with I. steenstrupi. These deposits are probably younger than the $C$. montanensis Zone but have unfortunately yielded no ammonites. Further study of the Greenland inoceramids, which is in progress, will be of fundamental importance to the stratigraphical correlation of the West Greenland Santonian-Lower Campanian deposits.

Correlation of North American and European Lower Campanian deposits is based partly on the occurrence of Scaphites hippocrepis DekAY and S.aquisgranensis Schlüter in both regions. Correlation of the European Diplacmoceras bidorsatum Zone (vide Sснмго, 1959; Young, 1963) with the North American Haresiceras montanaense (early form) Zone is tentative.

The Upper Campanian of the Western Interior of the United States has been extremely finely zoned by СовваN on the basis of baculites and other heteromorphs. Since Trachyscaphites spiniger and Hoplitoplacenticeras coesfeldiense occur in the North American sequence (CоBвAN, 1963; СовваN \& Scoтt, 1964) it is possible to correlate at least the Baculites mclearni and B. asperiformis Zones with the European Hoplitoplacenticeras coesfeldiense Zone. The correlation of the zones between the last appearance of Scaphites hippocrepis and the first appearance of Trachyscaphites spiniger is questionable. According to Coвban \& ScotT (1964) these zones may be referred to the Lower Campanian on the basis of the occurrence of Delawarella danei Young and Inoceramus agdjakendsis Aliev.

There are many diverging points of view on the position of the Campanian-Maastrichtian boundary. In 1957 I discussed the delimitation of the Maastrichtian in Denmark and placed the CampanianMaastrichtian boundary at the lower limit of horizons containing $B e$ lemnella lanceolata and Scaphites (Hoploscaphites) constrictus i. a. in accordance with JELETZKY (1951) and Schmid (1955).

Since some of the most useful European guide fossils are absent in the Western Interior of North America it is difficult to place the Campanian-Maastrichtian boundary in that region.

SEITz (1959) points out that the European Inoceramus caucasicus Dobrov is closely related to the North American I. fibrosus (MEek \& HAYDEN) and later JELETZKY (1962) considered I. caucasicus to be conspecific with $I$.fibrosus. According to Doвrov (in Moskvin, 1959) I. caucasicus occurs in the Bostrychoceras polyplocum Zone of the uppermost Campanian and in the lower part of the Belemnella lanceolata 
Table 2. Stratigraphical distribution of ammonite assemblages in the Upper Cretaceous of West Greenland.

\begin{tabular}{|c|c|c|}
\hline & Localities & Ammonite assemblages \\
\hline Maastrichtian & $\begin{array}{l}\text { Oyster-ammonite Conglomerate locs. I, } \\
\text { II and III, derived. } \\
\text { Ikorfat, } 970--990 \mathrm{~m} \text { above sea-level. } \\
\text { Tunorssuaq. } \\
\text { Hamiteskløft, } 240 \mathrm{~m} \text { above sea-level. } \\
\text { Angnertuneq, } 165-200 \mathrm{~m} \text { above sea- } \\
\text { level. }\end{array}$ & $\begin{array}{l}\text { H. (Neophylloceras) groenlandicum } \mathrm{n} . \mathrm{sp} . \text {, } \\
\text { Saghalinites wrighti } \mathrm{n} . \mathrm{sp} ., \text { Baculites } \text { of. } \\
\text { meeki EuIAs, Baculites sp. } 1, \text { S. (Disco- } \\
\text { scaphites) waagei } \mathrm{n} \text {. sp., S. (Discoscaphi- } \\
\text { tes) angmartussutensis n. sp. } \\
\text { Pseudophyllites sp. Diplomoceras sp., } \\
\text { S. (Discoscaphites) sp. aff. angmartussu- } \\
\text { tensis n. sp., S. (Discoscaphites) sp. }\end{array}$ \\
\hline $\begin{array}{l}\text { Upper } \\
\text { Campanian }\end{array}$ & $\begin{array}{l}\text { Niaqornat, } 220 \mathrm{~m} \text { above sea-level. } \\
\text { Angnertuneq, } 103-110 \mathrm{~m} \text { above } \\
\text { sea-level. } \\
\text { Kûk-anernilik, } 40 \mathrm{~m} \text { above sea-level. } \\
\text { ? Ikorfat, } 825-885 \mathrm{~m} \text { above sea-level. } \\
\text { Ikorfat, } 550-665 \mathrm{~m} \text { above sea-level. }\end{array}$ & $\begin{array}{l}\text { S. (Hoploscaphites) greenlandicus } \\
\text { Donovan, S. (Hoploscaphites) ravni n.sp. } \\
\text { Pseudophyllites skoui n. sp., Baculites } \\
\text { sp. } 2, \text { Baculites sp. } 3, \text { S. (Hoploscaphites) } \\
\text { ikorfatensis n. sp., S. (Hoploscaphites) } \\
\text { ravni n. sp., S. (Hoploseaphites?) sp. }\end{array}$ \\
\hline $\begin{array}{l}\text { Lower } \\
\text { Campanian }\end{array}$ & $\begin{array}{l}\text { Scaphitesnæsen, } 533-548 \mathrm{~m} \text { above } \\
\text { sea-level. } \\
\text { Itsako. }\end{array}$ & $\begin{array}{l}\text { Pseudophyllites skoui n. sp., Baculites ef. } \\
\text { haresi REESIDE, Baculites obtusus MEEK } \\
\text { (early form), Scaphites cobbani n. } \mathbf{\text { sp., }} \\
\text { Scaphites rosenkrantzi n. sp. } \\
\text { Haresiceras sp. }\end{array}$ \\
\hline Santonian & $\begin{array}{l}\text { Scaphitesnæsen, 519-523 m above } \\
\text { sea-level. } \\
\text { Nordre Baculiteskløft. } \\
\text { Søndre Baculiteskløft. } \\
\text { Tuperssuartâ. } \\
\text { Tunorqo. } \\
\text { Lille Tange V Kløft. } \\
\text { Ilugigsoq. }\end{array}$ & 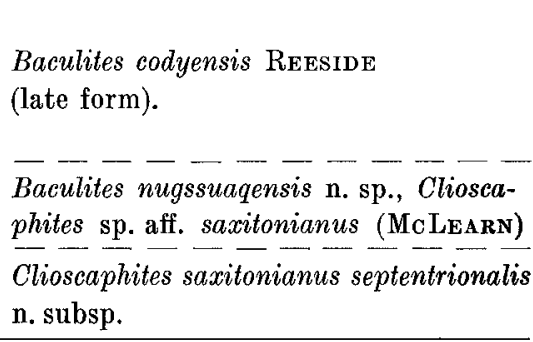 \\
\hline Coniacian & Alianaitsùnguaq. ----- & $\begin{array}{l}\text { Scaphites ventricosus MEEK \& HAYDEN. } \\
\text { Scaphites preventricosus svartenhukensis } \\
\text { n. subsp., Scaphites mariasensis umivi- } \\
\text { kensis n. subsp., Borissjakoceras rosen- } \\
\text { krantzi n. sp. (?) }\end{array}$ \\
\hline $\begin{array}{l}\text { Upper } \\
\text { Turonian }\end{array}$ & Store Tange V Kløft (displaced). & Scaphites cf. corvensis CoBBan. \\
\hline
\end{tabular}


Zone of the Maastrichtian. Inoceramus fibrosus appears in North America in the Baculites baculus Zone and ranges into the Trail City Member of the type Fox Hills Formation. JeLETzKy (1962) also points out that a Scaphites fragment from Hemmoor is indistinguishable from Scaphites nicolletii as described and figured by Мекк (1876a), and that some $S$. constrictus specimens figured by NowaK (1911, pl. 33, figs. 11, 12, 14, 22) may also be tentatively referred to $S$. nicolletii. On the basis of the stratigraphical distribution of Inoceramus fibrosus and the supposed occurrence of Scaphites nicolletii in the Lower Maastrichtian of Europe JELETZKY places the lower boundary of the Maastrichtian at the base of the Baculites baculus Zone and suggests that the B. baculus, B. grandis and $B$. clinolobatus Zones, and all the Fox Hills deposits, should be correlated with the Lower Maastrichtian of Europe.

In my opinion the specimen from Hemmoor, which JeLETZKY referred to $S$. nicolletii, is too poorly preserved for a certain identification and the specimens figured by Nowak differ from $S$. nicolletii in having a less marked ventral apertural projection and a smaller umbilicus (visible in pl. 33, fig. 14). As mentioned by Jeletzk y, the occurrence of Inoceramus fibrosus and absence of I. tegulatus in the Fox Hills Formation makes it probable that the Fox Hills Formation belongs to the Lower Maastrichtian. The common occurrence of Sphenodiscus species in the Fox Hills Formation could, on the other hand, indicate an Upper Maastrichtian age, as Sphenodiscus does not appear in Europe until the Upper Maastrichtian. In the present paper the lower boundary of the Maastrichtian is tentatively placed at the base of the B. baculus Zone (as in Cobban \& Reeside, 1952; Jeletzky, 1962) where multinodose discoscaphites gradually become more common. However, exact delimitation of the Campanian and the Maastrichtian and closer correlation of European and North American Maastrichtian zones is not possible at present: much more data are needed.

Correlation of West Greenland ammonite-bearing horizons with North American biozones and European stages is shown in table 1 (p. 154). A stratigraphical outline of the West Greenland ammonites is given in table 2 (p. 157).

The finding in Store Tange V Kløft (Svartenhuk) of a displaced Scaphites fragment, here tentatively referred to Scaphites corvensis, may indicate Upper Turonian marine deposits in that area.

The presence of Lower Coniacian at Umîvik (Svartenhuk) is more certain. These deposits are referred to the Scaphites preventricosus Zone because of the occurrence of $S$. preventricosus and $S$. mariasensis (n. subspp.). In the Western Interior of the United States Cobban (1951 b) divided the $S$. preventricosus Zone into two subzones, a lower Inoceramus erectus Subzone, and an upper I. deformis Subzone. In the I. erectus 
Subzone Scaphites preventricosus occurs together with $S$. mariasensis and in the Inoceramus deformis Subzone it occurs together with Scaphites impendicostatus. It is likely that the Umivik fauna is to be correlated with the lower part of the $S$. preventricosus Zone, if it is accepted that the small differences between North American and West Greenland S.preventricosus and $S$. mariasensis forms are due merely to great geographical separation. The small morphological differences may, however, also be explained by small differences in age.

Borissjakoceras rosenkrantzi n. sp. occurs together with undeterminate scaphites in displaced nodules at Umîvik. The genus Borissjakoceras in other areas is known only in beds of Cenomanian and Lower Turonian age, and Rosenkrantz's indication of the occurrence of a Borissjakoceras species at Umîvik (1942) was therefore questioned by IMLAY \& Reeside (1954, p. 227), who suggested that it belonged to the genus Binneyites. Borissjakoceras rosenkrantzi $\mathrm{n}$. sp. is more advanced in suture pattern than earlier Borissjakoceras species but it certainly belongs to Borissjakoceras and is here considered to be a late representative of that genus.

As mentioned above, the Scaphites preventricosus Zone is referred to the Upper Turonian by Seitz (1959) and Jeletzk y (in Stott, 1961).

A marine horizon at Alianaitsúnguaq (on the south coast of Nùgssuaq) is referred to the Scaphites ventricosus Zone of the Coniacian on the basis of the occurrence of the guide fossil of that zone.

In the United States the genus Clioscaphites appears at the beginning of the Santonian and disappears in the upper part of that substage All the clioscaphites from West Greenland are closely related to early Clioscaphites forms from the United States and the deposits are thus thought to belong to the early Santonian. The inoceramids (Inoceramus steenstrupi group) seem to indicate that the Clioscaphites-bearing shales at Tuperssuartâ (on the north coast of Nûgssuaq) are stratigraphically somewhat younger than the Clioscaphites deposits in Lille Tange V Kloft in Svartenhuk, where members of the Inoceramus steenstrupi group first appear in the overlying strata. Baculites nugssuaqensis n. sp. from Tuperssuartâ is related to a Coniacian species, B.mariasensis, and shows no close relations with early Santonian forms. Actinocamax groenlandicus Birkelund, 1956, also occurs at that locality, but is not known from other deposits and is thus of restricted stratigraphical value.

In Søndre and Nordre Baculiteskløft (central Nûgssuaq) no clioscaphites occur, but the presence of late forms of Baculites codyensis indicate a Santonian age. According to Dr. W. A. Cobban, B. codyensis s. l. occurs from the Scaphites ventricosus Zone to the Clioscaphites montanensis Zone. In the $C$. montanensis Zone the ribbing begins to be reduced and forms similar to the West Greenland specimens predominate. In the succeeding $C$. choteauensis Zone even more smooth forms occur. 
Thus, on the basis of the baculites, these deposits are here correlated with the $C$. montanensis Zone. The associated inoceramids belong to the Inoceramus steenstrupi group. The occurrence of similar baculites in the lowermost part of the Scaphitesnæsen section seems to show that these deposits belong to the same zone, which may be rather thick. The deposits consist partly of sandstone with many plant remains suggesting a near-shore origin.

In the Scaphitesnæsen section there is a remarkable difference in the ammonite assemblage of the lowermost part (519-523 $\mathrm{m}$ above sealevel) and the upper part (533-548 $\mathrm{m}$ above sea-level) (text-fig. 5). Both the lower and the upper ammonite assemblages occur in dark bituminous shales, but sandy shales alternating with sandstone layers intervene. The lower ammonite fauna with fragments of a small Baculites, tentatively referred to a late form of $B$. codyensis, is, as already mentioned, supposed to belong to the Santonian, and the upper ammonite assemblage, containing B. obtusus s. l., is referred to the upper part of the Lower Campanian. The upper parts of the Santonian (from the Clioscaphites choteauensis Zone) and parts of the Lower Campanian may be represented by the sandy shales. The Inoceramus steenstrupi-I. patootensis bearing deposits at Pautût, on the southern coast of Nûgssuaq, may belong to this Upper Santonian-Lower Campanian part of the sequence which is so poorly represented in the central part of Nûgssuaq. The only sure evidence of Lower Campanian ammonite-bearing deposits in West Greenland older than the Scaphitesnæsen assemblage is on the Itsako peninsula (Svartenhuk), where poorly preserved Haresiceras specimens occur. These are related to Lower Campanian forms from the Western Interior of the United States.

Baculites obtusus s.l. from the upper ammonite assemblage in Scaphitesnæsen compares well with early forms of that species, used as an index fossil of one of the uppermost biozones of the Lower Campanian of the Interior of the United States. Scaphites cobbani n. sp. and S. rosenkrantzi $n$. sp. also occur. They are closely related to early representatives of the $S$.nodosus group, which also appeared in the Baculites obtusus Zone in the United States. Pseudophyllites skoui $\mathrm{n}$. sp. is also present and is the only species which persists into the upper part of the Upper Campanian.

The occurrence at Umîvik (Tange I Kløft) of displaced concretions containing Scaphites cobbani n. sp. may also indicate some late Lower Campanian in Svartenhuk.

The deposits at Ikorfat (other than the highest levels), Niaqornat, Vestre Konglomeratkløft, and Kûk-anernilik (Nûgssuaq), are referred to the Upper Campanian on the basis of the occurrence of Scaphites (Hoploscaphites) species related to "S. roemeri" sensu SchlÜter. This 
"species" occurs in the European Bostrychoceras polyplocum Zone, but is also often mentioned from the Lower Maastrichtian deposits. No sure evidence of this "species" in the Maastrichtian of Europe can, however, be demonstrated (see p. 115). In the United States and Canada a related form (S. (Hoploscaphites) gilli СовваN \& JeLetzky) appears in the Baculites perplexus Zone and ranges into the B.crickmayi Zone, but similar Scaphites (Hoploscaphites) forms also occur in the younger Baculites zones (including the $B$. clinolobatus Zone). Thus, an exact correlation of the hoploscaphites-bearing deposits with the North American Baculites zones is not possible. The deposits at Ikorfat, $550-665 \mathrm{~m}$ above sealevel, are slightly older than the other localities. The fauna differs from the younger Upper Campanian assemblages mainly in the occurrence of Scaphites (Hoploscaphites) ikorfatensis n. sp. and Pseudophyllites skoui $\mathrm{n}$. sp. and in the absence of Scaphites (Hoploscaphites) greenlandicus. The presence of Actinocamax aff. groenlandicus BIRKELUnd at Ikorfat indicate that some specimens may be Turonian-Lower Senonian in age. Tectonic disturbance may account for these (BIRKELUnd, 1956). This Actinocamax species is related to A. sternbergi JeLETzKY, 1961, unfortunately also of uncertain age, from Kansas.

The Scaphites (Discoscaphites) deposits at Ikorfat overlie the Upper Campanian $S$. (Hoploscaphites) assemblages and are most probably Maastrichtian. The occurrence, in Hamiteskløft, of $S$. (Discoscaphites) species together with a Diplomoceras species related to D. cylindraceum seems to confirm the Maastrichtian age. The displaced fragments of Diplomoceras collected at Niaqornat together with displaced Scaphites (Hoploscaphites) greenlandicus specimens may have come from overlying beds. A few displaced $S$. (Discoscaphites) fragments and a Pseudophyllites specimen collected at that locality are also possibly derived from overlying beds.

The difference between the $S$. (Discoscaphites) assemblage at Ikorfat and that in the Danian Oyster-ammonite Conglomerate may be explained by a small difference in age. Because the Maastrichtian at Ikorfat directly overlies the Upper Campanian these Maastrichtian deposits are probably older than most of the Maastrichtian fauna preserved in the Oysterammonite Conglomerate.

The $S$. (Discoscaphites) species from West Greenland are closely related to multinodose discoscaphites from the type Fox Hills area, but are only exceptionally multinodose. North American discoscaphites gradually become more multinodose during the Baculites baculus, $B$. grandis and $B$. clinolobatus Zones, but these less nodose forms differ distinctly from West Greenland species in other characters. Comparison of West Greenland and North American discoscaphites indicates a similar age to the deposits of the Fox Hills type area. 
Hypophylloceras (Neophylloceras) groenlandicum n. sp. and Saghalinites wrighti $\mathrm{n} . \mathrm{sp}$. occur in the same concretions together with $S$. (Discoscaphites) species. Hypophylloceras (Neophylloceras) groenlandicum n. sp. is related to $H$. $(N$.) ramosum, which disappears in the Upper Campanian, Saghalinites wrighti n. sp. is also related to a species (S. hoepeni) mainly occurring in the Campanian. However, Hypophylloceras and Saghalinites belong to very conservative stocks, and the presence of slightly differing species in deposits of Maastrichtian age is not unlikely.

The occurrence in the Oyster-ammonite Conglomerate of baculites related to Baculites meeki, from the B. clinolobatus Zone of the Western Interior region, may show that the discoscaphites-bearing deposits are slightly older than the Fox Hills Formation, but the material of that species from the United States, is too poorly preserved for exact comparison.

A small Inoceramus, similar to Inoceramus fibrosus (MeEk \& HAYDEN, 1857), occurs in the Oyster-ammonite Conglomerate together with Scaphites (Discoscaphites) species. Inoceramus fibrosus first appears in the Baculites baculus Zone and ranges into the Trail City Member of the type Fox Hills Formation (Jeletzky, 1962, p. 1013). According to WAAGE (in JELETZKy, 1962, p. 1013) the Inoceramus fibrosus forms from the Trail City Member of the Fox Hills Formation differ from those of the Mobridge Member of the underlying Pierre Shale in having much weaker radial ribbing and stronger concentric ribbing. In some specimens the radial ribbing is almost completely lost and only local undulations of the concentric ribs indicate a tendency to radial ornamentation. The I. fibrosus forms from the Oyster-ammonite Conglomerate also have strong concentric and weak radial ribs, in some specimens hardly discernible, and these inoceramids thus seem to confirm the age of the fauna as similar to the lower part of the Fox Hills Formation in the type area. 


\section{PALAEOGEOGRAPHY}

De LORIOL (1882) made the first attempt to identify scaphites from Niaqornat and compared the material with scaphites from the North American Fox Hills Formation. Madsen (1897) referred Steenstrup's material to Scaphites roemeri from Europe and RavN (1918) referred the material to $S$. nicolletii from the Fox Hills Formation. Both Madsen and Ravn considered the two species to be conspecific, and Ravn therefore used the name $S$. nicolletii, it being the older name. Later, Rosenkrantz (1942) pointed out that $S$.nicolletii and S.roemeri are two quite distinct species and he referred the scaphites from Niaqornat to the European $S$. roemeri. Donovan (1953) established a new species, $S$. greenlandicus, based on the material from Niaqornat, and on new material from East Greenland, and some of ScHLÜter's European "S. roemeri" specimens (see p. 113). As well as the scaphites from the north coast of Nûgssuaq other "Senonian" invertebrates were also earlier described by de Loriol, Stanton (in White \& Schuchert, 1898), and RAvN, but much of that material came actually from Danian deposits and was misidentified (Rosenkrantz, 1942).

On the basis of these partly misidentified faunas Teichert (1939, p. 155) stated that the Senonian transgression can not have been from the south, via the Davis Strait, since the marine fauna of the Senonian sediments of West Greenland shows no similarity to the Cretaceous fauna of the Coastal Plains of North America, and does not indicate any connection with the Upper Cretaceous of East Greenland. The character of the fauna suggests rather a connection with the Cretaceous sea of Montana; the connection must have been round the northern margin of the Canadian Shield. Teichert further assumed that a land connection between Greenland and Baffin Land still existed in the vicinity of the Davis Strait in the Cretaceous, as the fauna of the West Greenland sequence differs markedly from that of equivalent rocks in eastern North America.

During the Nûgssuaq Expedition in 1939, Rosenkrantz discovered a Scaphites assemblage of Coniacian age related to the $S$. ventricosus group of the Western Interior of the United States ( $S$. mariasensis umivikensis n. subsp., $S$. preventricosus sqartenhukensis n. subsp.). This was 
the first ammonite assemblage discovered in West Greenland with indisputable Western Interior affinities. On the basis of this fauna Rosenkrantz suggested that there was a marine connection between central North America and West Greenland through the Arctic Seas across the archipelago north of Baffin Land, or possibly covering parts of Northern Baffin Land.

Based on a restudy of the faunas described by DE LoRiol, Stanton and Ravn from the Lower Senonian (Upper Santonian-Lower Campanian) and the Upper Senonian (uppermost Campanian), Rosenkrantz stated, contrary to Teichert, that the Upper Santonian-Lower Campanian fauna shows both European affinities (Inoceramus steenstrupi De Loriol, I. patootensis de Loriol) and Central North American affinities (Hemiaster humphreysanus Меeк \& HAYden, Oxytoma nebrascana Evans \& Schumard, Solenomya subplicata (Meer \& Hayden)). The Upper Campanian zone characterized by "Scaphites roemeri" has, according to Rosenkrantz, a purely European character. Rosenkrantz therefore concluded that the connection towards the north with the Coloradoan Sea disappeared before the Upper Campanian and he suggested that a connection towards the south, with Europe and the Atlantic provinces of the United States, was established in the Santonian and maintained during the upper part of the Senonian.

In his work on Actinocamax from the Upper Cretaceous of Manitoba Jeletzk y (1950) discussed the origin of the Canadian Actinocamax species. Because of the close similarity between the Canadian Actinocamax species and certain Actinocamax species of the Euroasian "boreal" sea, JELETZKY suggests their migration from that province. As almost all Belemnitellidae were exclusive inhabitants of the "boreal" Upper Cretaceous seas, JеLEтzк y points out that a migration to the "boreal" sea of the North American Interior through the "Mediterranean" province of North America is unlikely. The evidence in favour of a northern migration route is, in JELETZKY's opinion, much stronger. In support of this he cites Upper Cretaceous faunas with strong Canadian affinities along the Arctic coast of Siberia and in the Western Urals, the occurrence of Actinocamax in East Greenland (Swinnerton, 1943), and the Canadian affinities of the faunas from West Greenland, described by DE LORIOL, Ravn and Rosenkrantz. Jeletzky opposed the commonly accepted concept of the closing of the northern outlet of the Canadian Western Interior Sea as early as the Lower Santonian, with its successive gradual south-ward retreat interrupted by a few transgressions, and he tentatively suggested, partly on the basis of the assumed occurrence of "Scaphites nicolletii" (sensu RavN) in West Greenland (=S. greenlandicus Donovan), that this connection persisted into the Upper CampanianLower Maastrichtian. 
The Actinocamax species described by the writer from West Greenland (1956) are extremely closely related to Actinocamax species from the Interior of North America recently described by JELETzKy (1961) and JELETZKY's theory of a northern route of migration from Europe to America for this genus is thus confirmed.

The Upper Cretaceous faunas of East Greenland were described by Frebold (1934), Donovan (1953, 1954, 1957) and Swinnerton (1943). On the basis of the poorly preserved Santonian-Lower Campanian Knudshoved fauna FreBold (1934) suggested a sea-connection with Europe but no connection with the West Greenland Cretaceous.

Donovan described more material from the Santonian-Lower Campanian and showed also the presence of marine Upper Campanian beds. A list of all described species from the Upper Cretaceous of East Greenland was given by DoNovan $(1957$, p. 87,211$)$ who stated that among the Upper Santonian-Lower Campanian species, Inoceramus patootensis and I. steenstrupi are widely distributed occurring in both north-west Europe and West Greenland, and closely similar to western Canadian forms. Also Linuparus dülmensis has, according to Donovan, a wide distribution in both Europe and America. The rest of the fauna has affinities with West Greenland and Europe only. Among the Upper Campanian species, Donovan pointed out that Scaphites greenlandicus occurs in West Greenland and identical or closely similar forms occur in north-west Europe, and he suggested that allied species also occur in North America. Donovan also recorded a barely determinable fragment (Donovas, 1953, pl. 24, fig. 8), which he referred to Scaphites quadrangularis, described from Dakota and Montana, which has not been found in West Greenland. Donovas pointed out that as far as this East Greenland assemblage is concerned, it would be unwise to stress the European more than the North American elements, and the difference between the Upper Senonian faunas of the two continents may not be so great.

It is thus apparent that many different palaeogeographical hypotheses, based on the Upper Cretaceous marine fauna from West Greenland, have been put forward, and that these are based partly on misidentified species. The new ammonite material described in the present paper facilitates interpretation of the Upper Cretaceous palaeogeography of West Greenland, but study of the associated marine invertebrate fauna is also necessary before a full understanding is possible.

As stated by Rosenkrantz (1942), the ammonite fauna at Umivik, containing Scaphites mariasensis and S.preventricosus, shows that a marine connection between central North America and West Greenland, through the Arctic Seas, existed in the Coniacian. Borissjakoceras rosenkrantzi n. sp., also from the Umîvik area, has affinities with forms from 
the Lower Turonian of northern Alaska and confirm the presence of this northern sea-way.

All other ammonites from the Turonian?, Coniacian, Santonian and Lower Campanian (excluding the Baculites obtusus Zone) of West Greenland are also referred to genera and species described from the Western Interior of North America or to new species related to Western Interior forms. These include Scaphites cf. corvensis from the Upper Turonian, $S$. ventricosus from the Coniacian, species of Clioscaphites and Baculites from the Santonian, and a species of Haresiceras from the Lower Campanian. It must also be emphasized that the genera Clioscaphites and Haresiceras have previously been recorded from the Western Interior only and that the Scaphites and Baculites species in question seem to be restricted to that region. The only species which shows some affinity with forms outside that region is Baculites codyensis (p. 55). It is implicit that all these species migrated by a northern route.

Among the associated invertebrate fauna, it should be mentioned that Actinocamax species from the Coniacian and Santonian (described by Birkelund, 1956) are definitely similar to species from the Interior of North America, but also imply the presence of a connection with Europa. Inoceramus patootensis and I. steenstrupi, from the SantonianLower Campanian, are widely distributed, indicating connections with Europe, East Greenland, and with the Interior Region of the United States, Canada, and Alaska.

It thus seems that there was a sea-way through the Baffin Bay area with connections with both the Western Interior and the Atlantic regions at the beginning of the Senonian, although, the ammonites show no affinities with those of the Coastal Plains of North America or Europe.

The ammonites related to the late Lower Campanian and Upper Campanian species from West Greenland are much more widely distributed than those of earlier deposits.

Among species from the upper part of the Lower Campanian Baculites obtusus is widely distributed in the Interior of North America but is not known from other areas. The scaphites ( $S . c o b b a n i$ n. sp. and $S$. rosenkrantzi n. sp.) are related to early representatives of the $S$. nodosus group. This group occurs mainly in the Interior of North America, but is also recorded from other areas. STEPHENSON (1941) thus recorded S.rugosus Stephenson (p. 425, pl. 89, figs. 15-18), S. brevis Meek (p. 426 , pl. 90, figs. 7-8), S. pumilus Stephenson (p. 426, pl. 90, figs. 10-12) and $S$.yorkensis Stephenson (p. 427, pl. 90, fig. 9), all belonging to the $S$. nodosus group, from the Gulf Coast area. Whitfield (1892, p. 261, pl. 14, figs. 13-14) and Wellek (1907, p. 824, pl. 107, figs. 1-2) also referred material from the Upper Cretaceous of the Coastal Plains (New Jersey) to $S$. nodosus, but ReESIDE $(1962$, p. 126) stated that the 
form definitely has nothing in common, morphologically or stratigraphically, with $S$. nodosus, but shows much more similarity to $S$. leei ReEside (1927 c, p. 26, pl. 20, figs. 17-20, pl. 21, figs. 1-7). Jeletzky (in Cóban \& Reeside, 1952) referred S.elegans Tate, 1865 (p. 37, pl. 3, fig. 3), from the Antrim Chalk of Northern Ireland, to $S$. quadrangularis, one of the representatives of the $S$. nodosus group. The figured fragmentary body chamber has two rows of nodes and may well belong to that group, like the fragment from East Greenland which Donovan (1953, pl. 24, fig. 8) referred to $S$. quadrangularis, but neither of these are definitely determinable. S. tuberculatus Giebel, from the Upper Campanian of Europe (p. 102) also has two rows of nodes on the body chamber, but here it is evident that the nodes also extend on to the phragmocone. This species certainly shows close affinities with the late representatives of the $S$. nodosus group and it thus seems as if at least late representatives of that group occur in Europe.

The scaphites from the upper part of the Upper Campanian (S. (Hoploscaphites) ikorfatensis n. sp., S. (H.) ravni n. sp. and $S$. (H.) greenlandicus) are, as stated by Rosenkrantz (1942), related to the European "S. roemeri" group. $S$. (H.) greenlandicus and $S$. (H.) ikorfatensis n. sp.? also occur in East Greenland and recently a closely related form, $S .(H$.$) gilli Соввan \& Jeletzky, has been described from the$ Interior of the United States and Canada. This $S$. (Hoploscaphites) group is thus widely distributed.

It is most likely that the $S$. (Hoploscaphites) species migrated by a northern route between Europe and the Interior of North America, since apparently none of these are known from the Coastal Plains and the Gulf Coast area of North America.

The poorly preserved baculites from the upper part of the Campanian show no similarity at all with North American baculites of that age, but some have European affinities.

In both the upper parts of the Lower Campanian and the upper parts of the Upper Campanian of West Greenland Pseudophyllites skoui n. sp. occurs. This genus occurs in Europe and in the Indo-Pacific area. The most closely related species, $P$. peregrinus (p. 40), is recorded from Madagascar, the Antarctic, and New Zealand. The genus has never been recorded from the Interior of North America. The route of migration of this species is uncertain (see below).

In the Maastrichtian, in Hamiteskløft, a Diplomoceras occurs. This genus is also found in the Campanian-Maastrichtian of Europe and in the Indo-Pacific region, but has never been recorded from the Interior Region of North America. The species may be related to the European D. cylindraceum.

The scaphites from the Maastrichtian (Scaphites (Discoscaphites) 
waagei n. sp., $S .(D$.$) angmartussutensis n. sp.) are closely related to$ scaphites from the type Fox Hills Formation in South Dakota. According to WAAGE (1961) the ammonoid fauna of that area consists in part of indigenous species descended from very similar forms in the underlying Pierre Shale. The ammonoids in the lower levels (in the lower nicolletii concretionary layers) are, with rare exceptions, members of these indigenous stocks. At a higher level (in the Limopsis-Gervillia concretionary layers) there is a sharp change in the aspect of the Fox Hills ammonoid fauna since indigenous forms are accompanied by an abundance of Gulf Coast forms, principally members of the complex Discoscaphites conradi (Morton) group. The West Greenland discoscaphites are related to the indigenous stocks of the Fox Hills area, but not to the Gulf Coast forms. The occurrence of these scaphites in West Greenland can only be explained by the presence of a northern sea-way during part of the Maastrichtian. The presence of Baculites cf. meeki in the Maastrichtian of West Greenland also supports this suggestion.

In addition to the Maastrichtian discoscaphites Saghalinites wrighti n. sp. and Hypophylloceras (Neophylloceras) groenlandicum n. sp. occur. These are distinctly similar to Indo-Pacific forms as is the case with Pseudophyllites skoui n. sp. in the Upper Campanian. Hypophylloceras (Neophylloceras) groenlandicum n. sp. is very closely allied to a species from the Pacific coast of North America $(H .(N$.$) ramosum) and it is$ difficult to explain its presence in West Greenland without suggesting a northern sea-way between the Pacific and Arctic Seas during parts of the Upper Campanian-Maastrichtian.

However, the Upper Cretaceous fauna from the Pacific Coast of North America, most recently described by Usher (1952), Matsumoto $(1959 \mathrm{a}, 1959 \mathrm{~b}, 1959 \mathrm{c}, 1960)$ and JoNes (1963), is very different from that of the Interior Region of the United States and Canada. Consequently, Usher (p. 42) stated that there appears to have been no connection between these areas during the Upper Cretaceous and MATsumoto (1960, p. 171) pointed out that "it is evidently due to paleogeographical conditions that a great barrier had arisen in consequence of the Nevadan movements. How far the barrier extended and how long it continued to play a role in separating the two major marine regions of North America are questions to be studied."

The occurrence of these Indo-Pacific elements in the Upper Campanian-Maastrichtian fauna of West Greenland might also be explained by the mode of life of these forms, all belong to "open-sea" lytoceratid and phylloceratid stocks. The widespread distribution of some species belonging to these genera, for example Pseudophyllites indra, occurring extensively in the southern hemisphere and also recorded from the Pacific Coast of North America by Usher (1952) and from the southern 
Table 3. Affinities of Upper Cretaceous ammonites, belemnites and inoceramids from West Greenland.

\begin{tabular}{|c|c|c|c|}
\hline & $\begin{array}{l}\text { Affinities with species from the } \\
\text { Interior Region of North } \\
\text { America. }\end{array}$ & $\begin{array}{c}\text { Affinities with species } \\
\text { from the Northern } \\
\text { Europe. }\end{array}$ & $\begin{array}{l}\text { Affinities with } \\
\text { species from the } \\
\text { Indo-Pacific area. }\end{array}$ \\
\hline Maastrichtian & $\begin{array}{l}\text { Baculites cf. meeki ELIAS; } \\
\text { S. (Discoscaphites) waagei n.sp.; } \\
\text { S. (Discoscaphites) angmartussu- } \\
\text { tensis n. sp.; Inoceramus aff. } \\
\text { fibrosus (MEEK \& HАYDEN). }\end{array}$ & Diplomoceras sp.? & $\begin{array}{l}\text { H. (Neophylloceras) } \\
\text { groenlandicum } \\
\text { n. sp.; Saghalinites } \\
\text { wrighti n. sp. } \\
\text { Pseudophyllites sp. }\end{array}$ \\
\hline $\begin{array}{l}\text { Upper } \\
\text { Campanian }\end{array}$ & $\begin{array}{l}\text { S.(Hoploscaphites) greenlandicus } \\
\text { DonovaN; S. (Hoploscaphites) } \\
\text { ravni n. sp.; S. (Hoploscaphites) } \\
\text { ikorfatensis n. sp. }\end{array}$ & $\begin{array}{l}\text { S. (Hoploseaphites) green- } \\
\text { landicus Donovan; } \\
\text { S. (Hoploseaphites) ravni } \\
\text { n. sp.; S. (Hoploseaphi- } \\
\text { tes) ikorfatensis n. sp. } \\
\text { Baculites sp. } 2 .\end{array}$ & $\begin{array}{l}\text { Pseudophyllites } \\
\text { skoui n. sp. }\end{array}$ \\
\hline $\begin{array}{l}\text { Uppermost } \\
\text { Lower Campanian }\end{array}$ & $\begin{array}{l}\text { Baculites ef. haresi REESIDE; } \\
\text { Baculites obtusus MEEK s. } 1 . ; \\
\text { Scaphites cobbani n. sp.; } \\
\text { Scaphites rosenkrantzi n. sp. }\end{array}$ & & $\begin{array}{l}\text { Pseudophyllites } \\
\text { skoui n. sp. }\end{array}$ \\
\hline $\begin{array}{l}\text { Lower } \\
\text { Campanian - } \\
\text { Upper } \\
\text { Santonian }- \text { - }\end{array}$ & $\begin{array}{l}\text { Haresiceras sp.; Inoceramus } \\
\text { patootensis } \mathrm{DE} \text { LORIOL; Inocera- } \\
\text { mus steenstrupi DE LORIOL. } \\
\text { Baculites codyensis REESIDE s. I.; } \\
\text { Baculites nugssuaqensis n. sp.; } \\
\text { Clioscaphites sp. aff. saxitonianus } \\
\text { (McLEARN); Actinocamax groen- } \\
\text { landieus BIRKLUND; Inocera- } \\
\text { mus aff. steenstrupi DE LoRIOL. } \\
\text { Clioscaphites saxitonianus sep- } \\
\text { tentrionalis n. subsp. }\end{array}$ & $\begin{array}{l}\text { Inoceramus patootensis } \\
\text { DE LORIOL; } \\
\text { Inoceramus steenstrupi } \\
\text { DE LORIOL. } \\
\text { Actinocamax groenlandi- } \\
\text { cus BIRKELUND; Inocera- } \\
\text { mus aff. steenstrupi DE } \\
\text { LORIOL. }\end{array}$ & $---\cdots-$ \\
\hline Coniacian & $\begin{array}{l}\text { Scaphites ventricosus MEEK \& } \\
\text { HAYDEN; Scaphites mariasensis } \\
\text { umivikensis n. subsp.; Seaphites } \\
\text { preventricosus svartenhukensis } \\
\text { n. subsp.; Borissjakoceras rosen- } \\
\text { krantzi n. sp.; Actinocamax sp. }\end{array}$ & Actinocamax sp. & \\
\hline Upper Turonian & Seaphites ef. corvensis СовBAN & & \\
\hline
\end{tabular}

U.S.S.R. by Naidin \& Shimanskit (in Moskvin, 1959), suggests that an Atlantic route of migration may also be possible, although species closely related to the West Greenland species are so far unknown along that route. 
In conclusion it can be stated that the ammonites of the Upper Cretaceous of West Greenland, together with the belemnites and the inoceramids, so far as they are determined, show that a sea-way through the Baffin Bay area, connecting the Atlantic with the Arctic Seas and the Interior of North America, existed from Upper Turonian to the Maastrichtian. The Actinocamax species, the inoceramids from the Upper Santonian-Lower Campanian, and the scaphites from the uppermost Campanian are related to forms which are distributed in both Northern Europe and the Interior of North America. Baculites from the uppermost Campanian, and possibly Diplomoceras from the lower part of the Maastrichtian, in West Greenland have European affinities and the Campanian-Maastrichtian lytoceratid and phylloceratid stocks have mainly Indo-Pacific affinities. All the rest are endemic to Central North America-West Greenland. Table 3 (p. 169) gives an outline of the palaeogeographical relations of the faunas.

In text-fig. 125 the extent of the Upper Cretaceous Sea in North America and Greenland is indicated. The North American limits are based on a map prepared by GILl \& СовваN (in press). The limits of the Upper Cretaceous transgression in Northern Canada and the Arctic archipelago are uncertain.

Recent years mapping in these arctic islands (Thorsteinsson \& Tozer, 1957; Tozer, 1960, 1963; Fortier et. al., 1963) shows the presence of Upper Cretaceous marine deposits (Kanguk Formation) in the Sverdrup Basin and these help locate the position of the northern sea-way which has been suggested. To provide a source for the Upper Cretaceous-Tertiary sediments which fill the Sverdrup Basin, Tozer $(1960$, p. 13) believes that a land mass probably occupied the area of eastern and southern Ellesmere Land during the Upper Cretaceous and Tertiary. It seems however more acceptable, as mentioned by GiLL \& СовваN (in press), to place the route of the northern sea-way over areas which are known to contain Cretaceous rocks rather than over areas of Palaeozoic and Precambrian rocks further south.

The shales in the upper part of the Kanguk Formation contain Inoceramus species identified by McLeARN as belonging to the I.lobatus group characterizing the Santonian-Lower Campanian (in Fortie r et al., 1963, p. 92). Marine fossils of later Senonian age have not yet been found in the Sverdrup Basin. The presence in West Greenland of CampanianMaastrichtian faunas with close affinities to Central North-American assemblages is most important for postulating a late Senonian sea-way through these areas.

In West Greenland dark, bituminous shales seem to predominate during the Senonian, except in part of the Upper Santonian-Lower Campanian where more sandy sediments commonly occur. In the 


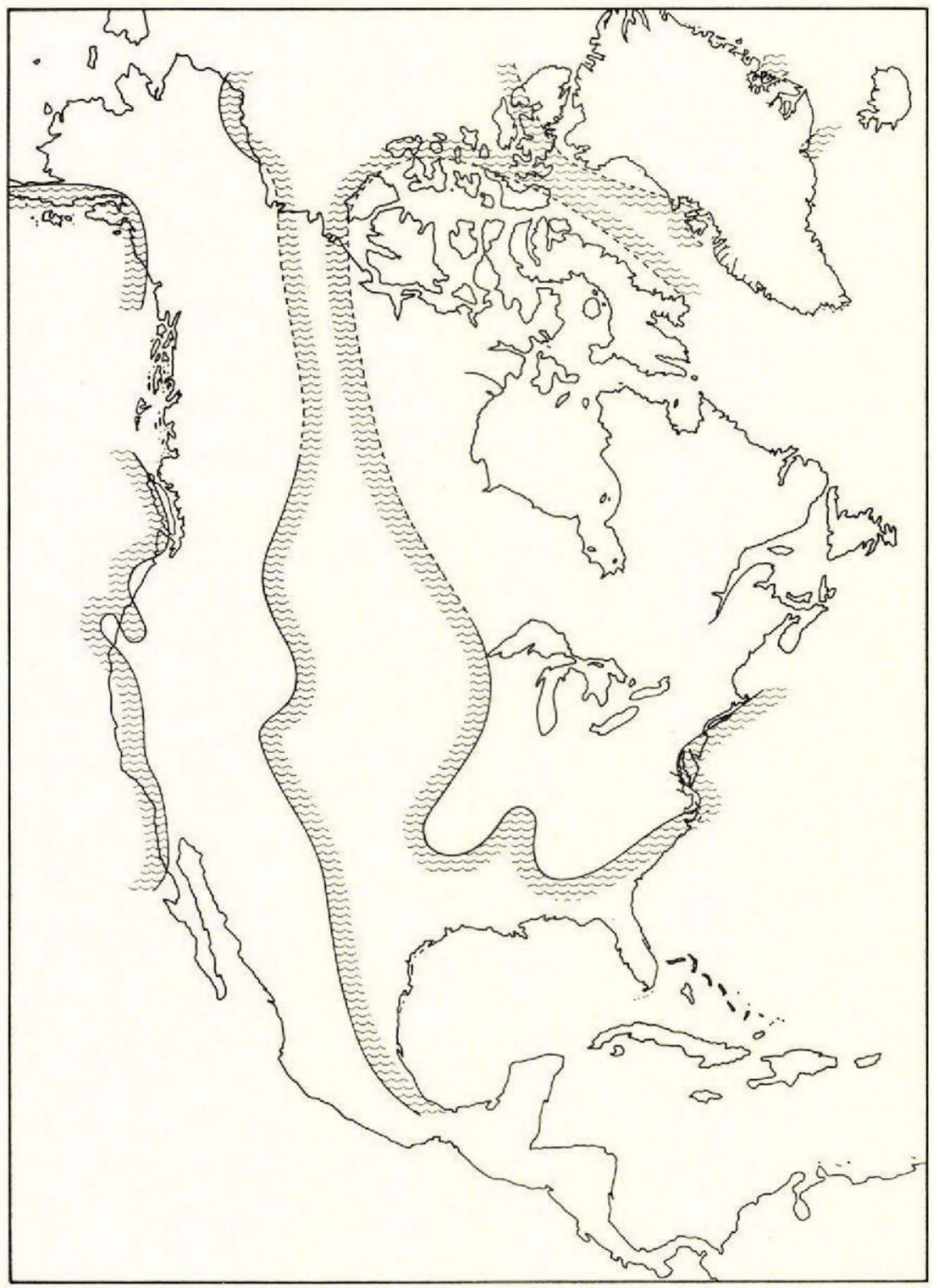

Fig. 125. Palaeogeographical map of North America and Greenland showing the boundaries of the Upper Cretaceous Sea. The limits of the North-American transgression are based on a map by GiLL \& Соввал (in press).

Western Interior Region of North America parts of Upper SantonianLower Campanian deposits are also more sandy than underlying and overlying rocks and the Upper Campanian of that area is also characterized by extensive deposits of dark shale (Pierre Shale). 
According to Reeside (1957, p. 528) the history of Upper Santonian and Lower Campanian times embraces a restriction of the sea-way through North America and possibly a severance of connection with the "boreal" region. Although the sediments are also sandy in parts of the Upper Santonian-Lower Campanian of West Greenland the faunal assemblages quite clearly indicate that there was a connection between West Greenland and North America at that time.

In West Greenland, as in the Fox Hills area in North America, the youngest Maastrichtian deposits contain a rich fauna of near-shore origin.

Broad comparison of the ammonite faunas from the Interior Region of North America and from West Greenland shows that the West Greenland assemblages are less diverse than the Central North American assemblages, the latter periodically being mixed with an abundance of Gulf Coast forms. Since the sedimentary facies of the Interior Region of North America and of West Greenland are so similar, the absence of Gulf Coast migrants in West Greenland is probably due to unfavorable climatic conditions. 


\section{DANSK RESUMÉ}

Materialet, der er behandlet i nærværende afhandling, er fra halvøerne Nûgssuaq og Svartenhuk på Grønlands vestkyst og hovedsageligt indsamlet under professor A. Rosenkrantz' Nùgssuaq ekspeditioner i 1938-39, samt senere under Grønlands Geologiske Undersøgelses fortsatte arbejde i dette område, ligeledes under professor A. Rosenkrantz' ledelse. Også ældre samlinger indgår i materialet, idet enkelte ammonitførende lokaliteter på Nûgssuaq's nordkyst (i Niaqornat-området) allerede tidligere var kendt og samlinger herfra behandlet af $\mathrm{DE}$ LORIOL (1882, 1883), Madsen (1897) og Ravn (1918). Desuden har RosenKRANTZ (1942) påvist, at en ammonitlokalitet fra coniacien ved Umîvik på Svartenhuk sandsynligvis også var kendt på et tidligt tidspunkt, idet nogle ammoniter i Mineralogisk Museums samlinger, mærket "Cornu Amonis aus Grönland", indsamlet i det 18. århundrede eller før, synes at stamme fra denne lokalitet.

Professor A. Rosenkrantz har omtalt en del af de senere års omfattende nyindsamlinger i arbejder fra 1940, 1942, 1951 og 1953, specielt coniacien-faunaen fra Umîvik på Svartenhuk og faunaen fra øvre campanien ved Niaqornat på Nûgssuaq (1942).

\section{O K A L I T E T E R}

Lokalitetsbeskrivelserne er hovedsageligt udarbejdet på grundlag af oplysninger fra professor A. RosenkRantz og hans medarbejdere.

Kridtaflejringerne på Svartenhuk (tekstfigur $1 \mathrm{og}$ 2) er beskrevet af Rosenkrantz (1942). De strækker sig fra Niaqornak langs sydkysten af Umîvik bugten og fortsætter videre nordpå langs Firefjelds østside. Også på Itsako og i Umîarfik fjorden (ved Simiútap-kùa) er kridtaflejringerne blottede. Sedimenterne ved Umivik består af finlamellerede, bituminøse, mørkegrå skifre med underordnede lag og linser af gullig, temmelig finkornet sandsten. Skifrene indeholder mørke, linseformede kalkkonkretioner, der ofte indeslutter ammoniter. Ammoniterne viser, at sedimenterne ved Umîvik tilhører coniacien. Sydligere, i Lille Tange V Kløft, er ammoniter fra nedre santonien repræsenteret, og på Itsako synes nedre campanien ammoniter at være tilstede. Løse blokke fra Store Tange V 
Kløft synes at vise, at øvre turon er repræsenteret i dette område, og løse blokke fra Tange I Kløft viser, at også øvre del af nedre campanien må være repræsenteret på Svartenhuk. Sedimenterne er overlejret af tertiær pillowlava og plateaubasalt.

Kridtaflejringerne på Nûgssuaq overlejrer grundfjeldet og overlejres af aflejringer fra danien og paleocæn, der atter dækkes af tertiær pillowlava og plateaubasalt. Stedvis mangler danien og paleocæn lagene. Et vældigt konglomerat indleder danien aflejringerne. På visse lokaliteter optræder der i dette konglomerat ammoniter, som viser, at det hovedsageligt var maastrichtien, der blev nedbrudt under danien-havets transgression. Både før og efter de tertiære lavaudbrud er der sket tektoniske forskydninger i området. Kridtaflejringerne er hovedsageligt blottede på sydkysten, på nordkysten, og i de store floddale, der gennemskærer halvøen. De ammonitførende aflejringer tilhører senon og består som på Svartenhuk af mørke bituminøse skifre med kalkkonkretioner og underordnede sandstenslag.

På Nùgssuaq's sydkyst er der kun fundet ammonitførende aflejringer ved Alianaitsúnguaq. Ammoniterne findes i mørke skifre, der overog underlejres af skiftende skifer- og sandstensbænke. I lagserien over den ammonitførende skiferhorizont findes desuden underordnede kullag. Ammonithorizonten kan henføres til coniacien.

I den centrale del af Nûgssuaq (tekstfigur $1 \mathrm{og} 3$ ) findes ammonitførende aflejringer fra nedre santonien ved Ilugigsoq og i Tunorqo. I Agatdalen findes aftejringer fra santonien og campanien, og desuden fra danien og paleocæn. En stor forkastning skærer denne dal som angivet på kortet tekstfigur 3. Sydvest for denne forkastning kendes aflejringer fra senon, danien og paleocæn, medens kun danien og paleocæn går i dagen nordøst for forkastningen. Vigtige senone ammonitlokaliteter sydvest for forkastningen er Baculiteskløfterne og Scaphitesnæsen. Tekstfigur 4 og 5 viser skematiske snit gennem lagserierne i Søndre Baculiteskløft $\mathrm{og}$ Scaphitesnæsen. Ammoniterne findes i mørke skifre, men der forekommer også sandede aflejringer i begge disse profiler. Ammoniterne fra Baculiteskløfterne viser, at aflejringerne tilhører santonien. Den nedre skiferserie i Scaphitesnæsen tilhører ligeledes santonien, medens den øvre skiferserie tilhører øvre del af nedre campanien. Den sandede serie, der adskiller de to skiferserier, repræsenterer sandsynligvis dele af øvre santonien-nedre campanien. Fossiler fra dette tidsrum er ikke påvist i den centrale del af Núgssuaq. I Agatdalen findes flere lokaliteter, hvor bundkonglomeratet fra danien er blottet. Dette konglomerat indeholder store mængder konkretioner, hovedsageligt stammende fra nederoderet maastrichtien. Disse konkretioner indeholder en rig ammonitfauna. Den skifrede matrix indeholder mange danien østers, heraf navnet østersammonit konglomeratet. 
Øst for Ikorfat på Nûgssuaq's nordkyst overlejres prækambrium af ferskvandsaflejringer tilhørende Kome- og Atane formationerne og derover følger en marin serie fra campanien-maastrichtien. Vest for Ikorfat findes marine aflejringer fra senon, danien og paleocæn. Adskillige forkastninger skærer kystlandet og mange kulisseskred er sket langs kysten (se pl. 48-49 og tekstfigur 6-7). Den ældste ammonitførende lokalitet, ved Tuperssuartâ, tilhører santonien. På kyststrækningen fra Niaqornat til Ikorfat er ammonitførende horizonter fra øvre campanian og maastrichtien repræsenteret. De ammonitrigeste lokaliteter er aflejringer fra øverste del af øvre campanien i Scaphiteskløften ved Niaqornat og aflejringer ved Ikorfat, hvor større dele af øvre campanien og maastrichtien er repræsenteret.

\section{S Y S T E M A T I K B E S K I V E L S E}

Dette afsnit indeholder beskrivelser af 31 arter, heraf er 14 nye, fire er henført til kendte arter, og 13 er på grund af sparsomt og dårligt bevaret materiale ikke endeligt navngivne. Slægterne Hypophylloceras, Saghalinites, Pseudophyllites, Baculites, Diplomoceras, Scaphites, Clioscaphites, Haresiceras og Borissjakoceras er repræsenteret. Specielt er scaphiter og baculiter talrige. Takket være det righoldige og velbevarede materiale har det været muligt at belyse de fleste arters variationsbredde og at foretage nogle ontogenetiske studier. Disse belyser først og fremmest relationerne mellem Scaphites s. str. og underslægterne Hoploscaphites og Discoscaphites og viser, at Hoploscaphites og Discoscaphites udvikledes fra nærstående repræsentanter for slægten Scaphites henholdsvis i slutningen af campanien og i begyndelsen af maastrichtien. Den store lighed mellem visse repræsentanter for de to underslægter forklares ved parallel udvikling. En analyse af udviklingslinierne Scaphites $\rightarrow$ Clioscaphites (fra coniacien-santonien) og Scaphites $\begin{aligned} & 7 \text { Hoploscaphites } \\ & \searrow \text { Discoscaphites }\end{aligned}$ (fra campanienmaastrichtien) viser, at visse karakterer har en tendens til at udvikle sig i samme retning inden for disse udviklingslinier.

Tilstedeværelsen af velbevarede juvenile eksemplarer af slægterne Scaphites og Saghalinites har muliggjort en analyse af beboelseskammerets ontogenetiske udvikling hos disse slægter.

\section{PALÆOØKOLOGI}

Det rige Scaphites materiale har givet anledning til nogle palæoøkologiske betragtninger. Det er påfaldende, at nogle af de grønlandske 
Scaphites-selskaber udelukkende er sammensat af helt udvoksede eksemplarer, medens andre består af en blanding af juvenile og udvoksede eksemplarer. Det må antages, at de selskaber, der udelukkende består af udvoksede eksemplarer, udgør rester af migrationssværme, medens selskaber, der indeholder mange juvenile eksemplarer, har ynglet i det pågældende område. Coniacien, santonien og en del af campanien-selskaberne hører til førstnævnte gruppe, medens maastrichtien faunaen fra østers-ammonit konglomeratet hører til sidstnævnte gruppe. Ledsagefaunaen er desuden langt rigere $\mathrm{i}$ østers-ammonit konglomeratets maastrichtien-konkretioner end i ældre lag, hvor inoceramer og krebsdyr væsentlig er repræsenteret ved siden af ammoniterne.

Forekomsten af juvenile og udvoksede eksemplarer af såvel phylloceratider og lytoceratider som scaphiter sammen i konkretioner i østersammonit konglomeratet er bemærkelsesværdig, idet de to førstnævnte grupper i almindelighed antages at leve på dybere vand end den sidstnævnte.

Scaphiterne fra nedre campanien i Scaphitesnæsen på Nûgssuaq viser en bemærkelsesværdig størrelsesfordeling. To arter findes repræsenteret, Scaphites cobbani n. sp. og Scaphites rosenkrantzi n. sp., og inden for begge arter findes der to størrelsesgrupper. Dette fremgår af histogrammerne i tekstfigur $121(1 \circ \mathrm{og} 2)$ visende størrelsesfordelingen af udvoksede eksemplarer. Sene juvenile stadier af de små former er rigeligt repræsenteret, medens ikke et eneste ikke-udvokset eksemplar af de store former er kendt. Ingen forskelligheder hverken i dimensioner eller suturafstande kan påvises hos de tidlige vindinger af store og små eksemplarer (tekstfigur 122). Størrelsesforskellen skyldes således ikke en retarderet vækst hos de små former, men udelukkende at det scaphitoide beboelseskammer hos de små former anlægges 1-2 vindinger tidligere end hos de store.

Maкоwsкi (1962) antager, at forskelligheder i størrelse og andre karakterer hos visse udvoksede ammoniter, der forekommer sammen, men som har ens indre vindinger, skyldes kønsdimorfi. Maкоwski baserer først og fremmest denne antagelse på undersøgelser over jura-ammoniter, men også hos goniatiter og hos Scaphites constrictus mener han at kunne påvise kønsdimorfi. MAKowski fastslår, at en af de vigtigste forskelle mellem skaller af hanner og hunner er antallet af vindinger, idet hanner skulle have et mindre antal vindinger end hunner. Hos alle de arter, МАкоwskı har undersøgt, skulle der således altid være mindst en hel vindings forskel mellem "hanner" og "hunner».

Størrelsesfordelingen hos scaphiterne fra Scaphitesnæsen og tilstedeværelsen af et ringere antal vindinger hos de små end hos de store former kunne måske tydes som kønsdimorfi. Imidlertid findes der her overgangsformer mellem de store og de små former, både med hensyn til størrelse 
og vindingstal (tekstfigur 121 (1-2)). En undersøgelse af udvoksede eksemplarers størrelsesfordeling hos andre Scaphites arter fra andre grønlandske lokaliteter har desuden vist, at der som regel er tale om en almindelig fordelingskurve; kun undtagelsesvis findes en fordeling $\mathrm{i}$ to størrelsesgrupper som i Scaphitesnæsen. Det er således højst tvivlsomt, om fænomenet overhovedet kan forklares ved kønsdimorfi. I Scaphitesnæsen tyder tilstedeværelsen af juvenile eksemplarer af de små former på, at disse er vokset op i området, medens den fuldstændige mangel på ikke-udvoksede eksemplarer af de store former tyder på, at disse udgør rester af migrationssværme. I dette tilfælde kan forskellighederne således muligvis være økologisk betinget. En endelig stillingtagen til dette spørgsmål er dog ikke mulig, før andre Scaphites-selskaber er yderligere undersøgt.

\section{S T R AT I G R A F I}

Den stratigrafiske inddeling af aflejringerne fra øvre kridt på Nûgssuaq og Svartenhuk, vist i tabel 1 (p. 154), er først og fremmest baseret på ammoniternes stratigrafiske udbredelse. I visse tilfælde er inddelingen yderligere støttet på oplysninger fra professor A. RosenkRantz om inoceramernes stratigrafiske forhold.

Da de fleste af de vestgrønlandske ammoniter er nært beslægtet med nordamerikanske arter fra den indre del af U.S.A. og Canada, er en korrelation af de grønlandske aflejringer med aflejringer i dette område forholdsvis simpel. Derimod er en nøjagtig korrelation med europæiske aflejringer vanskelig, fordi de fleste af de nordamerikansk-vestgrønlandske arter har en endemisk karakter. Den detaillerede zoneinddeling af det nordamerikanske øvre kridt, angivet i tabel 1, er først og fremmest sammenstillet på grundlag af CoвBans arbejder, medens korrelationen af nordamerikanske zoner med europæiske etager og subetager delvis er sammenstillet på grundlag af arbejder af Cobban, ReEside, Jeletzky og Seitz.

Tabel 2 (p. 157) viser den stratigrafiske udbredelse af de vestgrønlandske ammoniter.

ØVRE TURON. Ammoniter fra løse konkretioner fra Store Tange V Kløft på Svartenhuk kan formentlig henføres til Scaphites corvensis. Øvre turon må således formodes at være repræsenteret i dette område.

CONIACIEN. Aflejringerne ved Umîvik på Svartenhuk indeholder en rig ammonitfauna. På grundlag af scaphiterne er disse aflejringer henført til Scaphites preventricosus zonen, kendt fra U.S.A. Denne zone kan 
i U.S.A. yderligere opdeles i to subzoner, en nedre Inoceramus erectus subzone og en øvre I. deformis subzone. I I. erectus subzonen optræder $S$ caphites preventricosus sammen med $S$. mariasensis. Det er således sandsynligt, at de grønlandske aflejringer nærmest må korreleres med denne nedre del. De nævnte inoceramer er også kendt fra Europa, og lag med disse henføres ofte til øvre turon (f. eks. af SEITz, 1959). Slægten Barroisiceras, der er kendt fra typeområdet for coniacien, optræder imidlertid i Scaphites preventricosus zonen i U.S.A., hvorfor disse aflejringer her er henført til coniacien.

De yngste kendte repræsentanter for slægten Borissjakoceras uden for Grønland er fra nedre turon. Den grønlandske art er betydelig mere avanceret med hensyn til suturernes forløb end den nærmest beslægtede art fra nedre turon i Alaska.

En marin horizont ved Alianaitsúnguaq på Nûgssuaq's sydkyst kan henføres til den lidt yngre Scaphites ventricosus zone på grundlag af tilstedeværelsen af $S$. pentricosus.

SANTONIEN-CAMPANIEN. I U.S.A. og Canada optræder slægten Clioscaphites fra begyndelsen af santonien til henimod slutningen af denne subetage. De grønlandske Clioscaphites arter er nærmest beslægtet med den tidligste repræsentant for denne slægt, Clioscaphites saxitonianus (McLEARN), der i U.S.A. sammen med Inoceramus undulatoplicatus benyttes som zonefossil for den ældste zone i santonien. Clioscaphiter er fundet faststående i Lille Tange V Kløft på Svartenhuk og på Nûgssuaq ved Tuperssuartâ, Ilugigsoq og Tunorqo. I Lille Tange V Kløft og i Ilugigsoq er underarten Clioscaphites saxitonianus septentrionalis repræsenteret, medens Clioscaphites sp. aff. saxitonianus er repræsenteret ved Tuperssuartâ og Tunorqo. De sidstnævnte lokaliteter synes at være lidt yngre end de førstnævnte, idet repræsentanter for Inoceramus steenstrupi gruppen findes i disse aflejringer, men i Lille Tange V Kløft først i sedimenter, der overlejrer lagene med clioscaphiter.

I Søndre og Nordre Baculiteskløft på Nûgssuaq er slægten Clioscaphites ikke repræsenteret, derimod viser tilstedeværelsen af sene udviklingsformer af Baculites codyensis REESIDE, at aflejringerne her er fra santonien. Baculites codyensis optræder i U.S.A. fra Scaphites ventricosus zonen til Clioscaphites montanensis zonen og gennemgår i løbet af dette tidsrum en udvikling fra former med meget kraftige ribber ti] former med meget svage ribber. De grønlandske repræsentanter synes at stå de nordamerikanske Baculites codyensis former fra Clioscaphites montanensis zonen nærmest. Lignende baculiter optræder i den nederste skiferserie i Scaphitesnæsen. Repræsentanter for Inoceramus steenstrupi gruppen er almindelig udbredt i de Baculites-førende lag, både i Baculiteskløfterne og i Scaphitesnæsen. 
Over skiferserien med Baculites codyensis i Scaphitesnæsen findes en sandet serie, hvorfra ingen forsteninger er kendt. Den sandede serie, der overlejres af en skiferserie fra øvre del af nedre campanien, repræsenterer sandsynligvis dele af øvre santonien-nedre campanien. De marine aflejringer ved Pautût, der ifølge RAvN (1918) indeholder såvel Inoceramus steenstrupi som I. patootensis, repræsenterer formodentlig også en del af dette tidsrum. På Itsako er tilstedeværelsen af aflejringer fra nedre campanien fastslået på grundlag af forekomsten af en Haresiceras art.

Baculites obtusus fra Scaphitesnæsens øvre skiferserie tilhører tidlige, svagt ribbede udviklingsformer af denne art, og aflejringerne kan således henføres til den nedre del af Baculites obtusus zonen, der henføres til øvre del af nedre campanien i U.S.A. Scaphites cobbani n. sp. og Scaphites rosenkrantzi n. sp. fra samme lokalitet er beslægtet med tidlige repræsentanter for Scaphites nodosus gruppen, der netop begynder at optræde i Baculites obtusus zonen i U.S.A.

På Nûgssuaq's nordkyst er Bostrychoceras zonen (øvre del af øvre campanien) repræsenteret på en række lokaliteter. Disse lokaliteter er henført til denne zone på grundlag af tilstedeværelsen af nogle Scaphites (Hoploscaphites) arter beslægtet med "Scaphites roemeri" sensu Schl ÜTER. Hoploscaphiterne viser, at en del af lagserien ved Ikorfat repræsenterer ældre dele af Bostrychoceras polyplocum zonen end de ammonitførende aflejringer ved Niaqornat, Angnertuneq og Kûk-anernilik.

MAASTRICHTIEN. Aflejringerne fra maastrichtien indeholder Scaphites (Discoscaphites) arter beslægtet med former fra typeområdet for Fox Hills formationen i U.S.A.

Faststående maastrichtien aflejringer er kun kendt fra Nûgssuaq's nordkyst. Faunaen er her fattig og så fragmentarisk, at ingen endelige artsbestemmelser har kunnet foretages.

En langt rigere maastrichtien fauna, som antagelig er lidt yngre end faunaen på Nûgssuaq's nordkyst, er kendt fra østers-ammonit konglomeratet i Agatdalen. Discoscaphiterne fra dette konglomerat er nær beslægtet med $S .(D$.$) cheyennensis-abyssinus-mandanensis gruppen$ og med $S$. (D.) nebrascensis-intermedius gruppen fra Fox Hills formationen. De afviger dog fra de nordamerikanske ved næsten fuldstændig at mangle laterale knuderækker.

Discoscaphiterne i U.S.A. udvikles fra Scaphites nodosus gruppen ved gradvis at udvikle laterale knuderækker, og mangelen af disse knuderækker hos de grønlandske former kunne således skyldes en større stratigrafisk alder. Da de grønlandske discoscaphiter er meget avancerede med hensyn til andre karakterer, synes dette imidlertid ikke at være tilfældet. At de to faunaer er af samme alder bekræftes yderligere 
ved tilstedeværelsen i østers-ammonit konglomeratet af en Inoceramus art, der er nær beslægtet eller identisk med en særlig varietet af Inoceramus fibrosus, der forekommer i Discoscaphites lagene i Fox Hills formationen.

\section{PAL EOGEOGRAF I}

Allerede DE LORIOL (1882) sammenlignede scaphiter fra Niaqornat med scaphiter fra Fox Hills formationen i U.S.A. Senere henførte MADSEN (1897) scaphiterne fra Niaqornat til den europæiske art "Scaphites roemeri", som han anså for at være identisk med Scaphites nicolletii fra Fox Hills formationen. Ravn (1918) anså ligeledes "S. roemeri" og $S$. nicolletii for identiske, men på grund af prioritetsreglen benævnte han scaphiterne fra Niaqornat $S$. nicolletii. Imidlertid påpegede RosenKRANTz (1942) at " $S$. roemeri" og $S$. nicolletii er to helt forskellige arter, og at scaphiterne fra Niaqornat tilhører $S$. roemeri. Foruden scaphiterne fra Niaqornat blev andre "senone" invertebrate fossiler beskrevet af de Loriol, Stanton (i White \& Schuchert, 1898) og Ravn, men store dele af dette materiale hidrørte $i$ virkeligheden fra danien aflejringer og var forkert bestemt (RosenkRANTz, 1942).

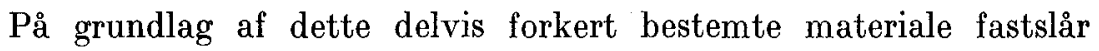
Tеichert (1939), at den senone transgression ikke kan være sket fra syd via Davis Strædet, men derimod fra nord gennem Baffins Bugt, og han antager, at der har været en nordlig havforbindelse med det centralnordamerikanske kridthav. TEICHERT antager yderligere, at der endnu var en landforbindelse mellem Grønland og den sydlige del af Baffins Land i kridttiden, da den vestgrønlandske fauna er helt afvigende fra faunaen langs østkysten af Nordamerika.

Under Nûgssuaq ekspeditionerne opdagede Rosenkrantz en coniacien fauna med ammoniter tilhørende den nordamerikanske Scaphites ventricosus gruppe. Dette er i virkeligheden den første ammonitfauna med ren centralnordamerikansk affinitet opdaget i Vestgrønland. På basis af denne fauna antog Rosenkrantz (1942), at der var en marin forbindelse i coniacien mellem det centrale hav i Nordamerika og Vestgrønland gennem det arktiske arkipelag. $\mathrm{På} \mathrm{grundlag} \mathrm{af} \mathrm{en} \mathrm{fornyet}$ gennemgang af materialet fra øvre santonien-nedre campanien og øverste campanien beskrevet af DE Loriol, Stanton og Ravn fastslår RosenKRANTz, i modsætning til TeIcherT, at øvre santonien-nedre campanien faunaen både viser europæiske affiniteter (Inoceramus steenstrupi og I. patootensis) og affiniteter til faunaen i det centralnordamerikanske hav (Hemiaster humphreysanus, Oxytoma nebrascana, Solenomya subplicata). Øvre campanien faunaen karakteriseret ved "Scaphites roemeri" har ifølge Rosenkrantz ren europæisk affinitet. Rosenkrantz kon- 
kluderer derfor, at forbindelsen mod nord med det centralnordamerikanske hav forsvandt før øvre campanien, og han antager, at en forbindelse med Europa og de atlantiske provinser i U.S.A. opstod i santonien og var tilstede i hele den øvre del af senon.

De forøgede samlinger fra det vestgrønlandske kridtområde viser, at der sandsynligvis har eksisteret en nordlig havforbindelse mellem det vestgrønlandske kridthav og det centralnordamerikanske hav gennem en langt større del af øvre kridt: lige fra øvre turon til et stykke ind i maastrichtien. Således er former beslægtet med de vestgrønlandske scaphiter fra turon? (Scaphites cf. corvensis), coniacien (S. mariasensis umivikensis n. subsp., S. preventricosus svartenhukensis n. subsp., S. ventricosus) og santonien (Clioscaphites saxitonianus septentrionalis n. subsp., C. sp. aff. saxitonianus) kun kendt fra det centralnordamerikanske kridthav. Også Baculites codyensis fra santonien er først og fremmest kendt fra dette område. Slægten Haresiceras fra nedre campanien er ligesom slægten Clioscaphites endemisk centralnordamerikansk. De vestgrønlandske scaphiter fra øvre del af nedre campanien (Scaphites cobbani n. sp., $S$. rosenkrantzi n. sp.) tilhører $S$. nodosus gruppen, der har sit hovedudbredelsesområde $\mathrm{i}$ den centralnordamerikanske provins, men som muligvis også er repræsenteret i Europa (S. tuberculatus Grebel). Baculites obtusus fra de samme lag er udelukkende kendt fra den centralnordamerikanske provins. Scaphiterne fra øvre del af øvre campanien (Scaphites (Hoploscaphites) ikorfatensis n. sp., S. (H.) rasni n. sp. og $S$. (H.) greenlandicus) er som allerede påvist af RosenkRaNTZ (1942), nært beslægtede med europæiske former; men nyere indsamlinger har vist, at disse former også er repræsenteret i den centralnordamerikanske provins. Scaphiterne og baculiterne fra maastrichtien (Scaphites (Discoscaphites) waagei n. sp., S. (D.) angmartussutensis n. sp., Baculites cf. meeki) viser udelukkende affinitet til centralnordamerikanske arter. Alle de beslægtede arter fra det centralnordamerikanske kridthav er først og fremmest udbredt i den nordlige del af U.S.A. og Canada, men ikke eller kun sjældent $\mathrm{i}$ det mexicanske golfområde, hvorfor en migrationsrute gennem dette område ikke er sandsynlig. Påvisningen af en havforbindelse mellem det centralnordamerikanske hav og Vestgrønland gennem det arktiske arkipelag så sent som i maastrichtien er særlig bemærkelsesværdig, idet man i almindelighed regner med, at det centralnordamerikanske havs forbindelse mod nord blev lukket langt tidligere (jfr. REESIDE, 1957).

Blandt de ovennævnte former viser speciel scaphiterne fra øvre del af øvre campanian, at der også har eksisteret en forbindelse med det europæiske kridthav. Også baculiterne fra denne zone og en Diplomoceras art fra de ældste maastrichtien aflejringer synes at vise affinitet til europæiske former. 
Andre faunaelementer fra det vestgrønlandske senon, Actinocamax arter fra coniacien-santonien, Inoceramus steenstrupi og I.patootensis fra santonien-nedre campanien, synes at vise forbindelse til både det europæiske kridthav og til det centralnordamerikanske område. De nævnte belemniter og inoceramer må antages at have migreret ad en nordlig rute ligesom de ovennævnte ammoniter.

I campanien-maastrichtien er der desuden et faunaelement af indopacifisk karakter til stede, nemlig arterne Hypophylloceras (Neophylloceras) groenlandicum n. sp., Saghalinites wrighti n. sp. og Pseudophyllites skoui n. sp. Specielt er den førstnævnte så nært beslægtet med en art udbredt langs den nordamerikanske Stillehavs-kyst, at en nordlig forbindelse mellem Stillehavet og det arktiske arkipelag i slutningen af kridttiden kunne formodes. En sammenligning mellem faunaen fra øvre kridt i Stillehavsområdet og i den centralnordamerikanske provins giver imidlertid ikke holdepunkt for antagelsen af en direkte forbindelse mellem de to områder. En migrationsrute gennem Atlanterhavet kan vel også tænkes, idet de nævnte slægter alle hører til former, som menes knyttet til åbne havområder.

En sammenligning af Vestgrønlands øvre kridt fauna med Østgrønlands viser, at de rent nordamerikanske faunaelementer ikke kan påvises med sikkerhed i Østgrønland, medens f. eks. I. steenstrupi, I. patootensis og $S$. (H.) greenlandicus forekommer her.

I Vestgrønland er mørke bituminøse skifre den dominerende facies i senon, men i dele af øvre santonien-nedre campanien er sandede aflejringer dog ret udbredte. Også i den centralnordamerikanske provins er øvre santonien-nedre campanien aflejringerne sandede (Telegraph Creek Formation, Eagle Sandstone), og i øvre campanien er ligeledes mørke, bituminøse skifre (Pierre Shale) vidt udbredte.

Den udstrakte regression af havet i maastrichtien forårsagede tillige fremkomsten af mere kystnære aflejringer i det yngste maastrichtien både i Nordamerika (Fox Hills Sandstone) og i Vestgrønland (sandholdige konkretioner i østers-ammonit konglomeratet).

En bred sammenligning mellem ammonitfaunaen i den centralnordamerikanske og den vestgrønlandske region viser, at den nordamerikanske fauna har en mere artsrig karakter, idet den indeholder en række sydlige former, som ikke nåede til Grønland. 


\section{REFERENCES}

Ager, D. V. \& Nichols, D., 1964: Marine ecology and palæoecology. Nature, Vol. 200, pp. 942-945, London.

Anderson, F. M., 1958: Upper Cretaceous of the Pacific Coast. Geol. Soc. Amer. Mem. 71, Richmond.

Arkhangelskx, A. D., 1916: Les mollusques du crétacé supérieur du Turkestan. Com. Géol. (Petrograd) Mem., n.s., Vol. 152, pp. 1-57.

Arkell, W. J., 1933: The Jurassic System in Great Britain. Oxford.

- et al., 1957: Treatise on Invertebrate Paleontology. Pt. L, Mollusca 4, Cephalopoda, Ammonoidea (ed. by R. C. Moore). Kansas.

BaIly, W. H., 1855: Description of some Cretaceous fossils from South Africa; collected by Capt. Garden, of the 45th Regiment. Quart. Jour. Geol. Soc. London, Vol. 11, pp. 454-465, London.

Berry, E. W., 1928: Cephalopod adaptions - the record and its interpretations. Quart. Review Biol., Vol. 3, No. 1, pp. 92-108, Baltimore.

Beurlen, K., 1928: Die Lebensweise der Ammoniten. Ber. senck. naturforsch. Ges., Bd. 58, Hft. 12, pp. 546-556, Frankfurt am Main.

Brdder, A. M., 1962: Use of the tentacles, swimming and buoyancy control in the Pearly Nautilus. Nature, Vol. 196, pp. 451-454, London.

Bink rorst, J. T., 1861: Monographie des gastéropodes et des céphalopodes de la craie supérieure du Limbourg. Classe des céphalopodes. Bruxelles-Maestricht.

Birkelund, T., 1956: Upper Cretaceous belemnites from West Greenland. Medd. Grønland, Bd. 137, Nr. 9, København.

- 1957: Upper Cretaceous belemnites from Denmark. Biol. Skr. Dan. Vid. Selsk., Bd. 9, no. 1, København.

- 1958: Senone scaphiter fra Nûgssuaq og Svartenhuk (Vestgrønland) og deres palæogeografiske relationer. Review by Chr. Poulsen and A. Rosenkrantz in: Festskrift udgivet af Kobenhavns Universitet, Nov. 1958, pp. 236-242, København.

Breistroffer, M., 1947: Sur les zones d'ammonites dans l'albien de France et d'Angleterre. Trav. Lab. géol. Univ. Grenoble, tome 26, pp. 1-104, Grenoble.

- 1953: Les ammonites albiennes de Peille (Alpes-Maritimes). In: Breistroffer, M. \& de Villoutreys, O., Trav. Lab. géol. Univ. Grenoble, tome 30, pp. 69-74, Grenoble.

Вӧнм, J., 1909: Neue Untersuchungen über die Senonbildungen der östlichen Schweizeralpen. II. Paläontologischer Teil. Mém. Soc. Pal. Suisse, Vol. 36, pp. 20-61, Basel.

CASEY, R., 1954: Falciferella, a new genus of Gault ammonites, with a review of the family Aconeceratidae in the British Cretaceous. Proc. Geol. Ass., London, Vol. 65, pp. 262-277, London.

- 1960-61: A monograph of the Ammonoidea of the Lower Greensand. Pal. Soc., part 1, 1960; part 2 and 3,1961 , London. 
Cobban, W. A., 1951 a: Scaphitoid cephalopods of the Colorado group. U.S. Geol. Surv. Prof. Paper 239, Washington, D.C.

- 1951 b: Colorado shale of central and northwestern Montana and equivalent rocks of Black Hills. Bull. Amer. Ass. Petrol. Geol., Vol. 35, No. 10, pp. 21702198, Tulsa.

- 1951 c: New species of Baculites from the Upper Cretaceous of Montana and South Dakota. Jour. Paleont., Vol. 25, No. 6, pp. 817-821, Tulsa.

- 1952a: A new Upper Cretaceous ammonite genus from Wyoming and Utah. Jour. Paleont., Vol. 26, No. 5, pp. 758-760, Tulsa.

- 1955: Some guide fossils from the Colorado shale and Telegraph Creek formation, northwestern Montana. In: Billings Geol. Soc. Guidebook Sixth Ann. Field Conf., Sweetgrass Arch-Disturbed Belt, Montana, pp. 198-207.

- 1958: Two new species of Baculites from the Western Interior Region. Jour. Paleont., Vol. 32, No. 4, pp. 660-665, Tulsa.

- 1961: The ammonite family Binneyitidae REESIDE in the Western Interior of the United States. Jour. Paleont., Vol. 35, No. 4, pp. 737-758, Tulsa.

- 1962a: New Baculites from the Bearpaw shale and equivalent rocks of the Western Interior. Jour. Paleont., Vol. 36, no. 1, pp. 126-135, Tulsa.

- 1962b: Baculites from the lower part of the Pierre shale and equivalent rocks in the Western Interior. Jour. Paleont., Vol. 36, No. 4, pp. 704-718, Tulsa.

- 1962c: Late Cretaceous Desmoscaphites range zone in the Western Interior Region. U.S. Geol. Surv. Prof. Paper 450-D, pp. 140-144, Washington, D.C.

- 1963: Occurrence of the Late Cretaceous ammonite Hoplitoplacenticeras in Wyoming. U.S. Geol. Surv. Prof. Paper 475-G, pp. 60-62, Washington, D.C.

- 1964: The Late Cretaceous cephalopod Haresiceras Resside and its possible origin. U.S. Geol. Surv. Prof. Paper 454-I, Washington, D.C.

- , Erdmann, C. E., Lemke, R. W. \& Maughan, E. K., 1959: Revision of Colorado group on Sweetgrass Arch, Montana. Bull. Amer. Ass. Petr. Geol., Vol. 43, No. 12, pp. 2786-2796, Tulsa.

- \& Gryc, G., 1961. Ammonites from the Seabee formation (Cretaceous) of Northern Alaska. Jour. Paleont., Vol. 35, No. 1, pp. 176-190, Tulsa.

- \& J JLetzky, J. A.: A new scaphite from the Campanian rocks of the Western Interior of North America. Jour. Paleont. (in press).

- \& ReEside, J. B., 1952: Correlation of the Cretaceous formations of the Western Interior of the United States. Bull. Geol. Soc. Amer., Vol. 63, pp. 1011-1044, New York.

- \& Scotr, G. R., 1964: Multinodose scaphitid cephalopods from the lower part of Pierre shale and equivalent rocks in the conterminous United States. U.S. Geol. Surv. Prof. Paper 483-E, Washington, D.C.

- , Scott, G. R. \& Gill, J., 1962: Recent discoveries of the Cretaceous ammonite Haresiceras and their stratigraphic significance. U.S. Geol. Surv. Prof. Paper 450-B, pp. 58-60, Washington, D.C.

Collignon, M., 1931: Faunes sénoniennes du nord et de l'ouest de Madagascar. Ann. Géol. Serv. Min. Fasc. No. 1, Tananarive.

- 1956: Ammonites néocrétacées du Menabe (Madagascar). IV - Les Phylloceratidae. V - Les Gaudryceratidae. VI - Les Tetragonitidae. Ann. Géol. Serv. Min. Fasc. No. 23, Paris.

Defrance, M., 1816: Dictionnaire des sciences naturelles. Tome 3, suppl. Paris.

Diener, C., 1912 : Lebensweise und Verbreitung der Ammoniten. Neues Jahrb. Min. Geol., Bd. 2, pp. 67-89, Stuttgart.

- 1925: Ammonoidea neocretacea. Fossilium Catalogus. I. Animalia. Pars 29, Berlin. 
Donovan, D. T., 1953: The Jurassic and Cretaceous stratigraphy and palaeontology of Traill Ø, East Greenland. Medd. Gronland, Bd. 111, Nr. 4, København.

- 1954: Upper Cretaceous fossils from Traill and Geographical Society Øer, East Greenland. Medd. Gronland, Bd. 72, 2. afd., Nr. 6, København.

- 1957: The Jurassic and Gretaceous Systems in East Greenland. Medd. Gronland, Bd. 155, Nr. 4, København.

- 1964: Cephalopod phylogeny and classification. Biol. Rev., Vol. 39, pp. 259-287, Cambridge.

ELIAS, M. K., 1933: Cephalopods of the Pierre formation of Wallace County, Kansas, and adjacent area. Univ. Kansas Bull., Vol. 34, No. 5, pp. 289-363, Topeka.

Favre, E., 1869: Description des mollusques fossiles de la craie des environs de Lemberg. Paris.

Faujas-Saint-Fond, B., 1798: Histoire naturelle de la Montagne de Saint-Pierre de Maestricht. Paris.

Forbes, E., 1846: Report on the Fossil Invertebrata from Southern India, collected by Mr. Kaye and Mr. Gunliffe. Trans. Geol. Soc. London, sec. ser., Vol. 7, pp. 97-174, London.

Fortier, Y. O. et al., 1963: Geology of the North-Central part of the arctic archipelago Northwest Territories (Operation Franklin). Canada Geol. Surv. Mem. 320, Ottawa.

Frebold, H., 1934: Obere Kreide in Ostgrönland. Medd. Gronland, Bd. 84, Nr. 8, København.

Frech, F., 1915a: Ủber Scaphites. I. Die Bedeutung von Scaphites für die Gliederung der Oberkreide. Zentralbl. Min. etc., pp. 553-568, Stuttgart.

- 1915 b: Loses und geschlossenes Gehäuse der tetrabranchiaten Cephalopoden. Zentralbl. Min. etc., pp. 593-595, Stuttgart.

GiebeL, C., 1849: Jahresber. naturw. Ver. Halle, pp. 18-20, Halle.

Gill, J. R. \& СовваN, W. A., 1961: Stratigraphy of lower and middle parts of the Pierre shale, Northern Great Plains. U.S. Geol. Surv. Prof. Paper 424-D, pp. 185-191, Washington, D.C.

- 1962: Red Bird silty member of the Pierre shale, a new stratigraphic unit. U.S. Geol. Surv. Prof. Paper 450-B, pp. 21-24, Washington, D.C.

Grandjean, F., 1910: Le siphon des Ammonites et des Bélemnites. Bull. Soc. Géol. France, Tome 10, pp. 496-519, Paris.

Hartz, N., 1896: Planteforsteninger fra Cap Stewart i Østgrønland, med en historisk Oversigt. Medd. Gronland, Bd. 19, Nr. 8, København.

HeER, O., 1868: Flora fossilis arctica. Zürich.

Hoepen, E. C. N. van, 1921: Cretaceous Cephalopoda from Pondoland. Ann. Transvaal Museum, Vol. 8, pp. 1-48, Cambridge.

HoFf, Тн., 1865: Om Alderen af de i Grønland optrædende geognostiske Formationer og om Forekomsten af nogle Malme i Sydgrønland. Förh. vid de skand. naturforskarnes 9. möte, 1863, Stockholm.

Howarth, M. K., 1958: Upper Jurassic and Cretaceous ammonite faunas of Alexander Land and Graham Land. Falkland Is. Depend. Surv. Sci. Rep. 21, London.

Hyatt, A., 1900: Cephalopoda. In: Zittel-Eastmann: Textbook of Palaeontology, 1st English ed., pp. 502-604, London.

Hölder, H., 1955: Über die Sipho-Anheftung bei Ammoniten. Neues Jahrb. Geol. Pal. Mh., Jahrg. 1954, pp. 372-379, Stuttgart.

ImLAx, R. W. \& REESIDE, J. B., 1954: Correlation of the Cretaceous formations of Greenland and Alaska. Bull. Geol. Soc. Amer., Vol. 65, pp. 223-246, New York. 
Jeletzky, J. A., 1950: Actinocamax from the Upper Cretaceous of Manitoba. Canada Geol. Surv. Bull. No. 15, Ottawa.

- 1951: Die Stratigraphie und Belemnitenfauna des Obercampan und Maastricht Westfalens, Nordwestdeutschlands und Dänemarks sowie einige allgemeine Gliederungs-Probleme der jüngeren borealen Oberkreide Eurasiens. Geol. Jahrb. Beiheft 1, Hannover.

- 1956: Cretaceous marine macrofossil zones of the Canadian Western Interior Region and their correlation with the European zones and stages. $X X$ Congr. Geol. Internat. Resumenes de Ios trabajos presentados, pp. 332-333, Mexico.

- 1961: Actinocamax from the Upper Gretaceous Benton and Niobrara formations of Kansas. Jour. Paleont., Vol. 35, No. 3, pp. 505-531, Tulsa.

- 1962: The allegedly Danian dinosaur-bearing rocks of the globe and the problem of the Mesozoic-Cenozoic boundary. Jour. Paleont., Vol. 36, No. 5, pp. 1005 1018, Tulsa.

Jones, D. L., 1963: Upper Cretaceous (Campanian and Maestrichtian) ammonites from Southern Alaska. U.S. Geol. Surv. Prof. Paper 432, Washington, D.C.

- \& Gry G, G., 1960: Upper Cretaceous pelecypods of the genus Inoceramus from Northern Alaska. U.S. Geol. Surv. Prof. Paper 334-E, Washington, D.C.

Kner, R., 1848: Versteinerungen des Kreidemergels von Lemberg und seiner Umgebung. Naturw. Abh. (Haidinger), Bd. 3, Pt. 2, No. 1, Wien.

Косн, B. E., 1959: Contribution to the stratigraphy of the non-marine Tertiary deposits on the south coast of the Nùgssuaq peninsula, Northwest Greenland. Medd. Gronland, Bd. 162, Nr. 1, København.

- 1963: Fossil plants from the Lower Paleocene of the Agatdalen (Angmârtussut) area, central Nûgssuaq peninsula, Northwest Greenland. Medd. Gronland, Bd. 172, Nr. 5, København.

Kossmat, F., 1895: Untersuchungen über die südindische Kreideformation, I. Beitr. Paläont. Geol. Österr.-Ungarns u.d. Orients, Bd. 9, pp. 97-203 (1-107).

Kummel, B., 1948: Environmental significance of dwarfed cephalopods. Jour. Sed. Petrology, Vol. 18, No. 2, pp. 61-64.

LAMARCK, J. B. P. A. DE, 1801: Système des animaux sans vertèbres.

LANDEs, R. W., 1940: Paleontology of the marine formations of the Montana group, pt. 2 of Geology of the Southern Alberta plains. Canada Geol. Surv. Mem. 221, pp. 129-223, Ottawa.

Lasswitz, R., 1904: Die Kreide-Ammoniten von Texas. Geol. Palæont. Abhandl., N.F., Bd. 6 (10), Jena.

Logan, W. N., 1898: The invertebrates of the Benton, Niobrara and Ft. Pierre Cretaceous. Kansas Univ. Geol. Surv., Vol. 4, Part 8, pp. 431-583, Topeka.

Loriol, P. DE, 1882: Om fossile Saltvandsdyr fra Nord-Grønland. Medd. Gronland, Bd. 5, No. 4, København.

- 1883: Ueber die marinen Thierversteinerungen von Nord-Grönland. In: Heer, O.: Flora fossilis grönlandica, pp. 251-256, Zürich.

Madsen, V., 1897: The genus Scaphites in West Greenland. Medd. Dansk Geol. Foren., Nr. 4, pp. 45-51, København.

Makowsкi, H., 1962: Problem of sexual dimorphism in ammonites. Palaeontologica polonica, No. 12, Warszawa.

Marshald, M. A., 1926: The Upper Cretaceous ammonites of New Zealand. Trans. New Zealand Inst., Vol. 56, pp. 129-210, Wellington.

Matsumoto, T., 1959a: Cretaceous ammonites from the Upper Chitina Valley, Alaska. Mem. Fac. Sci. Kyushu Univ., Ser. D, Vol. 8, No. 3, pp. 49-90, Fukuoka. 
Matsumoto, T., 1959b: Upper Cretaceous ammonites from California, Part I. Mem. Fac. Sci. Kyushu Univ., Ser. D, Vol. 8, No. 4, pp. 91-171, Fukuoka.

- 1959c: Upper Cretaceous ammonites of California. Part II. Mem. Fac. Sci. Kyushu Univ., Ser. D, Special Vol. I, pp. 1-172, Fukuoka.

- 1960: Upper Cretaceous ammonites of California. Part III. Mem. Fac. Sci. Kyushu Univ., Ser. D, Special Vol. II, p. 1-204, Fukuoka.

- \& OватA, I., 1963a: A monograph of the Baculitidae from Japan. Part I. The Baculitidae from Hokkaido. Mem. Fac. Sci. Kyushu Univ., Ser. D, Vol. 13, No. 1, pp. 7-73, Fukuoka.

- 1963b: A monograph of the Baculitidae from Japan. Part III. Concluding remarks on the Baculitidae from Japan. Mem. Fac. Sci. Kyushu Univ., Ser. D, Vol. 13, No. 1, pp. 93-116, Fukuoka.

McLean , F. H., 1929: Cretaceous invertebrates. In: Mesozoic palæontology of Blairmore Region, Alberta. Canada Nat. Mus. Bull. 58, pp. 73-79, Ottawa.

MEEK, F. B., 1858: Descriptions of new organic remains from the Cretaceous rocks of Vancouver's Island. Trans. Albany Inst., Vol. 4 (1858-64), pp. 37-49, Albany.

- 1870: A preliminary list of fossils collected by Dr. HAyden in Colorado, New Mexico and California, with brief descriptions of a few of the new species. Amer. Phil. Soc. Proc., Vol. 11, pp. 425-431, Philadelphia.

- 1876a: A report on the invertebrate Cretaceous and Tertiary fossils of the Upper Missouri County. U.S. Geol. Surv. Terr., Vol. 9, Washington, D.C.

- 1876 b: Descriptions and illustrations of fossils from Vancouver and Sucia Islands and other northwestern localities. Bull. U.S. Geol. Geogr. Surv. Terr., Vol. 2 (4), pp. 351-374, Washington, D.C.

- 1876c: Descriptions of the Gretaceous fossils collected on the San Juan exploring expedition under Capt. J. N. Maсомв. U.S.Army Engineer Dept. Rept., pp. 119-133.

- \& HAYden, F. V., 1857: Descriptions of twenty-eight new species of Acephala and one gastropod from Cretaceous formations of Nebraska Territory. Proc. Acad. Nat. Sci., Philadelphia, Vol. 8, pp. 81-87, Philadelphia.

- 1860: Descriptions of new Lower Silurian (Primordial), Jurassic, Cretaceous, and Tertiary fossils collected in Nebraska by the Exploring Expedition under the command of Capt. W. F. Raynolds. Proc. Acad. Nat. Phil., Vol. 12, pp. 415-447, Philadelphia.

- 1862: Descriptions of new Cretaceous fossils from Nebraska Territory, collected by the expedition sent out by the Government under the command of Lieut. Joh Mulla n. Proc. Acad. Nat. Sci. Philadelphia, Vol.14, pp.21-43, Philadelphia.

Miкнailov, N. P., 1951: The ammonites of the Upper Cretaceous of the southern part of the European part of the U.S.S.R. and their stratigraphic significance. Akad. Nauk S.S.S.R., Trudy Inst. Geol. Nauk, No. 129, geol. ser., No. 50 (In Russian).

Moв в R, J. C., 1885 : Cephalopoderna i Sveriges Kritsystem. II. Sveriges Geol. Unders. Ser. C., No. 73, Stockholm.

Morton, S. G., 1834: Synopsis of the organic remains of the Cretaceous group of the United States, Philadelphia.

- 1842: Description of some new species of organic remains of the Cretaceous Group of the United States; with a tabular view of the fossils hitherto discovered in this formation. Jour. Acad. Nat. Sci. Philadelphia, Vol. 8, pp. 207-227, Philadelphia.

Mornow, A. L., 1935: Cephalopods from the Upper Cretaceous of Kansas. Jour. Paleont., Vol. 9, No. 6, pp. 463-473, Menasha. 
Moskvin, M. M. (ed.), 1959: The Atlas of the Upper Cretaceous fauna of the Northern Caucasus and Crimea. State Scientific - Technical Press of the Oil and Mining-Fuel Literature, Moscow (In Russian).

Munck, S., 1945: On the geology and petrography of the West Greenland basalt province. Part V. Two major doleritic intrusions of the Nûgssuaq peninsula. Medd. Grønland, Bd. 137, Nr. 5, København.

Nowa , J., 1908: Untersuchungen über Cephalopoden der oberen Kreide in Polen. 1. Teil. Genus Baculites Lamarck. Bull. Internat. l'Acad. Sci. Cracovie, No. 4 , pp. 326-353, Cracovie.

- 1911: Untersuchungen über die Cephalopoden der Oberen Kreide in Polen. 2. Teil. Die Skaphiten. Bull. Internat. l'Acad. Sci. Cracovie, Sér. B, No. 7, pp. 547-589, Cracovie.

- 1913: Untersuchungen über die Cephalopoden der oberen Kreide in Polen. 3. Teil. Bull. Internat. l'Acad. Sci. Cracovie, Sér. B, No. 6, pp. 335-415, Cracovie.

- 1916: Zur Bedeutung von Scaphites für die Gliederung der Oberkreide. K.-k. geol. Reichanstalt Verh. Jahrg. 1916, No. 3, pp. 55-67, Wien.

Obata, I. \& Matsumoto, T., 1963: A monograph of the Baculitidae from Japan. Part II. Some baculitids from Honshu. Mem. Fac. Sci. Kyushu Univ. Ser. D, Vol. 13, No. 1, pp. 75-92, Fukuoka.

Orbigny, A. D', 1850: Prodrome de paléontologie. Paris.

OWEN, D. D., 1852: Description of new and imperfectly known genera and species of organic remains, collected during the geological surveys of Wisconsin, Iowa, and Minnesota. Report of a geol. surv. of Wisconsin, Iowa, and Minnesota, and incidentally, a portion of Nebraska territory, pp. 573-587, Philadelphia.

Packard, E. L., 1960: Hypotypes of Phylloceras onoense Stanton. Jour. Paleont., Vol. 34, No. 3, pp. 421-428, Tulsa.

Parkinson, J., 1811 : Organic remains of a former world. London.

Pervinquiere, L., 1907: Céphalopodes des terrains secondaires. Etudes de Paléontologie Tunisienne. Paris.

Pra, J., 1923: Über die ethologische Bedeutung einiger Hauptzüge in der Stammesgeschichte der Cephalopoden. Naturh. Mus. Wien Ann., Bd. 36, pp. 50-73, Wien.

PICard, L., 1929: On Upper Cretaceous (chiefly Maestrichtian) Ammonoidea from Palestine. Ann. Mag. Nat. Hist., Vol. 3, 10. Ser., pp. 433-456, London.

Pictet, F. J., 1847: Description des mollusques fossiles qui se trouvent dans les Grès Verts des environs de Genève. I. Cephalopodes. Mém. Soc. Phys. Hist. Nat. Genève, Vol. 11 (2), pp. 257-412, Genf.

Pом PEскJ, J. F., 1894: Ueber Ammonoiden mit "anormaler Wohnkammer". Jahresh. Vaterländ. Naturk. Würtenberg, 50. Jahrg., pp. 220-290, Stuttgart.

RAvn, J. P. J., 1902: Molluskeme i Danmarks Kridtaflejringer. II. Scaphopoder, Gastropoder og Cephalopoder. K. Dan. Vid. Selsk. Skr., 6. Rk., nat. og mat. Afd., Bd. 11, No. 4, pp. 205-270, København.

- 1918: De marine Kridtaflejringer i Vest-Grønland og deres Fauna. Medd. Grønland, Bd. 56, Nr. 9, København.

ReEside, J. B., 1927a: Cephalopods from the lower part of the Cody shale of Oregon Basin, Wyoming. U.S. Geol. Surv. Prof. Paper 150-A, Washington, D.C.

- 1927b: The scaphites, an Upper Cretaceous ammonite group. U.S. Geol. Surv. Prof. Paper 150-B, Washington, D.C. 
ReEside, J. B., 1927c: The cephalopods of the Eagle sandstone and related formations in the Western Interior of the United States. U.S. Geol. Surv. Prof. Paper 151, Washington, D.G.

- 1957: Paleoecology of the Cretaceous Seas of the Western Interior of the United States. In: Treatise on Marine Ecology and Paleoecology, Vol. 2, pp. 505-542. Geol. Soc. Amer. Mem. 67 (H. S. Lad d ed.), Baltimore.

- 1962: Cretaceous ammonites from New Jersey. In: H. G. Richards et al.: The Cretaceous fossils of New Jersey. State of New Jersey department of conservation and economic development, Bull. 61, Part II, pp. 113-137, Trenton.

Reyment, R. A., 1955: Some examples of homeomorphy in Nigerian Cretaceous ammonites. Geol. Fören. Stockh. Förhandl., Bd. 77, H.4, pp. 567-594, Stockholm.

- 1958. Some factors in the distribution of fossil cephalopods. Stockh. Contr. Geol. Vol. 1, No. 6, Stockholm.

Robinson, C. S., Mapel, W. J. \& Cobban, W. A., 1959: Pierre shale along western and northern flanks of Black Hills, Wyoming and Montana. Bull. Amer. Ass. Petr. Geol., Vol. 43, No. 1, pp. 101-123, Tulsa.

Roemer, F. A., 1841: Die Versteinerungen des norddeutschen Kreidegebirges. Hannover.

Rosenkrantz, A., 1940: see Rosenkrantz et. al. 1940.

- 1942: see Rosenkrantz et. al. 1942.

- 1951: Oversigt over Kridt- og Tertiærformationens stratigrafiske Forhold i Vestgronland. Medd. Dansk Geol. Foren., Bd. 12, pp. 155-158, København.

- 1953: Kridt. In: Oversigt over Grønlands geologi, ed. by de geologistuderendes klub, Steno, København.

-, Noe-Nygaard, A., Grx, H., Munck, S. \& Laursen, D., 1940: Den Danske Nûgssuaq Ekspedition 1939. Medd. Dansk Geol. Foren., Bd. 9, pp. 653-663, København.

- , Noe-Nygaard, A., Gry, H., Munck, S. \& Laursen, D., 1942: A geological reconnaissance of the southern part of the Svartenhuk peninsula West Greenland. Medd. Gronland. Bd. 135, Nr. 3, København.

SALFELD, H., 1924: Die Bedeutung der Konservativstämme für die Stammesentwicklung der Ammonoideen. Leipzig.

Schindewolf, O. H., 1960: Studien zur Stammesgeschichte der Ammoniten. Lieferung I. Akad. Wiss. Litt. Abh. Mat.-Nat. Klasse, Jahrg. 1960, Nr. 10, pp. 635-744, Wiesbaden.

Schlüter, Cl., 1871-72: Die Cephalopoden der oberen deutschen Kreide I. Palaeontographica, Bd. 21, pp. 1-120, Cassel.

- 1876: Die Cephalopoden der oberen deutschen Kreide II. Palaeontographica, Bd. 24, pp. 1-144, Cassel.

Sснмгд, F., 1955: Die bisherigen Untersuchungen über das Unter/ObermaastrichtGrenzprofil von Hemmoor (Niederelbe), seine Schichtfolge und Leitformen. Mitt. Geol. Staatsinst. Hamburg, Heft 24, pp. 75-86, Hamburg.

- 1959: La définition des limites Santonien-Campanien et Campanien inférieursupérieur en France et dans le nord-ouest de l'Allemagne. Congrès des Sociétés savantes, pp. 535-546.

Schmidt, H., 1930: Ueber die Bewegungsweise der Schalencephalopoden. Pal. Zeitschr., Bd. 12, pp. 194-206, Berlin.

Scotт, G., 1940: Paleoecological factors controlling the distribution and mode of life of Cretaceous ammonoids in the Texas area. Jour. Paleont., Vol. 14, No. 4, pp. 299-323, Tulsa. 
Scott, G. R. \& Coвban, W. A., 1962: Clioscaphites saxitonianus (McLeann), a discrete ammonite zone in the Niobrara formation at Pueblo, Colorado. U.S.Geol. Surv. Prof. Paper 450-C, p. 85, Washington, D.C.

- - 1963: Apache Creek sandstone member of the Pierre shale of southeastern Colorado. U.S. Geol. Surv. Prof. Paper 475-B. Article 25, pp. 99-101, Washington, D.G.

Seitz, O., 1959: Vergleichende Stratigraphie der Oberkreide in Deutschland und in Nordamerika mit Hilfe der Inoceramen. $X X$ Congr. Geol. Internat. Symposium del Cretacico, pp. 113-130, Mexico.

Shimer, H. W. \& Shrock, R. R., 1944: Index fossils of North America. New YorkLondon.

Shimizu, S., 1935: The Upper Cretaceous cephalopods of Japan. Part I. Jour. Shanghai Sci. Inst. Sect. 2, Vol. 1, pp. 159-226, Shanghai.

- \& OватA, T., 1934: Cephalopoda. Iwanami's series of Geol. and Pal. (In Japanese).

Sмгтн, J. P., 1901: The larval coil of Baculites. Amer. Naturalist, Vol. 35, No. 409, pp. 39-49, Boston.

Sмгтн, W. D., 1905: The development of Scaphites. Jour. Geol., Vol. 13, pp. 635-654, Chicago.

Sowerвy, J., 1813: The Mineral Conchology of Great Britain. Vol. 1, London.

- 1818: The Mineral Conchology of Great Britain. Vol. 2, London.

- 1836: Descriptive notes respecting the shells figured in pls. 11-13. In: Fitron, W. H: Observations on some of the strata between the Chalk and the Oxford Oolite in the South-East of England. Trans. Geol. Soc. London, Vol. 2, No. 4, pp. 335-349, London.

Spath, L. F., 1922a: On Cretaceous Ammonoidea from Angola, collected by Prof. J. W. Gregory. Trans, Roy. Soc. Edinburgh, Vol. 52, Part 1, No. 6, Edinburgh.

- 1922 b: On the Senonian ammonite fauna of Pondoland. Trans. Roy. Soc. South Africa, Vol. 10, Part 3, pp. 113-147, Cape Town.

- 1925: On Senonian Ammonoidea from Jamaica. Geol. Mag., Vol. 62 (1), pp. $28-32$, London.

- 1927: Revision of the Jurassic cephalopod fauna of Kachh (Cutsh) I. India Geol. Surv. Mem., Palaeont. Indica, n.s., Vol. 9, mem. 2, pp. 1-71, Calcutta.

- 1931-43: A monograph of the Ammonoidea of the Gault. Vol. II. Pal. Soc., London.

- 1933: The evolution of the Cephalopoda. Biol. Rev, Vol. 8, pp. 418-462, Cambridge.

- 1939: Problems of ammonite nomenclature VII. The genera Paraphylloceras and Neophylloceras Sнiмizu. Geol. Mag., Vol. 76, pp. 451-459, London.

- 1953: The Upper Cretaceous cephalopod fauna of Graham Land. Falkland Islands Dep. Surv. Sci. Rep., No. 3, London.

Stanton, T. W., 1893: The Colorado formation and its invertebrate fauna. U.S. Geol. Surv. Bull. 106, Washington, D.C.

Stemstrup, K. J. V., 1883: Om Forekomsten af Forsteninger i de kulførende Dannelser i Nord-Grønland. Medd. Gronland, Bd. 5, Nr. 2, København.

Stenzel, H. B., 1964: Living Nautilus. In: Teichert et al.: Treatise on Invertebrate Paleontology, Part K, Mollusca 3, Cephalopoda (ed. by R. C. Moore). Kansas.

Stephenson, L. W., 1941: The larger invertebrate fossils of the Navarro group of Texas. Univ. Texas Publ. No. 4101, Austin.

- 1955: Basal Eagle Ford fauna (Cenomanian) in Johnson and Tarrant counties Texas. U.S. Geol. Surv. Prof. Paper 274-C, Washington, D.C. 
Stoliczka, F., 1865: Fossil Cephalopoda of the Cretaceous rocks of southern India. Ammonitidae. India Geol. Surv. Mem. Palaeont. Indica, Ser. 1, Vol. 1, pp. 40216, Calcutta.

Sтотт, D. F., 1961: Summary account of the Cretaceous Alberta group and equivalent rocks, Rocky Mountain foothills, Alberta. Canada Geol. Surv. Paper 61-2, Ottawa.

Swinnerton, H. H., 1943: Belemnites from East Greenland. Ann. Mag. Nat. Hist. Ser. II, Vol. $10(66)$, pp. 406-410, London.

TAte, R., 1865: On the correlation of the Cretaceous formations of the North-East of Ireland. Quart. Jour. Geol. Soc. London, Vol. 21, pp. 15-44, London.

Teichert, G., 1939: Geology of Greenland. Geologie der Erde, Geology of North America I, pp. 100-175. Berlin 1939.

Thorsteinsson, R. \& Tozer, E. T., 1957: Geological investigations in Ellesmere and Axel Heiberg Islands. Arctic, Vol. 10, No. 1, pp. 3-31, Ottawa.

Tinbergen, L. \& Verwey, J., 1945: Zur Biologie von Loligo vulgaris Lam. Arch. Néerland. Zool., Vol. 7, livr. 1,2, pp. 213-286, Leiden.

Tozer, E. T., 1960: Summary account of Mesozoic and Tertiary stratigraphy, Canadian arctic archipelago. Canada Geol. Surv. Paper 60-5, Ottawa.

- 1963: Mesozoic and Tertiary stratigraphy, western Ellesmere Island and Axel Heiberg Island, district of Franklin. Canada Geol. Surv. Paper 63-30, Ottawa.

Troelsen, J. C., 1956: Groenland. In: Lexique Stratigraphique International, Vol.1. Europe (sous la direction du professeur P. PRUvost), Paris.

Trueman, A. E., 1940: The ammonite body chamber, with special reference to the buoyancy and mode of life of the living ammonite. Quart. Jour. Geol. Soc., Vol. 96, pp. 339-383, London.

Usher, J. L., 1952: Ammonite faunas from the Upper Cretaceous rocks of Vancouver Island, British Columbia. Canada Geol. Surv. Bull. 21, Ottawa.

VoGEL, K. P., 1959: Zwergwuchs bei Polyptychiten (Ammonoidea). Geol. Jahrb., Bd. 76, pp. 469-540, Hannover.

WaAge, K. M., 1961: The Fox Hills formation in its type area, Central South Dakota. Wyoming Geol. Ass. Symposium on Late Cretaceous Rocks, pp. 229-240.

Warren, P. S., 1930: Description of new species of fossils from parts of Peace River and Grande Prairie districts, Alberta. Research Council of Alberta, Appendix, pp. 57-68.

Weller, S., 1907: A report on the Cretaceous paleontology of New Jersey. Geol. Surv. New Jersey, Pal. Ser., Vol. 4.

White, D. \& Schuchert, Ch., 1898: Cretaceous Series of the West Coast of Greenland. Bull. Geol. Soc. Amer., Vol. 9, pp. 343-368, Rochester.

Whitfield, R. P., 1892: Gastropoda and Cephalopoda of the Raritan clays and greensand of New Jersey. U.S. Geol. Surv. Mon. 18, Washington, D.C.

Wiedmann, J., 1962: Ammoniten aus der Vascogotischen Kreide (Nordspanien) I. Phylloceratina, Lytoceratina. Palaeontographica, Vol. 118, Abt. A, pp. 119237, Stuttgart.

Wright, C. W., 1952: A classification of the Cretaceous ammonites. Jour. Paleont., Vol. 26, pp. 213-222, Tulsa.

- 1953: Notes on Cretaceous ammonites. I. Scaphitidae. Ann. Mag. Nat. Hist. Ser. 12, Vol. 6, pp. 473-476, London.

- 1957: In: Arkeld, W. J. et al.: Treatise on Invertebrate Paleontology, Pt. L, Mollusca 4, Cephalopoda, Ammonoidea (ed. by R. C. Moore). Kansas.

- 1963: Gretaceous ammonites from Bathurst Island, Northern Australia. Palaeontology, Vol. 6, Part 4, pp. 597-614, London. 
Wright, C. W. \& Matsumoto, T., 1954: Some doubtful Cretaceous ammonite genera from Japan and Saghalin. Mem. Fac. Sci. Kyushu Univ. Ser. D, Vol. 4, pp. 107-134, Fukuoka.

Yabe, H., 1910: Die Scaphiten aus der Oberkreide von Hokkaido. Beitr. Pal. Osterr.-Ungarns u.d. Orients, Vol. 23, pp. 159-174, Wien.

- 1915: Notes on some Cretaceous fossils from Anaga on the Island of Awaji and Toyajô in the province of Kii. Sci. Rep. Tôhoku Imp. Univ., Vol. 4, No. 1, pp. 13-24, Tokyo.

- 1927: Cretaceous stratigraphy of the Japanese Islands. Sci. Rep. Tôhoku Imp. Univ., Vol. 11, No. 1, pp. 27-100, Tokyo.

Young, K., 1963: Upper Cretaceous ammonites from the Gulf Coast of the United States. Univ. Texas Publ., No. 6304, Austin.

Ziegler, B., 1963: Ammoniten als Faziesfossilien. Paläont. Zeitschr., Bd. 37, Nr. 1/2, pp. 96-102, Stuttgart.

Zrtтex, K. A., 1884: Handbuch der Paläontologie: Abt. 1, Band 2. München-Leipzig. ØD M, H., 1953: De geologiska resultaten från borrningarna vid Höllviken. Del 5: The macro-fossils of the Upper Cretaceous. Sveriges Geol. Unders. Ser. c, No. 527, Stockholm. 
PLATES

All figures natural size.

Chr. Halkier fot. 


\section{Plate 1}

Hypophylloceras (Neophylloceras) groenlandicum n.sp. (p. 23).

1a-b. Holotype. MMH No. 9737. Lateral and peripheral views. Maastrichtian. Oyster-ammonite Conglomerate loc. I.

2a-b. MMH No. 9738. Lateral and peripheral views. Maastrichtian. Oysterammonite Conglomerate loc. I.

3a-b. MMH No. 9739. Lateral and peripheral views. Maastrichtian. Oysterammonite Conglomerate loc. III.

4a-b. MMH No. 9740. Lateral and peripheral views. Maastrichtian. Oysterammonite Conglomerate loc. I.

Saghalinites wrighti n.sp. (p. 30).

5. MMH No. 9741. Peripheral view of abnormal body chamber. Maastrichtian. Oyster-ammonite Conglomerate loc. III.

Anaptychus (p. 143).

6. MMH No. 9742. Upper Campanian. Scaphitesryggen at Angnertuneq. 


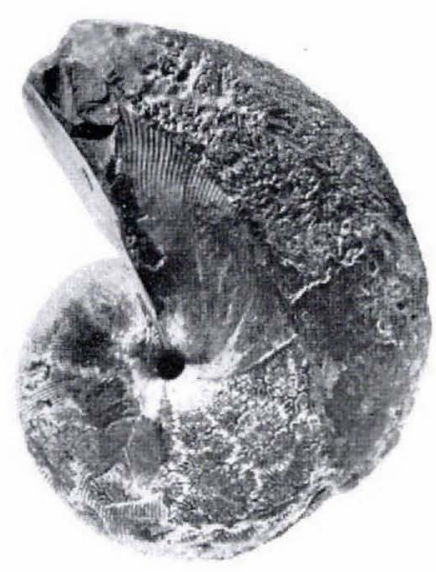

la

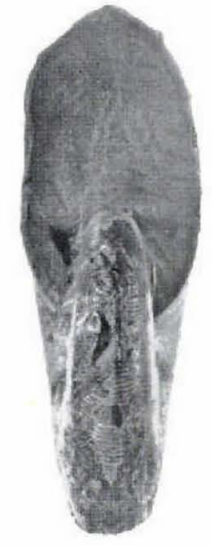

lb

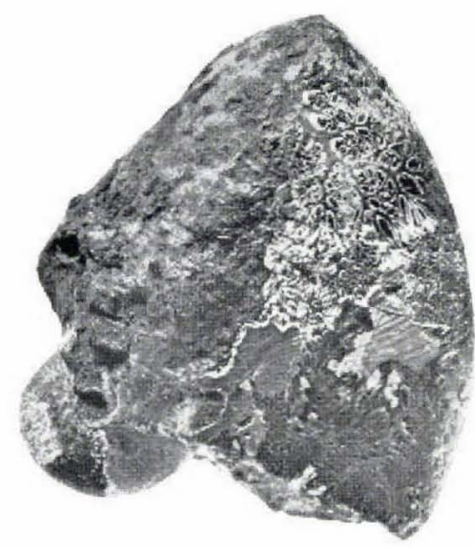

$2 a$

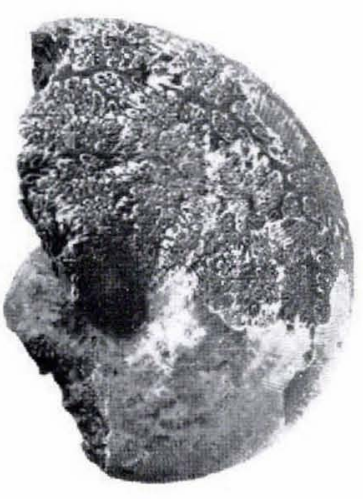

$3 a$

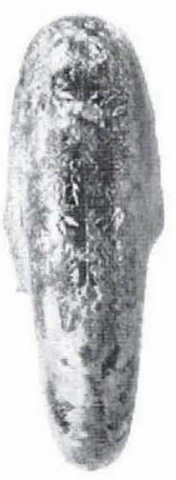

$3 b$

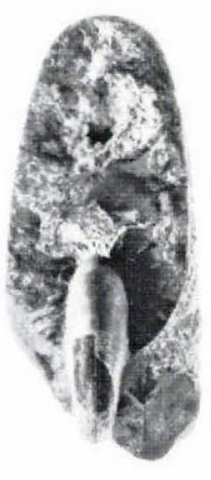

$2 b$

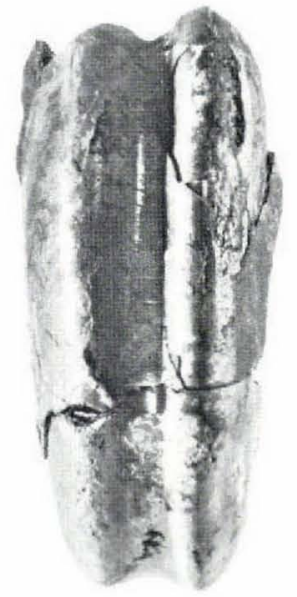

5

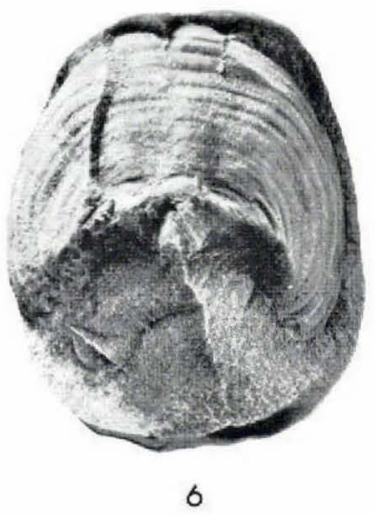




\section{Plate 2}

Saghalinites wrighti n.sp. (p. 30).

1a-c. MMH No. 9743. Lateral and peripheral views of juvenile specimen. Maastrichtian. Oyster-ammonite Conglomerate loc. I.

2a-b. MMH No. 9744. Lateral and peripheral views of juvenile specimen. Maastrichtian. Oyster-ammonite Conglomerate loc. I.

3a-b. MMH No. 9745. Lateral and peripheral views of juvenile specimen. Maastrichtian. Oyster-ammonite Conglomerate loc. I.

4a-b. MMH No. 9746. Lateral and peripheral views of juvenile specimen. Maastrichtian. Oyster-ammonite Conglomerate loc. I.

5 a $-\mathrm{c}$. Holotype. MMH No. 9747. Lateral and peripheral views of nearly mature specimen. Maastrichtian. Oyster-ammonite Conglomerate loc. III. 
Medd. om Gronl. Bd. 179, Nr. 7. [Toye Birkelund]

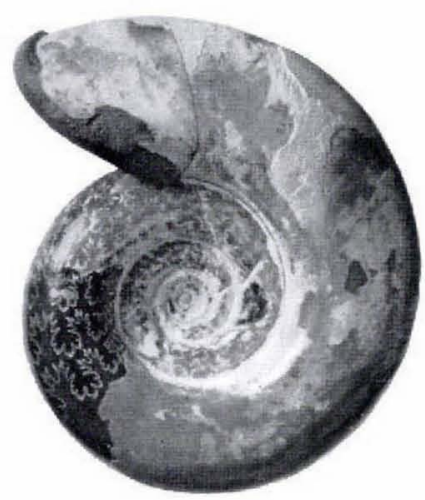

la
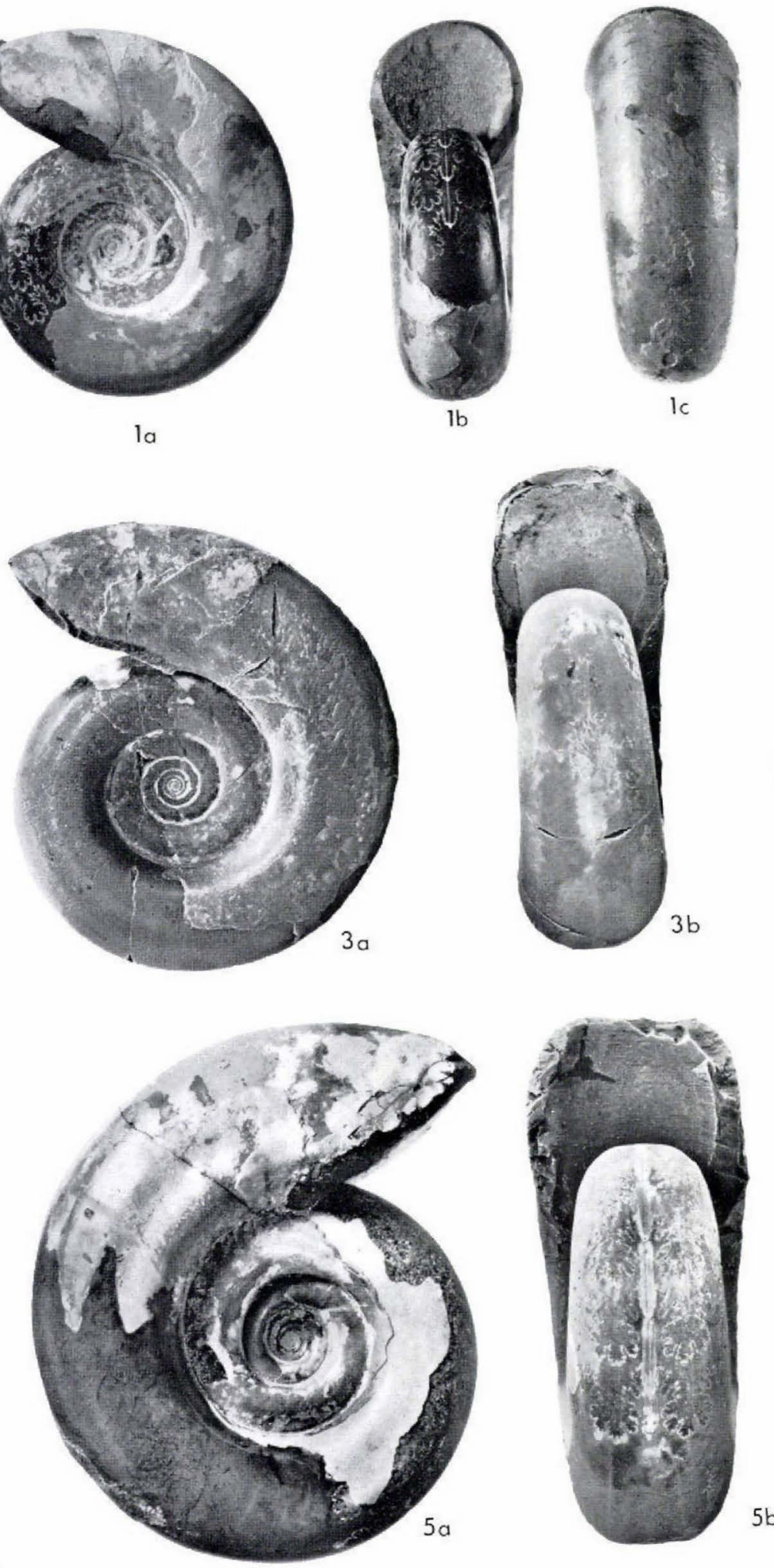
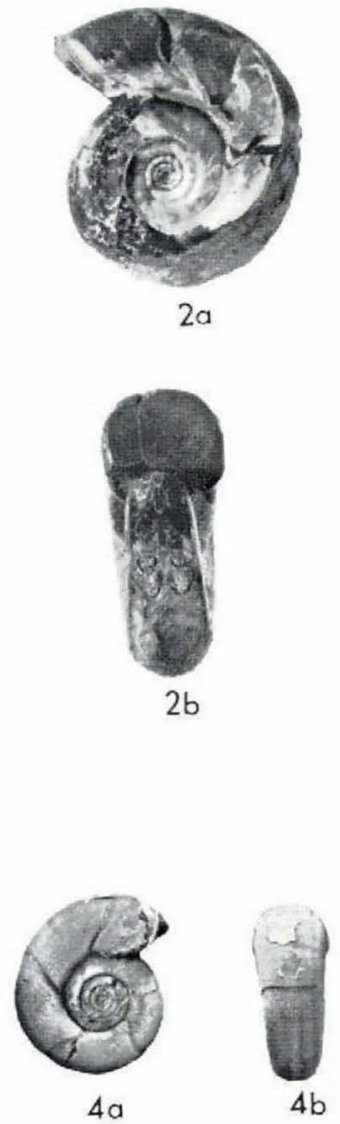

$3 b$

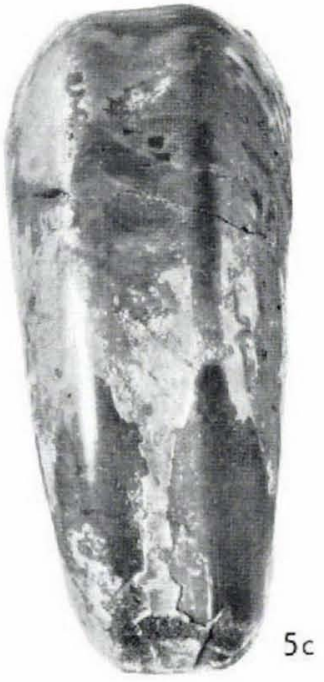




\section{Plate 3}

Saghalinites wrighti n.sp. (p. 30).

1. MMH No. 9748. Lateral view of mature specimen. Maastrichtian. Oyster-ammonite Conglomerate loc. I.

Pseudophyllites skoui n.sp. (p. 37).

2a-c. MMH No. 9749. Lateral and peripheral views of phragmocone. Upper Campanian. Ikorfat.

3a-b. MMH No. 9750. Lateral and peripheral views of phragmocone. Lower Campanian. Scaphitesnæsen.

4a-b. Holotype. MMH No. 9751. Lateral and peripheral views. Lower Campanian. Scaphitesnæsen.

5. MMH No. 9752. Lateral view. Upper Campanian. Brudkløft at Ikorfat, $550 \mathrm{~m}$ above sea-level.

6. MMH No. 9753. Lateral view. Upper Campanian. Brudkløft at Ikorfat, $560 \mathrm{~m}$ above sea-level.

Pseudophyllites sp. (p. 42).

7a-b. MMH No.9754. Lateral and peripheral views of phragmocone. Maastrichtian? Niaqornat. 

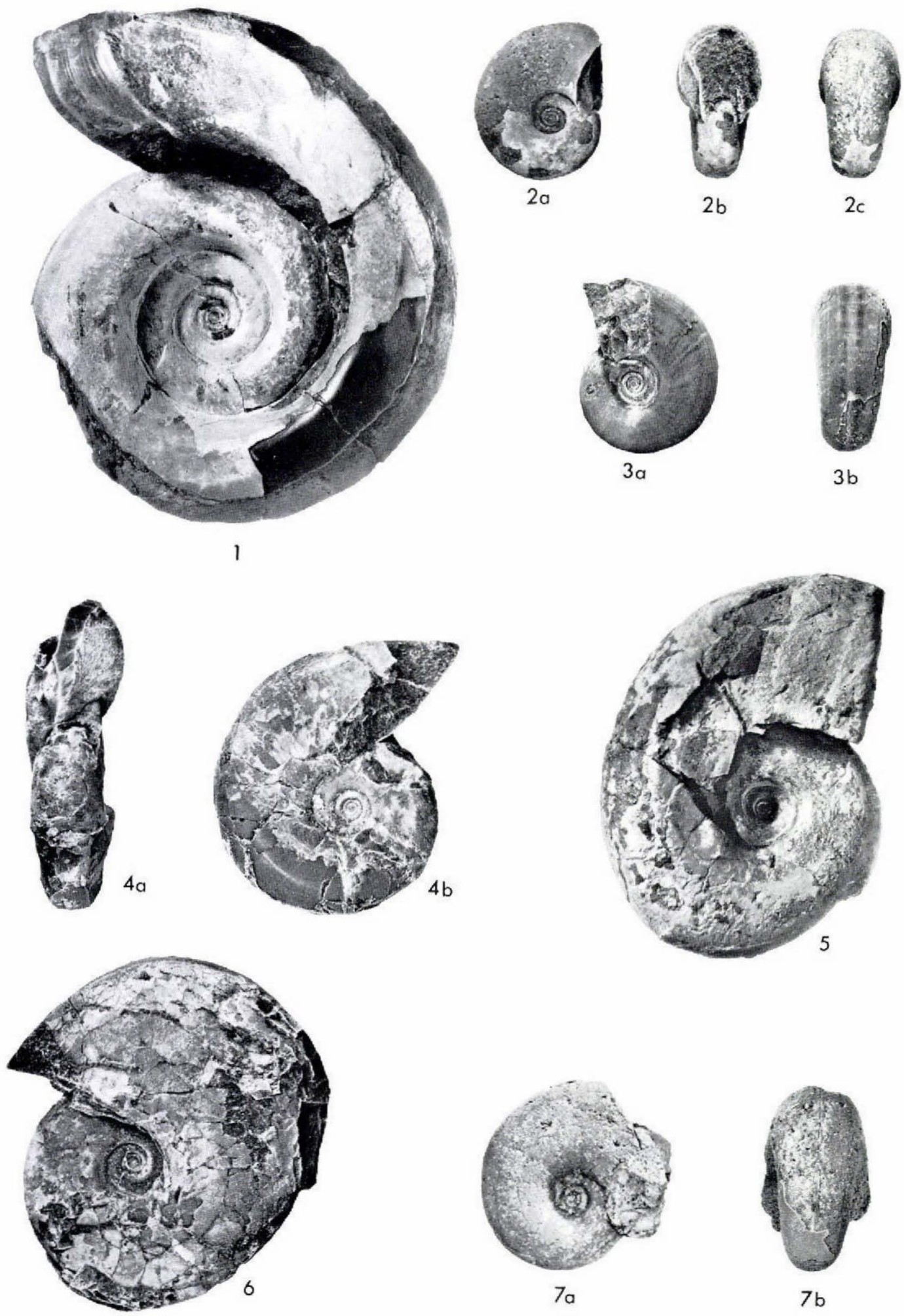


\section{Plate 4}

Baculites nugssuaqensis n.sp. (p. 48).

1 a-c. Holotype. MMH No. 9755. Lateral, ventral and dorsal views. Santonian. Tuperssuartâ, $47 \mathrm{~m}$ west of dolerite sill A, $10 \mathrm{~m}$ above sea-level. 
Medd. om Grøst. Bd. 179, Nr. 7. [Tove Birkelund]

PLATE 4

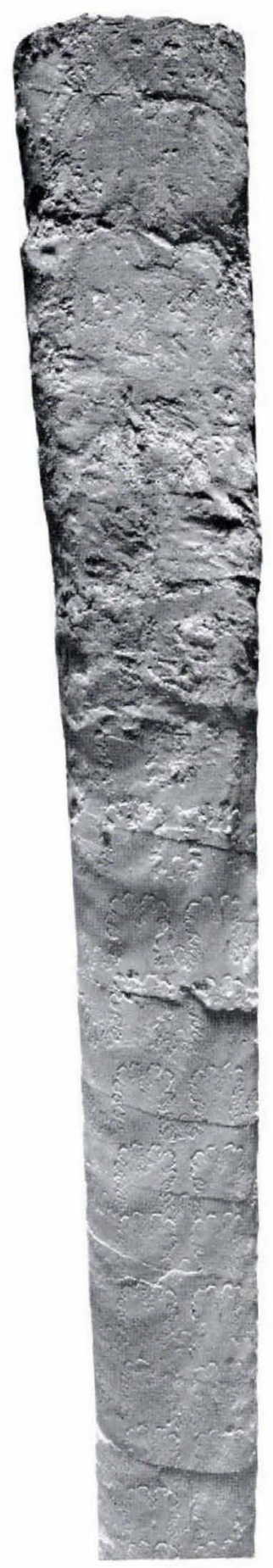

la

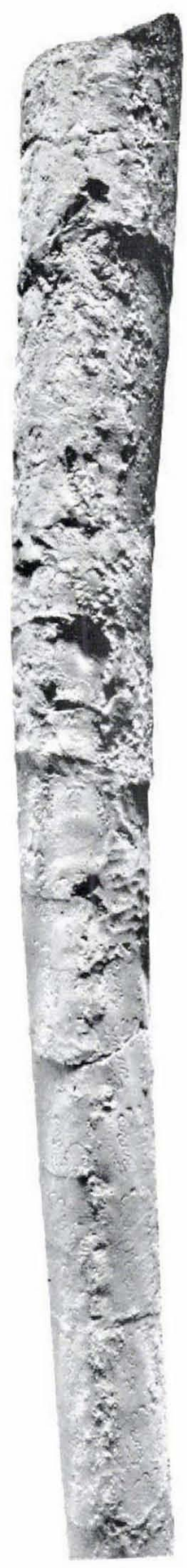

$1 \mathrm{~b}$

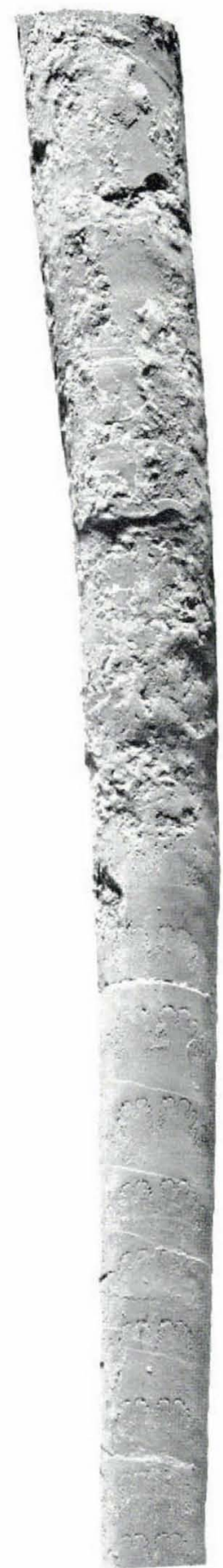

Ic 


\section{Plate 5}

Baculites nugssuaqensis n.sp. (p. 48).

1a-c. MMH No. 9756. Lateral, ventral and dorsal views of very large body chamber. Santonian. Tuperssuartâ.

2a-c. MMH No. 9757. Lateral, ventral and dorsal views. Santonian. Tuperssuartâ, $30 \mathrm{~m}$ west of dolerite sill A, $5 \mathrm{~m}$ above sea-level.

3a-c. MMH No. 9758. Lateral, ventral and dorsal views. Santonian. Tuperssuartâ, $75 \mathrm{~m}$ west of dolerite sill A.

4a-b. MMH No. 9759. Lateral and ventral views of body chamber with growth lines. Santonian. Tuperssuartâ, $47 \mathrm{~m}$ west of dolerite sill A $10 \mathrm{~m}$ above sea-level. 


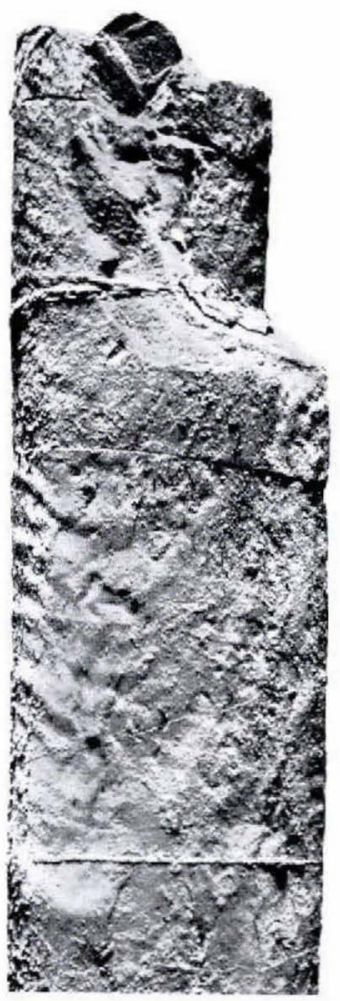

la

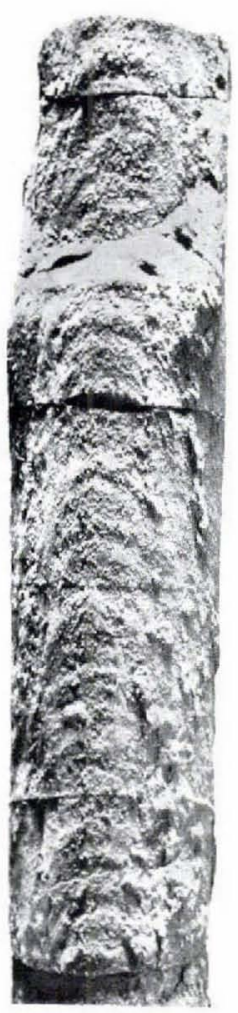

$1 \mathrm{~b}$

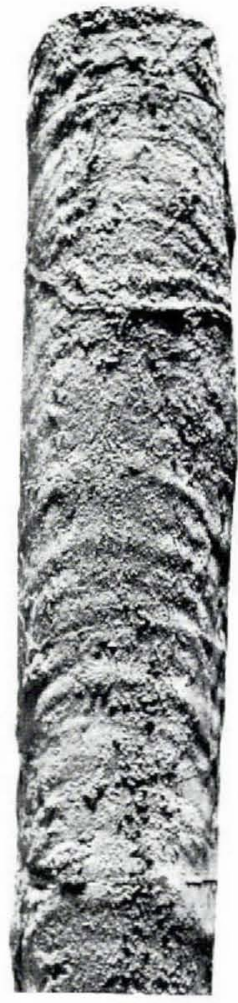

lc
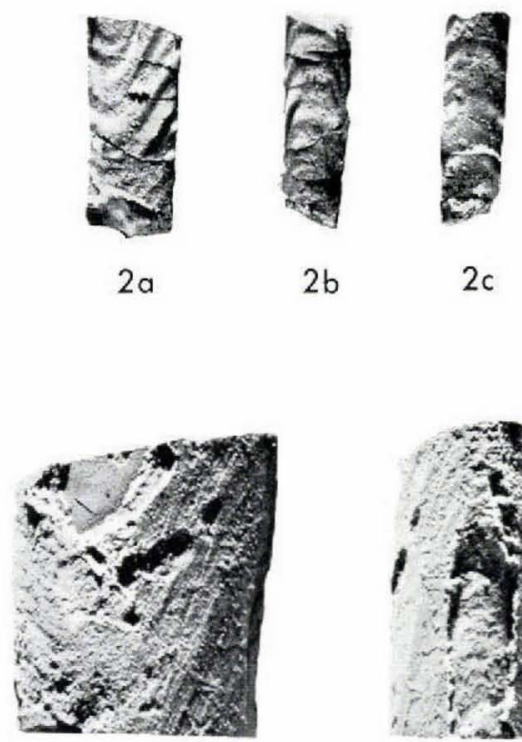

$4 a$

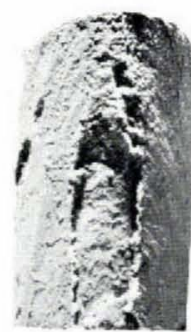

$4 b$

$3 a$

$3 b$

$3 c$ 


\section{Plate 6}

Baculites nugssuaqensis n.sp. (p. 48).

1 a-c. MMH No. 9760. Lateral, ventral and dorsal views. Santonian. Tuperssuartâ.

2a-c. MMH No. 9761. Lateral, ventral and dorsal views. Santonian. Tuperssuartâ, $47 \mathrm{~m}$ west of dolerite sill $A, 10 \mathrm{~m}$ above sea-level.

Baculites codyensis ReEside (late form) (p. 52).

3a-c. MMH No. 9762. Lateral, ventral and dorsal views. Santonian. Søndre Baculiteskløft.

4a-c. MMH No. 9763. Lateral, ventral and dorsal views of small, mature specimen with body chamber. Santonian. Søndre Baculiteskløft.

5a-c. MMH No. 9764. Lateral, ventral and dorsal views of youngest part of phragmocone of mature specimen. Santonian. Søndre Baculiteskløft. 

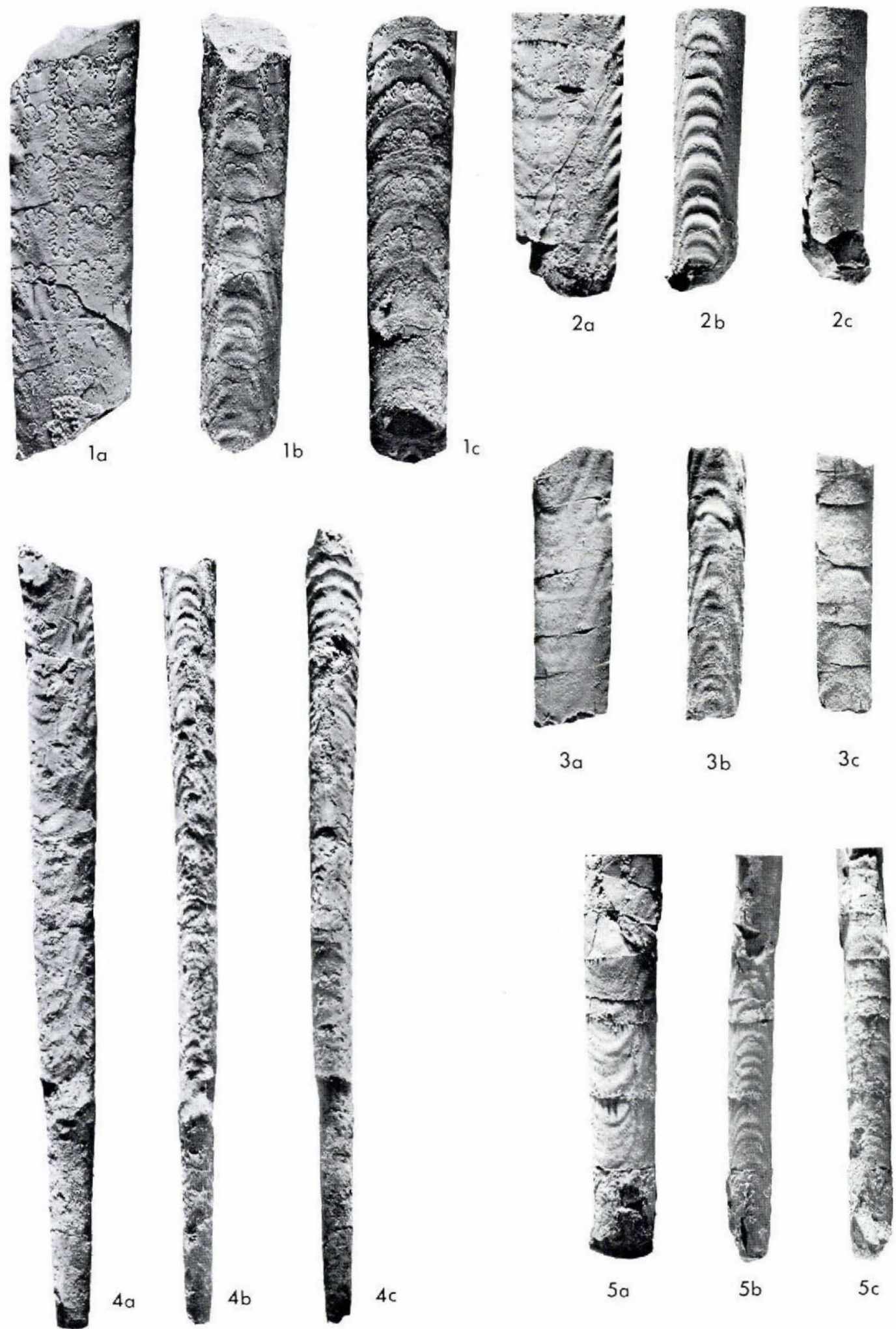


\section{Plate 7}

Baculites codyensis ReESIDE (late form) (p. 52).

1a-c. MMH No. 9765. Lateral, ventral and dorsal views. Santonian. Søndre Baculiteskløft.

Baculites cf. haresi ReEside (p. 56).

2a-c. MMH No. 9766. Lateral, ventral and dorsal views. Lower Campanian. Scaphitesnæsen, 535-537 m above sea-level. 

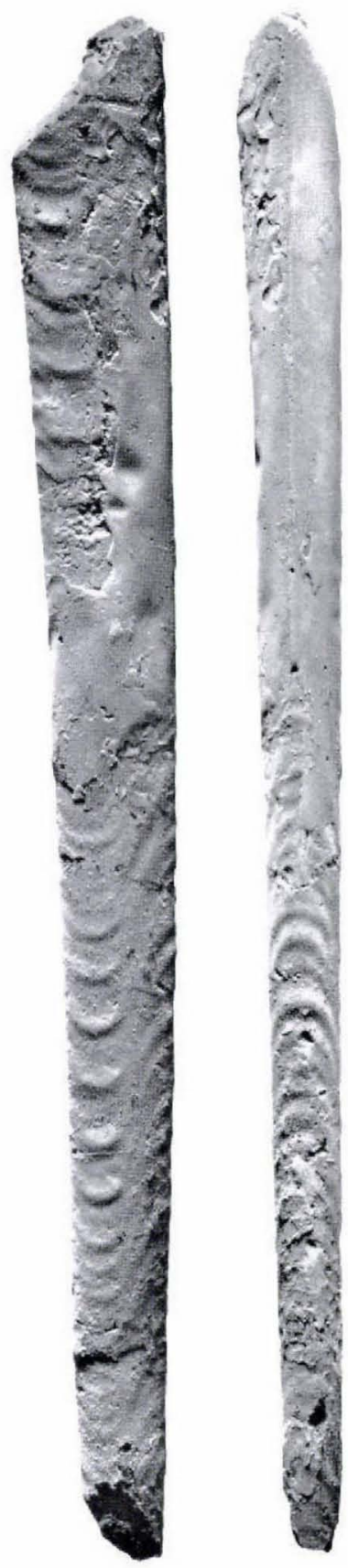

la

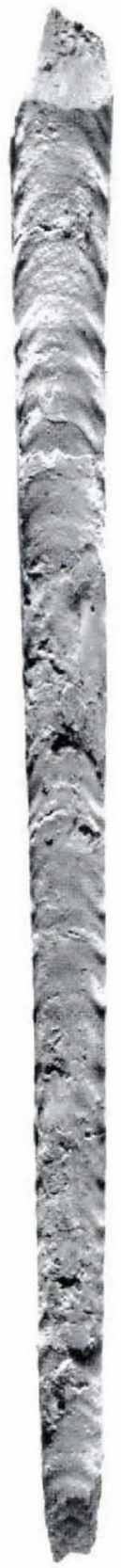

1c

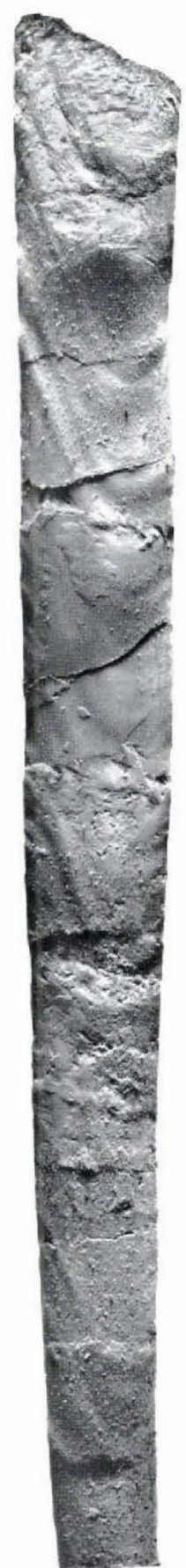

$2 a$
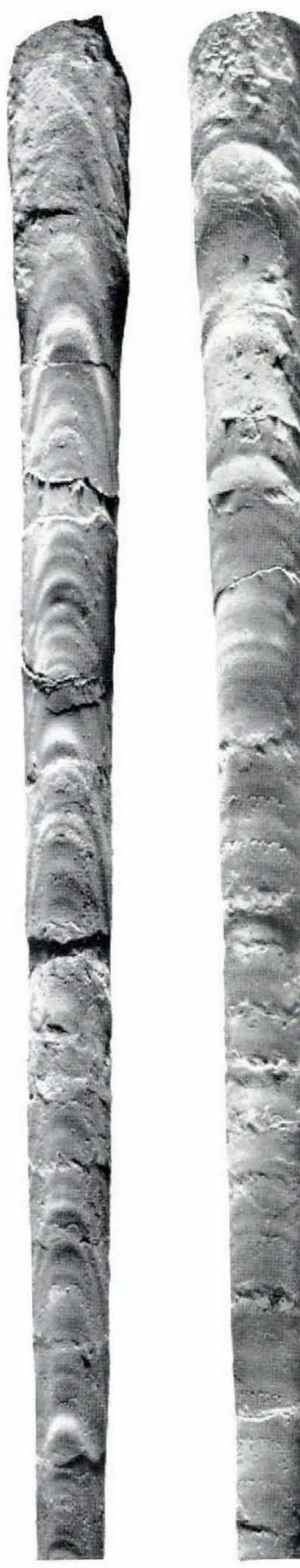

.

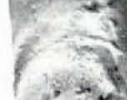

$\rightarrow \infty$

$r \leqslant 3$<smiles>c1ccncc1</smiles>

cis a

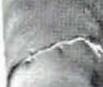

r
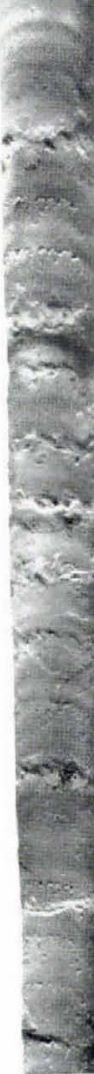

$2 b$ 


\section{Plate 8}

Baculites obtusus ME E (early form) (p. 58).

1a-c. MMH No. 9767. Lateral, ventral and dorsal views. Lower Campanian. Scaphitesnæsen, 535-536 $\mathrm{m}$ above sea-level. 
Mend. om Groni.. Bd. 179, Nr. 7. [Tove Birkelund]
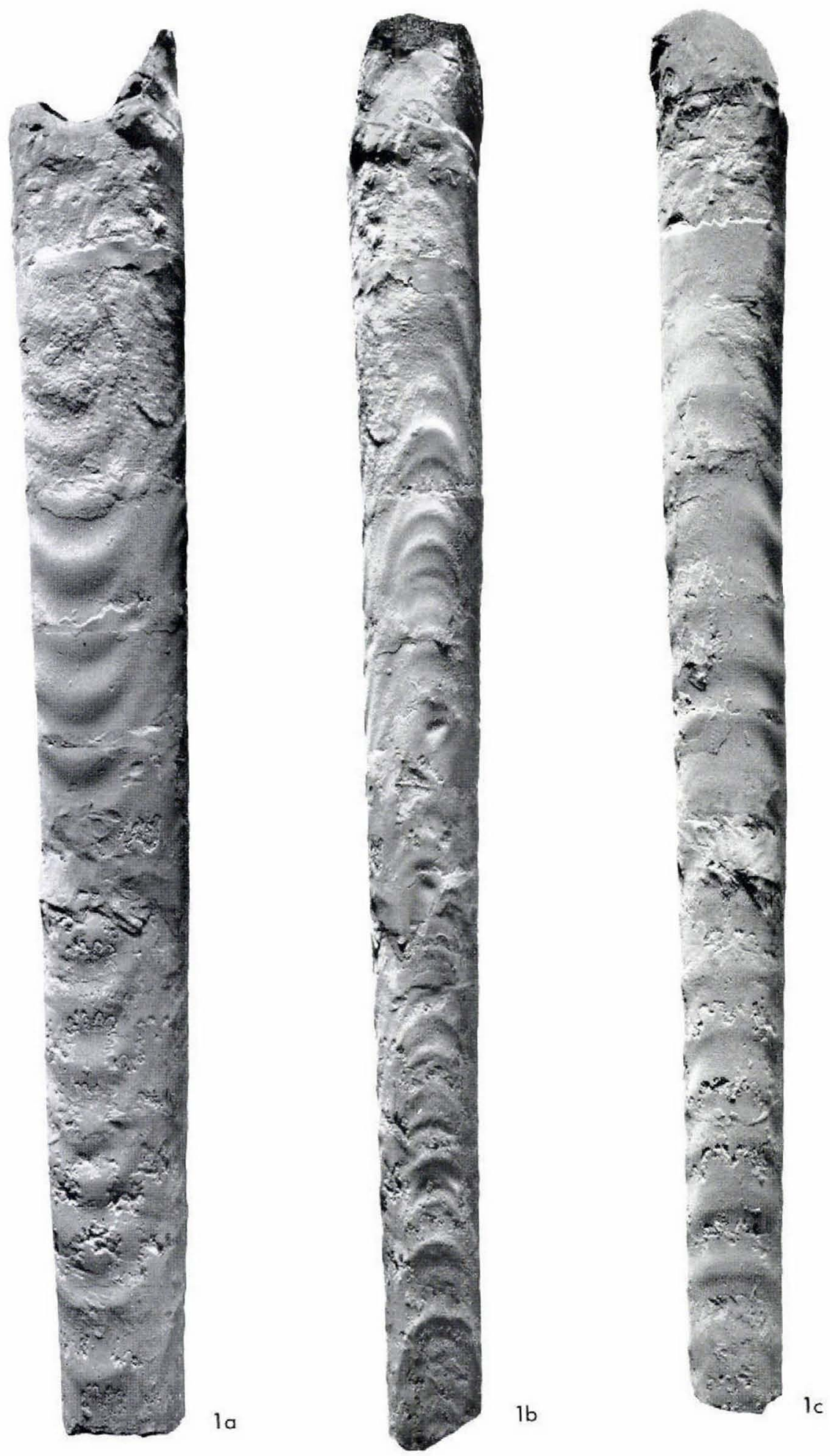


\section{Plate 9}

Baculites obtusus Mевк (early form) (p. 58).

1 a-c. MMH No. 9768. Lateral, ventral and dorsal views. Lower Campanian. Scaphitesnæsen, 535-536 m above sea-level.

2 a-c. MMH No. 9769. Lateral, ventral and dorsal views of phragmocone with growth lines. Lower Campanian. Scaphitesnæsen, $539-540 \mathrm{~m}$ above sea-level.

3a-c. MMH No. 9770. Lateral, ventral and dorsal views of phragmocone with trace of an early flared peristome. Lower Campanian. Scaphitesnæsen. 
Medd. on Gront. Bd. 179, Nr. 7. [Tove Birketund]

Plate 9
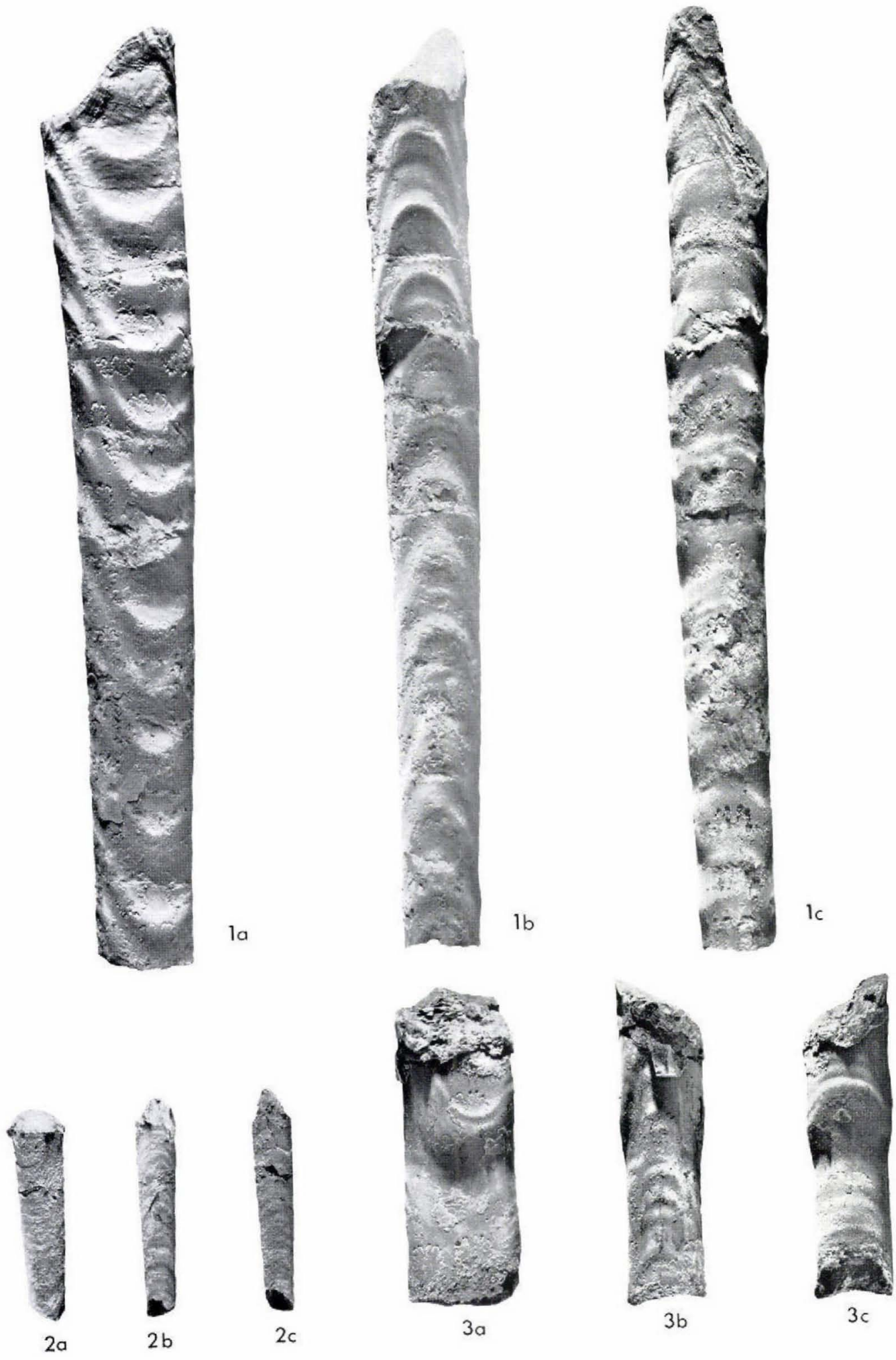


\section{Plate 10}

Baculites obtusus MEEK (early form) (p. 58).

1 a-c. MMH No. 9771. Lateral, ventral and dorsal views of specimen with very weak lateral ribs on body chamber. Lower Campanian. Scaphitesnæsen, 539-540 m above sea-level. 


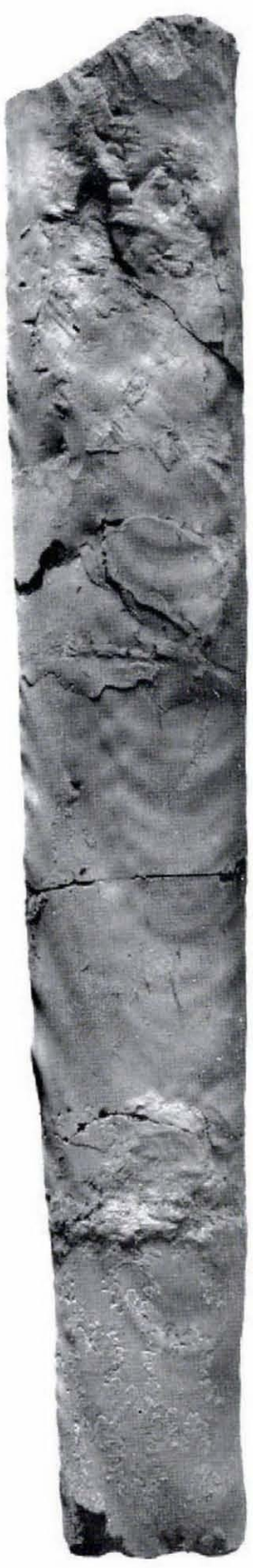

la

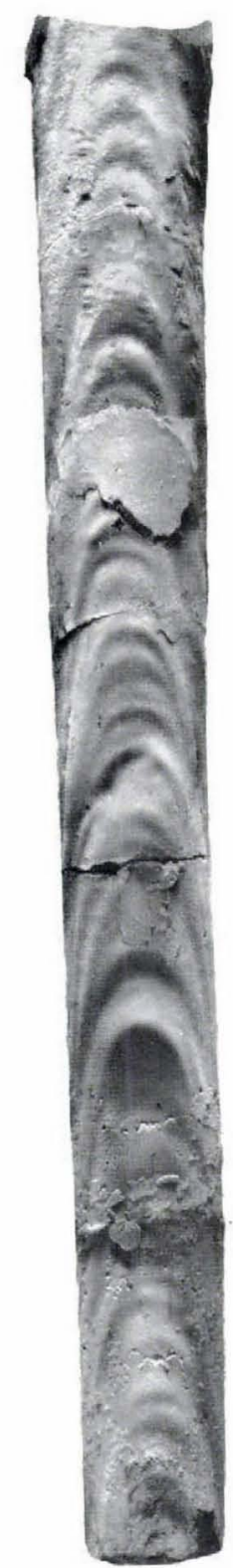

$1 b$

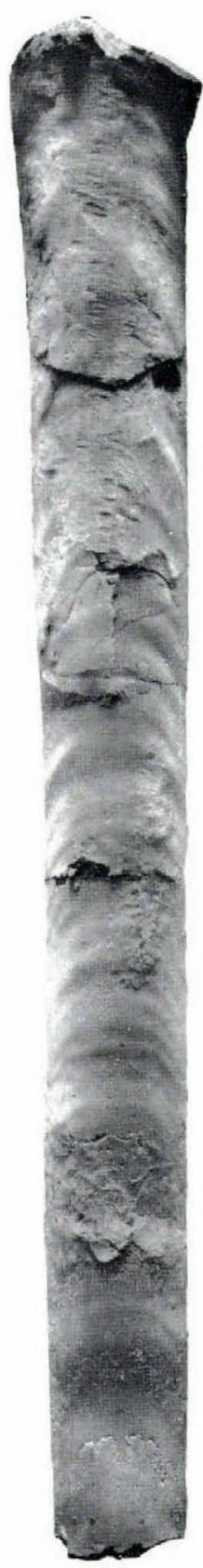

1c 


\section{Plate 11}

Baculites obtusus MeE (early form) (p. 58).

1a-c. MMH No. 9772. Lateral, ventral and dorsal views of body chamber with growth lines. Lower Campanian. Scaphitesnæsen.

2a-c. MMH No. 9773. Lateral, ventral and dorsal views of phragmocone with very weak ribs. Lower Campanian. Scaphitesnæen, $537 \mathrm{~m}$ above sea-level. 


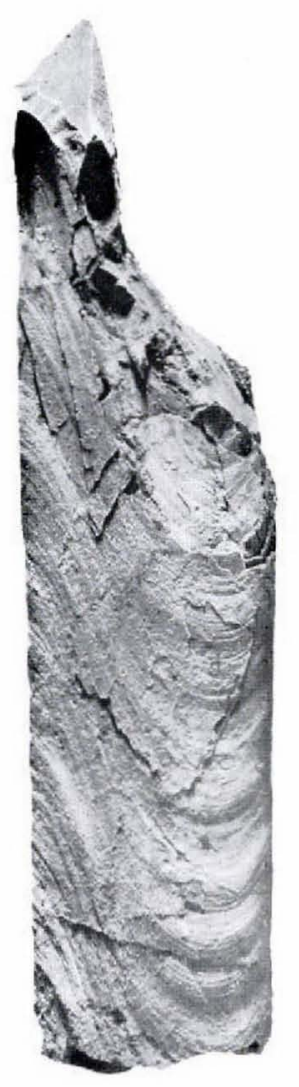

la

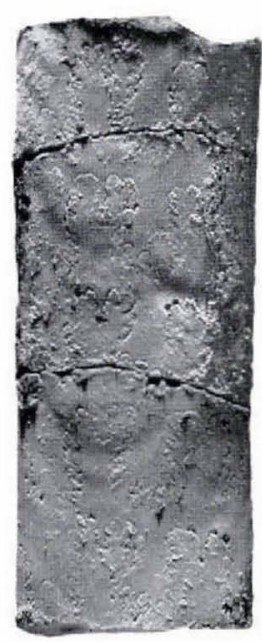

$2 a$

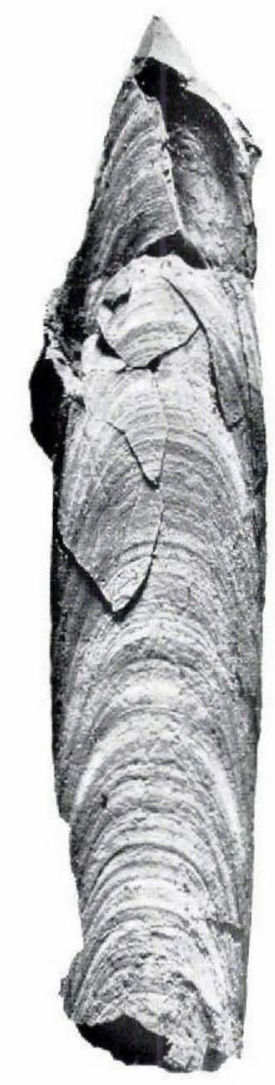

$1 b$

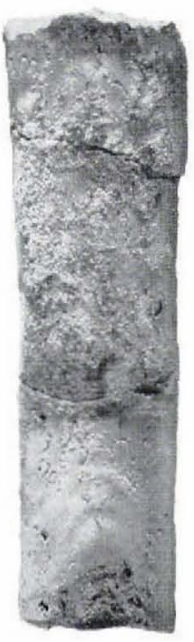

$2 b$

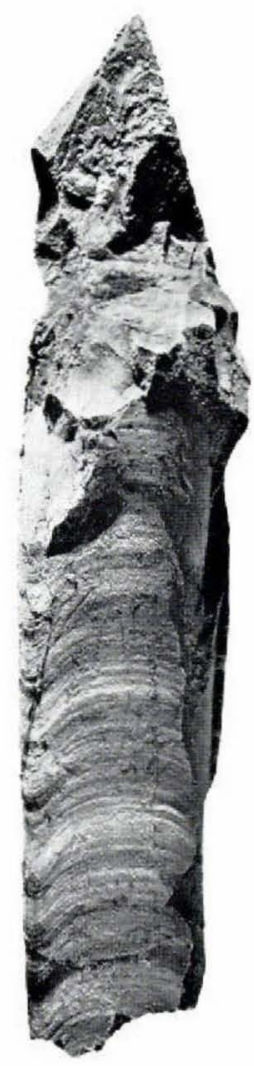

lc

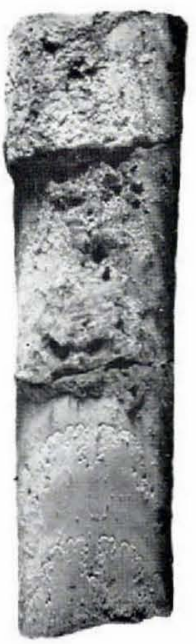

$2 c$ 


\section{Plate 12}

Baculites obtusus MeEx (early form) (p. 58).

1a-c. MMH No. 9774. Lateral, ventral and dorsal views of very large phragmocone. Lower Campanian. Scaphitesnæsen.

2a-c. MMH No. 9775. Lateral, ventral and dorsal views of body chamber with unusually closely spaced ribs. Lower Campanian. Scaphitesnæsen. 

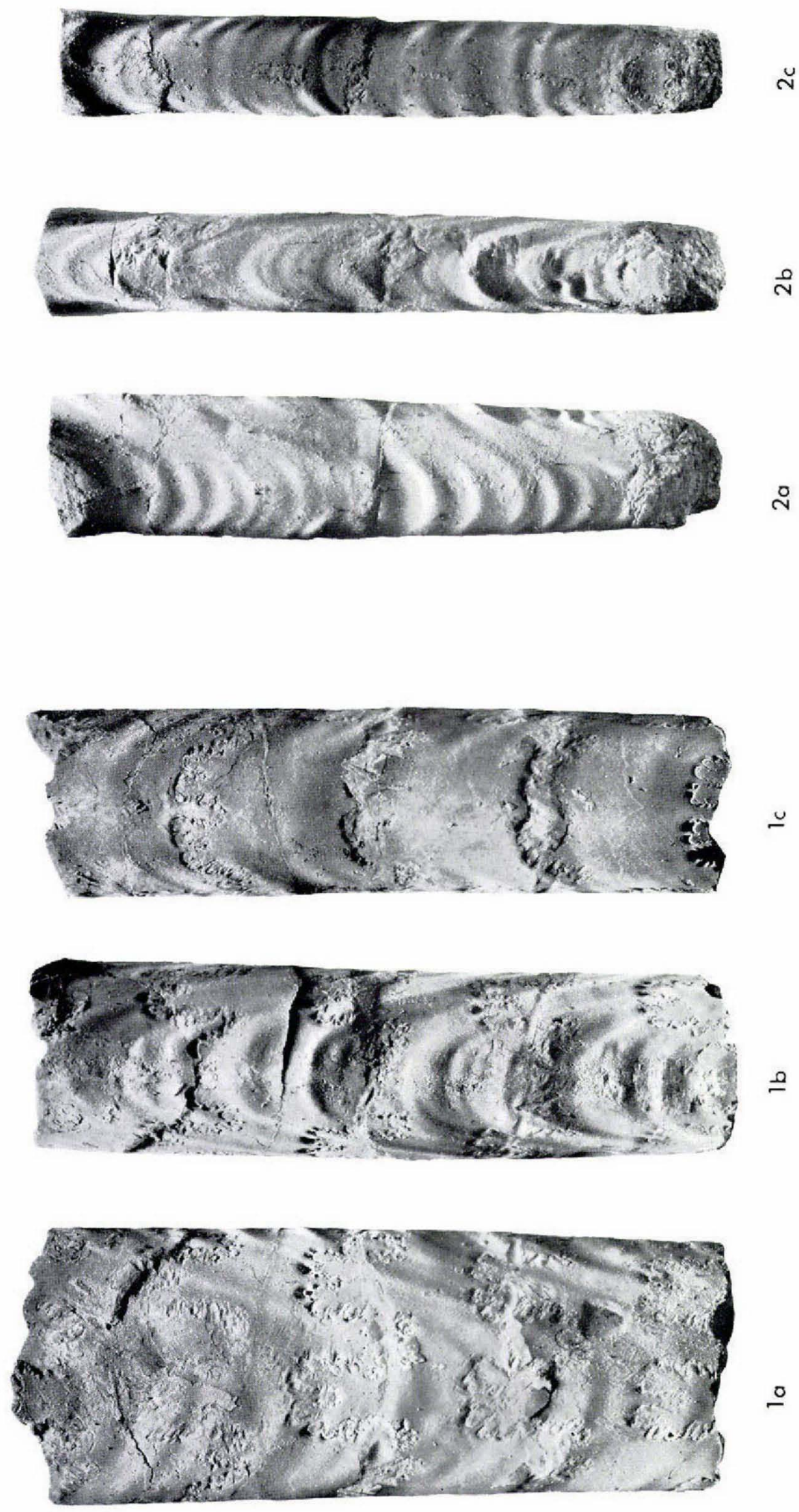


\section{Plate 13}

Baculites obtusus Mék (early form) (p. 58).

1a-c. MMH No. 9776. Lateral, ventral and dorsal views of large body chamber. Lower Campanian. Scaphitesnæsen, 537-538 m above sealevel.

2a-c. MMH No. 9777. Lateral, ventral and dorsal views of body chamber with growth lines and flared peristome. Lower Campanian. Small ravine west of Scaphitesnæsen. 

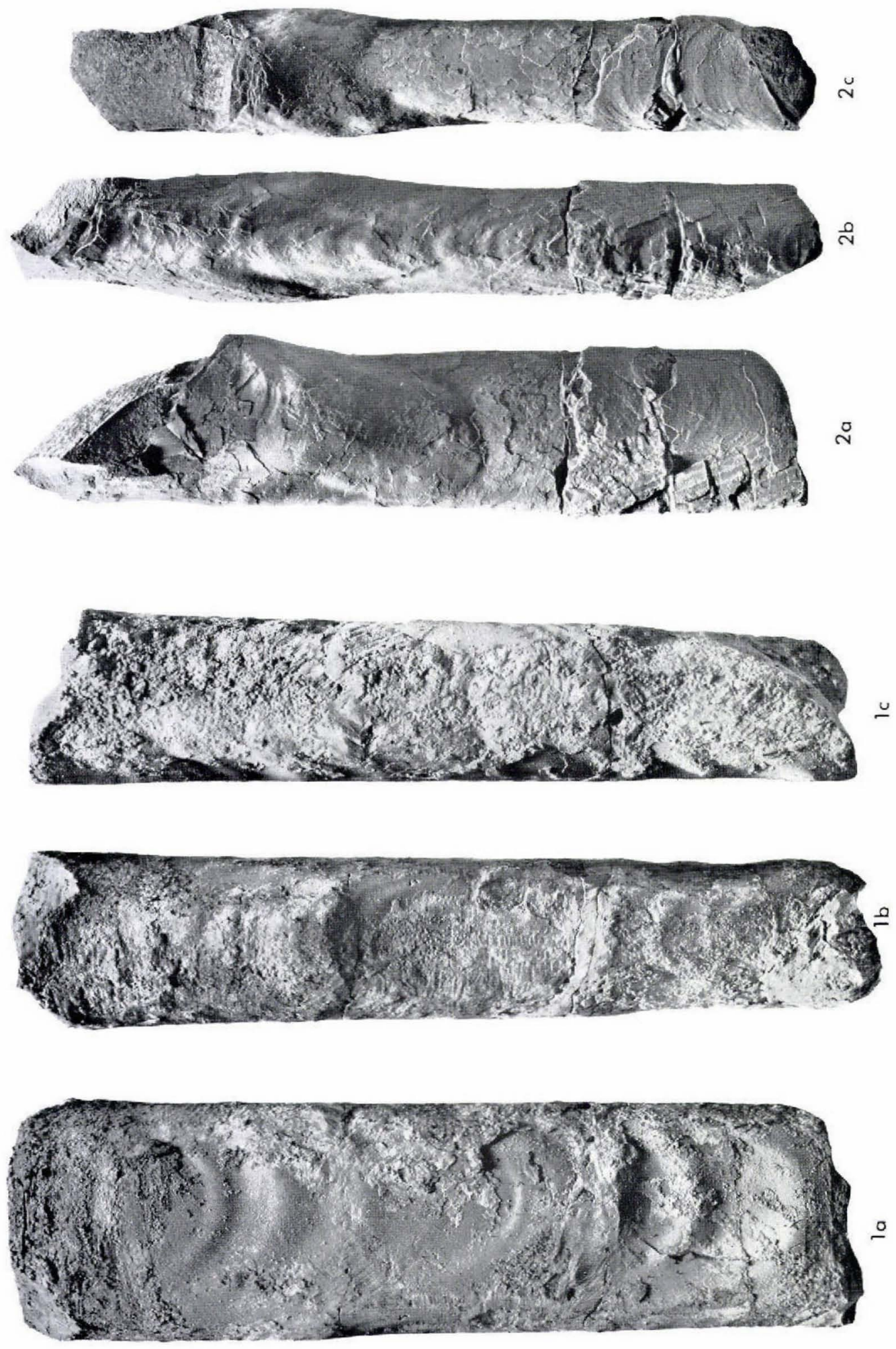


\section{Plate 14}

Baculites obtusus MEE (early form) (p. 58).

1 a-c. MMH No. 9778. Lateral, ventral and dorsal views of body chamber. Lower Campanian. Scaphitesnæsen, 535-536 m above sea-level.

Baculites cf. meeki Elias (p. 62).

2a-c. MMH No. 9779. Lateral, ventral and dorsal views of body chamber. Maastrichtian. Oyster-ammonite Conglomerate loc. I.

3. MMH No. 9780. Lateral view. Maastrichtian. Oyster-ammonite Conglomerate loc. I. 


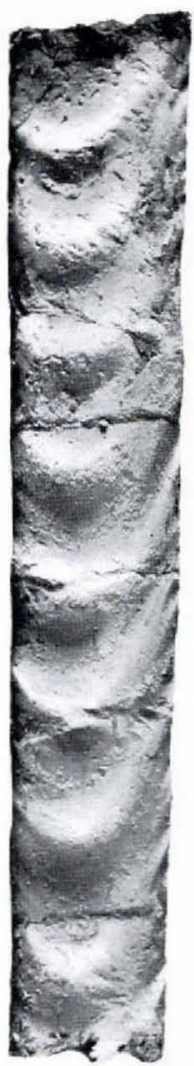

la

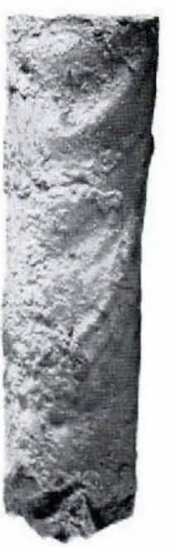

$2 a$

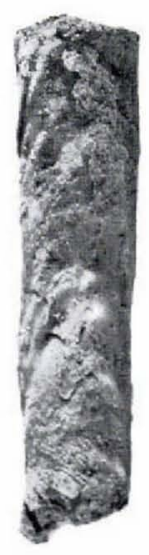

$2 b$

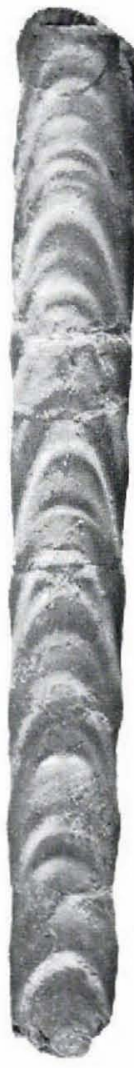

16

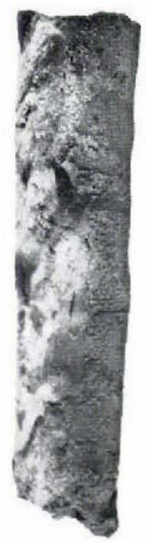

$2 c$

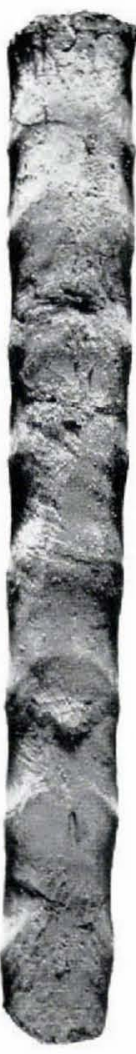

1c

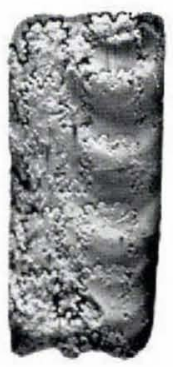

3 


\section{Plate 15}

Baculites cf. meeki Eisis (p. 62).

1a-c. MMH No. 9781. Lateral, ventral and dorsal views. Maastrichtian. Oyster-ammonite Conglomerate loc. I.

Baculites sp. 3 (p. 66).

2. MMH No. 9782. Lateral view. Upper Campanian. Brudkløft at Ikorfat, $550 \mathrm{~m}$ above sea-level.

Baculites sp. 2 (p. 65).

3a-c. MMH No. 9783. Lateral, ventral and dorsal views of body chamber. Upper Campanian. Brudkløft at Ikorfat, $550 \mathrm{~m}$ above sea-level.

4a-c. MMH No. 9784. Lateral, ventral and dorsal views. Upper Campanian. Brudkløft at Ikorfat, $560 \mathrm{~m}$ above sea-level. 


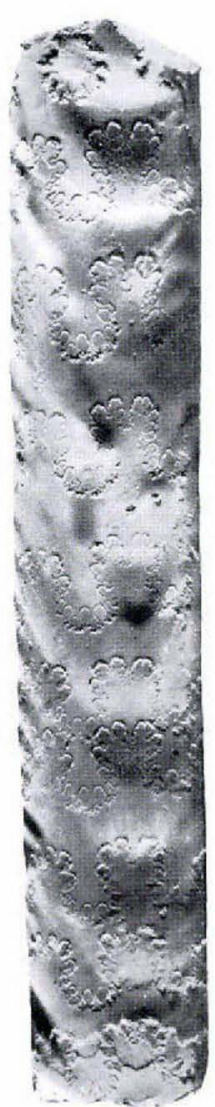

la
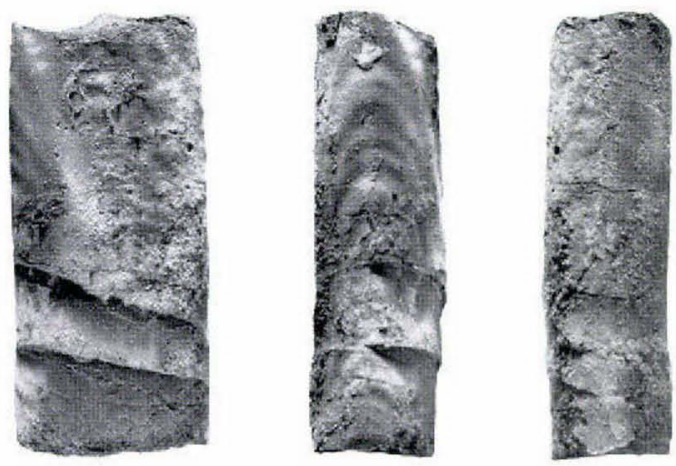

$3 c$

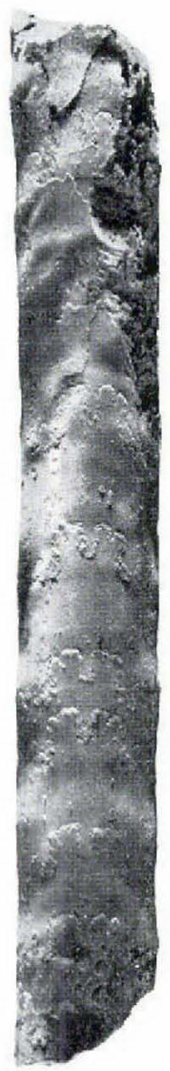

1c
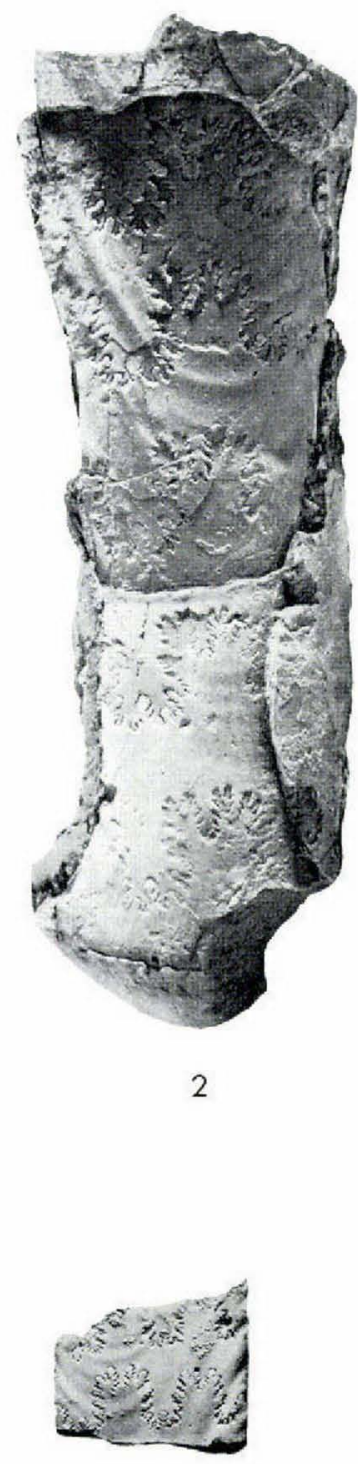

4a
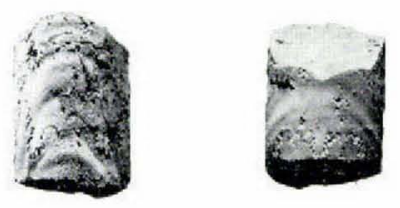

$4 b$

$4 c$ 


\section{Plate 16}

Diplomoceras sp. (p. 67).

1 a-c. MMH No. 9785. Lateral and dorsal views, and cross section. Maastrichtian? Niaqornat.

2. MMH No. 9786. Lateral view. Maastrichtian? Niaqornat.

Scaphites preventricosus svartenhukensis n.subsp. (p. 83).

3. MMH No. 9787. Lateral view of body chamber. Coniacian. The ammonite locality at Umîvik. 

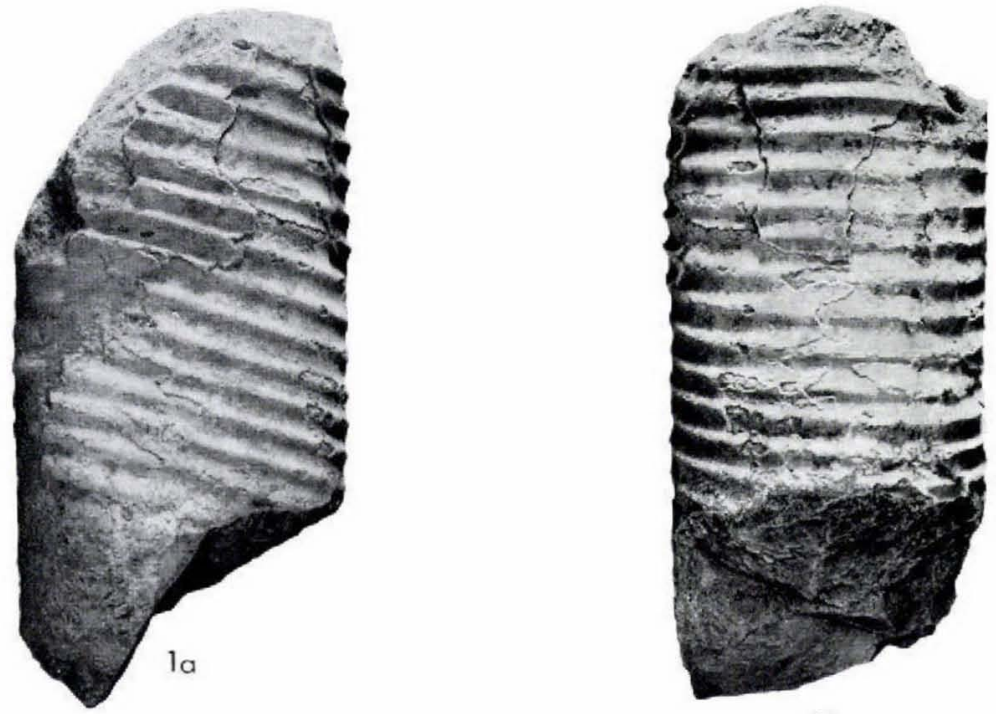

$1 \mathrm{~b}$
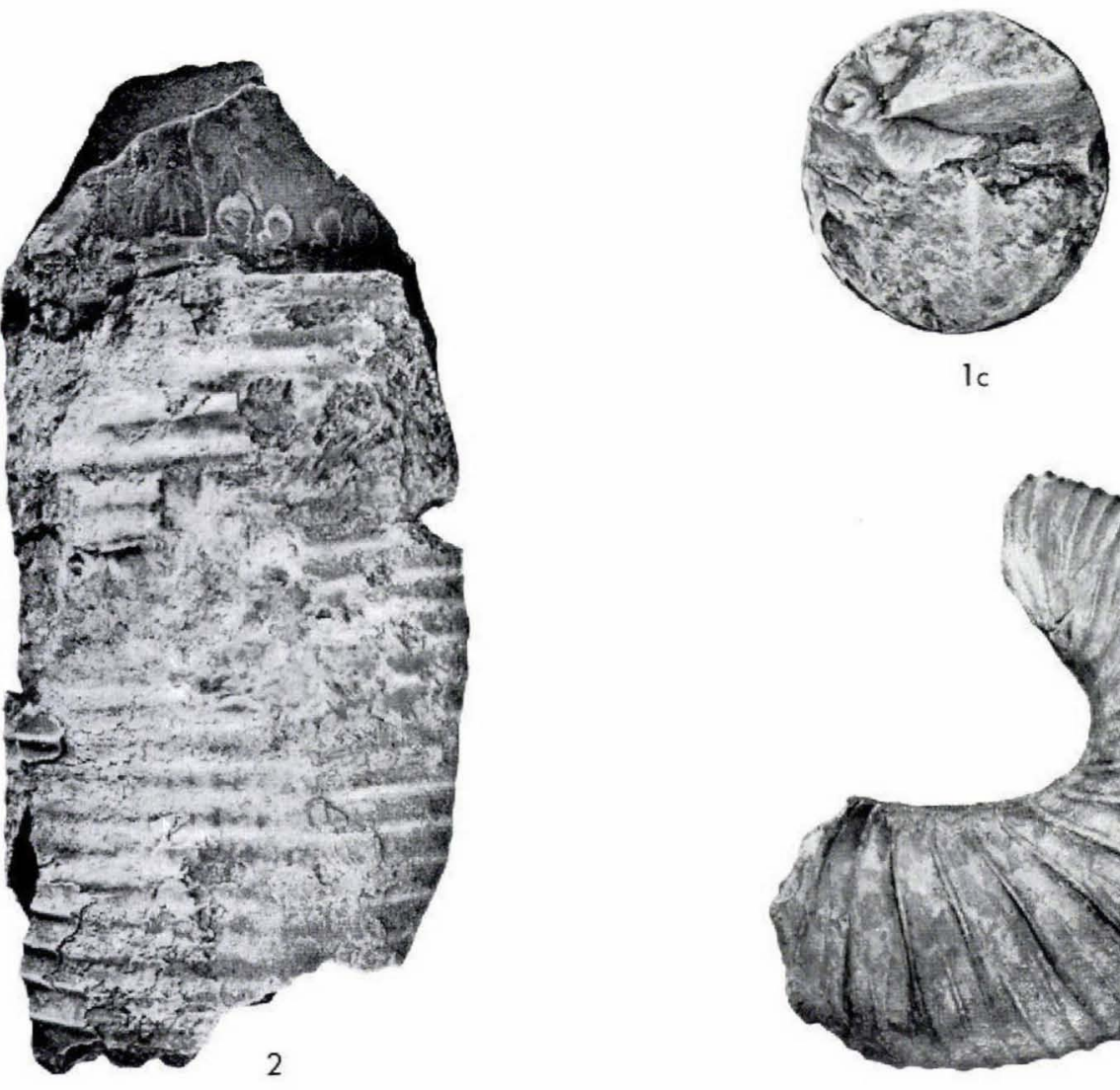

$1 c$

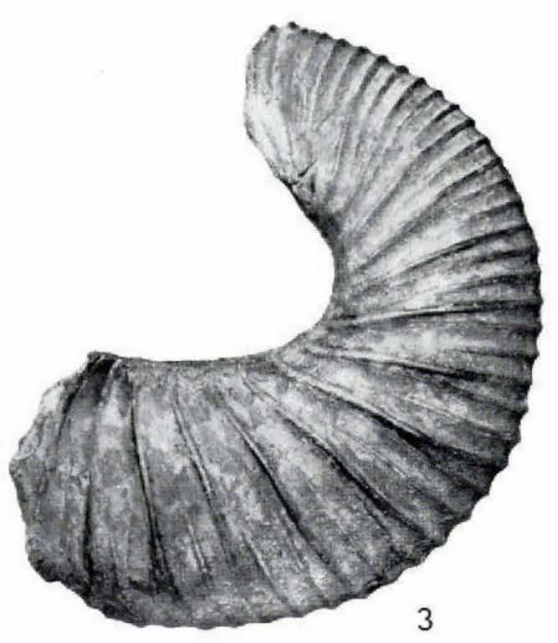




\section{Plate 17}

Scaphites mariasensis umivikensis n.subsp. (p. 81).

$1 \mathrm{a}-\mathrm{c}$. Holotype. MMH No. 9788. Lateral and peripheral views. The apertural angle indicated. Coniacian. The ammonite locality at Umîvik. 


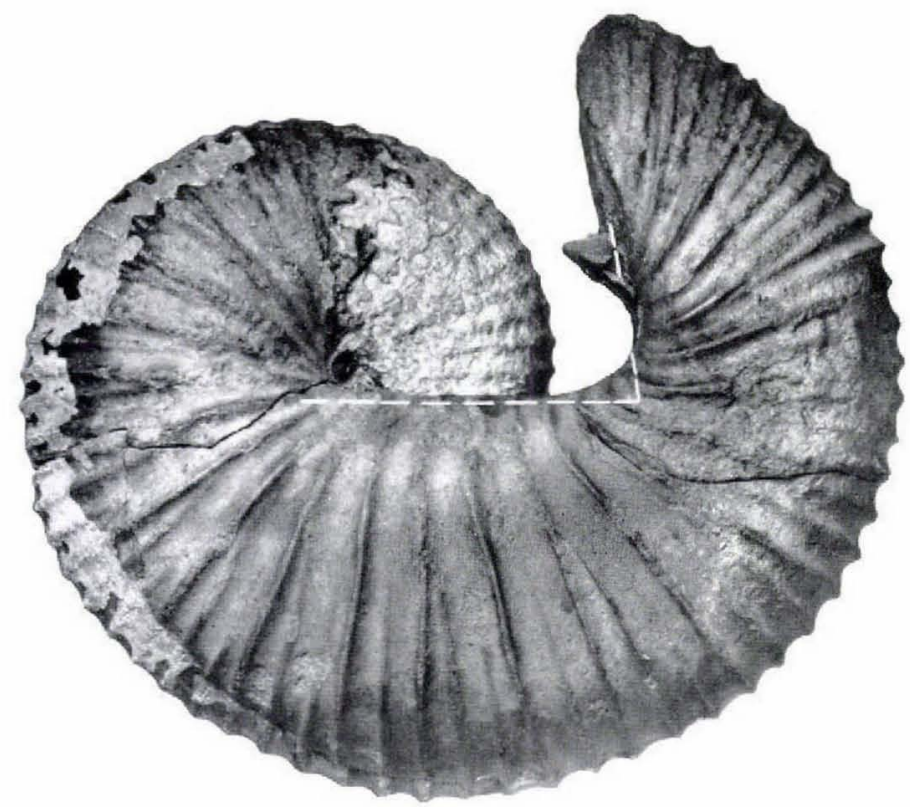

la

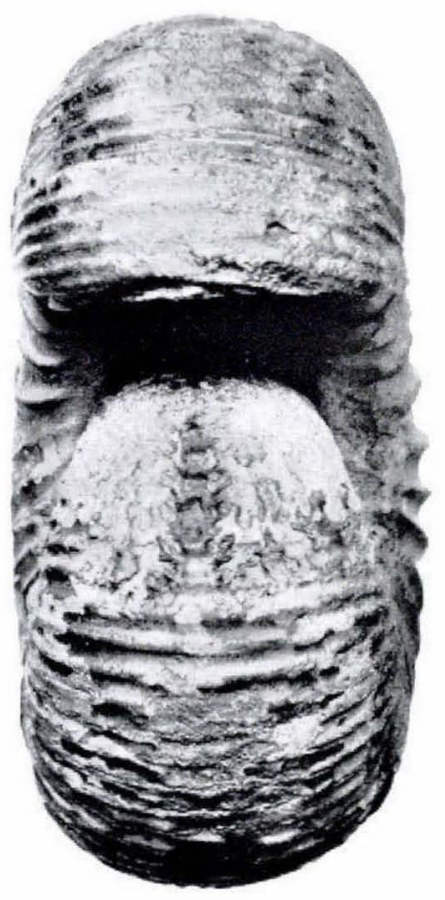

1b

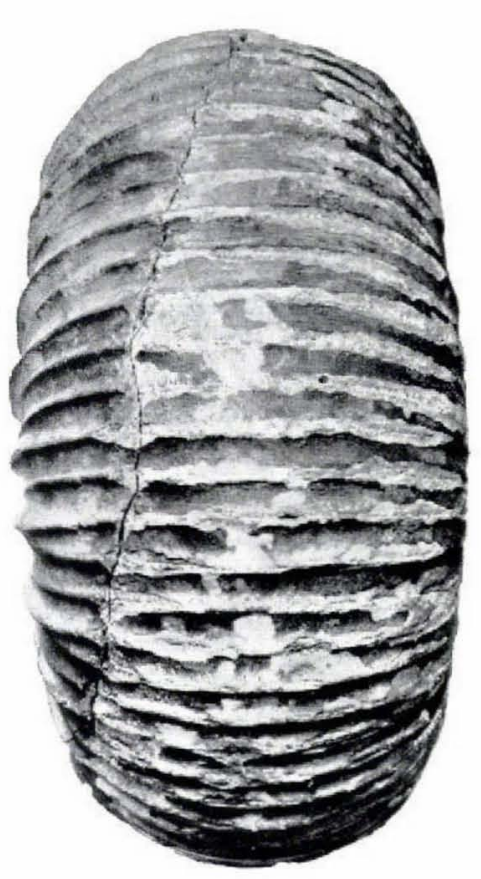

ic 


\section{Plate 18}

Scaphites cf. corvensis Соввал (p. 79).

1a-b. MMH No. 9789. Peripheral and lateral views of body chamber. Upper Turonian? Store Tange V Kløft, $60 \mathrm{~m}$ above sea-level.

Scaphites preventricosus svartenhukensis n.subsp. (p. 83).

2a-b. MMH No. 9790. Peripheral and lateral views of body chamber. Coniacian. The ammonite locality at Umîvik.

3a-c. Holotype. MMH No. 9791. Lateral and peripheral views. Coniacian. The ammonite locality at Umîvik. 
Medd. om Grove. Bd. 179, Nr. 7. [Tove Birkelund]
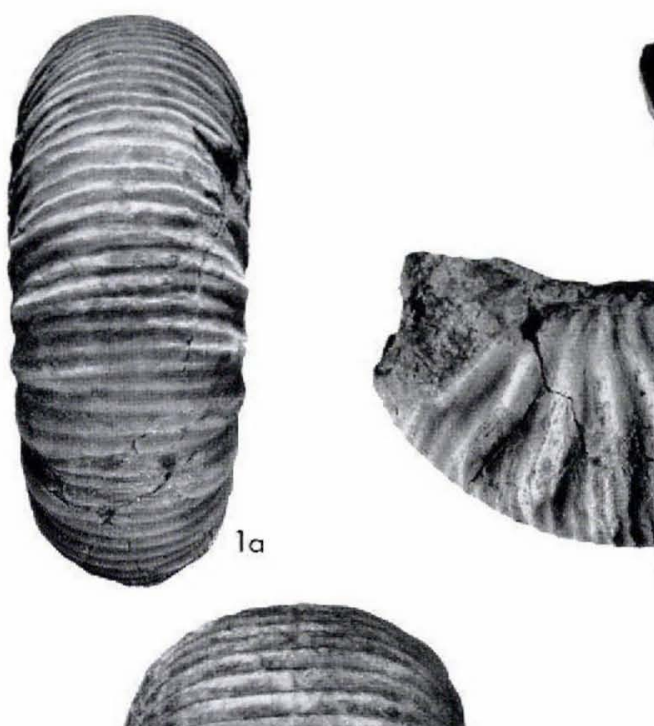

$1 \mathrm{~b}$

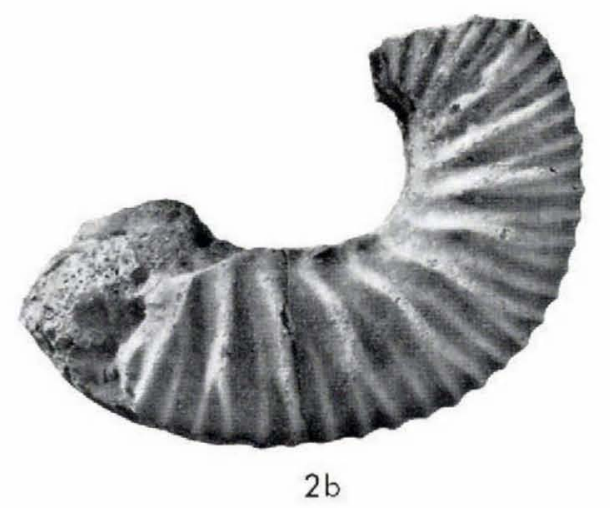

$3 a$

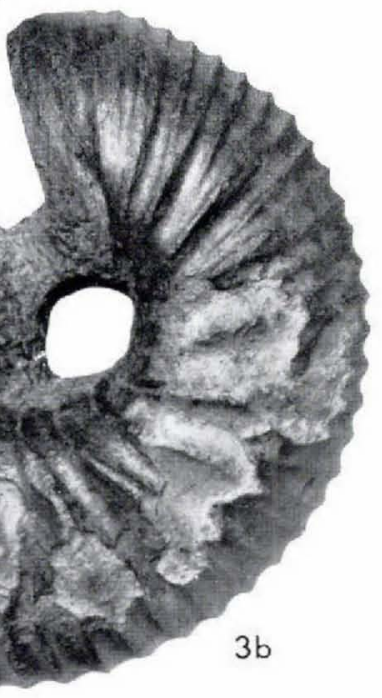

$3 c$

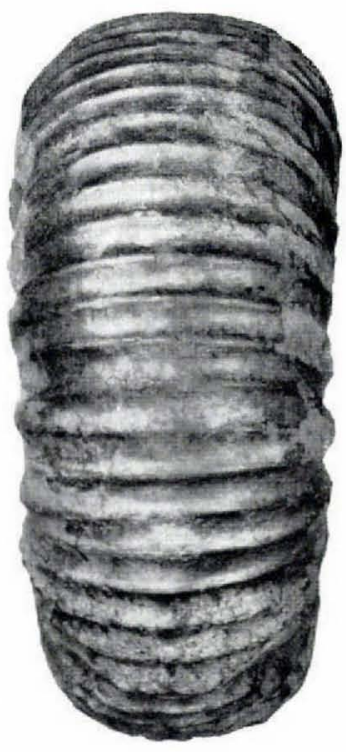




\section{Plate 19}

Scaphites preventricosus svartenhukensis n.subsp. (p. 83).

1 a-b. MMH No. 9792. Lateral and peripheral views. Coniacian. The ammonite locality at Umîvik.

Scaphites ventricosus MeEK \& Hayden (p. 87).

2a-c. MMH No. 9793. Lateral and peripheral views. Coniacian. Alianaitsúnguaq (horizon 20).

3. MMH No.9794. Lateral view. Coniacian. Alianaitsúnguaq (horizon 20). Scaphites cobbani n.sp. (p. 89).

4a-c. MMH No. 9795. Lateral and peripheral views. Lower Campanian. Scaphitesnæsen, 536-537 m above sea-level. 

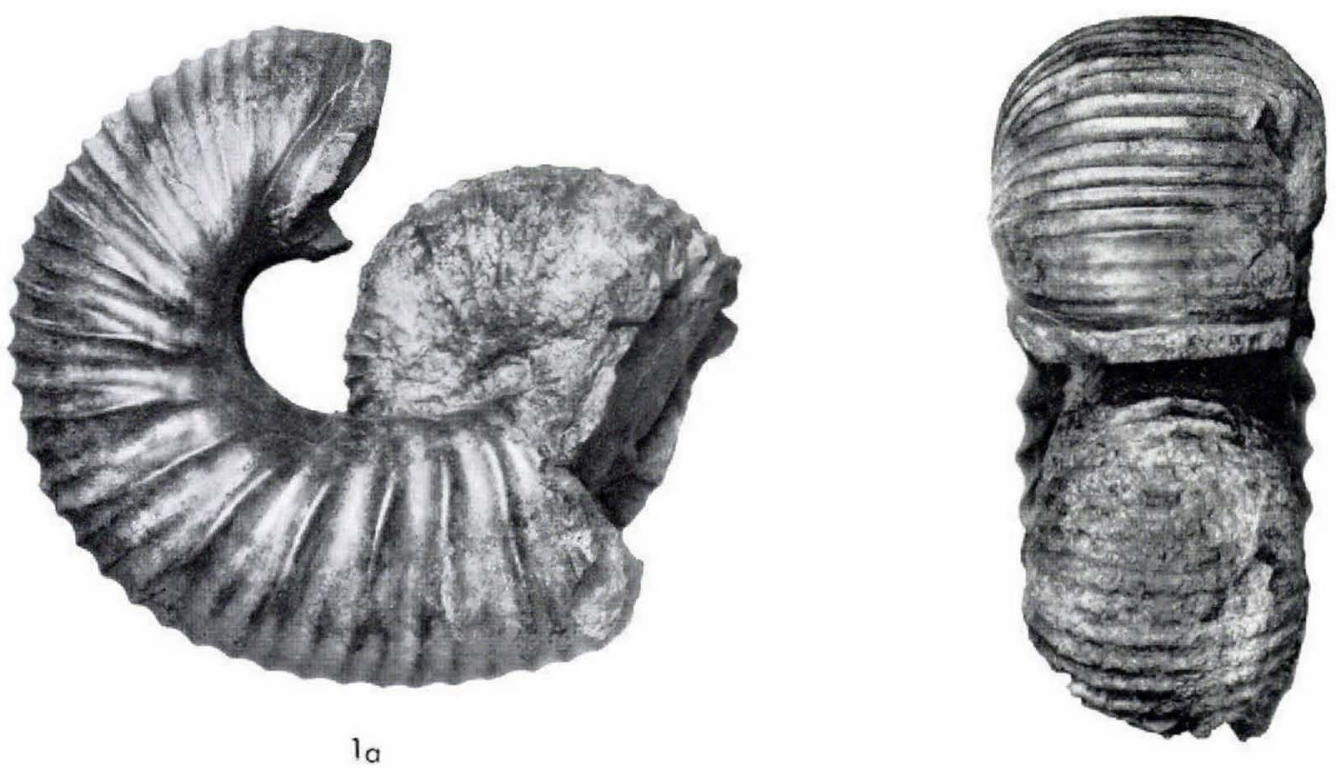

$1 \mathrm{~b}$

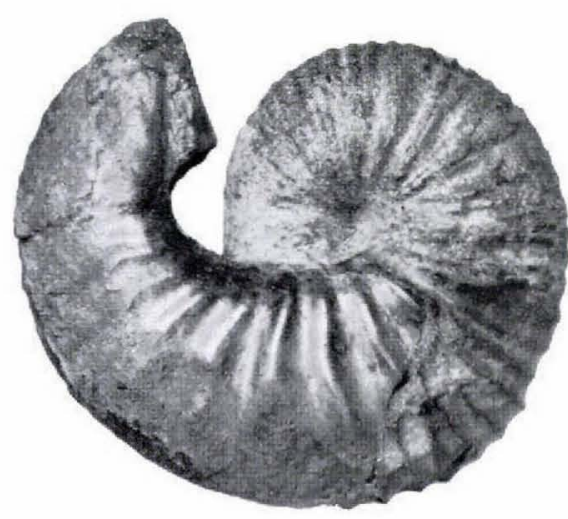

$2 a$

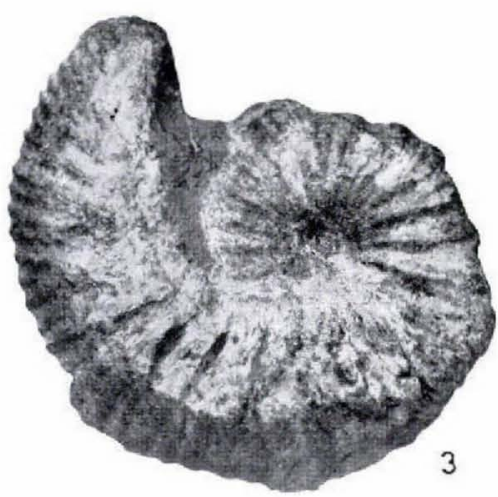

3
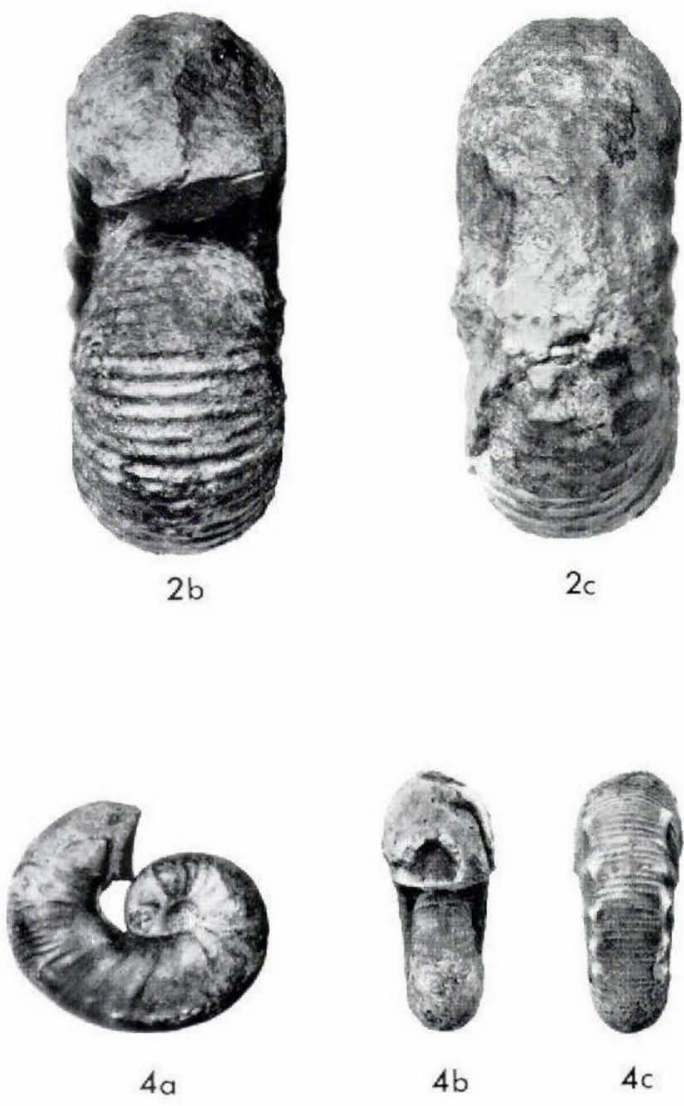


\section{Plate 20}

Scaphites cobbani n.sp. (p. 89).

1 a-c. MMH No. 9796. Lateral and peripheral views. Lower Campanian. Scaphitesnæsen.

2a-c. MMH No. 9797. Lateral and peripheral views. Lower Campanian. Scaphitesnæsen.

3a-c. MMH No. 9798. Lateral and peripheral views. Lower Campanian? From conglomerate in the Paleocene section in Turritellakløft.

4a-c. MMH No. 9799. Lateral and peripheral views. Lower Campanian Scaphitesnæsen, 539-540 m above sea-level. 

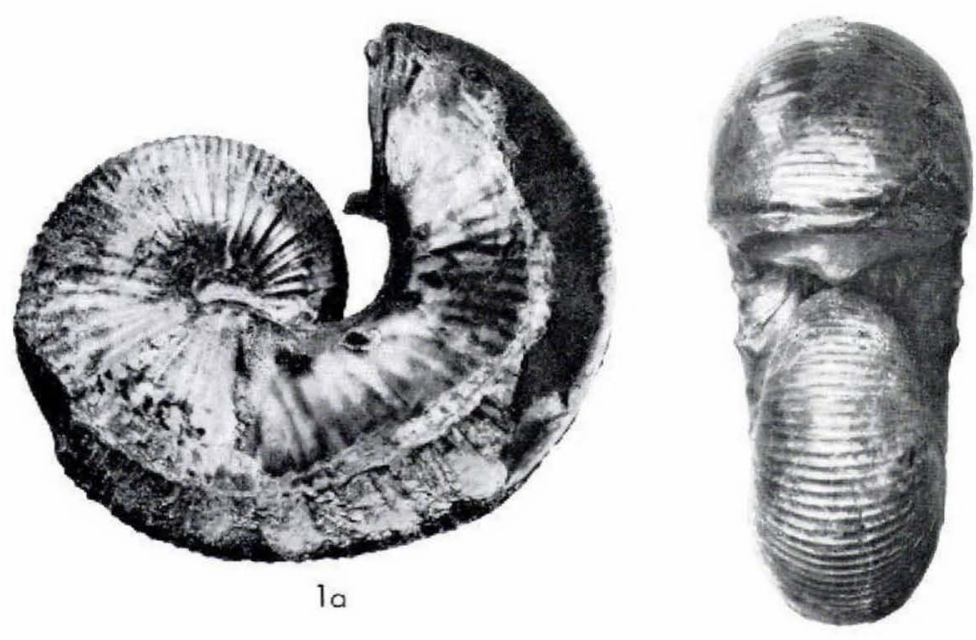

$1 \mathrm{~b}$

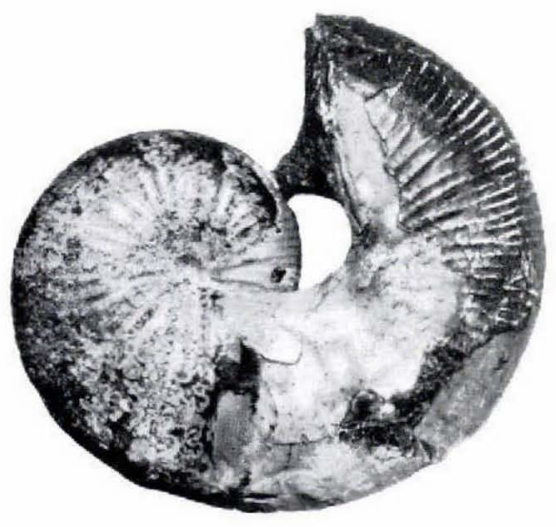

$2 a$

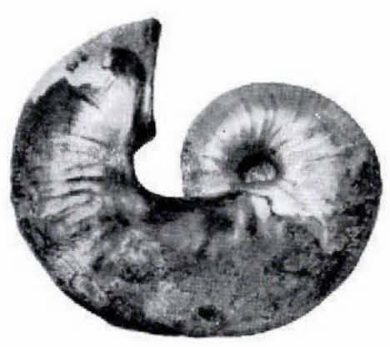

$3 a$

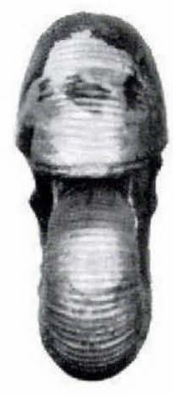

$3 b$

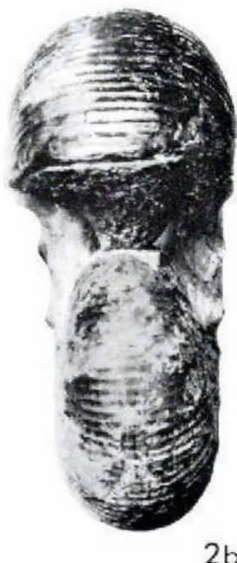

$2 b$

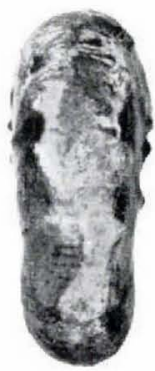

$3 c$

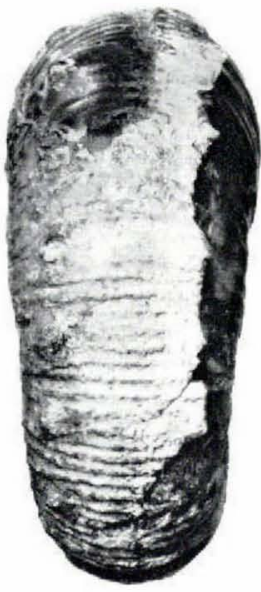

1c
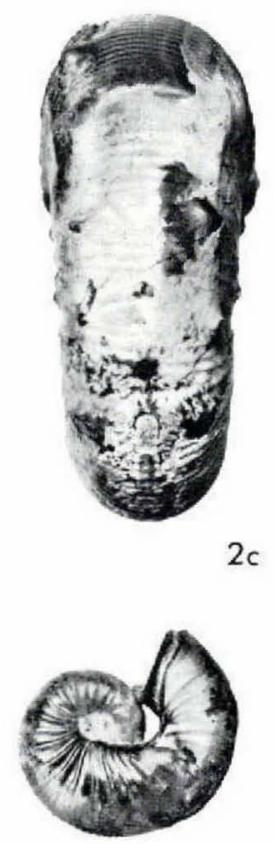

$4 a$
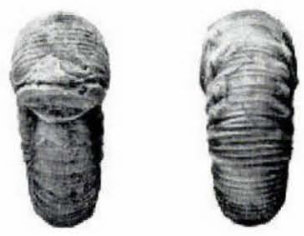

$4 b$

$4 c$ 


\section{Plate 21}

Scaphites cobbani n.sp. (p. 89).

1 a-c. Holotype. MMH No. 9800. Lateral and peripheral views. Lower Campanian. Scaphitesnæsen, 536-537 m above sea-level.

Scaphites rosenkrantzi n.sp. (p. 97).

2a-c. MMH No. 9801. Lateral and peripheral views. Lower Campanian. Scaphitesnæsen, 538-540 m above sea-level.

3 a-c. Holotype. MMH No. 9802. Lateral and peripheral views. Lower Campanian. Scaphitesnæsen. 

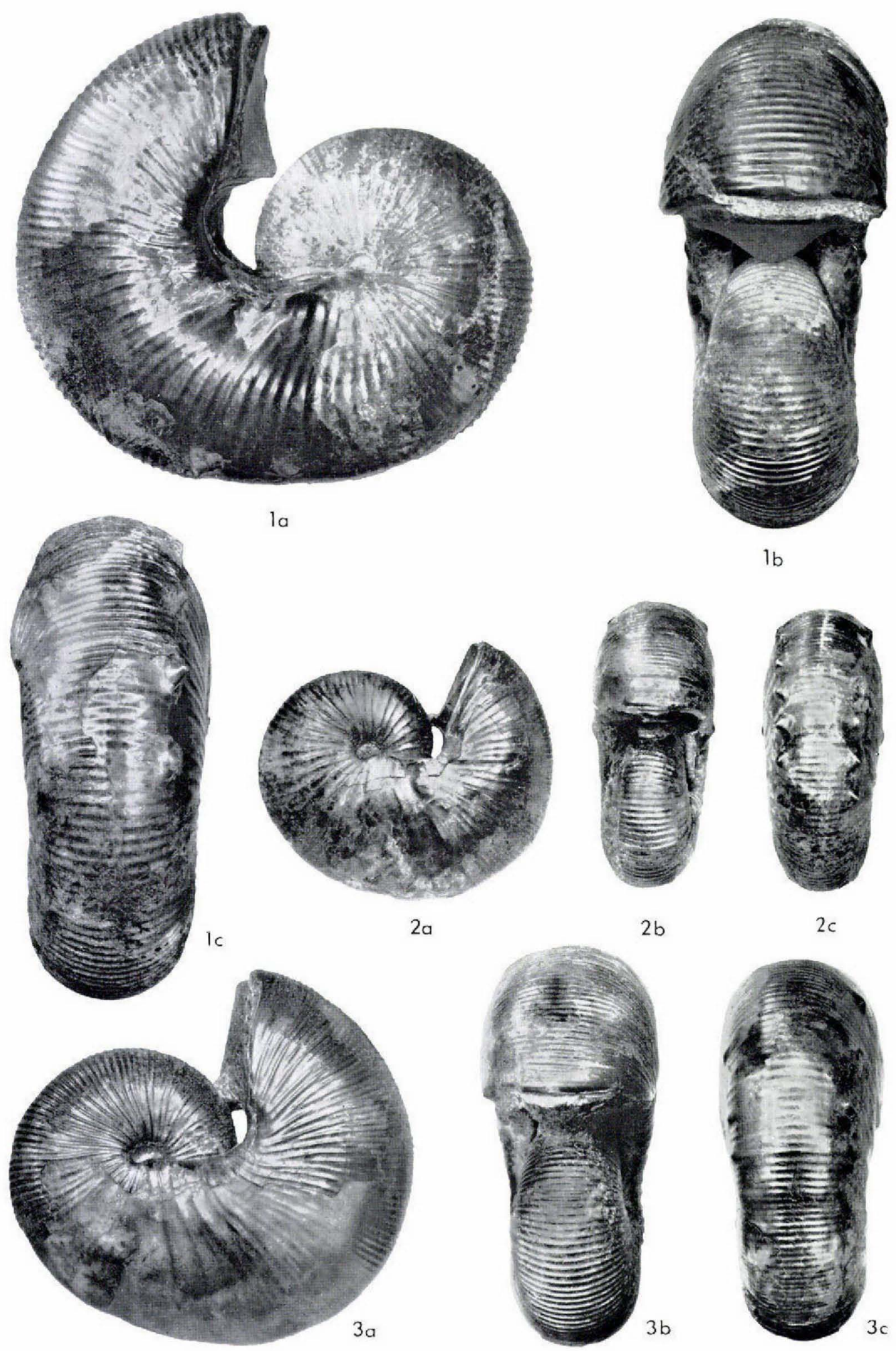


\section{Plate 22}

Scaphites cobbani n.sp. (p. 89).

1 a-c. MMH No. 9803. Lateral and peripheral views. Lower Campanian. Scaphitesnæsen.

Scaphites rosenkrantzi n.sp. (p. 97).

2a-b. MMH No. 9804. Lateral and peripheral views. Lower Campanian. Scaphitesnæsen.

3a-c. MMH No. 9805. Lateral and peripheral views. Lower Campanian. Scaphitesnæsen, 538-540 m above sea-level. 

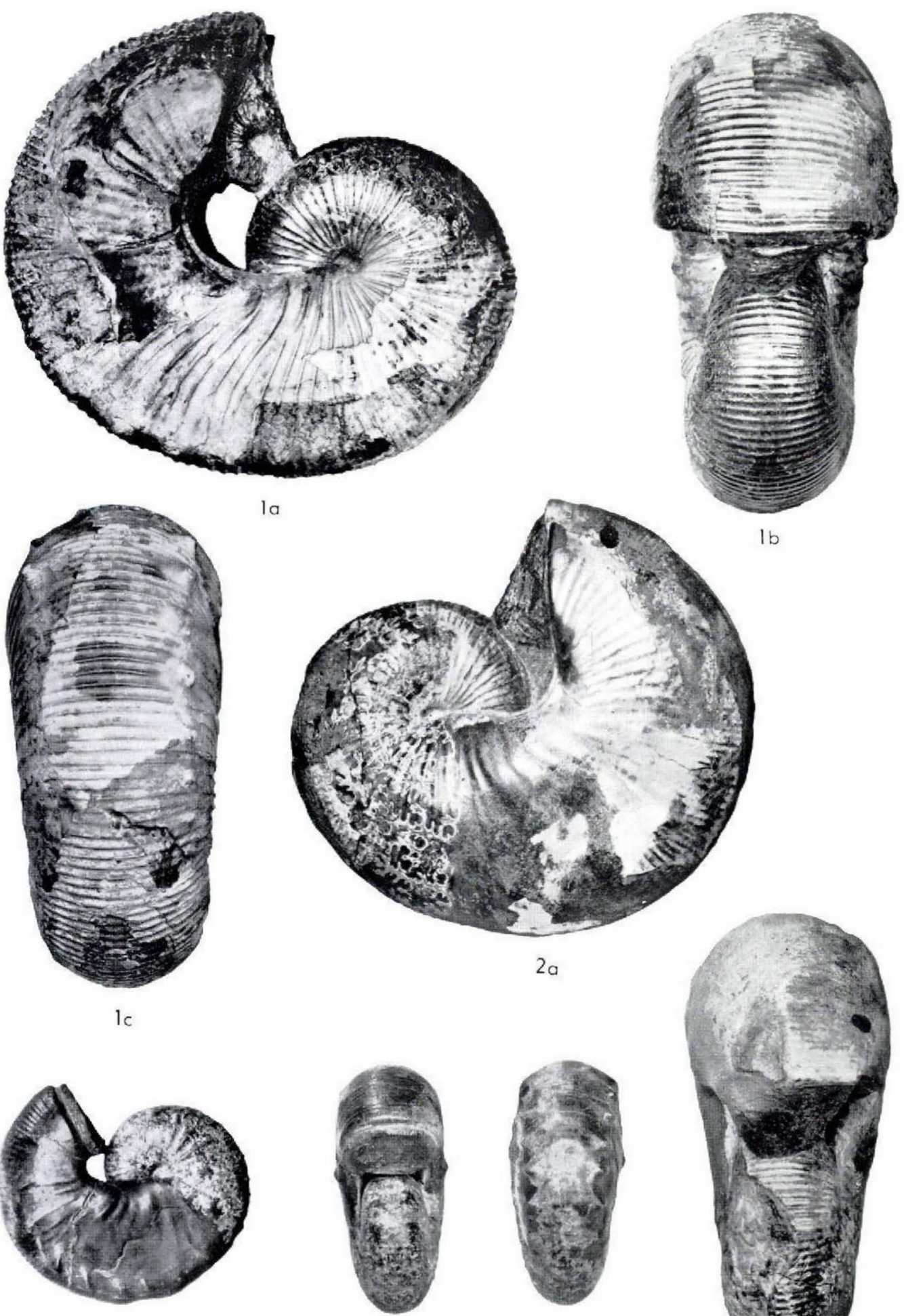

lc

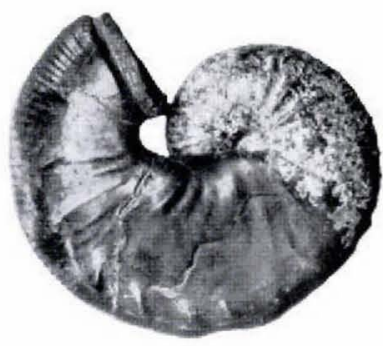

3a

$3 b$
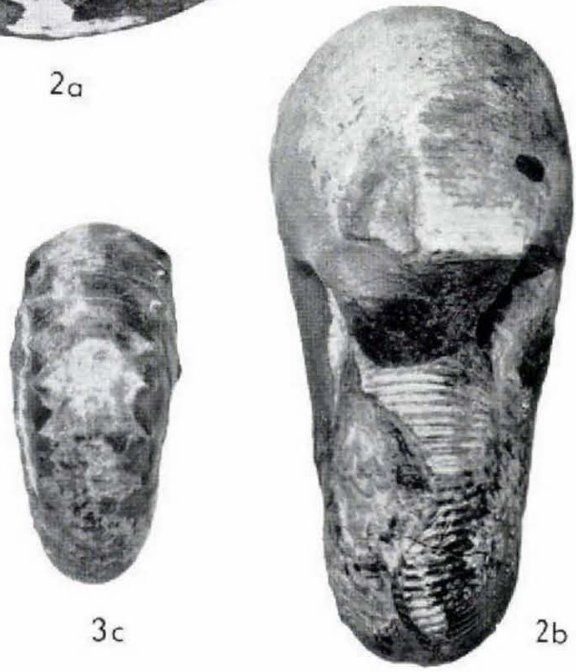


\section{Plate 23}

Scaphites rosenkrantzi n.sp. (p. 97).

1a-c. MMH No. 9806. Lateral and peripheral views. Lower Campanian. Scaphitesnæsen, $538-540 \mathrm{~m}$ above sea-level.

2a-c. MMH No. 9807. Lateral and peripheral views of nodeless specimen. Lower Campanian. Scaphitesnæsen.

3a-b. MMH No. 9808. Lateral and peripheral views of specimen with damaged and regenerated body chamber. Lower Campanian. Scaphitesnæsen, 536-538 m above sea-level. 


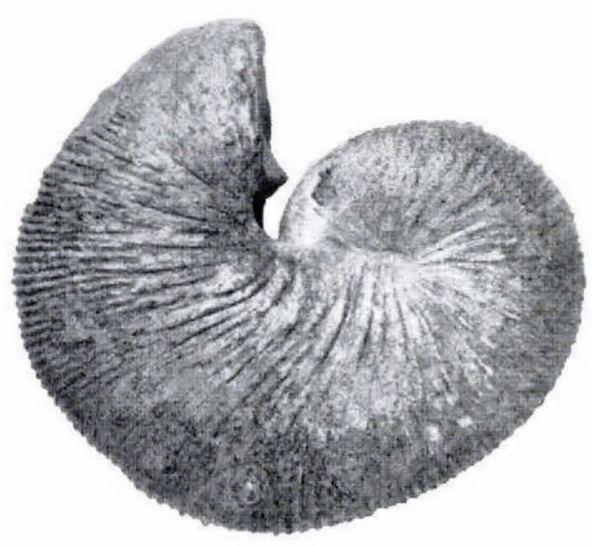

10

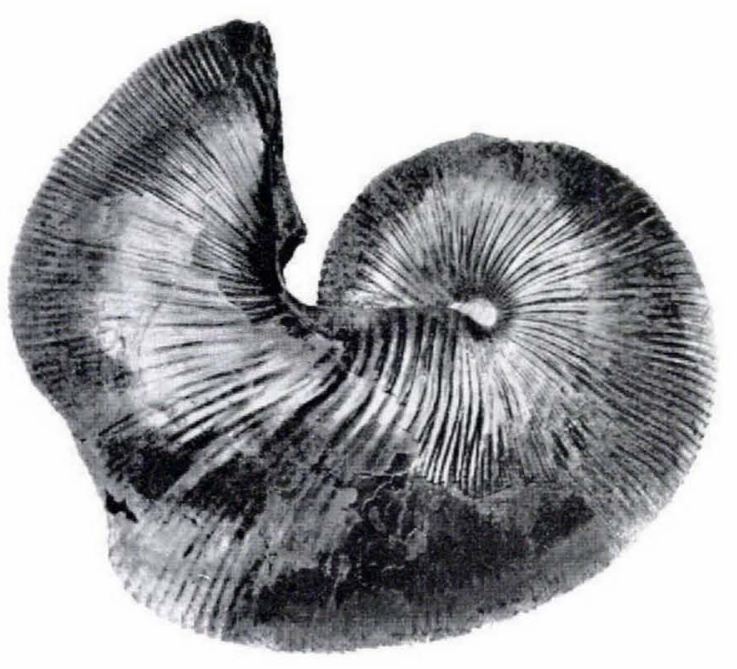

$2 a$

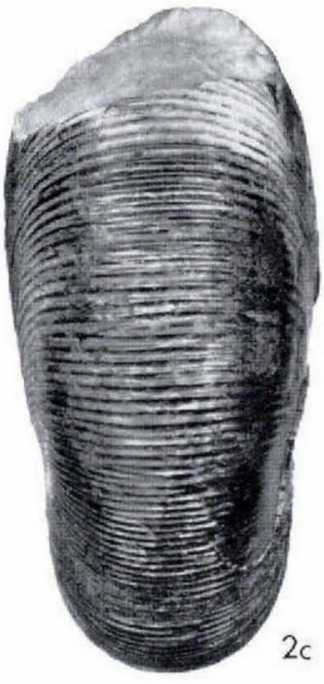

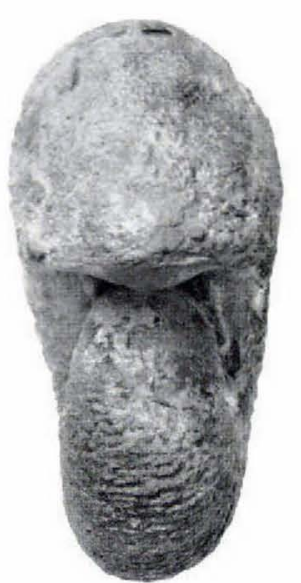

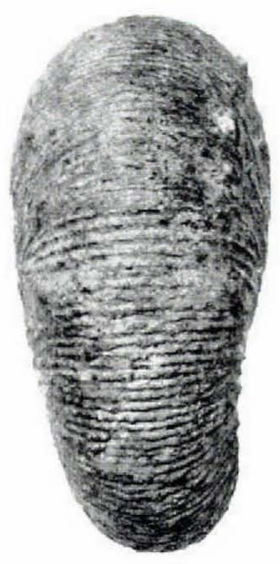

$1 b$

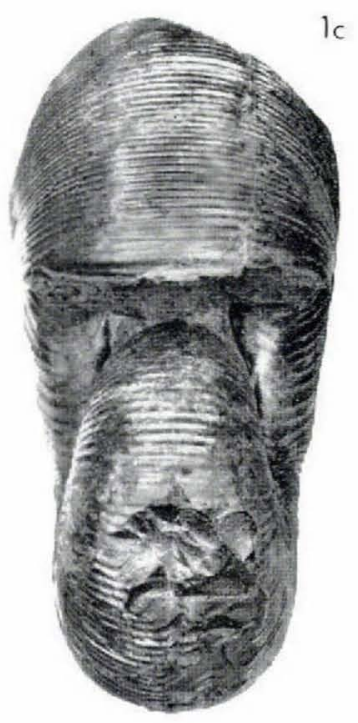

$2 b$
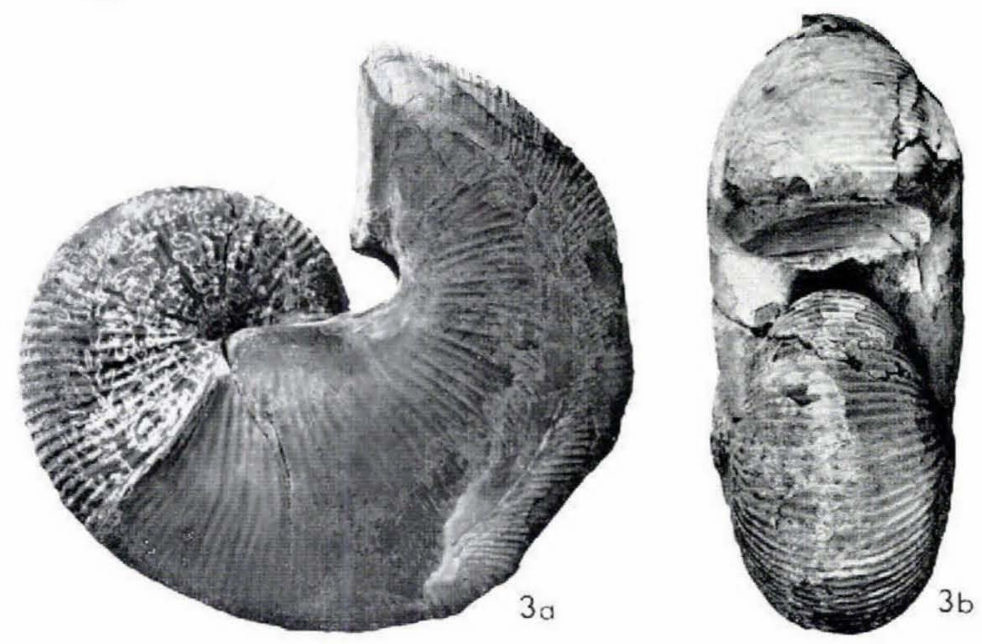


\section{Plate 24}

Scaphites (Hoploscaphites) ikorfatensis n.sp. (p. 102).

1a-c. MMH No. 9809. Lateral and peripheral views. Upper Campanian. Brudkløft at Ikorfat, $625 \mathrm{~m}$ above sea-level.

2a-c. MMH No. 9810. Lateral and peripheral views. Upper Campanian. Brudkløft at Ikorfat, $560 \mathrm{~m}$ above sea-level.

3a-c. MMH No. 9811. Lateral and peripheral views. Upper Campanian. Brudkløft at Ikorfat, $630 \mathrm{~m}$ above sea-level.

4a-b. MMH No. 9812. Lateral and peripheral views of specimen with two lateral nodes on body chamber. Upper Campanian. Brudkløft at Ikorfat, $625 \mathrm{~m}$ above sea-level. 


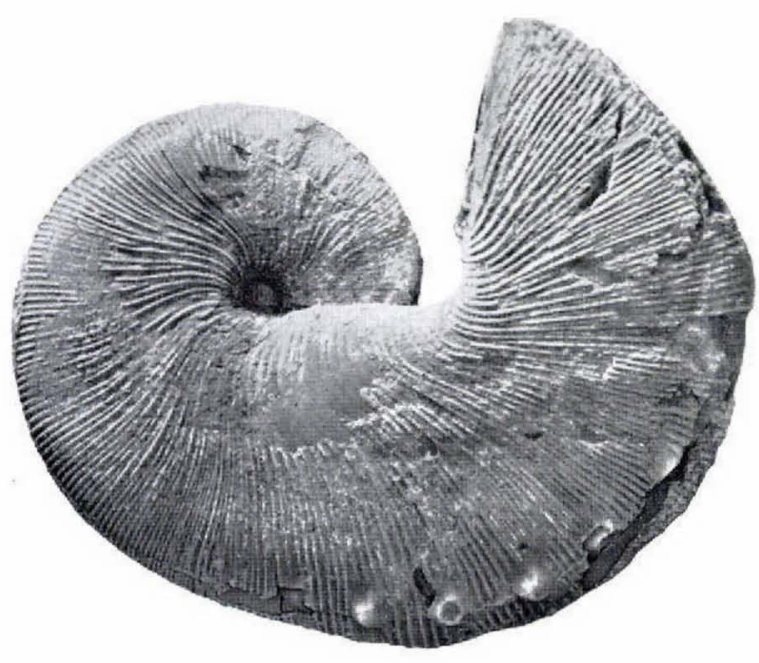

la

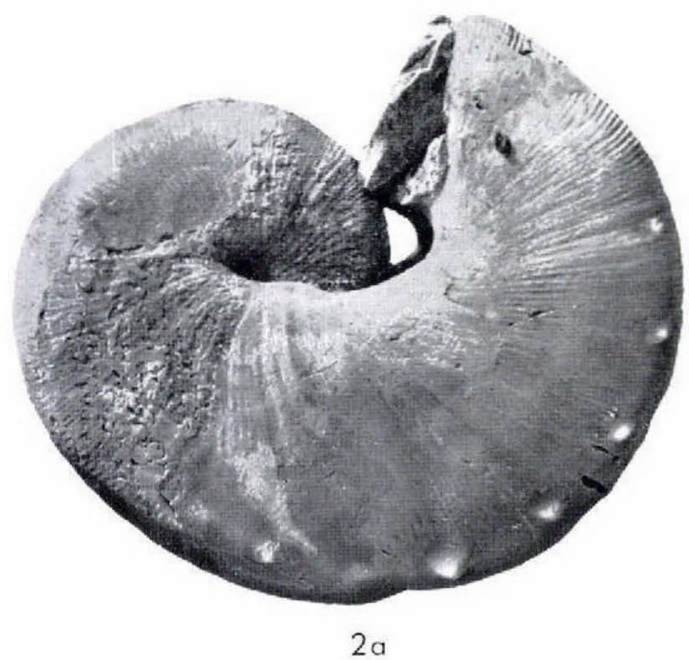

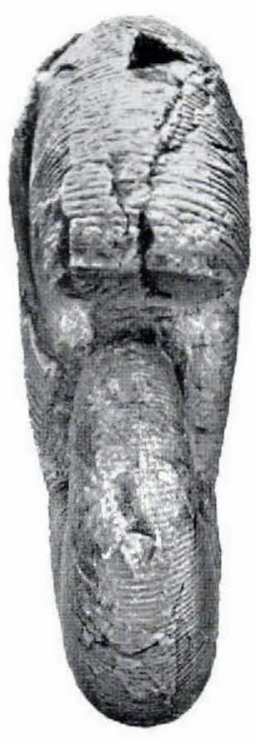

$1 \mathrm{~b}$

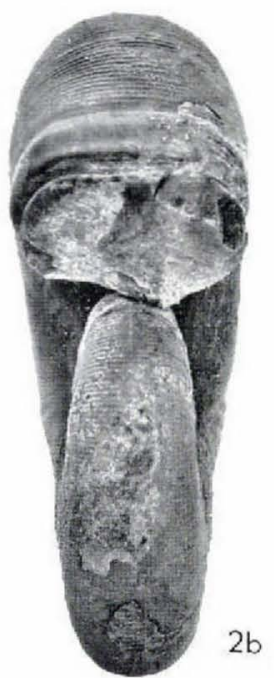

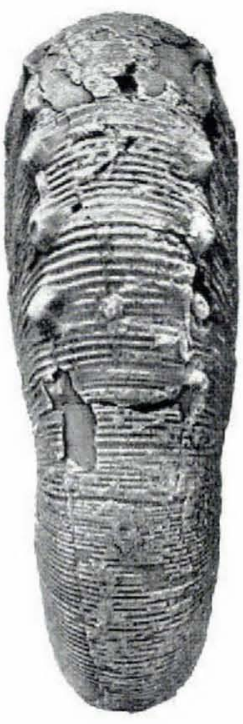

$1 c$

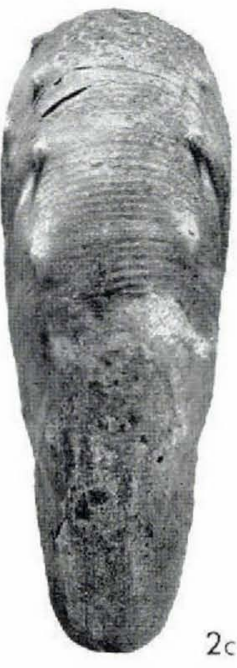

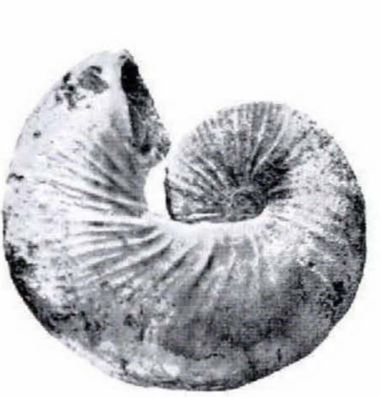

$3 a$

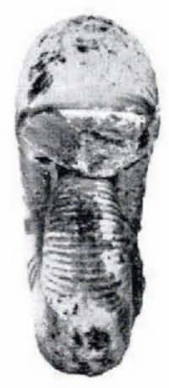

$3 b$

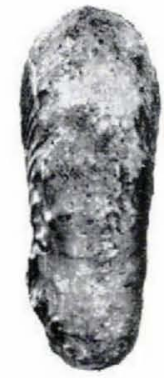

$3 c$

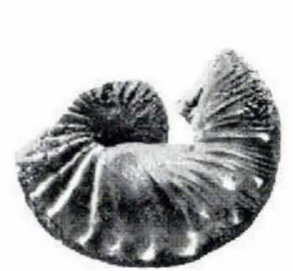

$4 a$

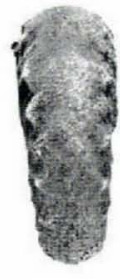

$4 b$ 


\section{Plate 25}

Scaphites (Hoploscaphites) ikorfatensis n.sp. (p. 102).

1 a-c. MMH No. 9813. Lateral and peripheral views of nodeless specimen. Upper Campanian. Brudkløft at Ikorfat, $560 \mathrm{~m}$ above sea-level.

2a-c. MMH No. 9814. Lateral and peripheral views. Upper Campanian. Brudkløft at Ikorfat, $625 \mathrm{~m}$ above sea-level. 


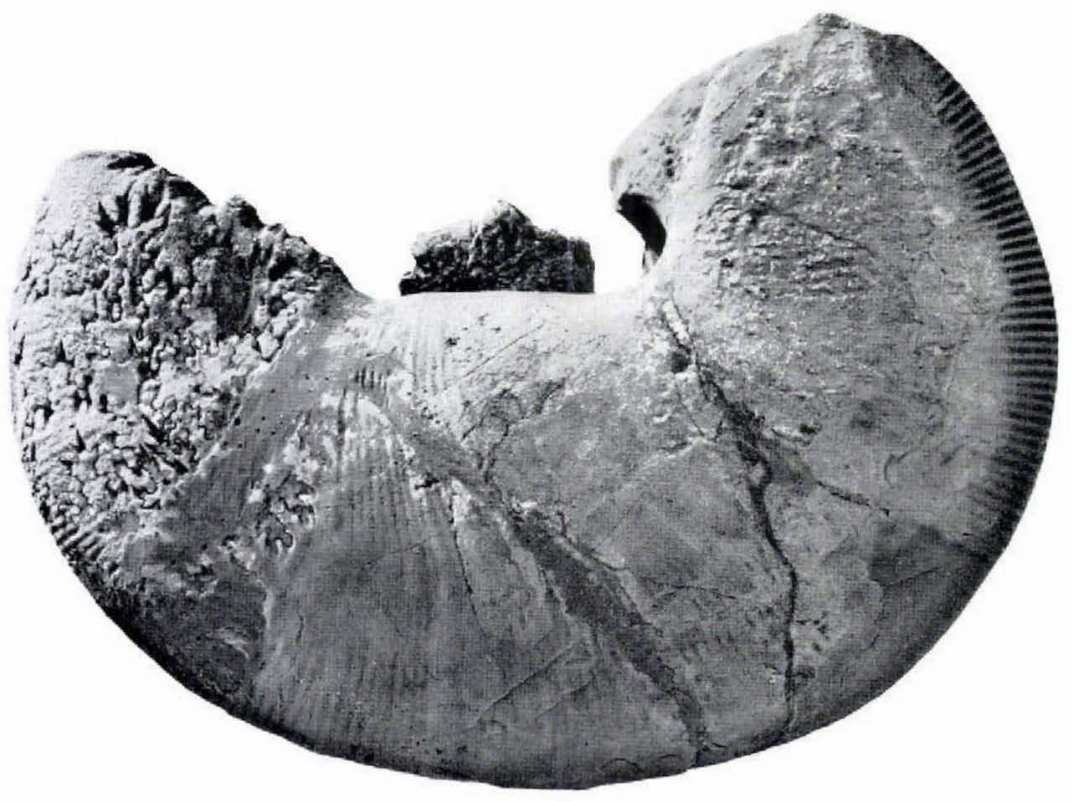

la

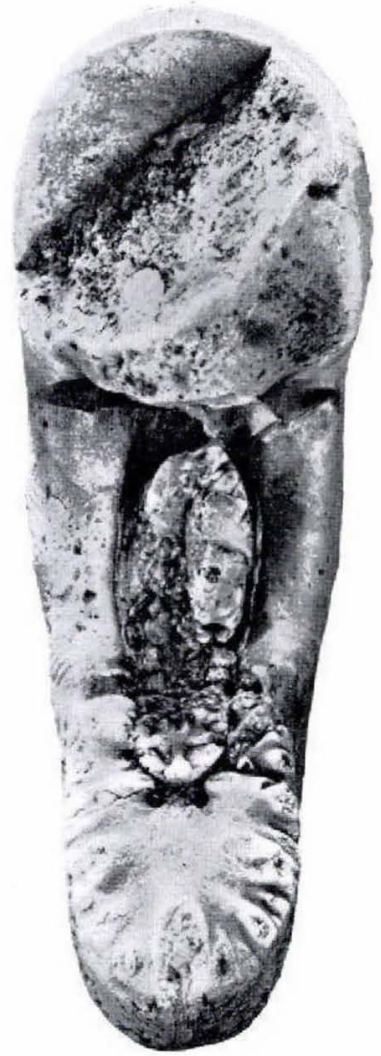

Ib

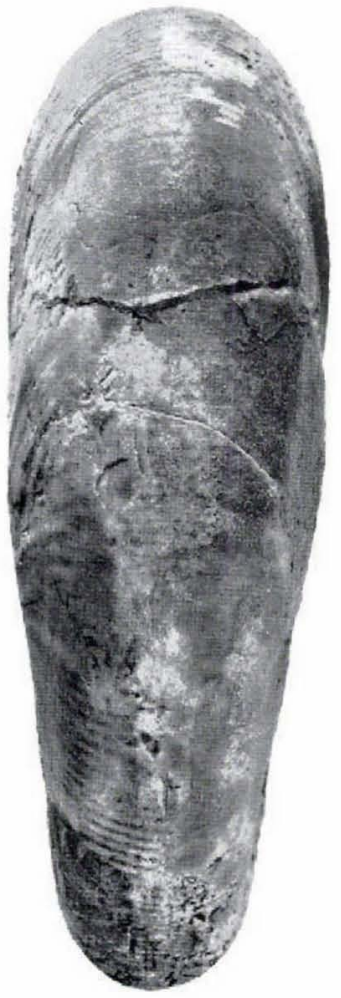

ic

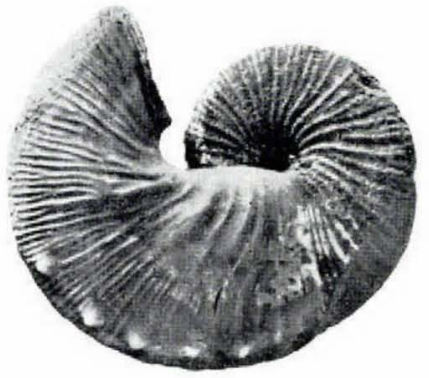

$2 a$

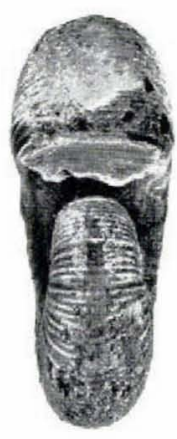

$2 b$

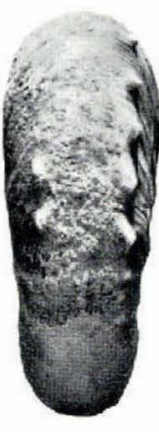

$2 c$ 


\section{Plate 26}

Scaphites (Hoploscaphites) ikorfatensis n.sp. (p. 102).

1a-c. Holotype. MMH No. 9815. Lateral and peripheral views. Upper Campanian. Brudkløft at Ikorfat, $550 \mathrm{~m}$ above sea-level.

Scaphites (Hoploscaphites) ravni $\mathrm{n} . \mathrm{sp}$. (p. 106).

2a-b. MMH No. 9816. Lateral and peripheral views of body chamber. Upper Campanian. Brudkløft at Ikorfat, $625 \mathrm{~m}$ above sea-level.

3a-c. MMH No. 9817. Lateral and peripheral views. Upper Campanian. Brudkløft at Ikorfat, $550 \mathrm{~m}$ above sea-level.

4. MMH No. 9818. Lateral view of specimen with weak umbilical bullae on body chamber. Upper Campanian. Brudkløft at Ikorfat, $550 \mathrm{~m}$ above sea-level. 

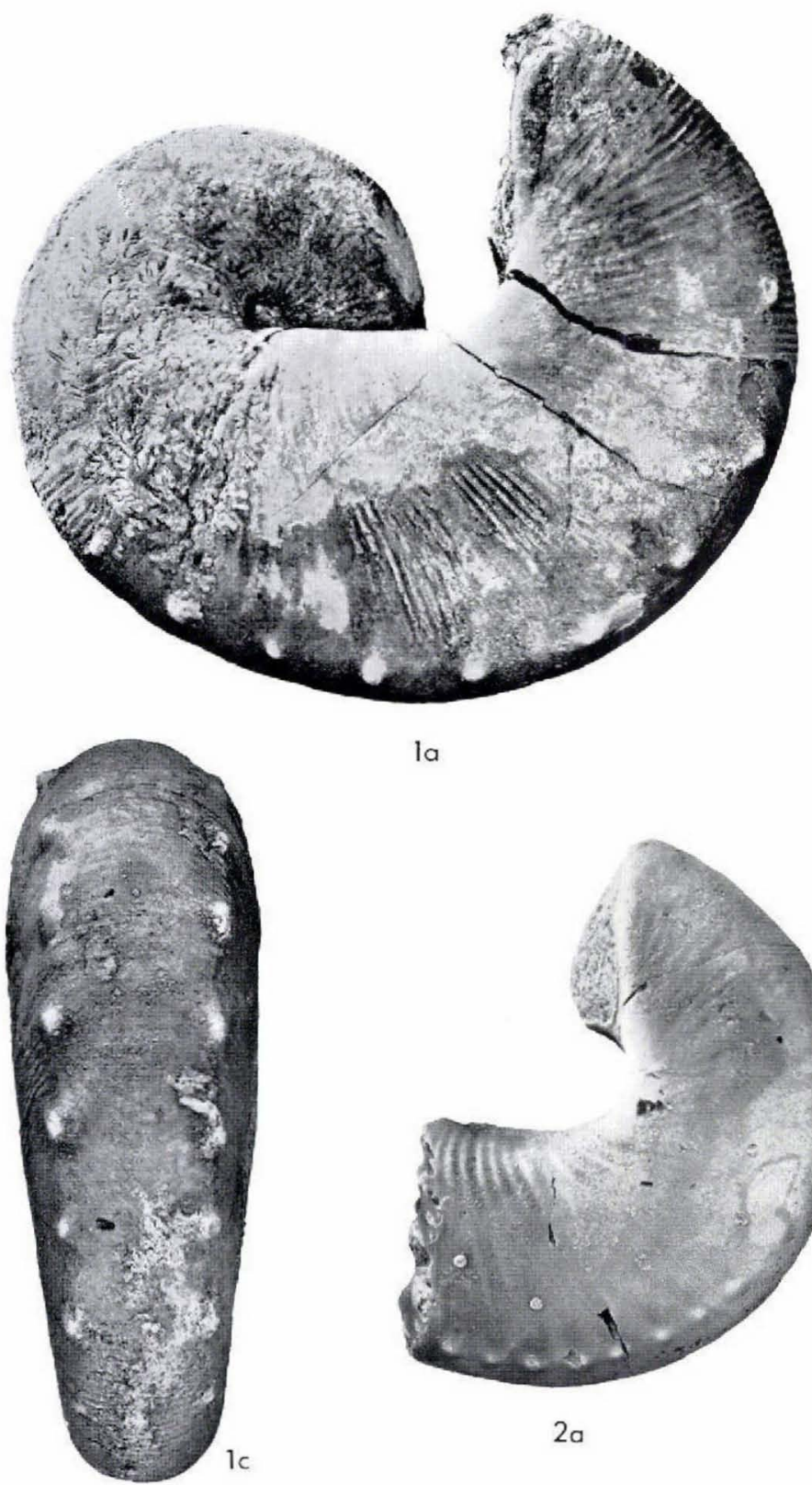

la

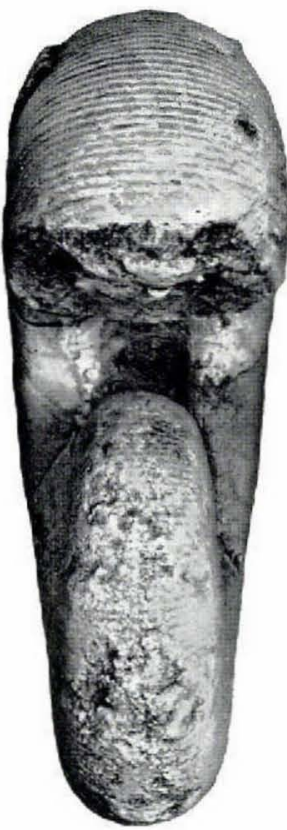

$1 \mathrm{~b}$

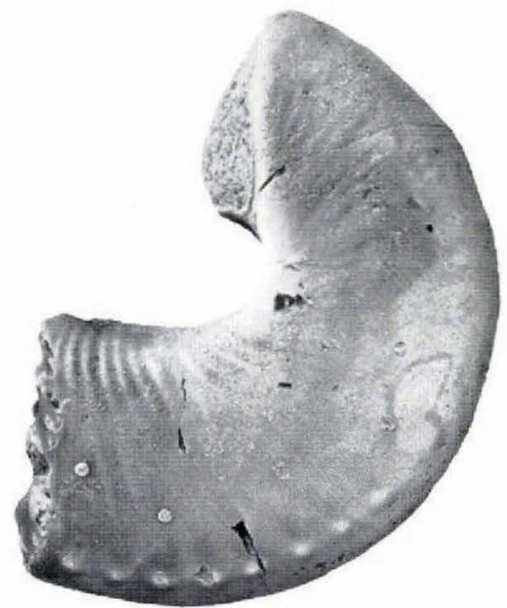

$2 a$

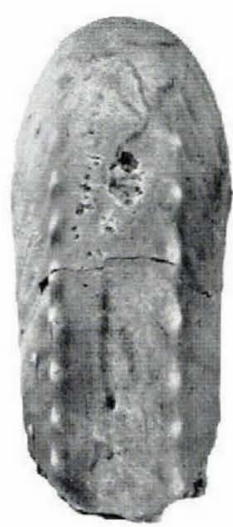

$2 b$
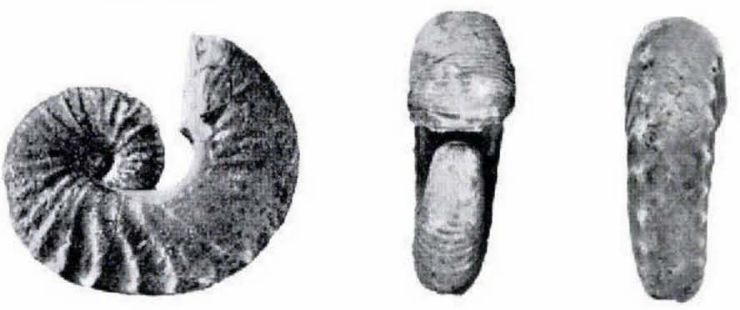

$3 b$

$3 c$

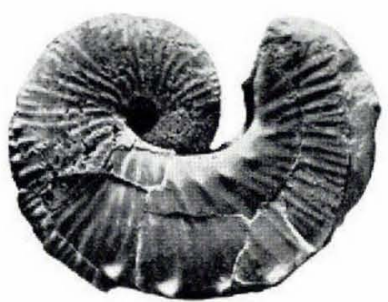

4 


\section{Plate 27}

Scaphites (Hoploscaphites) ravni n.sp. (p. 106).

1 a-c. Holotype. MMH No. 9819. Lateral and peripheral views. Upper Campanian. Brudkløft at Ikorfat, $550 \mathrm{~m}$ above sea-level.

2a-b. MMH No. 9820. Lateral and peripheral views. Upper Campanian. Brudkløft at Ikorfat, $625 \mathrm{~m}$ above sea-level.

3a-c. MMH No. 9821. Lateral and peripheral views. Upper Campanian. Brudkløft at Ikorfat, $550 \mathrm{~m}$ above sea-level.

4a-c. MMH No. 9822. Lateral and peripheral views. Upper Campanian. Brudkløft at Ikorfat, $625 \mathrm{~m}$ above sea-level. 
Medo, om Grovi.. BD. 179, NR. Z. [TONE Birkelund]

P1.ATE 27

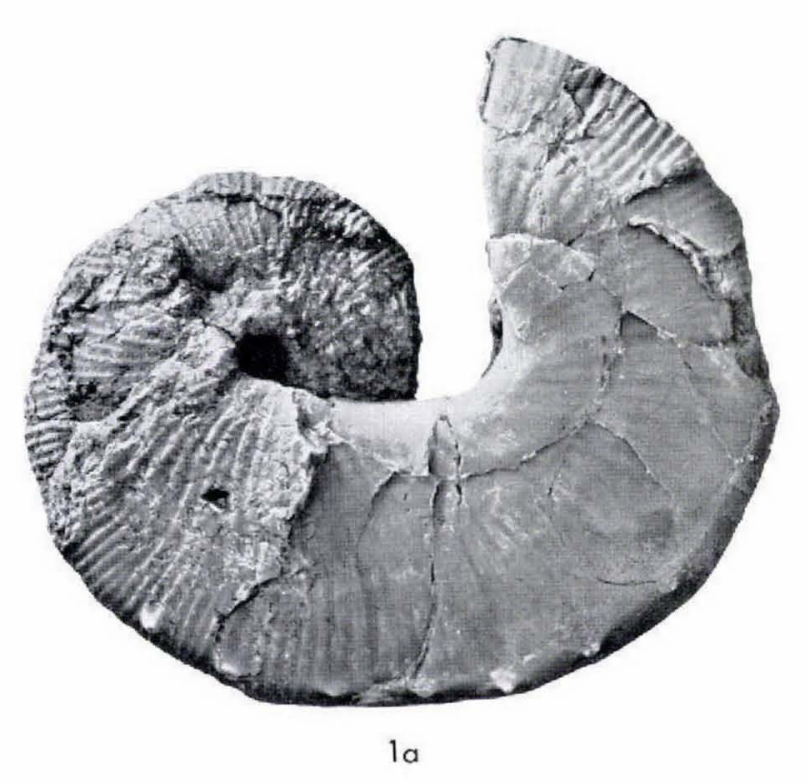

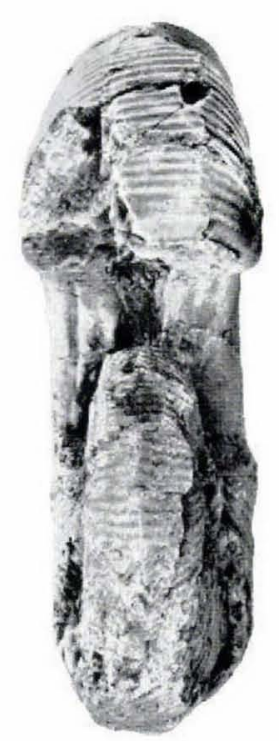

16

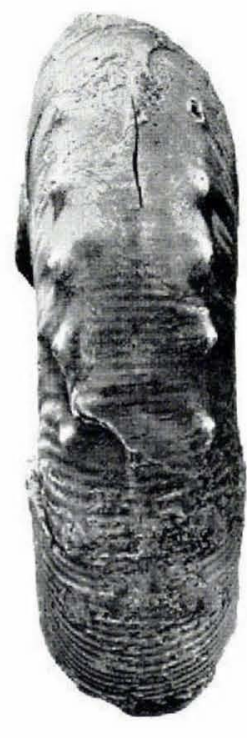

Ic

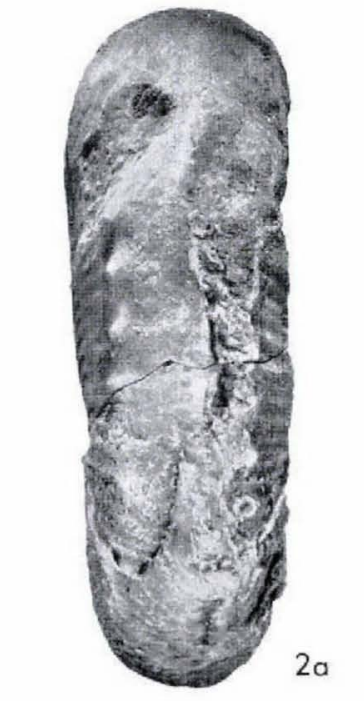

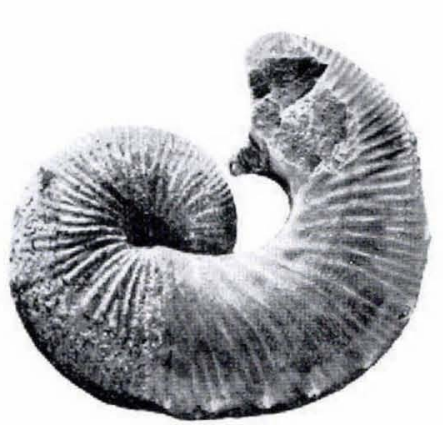

$3 a$

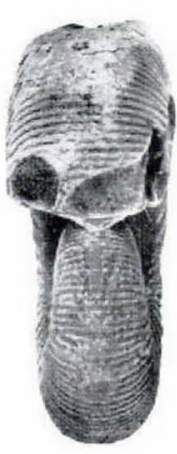

$3 b$

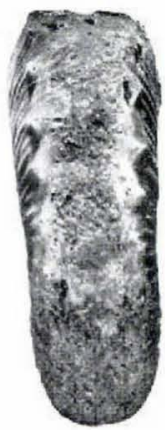

$3 c$
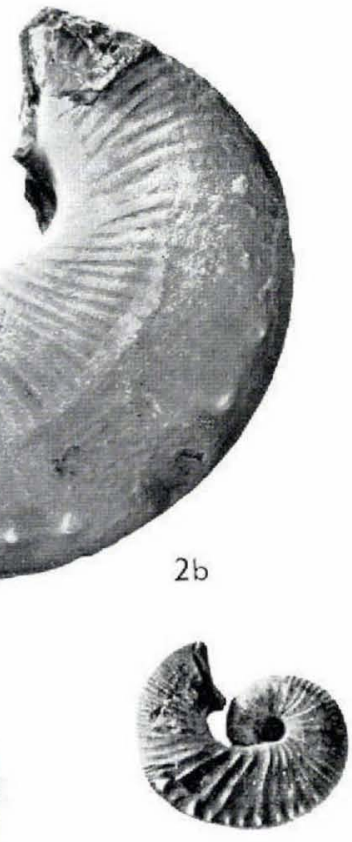

$4 a$
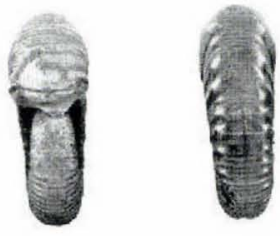

$4 \mathrm{~b}$

$4 c$ 


\section{Plate 28}

Scaphites (Hoploscaphites) ravni n.sp. (p. 106).

1a-c. MMH No. 9823. Lateral and peripheral views of partly reconstructed specimen. Upper Campanian. Niaqornat.

Scaphites (Hoploscaphites) greenlandicus Donovan (p. 110).

2. MMH No.9824. Lateral view of body chamber with weak ventrolateral nodes. Upper Campanian. Niaqornat.

3a-c. MMH No. 9825. Lateral and peripheral views of phragmocone. Upper Campanian. Niaqornat. 

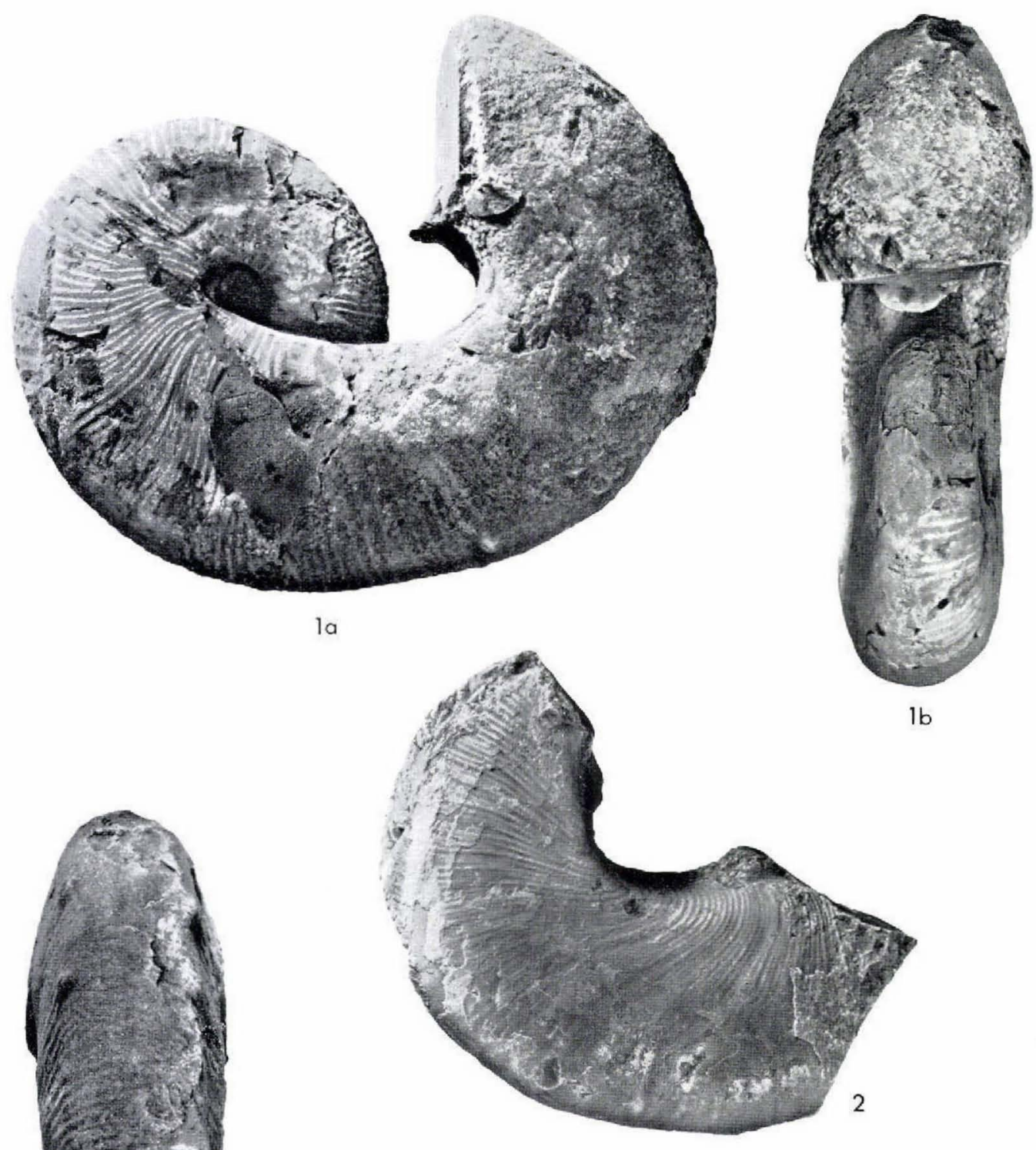

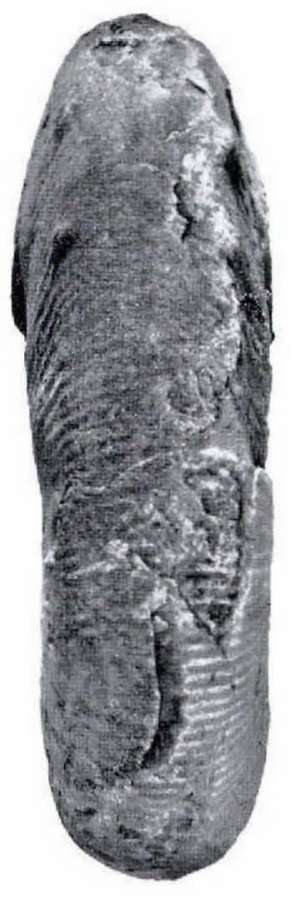

$1 c$ la

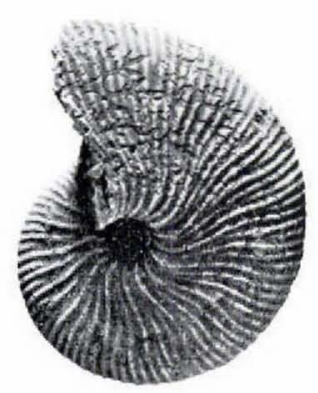

$3 a$

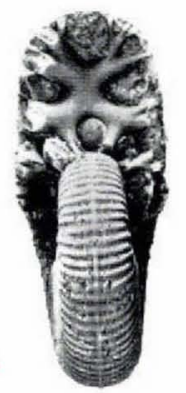

$3 b$

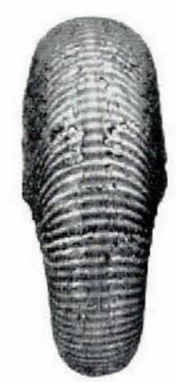

$3 c$ 


\section{Plate 29}

Scaphites (Hoploscaphites) ravni n.sp. (p. 106).

1a-c. MMH No. 9826. Lateral and peripheral views of nodeless specimen. Upper Campanian. Niaqornat.

Scaphites (Hoploscaphites) greenlandicus Donovan (p. 110).

2. MMH No. 9827. Lateral view. Upper Campanian. Niaqornat. 

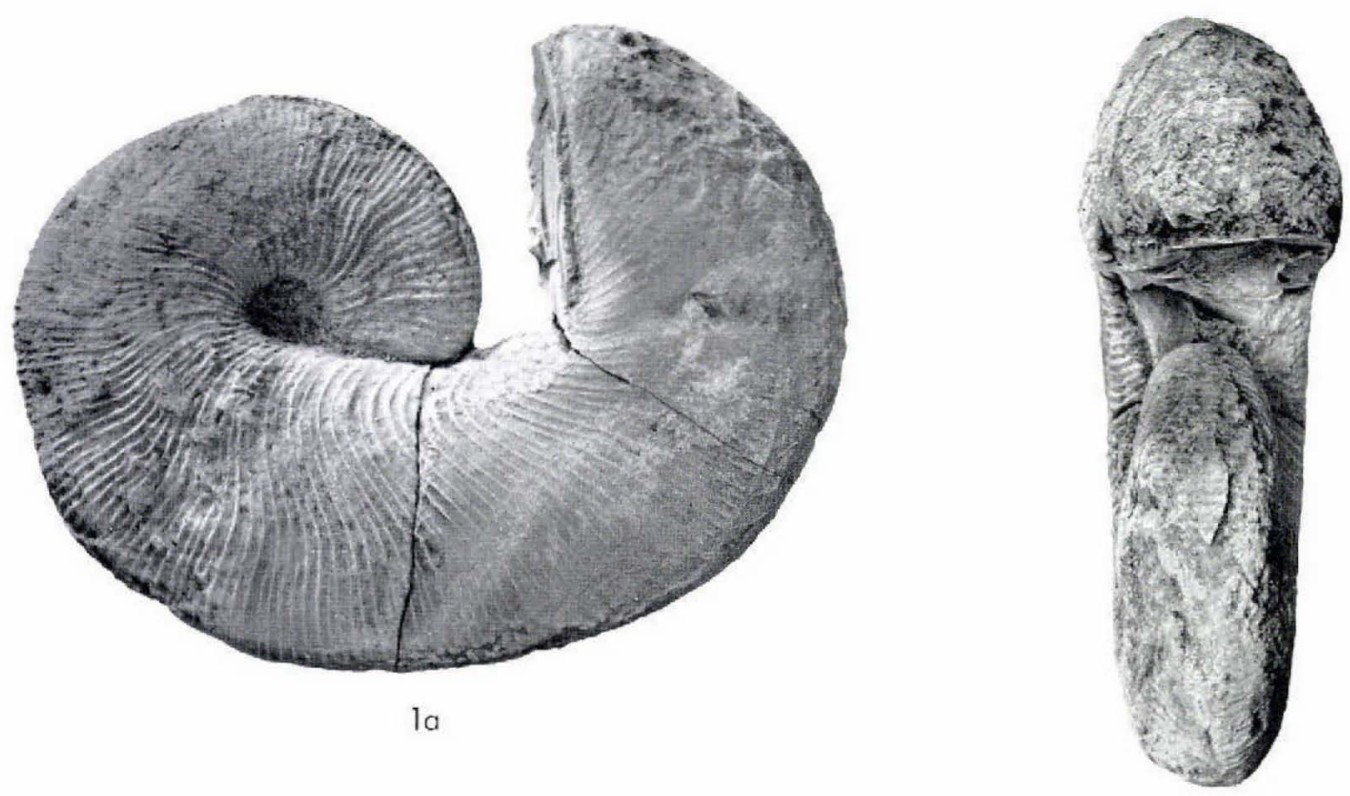

16

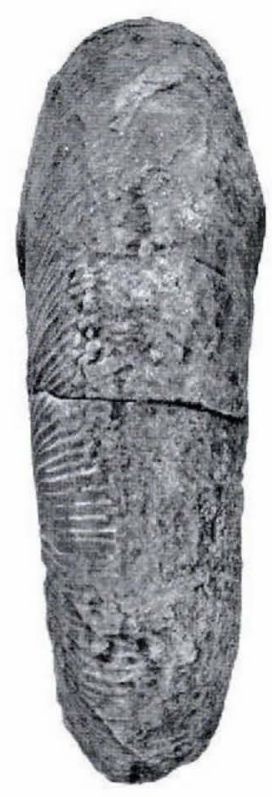

1c

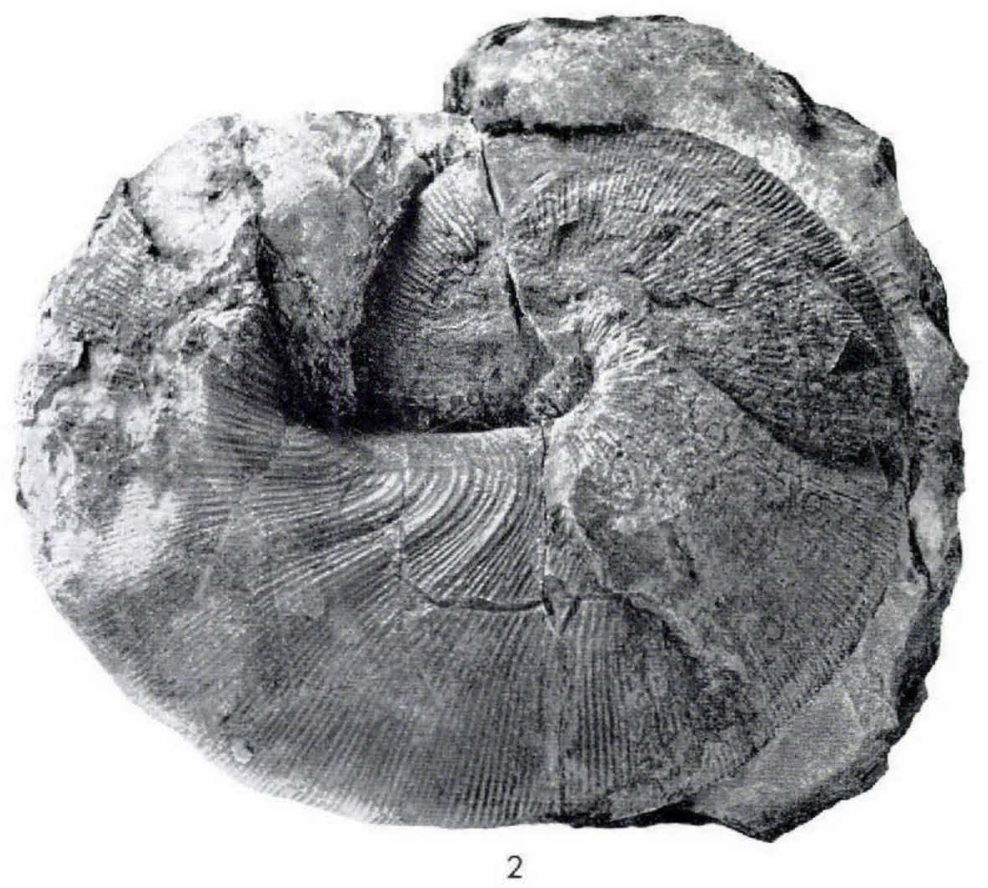




\section{Plate 30}

Scaphites (Hoploscaphites) greenlandicus Donovan (p.110).

1a-b. MMH No.9828. Lateral and peripheral views. Upper Campanian. Niaqornat.

2. MMH No. 9829. Lateral view of body chamber. Upper Campanian. Niaqornat.

3a-c. MMH No. 9830. Lateral and peripheral views of specimen tentatively referred to this species. Upper Campanian? Oyster-ammonite Conglomerate loc. II. 
PLATE 30

Bo. 179, Ne. 7. [Tove Bifikeluad
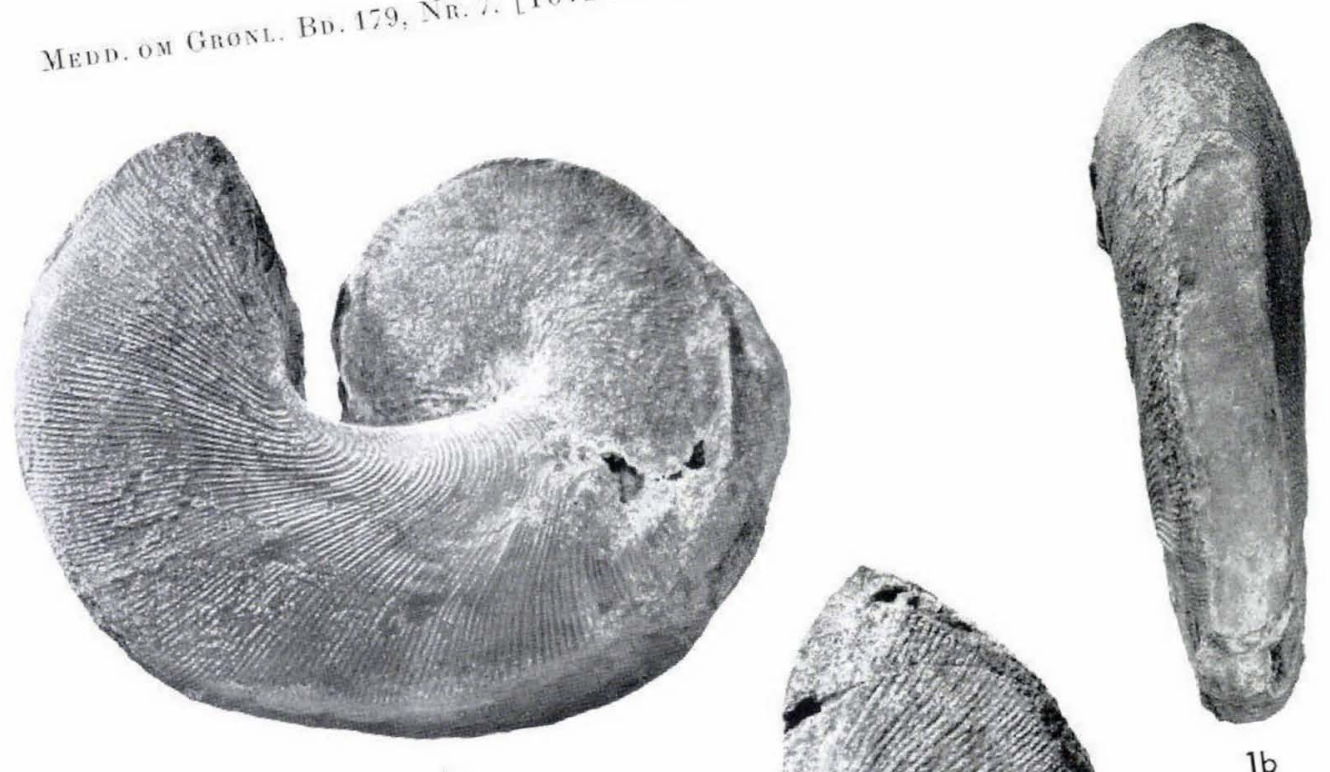

la

$1 \mathrm{~b}$

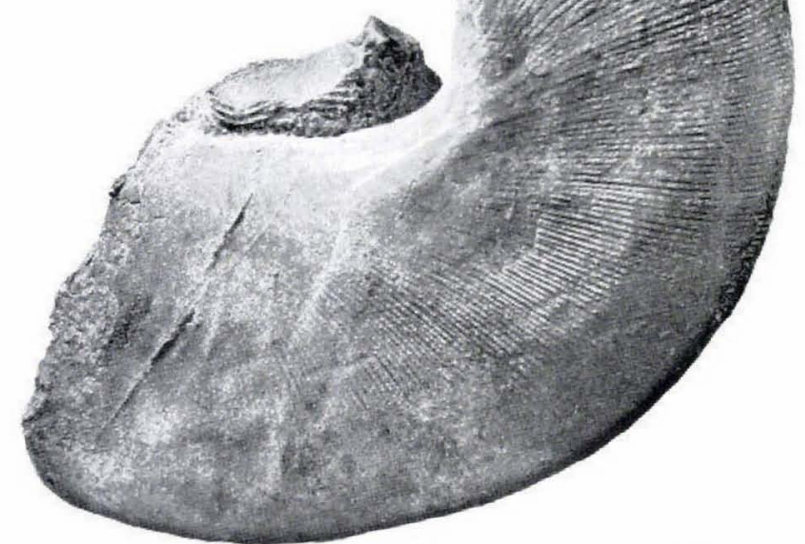

2
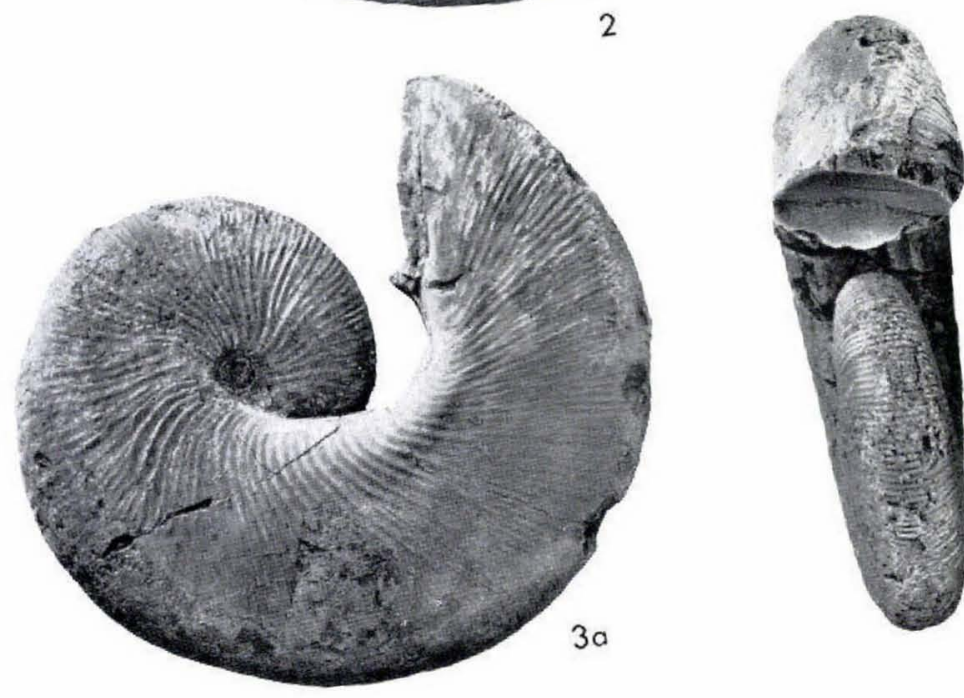

$3 b$

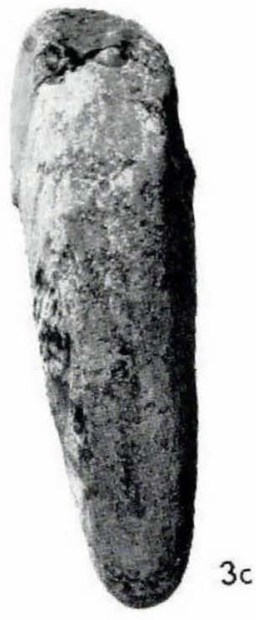




\section{Plate 31}

Scaphites (Hoploscaphites) greenlandicus Donovan (p. 110).

1. MMH No. 9831. Lateral view. Upper Campanian. Niaqornat.

2a-c. MMH No. 9832. Lateral and peripheral views of phragmocone tentatively referred to this species. Upper Campanian? Oyster-ammonite Conglomerate loc. III. 


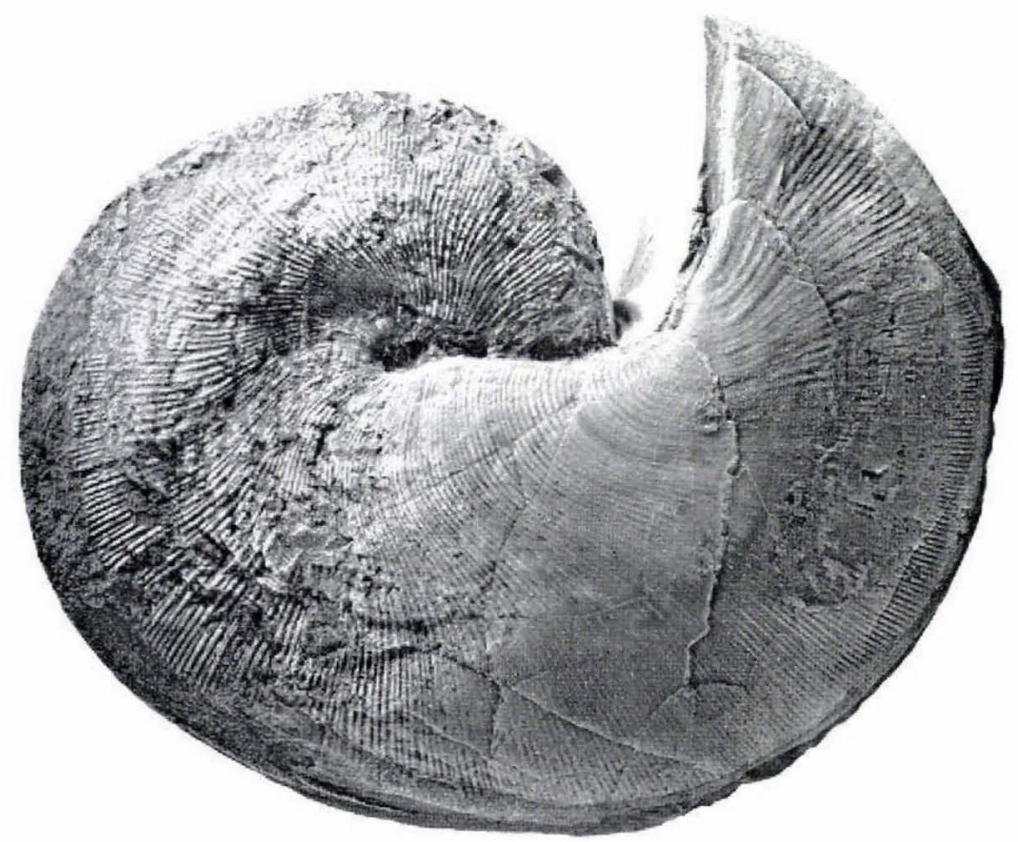

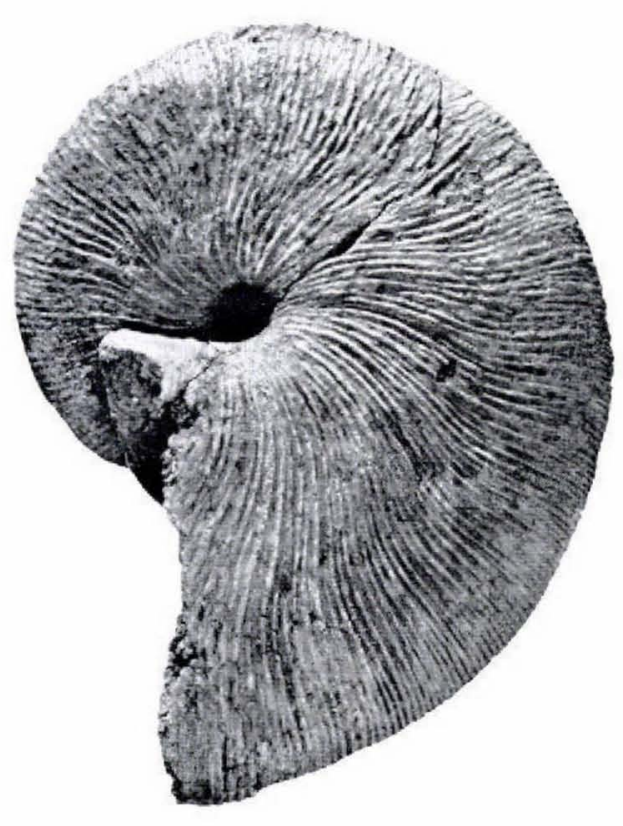

$2 a$

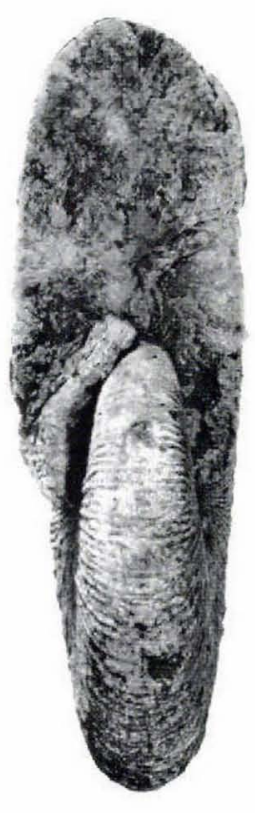

$2 b$

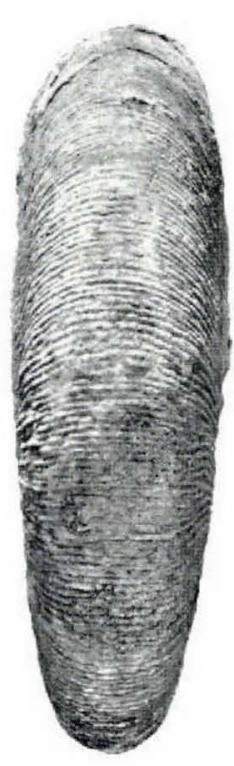

$2 c$ 


\section{Plate 32}

Scaphites (Hoploscaphites) sp.aff. greenlandicus Donovan (p. 113).

1a-c. MMH No.9833. Lateral and peripheral views of specimen with damaged and regenerated shell. Upper Campanian. Vestre Konglomeratkløft at Angnertuneq, $110 \mathrm{~m}$ above sea-level. 


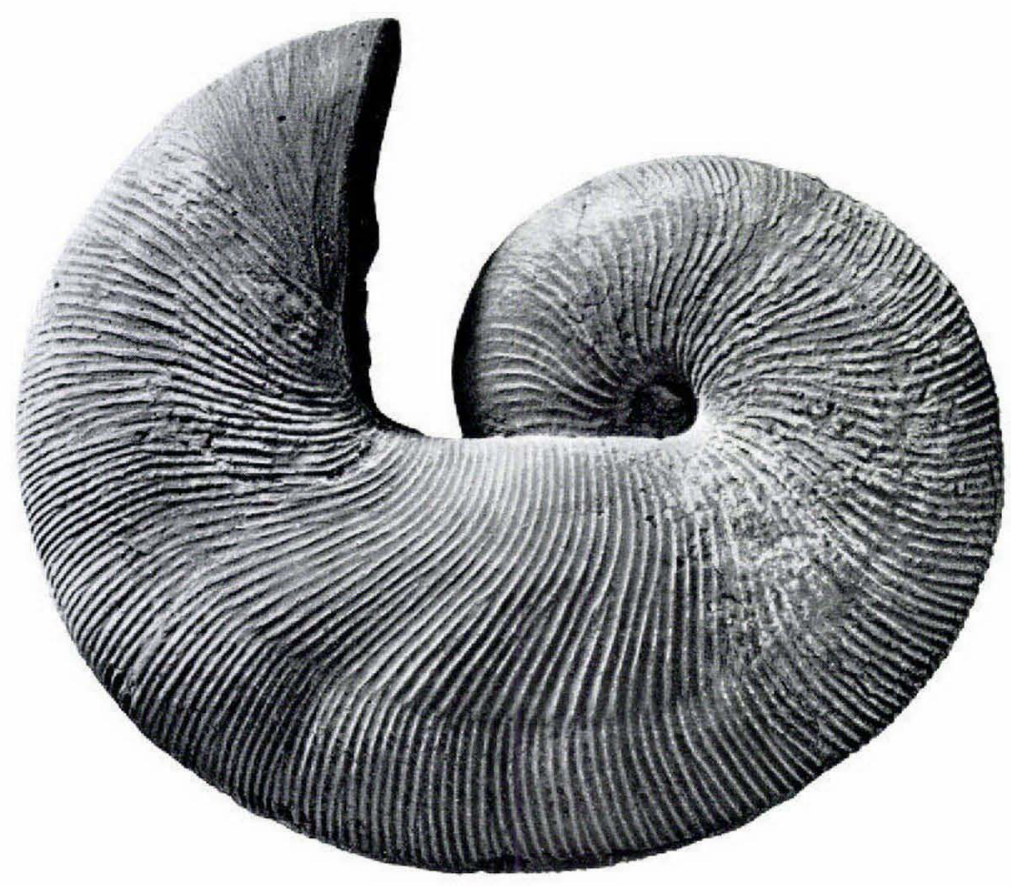

la

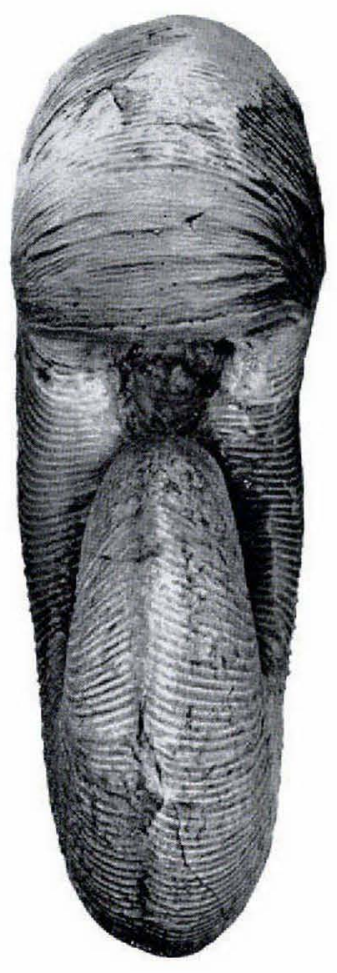

16

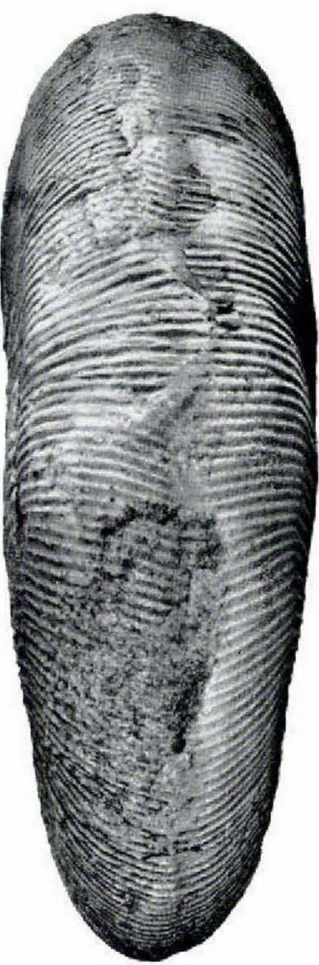

ic 


\section{Plate 33}

Scaphites (Hoploscaphites) sp. aff. greenlandicus Dovovan (p. 113).

1a-c. MMH No. 9834. Lateral and peripheral views. Upper Campanian. Scaphitesryggen at Angnertuneq. 


$$
8
$$




\section{Plate 34}

Scaphites (Hoploscaphites?) sp. (p. 116).

1 a-b. MMH No. 9835. Lateral and peripheral views. Upper Campanian. Brudkløft at Ikorfat, $550 \mathrm{~m}$ above sea-level.

2a-b. MMH No. 9836. Lateral and peripheral views of fragmentary body chamber. Upper Campanian. Brudkløft at Ikorfat, $550 \mathrm{~m}$ above sealevel. 

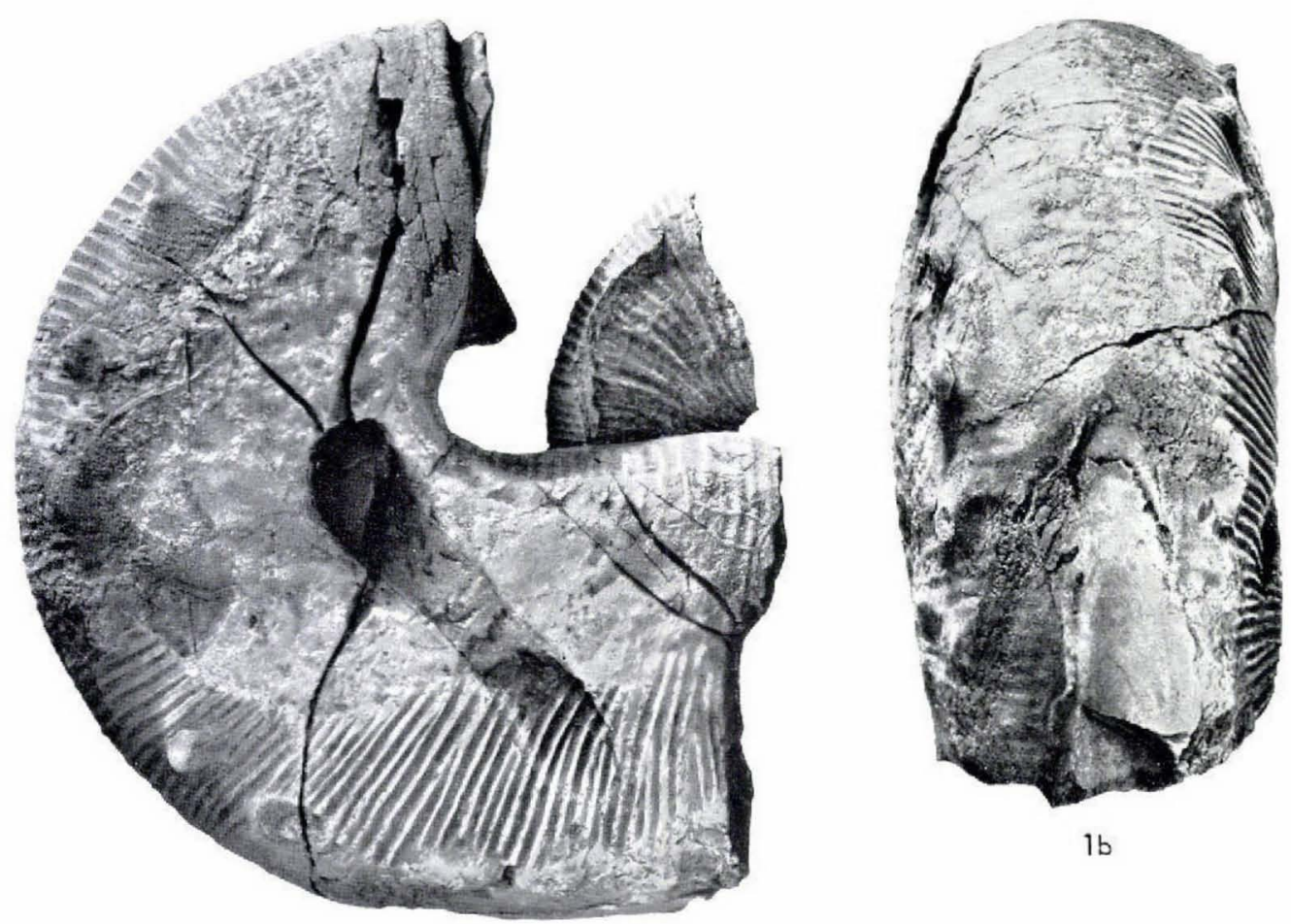

$1 b$

la
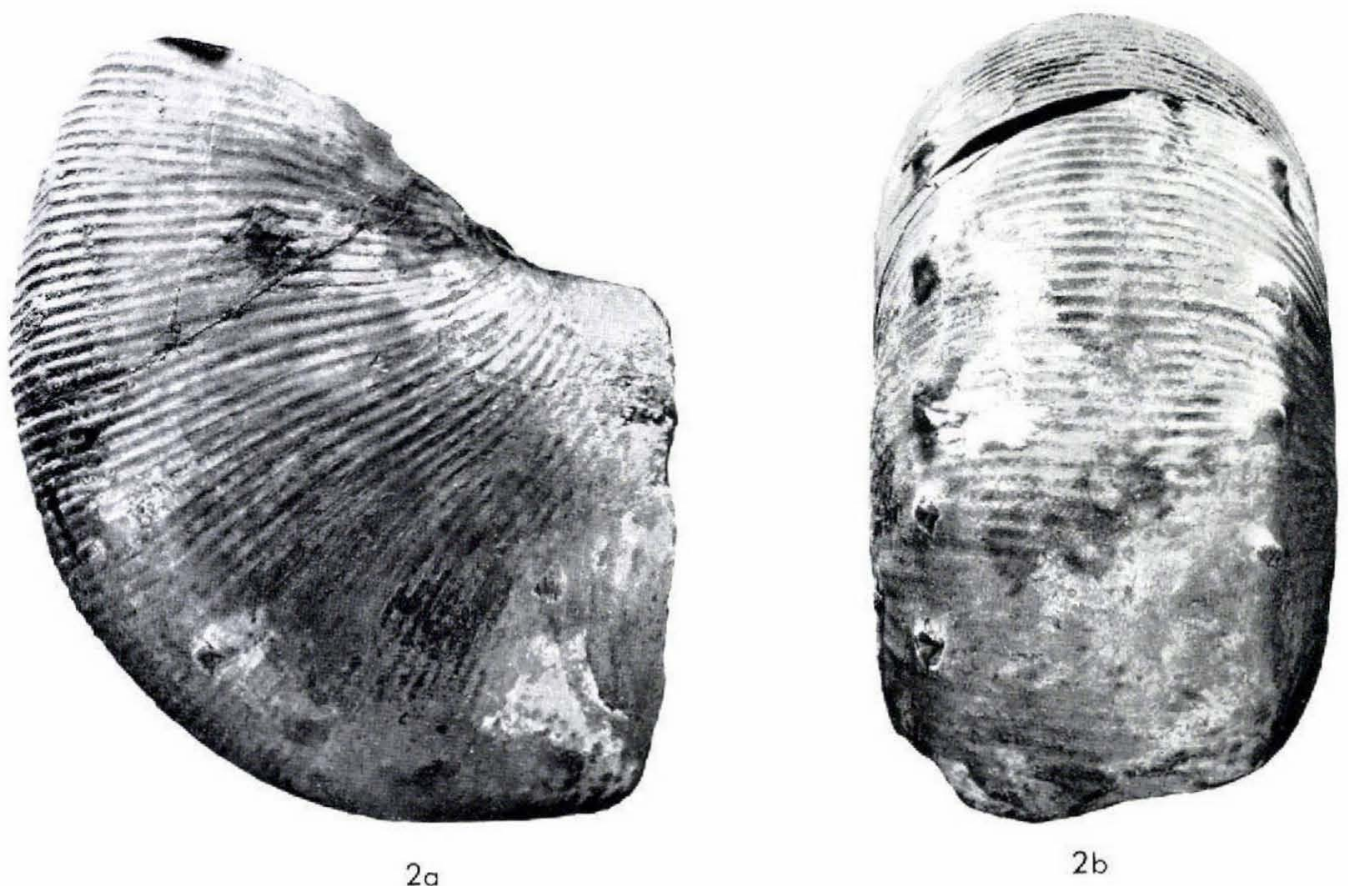


\section{Plate 35}

Scaphites (Discoscaphites) waagei n.sp. (p. 117).

1 a-c. Holotype. MMH No. 9837. Lateral and peripheral views. Maastrichtian. Oyster-ammonite Conglomerate loc. I.

2a-b. MMH No. 9838. Lateral and peripheral views. Maastrichtian. Oysterammonite Conglomerate loc. I. 


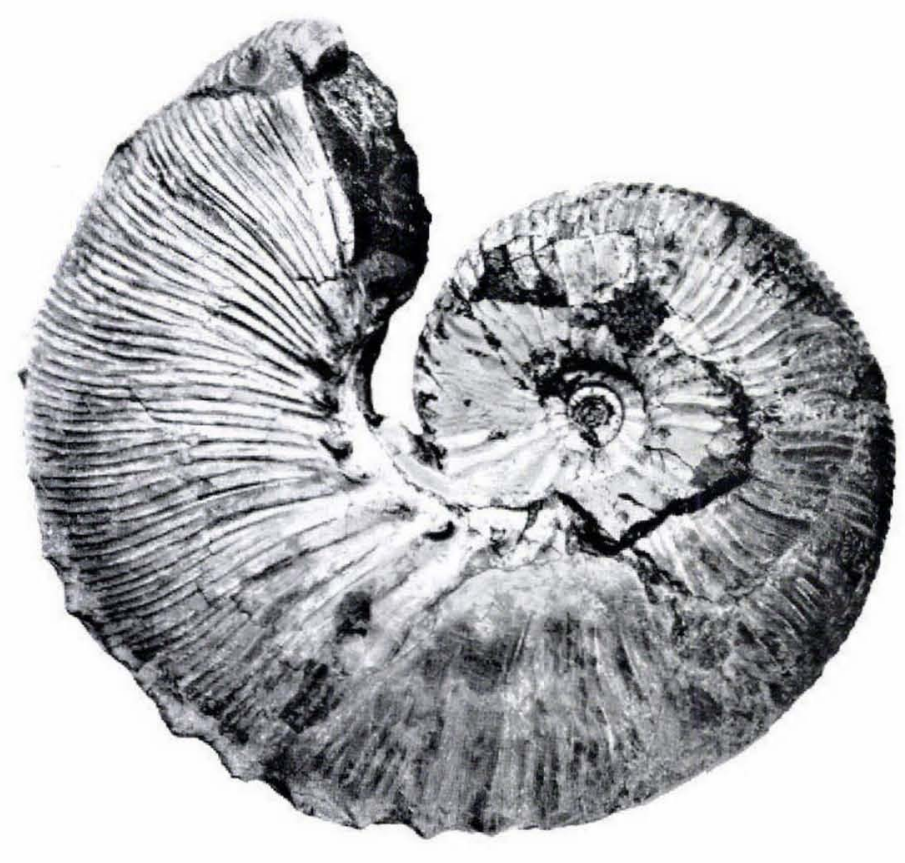

lo

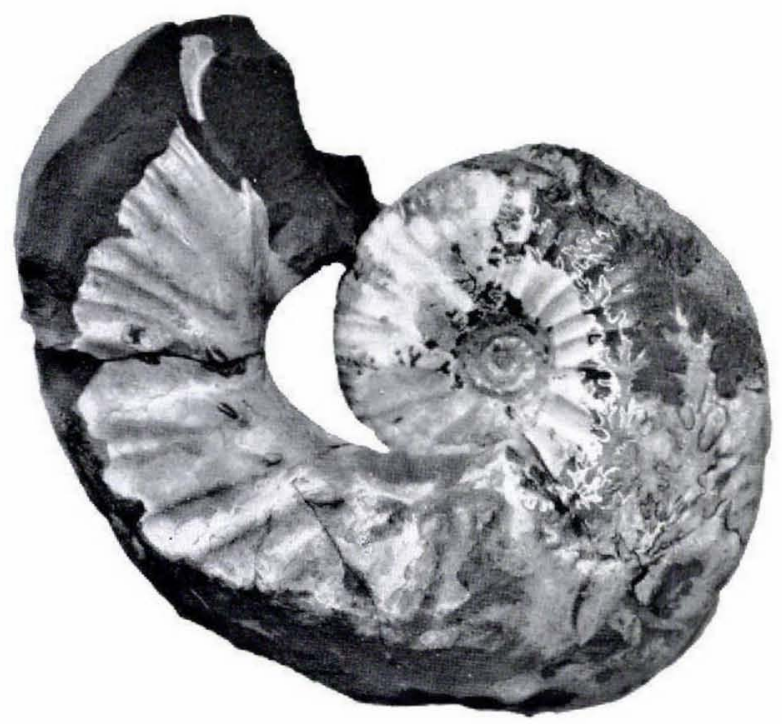

$2 a$

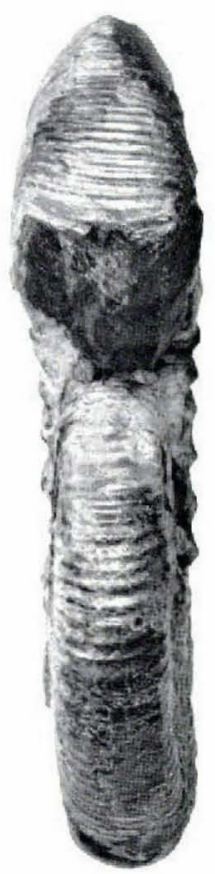

lb

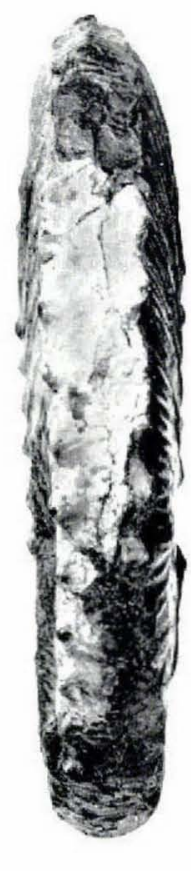

lc

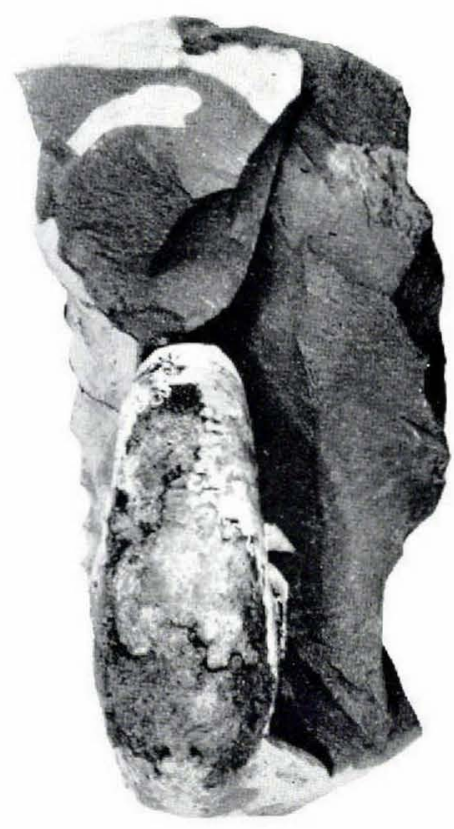

$2 b$ 


\section{Plate 36}

Scaphites (Discoscaphites) waagei n.sp. (p. 117).

1 a-b. MMH No. 9839. Lateral and peripheral views. Maastrichtian. Oysterammonite Conglomerate loc. I.

2a-b. MMH No. 9840. Lateral and peripheral views. Maastrichtian. Oysterammonite Conglomerate loc. II.

3. MMH No. 9841. Lateral view. Maastrichtian. Oyster-ammonite Conglomerate loc. I. 

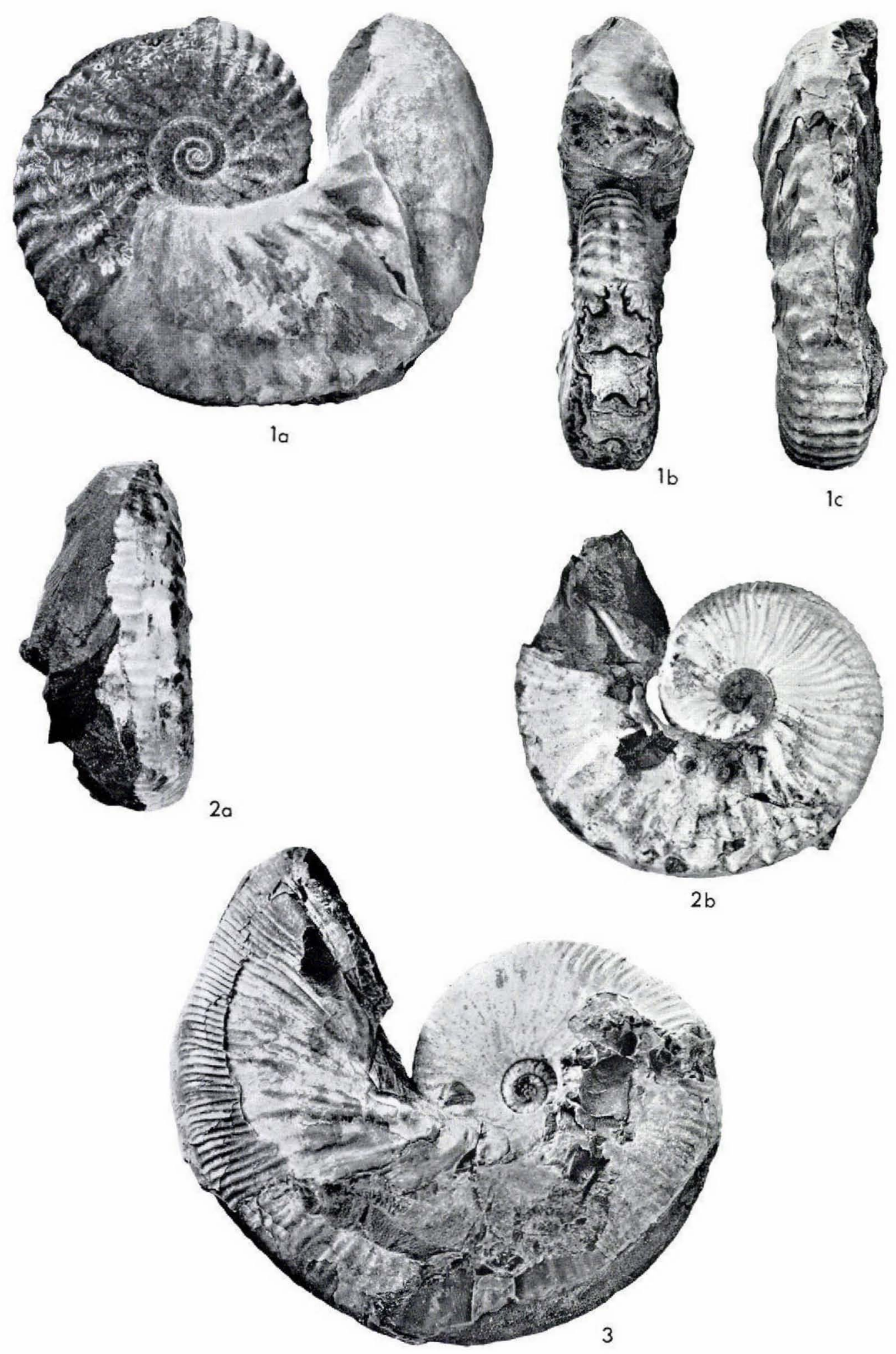


\section{Plate 37}

Scaphiles (Discoscaphites) waagei n.sp. (p.117).

1a-b. MMH No. 9842. Lateral and peripheral views. Maastrichtian. Oysterammonite Conglomerate loc. I.

2a-b. MMH No. 9843. Lateral and peripheral views. Maastrichtian. Oysterammonite Conglomerate loc. I. 


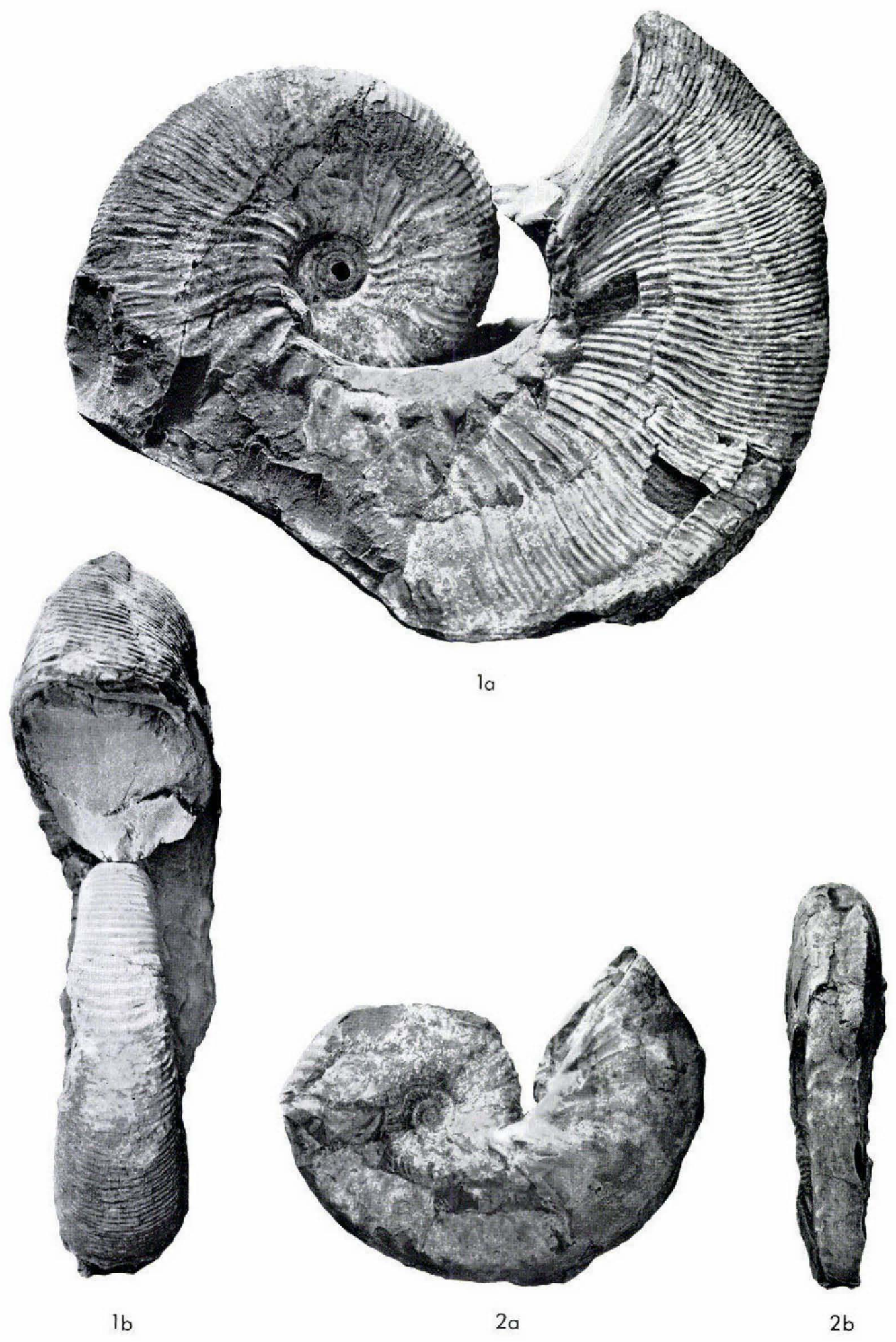




\section{Plate 38}

Scaphites (Discoscaphites) waagei n.sp. (p. 117).

1a-b. MMH No. 9844. Lateral and peripheral views of partly reconstructed specimen. Maastrichtian. Oyster-ammonite Conglomerate loc. I.

Scaphites (Discoscaphites) angmartussutensis n.sp. (p. 124).

2a-b. MMH No. 9845. Lateral and peripheral views. Maastrichtian. Oysterammonite Conglomerate loc. I. 

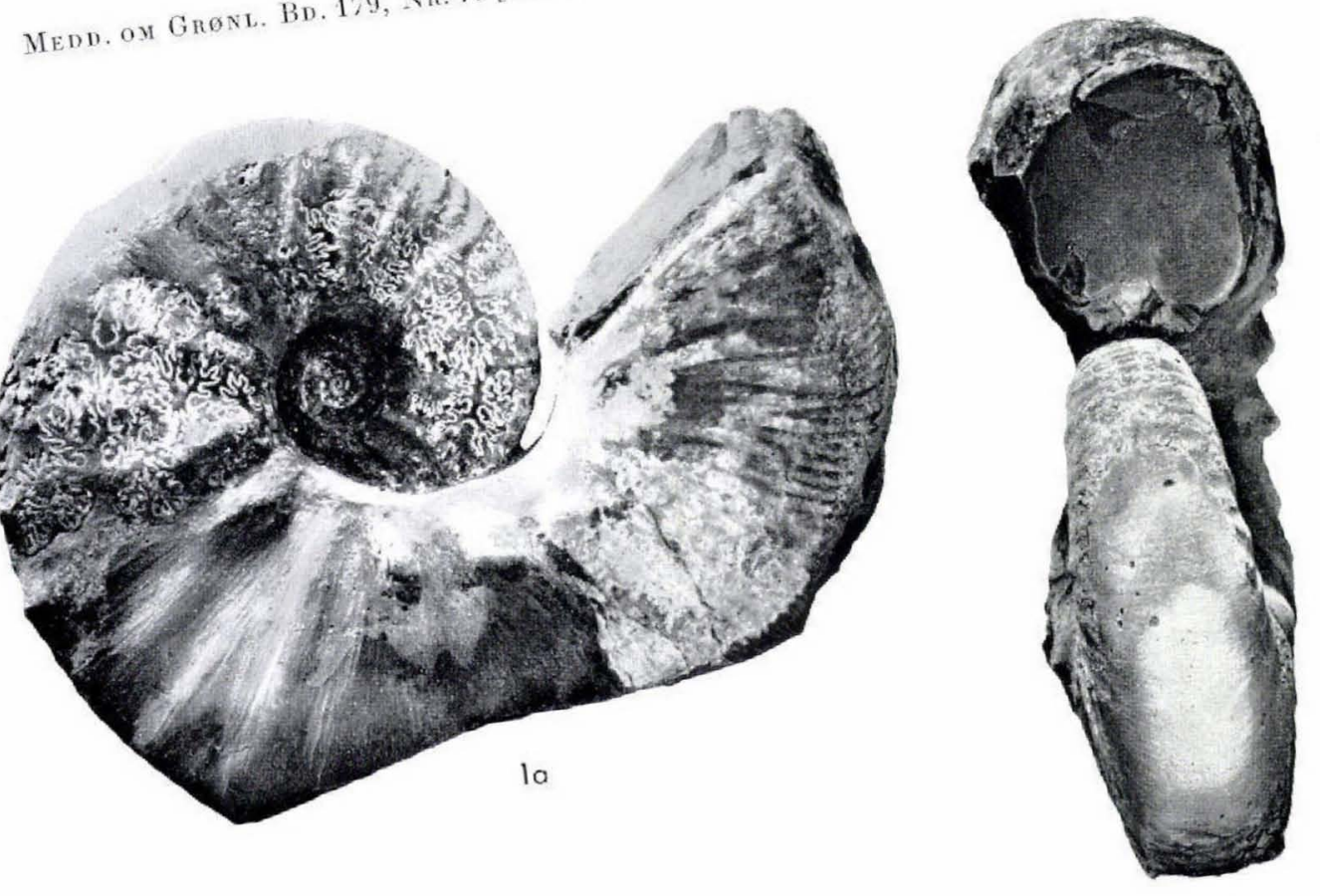

Ib
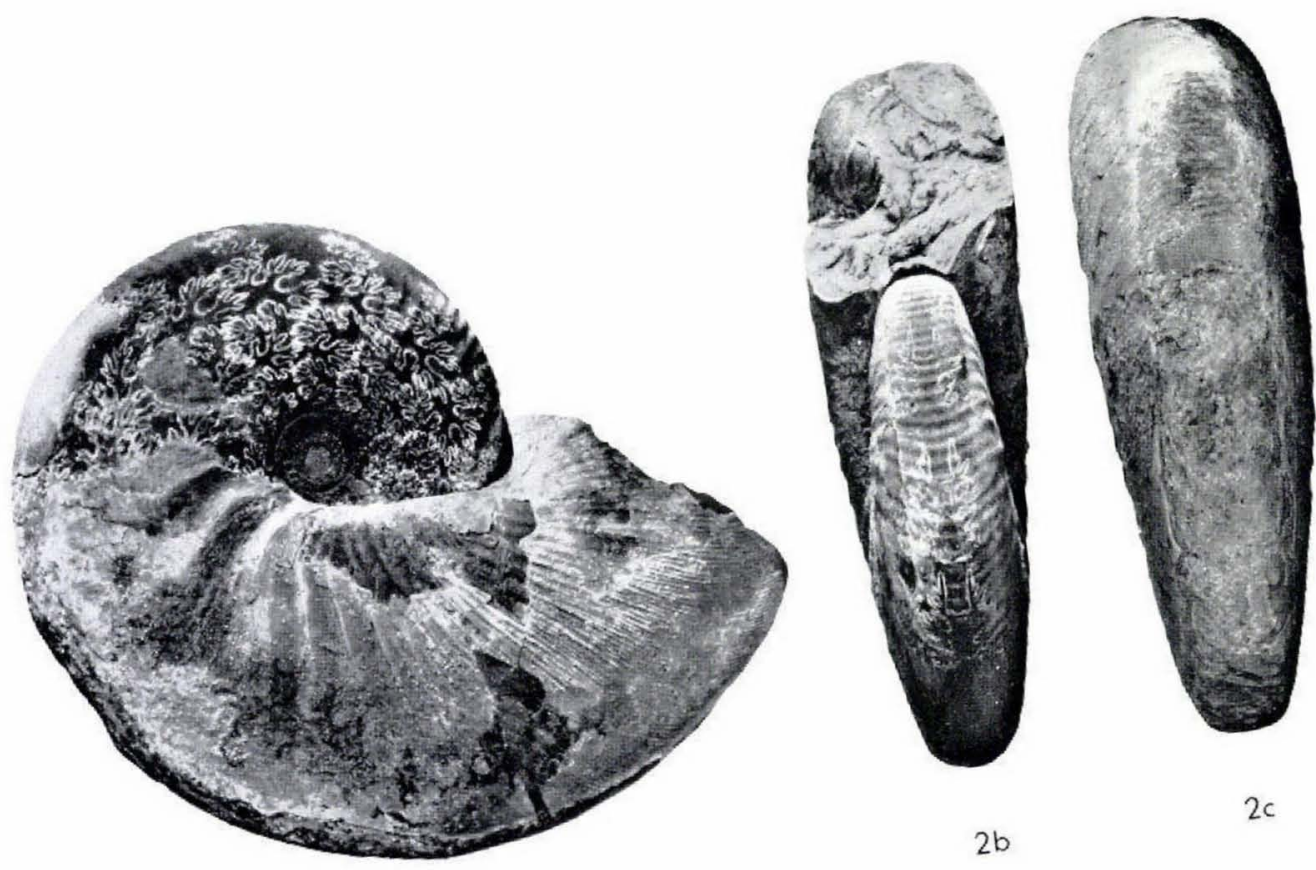

$2 a$ 


\section{Plate 39}

Scaphites (Discoscaphites) angmartussutensis n.sp. (p. 124).

1a-c. Holotype. MMH No.9846. Lateral and peripheral views. Maastrichtian. Oyster-ammonite Conglomerate loc. III. 

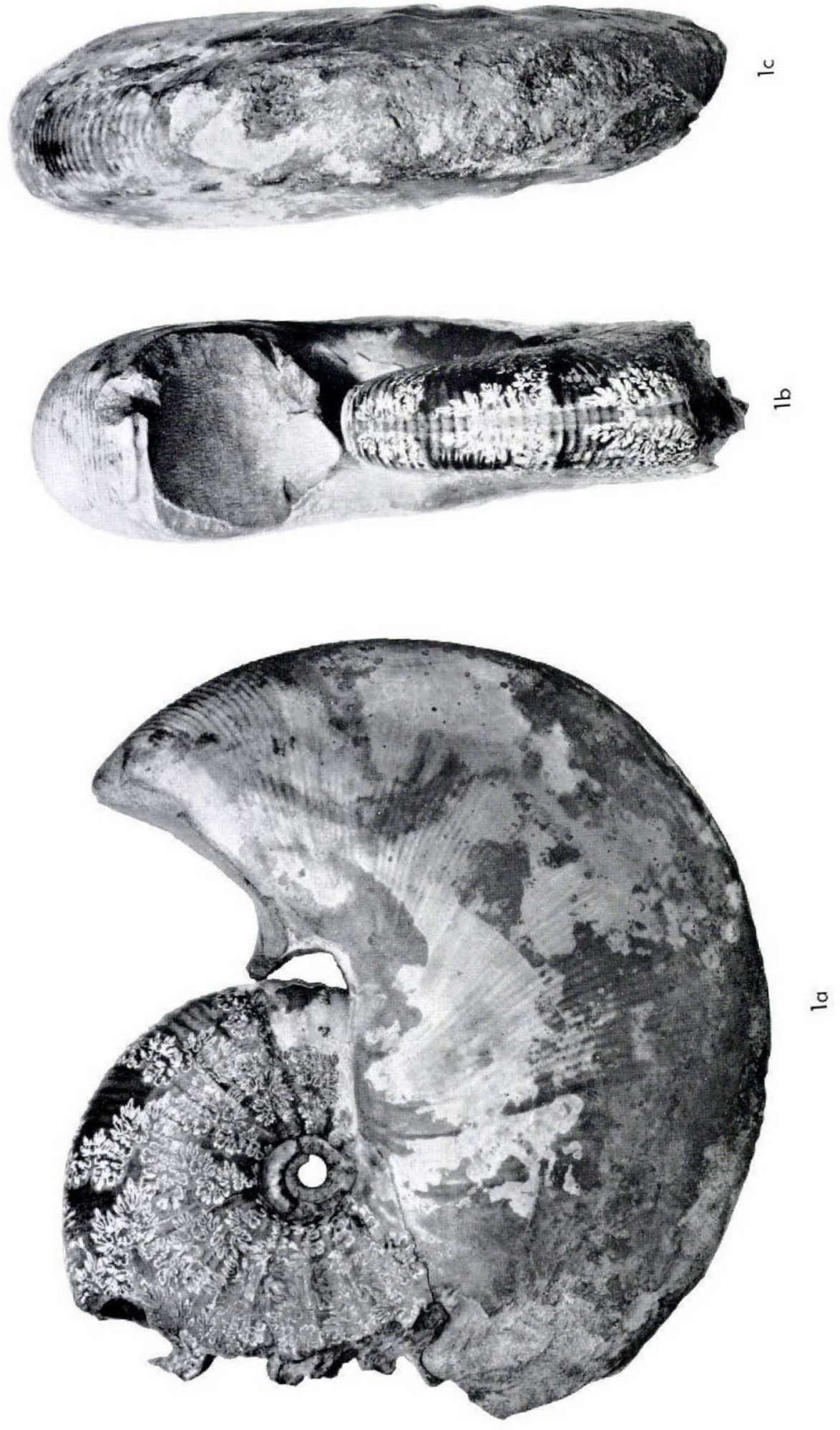


\section{Plate 40}

Scaphites (Discoscaphites) angmartussutensis n.sp. (p. 124).

1. Holotype. MMH No. 9846. Lateral view of plastic cast of the external mould. Maastrichtian. Oyster-ammonite Conglomerate loc. III.

2a-b. MMH No. 9847. Lateral and peripheral views of phragmocone (also figured pl. 41, fig. 1). Maastrichtian. Oyster-ammonite Conglomerate loc. III. 


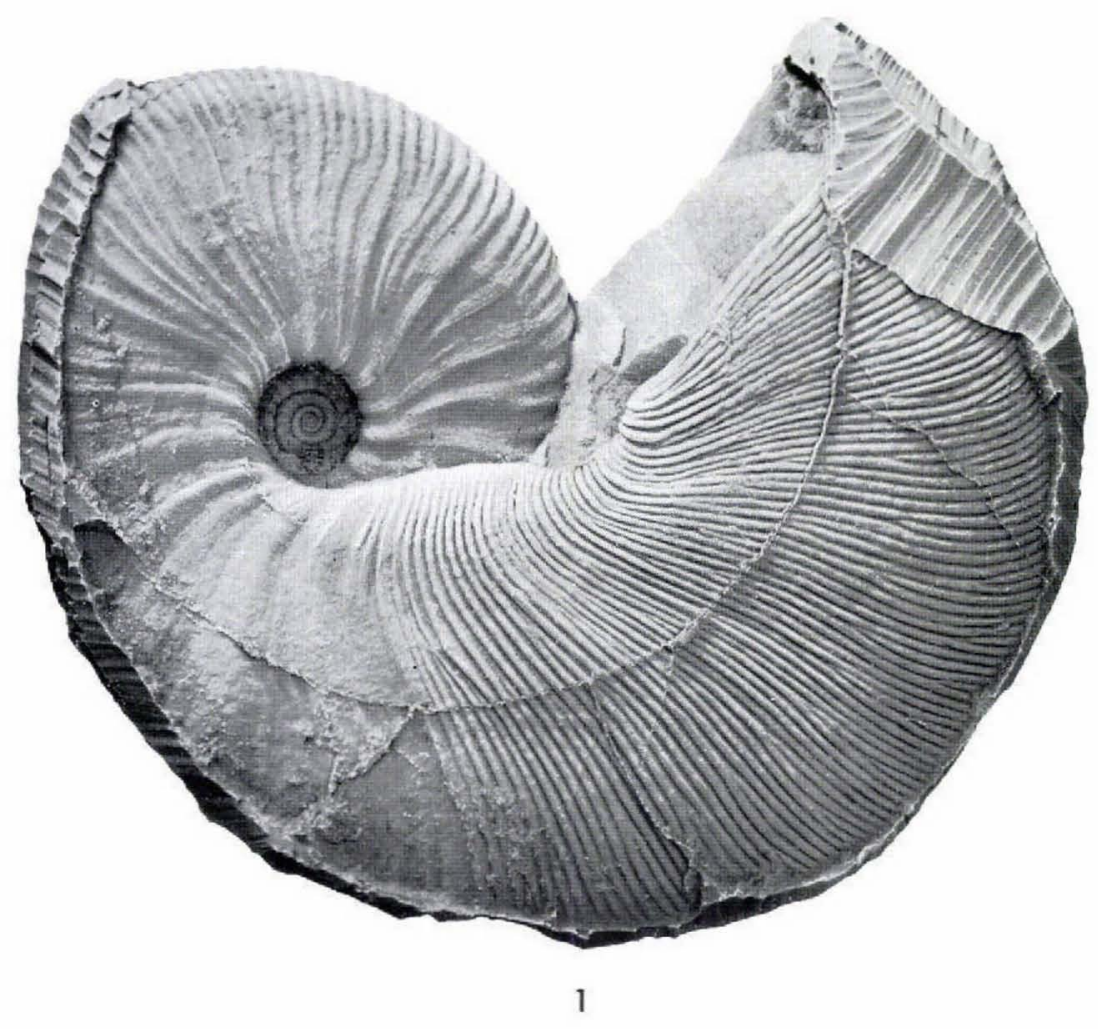

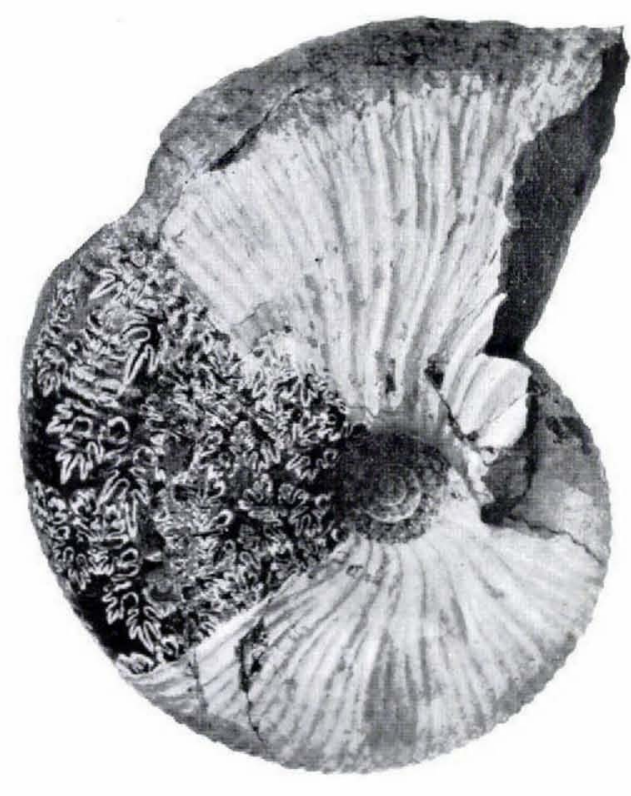

2a

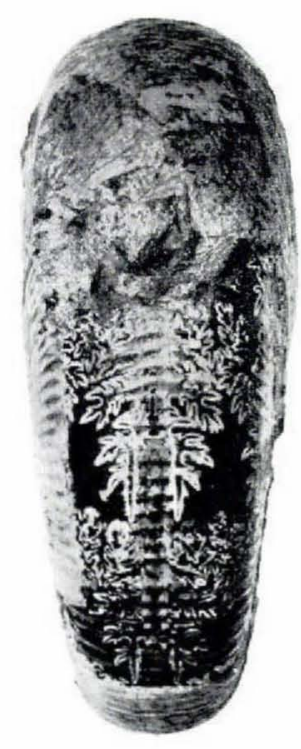

$2 b$ 


\section{Plate 41}

Scaphites (Discoscaphites) angmartussutensis n.sp. (p. 124).

1. MMH No. 9847. Lateral view of large specimen (the phragmocone also figured pl. 40, figs. 2a-b). Maastrichtian. Oyster-ammonite Conglomerate loc. III. 


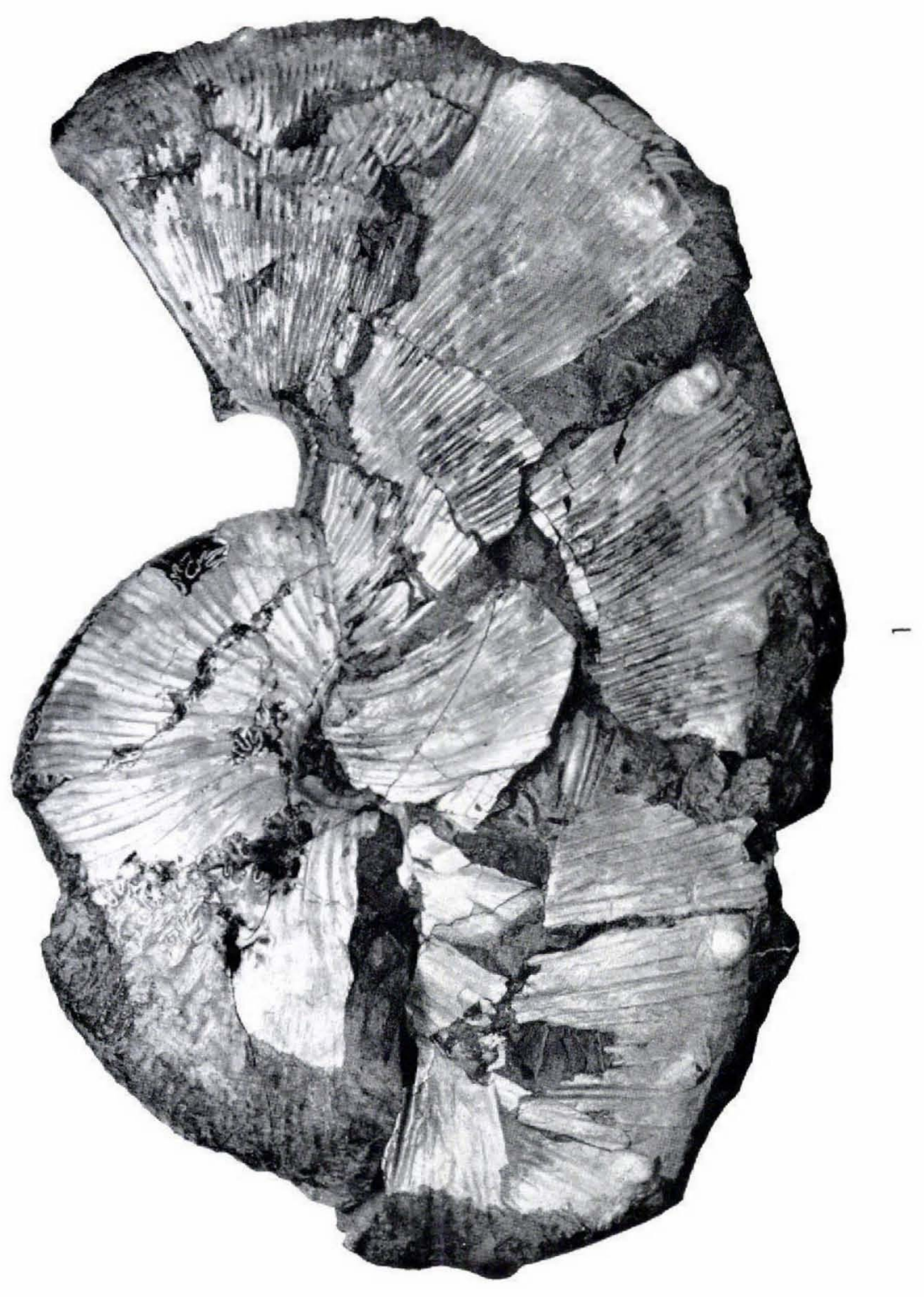




\section{Plate 42}

Scaphites (Discoscaphites) angmartussutensis n.sp.? (p. 126).

1 a-b. MMH No. 9848. Lateral and peripheral views. Maastrichtian. Oysterammonite Conglomerate loc. I.

Scaphites (Discoscaphites) sp. aff. angmartussutensis n. sp. (p. 130).

2. MMH No. 9849. Lateral view. Maastrichtian? Niaqqornat. 


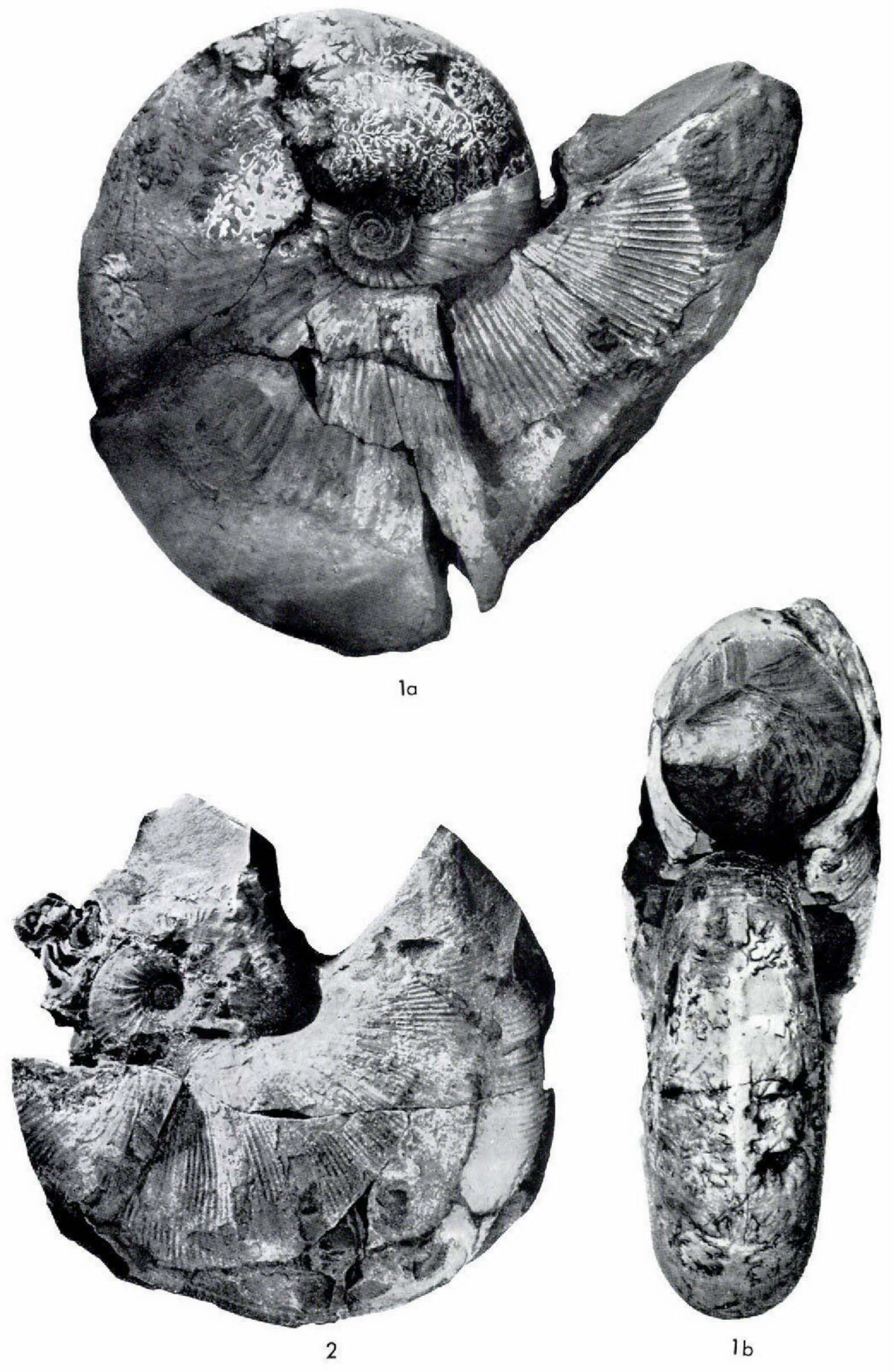




\section{Plate 43}

Scaphites (Discoscaphites) sp. aff. angmartussutensis n. sp. (p. 130).

1. MMH No. 9850. Lateral view. Maastrichtian. Hamiteskløft, $240 \mathrm{~m}$ above sea-level.

2a-b. MMH No. 9851. Peripheral and lateral views of specimen with phragmocone and part of body chamber preserved. Maastrichtian. Ikorfatnæsen, $990 \mathrm{~m}$ above sea-level. 


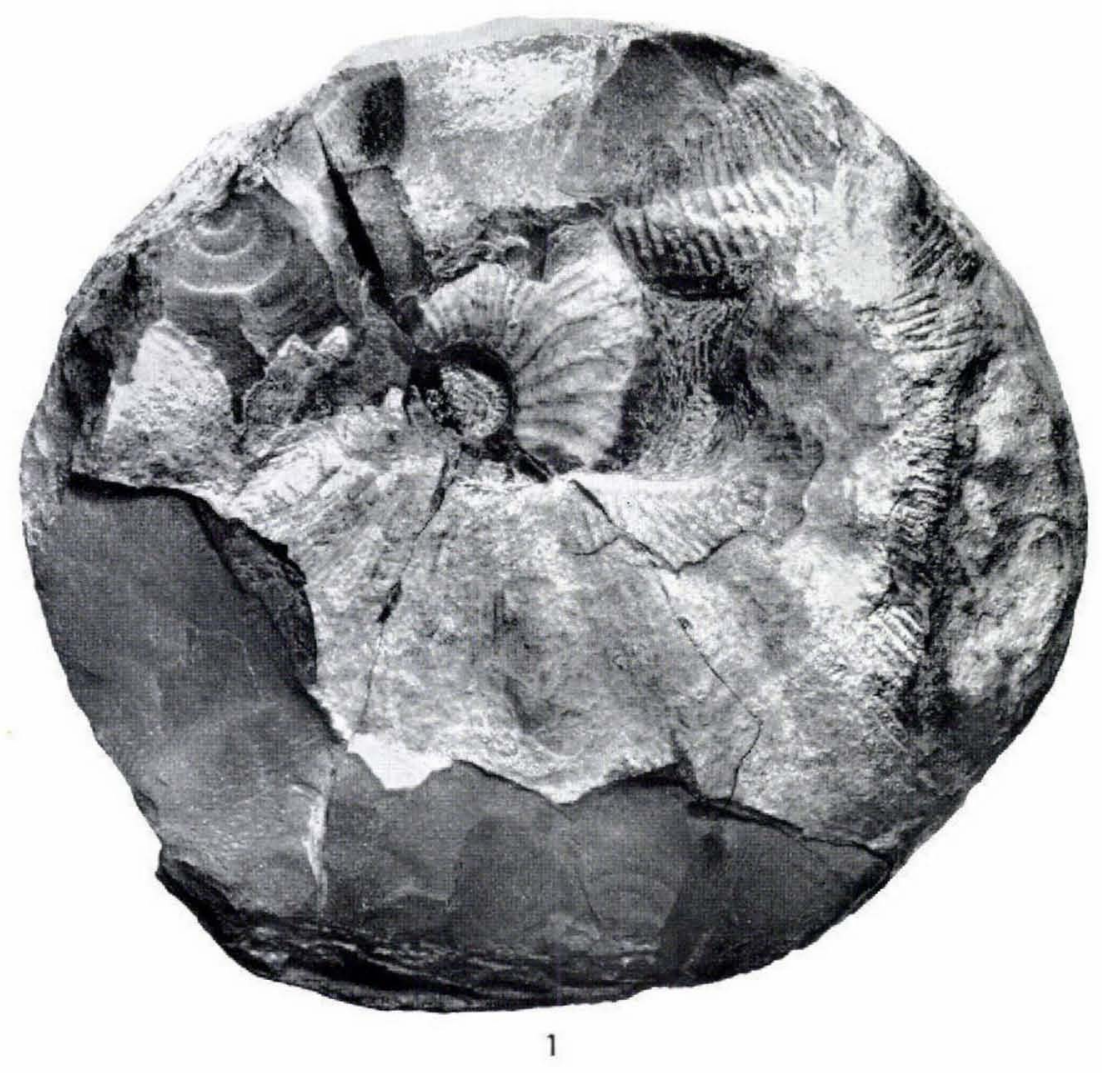

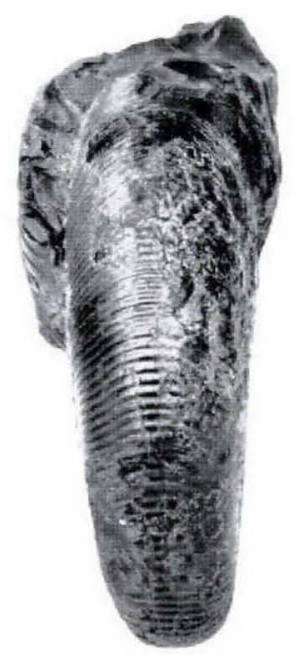

$2 a$

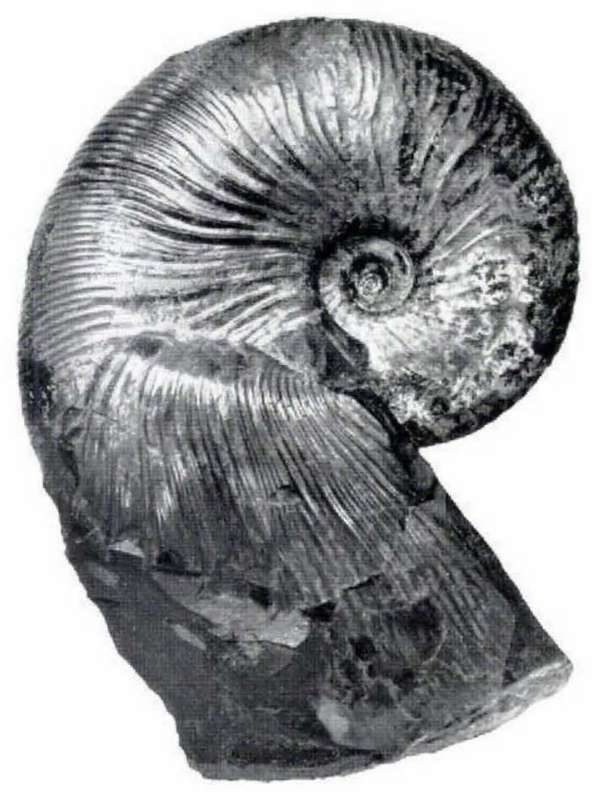

$2 b$ 


\section{Plate 44}

Scaphites (Discoscaphites) angmartussutensis n. sp. (p. 124).

1. MMH No. 9852. Lateral view. Maastrichtian. Oyster-ammonite Conglomerate loc. I.

2. MMH No. 9853. Lateral view of body chamber with lateral nodes. Maastrichtian. Oyster-ammonite Conglomerate loc. I.

Scaphites (Discoscaphites) sp. (p. 130).

3a-b. MMH No. 9854. Peripheral and lateral views of fragmentary body chamber. Maastrichtian. Ikorfat pass, $970 \mathrm{~m}$ above sea-level.

4. MMH No. 9855. Lateral view. Maastrichtian. Ikorfatnæsen, 980-985 m above sea-level.

5a-b. MMH No. 9856. Lateral and peripheral views of fragmentary phragmocone. Maastrichtian. Ikorfatnæsen, $980-985 \mathrm{~m}$ above sea-level. 


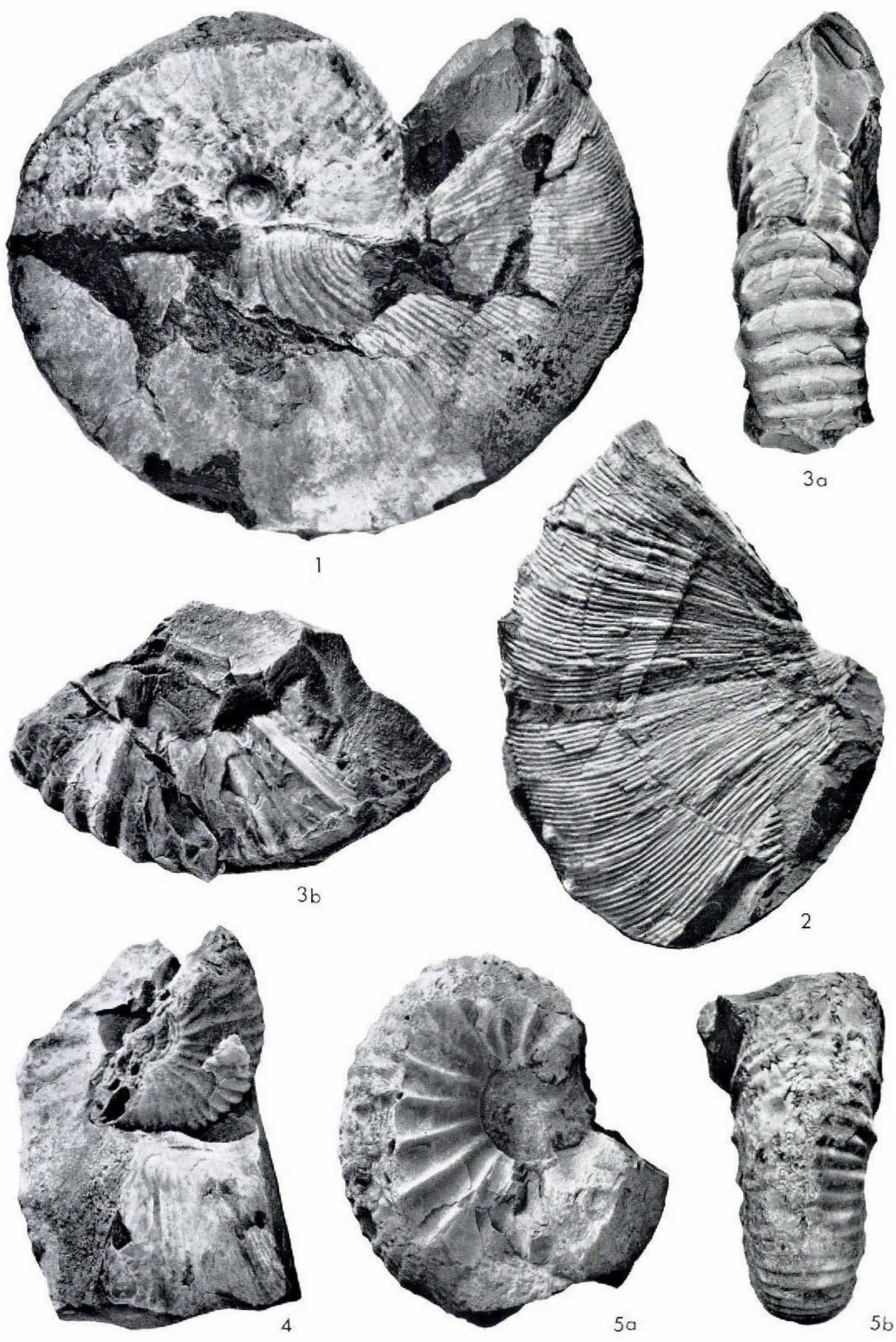




\section{Plate 45}

Scaphites (Discoscaphites) sp. aff. angmartussutensis n. sp. (p. 130).

1. MMH No. 9857. Lateral view. Maastrichtian. Ikorfatnæsen, 980-985 m above sea-level.

Clioscaphites saxitonianus septentrionalis $\mathrm{n}$. subsp. (p. 132).

2a-c. MMH No. 9858. Lateral and peripheral views. Santonian. Store Niaqornak Kløft, $60 \mathrm{~m}$ above sea-level.

3a-c. MMH No. 9859. Lateral and peripheral views. Santonian. Lille Tange V Kløft, horizon IV.

4. MMH No. 9860. Lateral view. Santonian. Lille Tange V Kløft, horizon III.

5. MMH No. 9861. Lateral view. Santonian. Lille Tange V Kløft, horizon VI. 

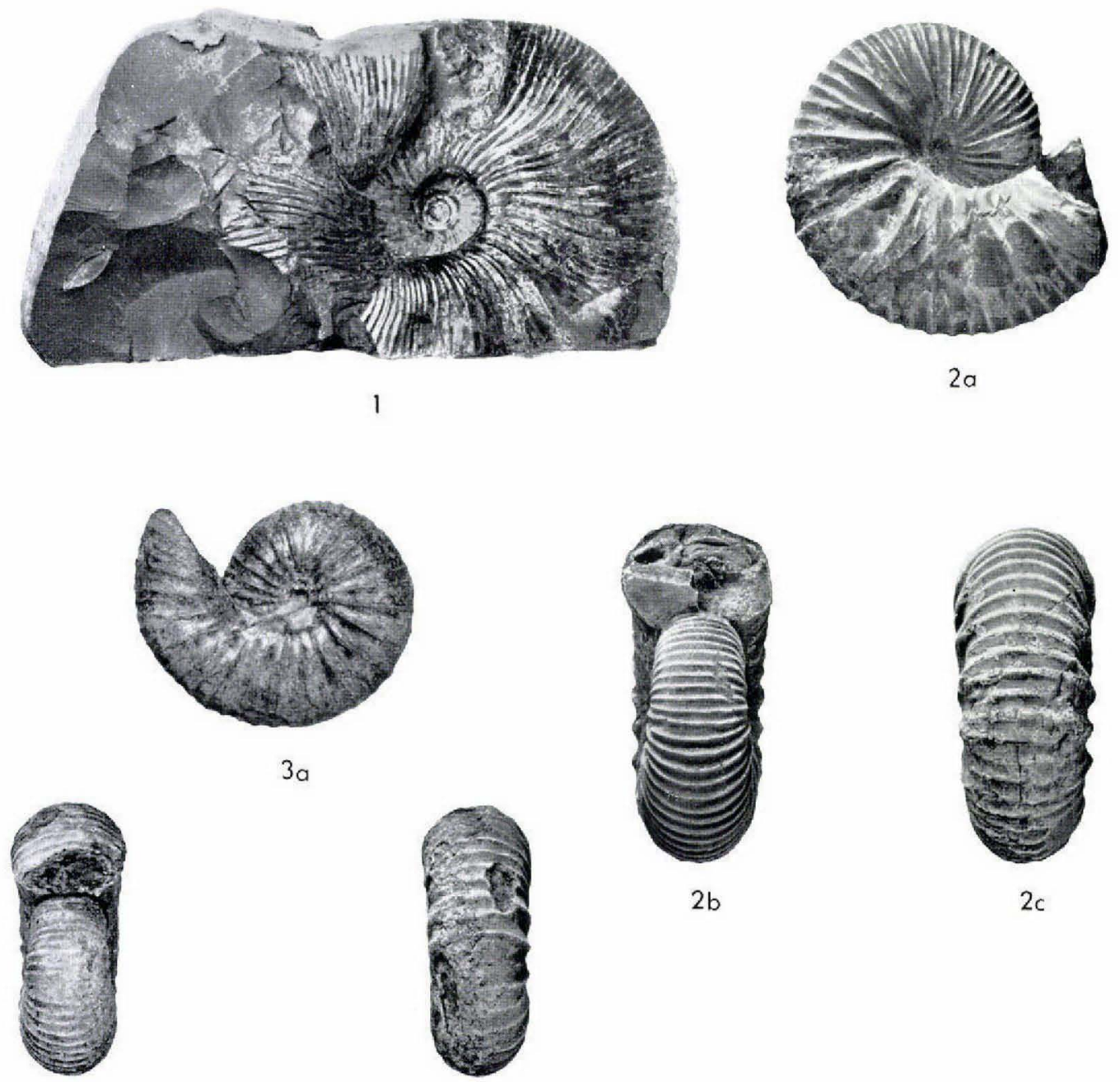

$2 b$

$2 c$

$3 b$

$3 c$

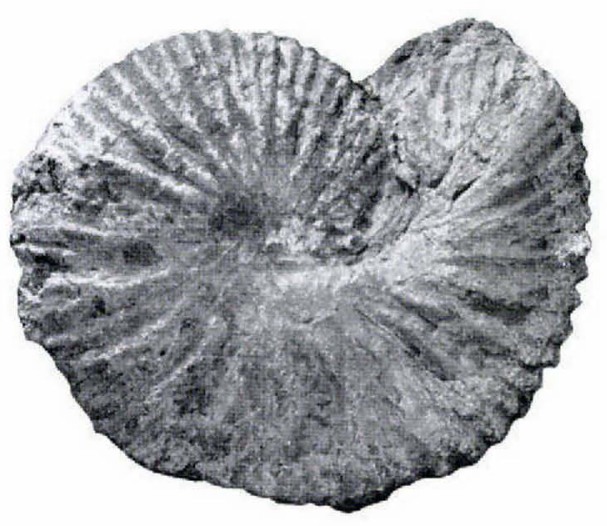

4

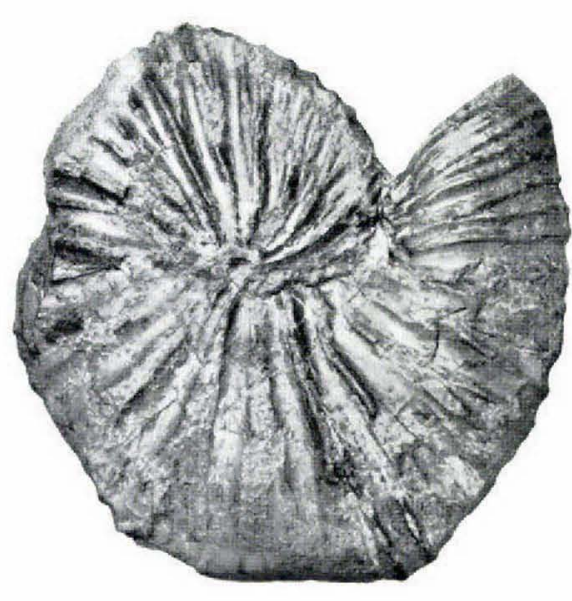

5 


\section{Plate 46}

Clioscaphites saxitonianus septentrionalis $\mathrm{n}$. subsp. (p. 132).

1 a-b. Holotype. MMH No. 9862. Lateral and peripheral views. Santonian. Lille Tange V Kløft, horizon IV.

2a-b. MMH No. 9863. Lateral and peripheral views. Santonian. Lille Tange V Kløft, horizon IV.

3a-b. MMH No. 9864. Lateral and peripheral views. Santonian. Lille Tange V Kløft, horizon VI.

Clioscaphites sp. aff. saxitonianus (McLears) (p. 135).

4a-b. MMH No. 9865. Peripheral and lateral views of fragmentary body chamber. Santonian. Tuperssuartâ, $82 \mathrm{~m}$ west of dolerite sill $\mathrm{A}$.

5. MMH No. 9866. Lateral view of fragmentary body chamber. Santonian. Tuperssuartâ, $82 \mathrm{~m}$ west of dolerite sill $\mathrm{A}$.

6. MMH No. 9867. Peripheral view of fragmentary body chamber. Santonian. Tuperssuartâ, $82 \mathrm{~m}$ west of dolerite sill A.

7a-b. MMH No. 9868. Lateral and peripheral views. Santonian. Tunorqo, $770 \mathrm{~m}$ above sea-level. 

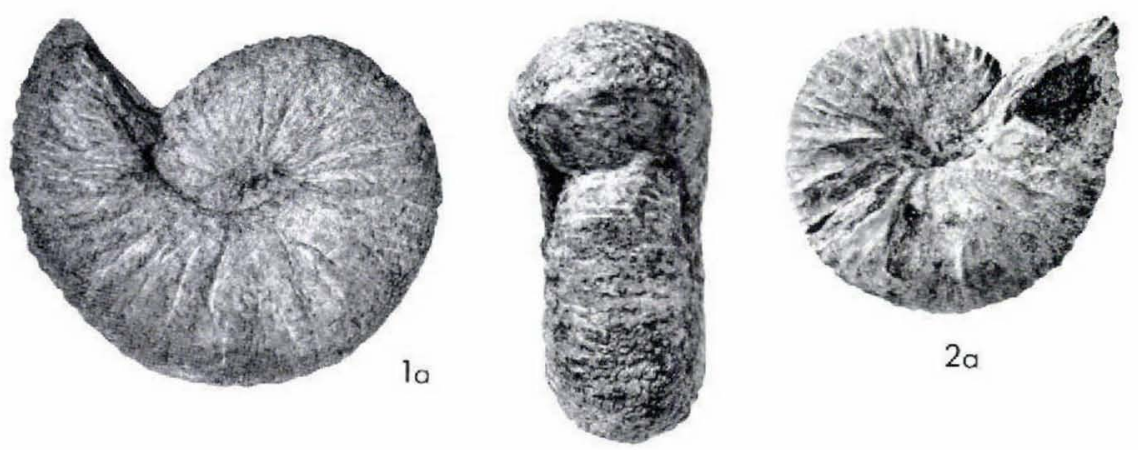

$1 \mathrm{~b}$

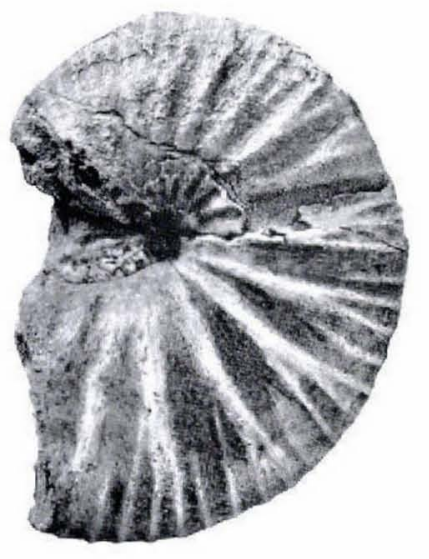

$3 a$

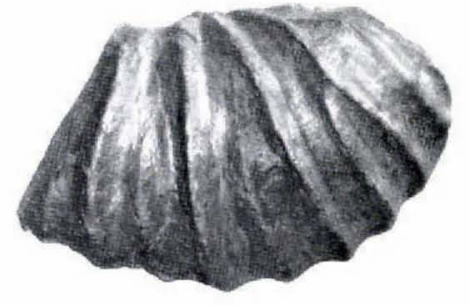

5

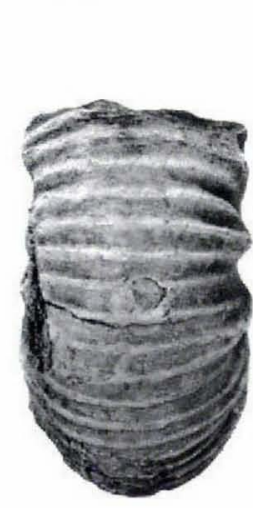

$3 b$
$4 b$

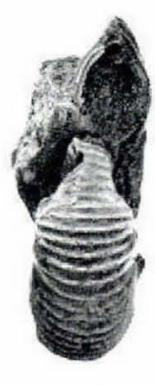

$2 b$

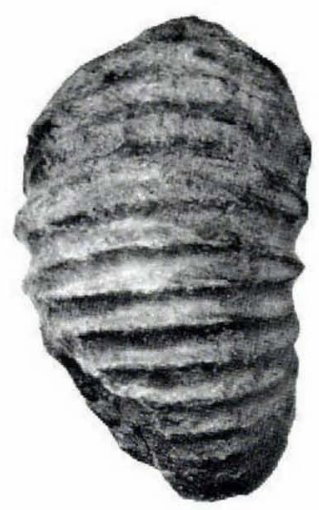

$4 a$

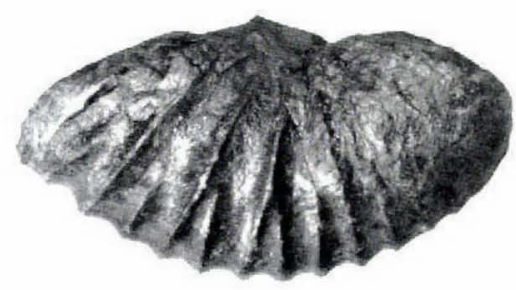

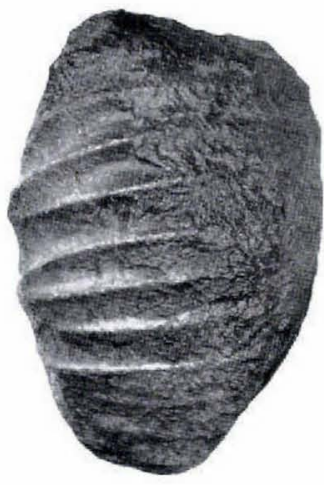

6

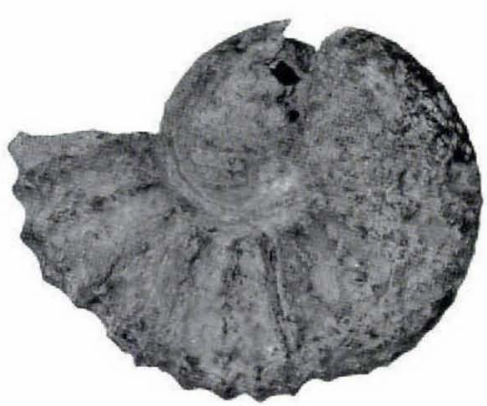

$7 a$

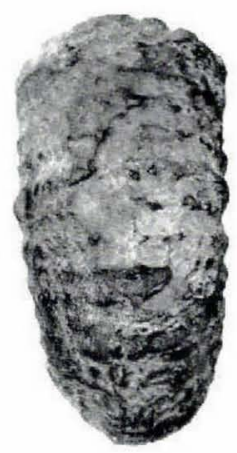

$7 b$ 


\section{Plate 47}

Clioscaphites sp. aff. saxitonianus (McLearN) (p. 135).

$1 \mathrm{a}-\mathrm{c}$. MMH No. 9869. Lateral and peripheral views. Santonian. From the beach or river-beds on the south coast of Umîvik bay.

$2 \mathrm{a}-\mathrm{b}$. MMH No. 9870. Lateral and peripheral views. Santonian. The ammonite locality at Umîvik.

Borissjakoceras rosenkrantzi n. sp. (p. 140).

3a-b. MMH No. 9871. Lateral and peripheral views. Coniacian? The ammonite locality at Umîvik.

4a-c. MMH No. 9872. Lateral and peripheral views. Coniacian? The ammonite locality at Umîvik.

5a-c. Holotype. MMH No. 9873. Lateral and peripheral views. Coniacian? The ammonite locality at Umivik.

Haresiceras sp. (p. 138).

6. MMH No. 9874. Lateral view of crushed specimen (plastic cast). Lower Campanian? Sydelv, Itsako, $95 \mathrm{~m}$ above sea-level.

7. MMH No. 9875. Lateral view of crushed specimen (plastic cast). Lower Campanian? Sydelv, Itsako, $95 \mathrm{~m}$ above sea-level. 

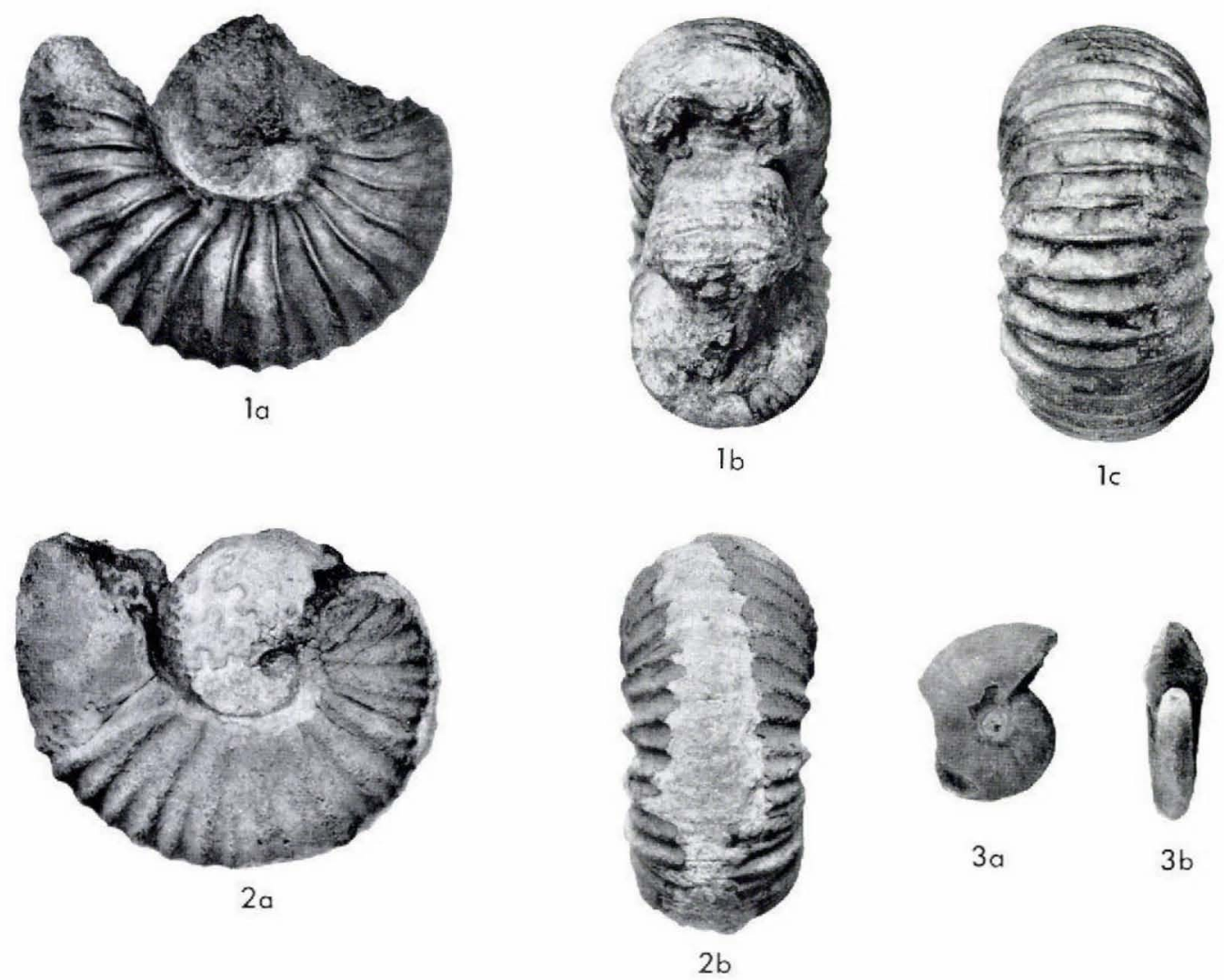
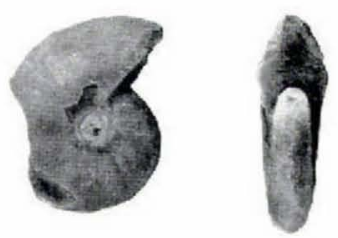

$3 a$

$3 b$

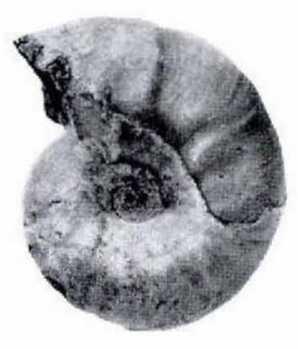

$4 a$

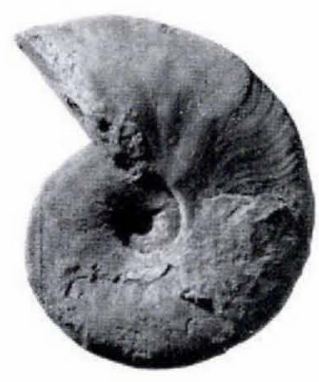

$5 a$

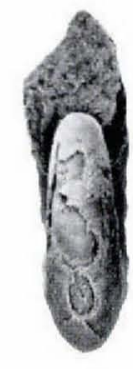

$4 \mathrm{~b}$

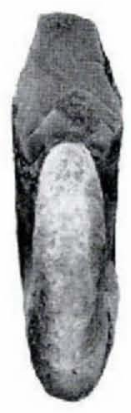

$5 b$
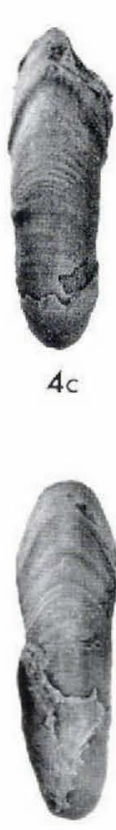

$5 c$
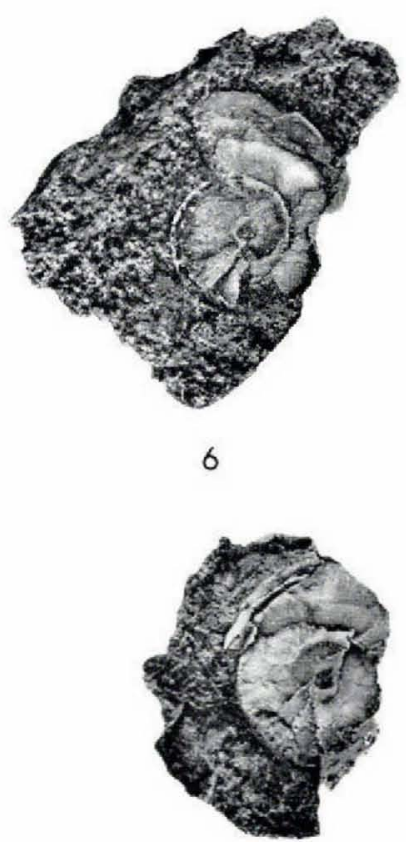

7 


\section{Plate 48}

Map of the north coast of Nûgssuaq from Niaqornat to Ikorfat 1:100,000, showing ammonite localities.

1: Scaphiteskløft at Niaqornat; 2 : Hamiteskløft; 3 : Sandstenskløft; 4 : Danienkløft; 5: Scaphitesryggen at Angnertuneq; 6: Vestre Konglomeratkløft at Angnertuneq;

7: Kangilia; 8: Skifer-peridotitnæsen at Kùk-anernilik; 9: Breccieelv; 10: Brudkløft at Ikorfat; 11: Breccienæsen; 12: Ikorfat pass; 13: Ikorfatnæsen; 14: large ravine east of Ikorfat.

Copyright: Geodetic Institute, Copenhagen. 


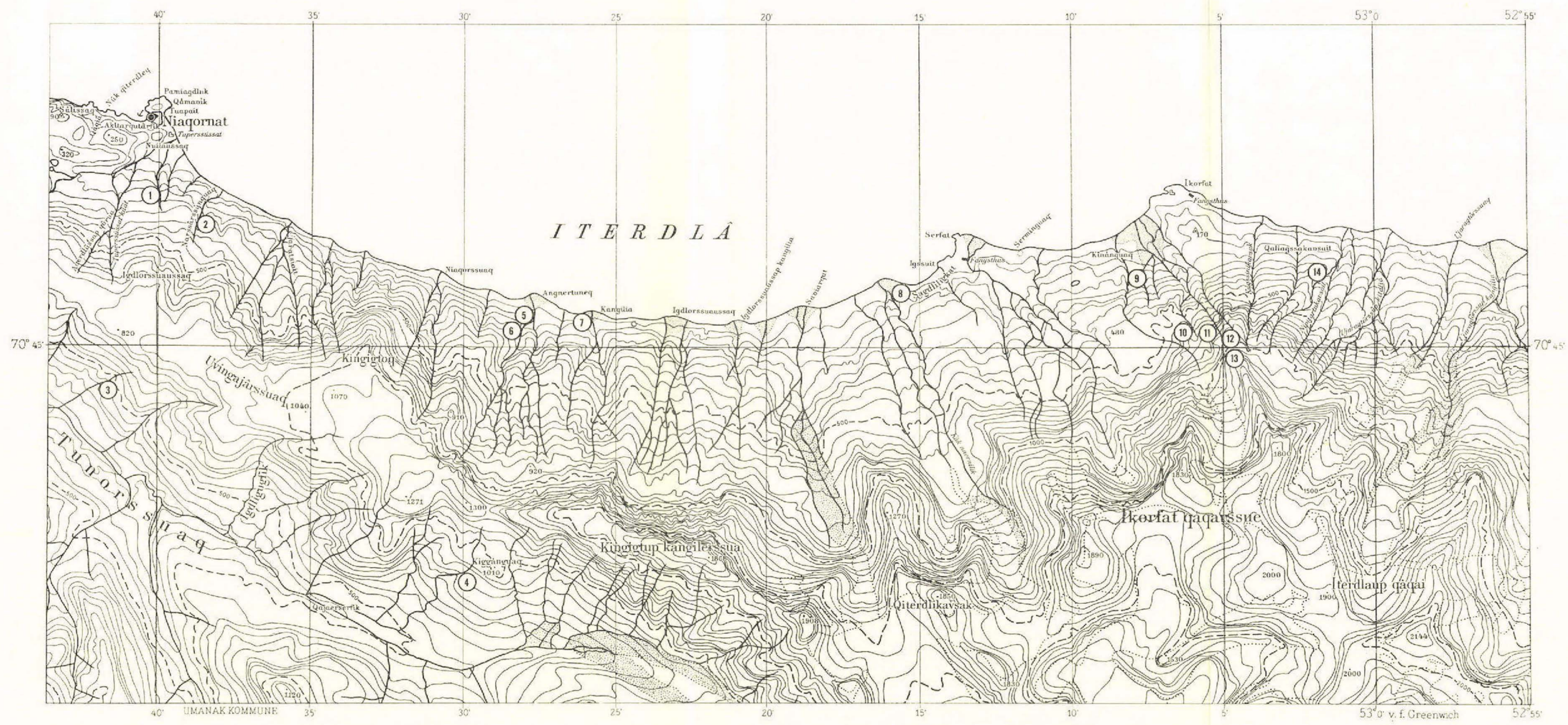

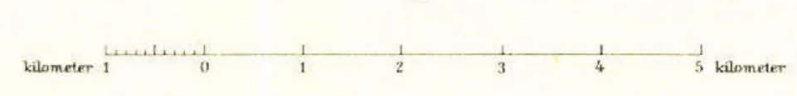


(18)

$\sum_{\text {Ikorfat froutt }} \frac{\text { Serfat }}{\text { kât }}$

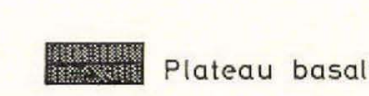

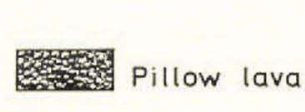

$\square$ Picrite $\square$ Danian and Paleocer

Danian basal conglomerate

Naqorssuaq toutt

$\square$ Kome and Atane Formations

Dolerite sill $\quad$ Gneiss $\quad \square$ Glacier 